\title{
FOREST ENTOMOLOGY
}

A. T. Gillanders 


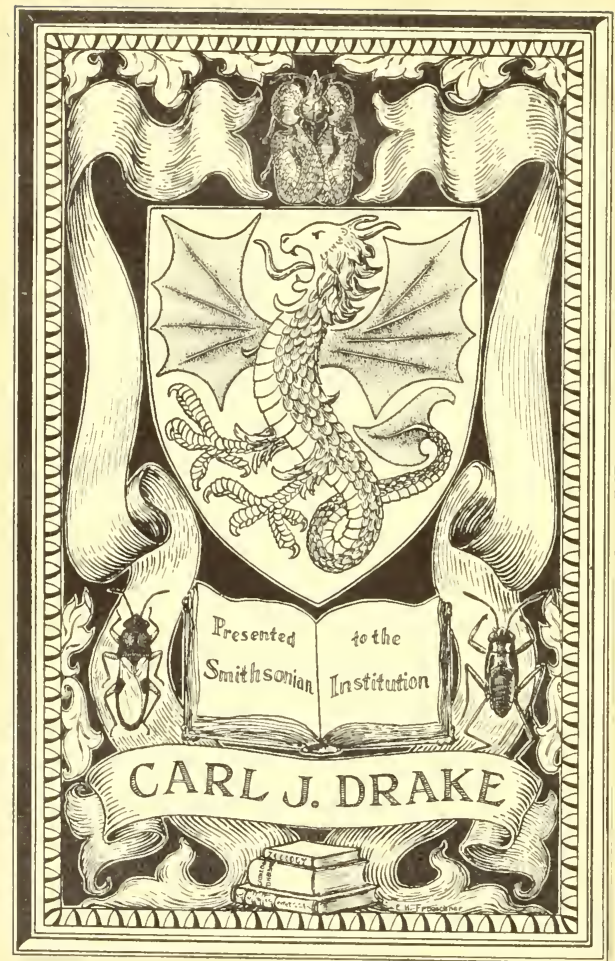


- Car f. Drabe - 



\section{Forest Entomology}





\section{Forest Entomology}

$\mathrm{BY}$

A. T. GILLANDERS, F.E.S.

WOODS MANAGER TO HIS GRACE THE DUKE OF NORTHUMBERLAND, K.,.

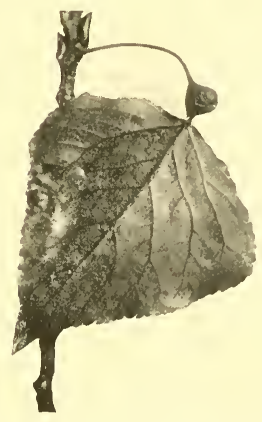

WITH 354 ILLUSTRATIONS

SECOND EDITION

William Blackwood and Sons Edinburgh and London

I 9 I 2 


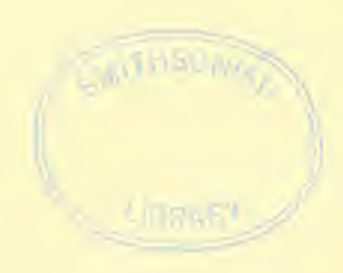


DEDICATED BY PERMISSION

TO

HIS GRACE

THE DUKE OF NORTHUMBERLAND, K.G. 



\section{PREFACE TO SECOND EIUTION.}

As author of a work on a subject which does not appeal to a very wide circle of readers, I realise that it is a very high compliment that a second edition has been called for in a comparatively short time. Hence there is no need for drastic changes. I have, however, tried to benefit by the kindly advice given by entomological friends and others interested in the subject; therefore the chapters have heen re-arranged more in accordance with the sequence of entomological classification. I have trierl also, as far as I possibly can, to correct the recognition of photos and drawings of several friends. In this respect the first edition showed a slight error in acknowledging special photos as emanating from a friend rather than the firm of which he was a partner, and to whom I am very grateful for assistance.

I am specially indebted to I'rofessor ('arpenter, of the lioyal College of Science, Dublin, for correcting several points in the Introductory chapter.

I have every reason to be gratified by the many lind letters received from all parts, _ from the landowner seeking further advice with regard to some special insect pest: and from the young forester or nature-student trying to besin making a 
collection of forest insects. It is therefore with very pleasant feelings that 1 submit this new edition, in the hope that it may command a wider circle of readers as associated with the growth and cultivation of forest trees, - a subject which is becoming more important every year.

Park Cottage, Alwwick, December 1911. 


\section{PREFACE TO FIRST EDITION.}

Is submitting a book on a branch of Natural science which has required any degree of research during its preparation, or which otherwise is intended as a guide for research, perhaps no one realises its shortcomings more than the writer. At least this is certainly the feeling of the author on the present occasion.

The book was begun in a very humble way. Having always had a strong inclination for Natural Science, and further for studying subjects associated with the scientific aspect of forest trees, I began as far back as 1887, while residing in Cheshire, to write papers on Forest Insects for the Warrington Field Club. To that district, with its Natural History clubs or societies, and the many excellent men I met in connection with them, I owe a very deep debt of gratitude. I cannot in the present circumstances enumerate all to whom I am indebted for assistance in the present book, but my first teacher in Entomology was the late Mr Berry Kendrick of Warrington, who gave me most ungrudgingly all the help any one could possibly give to a begimner. Of the Warrington Field Club itself it is impossible to speak too highly as a Natural History society. Composed of some fifty members, 
original papers were given every fortnight during the winter months, often accruing from investigation during the summer months, and the members freely criticised the paper of the evening. This, though perhaps not always appreciated at the time, was in itself a most excellent school.

In a similar way I am indebted to the Manchester Microscopical Society for a great deal of rearly help from its members. This Society, unlike the former, published the papers of its members, and I have therefore to sincerely thank it for publishing my papers on "Forest Insects," and, further, for kindly giving me the blocks prepared from my own negatives, some of which I have used for the present book.

I have also to thank the Chester Society of Natural Science for many extended courtesies given from time to time. The material for this book has been collected in Cheshire and Northumberland, but more especially the former county.

I am also indebted to the Comtry Gentlemen's Association, the Highland and Agricultural Society of Scotland, and the Royal English Arboricultural society for publishing papers on Forest Entomology.

Turning from societies to individnals, it is almost impossible to acknowledge withont being invidious those who have assisted me in the subject-matter of the volume. Two names may be mentioned. Mr Ii. Newstead, author of 'A Monograph of British Coccidie' gave me from time to time much assistance on Scale Insects. Mr A. Flatters, Manchester, has given me great help in microscopical manipulation, and has, in addition to the figures acknowledged with his name, photographed several specimens from my own microscopic slides, as, for example, the tiny Cecidomyia flies.

As regards the first works from which I derived considerable assistance, I may specially mention 'A List of Insects on 
Forest Trees,' by $\mathrm{Mr}$ S. L. Mosley, Huddersfield, and the splendid 'Manual of Injurions Insects' by the late Miss Ormerod. Of the latter I cannot speak too highly, more especially as Miss Ormerod gave me very great encouragement by correspondence.

As the period during which I have studied the subject has extended over twenty years, it is obvious that much original work has been done by many workers during that time. I have tried, so far as means or leisure would afford, to keep in touch with all original work. In order, therefore, that the student may get the full advantage of that, I have, whenever I found the work of others more suitable than ny own, quoted from those writers. In most cases this has been done by direct permission of the author, but in all cases when giving an extract I have endeavoured to duly acknowledge the same. In this advanced age of om's, knowledge, more especially Entomological knowledge, is no longer the property of any one individual. Hence all quotations are freely given as epitomised knowledge suitable for the student. They are given to obviate at first the necessity of consulting other works, and yet at the same time be a guide as to what other works he may consult for fuller information. It will be apparent that the majority of quotations are of a systematic nature. Hence the great difficulty in preparing the book has been to amalgamate the systematic with the economic, and so maintain a due proportion. On the one hand, if too many details of a systematic nature were given, the work would not only have been very much overladen, but the practical man wonld be impatient in reading it: on the other hand, if too few systematic details were given, it would not act as a guide to fuller inquiries, or form, as designed, a suitable text-book for students at agricultural and other colleges. The main 
feature which is attempted is recognition of the insect from the damage, together with systematie characters and life-history detcils.

In studying the subject from the economic point of view, I have become convinced, from a prolonged study of the subject, that the economic student must of necessity study the systematic sicle and associate himself with systematic men. Hence for example, I have added often, in extenso, extracts from valuable works like Fowler's 'British Coleoptera,' \&c. At the same time, the matter is so arranged that the beginner, or the practical man, may at first, if he chooses, skip them, and study the nature of the injuries, the life-history of the insect, and in some cases the remedies which may be adopted. If, however, the subject is to be thoronghly studied, the systematic points must be ultimately mastered.

With a view of making the work more reliable, I have submitted each chapter in proof to men who have specially studied particular sections or families of insects, and in all cases I am glad to count these specialists as personal friends. As the work embraces nearly all families of insects, this was considered all the more advisable, and though the changes made in the proof form by these specialists were comparatively few, yet in every case they were most important from the systematic point of view.

The following are the names of those who looked over the respective chapters in proof form-viz., Mr E. T. Connold, "Gall-Mites" and "Oak Galls"; Mr R. S. Bagnall, "Coleoptera"; Mr A. C. Forbes, "Scolytidze"; Rev. F. D. Morice, "Saw-flies"; Mr R. Newstead, "Scale-Insects"; Mr J. Collins, "Lepidoptera "; Mr F. V. Theobald, "Aphididie" and "Diptera."

I have also to thank Mr J. F. Amand, Lecturer on Forestry, 
Armstrong College, Newcastle, for kindly looking over the MS. previous to sending it to the publishers, and also for discussing many of the practical points with me.

I an specially indebted to Commander J. J. Walker, li.N., Oxford, for kindly correcting the final proofs.

With reference to the illustrations, for the loan of blocks or electros I am indebted to Messrs Sampson, Low, Marston, \& Co., Ltd., for figs. 14, 16, 20, and 21; to Professor Miall for fig. 18 ; to Messrs L. Reeve \& Co. for figs. 39, 41, and 42); to the Ray Society for figs. 300 and 308, and also for granting permission to photograph figs. 251, 25:, 255, 258, 282, 311, and 312 ; to Messrs Headley Brothers for figs. 175,241 , and 319 ; to the Proprietors of 'The Entomologist's Monthly Magazine' for figs. 157, 158, and 159. Mr W. R. Fisher has given me much encouragement from time to time, and I have to thank him for receiving from Messrs Bradbury, Agnew, \& Co., Ltd, the large number of blocksviz., figs. $47,48,49,50,60,61,78,79,92,121,126,127$, $163,164,209,210,211$, and 212. I also owe thanks to Messrs Blackwood for figs. 45, 46, 72, 73, 79, 101, 102, 104, and 216, from 'The Forester,' by Dr J. Nisbet. With the exception of the figures taken from the valuable German works, and acknowledged under each figure respectively, all the others are original.

Finally, I beg to say that I submit the knowledge contained in the book with a feeling that I have just about the necessary amount of knowledge to make a beginning rather than a finish; and I trust that the student will take up the subject with the object of making a study of it on his own account, and verify each point by observation and rearing. In other words, the student must consider the work as an introduction only. Further, there is the most important point left 
xiv PREFACE TO FIRST EDITION.

to the last-viz., the study of German literature. The Germans are our great teachers in this branch of knowledge, and I have added many points and illustrations from German sources with the distinct object of showing their superiority and indueing students to study their most valuable works.

Pirk C'OTTdGe, AlNWICK,

May $190 \mathrm{~s}$ 


\section{CONTENTS.}

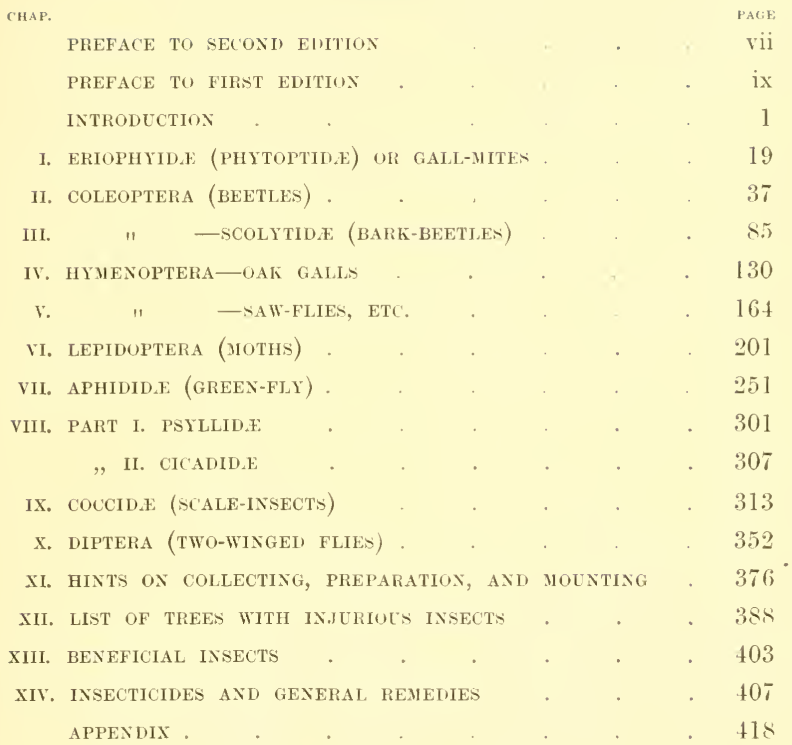

INDEX

423 



\section{LIS'T OF ILLUSTRATIONS'}

\section{INTROI)UCTION.}

1. Eggs of Arctia menthestri.

2. Egrs of Bombyx neustrie on birch

3. Typical forms of larve .

4. Typical pupal form of an insect. .

5. Pupal case of I'anessa urticu

(i. First emergence of 'Tortoiseshell Butterfly from pupal case

7. Emergence of Tortoiseshell Butterfly more fully alvaneed.

s, 9. Fully developed Tortoiseshell Butterfly

10. Typical month parts of insects

11. Compound eye of insect as seen under the microseope

12. Typieal forms of antenne.

13. 'Typical form of leg.

14. Diagram of longitudinal section of an insect

15. Horizontal section through the head of a blow-fly.

16. Diagram of the chief trunks of the tracheal system of an insect

17. 'Trachea of butterfly .

1S. Food canal of cockroach .

19. Diagrams of the heart of an insect

21. Female genital organs of the cockchafer
FIr.

21. Male genital organs of the cockehafer.

I'ACIF

PASIF

4

ERIOPHYIDE ((AAL-NITES).

22. Eriophyes rulis

2]

23. Abortive swollen buds on hazcl eaused by Eriophyes arellaner.

24. Abortive swollen buds on birch . . 25

2.). Abortive swollen luads on

Englislı yew . . 26

26. "Nail-galls" on leaf of lime-tree . .

27. Galls on leaves of field maple caused by Liriophyes macrochelus

2s. (ialls on leaf of field maple caused by Eriophyes macrorhynchus

27

25

29

29. (ialls on leaves of eommon alder causcd ly kriophyes laris.

29

30. lialls on midrib of the leaves of common alder cansed by Eriophyes arillaris.

31. Galls on leaf of Wayfaringtree eaused by kriopliyes tetunothrix:

32. Malformation of the flower of ash caused by biriophyes firuini

33. Edges of hawthorn leaf rolled inwards by Eiriophyes gowiothora. 
34. Surface of leaflets of mountain-ash injured by Eriophyes ancuparice .

35. Edges of leaves of blackthorn rolled inwards by species of Eriophyes

36. 1)orsal surface and side view of Phyllocoptes carpini .

37 . Galls on leaf of sycamore caused by Phyllocoptes acericola

\section{COLEOPTERA (BeEtles).}

38. Typical larve of beetles

39. Head of Cicindela (magnified)

40. True wings of beetle

41. Typical beetle (upper side)

42. Typical beetle (under side)

43. Stag - beetles, male and female. .

44. Portion of ash timber injured by larva of stagbeetle.

45. Young beech seedling, the roots of which have been destroyed by larva of Nay beetle.

46. The common cockchafer or May beetle: feelers, chrysalis, \&c.

47. Melolontha hippocastani

48,49 . Injury caused to beech saplings by $A$ gritusvividis

50. Agrilus virilits .

51. Portion of dead hawthorn stem burrowed by larve of Priobium castaneum .

52. Markings of larve of $\mathrm{Er}$ nobius mollis on spruce pole

53. Clytus arietis (Wasp beetle)

54. Rharinum inquisitor . .

55. Rhargium lifasciatum .

56. A canthocinus vilitis.

57. Saperla carcharia. . .

58. Larva of Saperda carcharias

59. Injury cansed to stem of aspen poplar by larve of saperda populnea.

60. Melu:ioma populi: beetle, larva, and pupa
61. Injuries done by Melusoma populi .

62. Phyllodecta vitelline (Willow beetle).

63. Willow leaf injured by larve of Willow beetle

64. Leaf of balsam poplar injured by larvæ of Willow beetle.

65. Oak leaves rolled by Attelabus curculionides.

66. Attelabns curculionides.

67. Birch leaves rolled by $D e$. poraïs betuil, . . 67

65. Deporaïs betule . . $\quad 68$

69. Otiorrhynchus picipes.

70. Otiomhynchus sulcatus (Vine weevil).

71. Foliage of mountain-ash eaten by Phyllobius: muculicornis.

72. Young sprice plants gnawed by Hylobius abietis. .

73. Hylobius abietis (Pine weevil), beetle, larva, and pupa

74. Cocoons of Pisodes mini on stem of Scots pine.

75. Piswoles pini . 7s

76. Young pine-stem barked to show pupal-beds of Pissodes notatus. .

77. Beech leaves showing injuries done by larva and holes eaten by Orchestes jayi

78. Larval burrows of Cryptorrhynchus lapathi in alder stems.

79. ('ryptorrhynchus leupathi .

so. Bulanimus nucum

81. Portion of beech timber injured by Rhopalomesites Turdyi

COLEOPTERA (SCOLYTID).

82. Typical workings of "barkbeetles". .

83. Antenna of Hyleximz.: crenatus. 
34. Markings of stcolytus clestructor in bark of linglish elm

85. Showing exit-holes of same

86. Nicolytus destructor.

s7. Markings of Scolytus muni in branch of apple

Ss. Markings of sicolytusmultistriatus in bark of eln.

89. Markings of S'colytus intricutus on oak pole

90. Scolytus intricutus . .

91. Markings of Hylastes palliatus.

9:2. Hylastes palliatus

93. Markings of Hylesinus crenatus.

94. Hylesinus crenatus. .

95. Markings of Hylesinus. fraxini

96. Hylesinus fraximi .

97. Markings of Hylesinus oleiperda

98. Hylesinus oleiperda .

99. Markings of Hylesinus vittatus. .

100. Iylesinus vittatus. .

101. Shoot of Scots pine showing the entrance-hole and boring of a pine beetle.

102. Showing mother and larval galleries in process of formation

103. Portion of bark of Sicots pine, showing two mother - galleries and larval workings of pine beetle.

104. IIyluryus piniperala

105. Markings of Phleophthorus rhododactylus on gor'se .

106. Markings of Phlivophthoru. rhododactylus on broom

107. Phluxophthores rhododactylus.

105. Markings of Cryphulus abictis

109. Cryphalus abietis.

110. Showing "exit-holes" of Cryphalus tilier. .

111. Markings of r'yphulus tilies on lime

11:. Markings of C'ryphulus fayj
113. Xylocleptes bispinus. .

114. Mother-gallery of Mryo-

cretes rillosus . 120

115. Divocartes cillosus

116. Dryocates almi . . 121

117. Tomicuss sexlentutus . 121

115. Markings of Tomicus an-

minatus. . 122

119. Markings of Pityogenes bidentatus (initial stage)

120. Fully developed markings of Pityoyenes bidentatus

121. Pityogenes bilentatus

120

123

123

124

100

102

103

104

105

105

106

106

107

122. Block of wood shown in perspective to illustrate the workings of the genus Tryporlendron.

123. Workings of Trypodendrom lineatmin . . 126

124. Trypodendron lineatum . 1:26

125. Markings of Trypodendion clonesticnn

127

126. Xyleborus dispar (male). 12s

127. Nyleborus dispar (female) 1:3

128. Burrows of Xyleborus dispar. .

129

HYMENOPTERA (OAK-GALLS).

129. Gall-fly of "oak-apple" and structural details. $\quad 138$

130. Galls of Neuroterus lenticularis . 140

131. Neuroterus lenticularis . 141

132. Galls of Spatheyaster baccurrm on male flowers of oak

142

133. Galls of spatheyaster baccarum on leaves of oak

134. Spatheyaster baccornm .

135. Gralls of Neuroterus fumipenmis

113

136. Galls of spatheyaster tricolor.

113

137. Gialls of Neuroterus luriusculus.

138. Galls of Spathergester allipes

117

139. Cralls of Neuroterus mismis-

mutis. . 146

11s 140. (iall of Aphilothrix matiris 147

141. (xalls of Aphilothrix corticis $14 \mathrm{~S}$

$11 \mathrm{~S} \mathrm{142.}$ (ialls of A philothrix rlobuti 145 115 143. Gall of indricus inflator. 149
142

143 48 
144. Galls of Andricus curvator. . .

145. Injury done to leading shoot by gall of Audricus currator

146. Galls of Aphitothrix quadvilineata .

147. Falls of Aphilothrix albopunctata . . 152

148. Gall of Andricus ramuli (cotton gall)

149. Galls of Aphilothix fecundatrix . .

150. Gall of Diyophante sentellaris

151. Gialls of Dryophantu longirentris

152. Galls of Dryophanta dirisa

153. Falls of Biorhiza aptera .

154. Ciall of Teras terminalis .

155. Galls of Biorhiza remum .

156. Galls of Cymips Kollari (marble gall)

HYMENOPTERA (SAW-FLIES).

157. Thorax of a saw-fly : dorsal surface.

158. Lateral or side view of fig. 157 . . .

159. Typical upper wing of saw-fly .

160. Trichiosome tibialis
161. Cocoon of Trichiosoma after escaje of fly .

162. Larvæ of Trichiosoma on hawthorn leaf.

163. Lophyrus pini (Pine sawfly), male . . $\quad 176$

164. Lophyrus pini (Pine sawfly), female.

165. Foliage of Scots pine eaten by larva of Pine sawfly. Injury done by first brood of the season

166. Pupal case of Lophyrus pini. . .

167. Foliage of scots pine eaten by larva of l'ine sawHy. Injury done by second brood of the season . .

168. (ialls of Euma pentandin
169. (ialls of Pontanie salicis 182

170. (ialls of Pontenia belle . 182

171. Galls of Pontenie gallicole. . . 183

150 172. Galls of Pontanic ischnocerus. . . 184

151 173. Leaf of goat willow eaten by larve of Pontanice salicis.

174. Larve of Crosus septentrionalis on alder. 185

175. Cressus septentrionalis: insect and larvæ . . 186

176. Foliage of larch injured hy larve of Nematus. Erichronii . . 15i

177. Nematu. Erichsonii. .

178. Larve of Nematus Erich. sonii . 185

179. Pupal cases of Nematus Erichsonii . . . 188

180. Plank of silver fir injured by sirex yigfes . . 189

181. Sirex figfos (female) . 190

182. Sirex gitres (male). . 190

183. Sprnce timber injured by sirex jurencus. . 191

184. Nirex jucencus (female) . 191

18.5. Sirex jurencus (male) . 191

186. Injury done to ash stem by hornet . . 192

187. Hornet ( Fespa Crabro) . 193

188. Galls on under side of leaf of dog-rose caused by Rhorlites eglanterio . 193

189. "Mloss or pin - cushion gall," caused by Rhodites rose . . 193

190. Needs of Douglas fir injured by Megastigmus sipermotrophus . .

191. Megastigmus spermotrophas (female) . . .

192. Meyastigmus spermotrophus (male)

193. Seeds of silver fir injured by Megastigmes strobilobius .

LEPIDOPTERA (Мотн). 
196. Timber of goat willow injured by larve of Trochilium bembeciformis.

197. P'upal case of Trochilinu bembeciformis

198. Trochilium bembeciform is

199. Oak plank injured by larva of goat moth.

200. Cosszls ligniperda. .

201. Larva of Goat Noth .

202. Pupa of Goat Moth .

2013. Zenzera asculi. .

204 . Orgyie antiqua . .

205. Pupa of Puss Moth on twig of birch. .

206. Dicrumuce rimula. .

207. Pysmera bucephale .

208. Larva of Buff-tip Moth on twig of oak. .

309. Larva of Bordered White Moth.

210. Pupa of Bordered White Moth.

211. Fidoniu piniaric (male):

212. Fidonir piniaria (female)

213. Foliage of lime-tree eaten by larvæ of Winter Noth.

214. Leaf of wych elm eaten by larva of Winter Moth.

215. Foliage of sycamore eaten by larve of Winter. Moth

-16. Winter Moth: male, female, and caterpillar.

217. Trachea piniperda. .

218. Cone of silver fir partially eaten by larvie of Dioryctria abietella.

219. Dioryctivit abietella. .

220. Foliage of oak destroyed by larve of the Green Tortrix Moth .

221. Foliage of hazel injured by larve of Tortrix ritieane

222. Leading shoot of poplar injured by larva of Hedlya ocellana. .

223. Shoots of English yew injured by larve of Batodes angustiorana.

2.24. Shoot of holly injured by Padisea ophthatmicance
225. "Leading" bud of Seots pine injured by larva of Retinia trionana.

2:26. "Leading shoot" of young Scots pine injured by larva of Retinia huoliana. . .

2:7. Retinia bnoliana, male and female

231

206

206

207

207

208

208

209

210

212

212

213

213

215

225. Gall of resin on ícots pine caused by hetinir resinella

229. Retimia resinella.

230. Hyponomenta evonymellu.

231. Web and empty pupal cases of Hyponomenta evonymellu.s.

232. Leading bud of ash-tree injured by larva of Prays curtivellus.

233. Young ash-tree "forked" by larva of Prays curtisellus.

234. Prays curtisellus : its lifehistory after Judeich and Nitsche

230

230

231

232

233

233

235

236

235. Leaves of osier drawn together by larva of Depressaria conterminclle.

236. Shoots of broom drawn together by larve of Depressaria assimilella.

237. Tops of young larch-trees injured by larve of Argyresthia levigatella

238. Leaf of lilac injured by the mining larve of Gracillarin syringella .

239. Normal foliage of larch .

240. Foliage of larch injured by larva of ('oleophora laricella

2+1. Coleophora laricella: pupal case and moth ? 244

242. Coleophore $\times p$. on birch . 245

243. Typical bloteh of Lithocolletis on oak leaf

244. Injuries to foliage of holn oak by larve of Lithocolletis messenciella

245. Foliage of laburnum injured by larvare of r'emi- 
Al'HII)ID.\& (GRLEN-FLY).

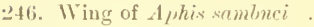

247 . Wing of sichizonenere ulmi

-48. Wing of Pemphigues pellidus. .

249. Wing of Chermes alietis .

250. Terminal shoot of will eherry injured by $\boldsymbol{H}_{\text {yzu: }}$ cercesi .

251. Melenoranthus salicis .

25:. Eggs of Aphis cretregi on thorn.

253. Aphis erectriti. .

254. A phis pali on bird-cherry

255. A phis sambei .

256. Chatophorus aceris (special peculiar form) .

257. Figgs of Lachnu: longipes: on oak

258. Phyllaphis fagi . .

259. Foliage of eopper beech (under side) eovered with Phyllaphis fergi .

260. Leaves of wych elm rolled by schisoneura ulmi.

261. Gall on leaf-stalk of poplar caused by P'emplizgu: burserius.

262. "Stem mother" of Pemphimps thurseriu. . .

263. Larval stage of $I^{\prime}(m)$ highu. burservius. .

264. Pupal stage of Pemphignes lurserius.

265. Winged form of $P$ imphigu. bursterius: .

266. "Corkscrew" gall on leafstalk of poplar caused loy Pemphigzs spirothe ene .

267. Gall of l'emphigns pallirlus on mirtrib of leaf

268. Galls of T'etraneure ulmi.

269 . (iall of thermes rividis.

270 . Warly stage of gall of Chermes rivelis.

271. Winged forms of Chermes alictis on spruee leaves

272 . ('hermes laricis on bark of larch.

273. Foliage of lareh injures by attack of chormes.
253

258

2.53

253

258

261

263

263

264

266

$\because 68$

272

273

274

276

279

279

279

280

280

281

281

282

286

286

288

290

291
274. Chermes laricis on foliage of lareh. . .

275. Chermes pini on stem of young scots pine.

276. Chermes pini on terminal shoot of Scots pine.

27\%. Terminal shoot of Scots pine killed by Chermes pini . . .

278. Chermes corticalis on branch of Weymouth pine . $\mathbf{2 9 4}$

279. Chermes picer on bark of silver tir

280. Hibernating winter forms of four species of ('hermes.

281. Under side of oak leaf infested with Phyllorerce punctata . .

282. Apterous female, eggs, and larva of Phyllovera menctata.

283. Winged form of Phylloxerre punctula.

301

\section{PSYLLIDE.}

284. Leaflets of ash injured by Payllopsis fraxini .

2\$5. Leaves of box injured by Psylla buxi.

286. Joung form of Psylla cretregi.

287. Tip of hawthorn shoot injured by P.ylla cratergi

2ss. Twig of alder injured by Psylla alni.

303

304

305

305

306

\section{CICADI1).E.}

289. Typhlocybe ulmi

311

290. T'yphlocilna nlmi . . 311

291. Young form of Typhlocyba ulmi . . . 31은

COCCIDE (NCALE-INSECTS).

292. Cerataphis lataniw (fringed aphis) on palm . .

293. Sicale - like secretion of Aleurorles on leaf of tomato 
294. Female scale of Aspidiotus 295. Male scale of Aspriliotus. 296. Female scale of Diaspis . 297. Male scale of Diaspis. 298. Female seale of Chionuspis and Mytiluspis

299. Male scale of Chionaspis . 300. Pygidium, or anal segment, of Mytilaspis pomorum, showing dorsal and ventral parts, \&c. .

301. Male scales of Chionaspis sulicis.

302. Female scales of Chionaspis salicis

3103. Life-history of Chionaspis salicis.

304. Scale of Aspidiotus on leaf of Lapageria

305. Scale of Aspidiotus on leaf of Stephanotis .

306. Scale of Aulacaspi. rosie on dog-rose

307. Female scales of Lecanium caprere, "brown scale," on sycamore

308. Adult female Lecanium after treatment with potash $\times 20$.

309. Typical antenne of female Lecanian

310. Male and female scales of Pulinaria .

311. Male of Pulvinaria, species found on currant

312. Male of Lecunium, species found on sycamore .

313. Sicales of Physokermes abietis

314. Depressions on twigs of oak caused by Asterolecunium rariolowum.

315. Pseudococcus acerison bark of hornbeam

316. Antenna of $I$ 'seudococcus aceris.

317. Leg of Pseudococcus aceris

318. Rostrum of Parulococeus aceris .

319. Cryptococcus fayi on beech.

320. Apterococcus fraxini . 351
$31 \mathrm{~s}$

\section{DIPTERA (Two-Winged Flies).}

321. Leaves of Sali, viminati. rolled by ('ecidomyia maryinemtorquens:

322. Cecidomyia maryinemtorquens (male) . . 3.57

323. Cecillomyia maryinemtorquens (female)

324. Shoot of hawthorn injured by Cecidomyia croturgi

325. Twis of yew injured by Cecidomyia taxi.

326. Shoots of Sali, cayiere injured by Cecilomyia rosaria 359

327. Cexidlomyia rosaria (male)

328 . Section of willow stem showing injuries caused by Cecidomyia saliciperda

329. Portion of bark and wool cut off to show the injuries of Cecilomyia saliciperda .

3611

330. Leading shoots of a species of willow injured by Cecidomyin heterobia.

331. Twig of Srelix caprea injured by Cecillomyia salicis.

332. Cecillomyiu sulicis (male).

333. Leaf of lime-tree injured by Cecillomyia tiliam volens.

334. Shoots of lime-tree injured by Cecillomyia tiliam volens. . .

335. Foliage of ash injured by Diplonis botularin .

336. Edges of oak leaves folded by Diploxis diyotira.

337. Galls on leaf-stalks of aspen poplar caused by Diplosis tremule .

362

363

363

364

364

364

36.5

366

335. Galls on upper surface of beech leaves caused by Hormomyia piliger . 367

339. Leaves of goat willow galled by Hormomyia caprear 
340. (ialls on broom caused by Asphonelylice sarothamni

341. Asphondyliue serothamni .

342. Pupa of A sphondylia sero-

themni . . 369

343. ( iall on stem of bramble caused by Lasiopterca rubi. .

344. Galls on stems of willow eaused by Agromyza schineri. .

345. Leaf of snowberry mined by Chromatomyiu obscurella.

346. Leaf of holly blotched by Chromatomyia ilicis

347. Bibio marci (males and females) . .

348. Three-year-old spruce injured by larre of Bibio marci.
$36 \mathrm{~s}$

369

369

370

372

372

374

374
COLLECTING, PREPARATION, AND MOUNTING.

349. Simple arrangement for dissecting specimens uniler i magnifyingglass . . . 380

350. Proboscis of honey-bee . 34.5

351. Tongue of house-fly . 3S5

352. Life-history stages of "Swallow-tail" Butterfly

\section{APPENDIX.}

353. Boring apparatus of the female of Nematus Erichsonii . . 418

354. Six-year-old larch injured by larve of Nemutus: laricis. . . 421 


\section{FOREST ENTOMOLOGY.}

\section{INTRODUCTION.}

IT may appear somewhat paradoxical to say that "Forest Entomology" differs from the "Entomology of the Forest." Under the latter hearing the major portion of the science of entomology may be included, inasmuch as the student of general entomology, or the specialist of any particular group, will often find the forest one of his happiest hunting-grounds. This is due not only to the varieties of arboreal food and the varied forest flora, but to the game-preserving laws or customs continually furnishing carrion food, and demanding a varied cover for game-birds and feathered songsters, which doubtless act as sources of dissemination for many species of insects with comparatively poor powers of locomotion. With regard to "Forest Entomology," even in its widest sense we can only embrace directly all insects preferring an arboreal diet, and indirectly all other insects parasitic on arboreal-feeding insects.

As the field of natural history becomes broader and broader, natural science tends more and more towards specialisation; and while it is essential that the young student should gain a comprehensive view of kindred subjects, the adult who aspires to pose as a public instructor cannot make progress in any branch without limited concentration. Perhaps this narrowing is more essential in entomology than in many other branches of natural history.

The science of entomology may be studied from two different aspects-viz., from that of the collector, and of the economic entomologist or investigator.

The collector, who generally limits his work to one or two groups, 
tries by observation and comparison to classify his eaptures according to the difference in colour, size, and other variations. He also strives to enrich the loeal fauna by fresh eaptures. On the other hand, the eeonomie entomologist seizes these data of the eollector or systematic biologist, goes a step farther, and eonsiders inseets in relation to man, his person and property, either in so far as they affeet his industrial products, his eultivated plants, or the wild plants of nature.

From a husbandry point of view, the seience of eeonomie entomology may be divided into three principal parts-viz., garden pests, farm pests, and forest pests. The last is obviously the most diffieult to deal with.

Before any pest ean be satisfactorily checked, it is indispensable to study the life-history of the insect-viz., the egg, the larva, the pupa, and the perfect inseet,- -and then to deal with that stage in which the most praetical results can be obtained.

Hitherto it has been enstomary to study only those inseets whieh, by their numerical strength, have been injurious in the forest, but I venture to think it would be far more interesting and edueational, either as an eeonomie or a biologieal subjeet, to study all inseets which prefer an arboreal diet. To earry this out, two methods of arrangement suggest themselves - viz., a botanieal and an entomological. With regard to the former, it would be neeessary to elassify the respeetive trees, and then arrange those inseets which feed on them. This method has been adopted by some American writers. It has, however, this drawbaek, that while several inseets are fastidious as to their diet, others (except for the distinetion between hardwoods and conifers) are general feeders. Several German writers follow an entomological method, and this course appears to be far more edueational to the student of forest entomology.

As the forest is a field literally teeming with varieties of animal life, it may just be as well in passing to remind the practical husbandman and general naturalist that there are numerous creatures in the forest, under rotten bark and so forth, which are not in scientific language insects. Such creatures are snails, centipedes, spiders, and worms of various genera.

Hence two questions arise-viz.: (1) What relative position do inseets ocenpy in the animal kingdom? and (2) What is an insect? As regards the position of insects in the animal kingdom, natur- 
alists differ slightly in their arrangement; but it may be said that insects constitute a subdivision of the animal kingdom known as Arthropoda, which are characterised by having jointed limbs, and, as a rule, a distinctly divided body.

They rise in an ascending series in the following order-viz. :

ARTHROPODA (4 classes).

1. Crustacea . Crabs, Lobsters, \& $\bullet$

2. Arachrida . Mites, Sronpions, Spiders.

3. Mrriapoda . Centipedes and Millepedes.

4. Ixsecta . . Inserts.

In answer to the question, What is an insect? the general definition, with some common exceptions, is that an insect is a creature whose body is divided into three parts, has two antennæ, six legs, and, as a rule, passes through four stages of metamorphosis.

Accepting this general definition, it may be said that the creatures which, in point of anatomical structure and economic injuries, approach nearest to insects, are mites and spiders; and as a rough-and-ready classification, it may be said that a mite is a creature whose body is of one piece, a spider two pieces, and an insect three.

The mites most injurious to vegetation are the Eriophyidæ (Phytoptidæ), or four-footed mites. Spiders do not affect trees directly, and therefore need not be considered. We find a certain species of red-spider ${ }^{1}$ injurions to the foliage of ivy and other plants, sucking the juices from the leaves, and causing them to assume a sere appearance.

The whole class of Insects is divided into seven general or principal orders-viz., Coleoptera (beetles); Orthoptera (earwigs, crickets, grasshoppers, and locusts); Neuroptera (dragon-flies); Hruenoptera (ants, bees, and saw-flies); Lepidoptera (butterflies and moths); the Hemiptera, including the varions species of bugs; and Diptera (two-winged flies).

The Ilemiptera is subdivided into two principal divisions-viz., Hemiptera-Heteroptera, including the bugs; and Hemiptera-Homoptera, including Aphidæ or plant-lice, Cicadæ, Psyllidæ, and Coccidæ or scale-insects.

1 The so-called "red-spider"--the dreaded enemy of the gardener--is only a species of mite. 
With the exception of Orthoptera and Neuroptera, all the other orders are represented in forest entomology. Hence the necessity of versatility in entomological knowledge will be apparent.

Insects are further arranged into Families, Sub-families or Tribes, Genera, Species, and Varieties. There is, of

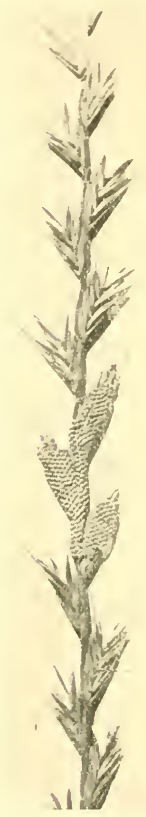

Fig. 1.-Eggs of White Ermine Moth (Aretia menthastri) on grass. (Photo by Flatters \& Garnett, Ltd., Manchester.) course, no sharp distinction between a species and a variety.

In order to understand our subject a little more fully, let us, by way of introduction, briefly consider the life-history and structure of a typical insect.

It has just been remarked that, as a rule, insects pass through four stages of metamor-

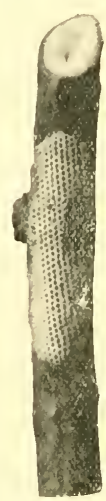

Fig. 2. - Eggs of the Lackey Moti (Bombyx nenstria) on birch twig. Found in Cheshire. phosis - viz., egg, larva, pupa, and perfect insect. When an insect passes through all these stages, the metamorphosis is said to be complete. When, however, it does not, - as, for instance, in the case of $A$ phidæ or plant-lice, - the metamorphosis is said to be incomplete.

Let us follow a typical example of a complete metamorphosis, commencing with the egg stage.

The eggs of insects are always deposited in the immediate vicinity of the food for the larve, as in figs. 1 and 2. In cases of many arboreal insects the eggs are often very difficult to discover. Sometimes they are concealed within the buds, in the midribs of leaves, the roots, bark, or other convenient places, according to the food of the larvæ. Insects adopt many devices to protect their eggs against weather and natural enemies, such as covering them over by a gummy secretion, the shedding of hairs, the formation of cocoons, and so forth. The eggs of insects possess very strong powers of vitality, and frost gener- 
ally has very little effect on them. They vary very much in size, form, and markings. Some are smooth and spherical, others corrugated, sculptured, elongated, and tailed.

The structure and development, as seen under the microscope, form not only a very interesting study, but present many difficult biological problems. Amongst the higher egg-producing animals no egg will develop without male fertilisation, but amongst insects there are many exceptions to this rule. In numerous cases eggs laid by virgin moths have been known to develop. Amongst saw-flies, certain generations of gall-wasps, plant-lice, and others, we have reproduction by virgin females. This law is known as parthenogenesis, or virgin reproduction without the intervention of a male, and a few special peculiarities will be considered under the respective families.

The morphological structure of the egg is somewhat complicated, more especially when we remember the philosophical writings of Weismann and others.

The term larva, caterpillar, maggot, or grub is generally applied to insects as they hatch out from the egg, and at this stage they generally differ in form and structure from the perfect insect. On the other hand, the term "nymph" is applied to the creature when it

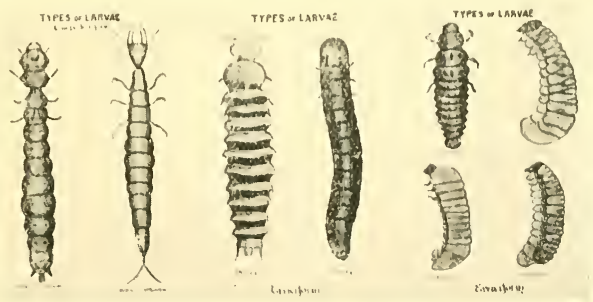

Fig. 3.-Typical forms of larve. (From drawings by Mr G. A. Dunlop.)

bears a very strong resemblance to the perfect insect, as, for example, in the case of mites and Hemipterous insects.

The larva of a moth, on hatching from the egg, is usually a segmented body possessing six true legs. The caterpillar of a saw-fly has six true legs, like the larva of a moth, but has also several additional "prolegs," and consequently is easily distinguished. The maggot of a fly is footless. Fig. 3 represents typical larvæ. 
In the case of the Aphidide or greenfly, scale-insects, and plant-bugs, the young in the first stage, whether hatched from eggs or produced alive by the parent insect, resemble the perfect insect very much more than those of beetles, moths, and flies. But whatever shape and form they may take, the young insect in the first stage is always scientifically known as a larve. The have in forest insects all forms and clisses of larvæ, and this variety is of great interest as a biological question. For instance, we find, as arboreal-feeding insects, active six-legged larvæ of a greenish colour, and harmonising with the foliage or lichens on the bark; while on the other hand we find the footless whitish grub feeding within the wood. Thus we have two important factors in the theory of evolution brought before us-viz., the absence and apparent absence of legs through disuse, and the harmony of colour to surroundings as a protection against natural enemies.

In the larval stage the insect feeds voraciously, and as a rule grows very fast. The skin of the creature, however, does not grow beyond certain limits, and when this stage is arrived at, the creature halts, as it were, throws off its skin, assumes a fresh coat, often of a different

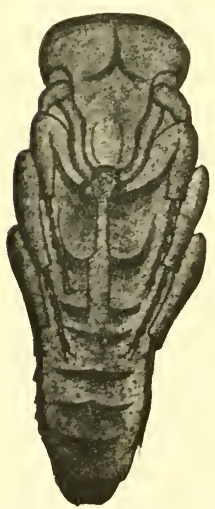

Fig. 4.-Typical pupal form of an insect. (From drawing by $\mathrm{Mr}$ G. A. Dunlop.) colour, and again commences feeding. This process is known as moultiny, and occurs several times during the larval stage until full growth is reached. The duration of larval life in arboreal insects is very varied indeed. In some cases the period occupies only a few days, in others several years.

The pupa, or third stage of the life of an insect, is a period of rest or quiescence, when the insect takes no food. It is the period of quiet transformation, when the ugly erawling caterpillar is being transformed into the beautiful moth, or the carrion maggot into the swift airy fly. The pupal forms and habits of forest insects are very varied. Thus in beetles all the parts of the future insect are visible, saw-flies and moths form cocoons, and the two-winged flies form cases. Some descend into the ground to pupate, while others form hard cases on the food-plant. Fig. 4 may be considered, for general purposes, as a typical pupa.

The stages thus referred to-viz., egg, larva, and pupa-are the 
periods of growth and development. As soon as bursting from the pupal case takes place, the creature is then literally the perfect insect, inasmuch as there is no further change or development. It is well to bear this in mind, as it is a popular notion amongst certain people not conversant with natural history that small moths and flies are simply "young ones." Such, however, is not the case, for while there is often a difference in size amongst individuals of the same species, it should be remembered that no growth takes place after full pupal emergence.

In demonstration of this, perhaps a typical case may be taken-viz., that of the Small Tortoiseshell Butterfly, Ianesza urtice. Fig. 5 represents the pupal case. In fig. 6 we have a representation of

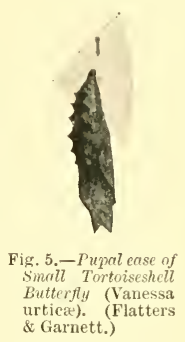
the first emergence from the pupal case; in fig. 7 , which is later,

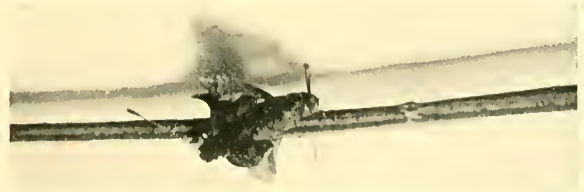

Fig. 6.-First emergenee of Tortoiseshell Butterfy from pupal ease. (Flatters \& Garnett.)

the wings are slightly more expanded; and in figs. 8 and 9 we see a representation of the fully developed butterfly. The whole process

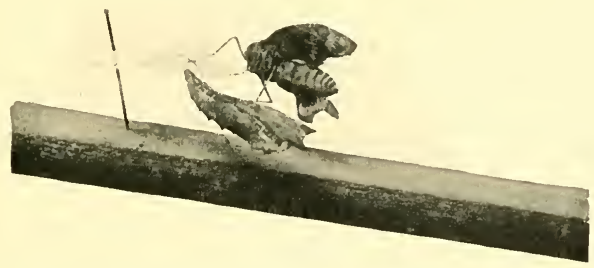

Fig. 7.-Emergenee of Tortoiseshell Butterfly more fully advanced. (Flatters \& Garnett.)

of development, which is chiefly a question of wing expansion, takes at most only a few hours. 
In many cases where we have incomplete metamorphosis, the insect is injurious in all its respective stages, as, for instance, in Aphidæe and Cicadæ. On the other hand, when the metamorphosis is complete, we find the insect injurious in larval and perfect stages, or

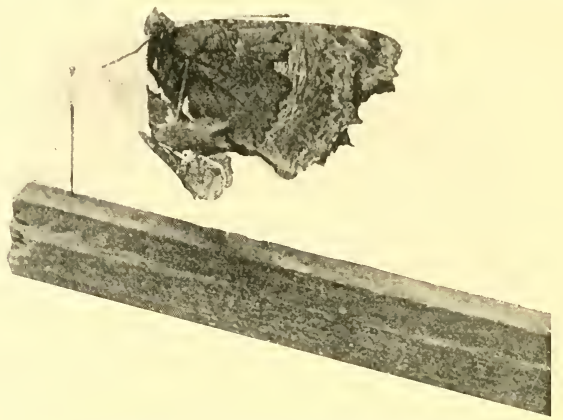

Fig. 8.-Fully developed Tortoiseshell Butterfly. (Flatters \& Garnett.)

simply injurious in the larval stage alone. The perfect insect (or "imago," as it is termed in entomology) often takes no food whatever, except sipping water or juices, and the duration of life is often so short as to have become proverbial.

As a branch of economic entomology, the student of forest insects should strive to ascertain where and when egg-deposition takes place,

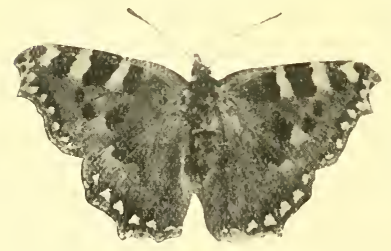

Fig. 9.-Fully developed Tortoiseshell Butterfly. (Flatters \& Garnett.) how long the insect remains in the egg stage, how long before the first moult and between the other larval moults, when and how long it remains in the pupal stage, and the time and appearance of the perfect insect - in short, a full life-history.

With regard to the structure of insects, it may be repeated, and must always be borne in mind, that an insect is a creature whose body is divided into three parts-head, thorax, and abdomen. As a biological subject, insect anatomy and physiology is a very broad and interesting 
one, inasmuch as serial section-cutting and the highest powers of the microscope must be employed. This, though highly interesting in itself, is certainly not of vital importance to the young student of forest entomology. It is, however, indispensable that the salient features of head, thorax, and abdomen should in all cases be well studied, and in some special instances be conmitted to memory. It is upon these points that generic and specific characters depend. The advanced student with a fair amount of leisure would do well to study the internal anatomy of insects.

The head is in reality composed of several segments fused together, but looks superficially as if made of a single piece. On the under side

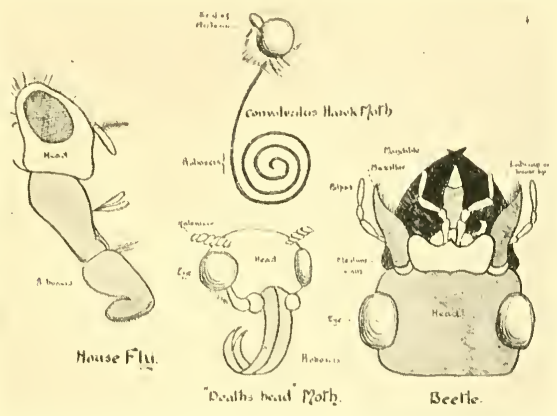

Fig. 10.-Typieal month parts of insects. (From drawings by Mr G. A. Dunlop.)

it bears the mouth, which is adapted either for biting or sucking. The mouth arrangement separates the whole of the class Insecta into two principal divisions-viz., Mandilulata, or biting insects ; and Haustellata, or sucking insects. The biting mouth of the beetle and the trunk-like proboscis of the moth are cases in point. Fig. 10 represents typical mouth parts of insects.

The eyes in many cases form a prominent part of the head, and are of two kinds-compound and simple. The latter are termed ocelli. In some insects-as, for example, in the house-fly and hive-bee-the compound eyes cover nearly the whole of the head. The orbit of the eye is covered by a transparent skin termed the cornea. An examination under the microscope shows that the surface of the cornea is 
made up of a large number of six-sided areas, each of which is termed a corneal facet (fig. 11). The ocelli or simple eyes are placed between the compound eyes, or just in the middle of the forehead.

The antenne, or horns, rise from the head. They are composed of several joints, and form good points for the discrimination of species. Any text-book of general entomology, or monograph of some particular group, will show that specific points very largely depend on the antenne. This, for instance, is the ease with the Aphididæ or plantlice. The joints of the antennæ have to be counted and compared. By a joint is meant not so much the division line between the pieces

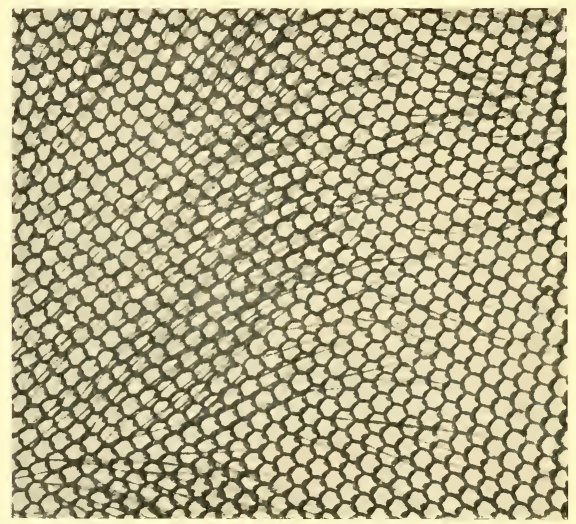

Fig. 11.-Compound eye of insect as seen under the microscope. (Flatters \& Garnett.)

as the actual portions themselves if separated at these lines. In counting joints we must begin from the head outwards, making sure the horn is properly and elearly separated from the head. As a rule, the antenna is stouter at the junction with the head, and gradually tapers towards the other extremity: thus we say in a general way, from base to apex. The antennæ receive various designations, according to the structure, as, for example, in fig. 12. The physiological functions of the antennæ are not fully understood, but they are supposed to be, to some extent, sense-organs.

The thorax or middle region bears the legs and wings. It is 
composed of three distinct segments-viz., prothorax, mesothorax, and metathorax, each of which may be built up of several pieces. These segments vary in proportion in different insects, and they also vary in the respective stages of the life of an individual insect. The thorax and its component parts are of considerable importance in the discrimination of species, as, for instance, in the Hymenoptera.

The third region is known as the abdomen, and is very variable in form, according to order and genus. It is generally composed of nine segments, and bears the organs of reproduction.
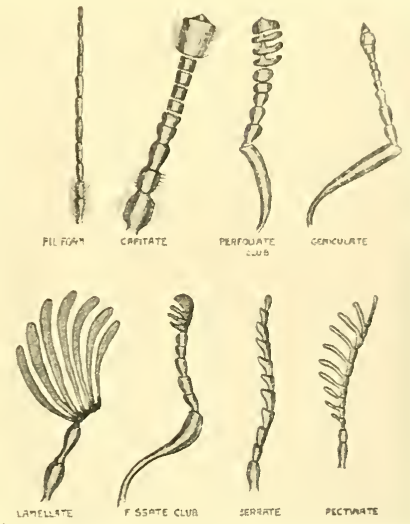

Fig. 12.-Typical forms of antenne. (From drawings by Mr G. A. Dunlop.)

The wings, as appendages, are very important points in the discrimination of genera and species. In fact, some writers use the wings as a basis of classification. So far as forest entomology is concerned, it is highly essential to make a detailed study of the structure of the wings of saw-tlies, gall-flies, Aphidirlæ, and IDiptera.

The structure of the leg is also of importance in the classification of species. If we separate a leg from the body of the insect and examine it, from the comnection with the body to the tip, we shall find it is composed of several parts. The leg is attached to the body by a

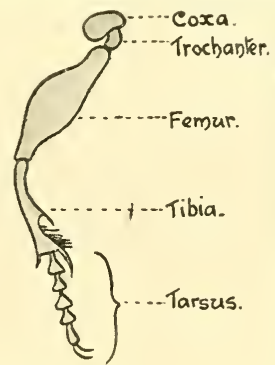

Fig. 13.-Typical form of leg. (From drawing by If G. A. Dunlop.) joint called the coxa; next to this is a very small portion known as the trochanter, which serves as a sort of joint or hinge connecting the 
femur; then we have a long joint called the titia; and finally, the joints (five or fewer) which make up the tarsus or foot. Fig. 13 is a representation of the different parts of the leg.

The foregoing characters represent the more important points as regards external structure, but it is somewhat more difficult to deal with internal structure and function. To deal with too many details would simply embarrass the ordinary student, and at the same time the subject cannot possibly be intelligible to the student if too few points are presented.

The accompanying diagram (fig. 14), representing a longitudinal

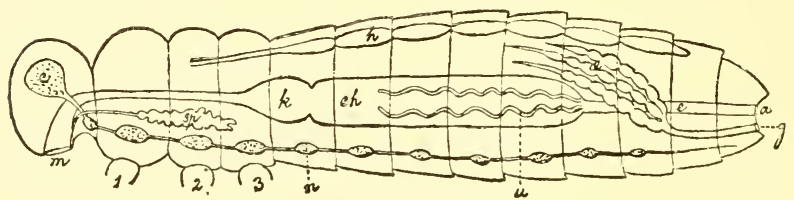

Fig. 14.-Diagram of longitudinal section of an insect, showing principal anatomical points of an insect. (From 'Text-Book of Zoology,' by Dr J. E. V. Boas.)

$1+3$, first and third pairs of legs cut away; $a$, anns; $c$, cerebral ganglion; $e h$, mesenteron; $e$, proctodieum ; $g$, genital apertnre; $h$, heart ; $k$, crop ; $m$, mouth ; $n$, ventral ganglion ; sp, salivary gland; $u$, malpighian tubule; $\alpha$, ovary.

section of an insect, shows the relative position of the more important anatomical points from a side view.

The nervous system of an insect resembles that of most other animals, inasmuch as the terminal seat of the nerve-centres is the brain, whence proceed other nerve-centres and nerves all over the

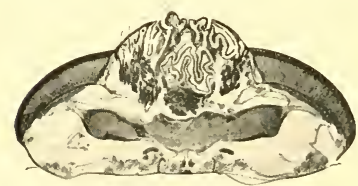

Fig. 15.-Horizontal section through the head of a blow*fy, showing eyes and brain. (Section and photo by $\mathbf{A}$. Flatters.)

body. The nerves receive impressions from the outside world, which react on the organism, and thus stimulate or restrain muscular action. Fig. 15 shows a photograph of a horizontal section through the head of a blow-fly.

The various convolutions of the brain should be noted; and as the development of these convolutions is indicative of intelligence, it is no wonder that certain insects, in this respect, are considered as approaching nearer to man than many other animals.

The respiratory organs of an insect are composed of a system of 
tubes, which are well represented in fig. 16. These tubes, or tracheæ, ramify throughout the whole of the body; and the air passes into them by means of special openings known as spiracles, which are situated alongside the body of the creature. These spiracles are somewhat eomplicated openings, inasmuch as they open to receive air, shut to maintain a supply, and again open for expulsion. The act of breathing, therefore, is somewhat after the nature of a bellows, inasmuch as air is received at a special opening and driven throughout the tubes. In adclition to the function of breathing, it is obvious that the inflating of the tubes is associated with the machinery of flight. Fig. 17 is a photographic representation of a trachea from a butterfly.

The organs concerned with feeding and digestion oceupy a considerable space in the bodycavity of many insects. From actual specimens this ean only be understood by careful dissection and microscopical manipulation. The accompanying figure, however (fig. 18), taken from Miall and Denny, will convey a very good idea of these internal organs.

In the centre of the figure the food-canal is represented.

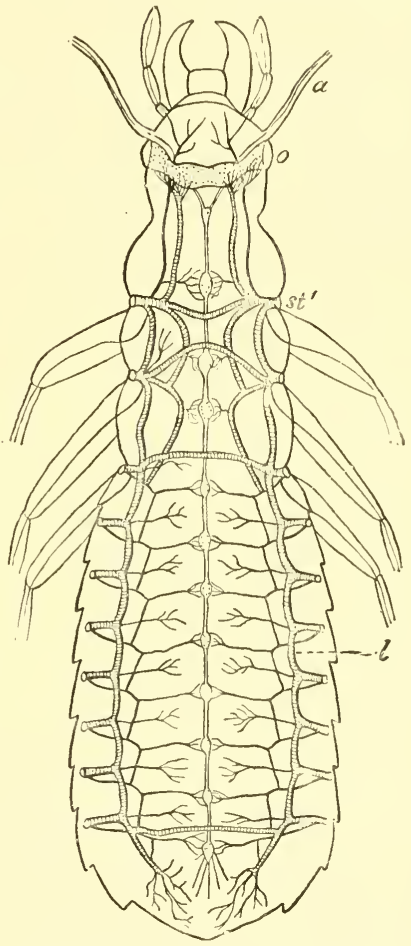

Fig. 16.-Diagram of the chief trunks of the tracheat. system of an insect; the centrul nervous system is also shown.

$a$, antennie ; 0 , eye ; st', anterior stigma ; $l$, longitudinal trunk. - After Kolbe. (From "Text. Book of Zoology,' by Dr J. E. V. Boas.) At $s$ we have the salivary glands and reservoir which contain the saliva, which is not only beneficial in digesting the food within the canal, but in some sucking insects is mixed with the crude 
sap of the plant before the juice is taken up by the proboscis. At $c$ we have the long crop, and below this we have the gizzard, which organism in some species is a favourite object for the microscope. Then we have a stellate arrangement of the cæcal tubes or blind tubes; and proceeding from this there is the stomach, which is simply a tube. At $k$ we have the kidney tubes, and then the small and large intestine, ending in the rectum and anus. In fig. 19

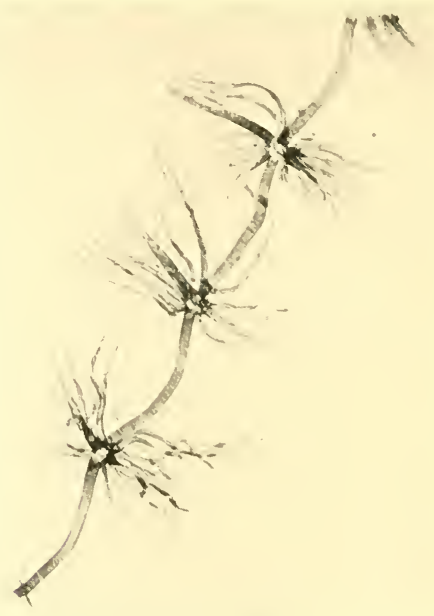

Fig 17.-Traehea of butterfly. (Flatters \& Garnett.)

we have a representation of the heart, which is a long muscular tube separated by valves.

Having now considered the various structural details of an insect, it may be well to turn briefly to the reproductive organs, the functions of which serve to perpetuate the race. Insect reproduction may be either sexual or asexual. In the former, the union of two dissimilar cells is required-viz., a small active (male) sperm cell (spermatozoon) with a large (passive) female cell (ovum) for the production of new individuals. In the latter class, female cells or 
eggs give rise to new individuals without the intervention of male (parthenogenesis).

The reproductive organs of insects may, according to instructions given in certain works on microseopy, be carefully dissected from the abdomen, but the accompanying figures, together with the explanation, convey a very good idea of the reproductive organs of insects. The accompanying figures and explanation have been selected because they are not only large insects, but arboreal in their habits. It may also be noted that, as regards inseets, the hive bee has been carefully worked out in this respect, so that reference to any of the more important works on the bee would be found very helpful.

Genital oryans. — "The female, as in other Arthropoda, possesses a pair of ovaries. Each consists of a varying number of tubules (ovarioles), which usually extend like fingers from the anterior end of the oviduct. Each ovariole is surrounded by a thin membrane, and is immature anteriorly, consisting of small homogeneous cells; farther back there are larger cells, young ova, lying

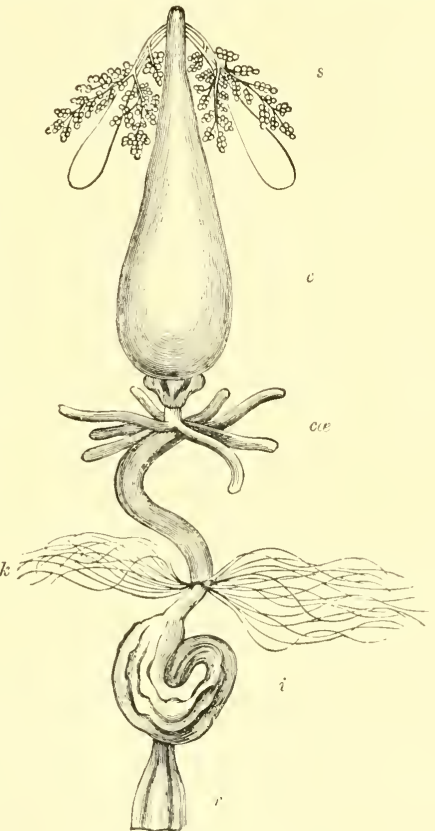

Fig. 18.-Food canal of cockroach.

$s$, salivary glands and reservoir; $c$, erop (the gizzard below it); car, carcal tubes (below them the stomach); $k$, kidney tubes; $i$, intestine; $r$, rectum. Twice natural size. (From 'The Cockroach, by Miall and Denny.) in the middle of the tube, and surrounded by smaller cells, which provide them with nutriment, and also secrete the shell (chorion) for the fully developed egg. The mature ova occupy the posterior ends of the ovarioles, and pass thence into the oviduct. When an 
egg passes into the latter, the corresponding portion of the ovarian tubule shrinks, and thus the egg next in front is brought nearer to the duct. The two oviducts unite to form an unpaired portion, the
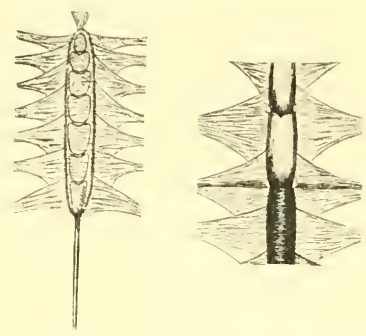

Fig. 19.-Diagrams of the heart of an insect. vagina, which opens ventral to the anus, either freely on the surface or into a cloaca, an invagination occurring at the hinder end of the body. There is usually an evagination of the vagina which serves as a receptaculum seminis, and one or a pair of accessory glands, which secrete either a sticky fluid to attach the ova to foreign bodies, or the mucus surrounding them (e.g., in insects which lay their eggs in water). Sometimes there is also an evagination of the vagina to form the bursa copulatrix, into which the

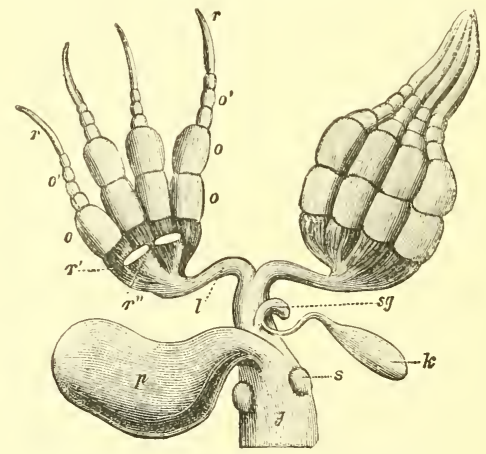

Fig. 20.-Female genital organs of the coekehafer.

On the right, the ovarioles are lying together in the natural position; on the left they are separated, and two are cut away. $g$, vagina; $k$, glands which open into the receptacula; $l$, oviduct; 0 , segments of the ovarioles, containing almost ripe ova; $o^{\prime}$, regions of the same, containing immature ova; $p$, bursa copulatrix, $r$, anterior; $r^{\prime}, r^{\prime \prime}$, posterior buds of the ovarian tubules; $s$, glands; $s g$, receptacula ovorum. (After Boas.)

penis of the male is inserted in copulation. Not infrequently there is at the female aperture an ovipositor (Locusts), consisting of complicated knife-like or dagger-shaped laminæ, or a sting 
(Hymenoptera); or the last abdominal segments, which then are thin and elongate, and may be telescoped, serve in this capacity (Diptera and others). The chorion is often very hard, frequently covered with a delicate and regular sculpturing, and always provided with one or more openings, the micropyles, through whieh the spermatozoa may enter. The outer form of the eggs varies: it may be spherical, oval, discoid, rough, stalked, \&e.

"The male genitalia are for the most part a repetition of those of the female. There is a pair of testes, each consisting of several long seminal tubes or shorter seminal pouches, situated at the end of the

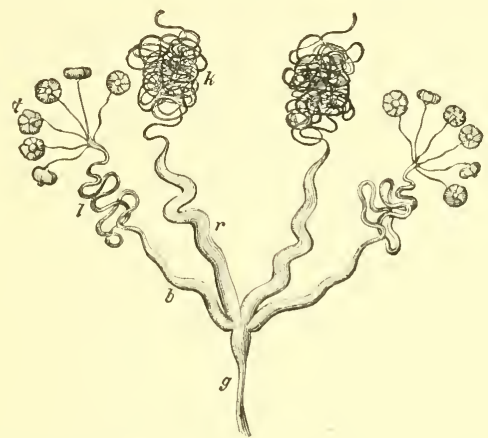

Fig. 21.-Male gen ital organs of the coekchufer (penis not drown).

$b$, vesicula seminalis; $g$, vas deferens; $k$, glandular appendages; $r$, widened region of the duct of the same; $t$, testis, consisting of six seminal pouches. (After Boas.)

vas deferens. The two vasa deferentia unite to form a single duct, which opens in a similar position to the vagina of the female. Each of the vasa deferentia widens posteriorly to form a vesicula seminalis. Special glandular appendages frequently open into these ducts, or into their common portion. There is a more or less complicated copulatory organ, an evagination of the body wall, through which the terminal portion of the seminal duct is continued, and capable of partial or complete retraction when not in use. In many it may possess hard chitinous portions, and lies hidden within the cloaca, from which it may be protruled during copulation.." 1

1 Text-book of Zoology by Dr J. E. V. Boas, pp. 242, 243. 


\section{References to Literature consulted.}

Boas, Dr J. E. V. Text-book of Zoology. Euglish transl. 1896.

Cambridge Natural History, The. 1899.

Carpenter, Geo. H. Insects, their Structure and Life. 1899.

Fisher, W. R. Forest Protection: Schlich's Manual of Forestry. 1907.

Kaltenbach, J. H. Die Pflanzenfeinde aus der Klasse der Insekten. 1874.

Köllar, V. A. Treatise on Insects Injurious to Gardeners, Foresters, and Farmers. 1840.

Nisbet, John. The Forester. 1905.

Packard, A. S. Insects Injurious to Forest Trees. U.S.A., 1890.

Taschenberg, Dr E. L. Einfuihrung in die Insektenkunde. 1899. $\therefore$ Theobald, Fred. V. Insect Life. 1896. 


\section{CHAPTER I.}

\section{ERIOPHYID E (PHYTOPTIDE) OR GALL-MITES.}

The Eriophyidæ, or gall-mites, are so small in size (being only visible when viewed under a very strong pocket lens or microscope) that we can only recognise them in the forest through the medium of their injuries. In other words, being practically invisible, the young student in forest entomology cannot associate the creature with its injuries, as in the case of most insects; and further, as the injuries caused by those creatures are in appearance so closely allied to the damage done by many species of parasitic fungi, the beginner may either overlook or misunderstand them. Perhaps, therefore, the best method of commencing the study of this group of arboreal mites is through the medium of a common horticultural species-viz, the currant-bud mite. In fact, it may be truly said that the study of gall-mites in this country has received special attention on account of the species on black currant having become a common garden pest in many parts of the country. The general appearance of this pest is only too easily recognised by the swollen buds, known in some localities by the graphic term "blind bud." The creature causing this wiclespread trouble has long been known by the name of Plyytoptus rilis (Westw.)

The common garden pest referred to has its equivalent in the forest, producing "blind buds" and other abnormal growths on several kinds of trees. The latter may be various forms of galls on the leaves, rollings of leaves, or deformation of flower and fruit, \&c.

The abnormal growths arising from the action of gall-mites were at one time considered by botanists as a species of micro-fungi, and termed "Erineum." Frank gives a very interesting account of those abnormal hairs on the leaves, ${ }^{1}$ which are either caused by the gall-

${ }^{1}$ Die Krankheiten der Pflanzen, Bd. iii. 1896. 
mites or otherwise associated with them. He says they were divided (where considered as micro-fungi) into three orders-viz., Taphrina, Fr., Erineum, Pers., and Phyllereum, Fr. The illustrations as given by Frank are suggestive of this being rather an interesting microscopical study, inasmuch as we see the contrast of normal with abnormal hairs through the action of mite agency. In some cases the apparent cluster of hairs may, on examination, prove a genuine micro-fungus, so that, by careful microseopical observation, the student can be acquiring knowledge in a kindred subject.

With regard to the "blind bud" on black currant, it may be noted, as showing the history of the study, that the first authentic public announcement of the existence of the disease was made at a meeting of the scientific committee of the Royal Horticultural Society held on Narch 2, 1869 :-

"Specimens of a disease in shoots of black currant from the Rev. A. Fitch were then produced, Mr Berkeley remarking that the outer bracts were hypertrophied, and in eonsequence the delicate divisions of the inner part of the bud were badly nourished, and death ultimately ensued. The chairman pointed out its probable analogy with the galls in hazel produced by a Cecidomyia, which was confirmed by Prof. Westwood, who stated that the disease in black-currant shoots was produced by an extremely minute four-legged Acarus."- ' R. H. S. Journal,' New Series, vol. ii., pt. 3, $1870 .^{1}$

With regard to the Eriophyide generally, it may be stated that Mr Andrew Murray was the first to collate the information concerning these mites in a general way, and he gives a very interesting account of them in his 'Economic Entomology.'

Within the last few years elaborate researches have been made by Dr Alfred Nalepa of Vienna, and to his writings all interested in the subject must refer. About forty-five species, arboreal and others, have been found in Britain. He has established various genera, families, and sub-families; but unfortumately he has seen fit to change the generic name Phytoptus to Eriophyes, and this term has been adopted by all writers on economic entomology.

The difference between a healthy and a diseased bud is very

1 "The Currant-bud Mite or Currant Gall-Mite," by R. Newstead, in Journal of Royal Horticultural Society, vol. xxv., pt. 3. 1901.

${ }^{2}$ Economic Entomology-Aptera : South Kensington Museum Science Handbooks. 
easily recognised. In the former the buds are comparatively small and pointed, whereas the latter are swollen and rounded. A longitudinal section made in winter or spring through the centre of both classes of buds will show a difference of structure. In the case of the healthy buds-as, for example, in the currant-bud mite-the embryo leaves can be seen, and they are always close at the apex, while in the diseased bucts the structural foldings of the leaf are broken up, and the apex always open. The same description holds good in forest trees infested by Eriophyida.

The life-history and microscopical characteristics of the genus Eriophyes form a most interesting study. It belongs to the sub-family Eriophyiclæ (Phytoptidæ),-gall-mites of the order Acarina.

The mite is of a light yellowish colour, and varies very much in size according to species. Perhaps the size of the creature may be approximately put down as the $\frac{1}{200}$ to $\frac{1}{1000}$ of an inch in length, and it is obviously indistinguishable by the naked eye. Fig. 22 may be regarded as a typical mite.

The body is of a vermiform shape, and, like mites in general, is of one piece, and with few appendages. Hence a creature of such simple structure affords but few points for specific differ-

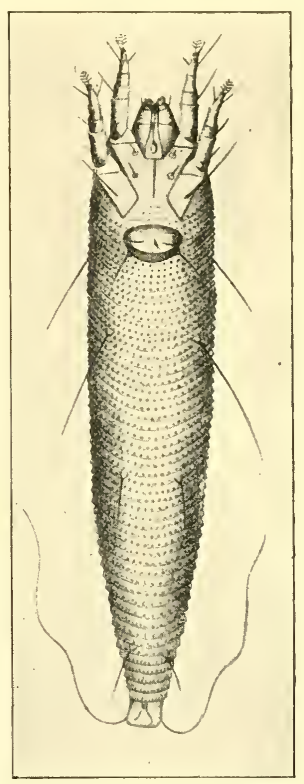

Fig. 22.- Phytoptus calyeophthirns, Nal. (Eriopliyes rudis, Canest.) (Photouraphed from Nalepa's 'Genera und species der Familie Phytoptida.' Wien, 1891.) ences; nevertheless, Nalepa gives a full description of a typical mite, together with a detailed description of the respective species. $^{1}$

The form of the body is an elongated ellipse, narrowing towards the posterior end; and the cephalo-thorax is about the same breadth as

1 Das Tierreich, 4 Lieferung (Eriophyidx). 1898. 
the abdomen. The head terminates in a snout-like projection, and the maxillary palpi are used as antennæ.

The group is known as the "four-footed" mites, and when viewed from the under side the four legs can be seen distinctly. The articulations of the legs, although well marked, are rather difficult to determine. The tarsus, or foot, is provided with a double claw : one half is terminated by a few fine bristles, called by the Germans "Fiederborste," or feather bristles, and the other half is a simple claw.

The abdomen is divided into a series of from 60 to 90 ring-like segments, according to species, and there are several hairs on the abdomen. These are variable in size, but should, as far as practicable, be noticed under the microscope, whether the dorsal, ventral, or side aspect of the creature is being presented for examination. The rings, hairs, and the regular or irregular markings afford good points for classification. At the extremity of the body are two very long hairs, and rather important claspers, which the creature uses as a means of anchorage. Doubtless, also, the hairs assist the mite in the act of locomotion.

The eggs are round or elliptical. There are two rather indistinct stages, larva and nymph. The species in the buds of black currant and hazel lend themselves for periodical examination, and the mites can be seen in their various metamorphic stages.

As regards the physiological functions of the mites, the following notes from Mr Connold ${ }^{1}$ may be quoted - viz. :

"The mites have no special respiratory or circulatory organs. The exchange of gases takes place throngh the body; nor is there any organ like a heart. The fluid, therefore, which is analogous to blood, moves freely and irregnlarly throughout the body. The nerves are in four pairs. The esophagus passes through the brain ganglia.

"They are devoid of stomach, digestion taking place in the larger intestine. Salivary glands are wanting, and also Malphigian tubules.

"The skin is an exceedingly thin, colourless layer of chitin. Beneath it lies a network of branched cells, which contain slight colouring pigments."

From a botanical point of view, or as regards the injuries done to the host-plant, the mites may be divided into three great classesviz., those feeding within the buds, and consequently causing "blind

${ }^{1}$ British Vegetable Galls, by Edward T. Connold, 1901, pp. 32, 33. 
buds"; those living in various forms of galls; and those causing malformations of flowers, fruit, or leaves. The last division presents a very considerable variety, inasmuch as the leaves may be folded or puckered, and the leaf-veins enlarged in various ways.

As regards classification, Nalepa divides the family into two subfamilies-viz., Eriophyinæ and Phyllocoptine.

I. Number of the back and belly half-rings almost equal; abdomen therefore similarly ringed; ventral side always, dorsal side as a rule punctured . . . . Eriophyinæ.

II. Abdomen not similarly ringed; dorsal half-rings distinetly broader than the belly half-rings . . Phyllocoptinæ.

\section{SUB-FAMILY ERIOPHYIN}

\section{Synopsis of the Genera.}

Ablomen without dorsal median furrow - 1, Genus Eriopirses. Abdomen with dorsal median furrow 。2, Gemus Monocmetus.

\section{Species living in Buds.}

These may very easily be seen under the microscope, eating the vital parts of the bud. The infested bud, therefore, is transformed into an abnormally large swollen "blind-bud," which, instead of bursting into flower or leaf, becomes the dwelling-place and feelingground of many mites. Here we may again quote from the literature on the "Currant-bud Mite."

With regard to the actual number of mites tenanting a single bud, Newstead says of Phytoptus (Eriophyes) ribis:-

"The number of mites tenanting a single bud would vary according to the time of year. By desire of Mr spencer-Pickering I last year (January 9, 1900) selected a medium-sized bud-gall, and in it counted 2748 individuals; allowing for many individuals destroyed in dissecting the bud, I should put the number in round figures at 3000 . Larger buds would contain considerably more, and in Mareh it would be safe to add half as many more." 1

1 "The Currant-bud Mite or Currant Gall-Uite," in Journal of Royal Horticultural Society. 1901. 


\section{Eriophyes avellane (Nal.)}

The nut-tree mite is found in filbert and cob-nut plantations. The swollen and deformed buds can easily be recognised before the development of the leaves; and they are also afterwards conspicuous, as shown in the accompanying illustration (fig. 23).

The species living in buds of hazel lend themselves more or less to periodical examination throughout the whole of the year. Having examined them in February from young hazel plants, I found the

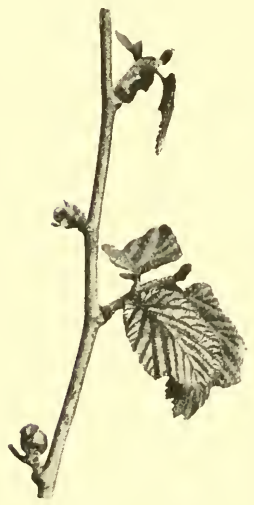

Fig. 23. - Abortive swollen buds caused by Eriophyes avellanæ on hazel. enlarged buds, more especially the infested terminal bud, conspicnous as globular balls about ${ }_{4}^{1}$ inch in diameter. Numerous mites were found in all portions of the bud, from the onter scales to the centre. They were discovered in all stages-viz., eggs, larvæ, nymphs, and perfect mites. This species of mite is larger than the species found on the black currant. The eggs are whitish, smooth, and oval. The nymph is approximately about one-half or one-third the size of the perfect mite, and the four legs are stretched out in the direction of the mouth.

An examination of the swollen buds during May, when the leaves were half developed, showed the infested buds to be tenanted in all parts, and a few mites crawling along the leaf-stalks. They were in all stages - viz., full-grown mites, nymphs, and eggs.

In July another examination was made, and it was found that the mites were chiefly in the interior portion of the swollen buds. There were a few on the leaf-stalk and on the portion of the stem adjacent to the infested buds. At this time the swollen buds were quite half an inch in diameter, and the young buds for the forthcoming season were just formed. 
Eriopiryes rudis, Canest., on the leaf-buds of Betula alba.

Synonymy of mite (Connold) :-

Phytoptus rudis, Canestrini.

Phytoptus calycophthirus, Nalepa.

In fig. 24 four swollen buds on birch are represented. They were found in High Legh, Cheshire, and cut from the same branch, and in close proximity to a "witches'-broom " - that peculiar bird-nest-like appearance seen on birch and hornbeam, of the growth and development of which Miss Ormerod gives a very interesting account, from personal observations made during 1876 and 1877 , while resident in the neighbourhood of Isleworth. ${ }^{1}$ There is no doubt, from the deseription and illustration given by her, and more especially from the appearance of the actual branch itself, seen in the South Kensington Museum, that the abnormal branch growths were heavily covered with swollen buds infested by Eriophyinæ.

I had, in consequence of Miss Ormerod's description, for a long time examined many "witches'-brooms," without finding a single "blind bud." The accompanying figure shows the

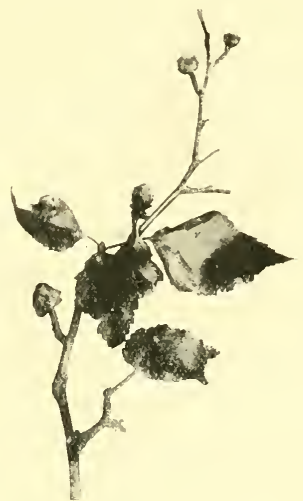

Fig. 24.-Abortive swollen buds caused by Eriophyes rudis on bireh.

first infested buds I discovered in any way closely associated with a "bird's nest." The orthodox opinion as to the cause of "witches'broom " or "bird's nest" is that it results from a fungus inhabiting the tissues, known as Exoascus.

With reference to "witches'-broom" being the result of fungal growth, Tubeuf, speaking of experimental infection, says :-

"In the case of the Exoascer, two points were cleared by the aid of artificial infection, - the penetration of spores into leaves of hostplants, and the production of witches'-brooms. Sadebeck, by means of infectious Exoascus epiphyllus on Alnus incana, has produced

1 Manual of Injurious Insects. Second edition. 
witches'-brooms artificially, thus proving that these malformations really originated from the mycelium of Exoascus." 1

As the cause of the "witches'-broom" is ascribed both to mites and fungi, it is suggestive of the advantages and pleasures of original microscopical investigation. Still, these abnormal growths might have accrued from excessive development of adventitious buds, caused by the constant irritation of the Eriophyinæ without the presence of Exoascus.

I have found this species in several parts of Northumberland.

\section{ERIOphyes psilaspis (Nal.) \\ Phytoptus taxi (Murray).}

This species (fig. 25) was first discovered by Professor Sir Thiselton Dyer in the spring of 1875 doing immense damage to young hedges,

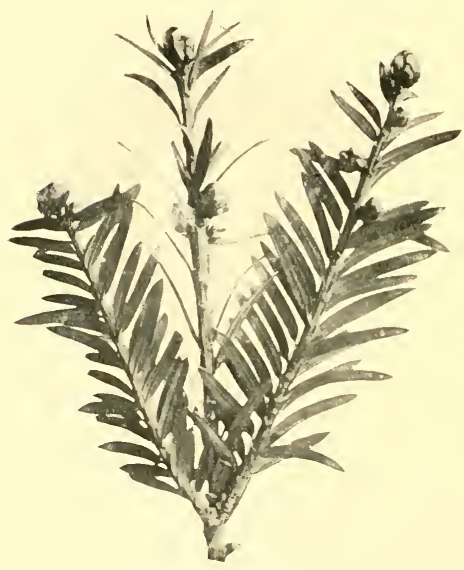

Fig. 25.-Abortive suollen buds caused by Eriophyes psilaspis on English yew. which damage had hitherto been ascribed to frost. I found it plentiful on the under side of the lower branches of a yew-tree at High Legh, Cheshire, from which the photographic illustration was taken. I have often found it very injurious to young yew-trees in the nursery - lines, and also occasionally on yew hedges.

As this species is certainly injurious, it is well to have recourse to some remedial measures. In the case of hedges, where regular trimming is resorted to, it would be well to burn all prunings; and as regards the young yew-trees in uursery-lines, it would be best to hand-pick or cut off the infested buds, say about the latter end of May, and burn them.

1 Tubeuf, Diseases of Plants induced by Cryptogamic Parasites. English edition, by W. G. Smith. 1897. 


\section{Species living in Galls.}

There are numerous species living in galls on the leaves of various trees, but the following are a few typical examples. They are not true galls, however, but simply pseudo-galls; and it is important to compare the structure of the psendo-galls of Eriophyinæ with the true galls of gall-forming insects. The former is simply an abnormal thickening of the leaf, with an opening or passage leading into the pseudogall. The opening is surrounded by hairs, which doubtless act as a protection against the inroads of parasitic acari and other natural enemies. The true gall, on the other hand, is always closed, and the form variable and immaterial. Some species of leaf-miners (Lepidoptera) form conical galls or cases on the upper side of the leaf, but the passage communicates between the epidermal skins, and has no opening through the under side of the leaf, as in the gall of Eriophyinæ.

\section{Eriophyes tilia (typicus) (Nal.)}

In fig. 26 we have represented what are popularly known as "nailgalls" on the leaves of the lime-tree-Tilia europuea. This is a very interesting species, inasmuch as nail-galls were first considered by Réaumur, the celebrated French entomologist, to be a special vegetable formation accruing from the action of animal life; but in the absence of any description it is doubtful whether he saw the real tenant, or simply a parasitic lodger.

Mr Andrew Nurray remarks: "Whether Réaumur saw them or not, at least no one else did for about 100 years after. About 1832 and 1834, however, the publication of M. Duges' valuable papers on the



Fig. 26. - "Nail-galls" on leaf of lime-tree (Tilia europiaa) caused by Eriopliyes tilia. elassification of the Acaridæ, to which we have already had so often to refer, gave an impulse to their study, which led to fresh discoveries; and M. Turpin observed in the nail-galls of the lime leaf a quantity of very minute, semi-transparent, fleshy mites, of a new and hitherto unknown form, - a narrow ereature with two pairs of small legs at its head, and some kind of sucker apparatus at its tail, on 
which it rests and raises itself, swaying about its body. He regarded it as a species of Sareoptes." 1

Here is an account of the first true conception of the family Eriophyidæ, and the species under consideration is in consequence a most important one.

\section{Eriophyes macrochelus (Nal.)}

To all lovers of natural history, no walk is more charming than a South Country lane, with its tall rough hedges and rich flora. The hedges are generally well stocked with the field maple (Acer cam-

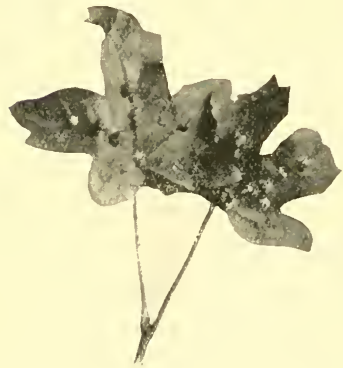

Fig. 27.-Gialls on lenves of field maple (Acer campestre) caused by kriophyes macrochelns.

pestie). The upper surface of the leaves of the field maple are often covered with small galls, and a careful examination will show that there are two sorts, - a larger and a smaller variety. The larger which are, as a rule, rather sparsely distributed on the leaves, and generally on the midrib and veins-are the galls of $E$. macrochelus. These galls are very variable in many ways, both as regards colour and structure. They may be solitary or gregarious, single or coalesced, glabrous or pubescent, and either on the veins or spread over the leaf. They appear quite early in summer, but may be considered fully developed in August. Fig. 27.

\section{ERIOPHYES MaCrorhyNChUS (Nal.) Phytoptus myriadeum (Murray).}

This is the other species of gall on the field maple, and may easily be recognised from the former species by being smaller in size, and much more crowded on the leaves. It is very abundant in southern England, but not at all common in the north or in Scotland. Fig. 28.

\footnotetext{
${ }^{1}$ Economic Entomology-Aptera: South Kensington Museum Science Handbooks.
} 


\section{Eriophyes Levis ( $\mathrm{Nal}$.)}

This species is found on the leaves of the common alder (Alnus glutinosa). The galls are found on the upper surface of the leaves, and are gregarious, often so abundant as to cover almost the entire surface of the leaf, generally glabrous, and very variable in colour. Fig. 29.

\section{Eriopityes axillaris (Con.)}

This species is also found on the leaves of the common alder, but they differ from the previous species, inasmuch as they are always found on the midrib, or in

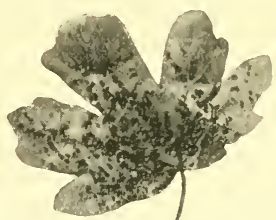

Fig. 28. - Galls on leaf of field mople (Acer campestre) caused by Eriopliyes macrorliynchus. the axils of the primary veins from the midrib. The galls are larger than the previous speeies, smooth, and varying in colour from

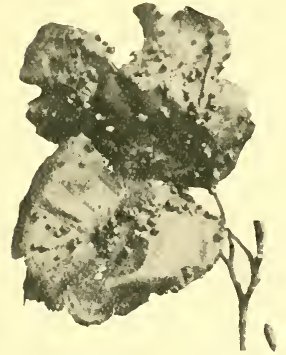

Fig. 29.-Galls on leaves of common alder (Alnus glutinosa) eaused by Eriophyes lavis.

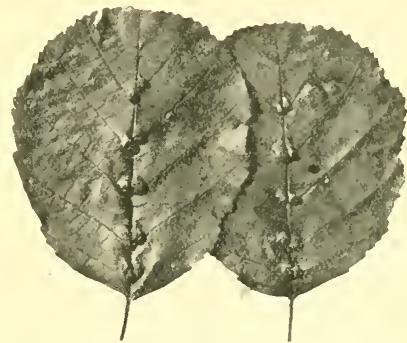

Fig. 30,-falls on midrib of the leares of common alder (Alnus glutinosa) caused by Eriophyes axillaris.

light-green to dark-brown, and always found in pairs. In section they are hollow, and lined with hairs. Fig. 30.

\section{Eriophyes tetanothrix (levis) (Nal.)}

This gall is found on the leaves of Salix caprea. This species of willow is very common, and, as every botanist knows, very variable as regards the size and shape of the leaf. The galls of this species are generally found on the small-leaved variety, and on the upper 
surface of the leaf. A section of the gall, which is comparatively easily made, shows that the walls are very thick.

There are many other species forming galls on leaves of our forest

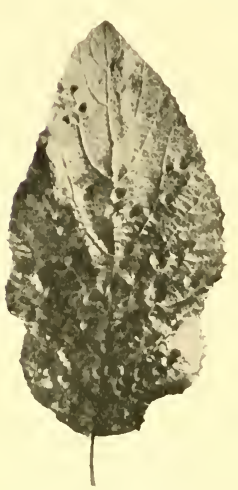

Fig. 31.-Cicells un leut of Hityfering tree (Viburnum lantima) corrserl by Eriophyes tetanothrix. trees and shruls in many parts of the comtry, as, for example, on the leaves of the "Wayfaring tree" (Viburnum lantana), fig. 31, which was photographed from a leaf taken in a surrey lane.

\section{Species causing Malformation of Flowers, Fruit, or Leaves. ${ }^{1}$}

\section{Enopheses praxixi (Karp).}

This speeies attacks the flowers of the common ash (Frarinus excelsior), and gives rise to what may popularly be called deformed fruit, as the injuries are most commonly oliserved when the fruit is ripe. It is, however, more correctly a malformation of the flower, as the mites attack the flower, and by means of a symbiotic action give rise to the forms as seen in fig. 32 . It is very local in some parts of the country, and sometimes peenliarly so to one tree in a whole district. It is very common in some parts of Northumberland and Berwickshire.

\section{Eriopityes tiliaries (Con.)}

This species attacks the flower-bracts of the eommon lime (Tilice enrmpera). llaving only found this species once, which was in Northumberlaud, I give the following note from Connolel, ${ }^{2}$ who has figured the speeies:-

"These galls begin to form on the margin of the bract as small elevations. The feeding of the mites causes the elge of the hract to rise upwarls and eurl over towards the millib, produeing a roll which sometimes extents 30 to $40 \mathrm{~mm}$. in length, and continues to roll

1 For a full and interesting account of "Gall-Mites" under similar classification to the above, see 'Die Kranklieiten der Pflanzen,' Frank, vol. iii., 1896.

2 British Vegetable fialls, p. 170. 
over upon itself until the midlle of the bract is reached. When thus affected, the bract may curve into a erescent shape, the roll itself

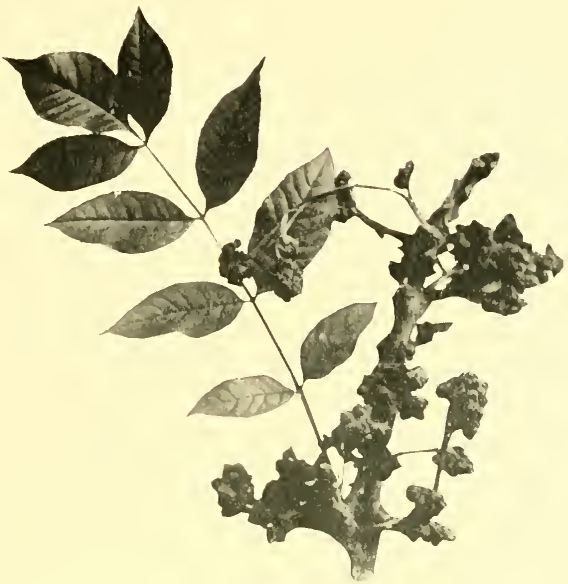

Fig. 32.-Malformation of the flower of ash (Fraxinus excelsior) cansed by Eriophyes fraxini.

forming the imner margin of the concavity, or it may be otherwise considerably distorted. No harm is done to the flowers, nor does the bract fall until the usual time, hence the mites are not destruetive to the fruit."

\section{Eriophiyes goniothorax (Nal.)}

This species is very common on the leaves of the common hawthorn (Crategus Orryct cantha). On healthy trees and hedges we may only find an isolated affected leaf, but sometimes on an isolated bush in a wood we may find almost every leaf affected. The damage itself is easily recognised, as the outer edges of the leaf are rolled inwards,-

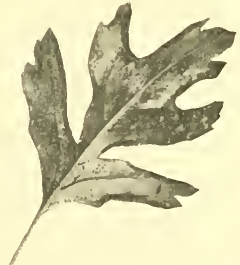

Fig. 33.-Filges of hawthorn loaf rolleal inwards by Eriophyes goniothorax. the roll itself being very slender, and of cord-like appearance. If fresh leaves are gathered, and kept in a box or on a table until they 
become slightly flabby, they can then be very easily opened; and if examined under the microscope, the mites can be seen in great numbers. Fig. 33 is a representation of a single hawthorn leaf rolled by this species.

\section{Eriophyes aucupalia (Con.)}

This species may be taken as a typical example of surface-injuries to leaves by gall-mites. The leaves are injured on both sides, but

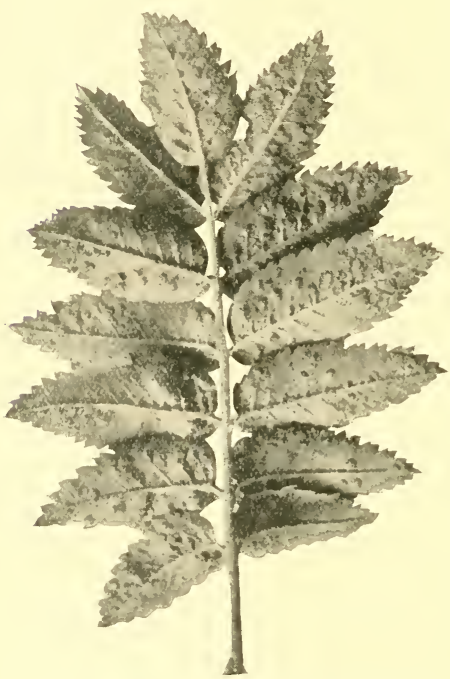

Fig. 34.-Surface of leaflets of mountain-ash (Pyrus aucuparia) injurcd by Eriophyes aueuparia. the form of the leaf is not injured. Examples of this injury are very common in Northumberland, but so far I have not been fortunate enough to see the mite under the microscope. Fig. 34 .

Several other arboreal species may be found; or, in other words, many instances of malformation on leaves, flowers, and fruit may be recognised, which on mieroseopical examination will show Eriophyinæ. Those mites, however, may not alway's be the direct cause of the injuries referred to, inasmuch as the primary cause may be due to minute parasitic fungi, and the mites simply finding congenial association in the diseased spots. Hence the enthusiastic student will find this dual nature of parasitic disease a stimulus to eneourage original investigation.

Several other species may be found rolling the leaves of our forest trees and shrubs, as, for example, the speeies forming rollings or small galls on the edges of the leaves of blackthorn (Prumus spinosa), fig. 35 . 


\section{Genus Monochets.}

\section{II. sulcates (Nal.)}

This genus contains a single species on beech, which is figured by Connoll. " "These most interesting galls do not appear to be common : they are very local where they oceur. The atfected leaves are situated on the new wood of the year. They are attacked while expanding, and insteal of opening out into a flat blade, the primary offshoots from the midrib are caused to remain as nearly parallel as possible with it, and the areas which they enclose are pushed upwards, giving both sides of the leaf a deeply striated appearance. They continue to grow in length, and ultimately bend inwards, assuming a cymbiform

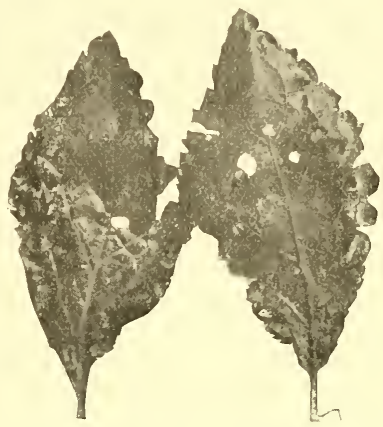

Fig. 35.-Eages of leaves of blaclithun (Prunus spinosil) rolled inwerds by species of Eriuphyes. shape. The edges of some meet and produce a pod-like growth. Owing to their excessive pilosity, they are like velvet to the touch."

\section{Sub-Faully PHYLLOCOPTIN}

In connection with this sub-family, it may be mentioned that Nalepa gives several instances of Continental mites belonging to the respective genera of the sub-family, and associated with many of our forest trees. It is therefore possible that we have here, so far as systematic forest entomology is concerned, a practically unworked field. Fig. 36, $a$, represents the dorsal surface, and $b$ the side view of Phyllocoptes carpini Nal. ${ }^{2}$ The figures are specially given as showing the variety of structure in these minute creatures, and the suggestiveness of this field for original microseopical research.

The most familiar instance, however, is the species attacking the

${ }^{1}$ British Vegetable Galls, p. 176.

22 From 'Beitrüge zur Systematik der Phytopten,' von Dr Alfred Nalepa. 1889. 
upper surface of the leaves of the common sycamore (fig. 37). It is now known by the name of Phyllocoptes arericola, Nal., and Connold gives the following synonymy-viz. :

\section{Phyllocoptes acericola, Nal. \\ Volvulifex: areris, Amer. \\ Ceratoneon vulyare, Bremi. \\ Phytoptus aceris, Murray.}

The galls are very common on the upper surface of the leaves of sycamore (Acer preurto-platamus). In some instances they are very

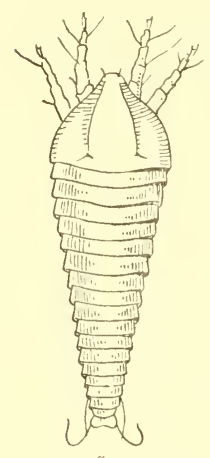

$a$ thiniy scattered over the leaf, in other cases quite gregarions. They are very beantiful in colour, varying from orange-yellow to purple. They appear soon after the leaves develop, and may be found throughout the whole summer season.

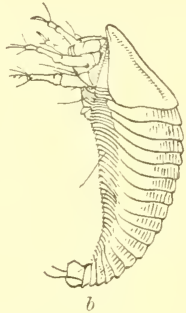

Fig. 36.-Pliyllocoptes carpini.

a, dorsal surface; $b$, sirle view. (Cofied from Nalepa.)
Such are a few typical specimens of arboreal Eriophyidæ living in buds or forming galls; and, as just stated, there may be many found on trees, but with the exception of two species-viz., those on hazel and yew - they are not very destructive, and certainly not to be compared with the species on black currant.

From the foregoing remarks it will be seen that the stuly of Eriophyilie is purely a microscopical one. The bases of classification are so minute, and the points of discrimination so difficult to determine, that the question naturally and suggestively arises whether we have the same or different species of mite doing several kinds of injury. As bearing on the specific differences of mites found on different food-plants, I may say, from practical and local examinations, that I have only once found Eriophlyes ritis on black currant in Northumberland, near Newcastle-on-Tyne, whereas the species on hazel is about as common as in Cheshire, where E. ritis is a direful pest. Hence it would conclusively appear that the mites on the 
respective food-plants are listinct species, and therefore very fasticlious as to fool.

$\mathrm{Mr}$ Newstead, Curator of the Grosvenor Musem, Chester, carried out a number of observations with regard to the species on black currant, and found that there was a succession of hroods from February to September. He also discovered that when the buds shrivel up and become unahle to support the mites, they migrate to the leaves and leaf-stalks, and enter the newly formed buds towards the end of July, where they remain until the following spring.

From preliminary observations I find that there is a slight difference between the habits of the species on hazel, comprared with that on black currant, inasmuch as the "blind buds" of the former do not shrivel up so quickly as the latter. Consequently the swollen buds of hazel are teeming with life about the latter end of July, while comparatively few are on the leaves and leaf-stalks. The buds for the coming year were then formed, and the mites would be able to move from one "house" to the other without camping out during nature's building operations.

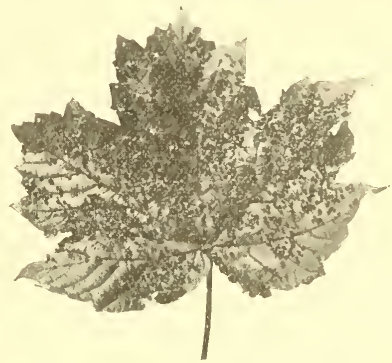

Fig. 3i.-Galls on leaf of sycomore (Acer pseudo. platanus) caused by Phyllocoptes acericola.

The life-history of those species living in galls is not so easily followed. For instance, I have examined the buds and twigs of a lime-tree, from the same branches which year after year produce galls on the leaves, without finding a single mite. Then, again, certain willow leaves are infested amnually by a micro-fungus of the rust order, on the under sicle of the leaves, which invariably harbour those mites, and yet neither "leaf-galls" nor "blind buls" could be found on the tree whither the mites would be supposed to migrate from the fungus excrescence, whose existence as a rust only lasts for a month or two.

On the under side of the leaves of some lime-trees a white growth is often found, which is known as a vegetable hypertrophy. This also harbours mites, and yet no nail-galls may be seen on the leares of 
the same tree. Hence it may be concluded that the life-history of some "locally" resident species is more or less involved in obscurity. Consequently the following remarks are appended from an authority on economic entomology. Mr French says :-

"With regard to the life-history of these singular little animals, Mr Crawford gives it as his opinion that there are two ways in which the mite survives the winter, when all leaves are shed: first, by hibernating among the hairs of, and in, the leaf-bud; and secondly, by forming colonies under the tender bark of the last year's growths, as I have found them in both situations. It may be the eggs are laid in the buds, as very young leaves, when still unfolding, have often very small galls, which are then of a pink colour. I expect, therefore, that the majority of the mites quit the leaves on the approach of their fall, to take up their winter quarters in these places. The mites that fall with the leaves would soon die, but their eggs might be blown about with the decayed leaves, and by chance alighting on pear-trees, colonise them. The wind, birds, and insects are doubtless the principal means of disseminating this pest in the summer time. The number of living Phytopti on an ordinary-sized pear-tree that is badly attacked must amount to thousands, if not millions, so that, allowing for a most lavish waste of life, the chances of a few being carried alive to other pear-trees in the neighbourhood must be considerable." 1

\section{References to Literature consulterl.}

Collinge. Black-Currant Gall-Nite. 1904.

" " " 1907.

Connold. British Vegetable Galls. 1901.

Frank. Die Krankheiten der Pflanzen, Bd. iii. 1896.

French. Insects of Victoria. 1891.

Murray. Economic Entomology-Aptera.

Nalepa. Phytopti-Genera und Species.

" Das Tierreich. 1898.

Newstead. The Currant-Bud Mite. 1901.

Réaumur. Mémoires des Insectes. 1732.

Tubeuf. Diseases of Plants, \&c. 1897.

${ }^{1}$ Insects of Victoria. 1891. 


\section{CHAPTER II.}

\section{COLEOPTERA (Beetles).}

UF all the families of Insects, with the exception of Lepirloptera, none appear so common, or so easily distinguished by the nonentomologist, as the Coleoptera or Beetles. They are easily recognised by their apparent absence of wings, though they are not wing. less, as the true wings are covered by two hard horny wing-cases known as elytra, which are sprear out during flight. The mouth is

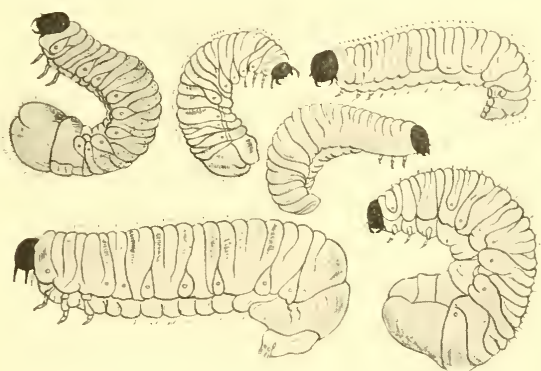

Fig. 38.-Typicel larew of beetles. (From photo by A. Flatters.)

formed for biting, hence they are mandibulate; and the body, like that of all other insects proper, is livided into three distinct portions - viz., head, thorax, and abdomen.

Beetles undergo complete metamorphosis, passing through the various stages of egg, larva, pupa, and imago or perfect insect. Fig. 38 represents typical larva of beetles.

The general student or collector of Coleoptera finds the forest a very happy hunting-ground, inasmuch as every portion of it is rep- 
resented by most of the respective families. Thus the ground underneath yields the various orler's of "ground-beetles" or Adepheya, while in the air above many species may be caught from time to time on the wing. Carrion-beetles may be found on "keepers' trees" and in lead carcases, while the bark of trees affords hiding-places for many species.

It is, however, from the economic point of riew that the Coleoptera are really of special interest to the forester, inasmuch as the various parts of the tree become the feeding-ground of respective families and species of beetles. Thus the roots are attacked by the larvæ of certain

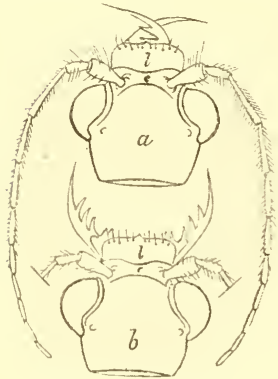

Fig. 39.- Head of Cieindela (nagnifiel)

$a$, with jaws closed; $b$, with jaws open; l, labrun; ;, clypeus. (From Fowler's 'British Coleoptera.") species, the bark tunnelled and trunk bored by others, while some beetles are injurious to the foliage and shoots in both larval and perfect forms.

In oreler to understand the anatomy of beetles, ${ }^{1}$ it would perhaps be best to take a common ground-beetle, trisect it into its main divisions, - viz., head, thorax, and abdomen, - and then carefully note the general structure of each division and its respective appendages. This is also very important from a biological point of view, for undoubtedly if insect anatomy be generally considered, it will be found that there is not a difference in structure of the various orders, but simply a modification of similar parts.

The anatomy of the mouth parts of the heetle affords a very good case in point.

Hearl. - Viewed from the top side, the eyes and antennæ are the most salient features. Fig. 39 shows all the respective parts : $l$ is the labrum or upper lip, which can be seen from the upper side. According to writers on beetle anatomy, the portion immediately behind this, l, is called the clypeus, $c$, or shield of the mouth, and behind this is the head proper, $b$.

In the Rhynchophora the head is prolonged into a snout, called the rostrum, which is a true portion of the head, and in no sense a

${ }^{1}$ For full particulars of structure, the student is advised to consult Fowler's 'Coleoptera of the Britislı Islands,' vol, i. 
trunk. On each side of the rostrum there is usually a groove into which the long first joint of the antennæ generally lies when the insect is at rest. These grooves are ealled scrobs, and are useful charaeters in the determination of the Rhynehophora. The anterior portion of the head is ealled the forehearl or front, and the central portion the vertex.

The antenne are very variable in the Coleoptera, and in many cases afford good points for the diserimination of genera and speeies. The eyes are generally very prominent.

The thorax, of eourse, can be easily recognised, but it must be remembered that the transverse division line as seen from the upper surface does not represent the length of this segment, inasmuch as it projects on the under surface and extends under the abdomen. In other worls, the under side of the thorax projects beyond the apparent divisional line, and the anterior portion of the abdomen therefore rests upon the thorax.

It is of importance to well understand the strueture of the thorax, more especially in the case of Scolytidæ or "bark-beetles." The thorax proper is made up of three parts-the mothorax, mesothorax, and metathorax; and here again we must study the upper and under surfaces of those divisions. In the upper surface these divisions are known as pronotum, mesonotum, and metanotim, and the under surfaces the prosternum, mesosternum, and metasternum. As regards the upper surface, the visible portion of the mesonotum is known as the scutellum, which is a small but important triangular space, werlged in, as it were, between the elytra and thorax. From the under surface of the thorax we get the legs, and from the upper the elytra and wings.

The aldomen does not, as a rule, present many important features, either as to external anatomy or as to points of elassifieation. The last segment or pygidium is rather important, inasmuch as it contains the organs of reproduction. The legs spring from the thorax, and are attached to the body by a joint called the coxa. The next joint is a very small portion known as the paracoxa (Fowler), and attached to this we have the strongest portion, known as the femur. The next portion is the titia; and the last division is a most important oneviz., the tarsus. Not only in beetles but in all orders the number of joints forming the tarsus must be noted. In the Coleoptera we have the whole family subdivided, according to the number of joints in 
the tarsus, into four divisions-viz., Trimera, Tetramera, Heteromera, and Pentcmera. This division is, of course, more or less arbitrary.

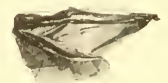

a

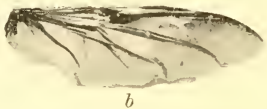

Fig. 40.-True wings of beetle. $a$, folded; $b$, unfolded.

The wings of beetles are rather peculiar, as what corresponds with the wings of other insects are the elytra or wing-cases. These have sometimes a very remarkable sculpturing, the use of which is unknown. In repose, these two elytra are very well fitted together:

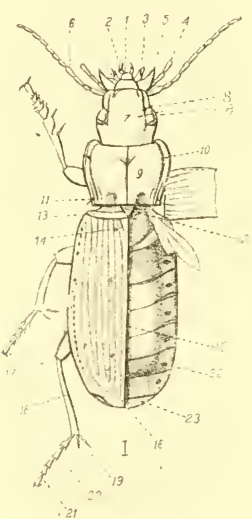

Fig. 41. - Typical beitle: Pterostichus vulgaris, L. (mule): "pper side. (From Fowler's 'British Coleop'tera.)

1. Labrimin.

2. Labial palpus.

3. Maxilla.

4. Maxillary palpus.

5. Mandible.

6. Anteman.

7. Front of hrad.

8. Supra-orbital setre.

9. Pronotum, ordinarily called "thorax."

10. Anterior lateral pore.

11. Angular pore.

12. Scutellum.

13. Basal fold of elytra.

14. Sentellary stria.

15. Suture of elytra.

16. Sutural angle.

17. Femux.

18. Tibia.

19. Spurs of tibia.

20. Tarsus

21. Onychium and claws.

22. Stigma.

23. Py gidium. the junction line is known as the suture. The wings proper, which correspond to the posterior pair of other insects, present a very variable structure, so far as the arrangements of nerves and cells are concerned. The size and general structure are compatible with the folding up under the elytra (fig. 40). In some forms they are considered apterous, but though in such cases the wings are never used, and the elytra sometimes soldered together, rudimentary wings may often be found.

Throughout the respective families various modifications of general anatomy present themselves. In the Rhynchophora or weevils, for instance, there is a prolongation of the mouth called a rostrum, which, as Canon Fowler remarks, is a true portion of the head, and in no sense a trunk.

Classification.-Notwithstanding the many works on Coleoptera, 
we have no fixed system of classification or method of arranging beetles. In catalogues they are generally grouperl into families accorling to the number of joints of the tarsi : thus those "possessing five joints to all the tarsi have been termed Pentumera; those with five joints to the front and midille legs, and only four to the hinder, ILeteromera; those with apparently only four to all the tarsi, Tetromera; and those with apparently only three to all the tarsi, Timer $\alpha$." I

In looking over a list of Coleoptera, the systematic student will obviously note that he enters the domain of beetles associated with forest trees deep down in his list. It is also, however, somewhat

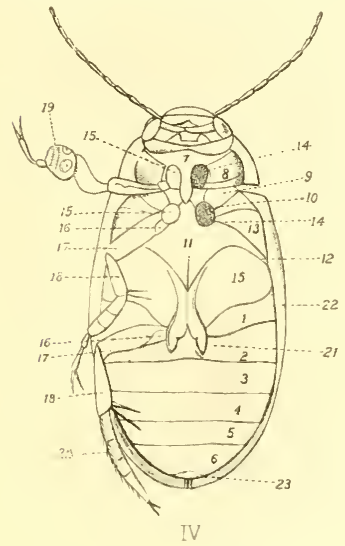

Fig. 42-Typical beetle: 1)ytiscus marginalis, I. (male), uniler side (router-beetle). (From Fowler's 'British Coleoptera.')

1. Ist ventral segment of ablomen.

2. 2 nd

3. $3 \mathrm{rdl}, "$ "

4. th ", ", ",

5. 5th " ", , ,

7. Prosternum, terminating "in prosternal process.

8. Episternum of prosternum.

9. Episternum of mesostermum.

10. Epimeron of mesosternum.

11. Metasternum.

12. Wing of metasternum.

13. Episternum of metasternum.

14. Coxal cavities.

15. Coxe (posterior pair very larely developed for the support of the swimming legs).

16. Trochanter.

17. Femur.

18. Tibia.

19. Dilater tarsus or palette, and cupules of male.

20. Oar-shapel tarsus.

21. Coxal procens.

22. Epipleura of elytra.

23. Genital armature.

remarkable, so far as hunting-ground is concerned, that where the student in forest insects begins, the systematic man and the student of many forest insects might claim mutual association all along a considerable portion of the list. It is, however, only essential to select the more salient species, and in doing so many arboreal species will have to be omitted. On the other hand, so as to present anything like completeness, many species would have to he considered which are not of great importance from the purely economic point of view.

As regards the details of structure, the student would do well to refer to figs. 41 and 42 , together with the explanation as given by

1 Rye, British Beetles, p. 41. 
Fowler. These points should be thoroughly mastered, as the ready diserimination of species from a systematic point of view will depend upon the same.

\section{FAMILY LUCANIDA.}

Fowler says that "the three British genera of the Lucanidæ may be clistinguished as follows:-

"I. Eyes more or less divided ; ligula and maxillæ covered by the mentum ; antennæ geniculate; posterior femora extending beyond margin of elytra.

"1. Eyes divided for scarcely half their diameter Lucanus, L.

" 2. Eyes divided for nearly the whole of their diameter

Dorcus, M'Leay.

"II. Eyes entire; ligula and maxillie not covered by mentum; antennæ straight; posterior femora not extending beyond margin of elytra . . . Sinodendron, F."

\section{Lucanus cerves (Limn.)}

This large handsome insect, which may be termed the king of British beetles, is chiefly confined to the southern counties. It is of

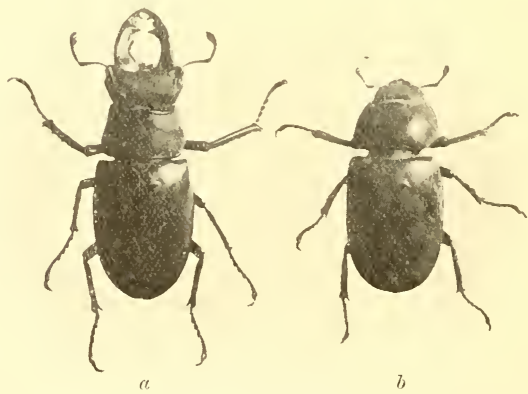

Fig. 43.-Stag-beetles.

$a$, male; $b$, female, slightly reduced.

a pitchy-black colour, with slightly brownish elytra, and often measures about two inches in length. The mandibles are very large, 
more especially in the males. In fact, these peculiar features easily distinguish the insect; and this abnormal development of the male gives rise to its name of "stag-beetle," because the mandibles projecting in front of the head resemble the horns of a stag. Darwin says that the size and strength of the mandibles are of great alvantage in fighting for the possession of the females. These insects fly during the evening, and rest on the stem, sipping at any juicy portion they can find. Fig. 43 represents the male and female insects.

It is in the larval stage that this species is most injurious to timber trees, more especially oak and ash (though hornbeam is conspicuously mentioned by Kaltenbach, ${ }^{1}$ and alder and beech by Altum ${ }^{2}$ ). The larva is white, with ferruginous head, nearly cylindrical, and of a soft fleshy consistence. It is said that they live for six years as larve, during which time they gnaw into the roots and eat the solid wood. In fig. 44 a piece

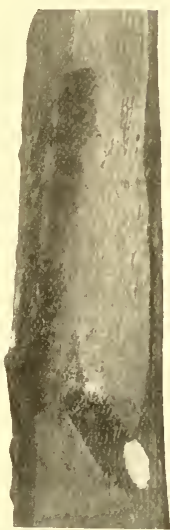

Fig. 44.-Portion of ash timber injured by larve of stur-beetle. of ash timber tunnelled by the larva of the stag-bectle is represented.

\section{Doreus Parallelopipedus (Linn.)}

To the beginner in entomology this species is suggestive of a small specimen of the female stag-beetle. At least, this was my incipient feelings when I first discovered this species under decayed bark in Gloncestershire several years ago. The larve live in old decaying beech and several other trees. ${ }^{3}$

\section{Sinodendron cylindricum (Fabr.)}

This is another beetle which may be found in decaying wood. I have reared the beetle artificially, taken from decayed wood and fed on damp sawdust. I have also tracked the perfect insects by

] Die Pflanzenfeinde aus der Klasse der Insekten, p. 638.

2 Forstzoologie, vol. iii. p. 120.

Commander J. J. Walker, R.N., informs ine that he has seen several very large ash-trees in Cobham Park, Kent, completely destroyed by Dorcus prerallelopipedus. 
following up the frass at the bottom of a decayed standing tree, which betrayed the presence of males and females. My first discovery of this sort was in Acklington, Northumberland, July 3, 1902. Mr R. S. Bagnall pointed out to me that the sickly beech and holly trees in Gibside, Co. Durham, were very much injured by this species.

The beeile is shining black, about half an inch long. The male has a conspictous hooked horn in front of the head. The female has also a slight horn, but it may require the aid of the lens to see it.

\section{FAMILY SCARABÆID无.}

\section{Genus Melolontha.}

This is exclusively an arboreal genus, inasmuch as it only contains two species, both of which are arboreal in their habits. Fowler gives the following specific characters-viz. :

"Two species of Melolontha are found in Britain; they may be distinguished as follows :-

"I. Pygiclimm elongate in both sexes, and gradually narrowed to apex; average size larger . . . H. vulyaris, F.

"II. Pygidium shorter, constricted at base, and very slightly widened at apex ; average size smaller . . M. hippocastani, F."

The chief distinguishing character of the genus is in the structure of the antemme, which are clubbed, and the club has seven lamellæ in the male and six in the female.

\section{Melolontha vulgaris, Fab. (Cockehafer).}

The cockchafer, otherwise known in this country as the May bug or May beetle, in Germany as the Maitrifer, and in France as Le Hameton, is injurious both in the perfect and larval forms. The fullgrown beetle feeds on the leaves of oak, elm, sycamore, and other trees, and the larvæ on the roots of grasses and young trees. In the midland and southern counties of England the seedlings in nurserylines often are lestroyed by the larvæ (fig. 45).

Its life-history, as given by all English entomologists, may be briefly tolu. The eggs are deposited by the female insect during the summer, a few inches deep in the soil, and generally preferring a grassy surface. About thirty or forty are said to be deposited by a single insect. They hatch out in about six weeks, and during the first 
year attain the length of abont 16 to $18 \mathrm{~mm}$. They live from three to - four years in the larval stage, and when full-grown are about $1_{4}^{1}$ inch to $1 \frac{1}{2}$ inch in length, and about $\frac{1}{4}$ inch to $\frac{1}{2}$ inch in brealth. They have six legs, the figures of which in various works appear to show the third or last pair as the longest, whereas they are considerably the short-

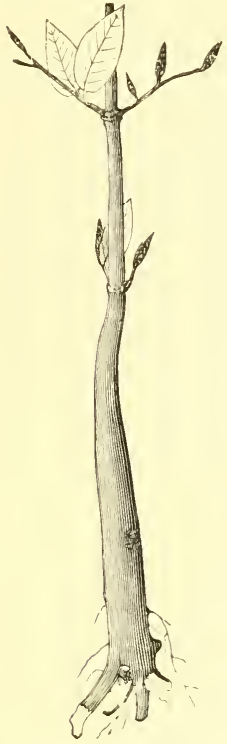

Fig. 45.-Young broch seedling, the roots of which hate been destrowed by tarva of Muy betle (nutural sis?). (From 'The Forester,' by John Nisbet.)
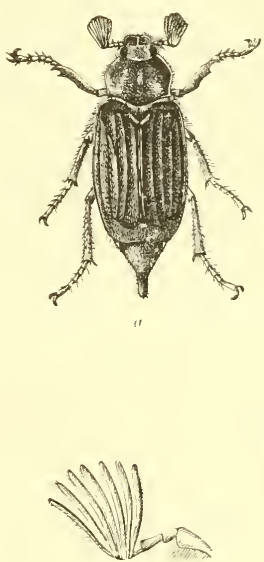

b
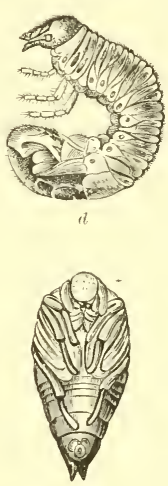

(1)

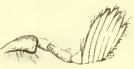

Fig. 46. - The remunom eochehafor or Muy beetle (Melolontha vulgaris).

$a$, beetle (male-natural size); $b$, feeler of male ( 7 lamellit - magnified fou times); $e$, feeler of female (6 lamella-magnified four times); $d$, larva or grub (natural size); e, chry salis (seen from befow - natural size). (From 'The Forester,' by J. Nisbet.)

est, and the middle pair are a trifle longer than the other two. All the legs are more or less hairy. The jaws are powerful. They are a dirty white colour, with a ferruginous head, and become darker after being lifted out by workmen when trenehing or levelling old "cops" or hedges. After feeding for three or four years the larva descends a trifle deeper, scoops out a recess, pupates in the autumn, and changes to a perfect insect in summer (fig. 46). 
The above account of the life-history may be only taken as regards England, or perhaps the north of France, as in Germany the cycle period is shorter in the south than in the north, thus showing that heat or geographical position is an important factor in life-histories.

\section{Preventive and Remedial Measures.}

This insect is injurious both in the perfect and larval stages, but more especially in the latter, and it is obvious that some remedial measures should be given. At the same time, it may be remembered that as this insect is so common and injurious in certain parts of the country, many practical men, according to local circumstances, have adopted their own respective methods of prevention and remedies. A few hints, however, may be given.

As regards the injuries done by the perfect beetle, they are of course cutirely confined to the foliage, and the only remedial measures which could be adopted with any degree of success would be to place sheets under the most likely resting-places or feeding-ground of the beetles, and then to beat them on to the sheets, collect, and destroy them.

The harve, however, are much more difficult to deal with, and as they live for three years in the larval stage, it is highly essential that some practical methods should be adopted to lessen their attacks. From a forestry point of view, we have therefore to deal with them either in the young plantation or in the nursery. It is, of course, more clifficult to deal with them in the former. In this case, before we can suggest any remedial measures, perhaps the most practical or effective way is to remember the nature of their life-history. It must be borne in mind that the female beetle prefers depositing her eggs on a grassy surface, as, for example, on an old pasture-field. If, therefore, it were practical to keep the young wood comparatively free from grass, it would obviously lessen the attacks, inasmuch as the females would not select the surface of the young woods for egg-deposition. How far this could be carried out would depend largely upon local circumstances or conditions. If, for example, it were possible to have either a clean surface or, say, to cultivate potatoes between the plants, we should do much to lessen the attack, and at the same time be adopting a method which, in the ease of portions of land planted for rapil landscape effect, would perhaps be the best means to adopt.

As regards the nursery from an estate point of view, we must 
remember that nurseries are of two kincls, - either temporary or permanent. The former, as is well known from a practical point of view, is very advantageous; but in selecting a site for a temporary nursery we should not choose a spot adjacent to a wool which is known to be swarming with cockchafer beetles, nor should we, as far as possible, select an old pasture-field, unless it were found possible to cultivate it with potatoes or other root crops, which, from the nature of the working, woukl either facilitate the picking out of the grubs, or otherwise checking them in some practical way, prior to the cropping with young trees. As, however, the larve are quite as partial to the roots of young trees in the nursery-lines as they are to the roots of grass, we must adopt one of two methods,-either to make the surface of the nursery very listasteful to the female beetle as a spot to lay her eggs, or otherwise we must eheck or trap the larve themselves. With regard to making the ground distasteful to the female beetle for eggdeposition, we might regularly, from the beginning of May to the end of July, sprinkle the surface with paraffin, sulphur, or in fact anything which would have a tendeney to keep the female beetles off. With regard to collecting the larvæ in the nursery, without dloing injury to the young plants a method of trap trenches might be adopted. If, therefore, the nursery plot is a comparatively large one, we might cut trenches at certain intervals, parallel with the lines, fill in those trap trenches with sods of grass, rolls of bark, weeds, partially decomposed turf, burned sods, layers of cow-dung, and such similar refuse as could be conveniently collected. From time to time those trenches might be turned up, the larve collected, and the materials replaced.

Another remedy for the larvæ is, of course, to periodically green-crop a portion of the nursery ground either for one or two seasons, as by so doing we should be able to pick out a great many of the injurious larvæ; and in the ease where the seedlings were to remain in the ground following such cropping, say for one season only, the nursery crop would be removed before any considerable clamage would ensue.

\section{Melolontha mppocastani (Fabr.)}

"The beetle (fig. 47) greatly resembles the common cockchafer, but is smaller, being only 20 to $25 \mathrm{~mm}$. long. Antenne and legs darkbrown or black. Tail shorter, more abruptly tapering, and somewhat clubbed at its extremity. 
"Liie-history and economy.-In W'est and South Germany, similar to those of the common cockchafer, with which it swarms, but in smaller numbers. In East and West Prussia in the midst of great

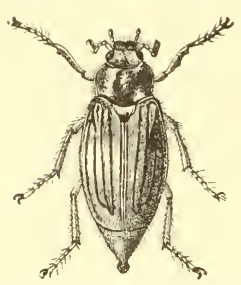

Fig, 4i. - Melolontha hippo'astani, (From 'Forest Protection,' by W. R. Fisher.)

Scots pine woods, this species alone destroys forests, the common cockchafer confining its attacks to agricultural lands. It does not merely attack horse-chestnut, as its name implies, but nearly all trees. The larvæ are highly destructive to young Scots pines three to six years old, but in their fourth summer they attack the roots of poles fifteen to eighteen years old, and even those of older trees. Season for swarming early (April). The eggs are laid eight to fourteen days afterwards, 10 to 14 inches deep in lry soil, but in moist soil only $2 \frac{1}{2}$ to $t$ inches deep. The larve appear in July, and pupate in August of the fifth year, about 1 $\frac{1}{2}$ foot deep. The chafers come out in september and October, but remain underground till the next spring. A more northern insect than the common cockchafer ; in Great Britain confined to Scotland and the extreme north of England." I

\section{Genus Agrilus.}

This genus is probably more important in forest entomology than hitherto considered. There are five British species, and it would be well for the student to give them special attention.

Agrilus viridis, Linn. (the Beech Ayritus). ${ }^{2}$

As this is a south-country species, and one which I have not found, the following is copied from Mr Theobald:-

"Although rare, this beetle has been complained about as a pest amongst sapling beech-trees, whilst it is also said to attack birch, alder, aspen, and oak.

"The damage is done by the larvæ of this beetle, which burrow

1 Forest Protection, by W. R. Fisher (Dr Schlich's Manual of Forestry), vol. iv. p. 209, second edition, 1907.

2 The Animal Pests of Forest Trees. 
between the bark and the sapwood, and form winding passages even into the wood, the tumnels inereasing in size as the larve grow. Now and again they completely girdle the stem, and then the upper part dies right away. Is a rule, the bark over the passage splits and leaves behind a ragged craek, which is very characteristic of the damage done by this beetle. It appears to prefer weakly and unhealthy saplings, but sound ones may be attaeked (figs. 48 and $49)$.

"The beetle (fig. 50) is about one-quarter of an inch long, and belongs to the family Buprestidæ, -long, slender beetles of usually metallic colour. This species varies from olive - green, bluish - green, to blue-black ventrally; the apex of the elytra diverge, and are slightly dentate. They appear in June and July, and fly in bright sunshine. The eggs are placed on the bark of the saplings near the ground, usually singly, and exposed to the

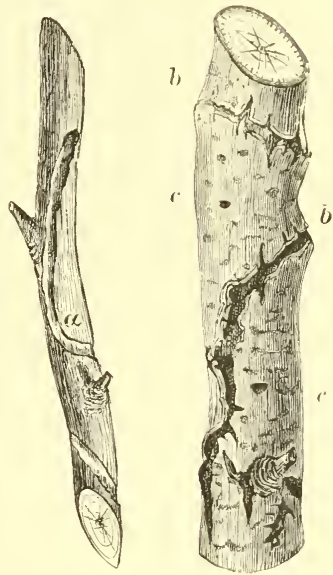

Figs. 48 and 49.-Injury caused to beech sanlings by Agrilus viridis, L. (natural size). $a$, larval gallery, exposed by removal of the bark; $b$, old larval galleries, exposed by rupture of the bark; $c$, transverse oval flight-holes of the imaso. (From 'Forest Protection,' by W. R. Fisher.) sun. The larvæ appear in August; they are white and legless, with broad first segment, usually somewhat flattened. They live in the trees for two or three winters, and pupate in April and May in the bark or sapwood, the eocoons being made of fragments of wood. The beetles emerge through holes which are oval below, straight above. They so seldom oceur in this country that no further reference is necessary. Where it does do damage saplings should be smeared with clay, lime, and sulphur to stop the bectles egg-

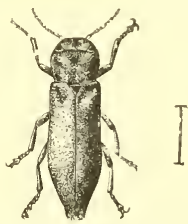

Fig. 50,- Igrilus viritis. (From 'Forest Protec. tion,' by W. R. Fisher.) laying, and all infested saplings should be pulled up and burnt early in May." 


\section{FAMILY ANOBIID王.}

The student of forest entomology, as a rule, finds his insects either on sickly or healthy living plants, but the members of this family are all found on dead wood, and are, therefore, apparently only indirectly connected with forestry, but they are nevertheless often very important as regards estate buildings. Perhaps the most familiar eximples of the injuries of beetles belonging to this family are the "holes" or "worm-eaten" furniture in our cottages, and the injuries of a similar character done to timbers in our buildings. Again, in the forest proper, we find small holes in dead thorns, and also on those portions of old-standing trees where the wood is often dead on one side.

With regard to these injuries in roofing timber, it is rather remarkable that home-grown timber should be more seriously affected than foreign timber. Hitherto I have not found any special reason assigned for this. It may be that in home timber more of the sapwood is nsed than in foreign timber-for, as a rule, insects do not attack the heart-wood ; or another explanation may be in the respective methods of seasoning.

There is nothing in the general appearance of the workings which can suggest any distinetion of species beyond the size of the exit - holes.

Judeich and Nitsche ${ }^{1}$ consider this group important in forest entomology, and therefore divide it in the following manner, according to the damage done by the respective species:-

I. The larve inhabit the bark of old stems without particular injuries.

II. The larvæ live in still standing trees, whose timber they technically injure.

III. The larvæ inhabit the upper branches, and their injuries often canse death.

IV. The larve gnaw the young shoots, and thus destroy them.

V. The larvæ inhabit and clestroy coniferous cones.

VI. The larvæ destroy comparatively old worked dry wood, planks, baulks in the wool stores, house utensils, furniture, \&c.

This biological arrangement, though departing from the systematic, is a very convenient one to the forester of this country, more especially

1 Forstinselitenkunde, vol. i. p. 343. 
as the insects themselves are not considered of primary inportanee, and it wonld be well, therefore, to give the respective insects which cause the particular injuries referred to in each division, but unfortunately we camnot get, owing to absence or rarity, the British species to fully coincile with the German arrangement in question.

In the first group Judeich and Nitsche give Anobium emarginatum, a speeies not recorded in Britain. These writers, however, say that it is not an injurious species, and only lives in the bark of old spruee-trees.

\section{Tribe ANOBIINA.}

Fowler livides the tribe into the following genera:-

I. Elytra with punctured strixe distinct, at all events at sides; posterior coxie distant.

1. Antennæe sub-eontiguous at base, with the last three joints slender and long, especially in male Dryophilus, Chevr.

2. Antennie distant at base, with the last three joints enlarged, evilently broader than preceding.

(1) Thorax not margined at sides . . Priobium, Mots.

(2) Thorax margined at sides . . Anobium, F.

II. Elytra without punctured stria ; posterior coxæ contiguous.

1. Tarsi with the fifth joint broad; tibiæ stout Xestobium, Mots.

2. Tarsi with the fifth joint elongate; tibiæ slender

Ernobius, Thoms.

\section{Priobium castaneum (F.)}

This beetle is very common in Northumberland, in old dead thom hedges. On May 26, 1905, I cut up a number of dead thorn stems from a hedge (fig. 51) and found several fully developed beetles, together with a few fully developed larve inside the stem. I laid asile a few pieces in a bag, and the beetles hatehed out about the middle of June, or three weeks later.

The beetle is oblong, of a dull reddish-brown colour; antennæ and legs red; head fairly large, with prominent eyes; thorax broader than long, and narrower than elytra. The division between the elytra forms a deep furrow, and the longitudinal markings on the wingcovers are beautifully parallel, so that under a strong lens it looks like corduroy. Length about $4 \mathrm{~mm}$. 


\section{Xestobiun tessellatun (F.)}

This insect, which is given as an example in the second group, is the largest of the British Anobiidæ, and, according to Fowler, is recorded from many English localities, but very rare in Scotland.

The beetle is a large species, being about $7 \mathrm{~mm}$. long. The head is rather leeply sunk in the thorax, and the whole body is therefore

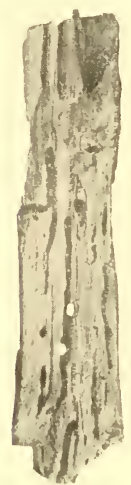

Fir. 51.-Portion of dead havethorn stem burrowed by lurite of Priobium castaneum. cylindrical and rather convex. The ground colour is dark-brown, but it is thickly covered over with a yellowish pubescence, and towards the abdomen there is an indistinct yellow band; antenne reddish, legs dark-brown.

I am indebted to Mr Hereward Dollman for kindly sending two specimens.

The tribe Anobiina contains the species found in old wood in houses, and in dead wood generally. With regard to the former, the beetle popularly known as the "Death Watch" is perhaps the most familiar example. The poet says,

"The solemn death-watch clicked the hour she died,"

and this saying is simply the expression of a superstitions belief that the noise which the creature makes, and which is obviously most distinct in the stillness of night by a sick-bed, is associated with the supposed prognostication of a solemn death-warning. Several species are said to produce this noise, but the best examples are Anobium clomesticum and Xestolium tessellatum.

\section{Eriobius mollis (L.)}

This species is very common in Northumberland, on larch and spruce palings or poles. It prefers very dry wood. I have hatched it from a spruce pole which had done duty as a flagstaff for several year's. On finding larvæ under the bark in September, I cross-cut the pole into small pieces, and placed them in a bag, hung from the rafters of an open shed, and the beetles hatched out in intervals from the middle of June to the end of July. I have discovered them 
in large slabs which had done duty as a rustic covering on an important hut for six or seven years. The larvæ feed on the surface wood, just below the bark, making irregular markings, as seen in fig. 52. They pupate below the surface of the bark, and often remain in their burrows after cutting out their exit-holes, or otherwise lodge in the burrows of the bark. In the middle of June they may be dislorlged by gentle tapping, and thus collected freely.

The perfect beetle is from $3 \frac{1}{2}$ to $5 \mathrm{~mm}$. long, oblong, of a light ferruginous colour, and slightly covered with a pale pubescence. Eyes large and black; antennæ slender.

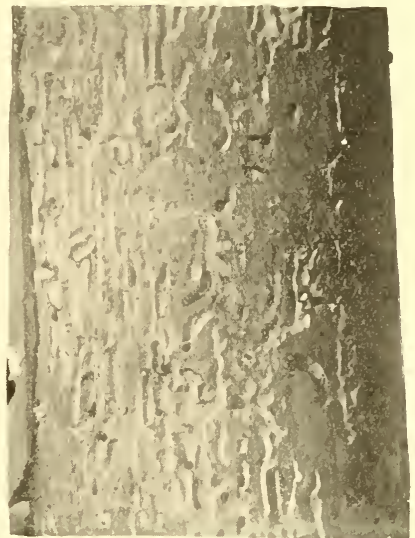

Fig. 52.-Markings of larwe of Ernobius mollis on siruce pole.

Elytra rather long, with parallel sides; legs rather lighter in colour than body, and comparatively slender.

\section{LONGICORNIA.}

This group (so named because of the length of the antennz) is one which the general collector of Coleoptera is very anxious to get well represented in his cabinet. They are of special interest to the student of forest entomology, inasmuch as the larvæ are wood-feeders, feeding both in the living stem and on dead timber.

The larvæ are large, whitish grubs, and in many cases may be easily recognised in consequence of the prothorax being broater than the rest of the body. The head is, as a rule, comparatively small, and armed with strong mandibles and short antennæ. The legs, when present, are short or rulimentary, and locomotion is often assisted by fleshy tubercules which protrude from the body. 
Fowler ${ }^{1}$ divides the Longicornia into the three following families :-

I. Prosternum considerably produced in a blunt process behind anterior coxæ; thorax margined, with the sides armed with spines or teeth; labrum very small, usually connate with clypeus

II. Prosternum not, or scarcely, produced behind anterior coxæ; thorax not margined, with the sides sometimes armed with spines and teeth, but usually simple in one species; labrum free and distinct.

(a) Anterior tibiæ not grooved on their inner side

Cerambycidæ.

(b) Anterior tibixe grooved obliquely on their inner sile

Lamiidæ.

\section{FAMILY PRIONID瓜,}

\section{Genus Prionus.}

This genus contains only one species, and that species embraces the whole of the family of Prionidæ as represented in this country.

\section{Priones coraries (Linn.)}

This handsome beetle is somewhat rare in this country, being chiefly confined to the south of England. The large larvæ bore into living oak-trees, and do considerable damage. There is only one British species, but several species are found in America, affecting various trees.

The beetle itself is about $1 \frac{1}{2}$ inch in length, of a dark-brownish colour, slightly shining, lighter below, robust antennæ, serrated in males, thorax black, comparatively square, and with spines at sides. It has the habit of fixing itself to the trunk, and flying at night. The female emits a very strong odour. The larvæ when fully fed are about 3 inches in length, of a whitish colour, and tapering considerably towards the anal end. At this stage they move towards the outer sile of the trunk, and form a cocoon, whence the beetles emerge in July. 


\section{FAMILY CERAMBYCID君.}

The most salient characters of this great family of beetles are-body more or less cylinirical, with very long slender antennæ; larve called "borers," their bodies cylindrical, usually footless.

This great family includes a large number of species, many of which are wool-borers, and they are alike interesting to the general collector and student of forest entomology. The latter may often be able to hatch them, from larve in either fresh or dead wood, while the former may often enrich his collection with specimens found on the flower's of large umbelliferous plants.

The duration of the larval stage is very varied. They may, as a rule, live from one to three years, but instances are given of the perfect insects appearing from furniture which hal been made of timber lying cut prior to using for several years. ${ }^{1}$

\section{Aroma noschata, Linn. (Musk Beetle).}

This species is so named because of the peculiar odour which it emits, which has been compared to the otto of roses. In the larval stage it is very destructive to willow-trees, and very often attacks lime-trees, but it is generally found in the rough stems of old pollarded

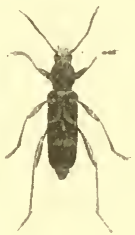

Fig. 53.--Clytus arletis (urasp beetle), natural size. (From photo by A. Flatters.) willows, and, in fact, is said to be very common in all willow-growing distriets.

The bectle is a very pretty and handsome insect, about an inch or more in length, with a strong spine on each side of the thorax. The colour varies from a rich sapphire to an iridescent peacock-green. In the male the antenne are $1 \frac{1}{2}$ time as long as the body ; in the female, a little shorter than the body.

\section{Clytus arietrs, Limn. (Wasp Beetle).}

This beetle (fig. 53) derives its common name from its general appearance, which resembles a wasp. The body is rather more than half

${ }^{1}$ As the genera and species in this family, given as arboreal, are so comparatively few, it is not considered advisable to add generic characters. 
an inch in length, black, with bright yellow bands, beautifully marked behind the head and across the body. The general appearance is rather suggestive of designs for carriage decoration. The legs are rather long, and of a light terra-cotta colour. The antennæ are about half the length of the body, partly black, and partly the same colour as the legs.

This beetle is not an arboreal insect, in the true sense of the term, inasmuch as it does not attack living trees, but it is nevertheless a timber insect. In looking for arboreal insects we may come across it under the bark, and its appearance, habits, and specific characteristics justify the student of forest entomology placing it in his cabinet.

\section{Genus Rhagium.}

This genus is one which, though entirely arboreal, is not of very great economic importance in forestry. It is, however, one of those insects which it would be well to get familiar with, inasmuch as I have perhaps had more specimens of Rhatrium bifasciatum sent me for identification, as being found in the forest, than any other class of insects. There are three species in the genus, two of which are very common in Northumberland-viz., $R$. bifasciatum and $R$. inquisitor.

The following, according to Fowler, ${ }^{1}$ are the specific characters :-

I. Antennæ very short; elytra rather strongly pubescent, without distinct oblique yellowish bands.

1. Head straight behind eyes; raised lines on elytra ceasing considerably before base . . . R. inquisitor, F.

2. Head narrowed behind eyes; raised lines on elytra continued almost to base . . . R indagator, Gyll.

II. Antennæ longer; elytra feebly pubescent, with two strongly marked oblique yellowish bands on each $\quad$ R. bifasciatum, F.

\section{Rhagium inquisitor (F.)}

The beetles may very easily be reared from the larvæ, which may be looked for in ash, oak, and other logs which have been lying in the woods until the bark has decayed and the sapwood dissolved into a black moist powder. The larve when full-fed are about an inch in length, pure white, with a light-brown head. If the larger-sized specimens are collected in February and Narch, and kept in the ${ }^{1}$ Vol. iv. p. 231. 
black material in a moist condition, they will develop into beetles about the beginning of April. Fig. 54 is from a photograph of the beetle.

\section{Rinagium bifasciatum (Fab.)}

This is a very common arboreal species in many parts of the country. In very warm lays in July the beetle may be seen flying about amongst young fir woods, or lodging amongst the leaves of young Seots pines. During the summer months it may be found in the early morning, amongst the freshly cut sawdust, in the pit underneath the circular saw, where a portable sawmill is erected in a fir wood. During the winter and spring months the perfect beetles may also be found, together with many speeimens of the larvæ, in old fir roots,

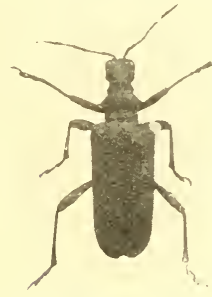

Fig. 54.- Rhagium inquisitor (natural siz).

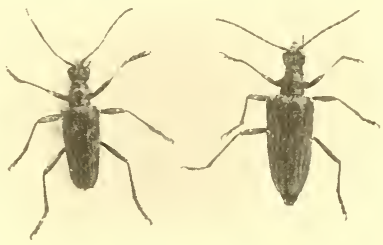

Fi:55,-Rhaginm bifaseiatum (natural size).

and more especially in roots where the trees have been blown down. I once found quite a colony in such a place in November, and as the beetles were fully developed, it is possible that they pass the winter in the perfect stage, after changing from the pupal stage in autumn, as so large a colony in one root could not be accounted for on the lines of hibernation. Another very happy hunting-ground for this species is in dead Scots pines which have been left standing until their condition is simply a mass of dry dust. I found quite a colony of the perfect beetles issuing from trees of this class on May 19, 1905, at Lyham, in Northmmberlancl. After the exit from such trees, the stem shows so many holes that it looks like having been severely shot at with small bullets. As a rule, it cannot be considered an injurious insect, though in Cheshire I once found an oak log considerably destroyed by the larvæ of this species.

The perfect beetle (fig. 55) is shining and of a darkish mottled 
appearance. The conspicuous features of colour are two yellow oblique spots on each elytron-that is, four spots on the abdomen. The antennæ are a uniform brown colour. Legs black, with brown coxæ,-brown next the bolly and black next the femur, and the remainder of the leg brown. The thorax has very strong lateral spines. Length 15 to $22 \mathrm{~mm}$.

\section{FAMILY LAMIID咂.}

From the systematic point of view, Fowler says, "The chief distinctive character of this family is found in the fact that the anterior tibiæ are obliquely grooved on their inner side : as a rule the palpi have the last joint cylindrical and pointed."

Fowler divides the family into twelve genera, the majority of which are associated with trees or timber, but two only may be consideredviz., Acanthorimus and Saperdu, the former because of its peculiar appearance and structure, and the latter because of economic importance.

I. Femora distinctly clavate; thorax with lateral spines or tubercles.

1. Antennæ much longer than the body; upper surface smoother.

(1) Antenne in male four times as long as the body; anterior coxæ rather widely distant; size large

Acanthocinus, Steph.

b. Antennæ 11-jointed

Saperda, F.

\section{Acanthociness emilis (Linn.)}

The following description of this handsome insect is taken from Rye's 'British Beetles':-

"Astinomus (Acanthocinus) cetlitis is conspicuous for the enormous length of its antenne, especially in the male. This also occurs at Rannoch, where it may be not uncommonly seen flying across the glades of the Black Forest with its long appendages streaming behind. It loves to settle on felled logs with its antennæ spread out like compasses, from which habit it is termed by the Highlanders 'Timberman,' a name curiously enough applied to it in Lapland and Sweden, where it is common. If two males come within range they inevitably fight, for which reason, and also on account of their delicate structure, it is difficult to obtain quite perfect specimens. 
"The larva makes wide galleries and perforations in pine stumps, forming a nidus with coarse-gnawed fragments, near the surface, in which it changes to pupa. In this state the antemne are turned downwards, and recurved towards the middle of the head. It appears to be full-fed at the beginning of the summer, and after remaining two or three weeks in the pupa state, changes to the perfect state, staying as such in its nest until the following summer."

The body of the beetle is about $\frac{3}{4}$ of an inch in length, while the antennæ measure quite 3 inches.

Rannoch, or the "Black Forest," in Perthshire, referred to, is a

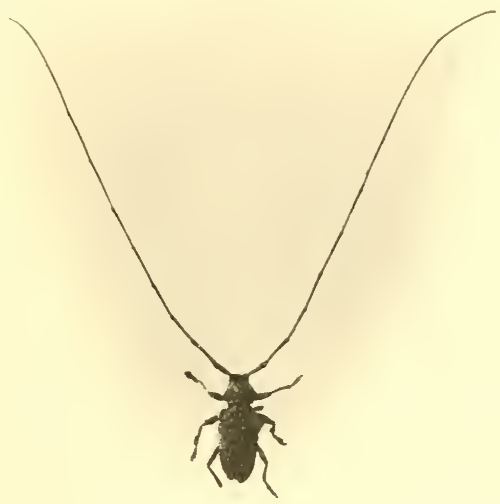

Fis. 56. -Acanthoeinus sedilis (helf neturel oize).

very happy hunting-ground for the entomologist. This is due to the filct that it is the remains of the old Caleclonian Forest. Fig. 56 is from a photograph of the beetle.

Genue Saperda.

Head with vertical forehead. Larve without distinet legs, almost parallel-sided, and 11-jointed. Thorax longer than broad, without side spine. Genus exclusively arboreal. 


\section{Synopsis of the Species.}

Size large, elytra contracted towards the extremity, without any distinct patches; boily covered with greyish-yellow hairs; legs dark

S. carcharias.

Size smaller, elytra cylindrical; thorax with yellowish side band; each elytron with four or five yellowish flecks . S. populnea.

I am indebted to friends for the specimens in my collection, but as I have not had any opportunities of studying this genus in the forest, the following account of the two species is taken from Professor Fisher's 'Forest Protection' (Schlich, vol. v., 1907 edition).

\section{Saperda carcharias, L. (Large Poplar Longicorm).}

Description.-Beetle (fig. 57) 23 to $30 \mathrm{~mm}$. long, grey or brownishyellow, dotted with many shining black points. Thorax short and

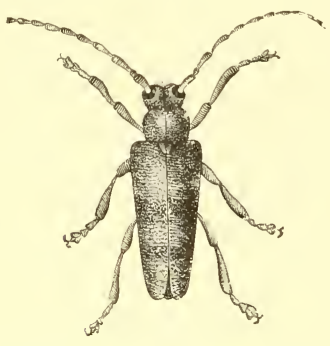

Fig. 57.- Saperda carcharias. (From 'Forest Protection,' by W. R. Fisher.)

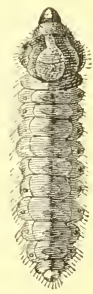

Fig. 5s. - Larve of Saperda carcharias. (From 'Forest Protection,' by W. R. Fisher.)

eylindrical. Elytra with the shoulders prominent, narrowed posteriorly, and bluntly spined at the apex.

Larva extending up to $36 \mathrm{~mm}$. in length, without legs, cylindrical, yellowish-white, with the mandibles and segmental shields brown, the latter on the dorsal surface of segments $3-10$, and the ventral surface of segments 2-10 (fig. 58).

Life-histor\%.-Season for flight: June and July.

The eggs are laid in June in crevices in the bark of poplars, especially near the ground. 
The larva emerge in July and Angust, and live and hibernate in the wood, pupating in May of the 3rd year.

The pupe lie head downwards in a chamber blocked with a plug of wood-dust.

The imagos emerge in June of the 3rl year.

Generation bieunial. The insect is rather common in a few parts of Great Britain, chiefly in the eastern counties.

Relations to the forest. - The larvie lore into young, healthy poplars, and also into willows; aspen and black poplar up to 20 years old are specially attacked. Seedling trees are liable as a rule to be attacked from their 5th year, and suckers from the 3rd year.

The larvæ make vertical galleries, which reach the centre of the tree: these become gradually filled with wood-dust, which is forced out of the tree by the grubs through a bore-hole, and becomes heaped up at the base of the plants. The stem is attacked near the ground, and reacts by developing a large irregular swelling, the bark of which is fissured. Such perforated saplings are easily broken by the wind. This insect is chiefly of importance where poplars are grown on a large scale, as in France. It is sometimes associaterl with Sesia apiformic, Fabr., and Cossus liyniperda, Fabr.

The beetles in June and July eat roundish holes in poplar leaves, but this injury is unimportant.

\section{Saperda populatea, L. (Small Poplar Longicom).}

Description.-Beetle $8-13 \mathrm{~mm}$. long, greenish-grey to dark brown, covered with yellow-grey pubescence; thorax with three lines of pubescence; elytra with the median line, and a broad lateral stripe, and three or four spots on each side pubescent. Antemnæ blackish, and each segment up to two-thirds of the length of the antennæ with grey pubescence. Larva $13-15 \mathrm{~mm}$. long, yellowish, and resembling that of the preceding species.

Life-histor'y. - The female deposits her eggs in May and June in cracks on the bark of young aspens, less commonly on other species of poplar, sometimes on willows. Seedlings of 2 to 6 years old and suckers are preferred.

Generation biemial. The larva hatches in July, bores through the hark, and eats a circular gallery round the sapwood. The stem, usu- 
ally one of the smaller branches, reacts by forming a gall-like swelling, which, however, is not found on willows. See fig. 59.

In the second summer the larva changes its course, boring upwards along the middle of the stem for about an inch. The flight-hole is

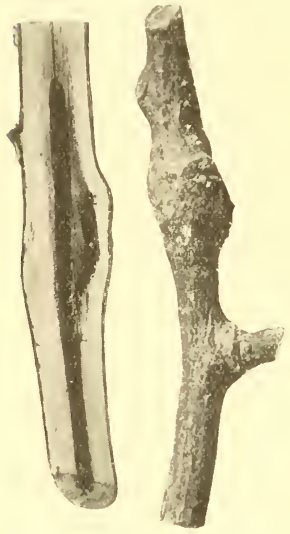

Fis. 59. - Injuily eursed to stem of aspen poplar by lurwe of Saperda yopulnea. circular, and situated on the swollen portion. Pupation in April of the third year.

This insect is usually found in open sumny places, and is not uncommon in the Midlands and south of England. It seldom kills the trees, but cripples the branches and prevents growth. Where it is abundant, hardly a branch can be found free from its gall. Fig. 59 is a representation of injuries.

\section{Tribe CHRYSOMELINA.}

\section{Genus Melasoma.}

There are three species in this genus, all of which are arboreal; but as two are very local, the species described may be taken as typical, and generic characters need not be given. Not having found the species considered, the following is taken from Fisher. ${ }^{1}$

\section{Melasoma populi, L. (Red Poplar-leaf Beetle).}

Description.-- Beetle 10 to $12 \mathrm{~mm}$. long, of an obovate shape, blackish-blue, the elytra brick-red, their extreme tip black; thorax narrower than the elytra, its sides rounded, broally raised and coarsely punctured; antennæ short, compressed, thickened towards the ends.

Larva 6-legged, of a dirty white colour, with many black spots, and two white lateral projections on the second and third segments.

Pupa sharply narrowed towards the posterior extremity, brownishyellow, with regularly distributed black spots and stripes.

Life-histor\%.- The season for flight is in May and June.

\footnotetext{
${ }^{1}$ Forest Protection, 1907 ed.
} 
The $q$ lays her yellowish-white eggs in clusters of 10 to 12 , in all 100 to 150 , on the under side of the leaves of young poplars. The larvæ emerge in June or July, feed openly on the leaves, and if disturbed exude a milky-white tluid, with an odour of bitter almonds.

Pupation takes place in July and August; the pupæ hang reversed from the leaves by their pointed end.

The beetles emerge by the end of August, and after October hibernate under leaves or moss, reappearing in the open in April.

Generation annual, but frequently double, when the beetles hiber-
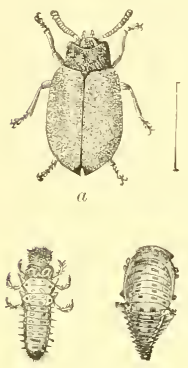

i)

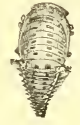

$c$

Fig. 60.-Melasoma populi. $a$, beetle: b, larva; $c$, pupa. (From 'Forest Protection, by W. R. Fisher.)

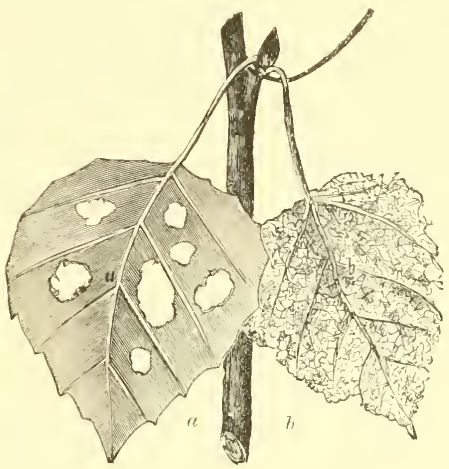

Fig. 61.-Injuries done by Melasona populi. a, leaf bitten by beetle; $b$, leaf bitten by larvit. (From 'Forest Prutection,' by W. R. Fisher.)

nate; larvæ appear in May and June; pupæ 3-4 weeks later, new beetles 10 days later. Fresh larvæ in August, the second generation closing in the middle of September. Locally common in many parts of the British Isles, chiefly in South England.

Relations to the forest. - The insect, both in the larval and beetle stages (fig. 60), attacks young poplars and sometimes aspen shoots. Occasionally they are found in osier-beds, especially on Salix: purpurea, L., and S. mulva, L., \&c. The larve attack the leaves, which are completely skeletonised, the parenchyma being eaten and the veins left intact. The imago eats holes ont of the leaves (fig. 61).

The attacks last from June to August. 


\section{Gemes Phyllodecta.}

This is truly an arboreal genus. The beetles are usually of a bronze or metallic colour, oblong shape, parallel sides, rather long antennæe, elytra with beautifully punctured striæ.

Fowler gives the following specific characters-viz.:

I. Punctured striæ of elytra irregular, colour blue

P. vulgatissima, L.

II. Punctured striæe of elytra regular.

1. Foreheal broadly excavated; antennæ longer; colour dark blue. . . . P. cavifions, Thoms.

2. Forehead with a slight depression, not excavated; antennæ shorter; colour, as a rule, bronze . P. vitelline, L.

The two species $P$. vulgatissima and $P$. vitelline are often confounded, and very difficult to distinguish by the practical man, affording, perhaps, a good case in point where the services of the systematic Coleopterist would be valuable.

\section{Phyllodecta (Phratora) vitellixe (Kirby).}

This beetle (fig. 62), which is in many parts of the country popularly known as the willow beetle, is about one-sixth to one-eighth of an inch in length, of a bluish-black

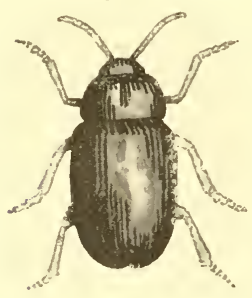

Fig. 62. - Phyllodecta vitelline (ivillow beetle), very much enlurged. (Drawn by P.J. Brown.) metallic colour, with a dash of bronze or green above and more below. The body is oval-shaped, with longitudinal punctured rows on the elytra.

The perfect insects hibernate in rotten wood and underneath the bark of trees, more especially such rough parts as those on Ontario poplar and the excrescences on ash caused by the fungus Nectria ditissima. In such places I have often found them in micl-winter. On the arrival of spring and the general appearance of vegetation they leave their sheltering places, and betake themselves to the osiers or poplars.

The female deposits her eggs in small clusters, generally six eggs in 
a cluster, on the under side of the leaves of willow, sallow, or poplar. Whether the female deposits more than one group, I am at present unable to say. The eggs very soon hatch out, and the larve do immense damage by eating the green portions, leaving only the vascular portion, - in fact, skeletonising the leaves, and giving the affected portion of the plant a very dirty-looking appearanee (figs. 63 and 64). They feed on the under side of the leaves, moving in straight rows like soldiers marching in single rank. They are rather larger than in the perfect state, and are of a dirty-looking colour.

The damage done to the willow, more especially the osier (Salix viminalis), is by no means confined to the larval stage. The perfeet beetles do immense damage to the young rods by eating the tender portion of the extreme point,-in fact, eating the growing point; and as length is the main object of osier-growing, it is obvious the damage cannot be exaggerated. Damage of a similar nature to rods of the second year's growth likewise causes a great loss to willow-growers, inasmuch as the shoots throw out a number of small lateral branches, instead of increasing in growth by length. Hence they are very much depreciated in value.

Hitherto I have not been able to work out the full life-history of this insect. Some naturalists assert that it is double-brooded, but in all probability we have a succession of perfeet insects appearing throughout the summer.

As regards remedies, the usual insecticidedressings of quassia, Paris green, \&c., would no doubt help to keep it in check, but I have found that the best way is simply to go over the

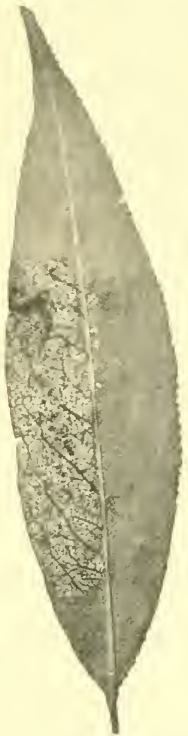

Fig. 63. - Willow. leaf injured by lerew of willow bectle (natural size). rows of twigs and shake the beetles into an old jar containing paraffin.

A very interesting account of the damage done to a large sewage farm in Lymm, Cheshire, will be found in Miss Ormerod's Manual; and my esteemed friend the late Mr J. Mort, who had then charge of the farm in question, assured me that the beetles had all but 
disappeared as the result of annually shaking them into paraffin. I ean fully endorse this, not only from adopting the same method, but also on aecount of frequent pleasant per-

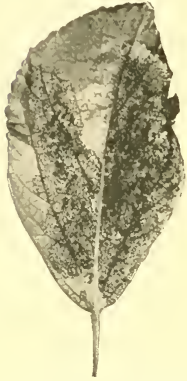

Fig. 64.-Leaf of balsam popler injured by levere of willow bectle (re(ducet). sonal inspections of Lymm Sewage Farm along with the late Mr Mort.

\section{RHYNCHOPHORA.}

This section embraces a very large series of inseets, both to the systematic student and the arborieulturist. As, however, the main distinguishing generic characters are given, it would be superfluous to give too many detailed seetional eharacters. In a general way (exclusive of the Seolytile) they may be characterised as "snouted" weevils. Many of them are easily rearel from the larval stage, but it would be well for the enthusiastie student to eolleet this class of inseets from palings, trunks of trees, stone walls, de., as by so doing he would not only gain a knowledge of the section, but many important points bearing on the life-history of arboreal speeies could be ascertained.

The family Curculionidæ eontain eertain weevils which are either injurious or otherwise interesting as forest inseets, perhaps more especially those which cut and roll leaves in a peculiar manner, either for the benefit of the larve or the perfeet insects.

To the systematic student of Coleoptera this is, comparatively speaking, a very large family, and many species may be beaten from different deciduous trees, but the student of forest inseets may confine his attention to the leaf-cutting and leaf-rolling species. With a view, therefore, not to overload the student in the details of elassification, it is intencled to give as few systematie eharacters as possible.

\section{Attelabus curculionides (Limn.)}

This leaf-rolling beetle is very plentiful in some parts of the eountry. I have found it in Delamere Forest, Cheshire, at Newball in Lineolnshire, and also in the southern side of the eounty of Northumberland. As regards the date of appearance, I found it, together 
with the rollings, in the former place on June 15, 1895, and on June 20, 1896.

The work of the female beetle is very easily recognised in the form of "thimble cases," constructed by rolling up the oak (or, more rarely, Spanish ehestnut) leaves (fig. 65). These are ehiefly found on young shoots, growing as underwood. On inrolling the cases on the dates men-

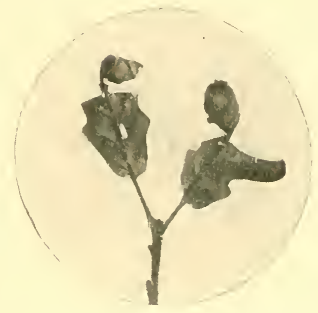

Fig. 65.-Oal-leares roller by Attela-

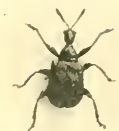

Fig. 66.-Attelabus curenlionites (metural sizf). (Photo by $\mathbf{A}$. Flatters.)

tioned, a single egro was found in each case. The egrg is a small spherical body, of an orange colour.

The perfect beetle (fig. 66) is about $6 \mathrm{~mm}$. long, of a bright rufous-brown colour; thorax and elytra smooth; legs all black and shining; antenne black and 12jointed; head black, and eyes of a ehocolate colour.

\section{I)porä̈s betule (L.)}

This species of leaf-rolling beetle is abundant in many parts of the country, but I have found it most plentifully at Kielder, Northumberland. The leaves (of birch) are eut much in the same manner as by the preceding species, but the ease is rolled lengthwise instead of in a globular form (fig. 6i). The rolled portion somewhat resembles a kind of paper bag used by grocers or

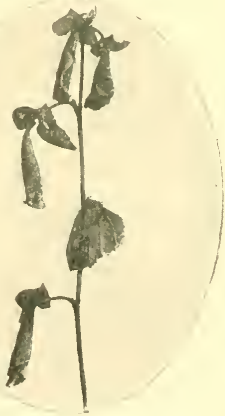

Fig. 67.-Bireh-leares rolled by Deporatis betulit. confectioners, and made by rolling a square-cut piece of paper round the hand. The ehief injuries are done by the female insect: she interferes only with the vitality of a certain portion of the leaf. She begins rolling operations by making an incision on the outer edge of 
the leaf in the form of an $\mathrm{S}$ or ogee curre, until she reaches the midrib, over which she skips and euts another $\mathrm{S}$ line, until she reaches the upper and outer edge of the leaf at about the same distance from the milrib as where she made the first incision. The rolled portion is partially weathered, and the other portion remains quite fresh. I have searched many of the cases, but hitherto

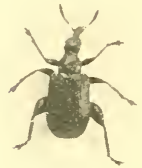

Fig. 68.-Deporaiis betulie (evlarged). (Photo by A. Flatters.) have not found any eggs as in Attelalus, though several perfect insects have been found sheltering within the folds.

The beetle (fig. 68) is about 2 or $3 \mathrm{~mm}$. long, of a black, shining, metallic colour, and striated. The beak is more or less widened at the tip end. The head is not narrowed into a neck behind the eyes. The antennæ are 11-jointed, and the beetle is on the whole a very pretty insect, though not so brilliant as the species of the closely allied genus Rhyncophora; but the metallic hue depends very much on the angle of light.

\section{Genus Otiorrhyschus.}

This genus is perhaps more important to the gardener than the forester, and the young student may get them in the first instance by collecting in the garden.

\section{Otionrhynchus picipes, Fabr. (Clay-coloured Weevil).}

This insect is most injurious in the perfect stage, and generally feeds at night on the shoots of various plants-viz., vines, raspberries, and strawberries in the gardens, and on thorns and other plants in the nursery and forest. I have only found it twice as a forest pest,-once doing much damage to several classes of young trees in the nurseries of Messrs Caldwell \& Sons, Knutsford, Cheshire, and also on young thorn hedges in High Legh, Cheshire. The latter case was accidentally discovered in the following manner. A farmer once applied to me for wire-netting as a protection against rabbits, which were, he said, eating the shoots of a recently cut-off hedge: the "eutting off" had been done the second year after planting. Knowing that the hedge in question was in the middle of a ploughed field, and where I thought no rabbits could be near, I at once refused the request pending a 
personal inspection. On arriving at the spot, I found the bark of the quieks bally eaten from the cut, half-way down to the soil. In vain I tried to persuade the farmer that it was insect and not rabbit damage; but on lifting the small clods of soil, the inseets were found in great numbers, and so beautifully did the soil blend with the colour of the inseet that only a praetised eye could detect them. As a remedy we sprinkled paraffin on the soil, but a sudden change of favourable wet weather following a prolonged drought perhaps had better effects than the paraffin dressing.

The perfect beetle (fig. 69) is about 7 to $8 \mathrm{~mm}$. in length, or from one-fourth to one-third of an inch. The head and thorax are blackish in colour, and the elytra bearing to brown. This blending

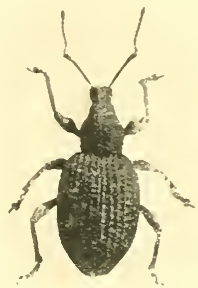

Fig. 69.-Otiorrhynehus pieipes (enlerged). (Photo by A. Flatters.) of black and brown gives it the appearance of clay, hence the name. Under the microscope the bodly has a sealy appearance. The legs are ferruginous, and the clubbed antennæ 12-jointed.

The larvæ live in the soil, and are whitish, legless, and somewhat hairy. The pupæ show all parts of the perfeet inseet.

\section{Otiorrhyxchus sulcatus (Eabr.)}

This beetle (fig. 70 ) is generally found in vineries, and is popularly known as the vine

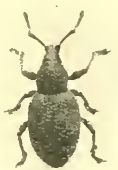

Fig. 70.-Otiorrhynchus sulcatus (vine veevil), natural size. (Photo by A. Flatters.) weevil. I onee found it in Cheshire eating the young leaves of the common blackthorn. It is larger than the previous species, and of a dull black colour, varied with ochreous-yellow seales on elytra.

\section{Genus Strophosomus.}

This genus may be eharacterised by the eyes being extremely prominent, appearing in some species as if almost detached from the head. The head is also large and triangular. There are several species in this genus, but only two, namely, S. coryli and $S$. capitatus 
(obesus), may be considered as arboreal. The former is often recorded as doing considerable damage in this country, and the latter as being injurious to certain young trees on the Continent. It is, however, possible that the injuries of the latter species may have been overlooked in this country.

\section{Synopsis of the Species. ${ }^{1}$}

I. Elytra not fitting tightly into the base of thorax; serobes slightly but plainly deflexecl.

1. Elytra with the sutmre denuded at base, forming a black longitudinal patch at scutellum . . . S. coryll, F.

II. Elytra with the suture not denuded at base.

1. Erect hairs on elytra very distinet, if viewed sideways; thorax rugosely punctured . S. cupitatus, De G. (obesus, Marsh).

\section{Strophosonus coryli (F.)}

Various accounts have been given of this beetle doing considerable damage by feeding on the foliage of larch, oak, birch, \&ce, in comparatively young plantations. It has also been recorded that considerable damage has often been done by it to several species of young trees in the nursery.

The insect, from a collector's point of view, may frequently be beaten from several species of young trees.

This beetle is from $\frac{1}{6}$ to $\frac{1}{4}$ inch in length, almost spherical in form, and of a uniform brownish-grey colour. The antennæ and legs are ferruginous, elytra with moderately punctured strie.

$$
\text { Strophosonus capitatus, De G. (obesus, Marsh). }
$$

This beetle is often found very injurious to the foliage of birch, and may be beaten in showers from young trees or coppice in early summer. The leaves are entirely riddled, so that where perfect foliage is an important point a slight depreciation ensues throughout the season.

The beetle is very much like the preceding species, but slightly smaller in size and very globular in form, - a character, however, very typical of the genus.

1 Fowler, vol. v. p. 189. 


\section{Polydrusus micans ( $\mathrm{F}_{*}$ )}

I found this species very abundantly feeding on oak leaves of the epicormic branches at Reedsmouth, Northumberland, Nay 15, 1901. It could not be sail, however, that they were doing appreciable damage to the trees. Usually local, and not common.

The beetle is rather large and conspienous, being from 7 to $9 \mathrm{~mm}$. in length, and the whole body is of a uniform coppery colour, and being rounded, the colour varies in detail as the result of refraction; legs and antennæe red, the club of the latter somewhat darker.

\section{Gemus Pirllobius.)}

This grenus contains a large number of species, most of which may be found in the forest. They are generally got in the early part of the year, and often do considerable lamage to the foliage. As a rule, the species may be recognised by their more or less brilliant colouring. One species, viz., $P$. urtice (alneti, F.), is very common on nettles, and though not an arboreal species, might nevertheless be taken as a typical example of the genus. It is quite possible the specific distinction, as associated with forest trees, may hitherto not have been earefully recognised.

\section{Phyllobids haculicornis (fiem.)}

This beetle was discovered as doing considerable damage on recently planted trees of mountain-ash and

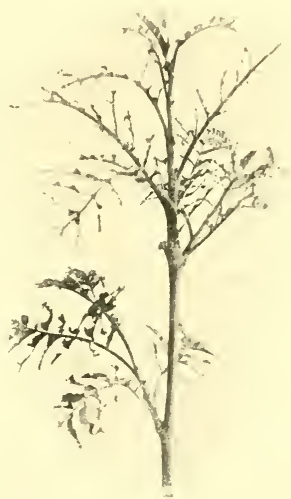

Fig. 71.-Foliege of mountrintesh eaten by Phyllobius maculicornis.

birch at Kielder, in Northumberland. In fact, the trees were quite defoliated as the result of their injuries.

On mountain-ash, fig. 71 is given as an example of the injury referred to by the beetle. 


\section{Hylobius abietis, Fabr. (Pine Weevil). ${ }^{1}$}

This is considered one of the worst insect enemies the forester has to deal with; in fact, it may be said to be the most dreaded beetle.

From an entomological point of view, it is very closely allied to the genus Pissodes, and it may therefore be well to state that the chief generic difference is that in Hylobius the antennæ are inserted on the rostrum near its apex, while in Pissodes the antennæ are inserted
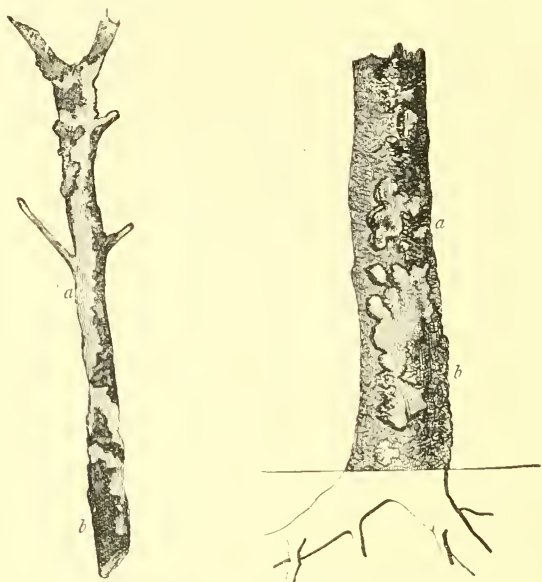

Fig. 72.-Young spruce plants gnawed by Hylobins a bietis. $a$, parts gnawed; $b$, parts still covered with bark.

about the middle of the rostrum. It is well to remember this important distinction, inasmuch as many specimens of Hylobius abietis are very small in size, and may therefore, to the non-entomologist, be confounded with specimens of Pissodes pini, more especially when fouml in fresh sawdust, and apart from the respective injuries with which they are associated.

The pine weevil is injurious in the perfect state alone, chiefly to young coniferous trees from four to seven years old. Older coniferous

${ }^{1}$ As there is only one species in the genus, generic characters need not be given. 
trees do not suffer so severely, but they have been known to attack young hardwoods, more espeeially when mixed with coniferous trees. They eat the tender shoots, both bark and eambium, in such a manner as to present an appearance of rabbit damage (fig. 72). In our country the plants most used for planting are abont three to four years old, and when such are attacked after being recently planted it is obvious they are not strong enough to resist the injuries, and the eonsequence is that many die off, and expensive replanting has to be resorted to. When the bark of older trees is eaten the injuries are not so severe. The weevil is espeeially fond of young shoots, and the vital cambium is therefore eaten with the bark.

The beetle (fig. 73) is a dull black colour, but brightened by several fairly large yellow spots on the elytra, which eollectively form irregular bars. There are also a few yellow scales on the thorax. The rostrum is very stout, with the antennre inserted at the apex. Legs black, and femora armel with a strong stout spine. Length from 8 to $14 \mathrm{~mm}$.

As regards the life-history of this inseet, it affords a very striking contrast to the life-history of some moths, as, for example, those which appear and disappear within cer-

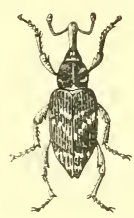

$\alpha$

Fig. 73.-Hylobius abietis (pine weevil). $a$, beetle (natural size); $b$, larva (natural size); $e$, pupa (natural size). (From 'The Forester,' by J. Nisbet.) tain prescribed dates. The pine weevil may, with special entomologieal knowledge, be found in all stages throughout the year. This fact, together with an unworked life-history, led to great diversity of opinion. Thus Altum, who carefully studied the species, maintained that a generation required two years for its complete development, while Eichhoff consiclered it more probable that there were two generations in a single year. This point has now been deeided by Von Oppen, who has done very valuable work by working out its life-history from observations carried on under eireumstances approximating to its natural conditions. As a result of his careful investigations, he found that the beetle was endowed with great vitality (extending over two years), and further, that it has the power of re-eopulation and repeated esgdeposition. Hence this would account for the insect being found in all its respective stages at one and the same time. A single gener- 
ation, however, takes about fifteen months for complete development. The beetles swarm, or rather leave their winter quarters, about the

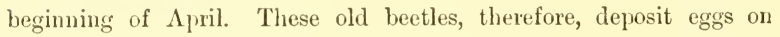
the roots of trees which have been felled about two or three years. The larve hatch out in about three weeks' or a month's time, and feed until about May or June of the following year. They then pupate for a short time, about three weeks being considered the regular period, and appear as perfect beetles about June or July. The late swarmers are comparatively harmless, as they soon hibernate under rough grass and heather, ready to do double duty the following year. The larve commence eating just under the bark, but do not reach the bottom of the bark and the surface of the wood until about the end of September. Then for the remainder of their feeding-period they make long winding galleries.

It may be noted that there is a common opinion that the insects lie for three years in the larval stage, and therefore it is alvisable to give the ground three years' rest in consequence. The amount of rest is quite practicable, but I am, from personal examination, of opinion that they rather prefer attacking the roots that have been cut for three years, and only live for a season in the larval stage.

\section{Preventive and Remedial Measures.}

As this is a very destructive beetle, it is advisable that, as far as practicable, the insect should be kept well in eheck.

As regards dealing with the beetle, the only remedy is collecting and destroying. Success in this respect will greatly depend on the method of local work and its associations. My own experience has been in connection with cutting a portion of a large tract of pure Scots pine every year with a movable sawmill in the wood, and also replanting a portion of the gromd ammally. $\Lambda$ t first the replanting was done on the heels of the cutting, and the result was that the plants were eaten off wholesale, and replanting had to be adopted. In the summer season the sawdust hole was carefully examined every morning and the beetles from the fresh sawdust destroyed. So much for beetle destruction. Now as regards the destruction of larve. In the winter season all branches accruing from the trees felled in summer were burned on the ground, and as many fires as possible made on the 
stools of felled trees. This had the effeet of destroying the breedingplaces. When the fires were in progress they were greatly augmented by loose heather and other rubbish on the ground. This to some extent had the effect of reducing the eongenial conditions for the hibernation of the prospeetive beetles during the coming winter; and finally, when the buming was completed, the land was temporarily fenced and stocked for three or four years with sheep and cattle. This had a remarkable effect, inasmueh as the bark was removed from the roots, thus utterly destroying the breeding-ground for the larva, and altogether improving the soil for the future planting.

It is obvious, however, that this method ean only be adopted where fir woods are on a large scale. If, however, sulden replanting has to be done with coniferous trees, where a mixture of pine-trees had formed the previous erop, it would be well, if at all practicable, to uproot the pines, or otherwise render the roots unfit for breeding-places. Trenches might be made in the ground, and fresh sawdust scattered in them; or otherwise, lay pieces of fresh pulled bark on the ground, rough bark upwards, to act as traps for eatehing the perfect beetles.

\section{Genus Pissodes.}

This genus is very elosely allied to the foregoing. The genus Pissodes contains two species in this country-viz., P. pini and $P$. notatus; but there are several species found on the Continent, and it may therefore be some inducement for British workers to keep a sharp look-out for additional species, together with their respective injuries.

So far as our present knowledge goes, it eamot be said that the Pissodes ean be compared with Hylobius as regards forest injuries, inasmuch as the former in the larval stage confine their attacks to sickly trees, and in the perfect stage gnaw at the tips of young Scots pine trees, but are not injurious in any appreciable sense.

The structural details of the genus are well described by Dr Stewart MaeDougall : ${ }^{1}$

"The species belonging to this genus have a longish rostrum. Near the midlle of the rostrum the elbowed antennæ are inserted, their

1 "The Biology of the Genus Pissodes." Proceedings of the Royal Society of Edinburgh, vol. xxiii. 
long basal joint almost reaching the small, slightly-projecting eyes. The prothorax is narrowed in front, and its posterior margin, on examination with a lens, may show two slight excavations. The scutellum is round and raised. The elytra quite cover the abdomen. Femur untoothed, tibia straight, and with a eurved hook at the point. The third joint of the tarsus is broad and two-lobed, and the terminal fifth joint ends in two simple claws."

\section{Synopsis of the Species.}

I. Size laryer: thorix short in proportion with the sides, more rounded; elytra with narrow transverse band behind the middle . . . . . P. pini.

II. Size smaller: thorax large in proportion with the sides, less rounded; elytra with a broad though not over-distinet transverse band behind their middle . . . P. notutus.

\section{Pissodes pini (Limn.)}

This species is very closely allied to Hylobius alietis, and to the young student very mueh like small specimens of the latter, inasmuch as both species may be found together in the mornings in the fresh sawilust pit underneath the circular saw. Where a temporary sawmill is erected in a scots pine wood, it may be well to try and distinguish the two species. As many specimens of $I I$. alretis are comparatively small, it is well, for the sake of distinction, to bear in mind that the chief difference lies in the position of the antennæ. In $H$. alietis, as already mentioned, the antenne are inserted on the rostrum near its apex; and in the genus Pissodes the antennæ are inserted about the midille of the rostrum.

Apart from the sawdust heaps, this species is fomd most abundantly in the larval stage. As a rule we may look for the larve in dead stanling Scots pine-trees from twenty to thirty years of age, more especially under the rough portion of bark. At times they may be found on cut trees lying on the gromend, but not so plentifully as on dead standing trees. Nitsche gives spruce and Weymouth pine as food-trees. In the winter season the presence of the larvæ may be recognised by the bark being very much torn about, from the ravages of insectivorous birds in seareh of the larvæ as food. 
As the larve are always found on baek-going or dead standing trees, this species eannot be considered as direetly injurious. It would therefore appear, on first consideration, that the forest should not only be kept free from dead trees, but also that all heavily suppressed trees, showing distinet symptoms of death or premature decay, should be cut. This principle, lowever, pushed too far, would not be in keeping with first-class forestry, inasmuch as mulroken eanopy must be maintained throughout the perior of growth, more especially in youth and middle age, and dying or recently dead trees are quite useful for estate purposes, provided proper creosoting be adopted. Fig. 74 is from a photograph of eocoons on dead standing trees underneath the bark.

The life-history of the genus has been most carefully worked out by $\mathrm{Dr}$ Stewart MacDougall, who proved from both observation and actual experiments that the dates of appearance of perfect insects were variable, as also the period of time required for larval and pupal duration itself. In Northumberland the perfeet beetles emerge most plentifully about the middle of July.

The female beetle lays her eggs in the bark, and the larvæ hateh soon afterwards. At first the larvæ move from the egg-ehamber in

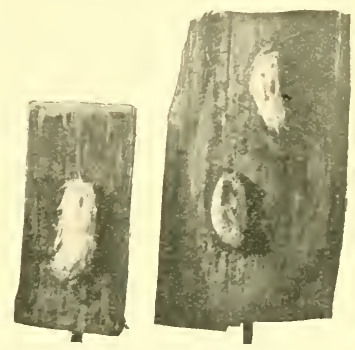

Fig. 74.-Coeoons of Pissorles pini on stem of Scots pine (reduced).

different directions, forming a sort of star, but later on the markings appear in long, broad, irregular lines, generally running lengthwise with the stem.

The larval markings are, as a rule, most conspicuous on the bark. After the larva is fully fed it seoops out a chamber in the stem, and covers itself over with the seooped-out chippings. Each larva makes a chamber for itself, and those specimens which are fully fed in the autumn pass the winter in the larval stage, pupate in the spring, and appear as beetles during the summer. The chamber acts as a double means of proteetion, inasmuch as it minimises the attacks of insectivorous birds, and also shields the creature from injuries when the loose bark is removed from the stem. 
The larva is a white, fleshy, legless, wrinkled grub, with brown head and strong jaws. It generally is in a semicireular form, and about half an inch in length.

The beetle (fig. 75) is dark pitchy-brown in colour, and sparsely sprinkled over with yellow scales. The rostrum is longer than the thorax; antennæ terra-cotta colour, with darker club. Thorax roughly punctured, with a distinct raised middle line; elytre deeply punctured, broader than the thorax at its base. On each elytron there are four yellow spots, two in front and two behind the middle. Length about $\frac{3}{8}$ inch or 8 to $10 \mathrm{~mm}$.

\section{Pissodes notates (Fabr.)}

It is very doubtful if this insect is so common as entomologists maintain. Fowler gives "Chat Moss, near Manchester; sunderland,

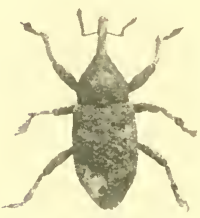
Fig. 75.-Pissodes pini
(enlarged). probably introduced in scotch timber-laclen ships," 1 and "Scotland, rare Highlands, on Scotch firs Dee and Moray districts." 2 Personally, I have not found it in this country, but found it in lelgium, Angust 1905, near the roots of Scots pine stems from five to eight years of age. Fig. 76 is a very good representation of the cocoons. It often happens that in plantations of pure Seots pine from four to ten years of age, many plants die off, just as we wish them to be protucing close canopy. Numerous suggestions have been given from time to time that the deaths referred to are due to fungi, but it is just probable that they die off in consequence of being badly handled in the nursery, or very badly planted by the noteh method, and therefore having their roots twisted. I have examined many dead Scots pines of the type referred to in Northumberland with a view to finding $P$. notatus, but so far the search has been unsuceessful. Dr R. Stewart MacDougall found that imported German specimens were spreading in Scotland, so that it is probable we might have an attack through insects having been imported in pit-props or other materials.

1 P. gyllenhali, Schön., and P. piniphilus, Hbst., are introduced.

2 It has been taken at Woking and Bournemouth by Commander Walker. 
As the genus Pissodes has been so admirably worked out by Stewart MacDongall, I take the liberty of quoting the following conclusions, which have important biological and practical bearings :-

" 1 . The Pissodes have a remarkably long life in the imago stage. This long life is characteristic of both sexes.

"2. Copulation and egg-laying are not single acts which, once aceomplished, terminate the life of the individual, but both may be often repeated. The same individuals which have paired and bred in one season may, after hibernation, still further proceed to a new season's reproduction.

" 3 . Hihernation takes place in the month of November, and in a season of average temperature ends in Mareh, in exceptionally mild weather even earlier.

"4. Egg-laying takes place in all months from April (in a very favonrable season, even in Nareh) to September inclusive.

"5. As adult beetles may be met with during all this period, the length of time necessary for individual development loses some of the significance that up till now has been assigned to it in relation to exterminative measures, because a comparatively limited flight-period leeing disproved, corresponding limited and

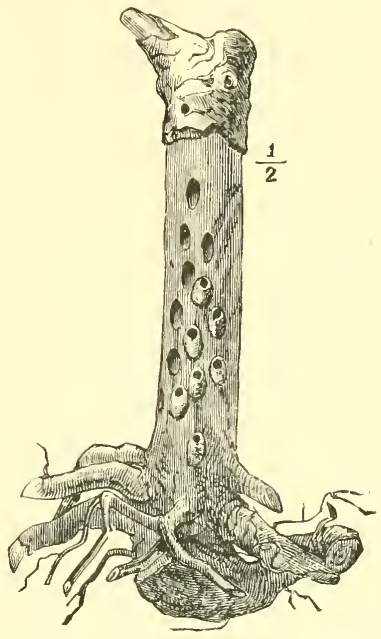

Fig. 76. - Foung pine-stem barked to show munal. bids of Pissodes notatus. (From "The Forester,' by J. Nisbet.) definite swarm-periods can no longer be relied on.

" 6 . Still, limiting our view to one cycle and the earliest-laid eggs of that cycle, the generation is typically a yearly one.

" 7 . As the first imagos issuing in the summer, as a result of eggs laid earlier in the same year, are not immediately able to proceed to an efficient copulation, but require some time for ripening, there is little likelihood of there being in our climate two generations in direct descent in one calendar year."

As regards remedial measures, however, they are very simple, 
inasmuch as all attacked trees are generally in such a back-going condition that the forester should, as far as practicable, cut them out of the wood as soon as the attack is observed.

\section{Genus Orchestes.}

Antennæ distinctly bent, and inserted behind the middle of the trunk; head small, and the upper surface almost entirely occupied by the eyes, which are only separated by a narrow bend; thorax very small in proportion to the abdomen. Seutellum small but distinct. Elytra long, and well covering the pygidium ; femora strongly developed.

\section{Orchestes fagi (Linn.)}

The Orchestes fagi, or beech-leaf miner beetle, is, as its name implies, very destructive to the foliage of beech-trees. The most conspicuous portion of the damage is that done by the larvæ, which gives the tree the appearance of having sufferell severely from late spring frosts. In fact, even practical men often erroneously attribute the injuries to frost. There is, however, this practical distinction between the two--viz., that frost generally shrivels up the entire leaf, whereas the injuries done by this beetle only affect one-half.

The beetle hibernates during the winter months under fallen leaves, in the crevices of bark, or, in fact, under any rough cover. It makes its appearance on the first warm days in spring, simultaneously with the opening of the leaves. It does not expose itself very much during the day, but in the night-time moves on to the young leaves, in which it euts small circular holes, giving the foliage the appearance of having been shot at. The female deposits her eggs in the midrib, ancl as a rule about half-way down. The eggs hatch in about ten days, when the larva immediately makes a straight cut across the leaf to the outer edge, but generally in the same direction as the lateral veins, so that it lands near the apex of the leaf. It then turns inwards, and eats a fairly large portion of the parenchyma, thus exposing the epidermal skins, and causing the large bloteh referred to (fig. 77). The small, straight, larval track from the midrib to the outer edge is very important, inasmuch as its method is entirely confined to Coleoptera, and is a decided mark of distinction from the injuries caused by Hymenoptera, \&c. The larvæ are full fed in 
about twenty days. Then they pupate in a small white cocoon within the leaves, and come out as perfect insects in about another fifteen days' time.

In 1904, at Alnwick, Northumberland, the eggs were deposited about 1st to 10th May, and the insects first appeared about June 24. On account of their pupating within the leaves, they are very easily hatched artificially.

The larva when full fed is about one-third of an inch in length, creany white in colour, and has a rather flattish brown head.

The beetle is about an eighth of an inch in length, of a slaty-black colour, with grey pubescence, and rather coarse lines of puuctures on the elytra. The legs and antennæ are bright brown in colour, and the femoræ of the hind legs are well

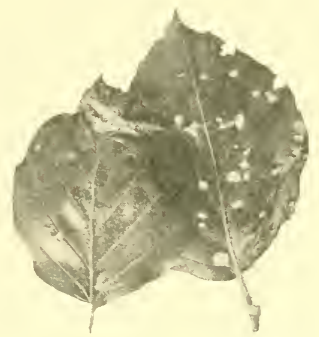

Fig. 17.-Beech lenves showing injuries done by larva and holes eaten by beetle (Orchestes fagi).

developed, which enables the creature to jump when startled, and this characteristic, together with the ample wings, which they can readily use, enables the creatures to get out of the way very rapidly.

The worst damage I have ever seen done by this insect was in Gibside, Co. Durham. This was pointed ont to me by my friend Mr R. S. Bagnall. The foliage of the old beech-trees looked as if it had been riddled with showers of shot: not a single leaf had escaped.

\section{Orchestes quercus (L.)}

This species is often found on oak leaves, and is red or brownishred in colour, and the body elothed with a silky yellowish pubescence. It is generally found on the leaves of suppressed or over-shaded trees, and if extremely abundant, imparts a yellowish tinge to the body of the foliage.

\section{Orchestes alni (L.)}

This species is somewhat variable in colour, and those specimens I have hatched out were from elm leaves collected in a Surrey lane. They were of the variety which had reddish elytre, with darkish head and thorax. 
This genus is well worth eareful study, more especially as they prefer an arboreal diet; and having regard to their habit of pupating within the skins of the injured leaf, they ean be very easily hatehed artificially. The small size of the inseets themselves, and the necessity of magnification for the diserimination of specifie characters, give

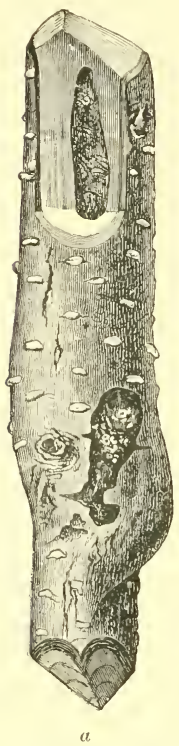

a

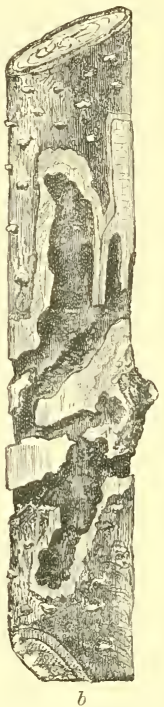

Fig. 78, a, b.-Larval burrows of Cryptorrhynclus lapathi in alder stems. (From 'Forest Protection,' by W. R. Fisher.) an additional interest to the study of the genus.

The student should make a eareful study of the specifie characters as given by Fowler.

\section{Genus Cryptorrhynchus.}

Seutellum large and distinetepisterna of metasternum not covered by elytra and well developed. ${ }^{3}$

\section{CRYPTORRHYNCHLS LAPATHI} (Linn.)

This inseet is often found in the south of England, doing considerable damage to alders of the black and white varieties, willows, poplars, and birch. It generally attacks alclers in preference to the other trees, and prefers young trees from four to six years of age. $^{2}$ The insect is injurious both in the larval and perfeet forms. The beetle eats the bark and sapwood of young shoots, and the larva gnaws under the bark, sometimes penetrating into the pith, thus doing considerable damage to the young stems-so much so, that they break off and die. Fig. $78, " l, l$, shows typieal damage.

The beetle flies about the end of April or beginning of May. The larvæ are said to appear in about fourteen days after egg-laying, and

${ }^{1}$ Fowler, vol. v. p. 328.

${ }^{2}$ Commander Walker has always found it in and about osier-beds. 
the beetle emerges in autumn, and winters either in the galleries or under moss.

The beetle, fig. 79 , is from 7 to $8 \mathrm{~mm}$. long, and is very characteristically coloured. The prevailing colour is black, with a distinct variegated band of pinkish-red at the base of the elytra, and with a more or less distinet band across the middle of the elytra. The whole body is covered with rather coarse, imbricate, yellowish-white scales. The rostrum is stout, and can be folded into a depression under the thorax.

As regards remeclies, it will obviously be the best means of extermin-

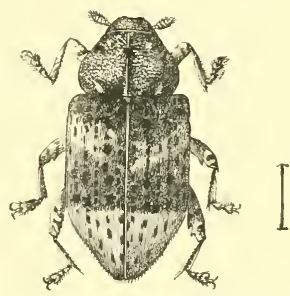

Fig. 79.-Cryptorrhynchus lapathi. (From 'Forest Protection,' by IV. R. Fisher.) ation to eut down the infested shoots containing the larva or perfect beetles, and burn them.

\section{Genus Balaninus.}

This genus contains several species which are all arboreal, and therefore of special interest to the student of forest entomology. The species $B$. nucum may, however, be taken as typical of the geıus. The most remarkable generic character is the very long, slender rostrum, which varies in length according to the species, but is often longer than the whole of the remainder of the body. The length of the rostrum enables the insect to pierce filberts, aeorns, wahnuts, ice, in which they deposit their eggs.

\section{Balaninus nucum, L.}

It often happens that on eating filberts or hazel-nuts we either find a very large white grub, or otherwise a hollow shell con-

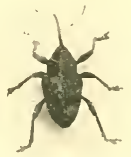

Fig. 80.-Balaninus nueum (enlarged). (Photo by A. Flatters.) taining frass or powder. Those grubs are the larvæ of the nut weevil.

The beetle, fig. 80, is easily recognised by its very long snout (being longest on the female) and elbowed antennæ. The whole body is dark-brown in colour, but brightened by variegated markings and short depressed hairs. Length 5 to $7 \mathrm{~mm}$. 
The beetles appear early in spring, and may then be beaten from the bushes. The female bores a hole with her proboscis in the very young nut, and then deposits an egg. In a short time the grub hatches out, and feeds on the fleshy portion of the nut. When full fed in the autumn, the larva leaves the nut and pupates in the soil, appearing as a perfect beetle in spring.

When filberts or hazel-nuts are considered of importance as fruit, the pest may be kept in check by beating the perfect beetles into

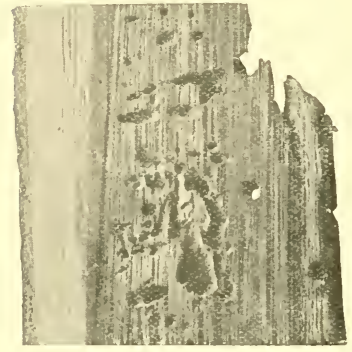

Fig. 81.-Fortion of beech timber illiured by Rhopalomesites Tardyi. a sheet or umbrella in spring; or the infested nuts, so far as they can be recognised, may be gathered before the escape of the larvæ and burned.

\section{Genus Rhopalonesites.}

\section{Rhopalomesites Tardi (Curt.)}

This beetle is considered almost exclusively an Irish species. It is injurious to half-dead beech timber, and it may therefore be said that it considerably hastens its decay. Fig. 81 is a representation of the damage done to half-lecayed beech planking. I am indebted to Professor Carpenter, Dublin, for the specimen from which the photograph is taken. ${ }^{1}$

\section{References to Literature consulterl.}

Altum. Forstzoologie, iii.

Carpenter, G. H. Entomological Papers.

Fisher, W. R. Forest Protection.

Fowler. British Coleoptera.

Judeich und Nitsche. Forstinsektenkunde.

Kaltenbach, Die Pflangenfeinde.

MacDougall, Dr R. Stewart. The Biology of the $e_{y}^{r}$ Genus Pissodes.

Nisbet. The Forester.

Niisslin. Leitfaden der Forstinsektenkunde.

Ormerod, E. A. Manual of Injurious Insects.

Packard. Insects Injurious to Forest Trees. U.S.A.

Rye. British Beetles.

Theobald. The Animal Pests of Forest Trees.

1 Comparatively rare in England. Commander Walker has taken it at Plymouth, and has it from the Hastings district. 


\section{CHAPTER III.}

\section{COLEOPTERA—SCOLY'TIDE (BARK-BEETLES).}

From the point of view of forest entomology, one of the most important groups of insects is that of the beetles known as Scolytidæ, inasmuch as they are practically all tree-feeders. As a general rule, they attack only dead, dying, or back-going trees, and therefore it is possible that, from a purely economic point of view, their importance may have hitherto been over-estimated by many writers. At the same time, there are a few exceptions to this general rule. For instance, in one stage of its life-history Hylurgus (Hylesinus) piniperdu attacks the healthy shoots of Scots pine trees; and Pityogenes bidentatus often attacks sickly and unhealthy young trees, and thus kills outright what otherwise would have recovered.

Many of the beetles are exceedingly small in size, which fact, coupled with their minute structural points, makes them of great interest to the working entomological microscopist.

In a general way the bulk of this family are known as bark-borers, and the Germans consequently call the whole group "Borkenkäfer," or bark-beetles. But this is only a general term, for, as a rule, the majority bore deeper, and leave their impressions, or all-important markings, just under the bast, and immediately over the surface of the wood. Others, again, bore directly into the timber, but, as a rule, these wood-boring species confine their attacks entirely to the sapwood, and rarely penetrate into the heart-wood. Thus we have, in a general way, three divisions-viz., those which bore into the bark, those which work on the surface of the wood, and those which bore directly into the timber. So far as elassification is concerned, we cannot make any arbitrary divisions, but the characteristic markings themselves are about as suitable data for the discrimination of species as it is possible to get. 
As the respective genera and species show variation in life-history and markings, it would perhaps be well for the student to study the salient features of a typical bark-beetle, as regards the formation of a brood, and its subsequent life-history.

With regard to the formation of the lrood, there is one important point to be noted-viz., that some genera are monogamous, whilst others are polygamous. In the case of the former, the initial operations are always conducted by the females, whereas, in the latter, they are always made by the males.

Take a typical monogamous species. Both sexes hibernate during the winter months, but the female awakes first, and betakes herself to a suitable tree, where she scoops out a small chamber, and then takes a sort of nuptial flight, as it were, for she returns generally accompanied by the male, and copulation takes place either within the chamber or immediately outside it. The female then commences her work in earnest. She makes a straight tunnel, and deposits eggs right and left alternately. Her presence can always be recognised by the frass, or bore dust, made by the workings, which is deposited outside the burrow. The male is generally found just at the entrance of the burrow. As the female moves along, she often makes little bore-holes over her tumel, for the purpose of ventilation.

In due time the larvæ hatch out, and moving along their respective galleries, which broaden according to larval growth, they finally scoop out a chamber, and then pupate. It is important to note, as we shall consider presently, that it is the particular angle made by the junction of the larval with the maternal galleries which gives the peculiar markings of the respective species. The fully formed beetle eats its way through the bark, which, after the swarming or flight period, looks as if it had been riddled with shot. The holes made by the exit of the beetle can, however, by careful inspection, be distinguished from those made by the mother for ventilation, as the latter are always made over her own tunnel.

In those cases where the initial operations are conducted by the males, the excavation is a sort of circular chamber, where several females, generally from four to six, assemble, and within which copulation takes place. Hence it is called by the Germans "Rammelkammer," or brood-chamber. The females then make their respective galleries, all radiating from the brood-chamber. The male very 
soon afterwarls dies. In nearly all cases the female clies at the end of the burrow, after the deposition of eggs.

In a general way the appearance of many species of insects is very much aflected by climatic conditions, and the Scolytide are especially susceptible to the influence of weather. Thus the first appearance of the hibernating species in spring depends on the warmth and sunshine. The weather also affects the swarming of the brood, and the colour of the beetle is therefore sometimes variable, as specimens which swarm soon after changing from the pupal to the perfect stage are light as compared with those fully developed specimens which, on account of unfavourable weather, have had to remain for a considerable time within the fool-plant. The markings, too, are sometimes affecterl, as the perfect beetles, in their quarantine stage, often make markings beyond the pupal recesses.

These remarks apply to the markings of a typical bark-beetle; but the student, we repeat, must make a very careful study of the markings, because they are so definite in character that from them alone the species can always be determined.

It must also be borne in mind that there is a sharp and definite distinction between certain species which feel on conifers and others which feed on hardwoods, inasmuch as we never find coniferous feeders living in hardwoods and vice versâ. This distinction, however, applies to species, and not to genera. For example, take the genus Cryphalus. Thus $C$. abietis and $C$. picece feed on spruce and silver fir respectively, while $C$. fagi and $C$. titice live on beech and lime.

The various parts of the tree itself also harbour different species, and therefore several species may be found on one tree. Take, for example, a comparatively young Scots pine tree. In the top twigs we may have Pityogenes bitentatus, and in the smaller branches Hylastes palliatus. The stem may harbour Hyluryus (Hylesinus) piniperda, and the root-surface Hylastes ater.

The mother-gallery is a most important character, and no illustration is quite complete unless it is shown. The mother-gallery, as a rule, is either perpenticular or horizontal - that is to say, it is perpendicular when running in the same direction as the standing stem, and horizontal when rumning across the direction of the standing stem. The mother-gallery may be either single- or doubie-armed, and in working she makes one arm at a time.

A more detailed consideration of the galleries or markings may now 
be made, taking the very lucid diagrammatical plate from Judeich and Nitsche. In fig. 82, a, we get a simple single-armed mother-gallery,
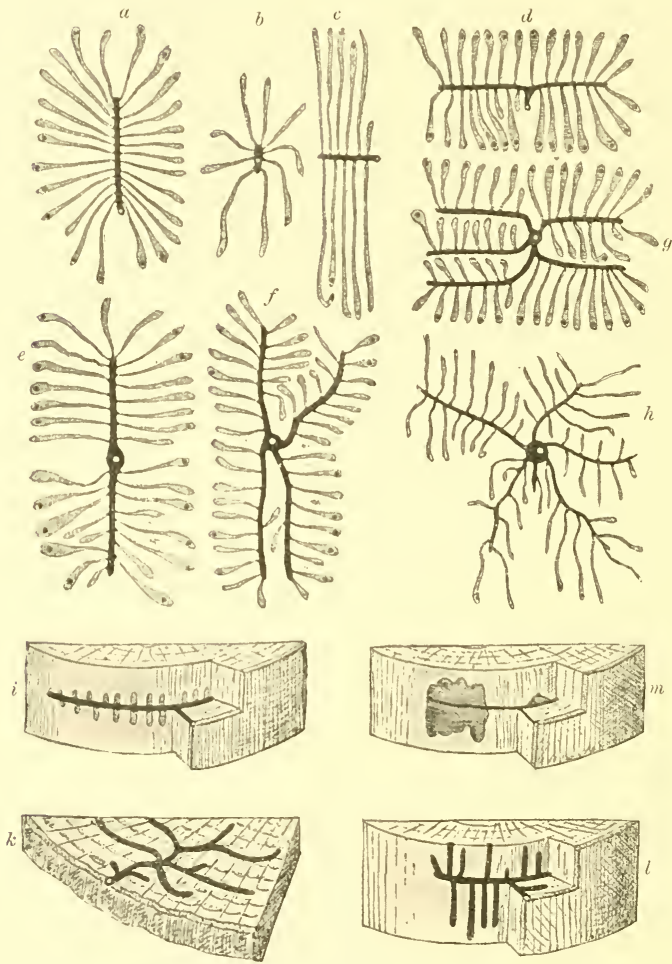

Fig. 82.-Typical workings of Scolytide.

«, Single-armed mother-gallery, showing equal larval galleries and pupal recesses; $b$, short mother-gallery and radiating larval galleries; ${ }^{2}$, simgle-armed short horizontal mothergallery and long right-angled larval galleries; $d$, donble-armed horizontal mother-gallery with right-angled larval galleries; $e$, two-armed mother-gallery of a polygamons siecies; $f$, four-armed mother-gallery of a polygamous species; $g$, five-armed mother-gallery of a polygamots species; $h$, star-gallery of a polygamous species; $i$, larkler-gallery of a woodboring species; $k$, forked mother and larval galleries; $l$, an irregular ladder-gallery; $m$, a fanily gallery. Copied from Judeich and Nitsche.

with the larval galleries radiating slightly from the mother-gallery. 
If we take, therefore, the milldle of the mother-gallery as a centre, we shall see that the larval galleries, in a geometrical structure, somewhat resemble the stones forming an areh, inasmuch as they all radiate from a common centre. In fig. $82, b$, we have a very short mothergallery, with radiating larval galleries. In fig. $82, c$, we have a singlearmed mother-gallery and right-angled larval galleries.

In fig. $82, d$, we have a double-armed horizontal mother-gallery, with practically right-angled larval galleries. In fig. $82, e$, we have similar mother-galleries of a polygamous species. In fig. $82, f$, we have a four-armed mother-gallery, with right-angled larval galleries.

In fig, 82,9 , we have practically a repetition of $82, b$, exeept that the mother-galleries are horizontal.

In fig. $82, h$, we have a star gallery formed in a slightly different way, inasmuch as the cireular central portion is made by the male, and the female galleries radiate from the male chamber, while the larval galleries again radiate from the mother-gallery.

In the foregoing it should be noted that all the young beetles finally leave (swarm) by gnawing new flight-holes; but in the remaining figures, as representing distinct wood-borers, the young beetles finally leave (swarm) through the old bore-holes.

In fig. 82, $i$, we have a "ladder gallery" in wood, where the mothergallery is horizontal and the larval galleries perpendieular. The larval galleries are very short, as in Trypodention lineatum.

In fig. $82, k$, we have forked mother and larval galleries, making collectively a sort of gallery of pipes, as it were, on a comparatively even plane, as in T. monographus. ${ }^{1}$

In fig. 82,1 , we have a representation of a horizontal mother-gallery and perpendicular larval galleries. It may be considered as illustrative of T. dispar:

In fig. $82, m$, we have a representation of a family-gallery, as in $T$. Saxesenii.

The generations of the Scolytilæ are very variable. In the German literature we note two or more broods per year of a species which only produces one brood in the north of England; and again we get some. times two broods per annum of a species in the south of Englanul which only produces one brood a-year in the north. These variations are by no means universal, but the student must be eareful to note them.

1 This species is not found in England. 
The general structure of the beetles themselves is somewhat peeuliar. The most salient feature, which gives the Scolytilæ their particular form, is the shape of the thorax, which is nearly always of equal breadth with the elytra; and in several genera the thorax also acts as a sort of hool which eovers the hearl, and thus, looking at the ereature, the heal itself is very often invisible. Hence, when looking at the beetle, it may be noted that the visible portions-namely, thorax and abdomen-present together a sort of oval or cylindrical form. In many speeies the elytra have anal hooks, which are oceasionally of importance in determining species.

The unter side of the abdomen is sometimes of considerable import-

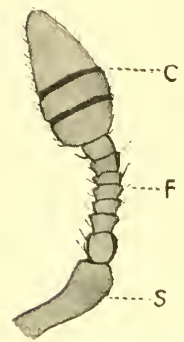

Fig. 83.-Antennu of Hylesinus crenatus. (Camera - lueida sketch.) ance, as one or more of the segments may have special projections, as, for example, in Scolytus multistriatus.

As regarls special struetural details, the mandibles are stout, eurved, or slightly toothed. The antennæe are short, inserted between the eyes, and form good points for the diserimination of species. They are liviled into three parts - fig. 83: the elub (c), the funiculus (F), and the scape (s). In German literature these parts are known by the names of club, whip, and shaft respectively. The eyes are of special interest, inasmuch as they may be of one body deeply cleft in the midille, or otherwise distinctly divided into two parts. The legs should be earefully noted, as in many species they are too small for examination by a good lens, and form interesting objects when prepared as mieroseopic slides. They are, as a rule, short and stout in all the respective parts, with toothed femur and a five-jointed variable tarsus, which is terminated by a clouble claw.

The larve are fleshy white or yellowish white, with pale yellowish head. They are footless, and broadest at the heal, tapering towards the anal segment. The respective species camnot always be recognised by their structure, but many speeies may be distinguished by their hahits and the nature of their galleries. The pupæ are, as a rule, pale white, and show all parts of the perfect inseet.

To the physiological biologist this group may, on the principles of Natural Sclection, be considered as of special interest as presenting 
some very suggestive points. For example, the white, footless, tapering larve associate the thought of adaptability for tunnelling; and the eireular form of the body, the short antemne, buried head, and stout legs of the adult, eloquently proclaim the suitability for boring and elearing out the bore dust without injury to, or obstruction from, the appendages.

There is also another very suggestive problem-viz., the assoeiation of the male and female in the same burrow. It has been noted that eopulation may take place outside the main entrance or, as a rule, just inmediately inside the entranee, where a special chamber, known as the chamlire de copulutrix, is formed. After fertilisation the female makes a burrow, in which she deposits eggs right and left in miniature recesses. The male remains hehind, and either guards the female or the eggs against natural enemies, or elears out the frass or bore dust exeavated by the female. In a single-armed gallery the sexes may therefore easily be determined by position, inasmueh as by following up the gallery from the entrance we come first upon the male, and afterwards the female. Such is the method in a single-armed gallery; but in many cases the gallery is double-armed, and the female works one arm at a time, then retires and works the other arm. Now, why this double arm? and why this seeond working shift? Is it possible that it may be for re-copulation? We know that in some insects this is an essential for reproduction, as, for example, in the ease of Hylotius abietis, and it may be possible that sueh is the ease in certain speeies of Seolytidx. This is only a suggestive thought, but doubtless much may be learned by observation in this sphere of entomology.

As regards general measures for getting rid of the beetles, various suggestions have been offered; but seeing that, as a rule, they only attack dead or dying trees, it is obvious that the best preventive measure would be, either to keep the plantations as healthy as possible or to get rid of the dead and dying trees. Branehes should always be burned, and, as far as practicable, when the inseets are in the larval stage.

With a view to collecting the beetles for the purposes of scientific stuly, it is well to eut down certain trees or branches and leave them on the ground, to aet as decoy stems or traps; and in searehing for certain speeies it is often advisable to look on the under side of the branch and in places where the ground is rather moist,-moisture 
being often an essential condition,-though, as they are rather fastidious as to the amount of moisture, it would be useless to look for them in extremely wet places.

\section{SCOLyTide.}

The family is divided by Fowler into the following sub-families -viz. : ${ }^{1}$

I. First joint of tarsi (or metatarsus) much shorter than the remaining joints united; sides of thorax not emarginate for the reception of the legs; eyes oblong or divided; head never broader than thorax . . . Scolytinæ.

II. First joint of tarsi (or metatarsus) almost as long as the remaining joints united; sides of thorax enrarginate for the reception of the legs; eyes romd, subconvex; head broader than thorax

- Platypodinæ.

\section{SCOLYTINe.}

This sub-family embraces the whole of the genera of Scolytidæ, with the exception of Platypus, which is a genus containing a single species. The whole of the other species in the family are divided by Fowler into the three following tribes:-

I. Thorax not prolonged over the head, which is always in part visible from above, and is terminated by a short snout; thorax without any marked asperities on its anterior portion; third tarsal joint nearly always bilobed.

A. Abdomen strongly raised obliquely from near apex; thorax bordered at sides .

Scolytina.

B. Ablomen not, or only slightly, raised, as a rule regularly cylintrical; thorax not borlered at sides . Hylesinina.

II. Thorax prolonged over the head, which is sunk in the thorax when the insect is at rest, and is more or less globose; thorax almost always furnished with more or less distinct warty asperities in front; third tarsal joint simple

Dryocætina.

1 British Coleoptera, vol. $\mathrm{x}$. 


\section{Tribe SCOLYTINA.}

\section{Genus Scolytus.}

The genus Scolytus confines its attacks exclusively to the broulleaved trees of the forest or fruit-trees of the orchard.

The chief generie characteristics are: Knob of antennæ large, larger than the whip; eyes longish and linear; body smooth; thorax much darker than the elytra.

\section{Synopsis of the species.}

I. (1) Second ventral segment of abdomen without projection. Elytra shining, thiekly punetured; third and fourth segment in both sexes furnished with a small tubercle. Mother-gallery perpendicular. Lives in elm . . . Scolytus destructor.

(2) Thorax very finely punctured, especially on the lise. Nothergallery long and perpendicular. Generally in fruit-trees.

S. pruni.

(3) Thorax very finely punctured, espeeially on the disc. Mothergallery short and horizontal; very long larval galleries. Lives in oak. . . . . S. intricatus.

II. (4) Second ventral segment with a strong horizontal projection. Perpendicular mother-gallery. Lives in elm, poplar, cherry, plum, pear, and oak . . . . S. multistriatus.

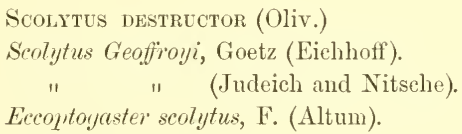

This beetle chiefly confines its attacks to elm-trees, and is therefore commonly known as the "elm bark beetle." It is a dreaded pest in elm-growing districts, as for example in many parts of the south of England and in the London parks. The perfect beetles appear about the middle of June, and the female commences her boring operations either in a newly felled trunk or an unhealthy tree. I'revious to making the burrow proper, she makes a sort of pseudo-track in a deep furrow of the bark; and as the male appears about this time, it is 
doubtless during this initial boring operation that copulation takes place. She then makes her burrow proper, which is from 1 to 1 inches in length, and therein deposits from 100 to 160 eggs. This operation is saill, as a rule, to take about three weeks to eomplete.

The markings are very characteristic, more especially when the mother-rallery is comparatively short. The mother-gallery is straight and single-armed (fig. 84). Taking, therefore, the midlle of the gallery as a rentre, it may he noter that the larval galleries do not quite

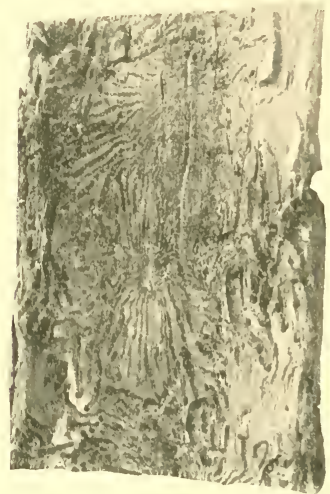

Fig. S4.-Marhings of Siolytus destruetor in lurli of Einglisi elm.

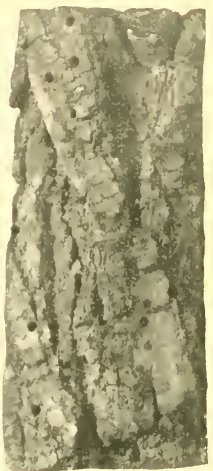

rig. 85.- Showing "exit. holes" of same.

run at right angles with the motler-gallery, but point slightly towards the extreme ents; and as we look towarls either end of the mothergallery, it is noticealle that the angle becomes more acute, and conseyuently the spaces between the extreme encls of the larval galleries widen. Hence if a line were drawn all rouml the extreme ents of the larval galleries, it wouk form an oval-shaterl figure, with the lines ratiating from the centre to the outer edge. Fig. 8.5 shows the holes whenee the beetles have emerged.

The beetle (tig. 86 ) is about $\frac{3}{6}$ of an inch in length. 'The thorax is black and shining, and the abromen light-brown. The beantiful sharp contrast of colour is a conspicuous feature, and thus affords a rapid 
means of recognition. The thorax is large, and the length exceeds the brealth. T'lue antenna and legs are ferruginous.

The larva are white, lleshy, footless grubs, with very strong chitinous head and wrinkled body. They are full-fed towards the end of July, and by the begimning of August perfect beetles may be fomml. Many of the larva pass the winter in cocoons, and appear as perfect insects in May.

As this species is very destructive, the following practical reminks regarding prevention may be quoted :-

"One of the most importint considerations, in regard to prevention of attack, is the removal of all centres of infestation, from which the heetles might spread to the somnd trees.

"The possibility of elearing away or treating infesterl standing trees or infested limbs depends, of comrse, on loeal circumstances; but whatever care is exereised in other ways, it is very mlikely that much good will be done in lessening attack, so long as the inexcusable practice eontinues of leaving trunks of infested elms lying, with their bark still on, when eontaining myriads of these maggots, which are all getting realy shortly to change to perfect beetles, and to fly to the nearest growing elms. Such neglected trunks may be seen in our parks and rural woodyards

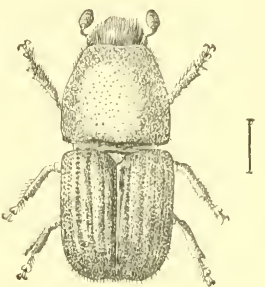

Vig. 8i. - Scolytus destructor. (From 'Forest l'rotection,'by W. R. lisher:) all over the country, where, without difficulty (as I have myself often found), the hand may he run under the bark, so as to detach feet and yauds in length from the trunk, all swarming with white Seolytus maggots in their narrow galleries.

"This hark, with its contents, ought never to be permitted to remain. Where it is loose, it may be eleared of many of the maggots by stripping it off and letting the ponltry have aceess to it; or, if still partly adhering, it may be stripned from the wood by larking tools, and burnt. Jiut if allower to remain swarming with maggots, it is a tangible and serious cause of injury; and if our landed proprietors were fully aware of the mischief thus cansed to their own trees, and those of the neighbourhood, they would quickly get rid of it." 1

1 Miss Ormerod, Manual of Injurious Insects, 1890. 


\section{Scolytus pruxi (Ratz.)}

At first sight this species very much resembles the preceding, but it is smaller, and the sculpturing of the elytra is very much finer. The thorax is shining black, and the elytra ferruginous. Antennæ and legs brown. Length $3 \frac{1}{2}$ to $4 \frac{1}{2} \mathrm{~mm}$.

This species is generally considered as exclusively belonging to the orchard, and living in plum, pear, or apple. Eiehhoff, however, says that it has been found in hawthorn, mountain ash, and elm.

Several years ago $I$ found in Cheshire very fine markings in a

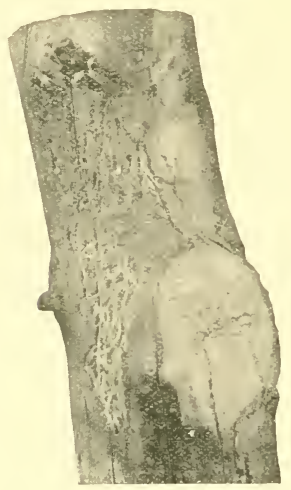

Fig. 87.-Markings of Scolytus pruni in branch of upple.

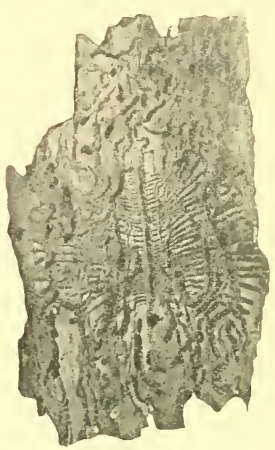

Fig. 88, - Markings of Scolytus multistriatus in bark of elm.

strong limb of wild cherry, which was doing duty as a fencing-post in a farmer's hedge, and I have since concluded that in all probability they were the markings of this speeies.

Fig. 87 is from a photograph of markings on branch of apple found in Gloncestershire. ${ }^{1}$

\section{Scolytus multistriatus (Marsh).}

Thorax black, shining, somewhat longer than broad; elytra pitehyred; antennæ and legs light-brown; elytra with close and finely

${ }^{1}$ Commander Walker has seen an apple-tree apparently killed by this species at Wolvercot, near Oxford. 
punctured stria; abdomen thickly covered with hairs, and, viewed sideways, there is a strong horizontal projection on the under side of the abdomen, which is peculiar to this species.

\section{Length 2 to $3 \mathrm{~mm}$.}

This species makes its galleries in thinbarked elm. The mother-gallery is from one to one and a half inch in length, and perpendicular with the stem. The litral galleries are approximately at right angles to the mother-gallery.

I found the piece of bark which produced the photograph for fig. 88 in Gloncestershire, and Mr Morse, Leeds, sent me insects for description.

This species is said to be double-brooded.

\section{Sconytes intioicates (Ratz.)}

The species is said not to be at all common, and only once have I found any trace of its markings in Northumberland. Mr A. C. Forbes informs me that it is common in Wilts on oak limbs broken by wind. I found the specimen which supplied the photograph for fig. 89 in Belgium, on an oak stake, and just recently I found it fairly common at Newball, in Lincolnshire. The mother-gallery is horizontal and short, being about $\frac{5}{8}$ to 1 inch in length. The larval galleries run at right angles to the mothergallery, and are about 2 inches in length.

The beetle, fig. 90, is described by Fowler as being about " $3-4 \mathrm{~mm}$. long, black, shin-

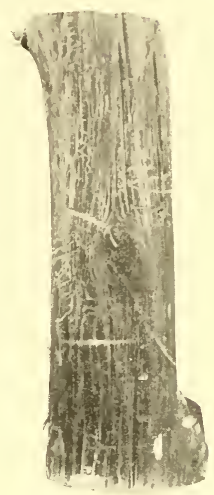

Fig.89. - Markings of Scolytus intricatus on ock pole.

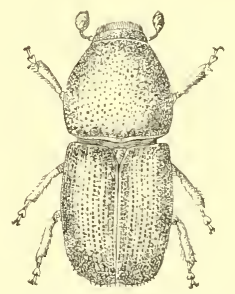

Fir. 90.-Scolytus intricatus. (From Fisher's 'Forest Protection.') ing, elytra duller, with the antennæ and legs ferruginous, and the femora and elytra pitchy brown or pitchy rec."

Altum cites a case $^{1}$ where 50,000 oaks, 25 to 30 years old, were killed by this species.

${ }^{1}$ Forstzoologie. 


\section{'TRIBE HYLESININA.}

The tribe Hylesinina is divided into the following genera by Fowler-viz. :

I. Eyes not divided; third tarsal joint nearly always dilated and bilobed.

(i) Funiculus of antemæe with seven joints.

1. Club of antennx globose or ovate.

A. Anterior coxæ contiguous ; first joint of the club of the antennæ very large, shining, the following very short .

Hylastes, Er.

B. Anterior coxa widely distant; first and second joints of the club of the antennæ large, almost equal, the following very short

. Hylastinus, Bedel.

2. Club of antennæe compressed, oblong .

Hylesinus, F.

(ii) Funiculus of antennæ with six joints.

1. Anterior coxæ narrowly separate; thorax with long villose hairs at sides; length 4-5 mm. . Myelophilus, Eich.

(Hylurgus pars, Birt. Cat.)

2. Anterior coxe rather widely separate; thorax evenly pubescent; length $2 \frac{1}{2} \mathrm{~mm}$. . Cissophagus, Chapuis.

(iii) Funiculus of antennæ with five joints.

Club of antemn oval, nearly globose, formed of four joints, fitting closely together Xylechinus, Chapuis.

(Carphoborus, Birit. Cat.)

Club of antennæ formed of three loose detached joints

Phlœophthorus, Woll.

II. Eyes completely divided; third tarsal joint entire, not broader than the preceding; antennæ with a solid ovate club, and with the funiculus five-jointed . . Polygraphus, Er.

\section{Genus Hylastes.}

This gemus is interesting to the collector, but not specially so to the forester. Fowler gives five and Barbey eight species. They can be readily distinguished by their general cylindrical appearance. The thorax is not broader than long, and has long, smooth, punctured lines, and the abdomen is practically uniform with the thorax. The 
whip of the antenne is seven-jointed, the club acorn-shaperl and not severely eompressed.

There are two species, more or less generally distributed throughout the comntry-viz., H. palliatus and $I I$. ater-which may be considered as the more important arboreal speeies.

\section{Synopsis of the species.}

Thorax not very long, and rugged at sides. Elytra distinctly regularly punetured. Centre line raisel. In stems of spruce or Scots pine. . . . . . . Hy. palliatus.

Thorax longer than broad, sides of pronotum almost equal and parallel. Centre line of thorax not raised. In stems of young Scots pine near the root. . . . Hy. ater.

\section{Hylastes palliates (fiyll.)}

The beetles libemate in dead trees, and appear about the latter end of March or beginning of April. They generally seleet sprueetrees which have been felled the previous winter, and it is best to look for them on stems of trees lying on the ground, especially where the branches have been cut off by the woodman's axe. If the woodman should have made a few false blows, and not have done his work very well, the imperfect result is an advantage to the beetle, inasmuch as the jagged pieces form a sort of lodgment, and often quite a eolony of twenty or even more beetles may be found in such places.

The larvæ appear about the latter end of April or beginning of May. The arrangement of the markings is very difficult to follow. At first the mother-galleries are perpendieular, but they often deviate, and the larval galleries may radiate in any direetion. Thus we simply get a confusion of markings.

In eomparatively large stems of spruee we generally find the markings made in the bark, but in branches of scots pine we find them on the wood. Fig. 91 is taken from a Seots pine braneh.

Eiehhofl says that this species is double-brooded. This is so in some eases in Northumberland, and often the seeond brood remains fully developed within the bark, and swarms in spring. Again, I have found that this species is often single-brooded in Northumberland, so that as regards life-history the matter requires further elueidation. 
The beetle (fig. 92) is about 3 to $3 \frac{1}{2} \mathrm{~mm}$. long, and of a darkishbrown colour throughout. The interstices are deeply, but uniformly,

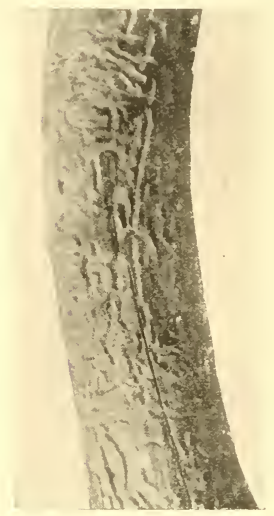

Fig. 91.- Markings of Hylastes palliatus on branch of Scots pine. resin which exules from the butt-end of the stem on newly felled Scots pine trees. Such embedded specimens are not much use for the cabinet, though they may to some extent be clarified by

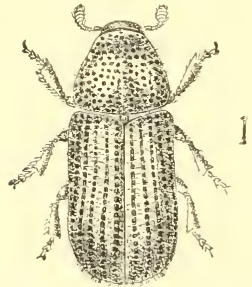

Fig. 92. - Hylastes palliatus. (From Fisher's 'Forest Protection.')

punctured, and studded with warts, so that it is slightly rough in appearance.

\section{Hrlastes ater (Payk.)}

This species is known as the black pine bast-beetle, and may be easily recognised by its uniform black colour and elongated appearance. I have found this species in Northumberland at Corbridge Fell. In the winter months it is fairly common uncler the comparatively thin bark of Scots pine logs of six to nine inclies diameter (tops left lying on the ground after removing large stems), more especially on the under side where lying in a fairly moist position. The perfect beetles, on leaving their winter quarters in early summer, are very much attracted by the immersion in turpentine. On July 3, 1907, I found a plentiful supply of this species at Corbridge Fell on a recently sawn stack of rails of Scots pine. They were moring about on the rails, but on attempting to bottle them they nearly all feigned death. The habits of this species would therefore appear to be somewhat different from the family, inasmuch as the beetles of this family generally pass their time within the food-plant.

As regards its true relation to the forest, the breeding-places proper are at the lower portion of the stems of young Scots pine trees from 6 to 10 years of age, more especially unhealthy trees, which are obviously going back, in consequence, perhaps, of the reaction from careless planting. 
The brood-gallery is very simple, of a slanting direction, and the larval galleries short and inconspicuous.

The beetle is elongated, cylindrical, black, shining, and smooth. Elytra with coarse crenate strix. Length 4 to $5 \mathrm{~mm}$.

\section{Genus Hrlesinus.}

This genus is a very important one to the student of forest insects, inasmuch as all the species are strictly arboreal insects, and the group therefore has been termed "Hylesinidæe or wood-devourers." Three of the species feed on ash and one on elm.

\section{Synopsis of the Species.}

(1) Black or dark-brown, without scales. Size large. Mothergalleries single- or double-armed; short, and horizontal. Larval galleries very long and tortuous. Found in strong bark of old ash stems . . . . H. crenctus.

(2) Variegated with greyish scales. Size smaller. Double-armed, fairly long mother-gallery, and right-angled or slightly radiating larval galleries. Lives in comparatively young ash stems or ash poles . . . . . . H. firaxini.

(3) Elytra black, with yellowish dorsal streak. Short horizontal mother-gallery; sometimes very long running larval galleries, at other times short crowded larval galleries. Lives in small branches of ash . . . . . H. oleiperda.

(t) Beautiful variegated colour. Size very small. Double-armed short mother-gallery; short larval galleries. Lives in elm.

H. vittatus.

\section{Hylesinus crexatus (Fabr.)}

This beetle is always recorded to have been fonnd in ash in this country, though two or three German writers give instances of its heing found in oak. It is also said to be widely distributed, but, so far as I ascertained, it was not at all common in Cheshire, though very common in Northumberland; and it appears to be common in Lincolnshire.

It is by no means elear that the eggs are always deposited in felled timber, though it may be looked for on recently felled old trees with 
rough bark, or on old standing trees which are consilerably past their best. It often happens with trees of the latter character that one side of the stem presents bark harder and more nearly dead than the other, aur the beetles should be looker for on the less vigorous side. The presence of a few exit-holes will often assist in revealing the abole of this species.

The life-history of this species is not quite so clear as one would wish. In some cases the generation is said to be double-brooded,

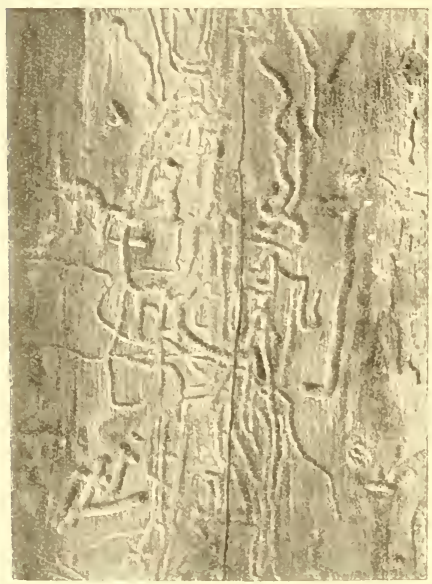

Fig. 93.-Marlings of IIylesinus crenatus on ash sten ifter removal of bark. whilst in other cases there are two generations in three years. The flight period is about the beginning of April, or about the middle of $\mathrm{Oc}-$ tober. The female makes a short, bent, and deep gallery, which is, as a rule, doublearmed, lut single-armed galleries are often found.

As a rule, the larvæ have no deciled method of making galleries, and it is therefore very difficult to accept any particular markings as typieal. This diffieulty is intensified by their boring habits, inasmuch as you may find them either in the deep bark or in the wood itself; therefore when the

bark is removed the markings found on the wood are often only part of the workings. When, however, we do find the extreme length of the workings, they are generally about 6 inches long, and often at right angles to the mother-gallery. In consequence of the extreme length of the galleries, much harm may he done to very old trees, as these galleries may encirele the stem, and thus hasten deeay. Fig. 93 is a representation of the markings of this insect.

The beetle (fig. 94) is about 4 to $5 \mathrm{~mm}$. in length, of a convex form, pitchy black thronghout, somewhat shiny, and with comparatively long antemne. The latter are often ferruginous in colour, with the shaft 
and whip elothed with long ciliate hairs. The elytra are very coarsely striated, thus imparting to the insect a rather rough appearance. The legs are generally pitchy black.

The larvæ are long, legless, white maggots, with brown heal and jaws. They pupate just immediately beneath the onter skin of the rough bark, so that in looking for the full-fed larve we must clig very lightly.

To prevent the spread of this insect, it is best to eut down all back-going old trees with very rough bark; ancl this is in keeping with gool forestry, as an ash-tree, above all others, depreciates very rapilly in value if left standing after it has reached maturity.

\section{Hylesinus fRaxini (Fabr.)}

This species is commonly known as the ashbark beetle. Miss Ormerod, in her valuable work, says: "The beetles are often attrated in large number by newly felled ash trunks, in the bark of which they propagate, and from whence the new brood spreals to

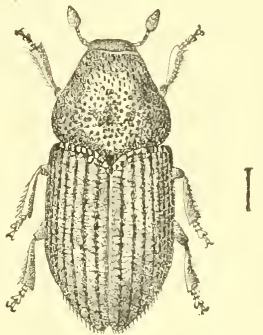

Fig. 94. - Hylesinus crenatus. (From Fisher's 'Forest Protection.") the neighbouring trees, mainly attacking those that are sickly or decayed, or young trees, which they sometimes injure to a serious extent." So far as my experience and personal observations go, I have found that the beetles only attack very sickly or half-deal trees, but never healthy or young ones. When marking trees in Cheshire, I have observed the dead standing trees had been attackerl by the beetle, but this had always been done just when the trees were in a half-dead condition.

The life-history of this beetle is very easily followed. About the encl of March or the beginning of April the beetles emerge from their winter quarters, and are attracted in considerable numbers to newly felled trees or poles. In Cheshire I always discovered this species on comparatively large stems, but in the south of England they are very common on poles. The female beetle generally appears liefore the male. She then commences to make a straight tunnel, and on the appearance of the male, copulation takes place. The female makes her tumnel perpendicular with the stem, deposits her egrs, 
and the male remains near the entrance. The mother-gallery, fig. 95 , is double-armed. The total length of the mother-gallery (including both arms) is about 4 to 6 inches when mate in the stem, and about $1 \frac{1}{2}$ to $2 \frac{1}{2}$ inches when made on the pole. Mr A. C. Forbes, who has studied very carefully the life-history of this insect, ${ }^{1}$ found that the female first bores one arm, and then proceeds to work the other. The eggs are laid right and left, and are rather variable in number. When found on the stem of a comparatively large tree, they often amount to 120 , but when on the

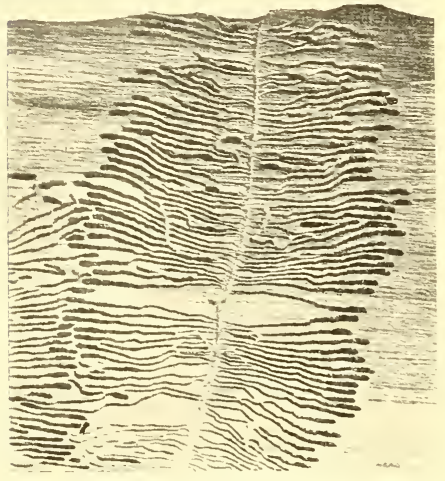

Fig, 95.-Markings of Hylesinus fraxini on ash stem after removal of bark. pole, half this number may be found.

The larve commence hatching out about the middle of April or beginning of May. At first they are of a slightly reddish colour, but the fully developed larvæ are white, with dark head and jaws, and tapering to a blunt point at the end. The larval galleries are about $1 \frac{1}{2}$ inch in length on the stem, and about $\frac{5}{8}$ to 1 inch long in the pole. The perfect beetles emerge about the first week in August,

through individual exit-holes, and the bark consequently looks as if it had been riddled with shot.

The perfect beetles then betake themselves to healthy ash-trees or newly felled ash logs, where they hibernate for the winter, and emerge in March or April. It is very questionable if they do any harm to the standing trees, as they simply bury themselves in the bark, though Judeich and Nitsche give a figure of "bark roses" resulting from the beetles hibernating, which in all probability is the work of the fungus known as Nectria ditissima following in the train of the bark puncture or wound made by the beetle.

\footnotetext{
${ }^{1}$ See Trans. High. and Agr. Soc. Scot., 1899.
} 
The beetle (fig. 96) itself is about $\frac{1}{8}$ inch in length, oval form, pitchybrown or ashy-grey colour; under side of abdomen covered with thick grey hairs; the antenne and tarsi of a yellowish-brown colour.

Various remedies have been given for this insect pest, including the recommendation of planting on suitable soil, \&c.; but such advice is largely unnecessary, inasmuch as it only attacks felled logs or dying trees and poles, and all practical forestry insists on cutting backgoing asli-trees more quickly than any other species of tree, in orler to prevent rapid depreciation of the timber.

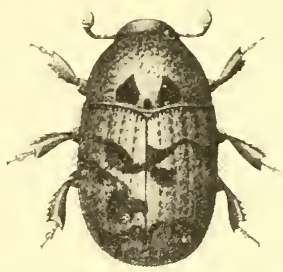

Fig. 96.-Hylesinus fraxini. (From Barbey.)

\section{Hrlesinds oleiperda (Fabr. ${ }^{1}$}

This beetle is found on ash, but, in contrast to the preceding species, is always got on the small topshoots. It is, however, as a rule, a South Country species, the branches shown in fig. 97 being from a tree in Wiltshire. It is a species which hatches out very readily in confinement, so that the branches containing the larve may simply be put in a box in winter and left there until the beetles appear, about the end of July.

The mother-gallery is very short, being only about half an inch in length, and apparently only singlearmed. The larval galleries vary

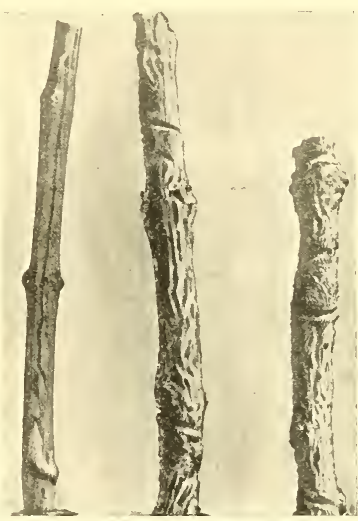

Fig. 97.-Markings of Hylesinus oleiperda in small branches of ash. very much in length, being from half an inch to two inches. They are often crowded so closely together that every portion of the space becomes pitted with larval furrows.

${ }^{1}$ I found the three species-viz., H. erenatus, $H$. fraxini, and $H$. oleiperdaall in Belton Park, Lincolnshire, July 1907. 
The beetle (fig. 98) is comparatively small, being about 2 to $3 \mathrm{~mm}$. in length, bluntly ovate, pitchy black, and covered with yellow bristles and hairs. The thorax is broad at the base, tapering towards the head. The wing-cases are marked with punctured lines. There is

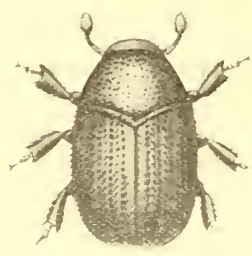

Fig. 98. - Hylesinus oleiperda.

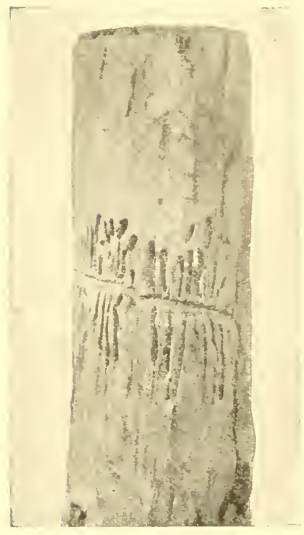

Fig. 99,-Markings of Hylesinus vittatus in branch of elm. an irregular yellowish dorsal streak between the two elytra. The legs and antemne are yellowish.

The beetle derives its specific name in consequence of attacking the olive-trees in Italy. Fowler says the species has been found abundantly in beech near Frankfort.

\section{Hrlesines vittatus (Fabr.)}

This species is found on branches of elm. The specimens in my collection have been hatched out from branches received from Wiltshire, and judging from those hatehed, the time for swarm ing is somewhat variable. In 1904 the beetles did not appear until the end of June and begimning of July. In 1905 I found that a few had escaped by the end of April, and on cutting into the branch on May 6, I found perfect beetles in several burrows on one side of the mother-gallery, and active larvæ in the arms of the opposite side, hence one might infer that the flight period varies. It is possible, however, that the general time for swarming is just after midsummer. My friend, Mr A. C. Forbes, who las carefully worked up the family in the south of England, informs me that he never could find any workings mil the beginning of August. It would seem that Eichhoff har not been able to work up this species personally, for he says that one person informed him that it swarmerl on May 21, and another worker found it swarming in August. Hence he conclutes, reasoning from analogy, that the 
species is double-broodect, whereas it was possibly due to erratic swarming.

It may be noted that the larvæ work in the bast and on the surface of the wool. The bast is a lightishcream colour, and the frass from the larva is a deep dark chocolate.

The mother-gallery is two-armel, the total length being about $1 \frac{1}{4}$ inch. The larval galleries are at right angles with the mothergallery, and vary in length from $\frac{1}{t}$ to $\frac{1}{2}$ an inch. The workings are generally in comparatively small branches (fig. 99).

The beetle (fig. 100) is the smallest species of the group, and, viewed with a strong lens, certainly the prettiest. The form is more linear than any of the other species. The

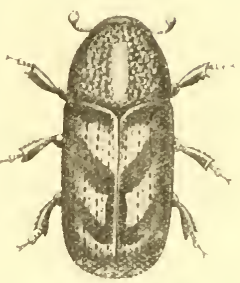

Fig. 100.-Hylesinus vittatus, (From Barbey.) thorax is slightly grey, and the elytra are beantifully variegated,-so much so, that the colouring is suggrestive of a moorfowl's egg. The antenne are lightish-brown, and the whip portion is comparatively long. The legs are also light-hrown.

\section{Genus Hrlurgus.}

Upper side of body clothed with seanty hairs; thorax long hairs at the sides. Eyes entire and longish. Whip of antennæ threal-like and six-jointed; club ovate. First tarsal joint longest; thirl very broact. Elytra extremely punctured.

\section{Hylurges PINAPERDA (Linn.) \\ Myelophitus piniperta, L. (Eichhofì and Fowler). \\ Hylesims: pinipurla, L. (Juteich and Nitsche).}

The above synonyms show that leading entomologists use tifferent generic names. The practical forester of this country has always understood it as Hylurgus, but Fowler arlopts Myelophilus as the generic term.

The genus contains two species, and Fowler ${ }^{2}$ gives the following key-viz. :

1. Second interstice of elytra Hattener, and without tubercles at apex . . . . . II. piniperla, L.

II. Second interstice of elytra not depressed, and with a row of small tubercles at apex . . . II. minor, Hart.

1 British Coleoptera, vol. i. p. 419. 


\section{IIylurgus PINIPERdA (Limn.)}

This beetle is very destructive to the young shoots of Scots pine, and has an interesting life-history. During the winter months many of the perfect insects hibernate in rough bark, or otherwise bore a hole in the bark of healthy standing trees, just enough for covering, but this winter burrow is in no way injurious to the standing tree. The burrows, however, on the stem of the tree may be best seen

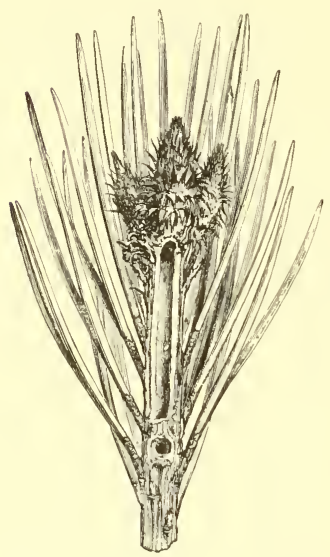

Fig. 101.-Shout of Scots pine, showing the entrance-hole, and a slice remored to show the boring of a pine bertle. (From Somerville's 'The Pine Beetle,' pub. lished by the Highland and Agricultural Sueiety of Scotland.)

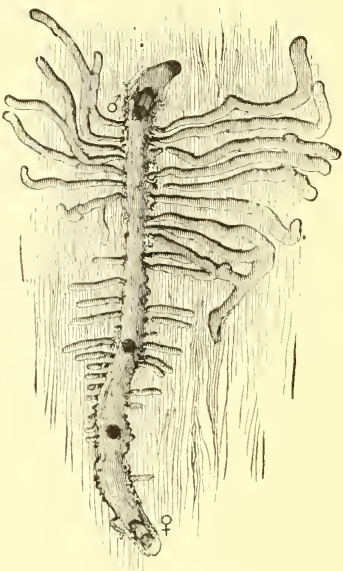

Fig. 102. - Showing mothes and lartal galleries in process of formation. (From Somerville's 'The Pine Beetle,' pub. lished by the Highland and Agricul. tural Society of Scotland.)

months after the exit of the beetle. The exit-holes are clean-cut openings, surrounded by a fringe of hard resin, which has in consequence issued from the bottom of the excavation, as the boring has been sufficiently deep to reach the vital bast. A few of the beetles hibernate in the shoots, which fall with the buried insect in autumn (fig. 101). In early April or the end of March they withdraw from their winter-quarters and commence their breeding operations. The female beetle either selects a sickly standing tree or the stem of healthy trees which have been felled during the previous winter, and 
makes a slight burrow in the bark. Having seooped out a circular clamber, she then returns to the onter world, and re-enters the chamber accompanied by the male. In this chamber eopulation takes place, after which the female proceeds to bore farther into the stem, almost at right angles to the first-scooped portion of the chamber. The main or mother gallery is therefore a straight line, with a bend at the bottom, or entrance, somewhat resembling a golf club (fig. 102). The total length of the mother-gallery is about three inches, and there are generally two or three air-holes directly over the gallery. In about ten or twenty days after the first eggs have been deposited the larvie hatch out, and proceed to eat their way, more or less at right angles, to the mother-gallery. At first, therefore, the markings are very characteristic, as in fig. 102 ; but later on the larval markings are very much intermingled, as in fig. 103, which is a photograph from a portion of bark, and shows the intermingling of larval galleries from several adjacent broods.

At first the larval galleries are very fine and thread-like, but as the grubs enlarge the galleries widen, and pupation

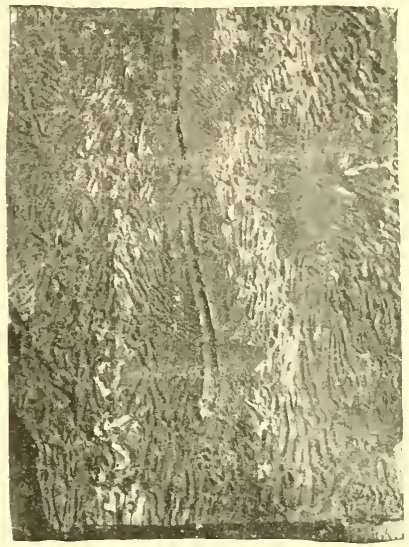

Fig. 103,-Portion of bark of scots pine, showing two mother-galleries and lerwal workings.

takes place at the end of the larval gallery. It shonld be noted that both larval and mother galleries are always made in the bark, and never in the wood, though the frass always lies on the wood after the removal of the bark. Thus the beetle in question is a bark beetle.

The beetles escape from the pupal chamber by making direct exitholes, and thus the numerons flight-holes in the bark indicate that a new generation has escaped.

The beetles arising from the first-deposited eggs hateh out in abont three to five weeks, generally towards the end of June, and these early hatched beetles, on quitting the galleries, deposit eggs in the 
bark of felled trees, preferring those trees which have been felled in late spring or early summer. But meanwhile the stem-mother has kept on depositing eggs, and beetles hatch out from the parent burrow throughout the season, but more especially in the autumn. Thus the perfect beetles arising from the second brood, together with the late swarmers just referred to from the original burrow, quit the bark practically simultaneously, and bore into the young leading shoots of the Seots pine branches, entering the pith, and thus damaging the shoots, so much so that they fall to the ground, and the beetles therefore may be found inside the pith of those shoots which so literally strew the ground of pine woods in autumn.

Some specimens leave the shoots to hibernate in the bark, and

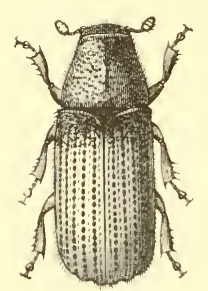

Fig. 104.-H,lurgus piniperda. (From somerville's 'The Pine Beetle, published by the Highland and Agrienltural Society of Scotland.) others remain in the shoots over winter, to come out again in the following spring. The continual destruction of shoots gives the tree the appearance of being elipped or stumped, and the pruning habits have given rise to the insect being ealled in Germany the "wood-gardener" or "forester."

The perfect inseet (fig. 104) is about $5 \mathrm{~mm}$. or $\frac{1}{5}$ of an inch in length, of a pitchy bronze colour, head and thorax approaching to black, legs same colour as boty, with light tibiæ. The elytra, or wing-cases, are rough, and rounded over the sides, so that a transverse section of the abdomen would be nearly cireular. The elytra should be carefully noted, and Dr Somerville gives the following detailed description :--

"The elytra are lustrous, slightly pubeseent, and traversed longitudinally by rows of fine punctures. The interspaces between the punctated rows are somewhat wrinkled, and each contains a row of hairy tubercles. These tubercles, in the ease of the second interspaces on either side of the middle suture, are only present as far as the point where the elytra begin to bend downwards towards the apex; whereas in the other interspaces they are continued down the apical declivity to the edge of the elytra. This peculiarity is most marked in the male, though in both sexes it is quite observable with the unaided eye when the insect is held in a good light with its back towards the observer-that is to say, when the apical declivity is examined obliquely. Owing to the want of hairy tubercles in the 
two interspaces mentioned, these are seen to be smooth and lustrous, and appear like shining lines or shallow grooves on the apical declivity. This point is of much importance, for it is only ly means of it that we can with certainty distinguish this insect from IIylevims minor." I

The larva is a white footless grub, with a light canary-coloured heal. The middle portion of the grub is yellow, and the tail portion pure white. The pupa is whitish and shining, showing all the parts of the perfect insect.

\section{Preventive and Remedial Measures.}

Though this is certainly a very destruetive insect, yet, in the absence of special damage by gales, it can be held in check by fairly good forest management. This consists largely in destroying the breeding-places, which, it must be remembered, are either in the stem of eut trees or in sickly standing trees. Much, of course, will depend on the felling season, and on the interval elapsing before manufacturing. If, say, the trees were eut in September and manufactured by March, no evil effects would accrue; but if they were felled in March and not cut up at the sawmills until September, it would be entirely to the advantage of the beetle. Hence, if cut during the latter period, various checks should be adopted. For instance, the bark might be partially cut off as in the custom of chipping the "four sides" of the $\log$ to lessen railway carriage, which would have the effect of so drying up the bark, or otherwise separating it from the log, to such an extent that the necessary conditions for propagation would be very much destroyed. If, however, the logs are not thus dealt with, then they should be barked at the sawmill from Jume to August, and all bark burned. Thus many larve and beetles would be destroyed.

If, on the other hand, we wish to lessen the breeding-places in standing trees, all sickly trees should be removed. But while the latter may be recommended on entomological grounds, we should bear in mind that "pure" woods of Scots pine should never be heavily thinned, but, on the contrary, an unbroken canopy should always be maintained. Another measure for eradication may be adopted in felling certain trees as catch or trap trees, and then burning the bark of the same.

From a practical point of view, it may well be asserted that the

1 Trans. High. and Agr. Soc. Scot., 1891. 
barking referred to would not pay; but having regard to the lamage arising from the perfect beetle to the shoots of young trees, or where a nursery with young Seots pines is in the neighbourhood, it might be quite advisable to check the pest in this way. It often happens that young Scots pine plants in the nursery are injured by the beetle.

The very small tops and branches of Scots pine lying on the ground are not suitable for the breeding purposes of this insect, though they are used by other beetles. The larger branches, however, may be used for breeding purposes, and it is therefore alvisable, both for checking the beetles and for the health of the crop, to keep woods entirely free from dead trees and all brushwood. Hence it may be seen that, so far as the health of the woods is concerned, it is not a good practice to leave the fresh or half-lead branches on the ground for eover. At the same time, it is only fair to note, in the interests of game-eover, that the perfectly dry dead branches which may at times be pruned off from the base of the stems of Scots pine are not used by beetles for breeding purposes.

\section{Hylurges Mixor (Hart.)}

This insect is considered by many colcopterists as purely a Continental species, though a few workers consider it a British species. Hence Fowler says it is rare, and gives leeside and Braemar as districts.

The beetle is smaller than the preceding species, and may be recognised by noting the bristle-bearing tubercles continued on the second interstice of the elytra.

Not having found the species, I quote from Professor Fisher as regards the relation to the forest:-

" $H$. minur, Hart., chiefly attacks the Seots pine, but has also been found on the spruce. It prefers poles, but may attack 50- to 70 -yearsold trees. The mother-galleries are large, regular, double-armed, and horizontal, with a rather long entrance-burrow, and groove the sapwood deeply. The injury which its breeding causes is therefore greater than that of $H$. piniperda, as the eirculation of the sap is more endangered by these horizontal galleries. It is not, therefore, surprising that quite sound trees are killed by it, or, at any rate, become stag-headed.

"The larval galleries are short, not very numerous, and terminate 
in a leeply cut pupal ehamber. This beetle, unlike the preceding speeies, is said not to confine itself to the borders of a pine wood, but to be found deeper in its interior.

" $H$. minor also bores into the pitl of young pine shoots in the same way as $I$. pimiperila." 1

\section{Genus Phlqophthords.}

Antennal whip five-jointed; elub of antennæ three-jointed and very distinctly divided; abdomen not raised towards apex.

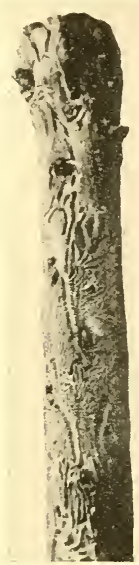

Fig. 105. - Metkings of Phlceophthorus rhododactylus on gorse (whin) stem.

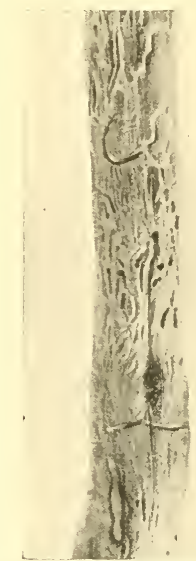

Fig. 106.-1Larkings of Phleeplithorus rhododartylus on broom.

\section{Phlegphthorus rhododactylus (Marsh).}

This is one of our smallest British wood-feeding beetles, and is found in gorse and broom stems. It is very common in Northumberlani. Fig. 105 represents the markings on whin and fig. 106 on broom. The beetles may be looked for about the begiming of April, more especially on half-dead gorse stems, - those stems, in fact, which were alive the previous year, but have been broken down by the heavy snows of

1 Forest Protection, 1907. 
winter. They deposit their eggs in small irregular clusters, and the larve move about in all directions from the mother-gallery, so that the markings are very irregular. These larve

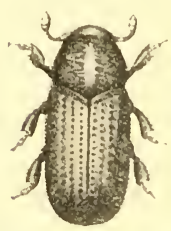

Fig. 107.-Phleophthorus rhododactylus. (From Barbey.) are transformed into fully developel beetles by early antumn, when some leave the brootplaces, whilst others remain at the far end of the larval galleries for the winter and leave the following spring. I have kept them in confinement over the winter, and they worked the same stem as they had done the previous year.

The beetle (fig. $10 \tau$ ) is about $1 \frac{1}{2} \mathrm{~mm}$. in size, of a dull, blackish slaty colomr, with slight greyish pubeseence. The thorax is beantifully striated, and the body somewhat globular in shape.

\section{SUB-FAMIL DRYOCETINA.}

This is rather an extensive tribe, and as the whole of the genera are practically arboreal insects, it is perhaps well to append the following synoptical key, slightly modified from Fowler - riz. :

I. Funiculus of antemme with four or five joints, size variable.

i. Eyes entirely divided; elub of antenne without sutures. Beetles bore directly into the woody stem.

Trypobeximox, Stepls.

ii. Lyes entire or slightly emarginate.

1. Lilytra clothed with seale like pubescence, and sometimes with fine raised hairs in aldition, not excavate at apex; scutellum very small; club of antenne with listinct sutures. lieetles small, generally working in thiu bark.

Criphales, Er.

2. Elytra without scale-like pulescence, glabrous or with outstanding hairs; club of antenne orbienlar and compressed.

1 There appears to be some confusion as regards the nomenclature of the two species of l'hlocophthorus-namely, P. rhododectylus and P. Sipurtii. The insect known abroad as $P$. Spartii is given by Barbey as feeding on broom, and P. rhododactylus as feeding on branches of the sinuce. 
A. Base of thorax finely bordered; prosternum with a short process; size very small; club of antenna divicled by three constricting sutures into four joints . . . Pityophimorus, Eich.

B. Ijase of thorax not borlered.

$\alpha$. Club of the antennæ with the second joint ereseent-shaped, and completely embracing the sides of the first joint, which is oval; sentellum rulimentary; elytra with reflexed portion dentate in the male, not dentate in the female

Srlocleptes, Ferr.

b. Club of antenux truncate at apex, the basal joint being corneous, and the remaining joints lying within it; mentum broally cordate, sub-mentum large and concave anteriorly . Dryoc.etes, Eieh.

b'. Elytra exeavate at apex, which is horizontal or almost horizontal behind the apex of ablomen.

Tomicus, Latr.

$b^{\prime \prime}$. I'rosternmm without or with a very short process between the anterior coxx.

(a) Tibir almost linear, withont furrows for the reception of the tarsi; apex of elytra with large teeth in the male, and with a strong impression on each sicle of suture in the female.

Pityogenes, Bedel.

(b) Tibire dilated, furnished with furrows for the reception of the tarsi; ajex of elytra without large teeth or deep impressions in the sexes.

Xyleborus, Eich.

\section{Gemus Crypinalus.}

The members of this genus are very small insects, and may certainly be overlooked by nearly all except the trained economic entomologist. Six British species have hitherto been recorded on poplar, lime, spruee, beech, \&c. They are all so very small in size that they cannot be seen to any atvantage without the microseope or strong pocket-lens.

Fowler gives six liritish species, but as two are rather rare, we may confine ourselves to four species. As the beetles are exceedingly small 
in size,- from 1 to $2 \mathrm{~mm}$., - the characters are entirely microscopical. The following generic characters may be given :-

Pronotum as broad as long, with small hump projecting in front portion. Elytra slightly hairy, conspicuously punctured, and well covering the abdomen. Whip of antennæ four-jointed; joints very small; club comparatively large; tibia broad, and toothed on onter edge.

The following are the specific characters, according to Fowlerviz. :

I. Club of antennæ with the sutures transverse, almost straight; body behind thorax, only twice as long as broad.

I. Eyes entire; thorax with four transverse rows of granules in front

C. tilice, Panz.

2. Eyes emarginate on their anterior border; thorax confusedly granulate.

A. Elytra with very short, scarcely visible, hairs; rows of punctures on elytra not very fine, and placed in somewhat impressed striæ . . C. alietis, Ratz.

$B$. Elytra with long raised hairs; rows of punctures on elytra very fine . . . C. picece, Ratz.

II. Club of antennæ with the sutures strongly curved; body behind thorax three times as long as broad; elytra withont striæ C. fari, Nord.

\section{Cryphalus abietis, Ratz.}

This species is found on dead spruce branches,- -generally at knots of the branches. It is considered rare, but this arises probably from its being overlooked, for I have found it in the south of England, and again in the north-east of Scotland. Figs. 108 and 109 .

Eichhoff says it is double-brooded, as the first brood swarmed in February and March, while snow was still on the ground, and the second brood appeared about the latter end of July.

I received a portion of a stem of young Douglas fir, heavily attacked by this insect, from Mr A. C. Forbes, Bowood, Wiltshire. As a rule, this tree is almost immune from insect attacks. Mr Forbes has again sent me an example of this species on Douglas fir from Cockle Park, Northumberland. 
Crypilalus tilie, Panz.

This species confines its attacks to deal or dying branches of the lime, and is said to be extremely local. I am indebterl to Mr Norse, Leeds, for the specimen as represented by photograph in figs. 110 and 111. He found it at Newnham, Gloucestershire, in May 1906. The mother-gallery is horizontal, and may be either single- or double-armed. The bark, at the selected portion of the branch, is exceedingly thin, and the female beetle bores just deep enough to skim the surface of the wood. The larval galleries rum at right angles to the mother-gallery, but owing to the thinness of the bark, and the peculiar structure underlying the thin covering, it is with great difficulty that a specimen may be prepared for illustration.

All German writers say there is a double generation.

The beetle is small in size, oval, and circular if considered in section through the

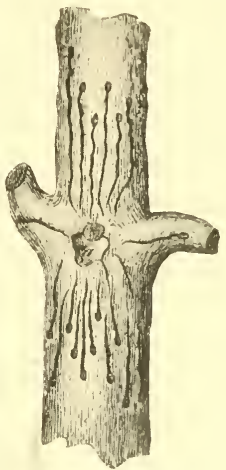

Fig. 108. - Markings of Cryphalus abietis. (From Altum.) body, pitchy brown, with reddish-brown antennæ and legs. Thorax broader than long, with small protuberances on the sides. Elytra with very finely punctured strix, but the general appearance is rough and sealy. Length 1 to $1 \frac{1}{2} \mathrm{~mm}$.

\section{Cryphalus ploee.}

I have not found this speeies. Fowler says it is very rare. Barbey says it lives exclusively on the silver fir (Weisstanne), though at the same time he gives two exceptions, one on the root of spruce and the other on the larch. $\mathrm{He}$

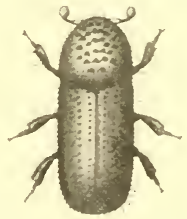

Fig. 169, - Cryphalus abietis. (From Barbey.) also adds that it is a very deadly enemy of silver fir when associated with another beetle named Tomirus curvidens, Germ., and gives a very interesting account of the injuries. It would be well, therefore, for students in this group to keep a good look-ont for this species (hitherto considered rare), more especially in the south of Fngland. 


\section{Cryphalus fagi, Fabr.}

This species is found generally on branches or small stems, but is said to be very local. Mr Morse supplied me with the specimen from which the photograph is taken (fig. 112).

I only got one specimen from the branch, which was elongated, slender, and of a shiny, dull black colour.

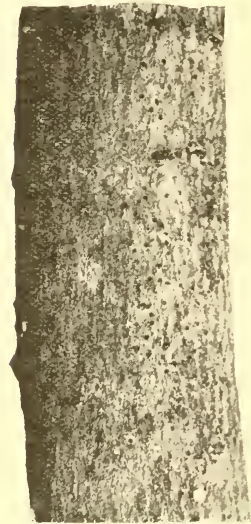

Fig. 110.-, showing "exithioles" of Cryplatus tilike in lime.

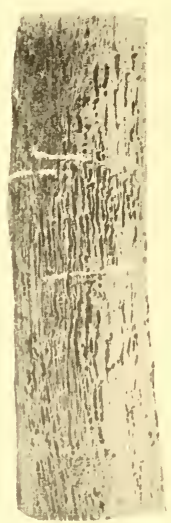

Fig. 111.-Markings of Cryphalus tiline on lime. The white hori. zontul lines are the mother. galleries.

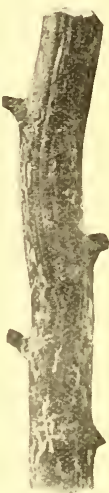

Fig. 112.-3 Jartings of Cryphalus fag on brinch of beeeh.

Barbey says the chief character lies in the form of the antemn club. ${ }^{1}$

\section{Gemus Pityophthorus.}

Fowler says-_"Genus as defined by Eichhoff presents the following characters: Antennæ with a five-jointed funiculus and an oval non-compressed club, which is constricted by transverse sutures dividing it into four distinet joints; thorax as long as or longer than broad, borlered at base and distinctly narrowed in front; elytra cylindrical, with simple rows of punctures, and with impunctate interstices; the apex is obliquely truncate, and presents a depression on either side of

1 Die Bostrichiden Central-Europas. 
suture; it is not armed with spines or teeth, but the raised sides of the apical depression and the sutural margins sometimes possess a row of small setigerous tubercles." I

\section{Pityophthorus pubescens, Marsh.}

This is a very small species of beetle, which often follows in the train of unpractical planting of young Seots pine trees. There is an age of plant known in the trade as 2 yrs.-3 yrs., - that is, two years in the seed-bed and three years in the nursery lines; in other words, only once transplanted in five years. In this class the bill of mortality is a very high one, and the beetles prefer the dead trees of the class referred to, and may be looker for near the top of the stem, where the thickness of the stem is about equal to that of an ordinary drawing-pencil.

\section{Gemus Xylocleptes.}

Fowler remarks: "The genus may be known by having the second joint of the club of the antennx crescent-shaped, and completely embracing the sides of the first; the funiculus is five-jointel; the scutellum is indistinct; and the apical portion of the elytra is strongly inflexed in the male and fully inflexed in the female." 2

\section{Xylocieptes bispincts (Duft.)}

This species is found on the dead stems of Clematis vitalba, and is, generally speaking, a South Comntry species. I am indebted to Mr Hereward Dollman for the specimens in my collection. He records them as being common at Ditching, in Sussex. ${ }^{3}$

According to Eichhoff, the mother-gallery is two-armed, and the insect has a rouble generation. The beetles pass the winter in the galleries, and appear in April or May. The first generation is developed by June or July, and the second from Angust till Oetober. As the latter time is rather a prolonged period, it is probable that the late swarmers from the first brood may be confounded with the early swarmers of the second brood.

1 British Coleoptera, vol, v. p. 433.

2 Ibid., p. 435.

${ }^{3}$ Commander Walker has found it abundantly in Kent, and sparingly in the Oxford district. 
The beetle (fig. 113) is elongated and cylindrical, of pitchy brown colour. The thorax is darker than the elytra, and longer than broad. Legs rusty brown colour, and the antemnæ and tarsi lightish-yellow.

In the male the apex of the elytra is much inflexerl, with a tooth

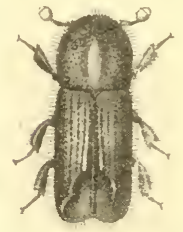
on each elytron, and the suture is so raised on the inflexed portion as to form a small keel.

In the female the apex is most feebly inflexed, and the extreme apical edges are rounded.

\section{Gemus Dryoc.etes.}

The genus Dryocætes may be said to Fig. 113. - Xylocleptes bispinus. be of very minor importance, so far as economic forest entomology is concerned.

The whip of antennæ five-jointed ; elytra distinctly punctured, and covered with fine pubescence and smooth.

\section{Dryocetes villosus (F.)}

I found this species very plentifully in the rough bark of an old dead standing oak in Chatsworth Park, Derbyshire. I have also, more

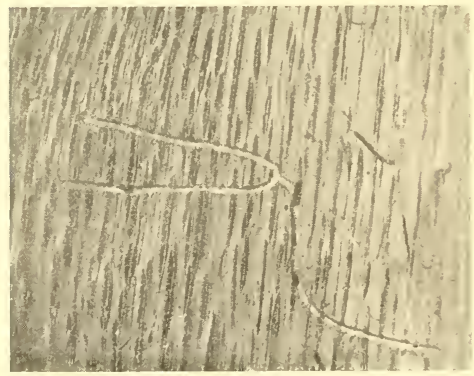

Fig. 114.-1Lother-gallery of Dryocates villosus in bark of oal:

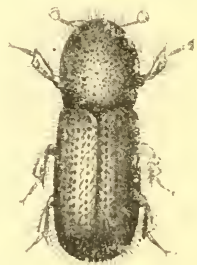

Fig. 115.-Dryocates vil. losus. (From Barbey.)

recently, hal its markings pointed out to me by my friend Mr R. S. Bagnall, in Gibside, Co. Durham (see fig. 114). These markings were on an old dead standing oak. The beetle (fig. 115) is of a reddish- 
brown colour, and elothed with pale pubescence which might almost distinguish the species. Length $2 \frac{1}{2}$ to $3 \frac{1}{2} \mathrm{~mm}$.

The other two species of this genus, which may be overlooked, are D. alni (fig. 116) and I). coryli. The former is said to be found on becch, and the latter on deal twigs of hazel and hornbeam, but both rare, especially the latter.

These two species are about the size and appearance of $P$. birlentutus.

\section{Genus Touious.}

The species of this genus are all feeders on coniferous trees, but some of the species are rather rare. They all make peculiar markings, - so much so, that in eonsequence of the strongly marked patterns the species have been termed "typographers."

Some of the species are polygamous, and the main galleries can be traced from the starting - point or breeding - chamber (Rammellammer).

Fowler gives five species as British, but I have only found

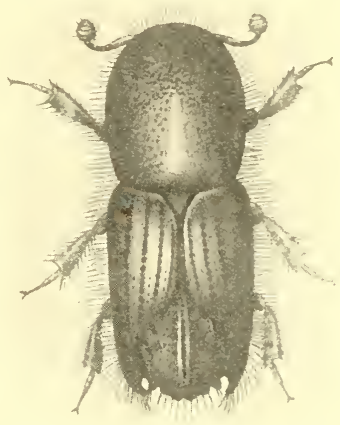

Fig. 117.-Tomicus sexilentatus. (From Barbey.) one in Northumberland-viz., T. aruminutus. It is perhaps the first record for the county, and I am obliged to Mr R. S. Bagnall for identification.

The principal generic characters are: antennæ whip five-jointed; thorax large, with a wrinkled little lump in front and punctured behind ; wing-covers at the point pressed and toothed.

\section{Touicus sexdentatus (Börn.)}

This is a large handsome beetle (fig. 117), pitchy dark-brown colour, 
pronotum smootl, and elytra deeply punctured; abdomen covered with long hairs; and the apex deeply and obliquely excavated, showing teeth on each side. Antennæ and legs ferruginous. Length $5 \frac{1}{2}$ to $7 \mathrm{~mm}$.

Fowler gives as a habitat recently dead firs near London, and $\mathrm{Mr}$ R. S. Bagnall places it as an introduced species to Hartlepool. It is a very rare insect.

\section{Tomicus acuminatus (Gyll.)}

This insect is of a uniform terra-cotta colour, and slightly pubescent. Thorax longer than broad, and a slight depression in centre; the elytra fully cover the abdomen.

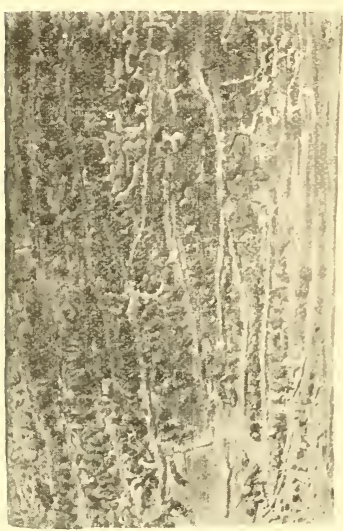

Fig. 118,-Merkings of Tomicus acuminatus on stem of Suots pine after the bark: was scraped off. Eyes black; antennæ and legs yellowish.

The main characters, which are microseopical, are found in the toothed abdomen. There are three teeth on each elytron; the third tooth is the longest. In the female the third tooth is formed into a sort of hook, whereas in the male it is a sort of blunt forked spine.

This is by no means a common species, and I found it in Beanley Wood, Northumberland, July 1906. Fig. 118 shows the markings.

\section{Genus Pityogenes.}

The genus Pityogenes, according to Fowler, contains three species, but I have only one species, viz., $P$. lictentatus, which in many distriets is very common. Barbey, who may be considered as a leading German authority, places $P$. bidentatus in the genus Tomicus, but I venture to think that Fowler's separation is a very good one, on the ground that in Pityogenes "in the males only the apex is excavate, and is furnished with strong teeth," and also that "the females have a deep impression at the apex of the elytra near suture." Under a strong leus this character is well maintained,- - so much so, that the thorax has a quite "nipped"-like appearance. 


\section{Pityogenes Bidentatus (Ilerbst.) \\ Pityogenes bidens (Fabr.)}

This is a common beetle, but, being small in size, is very apt to be overlooked. Its breeding-plaees may be broarlly dividerl into two elasses-viz., on small dead fir-branehes, and on siekly trees, say from 18 inehes and upwarls, which have been transplanted in the nursery-lines, or those which have been transplanted in young woods.

As regards the former elass of fookmaterials, and as forming a commencement in the study of its life-history, it may be looked for amongst the small branches of seots pine, ehiefly on the under side of the branch, either where trees have been felled during the previous winter, or on branches which have been broken off by the wind. The small boreholes, together with the frass, reveal the abode of the inseet. If the thin bark be removed earefully, we may find a starshaped marking, as in fig. 119 . 'This is a typieal beginning of the markings of this species. The eentral portion is seooped out by the male, where several females, gencrally from four to six, assemble, and after copulation each female makes her own gallery. The larvæ arising from eaeh respective female make their own particular design of markings, and this confusion gives rise to various irregular designs, such as shown on fig. 120. The same branches may harbour beetles the following year, but the markings are always best followed in recently eut branches.

As regards the sickly trees infested by

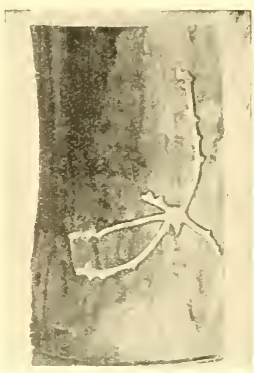

Fig. 119.-Markings of Pity ogenes b dentatus (initial stage).

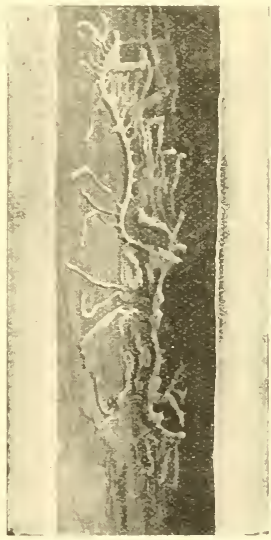

Fig. 120.-Fully developed mark. ings of Pityogenes bidentatus. this insect, the prineipal damage is to pines, large transplanted Douglas firs, and so on. The transplanting of such elass of trees, 
say from six to twelve years of age, is often rather risky, more especially if followed by a dry summer. Under such circumstances the bill of mortality is a heavy one, and the beetles are generally found on the dead or most sickly trees. It is just possible that, though the beetles are always found on dead or dying trees, they may be the means of partially killing several trees of the pine tribe.

It often happens that many transplanted Austrian pines hang, as it were, for one season, - that is to say, they make no growth, but simply remain green. If there be no insect enemies, the trees will recover the following year, but a severe beetle attack often kills what

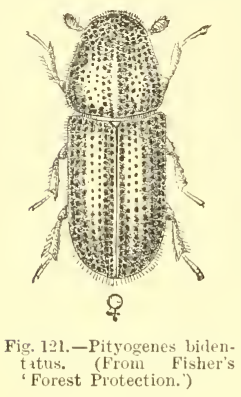
might otherwise recover. In the case of Douglas firs, the brown foliage emphatically declares the dead plants.

Altum ${ }^{2}$ relates that 100,000 seven-year-old plants were killed in one season by this beetle. In this country such an attack would be considered primarily due to, and afterwards accelerated by, the absence of healthy conditions, - that is to say, that the trees had been planted at the wrong season of the year, and on too dry a situation.

With regard to the life-history of the insect, I have found it in all its various stages throughout the whole year, and am therefore persuaded that Eichhoff's remarks regarding the respective broods are right-viz. :

"I. Spring swarm in Niay or June; larvæ in Nay, June, and July ; pupæe and imagines in July and August.

"II. Summer swarm from July till October; larvæ in July, August till October, and over winter; pupe and imagines in September or October till May.

"III. Autumn swarm from August till October, larva over winter, imagines and swarms and broods in May and June." 2

The beetle (fig. 121) is from 2 to $3 \mathrm{~mm}$. long, pitchy black in colour, shiny, and covered with a very fine pubescence; antennæ and legs ferruginous; thorax constricted in front and punctured behind, and it has a sort of pinched appearance. The elytra have distinctly punctured rows. The male can be very easily distinguished by its having a projecting hook on each elytron.

1 Forstzoologie.

${ }^{2}$ Die Europäischen Borkenkäfer. 
As this beetle has proved a veritable pest on the Continent, and also occasionally in this country, it would be well to guard against its ravages. Perhaps the best preventive would be to remove or burn all comparatively young fresh branches which would come in proximity with any fairly large coniferous trees planted out, either in parks or villas, for immediate effect.

\section{Genus Trypodendron.}

The beetles of this genus are entirely different in their workings from the sections hitherto considered. The Trypodendron motherbeetle bores directly into the stem of the tree for about $\frac{1}{2}$ to $\frac{3}{4}$ inch deep, directly towards the centre or pith, but when this depth is

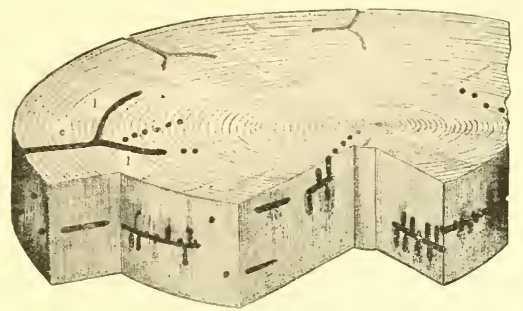

Fig. 122.- Block of wond shor"n in preswective to illustrate the workings of the gen ws Trypodendron. (After Eckstein, and copied from Nisslin.)

reached she bends slightly round and then bores in a somewhat curved direction, parallel to the circumference of the tree, and always preferring the sap-wood. After she has taken the bend referred to she makes a sort of recess or basket, alternately right and left, of the main gallery, and places a single egg in each recess. In due time the eggs hatch out and make short galleries at right angles to the parent gallery. Each gallery points upwards or downwards. As regards space, each gallery alternates, and thus we get "ladder galleries" formed. When fully developed, the offspring creep out at the entrance made by the mother-beetle.

The accompanying figure, fig. 122, taken from Niisslin, is a sort of perspective representation of an infested block, and gives a very good idea of how the insect bores into the stem.

The generic characters are: Eyes divided in two parts; knob of 
antennæ large and solid, longer than the four-jointed whips; thorax transverse or globose, with four projecting corners. Female with a convex forehead. Elytra ending abruptly, but without teeth.

The following are the specific characters, according to Fowler:-

"I. Apical declivity of elytra with a very distinct furrow on each near suture; elytra without distinct longitudinal streaks at siles; thorax black . . . . T. domesticum, L.

"II. Apical declivity of elytra without, or with an indistinct, furrow on each near suture; elytra with more or less distinct longitudinal streaks at sides; thorax more or less red, at all events behind.

i. Elytra with the punctured striæ moderately deep; club of antenne subsecuriform, straight on one side, and somewhat rounded on the other . . T. quercus, Eich. (signatum, F.)

ii. Elytra with the punctured striæ superficial ; club of antennæ rounded on both siles and at apex T. lineatum (Ol.)" 1

\section{T. hineatum (Ol.)}

This insect bores into spruce timber. It will bore into timber lying on the ground, which may have been cut during the winter, but

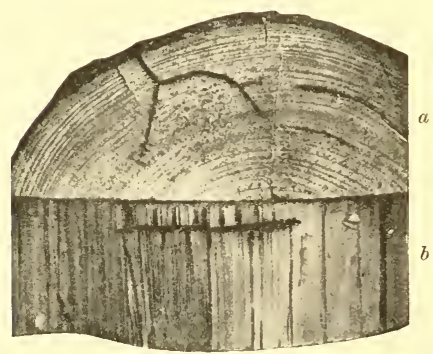

Fig. 123. - Horkings of Trypodendron lineatum in spruce timber.

$a$, cross section of wood; $b$, longitudinal section.

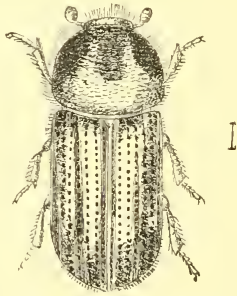

Fig. 124. - Trypodendron lineatum. (From Fisher's 'Forest Protection.').

by preference it attacks broken stumps-that is, standing portions of trees which have had two-thirds of their tops broken off by a winter gale. The female seems to be rather fastidious, as the material must

${ }^{1}$ Fowler's British Coleoptera, vol. v. 
neither be too fresh nor too lly. She bores into the tree for an inch or more, and at about half an inch from the entrance commences to deposit her eggs. The larve soon hatch, and bore at right angles to the tumnel of the parent, but in the longitudinal direction of the stem, either upwarls or downwarls; but the larve eat only a small portion of the timber, about twice the length of their own bodies, and they pupate in the recess thus formed. The perfect insect eats, or rather makes, its way out at the hole in the stem made by the entrance of the female. Fig. 123 shows the workings of this beetle.

The beetle (fig. 124) is about 3 to $4 \mathrm{~mm}$. long, and eylindrical in form. The head is generally buried, as it were, in the thorax, which is blackish in colour. The elytra are yellowish-brown, with irregular black bands running along them. These hands are not always complete, but they are the salient feature distinguishing this from the species next mentioned.

I have fomm this species in two districts in Northumberland -viz., at Lyham, near Belford, in spruce, and in Scots pine, at Comntess Park, North Tyne; but it is by no means common in the county.

\section{Trypodendron DOMEsticum} (Linn.)

This speeies bores in oak, beech, and birch, selecting the large limbs of trees which have been

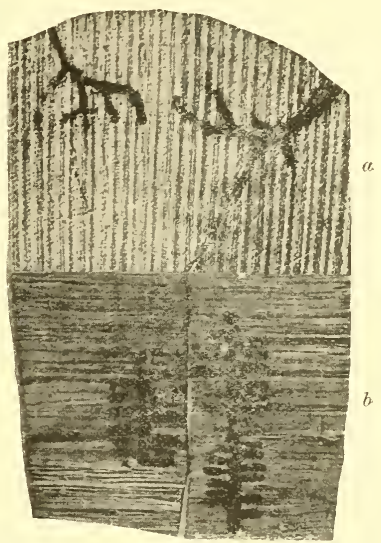

Fig. 125.-Markings of Trypodendron domesticum in oak timber.

$a$, cross section of wood; $b$, longitudinal section.

felled the previous year and left lying on the gromul. Its presence may be very easily recognised by the amomnt of bore-dust lying on the surface. It should be looked for about the end of May or beginning of June, when many specimens may be found, as whilst at work it often appears on the surface of the trunk. Fig. 125 shows the workings of this beetle. In size it is about the same as the preceding species; but the prothorax is entirely black, and the elytra 
livid yellow over the whole surface, the irregular lines in the previous species being entirely absent.

Trypodentron quercus, Eich., is a species I have not found, but Fowler says it is fairly common in Sherwood Forest.

\section{Gemus Xrleborus.}

The following are the chief characters of the genus, according to Fowler :-

"Tiliz broad, more or less serrate, and furnished with furrows for the reception of the tarsi, which are rather short; prosternum excised as far as the coxe, and furnished with a very short process; thorax rough in front, and not margined behind ; elytra without an impressed

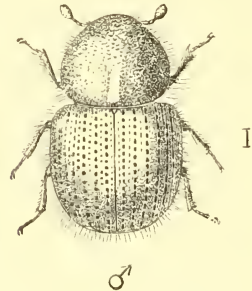

Fig. 126. -Xyleborus dispar (mule).

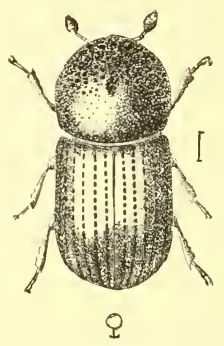

Fig. 127.-Xyleborus dispar (female).

line along suture, with the apex not excavated but slightly reflexed, furnished with more or less distinct tubercles, which are sometimes almost obsolete; punctured striæ distinct, interstices closely and rather finely punctured in rows; eyes emarginate; the club of the antennæe has the sutures very slightly curved, and the funiculus is five-jointed." 1

\section{Xyleborus dispar (F.)}

"Beetle, of $2 \mathrm{~mm}$., o $3 \mathrm{~mm}$. long (figs. 126 and 127). Pitch-black, the antennæe and legs testaceous-red. \& short, convex, ovoid, and very hairy, with the thorax granular in front, punctured towards the base, with a smooth median line. The $q$ cylindrical, its thorax in front

\footnotetext{
1 Fowler's British Coleoptera, vol. v.
} 
strongly asperate. Elytra strongly arched at the declivity, with rows of deep punctures, and raised tuberculate interstices between them.

"The season for llight is in May. The q bores into several kinds of broak-leaved trees to lay her eggs, in preference below a branch, but never near the gromul, attacking felled wood and young standing trees. Fig. 128 represents the workings.

"The larve appear in June, pmpate in July in the secondary galleries, and the beetles emerge in August. They hibernate in the galleries, and there is only one generation. This beetle is not everywhere common on the Continent, and till recently it was resarded as one of the rarest British insects, but since 1891 it has been destructive in certain Gloncestershire fruit-orehards." I

\section{Reforenes to Literature consulted.}

Altum, Dr Bernard. Forstzoologie. 1875.

Barbey, A. Die Bostricliclen Central-Euroyas. 1901.

Eichhoff, W. Die Europäischen Borkenkäfer. 1881.

Forbes, A. C. "The Bark-beetles of the Ash" -Trans. High, and Agr. Suc. Scot. 1899.

Fowler, Rev. Canon. British Coleoptera, vol. v. 1891.

Fürst, Dr Hermann. The Protection of Woodlands. 1893.

Hopkins, A. D. Insect Enemies of the Spruce. U.S.A. Bulletin, No. 28. 1901.

Judeich und Nitsche. Lehrbuch der Mitteleuropäischen Forstinsektenkunde. 1895.

Niisslin, Dr Otto. Leitfaden der Forstinsektenkunde. 1905.

Ormerod, Miss E. A. A Manual of Injurious

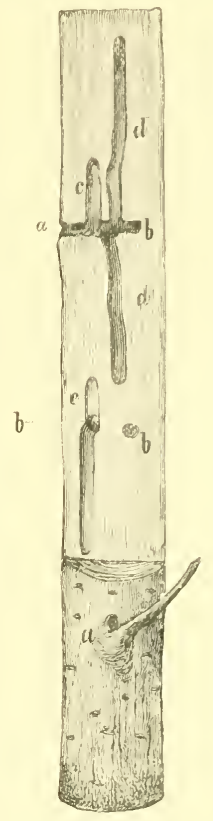

Fig. 128.-Burrous of Xyleborus dispar in an oak sopling (natural size).

a, entrance-hole, usually under a twig; $b$, mother-fgalleries ; $c$, commencement of lateral galleries ; $\boldsymbol{t}$, completed lateral galleries, in which the larvar lie. (Firures and explanation from Fislier's 'Forest Protection.') Insects. 1890 .

Somerville, Dr W. "The Pine Beetle" (IIylesinus piniperda L.) - Trans. High. and Agr. Soc. Scot. 1891.

${ }^{1}$ Forest Protection, by W. R. Fisher: Schlich's Manual of Forestry. 1907. Cf. Miss Ormerod's report on this very interesting beetle, 1889, pp. 92-98; quoted in Fowler, vol. v. p. 448. 


\section{CHAPTER IV.}

\section{HYMENOPTERA-OAK GALLS.}

Coxsideren entomologically, the subject of gall-forming insects is a very wide one, inasmuch as we find that certain insects belonging to the various orders, from Aearina to Hymenoptera, form galls. The galls on oak-trees are of special interest to the student of forest entomology, and also to the biologist.

Althongh the systematic study of "galls is a comparatively moderu one, many kinds of galls were known to the ancients, and several strange theories were from time to time propounded as to their origin and growth. As it was known that vegetable galls were tenanted by animal life, it was thought the plant contained a soul, able to impart life to the animal. Some consilered that galls were stepping-stones from vegetable to animal life, while others thought eggs were drawn up by the sap and ultimately developed into galls. Pliny, the Roman naturalist, knew that flies were produced from certain vegetable galls, but he associated many superstitions with his knowledge. For instance, he says that the events of the year were prognosticated as to the respective larvæ transforming into spiclers, worms, or flies.

The first systematic writer on galls was an Italian physician, who gave an account of the galls of Italy and Sicily in 1686 . The second writer recorded, on the subject, was Dr Derham, Canon of Windsor, who published his observations in the Boyle Lectures, 1711-1712. It is questionable whether he knew of the Italian writings, but it is said that when the two lists are compared the coincidence is very striking. Neither of these writings was known to Limneus or Fabricius. Limnæus called the group Cynips, but comprised all species of Hymenopterous parasites with true gall-makers. Westwook, in 1839, working out the genus Cynips of Limnæus, termed the order Cynipidx, and gave some descriptive details. These, briefly 
considered, are as follows: "Antennze 13- to 15-jointerl; wings few nervures; palpi short; heal small and transverse; thorax thick, oval; abdomen much compressed; peduncle short; antennæ inserted mildle of face."

Hartig was the first to restore order and improve the classification. He separated the true gall-makers from the various speeies of parasites, and then subdivided the parasites into true parasites, inquilines or guest-flies, ant commensals.

Thus a true parasite preys directly on the larva of the gall, and after undergoing its own metamorphosis finally kills its host. Inquilines or guest-flies prey on the substanee of the gall, and, as a rule, indireetly kill the gall-forming inseets. Commensals are generally found in large galls, living as lodgers in the substance of the gall, but do not lill the inseet.

These statements are corroborated by Ratzeburg in his 'Forstinsekten,' published in 184t. Afterwarls we find several workers in the field: Bassett, a Canalian, 1865; Riley, an American, 1873 ; Adler, ${ }^{1}$ a German, 1875 ; and Cameron of Nanehester, 1892. The work of the last-mentioned writer was published by the Ray Society in 1892 .

Before dealing with galls from a purely entomologieal standpoint, it may be interesting, in view of the seientific importance of the subjeet, to consider galls botanically, in so far as their morphological strueture and origin are concerned. With regard to morphology, it must be borne in mind that a gall is not a struetureless tumour, but a distinctly differentiated strueture, and, as a subjeet, the histology of gall structure would prove an interesting study in itself.

Firstly, we have galls of cellular tissue, but with no differentiation of separate layers, as, for example, the eurrant gall or Sputhegaster baccarum. Secondly, galls similar to these, but containing an imner gall, as, for instance, the leaf-twisting gall eaused by Andricus curcator. Thirdly, galls developing vascular bundles throughout the cellular tissue, with distinet epidermis as well as differentiated inner galls, as, for example, the large root-gall eaused by Aphilothirix noduli. Fourthly, galls, as, for instance, the marble gall, having a complicated strueture.

1 This work was translated by Dr Stratton, and published by the Oxford Clarendon Press in 1894; and I beg to acknowledge my indebtedness to this important work for much of the foregoing, and also for many of the statements which follow. 
In support of the complieated structure of the marble gall the following may be quoted-viz. :

"If a transverse seetion of a young marble gall, $3 \mathrm{~mm}$. in thickness, be made at the end of June, it will be found, according to Beyerinck, to exhibit the following strueture: a larval chamber surrounded by (1) a thin layer of primary nutritive tissue; (2) a thin layer of cells containing crystals; (3) a thin layer of primary starch cells; (4) the layers of the eambium ring; (5) a thick layer of large eells, rich in tannin and traversed by vascular bundles; $(6)$ a layer of small meristematic cells; ( 7 ) colourless hypodermal cells; (8) epidermis with unicellular hairs containing red pigment in their cell contents." 1

The origin and development of vegetable galls, more especially those on the oak, is a subjeet which has puzzled eminent seientists. It was at first considered by naturalists that the Cynips deposited simultaneously with the egg a lrop of irritating fluid, which eaused the sap to flow round the egg, and thus a globular form would be the result. In other words, gall-formation was considered the result of chemical action. Darwin alopted this view, and says: "As the poisonous secretion of insects belonging to various orders has the speeial power of affecting the growth of various plants; as a slight difference in the nature of the poison suffices to produce widely different results; and, lastly, as we know the chemical eompounds seereted by plants are eminently liable to be modified by changed conditions of life,-we may beliere it jossible that various parts of a plant might be modified through the agency of its own altered conditions." In the 'Origin of Speeies,' p. 572 , he says: "When we see the symmetrical and complex outgrowths caused by a minute atom of the poison of a gall-insect, we may believe that slight changes in the ehemical nature of the sap or blood would lead to extraordinary modifieations of structure." In another work he says: "The complex and extraordinary outgrowths which invariably follow from the insertion of a minute drop of poison by"a gall-produeing insect show us what singular modifieations result in the case of plants from a chemical change in the nature of the sap." 2 This view, on the strength of the great naturalist, was adopted by Sir James Paget, Prof. Riley, and others. From the faet that so many eminent men have been puzzled with this subject, it is obvious that the question is a difficult one.

${ }^{1}$ Adler, p. 163, written by Dr Stratton.

2 Animals and Plants under Domestication, p. 9. 
The two important factors at work in connection with gall-formation are the activity of the vegetable sap on the one hand and the influener of the animal agency on the other. Botanically considered, gallformation cannot take place unless in direct contact with vital cells -that is, those cells specially set apart for growth and development. In the woody portion of the tree, from the root to the extremity of every branch, there is a special zone of formative cells known as the cambium ring which plays the part of growth in the theatre of life. A section of leaf show's practically two layers of cells, - a layer of closely packed cells on the upper side, known as palisade cells in consequence of their resemblance to a paling fence; and a sort of double layer on the under sile, arranged in opposite direction to the palisade cells. The uncler cells of the leaf are considered to be those most actively associated with growth and assimilation. When eggs are deposited in a normal winter bud, before there is any differentiation of structure hetween the upper and mder side of the leaf, we often find the gall structure on both sides of the leaf, but the preponderance of structmre is always on the under side. This is noticeable in the case of Spathegaster baccamm. In order to fully understand the formation of gall structure on different parts of the tree, as associated with special cells, it is obvions that recourse must be had to section-cutting with the microtome, as well as to minute microscopical investigation. ${ }^{1}$

As gall-formation cannot take place unless in contact with special cells, it follows, therefore, that the insect must deposit the egg with the greatest exactitude, otherwise abortive galls would be the result. In the artichoke gall, for example.-a species formed in buds,--we often find many abortive galls. This may be the result of an egg being deposited in a bud which had been previously pricked by another gall-forming insect, and the vital cells of the plant thus becoming injured; or the premature death of the larval creature within the gall may have arrested the development of the gall. Considering, from the entomological side, the effect of the insect on the vegetable structure, it has been proved that the wound resulting from egg-laying is at once healed up, and that there is, according to the specics, a considerable lapse of time from ego-deposition to hatching. Turing this period the egg derives oxygen from the air, through the medium

${ }^{1}$ For a full account of gall structure see 'Pathologische Pflanzenanatomie, von Dr Ernest Küister. 
of the prolonged egg-stalk. Adler discovered that in two species gallformation commencerl just as the larva was about to escape from the egg. It is, of course, difficult - in fact, in most cases impossible - to see the egg within the gall, but the same observer found that as the larva grew and fed, so the gall increased in size. In other words, no gall-formation took place until just immediately before hatching, but the growth of the gall proceeded simultaneously with the development of the larva. Hence it may be inferred that oak-gall formation is the result of the excitatory action of the larva acting in conjunction with the vitality of the vegetable cell. It must be borne in mind that this special method of gall-formation is only applicable to oak galls, as galls formed by some species of Hymenopterous insects, as, for example, in the case of the common bean-like gall-Pontania yallicola-formed on both sides of the willow leaves, is more or less of an amorphous structure, and practically fully developed before any embryological changes take place within the egg.

In consideration of the variety of gall-structure, and the comparative sameness of larval anatomy, the question may be askerl, Is there a mechanical difference in the direct action of the larva or a chemical difference in the composition of the excitatory emanations? In other words, as the larve are exactly similar in structure and action, what are the factors which produce variations of structure, size, and colour? Thus in point of anatomical structure the larve of the Cynipidæ are practically identical, and, as previously remarked, the galls vary in size, colour, and complex structure.

The question of gall-formation, as considered in relation to the theory of evolution, is somewhat difficult to understand, but, at the same time, is extremely interesting to the philosophical scientist. Darwin somewhere in his writings remarks that if it could be proved that any one creature worked for the good of another creature, his theory would fall to the ground. Of course, this remark is only illustrative of the general principle of natural selection and the "survival of the fittest," and must not be confounded with the principle of altruism, as, for example, the care of the parent for the offspring. Now, in oak-gall formation, and all its complexity of morphological structure, we cannot believe that the oak would form these galls in a disinterested way for the good of the insect, nor, on the other hand, as being of any advantage to the oak itself, considered as a vegetable organism. The oak gall is, therefore, a distinctly differentiated struc- 
ture, apparently formed for the good of the insect, which, as remarkerl, would be against the principle of the theory of evolution; and in view, therefore, of the extreme interest of this question, I lave taken the liberty of quoting the following on "Vegetable Galls" by $\mathrm{Mr}$ G. J. Romanes in 'Darwin and after Darwin.' Mr Romanes says-

"The other instance to which I have alluded as seeming at first sight likely to answer Darwin's challenge is the formation of vegetable galls. The great number and variety of galls agree in presenting a more or less elaborate structure, which is not only foreign to any of the uses of plant-life, but singularly and specially adlapted to those of the insect-life which they shelter. Yet they are prodnced by a growth of the plant itself, when suitably stimulated by the insect's inoculation ; or, according to recent observations, by emanations from the body of the larve which develop from the eggs deposited in the plant by the insect. Now, without question, this is a most remarkable fact; and if there were many more of the like kind to be met with in organie nature, we might seriously consider whether the formation of galls should not be held to make against the ubiquitous agency of natural selection. But inasmuch as the formation of galls stands out as an exception to the otherwise universal rule of every species for itself, and for itself alone, we are justified in regarding this one apparent exception with extreme suspicion. Indeed I think we are justified in regarding the peculiar pathological effect produced in the plant by the secretions of the insect as having been in the first instance accidentally beneficial to the insects. Thus, if any other effect than that of a growing tumour had been produced in the first instance, or if the needs of the insect progeny had not been such as to have derived profit from being enclosed in such a tumour, then, of course, the inoculating instinct of these animals could not have been developed by natural selection. But given these two conditions, and it appears to me there is nothing very much more remarkable about an aceidental correlation between the effects of a parasitic larva on a plant and the needs of that parasite, than there is between the similarly aceidental correlation between a hydatid parasite and the nutrition furnished to it by the tissues of a warm-blooded animal. Doubtless the case of galls is somewhat more remarkable, inasmuch as the morbid growth of the plant has more concem in the correlation -being, in many instances, a more specialised strueture on the part of a host than oceurs anywhere else, either in the animal or vegetable 
worli. But here I may suggest that although natural selection cannot have acted upon the plant directly, so as to have produced galls ever better and better allapted to the needs of the insect, it may have so actel upon the plants indireetly throm th the inserts. For it may very well have heen that natural selection would ever tend to preserve those indivilual insects, the quality of whose emanations tender to produce the form of galls hest suited to nourish the insect progeny; and thus the character of these pathological growths may have become ever better and better adapted to the needs of the inseets. Lastly, looking to the enormous number of relations and inter-relations between all organic species, it is scareely to be wondered at that even so extraoritinary an instance of correlation as this should have arisen thus by accident, and then have been perfecterl by such an indirect agency of natural selection as is here suggested.

"Again, quite independently, and still more recently, Mr Mivart alluded in 'Nature' (vol. xli. p. 41) to the diffieulty which the apparently exceptional case of gall-formation presents to the theory of natural selection. Therefore I supplied (vol. xli. p. 80) the suggestion criven in the text-viz, that although it appears impossible that the sometimes remarkably elaborate and adaptive structures of galls ean be due to natural selection acting directly on the plants themselves, - seeing that the adiptation has reference to the needs of their parasites, - it is quite possible that the phenomena may be due to natural selection acting indirectly on the plants, by always preserving those indivichal insects (and larvæ) the charaeter of whose seeretions is such as will best induce the particular shapes of galls that are required. Several other correspondents took part in the diseussion, and most of them accepted the above explanation. $\mathrm{Mr}$ T. D. A. Cockerell, however, alvanced another and very ingenions hypothesis, showing that there is certainly one eonceivable way in which natural selection might have produeed all the phenomena of gall-formation by acting directly on the plants themselves (vol. xli. p. 344). Subsequently, Mr Cockerell published another paper on the subject, stating his views at greater length. The following is the substance of his theory as there presented:-

"Doubtless there were internal plant-feeding larvæ before there were galls; and, indeed, we have geological evidence that boring insects date very far back indeed. The primitive internal feeders, 
then, were miners in the roots, stems, twigs, or loaves, such as oceur very commonly at the present tay. These miners are excessively harmful to plant-life, and form a class of the most destructive insectpests known to the farmer: they frequently cause the death of the whole or part of the plant attacked. Now, we may suppose that the secretions of certain of these insects caused a swelling to appear where the larva lived, and on this excrescence the larve feel. It is easy to see that the greater the exerescence, and the greater the tendency of the larve to feed upon it, insteal of destroying the vital tissues, the smaller is the amount of harm to the plant. Now, the continued life and vitality of the plant is beneficial to the larre, and the larger and more perfect the gall, the greater the amount of available food. Hence natural selection will have preserved and accumulated the gall-forming tendencies, as not only beneficial to the larva, but as a means whereby the larve can feed with least harm to the plant. So far from being developed for the exclusive benefit of the larve, it is easy to see that, allowing a tendency to gall-formation, natural selection would have developed galls exclusively for the benefit of the plant, so that they might suffer a minimum of harm from the mavoidable attacks of insects.

"Int here it may be questioned, Have we proof that internal feeders tend to form galls? In answer to this I would point out that gallformation is a peculiar feature, and cannot be expected to arise in every group of internal feeslers. lint I think we can afford sufficient proof that wherever it has arisen it has been preservet; and further, that even the highly complex forms of galls are evolved from forms so simple that we hesitate to call them galls at all ('Entomologist,' March 1890). The paper then proceeds to give a number of individual cases. No doubt the prineipal objection to which Mr Cockerell's hypothesis is open is one that was printerl out by Iferr Wetterhan-viz., 'the much greater facility afforded to the indirect action through insects, by the enormonsly more rapid succession of generations with the latter than with many of their vegetable hosts -oaks above all' ('Nature,' vol. xli. p. 394). This diffieulty, however, Mr Cockerell believes may be surmounted by the consileration that a growing plant need not be regarded as a single indivilual, but rather as an assemblage of sneh" (vol. xli. 1p. $559,560)$.

With regard to the insects producing, oak galls, the transformations 
of the Cynipicla are complete. They pass through four stages-viz., egg, larva, pupa, and imago (fig. 129).

The egg (fig. 129, a) is pyriform, with one end elongated, terminating as a prolonged penduncle. Adler supposed the function of this organism to be respiratory, it having long peduncles when deeply embedded and difficult of access to oxygen, and shorter when access is easy.

The eggs of the Cynipicle are often laid in winter, thus contrasting
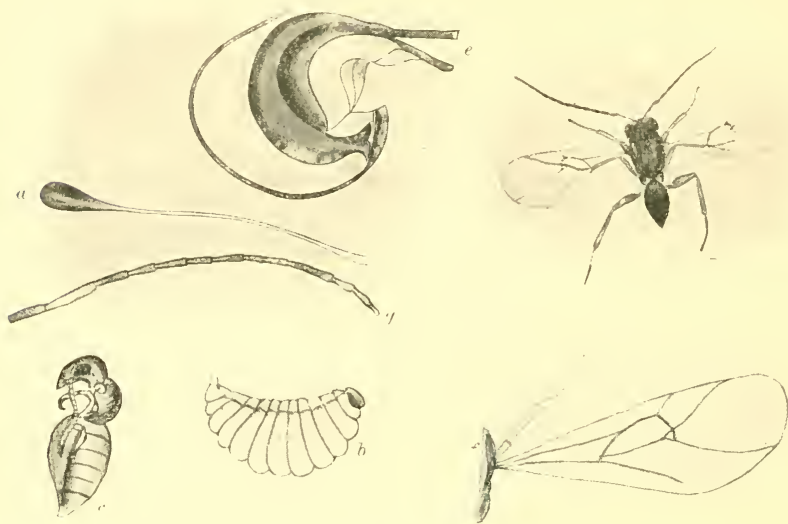

Fis. 129.

a Egg of Cynips. (Copied from Adler and Stratton.)

b Larva of Cynips.

- Pupa of Cynips.

d Gall-fly, Teres terminatis (oak-apple) Male. (From photograph.) $e$ Ovipositor of Neuroterus lenticularis. (From camera-lucida sketich.) $f$ Wing of Sputheguster baeearum. (From photograph.)

$g$ Antenna of Spathegaster bacearum. (From camera-lueida sketch.)

with the egrgs of many species of saw-flies, which are deposited when nature is active. There are other interesting points about the eggs which will be considered later on.

The larva are white, footless, and fleshy grubs, with thirteen segments (fig. 129, b). There is considerable diversity of time regarding the larval stage.

In appearance the pupæ are similar to the larvæ, and some organs of the perfect insect are discernible. Fig. 129, $c$. 
The imagines, apart from the salient features to be considered under general anatomy, present very few interesting habits. They are inactive, take no food, but are known to imbibe water, and a most interesting point is the variation in the time of appearing.

The males differ from the females in having longer antennæ, and also have one or two more joints than in the case of the female (fig. $129, d)$. The female has a very large abdomen, and the precise shape of the abdomen again differs according to species, which depends on the form of the ovipositor (fig. 129,e). It is to be remembered that we have two forms, the sexual and asexual or agamic, and that specific characters are not very distinct; therefore we have to rely on the galls themselves for the most important points of discrimination of species.

The following are the most distinguishing features, accorling to Cameron' ${ }^{1}:-$

"Cynipidz.-Abdomen petiolated-i.e., not attached by its entire breadth to the thorax.

"Ablomen perlmeulated, trochanters biarticulate, antennæ 12 to 15 jointed and never elbowed, prothorax reaching to the insertion of the wings; wings without a stigma, and with 1 ralial and 1 to 3 cubital cellules, the second when present being minute, usually triangular; the sub-costal cellule large, always present; the other cellules badly defined or absent; submarginal nervure absent; abdomen compressed, ovipositor originating close to the base of the abdomen, the borer usually semi-spiral, and with parts free; larvæ apterous, never spinning a cocoon; eggs stalked; antenne in $q$ stouter than $\delta$; legs, claws simple in Cynips, eleft in some species of Andrieus and Neuroterus.

"Chaleidide." - Wings having a stigma; no radial or cubital cellules; antennæ elbowed; prothorax not reaching to insertion of wings."

The details of a wing of Cynips, fig. 129, $f$, should be carefully studied, as the wings of the genuine oak-gall fly differ very much from the varions species of parasitic flies which are associated with the Cynipiclæ.

\footnotetext{
1 Monograph of the British Phytophagous Hymenoptera, vol. iii. pp. 142, 147. Ray Society.

2 This fanily contains many of the parasites found in oak galls, therefore it is most important to recognise the contrasting points.
} 
Adler ${ }^{2}$ arranges the species in the four following groups-riz. :
I. Neuroterus.
III. Dryophanta.
II. Aphilothrix.
IV. IBorhiza.

In attempting to give some detailed account of the various species of oak galls whereby the galls themselves may be recognised in the forest and the insects verified after hatching in confinement, it is obvious there are several ways open for adoption.

We might follow a botanical methor and leseribe the galls on buds, leaves, fruit, and roots; or we might adopt an entomological course, and describe and compare the various species as found on the respect-

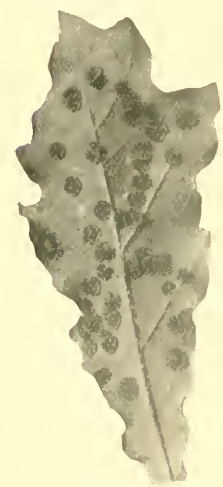

Fig. 130.-Galls of Neuroterus lenticularis (ook:spangle gail). ive parts of the tree. But we shall adhere to the arrangement of Adler, becanse we may then follow the commonest species and have a direct bearing on a most important biological law-viz., the alternation of generations.

Firstly, take

\section{Neuroterus lexticularis, ()1. ${ }^{2}$ (Oak- spangle Gall).}

This gall is very common throughout the country from July to September. The galls are scattered promiscuonsly on the under side of the leaves (fig. 130), are more or less circular, and develop in July from objects resembling pin-points. They are clothed with stellate hairs on the upper sile, but smooth on the under side of the surface, pressing against the leaf and very slightly attached to the leaf. They are miserl in the centre, tapering to thin edges on the leaf, and with the outer edge lying flat on the leaf. If specimens which lie on the ground over winter be measured in March, just before the flies hatch out, it will be found that they have the same breadth as in autumn, but have increased considerably in thickness. At this time of the year they will measure about $4 \mathrm{~mm}$. in breadth and $2 \frac{1}{2} \mathrm{~mm}$. in thickness.

${ }^{1}$ Alternating Generations, p. 8. Translated by Dr Stratton. 1894.

2 The figures 1 and 1 a represent alternating species. Thus 1 alternates with $1 a, 2$ with $2 a$, and so on. It should be noted also that the generations marked $1 a, 2 a, \& c .$, produce insects of both sexes, whereas insects in the generations marked 1, 2, \&c., are all females. 
Fly : colour black, shining, length about 2 to $2.5 \mathrm{~mm}$. The thorax is rather dull in appearance; abclomen shining and almost round in form when looked at from the side. The legs are of a lightish-brown colour. The wings are iridescent and considerably longer than the bouly; antenne brownish, 15-jointed, the seven apical joints heing nearly equal in size and much smaller than the basal joints (fig. 131). The insects hatched out in Northmberland from March 23 to April 12, 1906, and only lived for about ten clays within the glass case.

Prior to understanding the subject, a curious fact had often suggested itself to me as a problem difficult of solution-viz., if the insect appears in March, and lives only for a short time, where does it find leaves to deposit its eggs on for the next generation, seeing that leaves do not often appear until the end of May or begimning of June? The first thought which suggested itself was that the eggs were deposited in the buds, and when the leaves unfolded the galls would develop. Then the problem appeared more diffieult, inasmuch as the spangle galls chiefly appear, not on the first developed leaves from the winter buds, but on leaves not appearing

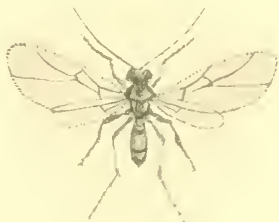

Fits. 131.- Newroterus Jentıcularis. (Drawn by J. Patten, jun.) until July-in other words, on the young shoots which grew after the fly of the Neuroterus lenticularis must have been dead.

Dr Adler, before conmencing to work out the subject, must have been likewise puzzled, and accordingly he commenced a series of experiments in 1875. He grew a number of young oaks in flower-pots, hatched ont the spangle-gall flies in March, and induced them to deposit eggs in the young oak buds, under glass, when the leaves unfolded and developed, together with the galls resulting from the previous deposition of Cynip eggs of the spangle-gall species. The galls, instead of being spangle galls, were another type-viz., Spathegaster baccarum or currant gall (figs. 132 and 133). The galls were different, and the tlies also, for they were sexual, males as well as females being found, whereas in the previous species the insects were all females. Aller then induced Sputheyaster baccarum to deposit eggs on the leaves, and obtained as a result the oak-spangle galls, - the galls on the leaves of the young shoots. Thus the oak-spangle 
gall-fly - Neuroterus lenticularis - deposited eggs in the bud and produced the currant gall; and the gall-flies of Sputhegaster bacearum or currant gall produced the spangle gall. In short, flies of the one speeies deposited its eggs and produced the galls and flies of the other species. Thus Adler demonstrated to the scientifie world what hat only been previously guessed at-viz., the important biological law of the alternation of generations in oak galls. This is a very important biological law which is not uncommon amongst certain animals comparatively low in the scale of organisation, and is no doubt essential to the wellbeing and continuation of species. In view, therefore, of

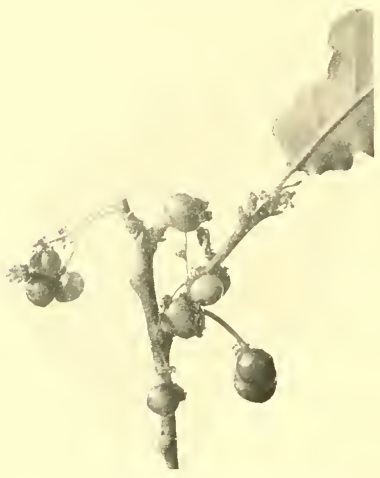

Fig. 132. - Galls of Spathegaster hacearum on male flowers of oak.

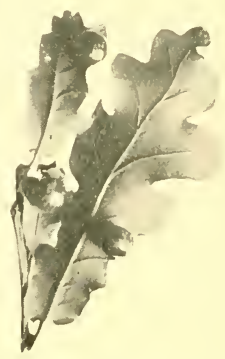

Fig. 133.-Galls of Spathegaster bacearum on leares.

the biological importance of the subject, it may be well to contrast two important and to some extent allied phenomena-viz., Dimorphism and Heterœeism-as compared with alternation of generations.

Dimorphism means, two forms of the same thing. Thus certain chemicals and minerals crystallise in two forms, and are called Dimorphous, and if in three forms, Trimorphons. In animals we have seasonable dimorphism, as ehange of colour in winter or adaptation to environment; sexual dimorphism, as instanced by the difference between male and female in the peacock and pea-hen. In the lower order of plants and animals many instances might be given.

Heterœeism in animal and plant life means a change from host to host in order to complete a life cycle. Thus the tapeworm found 
in man passes its early stage in the pig, and the latter stage in man. Certain plant diseases pass one stage on weeds and the other on trees. These are two typical instances from animal and plant life.

Altemation of generations is totally different from these phenomena, inasmuch as two distinet generations alternate one with the other. In fact, this may be best understood when we say that the ehildren never resemble their parents, but are always facsimiles of their grandparents.

Having mentioned two distinct genera resulting from alternating generations, the question arises, Are the two genera widely separated in point of general appearance or anatomical details? Adler considers they are, and accorlingly adopts Neuroterus and Spathegaster as generic terms. But Professor Mayr of Vienna classifies the two genera as Neuroterus, and this classification is adopted by Cameron.

The main distinguishing features are slight differences in colour and in general stoutness, Neuroterus being stouter than Spathegaster. The abdomen differs in size and appearance, resulting from the size and shape of the ovipositor (fig. 129,e), which must be viewed in the relation of adaptation, a long ovipositor being necessary for penetrating buds, and a short one for leaves.

\section{1a. Spathegaster baccarum (Htg.)}

The galls are found on the flowers and leaves (figs.132 and 133). They are pea-shaped, smooth, glossy-looking, soft and succulent, of a greenish colour, but have often a few bright-red spots. They are situated on the under side of the leaves, but often penetrate through the upper side and rise slightly above it. The speeimens found on the male catkins are generally smaller than those on the leaves, and slightly more redelish in colour.

The fly (fig. 131) has a blaek shining body, abont $2.2 \mathrm{~mm}$. in length,

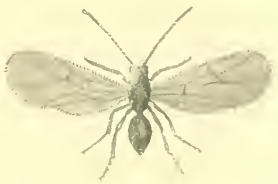

Fig. 134.-Slathegaster baccarum.

antennæ brownish, 14-jointed in the male. The legs are yellow, with black coxre at the base. Tarsi 5-jointed; wings longish, broad at the apex, and about $\& \mathrm{~mm}$. in expanse. In a comparatively forward 
season they may be fomm in the Millands about the end of May, lut more commonly in the midile of Jume. It the same season of the year as we fiml the spangle gall, two or three other species of Nemroteris maty be foumd.

\section{Neunoterus fumipennis (IItg.)}

Gall on the muder side of oak leaves, circular in outline, smaller in size and brighter in colonr than the spangle gall (fig. 13.5); but the principal differenee is that the spangle gall is receed in the centre and

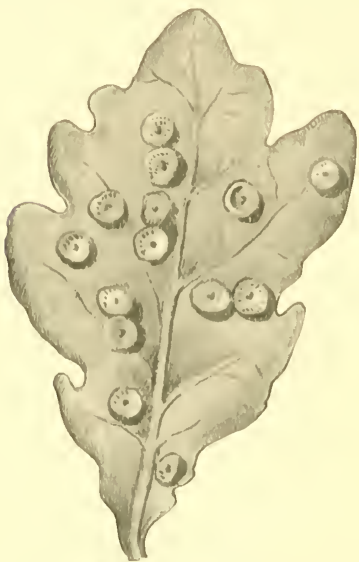

Fig. 135. Girlls of Nemroterus fimipenis.

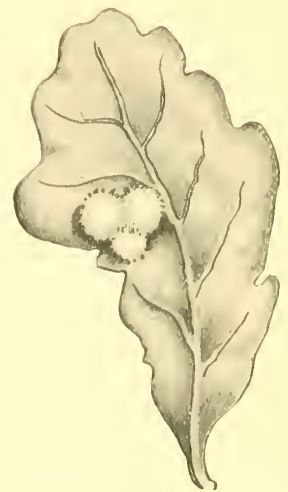

Fig. J:iti. - Ciull of Syathoraster trieolor. (Drawn by P'J. Brown.)

the outer erge lying flat on the leaf, whereas the species in question has the outer elge of the gall raised and slightly depressed in the centro. Thus the intividual galls somewhat resemble a sancer.

Accorling to Adler, harval development dues not hegin until March (by the time Neuroterus lentirularis has hatchet), and the flies appear about the end of liay. The same authority says this fly is easily distinguished from all the other species of Neurotorus. Size $2 \mathrm{~mm}$. Thorax dull hlack; hase of abdomen orange; legs, including the femoril, orange; wings, especially at the tips, smoky.

1 Nay 27, 1895, in Cheshire. 


\section{2a. Sipathegaster tricolor (IItg.)}

The sexual species forms a pea-shaped hairy gall of light-yellowishgreen colour (fig. 136), appearing about the end of June or heginning of July. They are found in clusters on the under side of the leaves. The hairs fall off when the gall matures, and then it may be mistaken for spathegaster barrainn, which, however, is over by this time.

The fly is a very slender insect, the wings when sprear out being comparatively long in proportion to the boly.
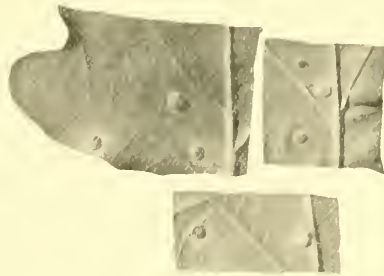

Fig. 137.-Gull. of Neuroterus lisviusculus.

The borly is about $2 \mathrm{~mm}$. long, and the expanse of wings $8 \mathrm{~mm}$. The body is black throughont, legs all yellow, and the wings rather cloudy. Males and females very much alike.

\section{Neuroterus leviusculus (sichenck.)}

This gall (fig. 13i) is very much like the two previous species in general appearance, but not so common or so numerons on the leaf. The form is similar, but in this species the gall is nearly smooth except on a well-defined knob in the centre, which is covered with hairs. I have not reared the fly, but found the gall fairly common both in Cheshire and Northumberland.

\section{3\%. SPATHEGASTER ALBIPES (Schenek.)}

This is the agamic species of $N$. leviusmlus, and I have only found it in one district-

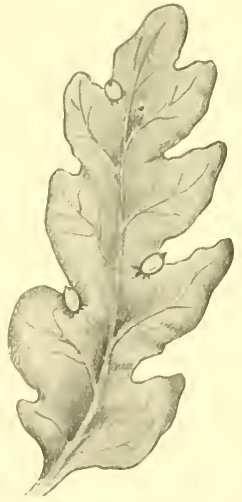

Fig. 138.-Galls of Spathe. faster albipes. (Drawn by P. J. Brown.) viz., at Pauperhaugh, in Northumberland, about the beginning of June. The gall of this species (fig. 138) is more or less oval, tapering to a blunt point, and of a slightly yellowish-green colour. The galls 
sit closely on the leaf, and they give rise to deep windings on the edge of the leaf, which is said to be cansed through the gall originating on a rudimentary leaf within the bud.

\section{Neuroterus numismatis, Ol. (Button Gall).}

This gall (fig. 139) is very common in the autumn. It is very pretty, circular in shape, about $2 \mathrm{~mm}$. in diameter, hard, with a shallow depression in the centre. I have not hatched the flies nor found the alternate form-viz., $4 a$ Spathegaster vesicatrix (Schltill.), which are found on the under side of the leaf, and are rather incon-

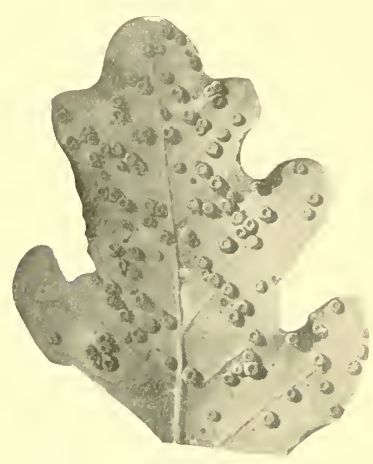

Fig. 139.-Gulls of Neuroterus numismatis. spicuous, as they are embeilded in the substance of the leaf. ${ }^{1}$

There is another species in the group of which Adler was not quite sure about fixing the generation cycle. This is the gall of

\section{Neuroterus ostreus (Htg.)}

This is a very small gall, not larger than a leaden pellet, and always formed on the millrib of the leaves, and very slightly attached. It is very prettily marked, and the pale-yellowish colour brightened by red spots is suggestive of the markings of a miniature egg of some bird. It is common in September and October. From the early matured galls flies hatch out in October, but those not maturing until October do not yield gall-flies until the following spring. I kept some in confinement, and they hatched out on April 25, 1895. The fly is about 2 to $2 \frac{1}{2} \mathrm{~mm}$. in length, of a llack shining colour, with dull thorax, legs yellowish in slender portion and dark at top next to body ; antennæ longish and slender, wings comparatively long.

As Dr Acller is not quite certain about the generation cycle of this species, it may be best to quote his own words-viz. : "I strongly suspect that the sexual generation belonging to Neuroterus ostreus is to be sought for in Spathegaster aprilinus," and this conjecture has since proved to be correct.

${ }^{1}$ I have since received this species from Mr E. T. Connold. 


\section{5a. Spathegaster aprilinus (Gir.)}

The galls of this species are formed in buds, but the formation is so obseure as to be frequently overlooked. In fact, we should consider them abortive buds, and the best way to find them is to look for abortive buds just after the leaves develop. It should be noted that undeveloped burls, frequently found in oaks after the early flushing of the leaves, are due to the attacks of this species. In order to hatch those galls it is best to collect them about the end of April or beginning of May.

The fly is described by Adler as follows: "Length $2.5 \mathrm{~mm}$., black thorax, somewhat shining; seutellum wrinkled, abiomen shining, antenne black, legs dark-yellow, coxi and basal half of the femora blackish. Males and females similar in colouring."

\section{Gemus ApHilothrix.}

The second group, according to Adler, having alternate generations, is the Aphilothrix-Andricus Group. The genus Aphilothiti ineludes a large number of gall-flies found only in the female sex. The genus Andricus yields the sexual form.

\section{Aphilothrix radicis ${ }^{1}$ (Fabr.)}

This gall (fig. 140) is found on the lower part of the trunk, or just on the horizontal portion of the root above ground. At first it

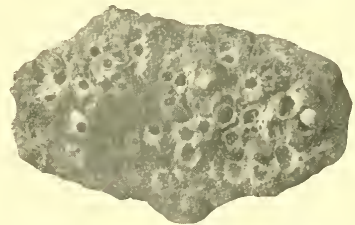

Fig. 140.-Gall of Aphilothrix radicis. In section to show chambers. appears as a large softish mass, but ultimately it becomes quite hard in the centre, and a section made in mill-winter will reveal a manychamberel gall with a fully developed fly in each chamber. They hatch out about the latter end of April.

The fly is reddish-brown, with longitudinal stripes on the thorax. The abdomen is somewhat rlark, and the thorax is covered with a fine silky pubescence. The antennæe are dark-brown. Length from 5 to

1 Ir Denis C. Trier, Gittisham, Honiton, Deron, informed me of considerable injuries done by this species, and $\mathrm{Mr}$ R. P. Mair, The Hammonds, Udimore, Sussex, on whose property the injury was done, kindly sent me specmens, together with a very interesting and lucid account of the damage. 
$6 \mathrm{~mm}$. The altemating species is $6 a$ ANDrices sodull (Htg.), which makes galls in the woorly portions of young shoots.

\section{Aphllothrix corticis (Lim.)}

The galls of this species are found inserted in the young bark which is formed where the stem has been injured, or in the tender bark which forms in the "healing over" process after a branch has been sawn off (fig. 141). Sometimes they may be found in clusters,

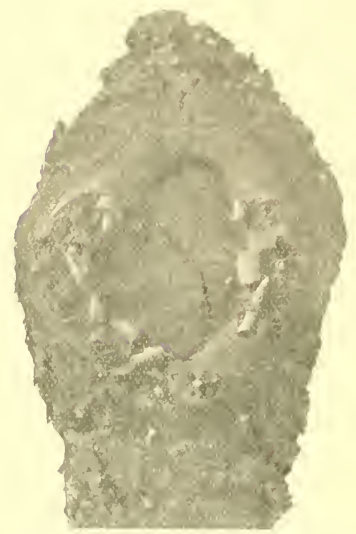

Fig. 141. - Gulls of Aphilothrix corticis in portion of bert: "healed over by ocelusion."

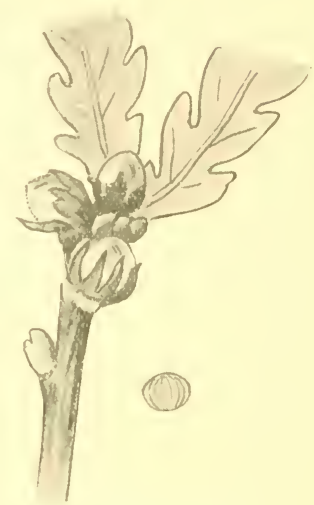

Fig. 112.-Galls of Aphilothrix globuli.

but as a rule they are clistributed over the young bark. It often happens that the rim of under-bark surrounding the eut-off branch is very much torn, and this arises from birds tearing out the galls and lacerating the bark. The flies hateh out in June, and the alternating species, according to Adler, is $7 a$ Andricus genmatus, a species found in the terminal buds.

\section{Aphilothrix globuli (Htg.)}

The gall (fig. 142) of this species is a beautiful green globular gall, formed in the lud for the coming year. It may be found in Sept- 
ember projecting from the bud-scales, and would perhaps measure about $\frac{1}{t}$ inch in diameter. I found it very common in Delamere Forest, Cheshire, but have not hatcherl the fly.

\section{8a. Axdrices ixflator (Htg.)}

This gall (fig. 143), which is the alternating species of $A$. globuli, is originally formed from a bud. In general appearance it is somewhat like the thickened portion of that part of a turnip immediately above the bulb which is finally surmounted by the leaves. The gall proper is really within the woody portion, and during the year in which eggs are deposited growth is not perceptibly interfered with, but the next year the portion affected by the insect agency swells, and the adventitious buds formed thereon give rise to the tuft of leaves referred to. The galls are not very common, but may be lookel for in June, and the flies emerge only in July.

"Fly-size 2 to $4 \mathrm{~mm}$.

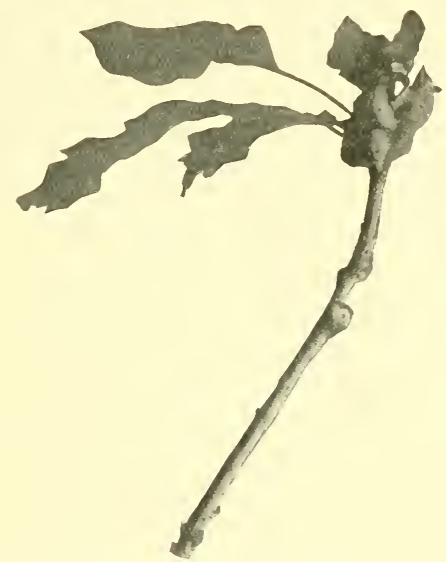

Fig. 143.-Gall of Andricus inflator. Head and thorax black, slightly shining; abdomen in the female black above, red or orange beneath,-in the male entirely black; legs orange, but the posterior tibiæ and coxæ dark; antennæ dark, pale at the base."-Adler.

The next gall to be considered is very common in the sexual form, but not so general in the agamic stage. The latter is, according to Adler's elassification, Aphilothrix coliaris (Htg.), and the former, Axpricus curvator ( $\mathrm{Htg}$.), or the leaf-twisting gall.

The gall of (9) ApHiLoturix collaris is formed upon a bud, and, being concealed, may easily be overlooked. Adler says: "In Sept. 
ember and October the gall becomes loosened and falls to the ground, and a few may remain, but only inquilines and parasites are reared from those adherent galls." The flies are said to be difficult to rear from the galls, as after the galls are mature a year and a half passes before the appearance of the flies.

\section{9a. Andricus curvator (Htg.) ${ }^{1}$}

This alternating generation with Aphilothix collaris is a very common gall, and may be found about the beginning or mildle of



Fig. 144.--Galls of Andricus eurvator.

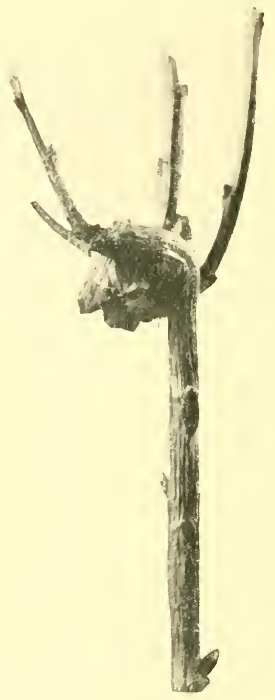

Fig. 145.-Injury done to leading shoot by gull of Andricus eurvator.

June. The galls are formed on the ribs of the leaves. They form irregular thickenings of the leaf-surface, and cause the leaf to twist inuards (fig. 144). Sometimes we find the extreme tip of the twig affected by the gall-formation, and, as a consequence, a swelling takes place where the terminal shoot bends, and grows at right angles

${ }^{1}$ From this point the alternation of generations is not followed. 
to the more upright twig. The portion thus affeeted seldom does any more good, but, when this occurs on minor twigs, the tree is not appreciably injuretl (fig. 145). When, however, several galls are on one leaf and very abundant on a young tree, the leaves are arrested in their development, and the result in the aggregate woukd diminish growth and eause disfiguration. The gall itself is an irregular swelling, of a green colour, and pod-like in structure. When opened, the eentral eavity is eomparatively large, and contains a small brownish seed-like pod, which is the inner gall, wherein is found the larval form

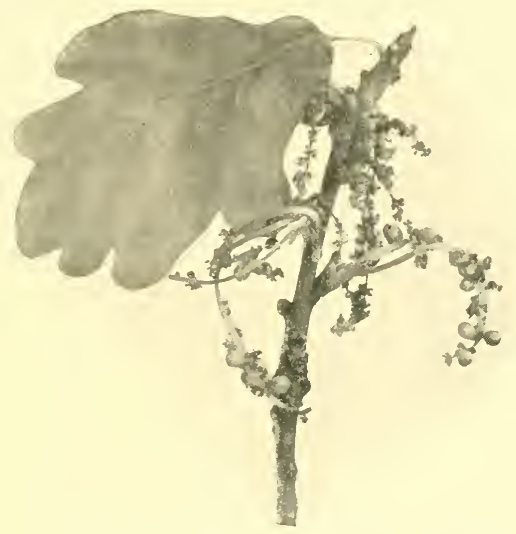

Fig. 146. -Galls of Aphilothrix quadrilineata on flowers of oak.

of the gall-fly. This inner gall is not attached to the wall of the outer gall. The galls may be looked for in May, and the flies appear in June.

The fly is about 1.5 to $2 \mathrm{~mm}$. in size. Borly and antennie shining black; legs lighter in eolour; wings more or less hyaline.

The two following species of the Aphilothrix group are not associated by Adler as connected with the alternation of generations, but are nevertheless more or less common.

\section{Aphilothrix quanrilineata (IItg.)}

The gall of this species, fig. 146, is found on the flowering catkins about the end of May or beginning of June. It is very small in size, 
and may not inaptly be compared to a miniature rifle-bullet with longitudinal ridges added on.

I have not succeeded in rearing the fly, which Adler says is very difficult, and does not appear until the following April. It is very common in Alnwick parks.

\section{Aphllothrix albopunctata (Schltill.)}

The gall of this species is a very pretty little object, and is formed in the bud (fig. 147). It somewhat resembles a small acorn. It is green, spotted with red, and

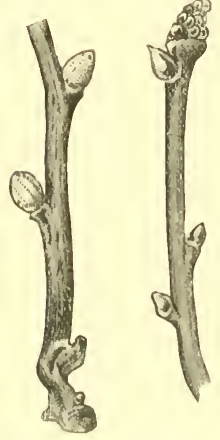

Fig. 147.-Galls of Aphilothrix albopunctata.

\section{ANdricus raudul (Linn.)}

This gall is known as the cotton gall, as it occurs on the flower and resembles a ball of cotton-wool (fig. 148). The hairs are interwoven so as to form a sort of felt. The galls are many-chambered, or polythalamous. : This is by no means a very common gall. I have found it twice, - once in Wales, in June 1891, and again in the Alnwick parks, July 1898. The flies hatch ont in July.

\section{Apmilotmitx fecundatrix, Htg. (Adler).} Antrimes fertumlatrir, Mayr (Cameron).

This gall is known as the artichoke gall. It very much resembles a hop-flower, with imbricated scales. $\Lambda$ t first it is of a green colour, but becomes brown with age. In collecting those galls when mature much care is necessary to obtain the imagines. The real gall is a small acorn-shaped body within these seales, but so very loosely 
attached that, if not careful, our hop-like galls may be nothing else bnt empty lunsks (fig. 149).

\section{Dryophanta Group.}

The galls of this group are always found on the uncler side of the leaves, and in order that we may verify the galls in the forest, it may

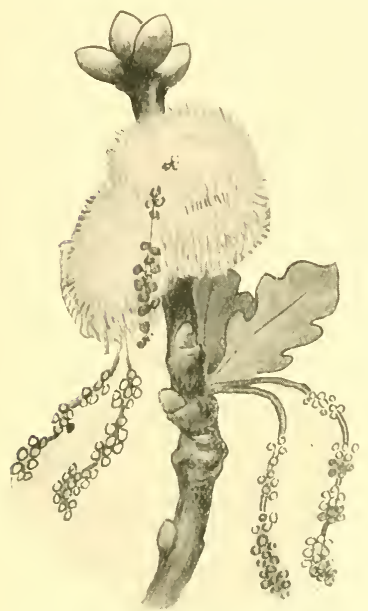

Fig. 148.-Gall of Andricus ramuli (cotton gall). (Drawn by P. J. Brown.)

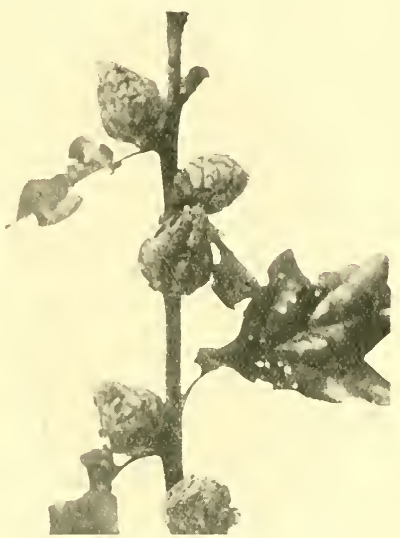

Fig. 149.-Galls of Aphilothrix fecundatrix (ertichole gall).

be better to confine ourselves to the group and not to the cycle generation.

Dryopianta scutellaris, Itg. (Adler).

Inyoulhanta folii, Mayr (Cameron).

This is known by the graphic name of "eherry gall." It is comparatively large, about the size of a small cherry or marble, and always springing from the veins of the leaves, more especially the midrib. It is slightly attached to the vein. The colour varies from light-green 
and yellow to red on one side. It is fairly common in some parts of the country, but is more or less local (fig. 150).

\section{Dryophanta longiventris (Htg.)}

This gall (fig. 151) is somewhat like the previous species, and is also found on the midrib of the leaves. It is brilliantly colonred with red

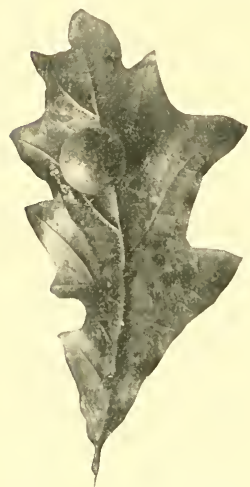

Fig. 150.-Gull of Dryophanta scutellaris (cherry gall). and white stripes, and its rind may be either smooth or slightly corrugated. It is fairly common in some parts of Northumberlanıl.

\section{Drtophanta divisa (Adler).}

The galls are about the size of a small pellet or buck-shot, and are found thickly studded on the under side of the leaves, springing from the veins (fig. 152). They may be looked for from June to October, and at first they are of a bright-red colour, but they gratually change to a light-brown towards maturity. The surface is smooth, with a slight depression in the centre. The structure is hard and woody, with a comparatively thick wall and small single larval chamber.

From a dozen to twenty may sometimes be foum on one leaf.

The flies hatch in October and November, and are about 4 to $5 \mathrm{~mm}$.

long. Antenmæ dark-brown;

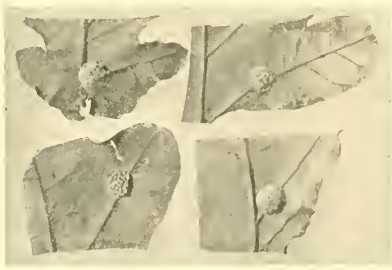

Fig. 151.-Galls of Dryojhanta longiventris.

head and thorax brown; abdomen black, and legs of a lighter brown than body; wings longer than body.

\section{Biorhiza Group.}

The first to be considered in this gromp is Bronimza aptera (Fabr.) The galls of this species are found on the roots of the oak, sometimes on the smallest tips, at other times on strong roots. The galls may 
very often be found by workmen when trenching or uprooting trees in winter. They are of a coffee-brown colour, and vary in size, lout the average is about the bulk of a common pea (fig. 153). They are generally proeured in clusters, which very much resemble the honeycombs of the moss-bee, Bombus muscorum. Adler says that, after many observations, he found that the flies issue in Iecember and January, but adds that other observers found the time of their appearance rather variable. This last remark I can quite endorse, inasmueh as galls found by workmen in February did not hateh until well on in spring. In this case there is no mistaking the species or confounding with parasites, inasmuch as the specimens are all apterous.

The fly varies in size from 4 to $T$ mm. long, wingless, with a rather slender thorax. The form is somewhat spider-like, and the whole body of a uniform brownish colour.

With regard to the alternate form, Adler made many observations, and found that the

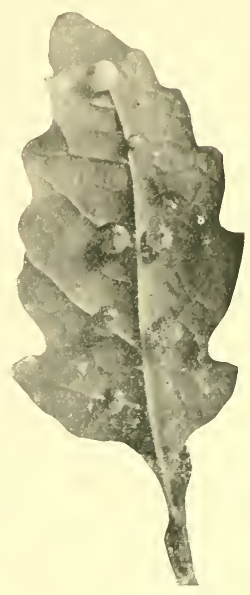

Fig. 152.-Galls of Dryophanta divisa. eggs deposited by Bimfiza aptera result in the formation of the well-known oak-apple.

Adler watehed the egg-laying process very closely, and found that the insect did not deposit the egg immediately after making the incision, but acted on the principle of "one thing at a time," inasmuch as she carefully pricked the buds and then returned to deposit the eggs in previously prepared channels. In this way he found that

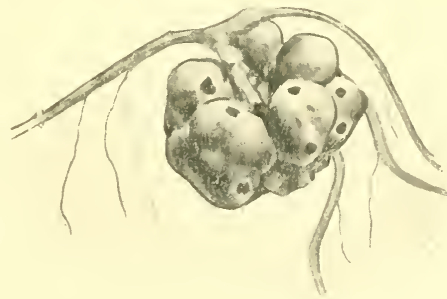

Fig. 153.-Galls of Biorhiza aptera. on January 27,1878 , the fly deposited 582 eggs luring 87 hours. Towards the end of May these galls were fully developed oak-apples. 


\section{Teras terminalis (Fabr.)}

The gall of this species (fig. 154) is the well-known oak-apple or King Charles apple, which is worn by country boys in the south of England on the 29th May. When first the oak-apple appears, it is of a very beautiful scarlet colour. On making a longitudinal or transverse section, we find that the interior of the gall is manychambered, and the outside soft, spongy, and rich in tamnin.

The gall matures in June, and the flies emerge in July. This being

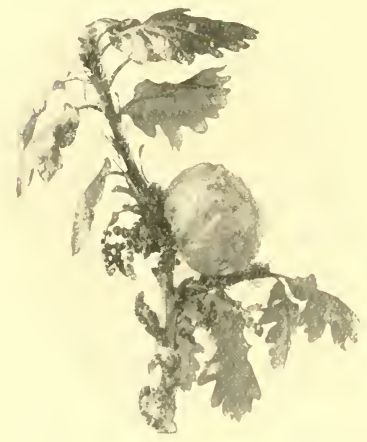

Fig. 154.-Girll of Teras terminalis (oak-apple). the case, and considering that the gall is abundant and common, it is very easily reared.

With regard to the fly, I have made from microscopical observations the following notes:-

Length of body $2 \mathrm{~mm}$.; breadth or expanse of wings $5 \mathrm{~mm}$. ; wings slightly pubescent, with short hairs; head and thorax brownish; abdomen considerably narrower than thorax, blackish, shining, egg-shaped, and pointed; eyes black and shining; three terminal joints of antemie more slender than the other joints.

The males are paler than the females, and always winged, but the females have often rudimentary wings.

The alternate generation between Biorhiza aptera and Teras terminalis has been demonstrated by Adler and corroborated by Beyerinck, and yet notwithstanding this there are apparent natural difficulties to fully realise the same correctly. First of all, we have the agamic generation Biorhiza aptera living on the roots and always apterous. But the next generation is often found on the tops of comparatively tall trees, and the question arises, How do the apterous flies in a natural state reach the topmost boughs to deposit their eggs?

We have seen that apterous insects are often born amongst oakapple flies. This might be considered advantageous in assisting the insect to deposit its eggs on the roots. The apterons flies on the oakapple are the exception, but the apterous flies from the root galls, so 
far as hitherto ascertained, are a rule without any exception. Yet another point is noticeable - viz., that galls appear on certain levels, certain zones of height; and here we find the apterous flies, in order to reproduce the next generation, have reached the highest zone.

There is a special entomological interest attacher to the oak-apple gall, inasmuch as the list of parasites reared and given by Cameron is quite a little study in itself. The interest is intensified on account of various species appearing throughout the whole year

\section{Biorihza ReNum (Htg.)}

This is a kidney-shaped gall, as the name implies (fig. 155). It is not very common, but when found is generally abundant on the under sicle of the leares, and arranged in rows attached to the veins. It is found in September and Oetober, but though I found it several consecutive years in a Cheshire lane, I yet failed to rear a single $\mathrm{fly}$, which is deseribed as wingless, and of a brownish-red colour.

By experimental breeding Adler found the fly alternated with TrigonASPIS MEGAPTERA (crustalis), which is found on adventitious buds on old oak stems near the roots. The gall is about the size of a large pea, of a beantiful pink colour, soft and

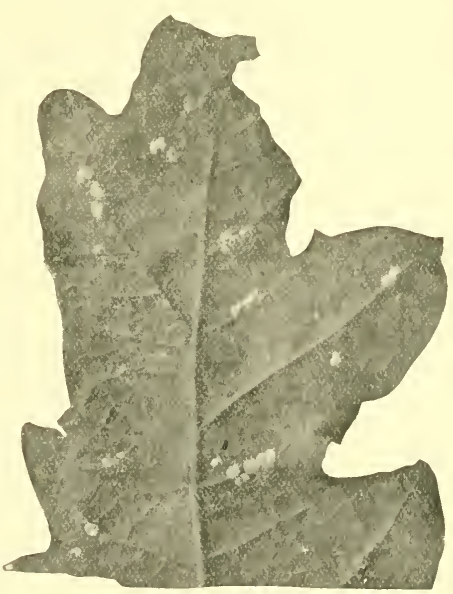

Fig. 155.-Galls of Biorhiza renum (liilney gall).

succulent. This gall may be first observed towards the latter end of April, and by the middle of May we find it fully matured, and the inseets hatching out. It is very generally distributed throughout the country, but is not always equally abundant every year. Thus in 1893 it was very common, but comparatively rare in 1894 and in 
1895, and again fairly abundant in 1896 . In 1897 I found one as late as May 23 in Cheshire, and it hatched out next day. It may be found either singly or in masses, and each gall is single-chanbered.

The perfect insect is one of the prettiest of the gall-flies. The head and thorax are black, and abdomen of a bright shining appearance. The wings are considerably longer than the body, and the general appearance handsome and slender. Having olsserved that the fly from $B$. remum on the leaves was apterons, contrasted with long-winged flies

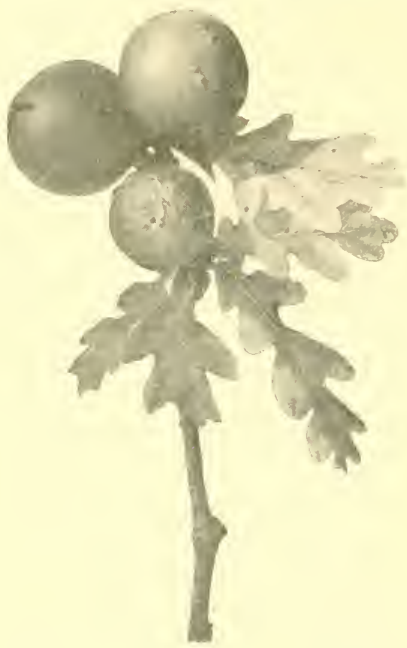

Fig. 156._Galls of Cynips Kollari (marble gall). from Trigonasy is' meyaptere, it may be observed in passing that the apterons flies deposit their eggs on adventitious buds on the stem from one to three feet from the ground.

There is another curious point worthy of notice. Cameron gives Trigonaspis megaytera as the agamic form, and Biortiza remum as the sexual. Adler, on the other hand, gives Trigonuspis megaptera as the sexual, and Biorthar renum as the agamic form. Cameron tescribes the male of Biortizu renum, and Adler deseribes the male of Tirifonaspis megaptera under the synonym of Trifonuspis crustalis, Htg.

Perhaps the inference which might be drawn from this apparent contradietion is, that while the various families of insects appear to be well worked by leading anthorities, it is nevertheless essential in practical entomology that all points should still be verified.

\section{Crnips Kollari (Htg.)}

The next and last species I shall deal with is the very common one known as "marble galls" or Cynips Kollari,-often very abun- 
dant on oak bushes and youmg trees. This gall is now wirlely distributed over the British lsles (fig. 156). It is often called the Devonshire gall, from the fact of its first appearing in that eounty and causing great alarm.

The galls are from $\frac{3}{4}$ inch to 1 inch in dimmeter, ancl, as a rule, almost a perfect ball. In some cises two galls coalesced, but in the centre one grub may only be found. As a rule, the gall may be perfeetly smooth, hut in some cases it is warty. At other times they may be found dwarfed in size and shrivelled, but when sueh is the ease they are generally ehambered, and inhabited by parasites, - thus contrasting with the true larval chamber, which is normally single and smooth.

The Hy appears at various times, according to locality, from the latter end of April to begimning of Jume. As the fly is very easily hatehed out, and being of a fairly large size, the following detailed deseription from Adler and Stratton may be given-viz. :

" Fly.-Length 4 to $6 \mathrm{~mm}$. ; whole body reddish-yellow; looked at from above, the head appears widened behind the eyes; cheeks half as long as the eyes, without wrinkles; antennæ filiform, thirteenjointed, second joint longer than thick, third joint the longest, twelfth and thirteenth joints partially united. Thorax brown, covered with short hairs; parapsidal furrows complete; scutellum with two thickly haired fovere at its base; metanotum black, vertical, overhung by the scutellum. Abdomen smooth and shining; second segment eovering half the dorsum, very dark above, with two large hairy spots; the other segments fringed with silky hairs. Ovipositor long and spiral. Venter exposed. Wings as long as the fly, lyyaline, finely haired; ralial cellule open at the margin, elongate, with the areolet opposite its base; basal abseissa of the radius angled; eubitus opposite to, but not reaching, the middle of the transverse basal nervure; legs yellow, margin of the fore tibize fringed with short depressed hairs; hind coxie broal; claws bificl." 1

\section{Syaptical Tabie of OaK Galls.}

With a view to readily ascertain the name of any gall, it may be eonsidered advisable to arrange them aceording to the respective parts of the oak-tree on which they may be found.

\footnotetext{
${ }^{1}$ Arller and Stratton, p. 164.
} 


\section{On the Leaf.}

A. On the under surface of the leat:

Currant gall found either singly or in groups-green or tinged with red-soft, succulent, smooth, about $5 \mathrm{~mm}$. diameter. In May and June; soon shrivels up after escape of fly

Sirathegaster 7accurum.

Pale, ahout $4 \mathrm{~mm}$. diameter, soft, in clusters and hairy. July

Spatheyaster tricolor.

Cherry-like gall, softish, generally singly but sometimes in elusters. July and October . . . . Diyophuntu scutellaris.

Smaller than previous species; harder, and beautifully marked with redish stripes. July to October. Diyoplianta longiventris.

Like a small pellet, smooth, beautifully spotted. August to October

- Neuroterus ostreus.

Kidney-shaped, often in clusters on veins. September and October

Biorthiza revum.

Button-like gall, conspicuously depressed in centre, surface like silk velvet, light-brown colour. Antumn . Neuroterns mumismatis.

Covered with stellate hairs, raised in centre, flat at outer edge, spangle gall. Late summer and autumn. Neuroterus lenticularis.

Not covered with hairs, nearly smooth, white or yellowish, outer edye turned. up. Late summer and autumn Neuroterus levinsenlus.

Centre of gall comcave, edges conspieuously turned up

Neuroterus fumipennis.

B. On the margin of the leaf.

(1) No inuer gall.

Smootl, spindle shaped, causing fairly deep indentations of leaf

Neuroterus albipes.

Smooth, red-ribbed, and leaf on which it is found often looking as if abruptly cut . . . . Aphilothrix marginalis.

(2) With an inner gall.

An irregular globular swelling, outer surface hard, lightish-yellow colour. 


\section{In Buds.}

Polythalamous; very large, spongy, apple-like. In terminal buls, or often on lateral buds on terminal shoots. May and June

Teras terminalis.

Monothalamous. In April and May, on trunks of old trees, generally near the ground, like a round drop of sealing-wax

Trigonrspis megajtera.

Like marbles on twigs or young trees in nursery ; green from July to September, and light-brown throughout the winter; either singly or in elusters. . . . . Cynips Kollari.

Spindle-shaped, with long peduncle. July and Angust

Ovoid, green, spotted, smooth, hard Aphitothrir albopnowata. Gall wholly enveloped in leaf-seales . Aphilothrix fecuntatrix. Gall very thin, and to all appearance only an mdeveloped but. In April and May . . . . . Spatheyaster apmilimus.

Globular, green, projecting from bud scales in September and Uetober .

Aplitothrix gloluti.

Terminal twig inflated with a tuft of leaves, growing from the inflated portion. . . . . Antricus inflator:

Irregular swellings on twig. . . Andricus notuli.

\section{On Roots.}

Polythalamous; soft when young, woody when mature. At base of trunk, or on strong roots, on surface of gromnd. October and winter

Aphilothrie rarlicis.

Monothalamous, but often in irregular elnsters on rootlets of old trees. October and winter. . Biorkiza aptera.

\section{On Bark.}

On young bark around a pruned branch, when cut off close to stem. Early summer . . . . . Aphilothric corticis.

\section{On Flowers.}

Large mass of woolly hair, resembling a ball of cotton-wool. In June and July . . . . . . Andirus ramuli. 
Spherical, smooth, and soft eurrant-like mass. May and June

Spathegaster baccarum.

Ovoid, slightly ribbed on sides like miniature rifle-bullet

Aphilothrix quadrilineata.

Note.-In the above synoptical table I have largely followed the arrangement of Adler, but I have given only those species I have collected, with the exception of Aphilothrix callidoma, which I received from Mr Connold of St Leonards-on-Sea.

\section{Oak Galls: Their Economic Interest and Teachings.}

With regard to oak galls, or the Cynips, considered as an insectpest, the only species I have ever found so numerous as to cause appreciable damage was Cynips Kollari. This was in a plot of transplanted oaks in a nursery in Cheshire, and the galls were so abundant that the whole of the trees had to be burned.

Though individually the species of galls are not, as a rule, so numerically strong as to be looked upon as a pest, yet collectively they give rise to injuries which retard the longitudinal growth, and, in many cases, "prune" the tree into shapes and forms exactly the opposite to what practical forestry requires - as, for example, see fig, 145. Hence they have important associations in practical forestry, as well as interesting biological teachings.

There is no tree more difficult to train into a straight pole than the oak, and it is just possible that this is often due to the effects of the gall insects; therefore the best preventive against the injurious effects is to be found in careful cultivation in the nursery and young plantation. The evil practice of selling by height, irrespective of age, has had disastrous results on the sylvicultural growing of oak. Thus it often happens that nurserymen, having height in view, allow seedlings to grow for three years prior to transplanting, and then after transplanting allow them to stand for three or four years in the nursery-lines, then again transplant, and finally sell individually over several consecutive years. But if the nursery work is bad, the method of planting out by the purchaser is sometimes worse; for we often see large oaks planted out in a "nixed" plantation, and towering three or four feet above the more hardy species, which were planted under the name of "nurses." Apart from the excellent 
method of sowing the acorns direct, the better sylvicultural method, and one which will overcome gall insect-pests, is to transplant in nursery-lines good seedlings at one year old, because at this age we get a better root in proportion to the top than at two years. Then if growth is vigorous in the nursery-lines, transplant the very best speeimens only the following year into the mixed wood, together with the more hardy nurses, or otherwise in a young wood, where the nurses have been planted as an ameliorating species in advance. The remainder of the oaks in the nursery-lines, which will obviously improve as the result of "quartering," may also be planted out in the young wood during the following year.

Of course it must be borne in mind that the above remarks apply only to planting extensively, and under the protection of wirenetting.

\section{References to Literature consulted.}

Adler and Stratton. Alternating Generations : A Study of Oak Galls and GallFlies. 1891.

Cameron, Peter. A Monograph of the British Plytophagous Hymenoptera. Vol. iv. Ray Society. 1893.

Cameron, Peter. Galls of Mid-Cheshire. Manchester Mic. Soc. 1891. 8 pp., $1 \mathrm{pl}$.

Fitch, E. A. The Galls of Essex. Trans. Essex Field Club.

Gardeners' Chronicle. Articles on Galls from 1854.

Lubbock, Sir John. Origin and Metamorphosis of Insects. 1876.

Mosley, S. L. Yorkshire Galls. Naturalist, Sept. 1892.

Romanes, G. J. Darwin and after Darwin. Pt. I. 1892. 


\section{CHAPTER V.}

HYMENOPTERA-SAW-FLIES, ETC.

Considered as a division of entomology, perhaps no class of insects is more important than the Hymenoptera. To the student of insect anatomy and physiology they are, as a whole, the most highly differentiated and organised creatures in the insect world. The student of mental phenomena finds in this group instances of rare intelligence and instinctive forethought, often surpassing anything in the animal kingdom; and the humble but patient observer who studies life-histories will also find abundant scope in this important division. When we remember that this order embraces (besides many others no less distinct in their structure and their habits) saw-flies, gall-flies, ichneumons, ants, bees, and wasps, the truth of the above assertions will be apparent.

To the student of forest entomology they present a fairly wide field, inasmuch as saw-flies and gall-flies may be considered as injurious insects (though not always to any great extent), and ichneumons, on the other hand, may be considered as beneficial insects.

To some extent, therefore, in a general way, the student must study the salient features of the whole order, but unfortmnately at the present time entomologists are by no means agreed as to classification either as regards the whole order or some of the most important sections.

As regards the special study of Hymenoptera in its relation to the forest, it may be said that on beating trees and bushes many larvæ of several species may be found, and by breeding the same a good representative collection might be obtained. This, however, would be too general for forest entomology, and it is better, therefore, to confine our studies to the more destructive or general species.

The Hymenoptera have by some been divided into Terebrantia and 
Aculeata, according as the ovipositor of the female is modified into a "boring instrument" or a "sting." But this distinetion is often hard to maintain, and also appertains only to one sex, which is unsatisfactory. Another division-viz., into Sessiliventria and Petiolata, accorling as the abdomen is attached to the thorax over its whole width, or at one point only by a narrow and stalk-like first segmentis not open to the above objections, and is here adopted.

The Sessiliventria are also called by English writers "Saw-flies," and by German "Blattwespen" (i.e., leaf-wasps). Such Hymenoptera as are of special interest to the forest entomologist belong mostly to this division, and I have therefore thought it worth while to call attention to the further classifications which have been introduced into it by specialists, and to indicate some of the writings on the subject which are likely to assist such students as desire to master it to a greater or less extent.

The most useful complete works dealing with the saw-flies of large areas as a whole are-

Kriechbaumer's collection of Klug's writings on Blattwespen (Berlin, 1884); Hartig's 'Families of Leaf and Wood Wasps' (Berlin, 1860); Thomson's 'Hymenoptera Scandinaviæ,' vol. i. (Lund, 1871); Antre's 'Species,' vol. i. (Beaune, 1879); and (for British genera and species) Cameron's Monograph, \&c. All these works, however, are beginning to get old; and since their appearance much new light has been thrown upon the group by a very able and original German naturalist (Pastor F. W. Konow), who has published a vast number of short articles and revisions of particular genera, and is now issuing a monograph (on the very largest scale) of the saw-flies of the whole world. Consequently several names of species, and even genera, hitherto in conmon use are destined to be superseded before long, and some may be said to be already out of date. A series of papers by Mr Morice now appearing in 'The Entomologist's Monthly Magazine,' entitled "Help-notes," \&c., has for one of its chief objects to inform English students of the alterations in the British list (at present resting mainly on Cameron's work), which seem to be required in consequence of Konow's researches hitherto; and also to facilitate the study of the subject, by fresh tabulations of generic and specific characters, which the writer hopes will generally suffice to guide collectors to a correct determination of the specimens taken by them.

In view, therefore, of the importance of Morice's "Help-notes," I 
heg to give at considerable length some of his "notes," together with his illustrations, as I know of nothing more helpful to the student who wishes to make a thorough study of the insects in question.

"The head is nearly always broader than long, and generally about the same breadth as the thorax. The eyes are large, and ocelli are also present. Behind the ocelli there is a quadrangular space, bounded latterly by distinct furrows, known as the vertical area. The spaces bordering the compound eyes are the orlits. The space containing the ocelli, and reaching to the insertions of the antenne, is the frons, and part of this space surrounded by furrows is called the pentagonal area.

"Looking at the face and below the antennæ we see the clypeus and latrum. The space between the eye and base of the mandible is termed the gena.

"The back of the head, facing the thorax, is the occiput. Between the occiput and the compound eye lie the tempora.

"The details of the thorax, which furnish many very important characters, can hardly be made elear except by diagrams. I give therefore now an outline camera-lucida sketch of the thorax in Tenthredo mesomela, L., viewed from two aspects-(fig. 157) dorsally, i.e., from above; (fig. 158) laterally, i.e., from the side :-

$a$ (in both figures), pronotum. $b b$, tegula.

$c$, middle (or front) lobe of mesonotum.

dd, side lobes of mesonotum.

$e$, scutellum (or better, perhajs, seutellum mesothoracis, to distinguish it from $f$ ).

$f$, postscutellum (better scutellum metathoracis).

$g$, propodem or median segment (the central slit in this is what Cameron ealls the blotch).

$h h$, cenchri (the space between them is the metanotum).

$k$ (in fig. 158), prosternum.

$l$, mesosternum.

m, metasternum.

n, mesoplemra.

$o$, metapleura.

PPP, coxa.

"Note.-The mlettered areas in fig. 157 are parts of the meso- and meta-thorax, which are seldom, if ever, referred to in descriptions, and I therefore ignore them. The shaded space indicates a very deep impression between the meso- and meta-thoraeic regions.

"I may add that-

the pro-thorax includes the areas $a$ and $k$;

the meso-thorax includes the areas $e, d$, and $e$ in fig $157 ; n$ and $l$ in fig. 158; 
the meta-thorax includes the areas $f$ in fig. $157, o$ and $m$ in fig. 158 ; the propodeum ( $g$ in both figures) is an originally abdominal segment, transferred to the thorax in pupation.

"The thorax of a saw-fly ean easily be broken up into its three constituent parts of pro-, meso-, and meta-thorax. If the front and mildle coxæ are seized in two pairs of pincers and pulled apart, the pro- and meso-thorax part company. Similarly, by tearing the michle coxæ away from the hind coxre, the meso-thorax ean be separated from the meta-thorax. The so-called propodeum, though theoretieally an abdominal segment, is so fimly attached to the meta-thorax that when the abdomen is broken off (e.g., in a dried speeimen by

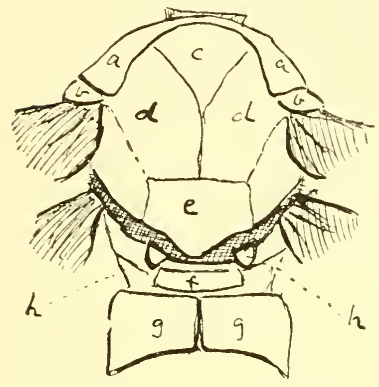

Fig. 15T.-Thorax of a saw-fly: dorsal surfacei.e., as seen from above. (Sketch by Rev. F. D. Morice. From 'Entomologist's Monthly Magazine.')

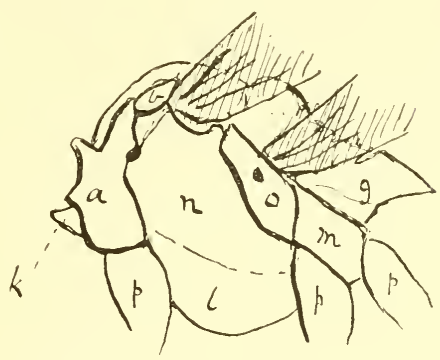

Fig. 158.-Lateral or siale view of fir. 157.

pushing it roughly downwards), the propodeum always remains with the thorax.

"In fig. $157, h, h$, the 'cenchri' are two singular organs with some resemblance to little tegulæ. They are always present in Tenthredinilæ, but I eannot find that their funetion has as yet been discovereel. They belong to the meta-thorax, and mark its base.

"Regarding the neuration of a saw-fly's wing, the first thing to be done is to realise the course of the longitudinal nervures $=$ the 'veins,'-the thiek single lines. It will be seen that they are much longer than the transverse $=$ the 'nerves.' They are also more uniform throughout the whole group, and much less liable to vary abnormally in individual specimens. We commence with them partly 
on this account and partly beeanse they divite the wing into areas named from them, and from these areas again are named most of the (trinsverse) 'nerves' and the 'cells' or divisions of the areas boumled by them.

"Starting from near each other, and near the base of the wing, five main 'veins' run, all more or less in the direction of its apex, but ratiating apart, like the fingers of an extended hand.

"The first pair stalt at $a$ and $b$ : these are the costa and the subcosta. The costat follows the actual margin of the wing, and the sub-costal runs nearly parallel to it for about half the length of the wing, when it hends upwarls and unites with the costat at $f$, just before the stigma (the shated area in fig. 159).

"From d and e start another pair, the brachins and the humeris.

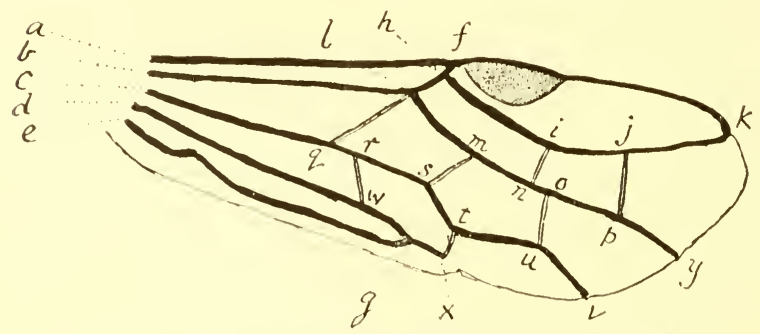

Fig. 154.-Thpical upper wing of sem-fly. (Sketeh by Riv. F. 1). Morice. From "Entomblogist's Monthly Magazinc.')

These run both semewhat parallel to the lower margin of the wing but neither of them coinciding with it. Again, for about half the total length of the wing, the humeriss turns upwarl and joins the brachins at ! (just as at $f$ the sub-costa joins the costa). The brachius is continued a little farther to $x$, and there disappears.

"The lifth of these 'veins,' starting at ', is ealled the medius. It runs at first straight along the midllle of the wing (equidistant, therefore, between the two pairs described above) for half its length. Then it bends downwards as though to join the brachins, but at $f$ turns suldenly off, resuming its horizontal eourse, then (at $u$ ) is again deflected, and reaches the margin at $u$.

"Besiles the above five main veins, we have two which may be called sulsidiary. They are confined to the superior (apical) quarter 
of the wing, and have the appearance of branching ont of the subcosta. One leaves it just before its junction with the eosta (at a point about $h$ ), and, bending first down and then a little wp, finally joins the costa (on the margin of the wing) at its apex $k$. This is the radius. The other-called the cubitus-leaving the sub-costa carlier (i.e., nearer its base) at $I$, bisects, roughly, the area between the radius and the apical portion of the merlins, and so procerels not always in so straight a line as the figure shows to the point y on the muargin.

"Thus we have in all five main and two subsiliary longitudinal nervures or 'veins,' and these divide the wing into longitudinal areas or 'fickls,' as follows.

"letween the costa and the sub-costa is contained the intereostal field. Between the brachins and the humerus is the humeral field, familiar to all students of saw-flies under the name of the 'lanceolate cell.' 'Then between the sub-costa and the merlins lies the modial fiekl, and between the medius and the brachins the brachial field. (A certain similarity in form and size will pobably have been noticer by the reader between the intereostal and humeral fiekls and the medial and brachial fields respectively. This will help him perhaps in forming a mental picture of the neuration as a whole.)

"Next we have the ratial area lying above the ralius, and the cubital area below the radius and above the cubitus. between the cubitus and the apical half of the modius comes a continuation of the medial area, which, if regarded as distinct from it, may be called the discoidal field. That part of the wing lying below and as it were outsirle of the neuration system-i.e., that which is bounderl inferiorly by the actual inferior margin of the wing and superiorly by the humerus as to its basal half, and by the medius as to its apical jortion-is called the anal field.

"Owing to the disappearance of the brachius without reaching the margin, there is no complete longitudinal line of division between the brachial and anal areas. But for practical purposes the transverse nerve, $f: r$, may be regarded as separating them.

"We come now to the transverse elements of the neurationKonow's 'Nerven' sen:u restricto.

"Often (though not in my figure) the radial area is erossed by one, very rarely by more than one. Then the radial area is sain to he 'divirted,' or, as some authors express it, 'there are two radial cells.' 
Similarly, the cubital area shows, practically without exception, either, as here, two, or perhaps more often three, nerves connecting the radius with the cubitus $(i n, j p)$. These, as crossing the cubital field, are called the cubital nerves (1st, 2nd, \&c.), and the divisions into which they cut up that field are the cubital cells. (Three seems to have been the original number of the cubital nerves. Where only two appear, either the first or second of the original three has vanished. Thus in Emphytus the first has gone, leaving only the second and third; whereas in Dolerus the two surviving nerves are the first and third, the second being absent.)

"Although these radial and cubital transverse nervures give, both as to their number and direction, obvious and easy characters for distinguishing both genera and species, they are unluckily liable, as already mentioned, to considerable variation,--disappearance, duplication, displacement (within certain limits), irregular (atavistic) reappearance, \&c., in particular specimens, or even in one wing of a specimen and not in the other; so that it is very unsafe to trust wholly, or even chiefly, to them in 'determinations.'

"Very much more constant and trustworthy are the characters to be drawn from the three nervures which cross the median field-viz., $l q$ (perhaps the most important nerve in the whole wing), the discoidal nerve, $m s$, and on the medial nerves (1st and 2nd), the two latter being better known probably to English readers as the 1st and 2nd 'recurrent,' and the former as the 'basal.' The characters of these nerves can hardly ever mislead us, and are of the utmost consequence in determining not merely genera or species, but families and tribes,-such characters, e.g., as whether the discoidal nerve strikes the sub-costa close to the origin of the cubitus (as in fig. 159), or consiclerably before it (i.e., between the points $b$ and $l$ in that figure), or whether it strikes (e.g., in $L y d a, \& c$.) not the sub-costa at all, but the cubitus; and again, whether the discoidal and lst medial nerves are convergent (upwards) or sub-parallel, whether the two medial nerves are received in the same cubital cell or in two different ones, \&c. The importance of these points for 'determination' will appear abundantly when we come to construct our future tables. Two more transverse nerves only appear in my figure-viz., $r$, $w$, the areal nerve (called by Thomson rather oddly nervus transversus ordinarius, and by Mr Cameron - e.g., see his Tables of Species for Emphytus-the transverse median), and $t, x$, the anal nerve. Of these the former is 
the more important, its direction and the point at which it is received in the cell above it giving several useful characters.

"We have now, I believe, dealt with all the nervures which are regularly present in the upper wing of a saw-fly. But certain others which appear only in particular genera or families are for that very reason especially useful for 'determinations.' 'Thus, between the costa and sub-costa may lie a 6th longitudinal nervure, and this may ultimately either run simply into the sub-costa somewhere near $l$, or be forked at its apex into two branehes, one joining the sub-costa and the other the costa. Ur, in the same region (the intercostal field), there may be a transverse nerve stretching from the sub-costa to the costa, either before or after the point where the former receives the discoidal nerve. Or, as in Arge, the costa, instead of lying wholly on the margin of the wing, may quit it just before its apex, and bend down to meet the radius, thus cutting off from the rest of the radial area a little subtriangular apical cell (cellula ralialis appenticulata). Lastly, in the humeral area ('lanceolate cell') we have a number of important characters for determining genera depending partly on the presence or absence of transverse in that ficld, and partly on certain modifications in the structure of the humerus itself, especially in its basal part. These characters we have now to examine.

"It will be seen by reference to fig. 159 that the humerus (quite near its base) shows a strong inclination to unite with the brachins, long before it ultimately does so, at $\%$. Generally this inclination is, if we may say so, suddenly checked: the humerus, though approaching very near the brachius, starts off at a tangent, and gradually recedes to a respectful distance from it, before taking the final eurve by which it nltimately reaches it. Sometimes, however, the inclination is not checked: the humerus continues its approach to the brachius till it actually reaches it, and so the two veins for a while coincide,-it may be only for a moment or for a considerable listance,- but always separate again, so as to enclose a spindle-shaped space between them before their final point of union. Again, sometimes the humerus, without quite reaching the brachius at the (sub-basal) point alluded to above, all but does so, and throws a 'short perpendicular' nerve across the narrow interval which separates it from its companion vein. Yet again the humerus, soon after its origin, seems to vanish and presently to reappear emerging from the brachius, though it has never been seen to join the latter. Lastly, sometimes-though never, I 
believe, in conjunction with any of the phenomena described abovean 'oblique cross nervure' runs over (the apical portion of) the humeral area, eutting it into two divisions, the apical one 'completely encloserl,' and very much smaller than the other."

\section{TENTHREDINID A (LEAF - WASPS).}

This family is known in Germany by the name of "Blattwespen" or Leaf-wasps, and the designation answers our purpose very well, inasmuch as the larvæ are always injurious (in very varying degrees) to the foliage of many species of forest trees, but more especially to Scots pine, larch, thorn, willow, and poplar. They are, however, only injurious in the larval stage.

The classification, for the purposes of the present work, of this family is somewhat difficult, for two reasons-(1) I need only to deal with a few genera and species, taken as it were here and there from the whole family; and (2) the publication, now slowly proceeding, of a very important German monograph of the saw-flies of the world has already caused the abandonment in many cases of generic and specific names hitherto employed in British works, and will doubtless yet more disturb our present nomenclature within the next few years.

I propose, therefore, to adopt the following merely provisional division of the insects into three sub-families, according to Konow, as follows-Cimbicides, Lophyrides, and Nematides.

\section{CIMBICIDES.}

\section{Gemus Trichiosona.}

The following are the generic characters according to Morice $:^{1}$ -

"Claws simple; hind femora generally toothed conspicuously beneath; very pilose, brown-looking insects, with abdomen fuscous or black above (but sometimes more or less rufescent at the apex and beneath).

\section{"Synopsis of British Trioniosonla.}

1. Abdomen black, not bronzy; dull, closely and rather coarsely punctured, and clothed right up to the apex with long, loose, grey, sub-erect hairs. (Attached to the birch) T. LUconum, L.

1 'Entomologist's Monthly Magazine' for Aug. 1903. 
Abdomen at least slightly metallic, somewhat shining, puncturation finer and more remote, hairs on apical segments shorter . $\quad 2$

2. Abdomen rufescent beneath and often at the sides. (Attached to willow) . . . . . T. silvatica, Leach.

Abdomen bronzy-black throughout . . . . 3

3. Tibiæ, at least in + , black or dark-brown. (Attached to hawthorn)

T. tibialis (Steph.)

Tibix yellow. Apical segments of abdomen clothed with longer hairs than the last species. (Attached to willow)

T. Latreillei, Leach."

This synopsis is extremely interesting from a collector's or naturestudent's point of view, but for practical purposes any species which the local collector may find most abundantly may be taken as a type of the other species.

\section{'Trichiosoma tibialis (Steph.)}

This species is generally attached to hawthorn, and the pupal cocoons may generally be found on the twigs of switched hedges, more especially on twigs near the base of the hedge. As a rule, however, the cocoons are opened by insectivorous birds. The collector, therefore, should try as far as possible to gather these cocoons in the early autumn, and place them in a jar for hatehing purposes. When this is done, the flies are

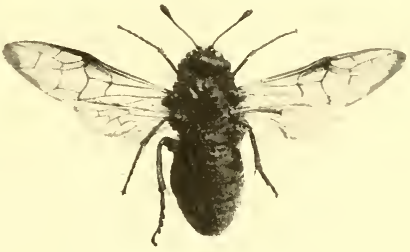

Fig. 160.-Trichiosona tibialis. very easily reared, and they hatch out from the middle of March to the end of April. Fig. 160 is from a photograph of this species, and fig. 161 is a representation of the pupa.

It is best, in rearing flies from the larval stage, to try and collect, as far as possible, the fully developed larvæ, as when the larvæ are collected at an early stage they do not feed readily in confinement, and a great proportion of them die off. Fig. 162 is a representation of the larva on a hawthorn leaf. 
It should be noted that, from a systematic point of view, the species attached to hawthorn has hitherto been known as Trichiosoma lucorum, but modem classification associates the latter name with another species which is attached to birch-trees.

This species is in every way an interesting forest insect, but in no sense whatever can it be termed an injurious insect. The large

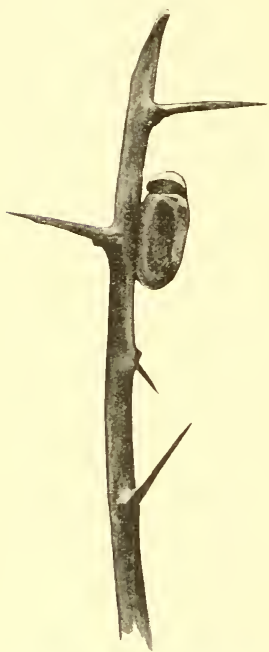

Fig. 161.-Puje of Trichiosoma on hawthorn after esectipe of fly. (From drawing by P.J. Brown.) and somewhat pretty larva may often be found on thorn hedges, when we are quietly searching for anything of an arboreal interest.

The larva (fig. 162) when young has a greyish-white appearance, largely due to a powdery covering, which appears dusted over the body. As it gets older the colour is a blend of green with light yellow, with a yellowish face and black eyes. It may be looked for in July. It is not a voracious feeder.

The pupa (fig. 161) is a hard brown cocoon, $\frac{7}{8}$ inch to 1 inch long, and $\frac{3}{8}$ inch to $\frac{1}{2}$ an inch in breadth. It opens by a lid for the exit of the perfect insect. It may be looked for during the winter months on thorn hedges, more especially towards the bottom of the hedge.

The perfect insect may be seen hovering in thom hedges in March and April. It may be mistaken by the uninitiated for a bee. It is a brownish colour, head, thorax, and abdomen hairy. Antennæ dark-brown. Legs a lightbrown. The wings are clear. Length 6-10 lines.

The genus Cimbex is very closely allied to Trichiosoma, but in a general way the former may be distinguished from the latter as being less hairy. For practical purposes we may group the two genera together; and Judeich and Nitsche, though giving different generic characters, adopt this method for general description. 


\section{LOPHYRIDES.}

\section{Genus Lophyrus.}

The species belonging to this genus are relatively very small. The males are smaller than the females, and have double pectinated antennæ; and the larger females have single (but slightly) pectinated anteme. In this comtry only two species have been recorded, but in Germany eight or ten species are mentioned. All the species are arboreal in their habits, and litherto recorded as feeding on the foliage of Scots pine. It would be well for the student of forest insects, more especially those living in Scotland, to keep a sharp look-out for unrecorded species. They are double - brooded during the year, and therefore lend themselves for rapid results as regards observation.

LOPHYRUS PINI (Linn.)

In consequence of the immense damage done to young Scots pine plantations, this insect may be classed as a veritable

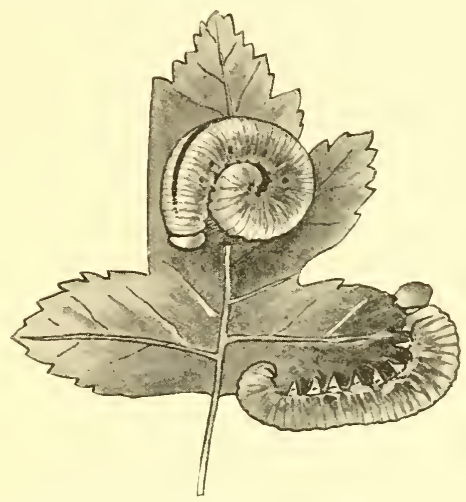

Fig. 162.-Larve of Trichiosoma on havthorn leaf. (From drawing by P.J. Brown.)

forest pest. The larvæ live sociably, and have voracious appetites,so much so, that the leading shoots are quite defoliated, giving the twigs the appearance of having been elipped with a pair of scissors; and wherever such wholesale damage is to be gauged by area, it is obvious a severe visitation is in reality an alarming pest.

The saw-flies appear in early summer, but the time seems to vary in localities. Thus in Cheshire I often found the females lodging amongst the leaves about the end of May, whereas in Northumberland the males (which generally preceile the females) appeared on July 4, 1901. This was from specimens I had kept from an autumn 
brood over the winter. Of course it is possible that this may be by no means considered the first appearance in the county, or in fact any reliable guide as to dates for the country generally, as (fortunately) it is not very plentiful in Northumberland.

The females deposit their eggs on the leaves, and the larvæ hatch out in from two to three weeks.

The larvæ, when full fed, are about $25 \mathrm{~mm}$. long. The general colour of the body is a light yellowish-green. The head is lightbrown. At every pro-leg are two black dots, and often black dots are conspicuously scattered over the body.

The pupæ, or rather the pupal cases, are very hard and brown. The male puparia are about $10 \mathrm{~mm}$. long by 5 broad. The female

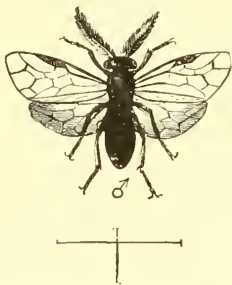

Fig. 163.-Lophyrus pini, Pine sam-fly (male). (From 'Forest Protection,' by W. R. Fisher.)

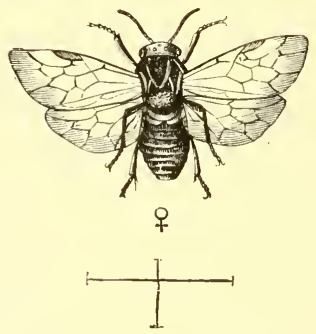

Fig. 164.-Lophyrus pini, Pine saw-fly (femalv). (From 'Forest Protection, by W. R. Fisher.)

puparia are about $15 \mathrm{~mm}$. long by about 7 broad. The perfect insects escape by a lid, but if the pupa has been parasitised, the parasite simply escapes by a minute circular opening.

The male (fig. 163) has a wing expansion of $15 \mathrm{~mm}$. ; body black, legs testaceous, with black femorie; antennie doubly pectinated. The female (fig. 164) has a wing expansion of $20 \mathrm{~mm}$. The head and thorax are darkish-brown, and singly serrated antennæ. The middle portion of the abdomen is strongly banded black, while the portions above and below this black band are, on careful examination, double bands of yellow mixed with black. The upper wing has one radial and four cubital cellules.

Life-history. - As before stated, the life-history is somewhat variable. In a general way it may be said that the female (which 
is very sluggish) cuts slits in the leaves with her saw-like ovipositor, and lays her eggs in the slits. These hatch out in about two or three weeks' time, feed on the leaves of last year's terminal shoots (at this stage they often eat abont half of the leaves-see fig. 165), ancl pupate in July. A portion of those larve hatch out in August, and thus we get a second brood from a portion, while others remain in the pupal stage (fir. 166) until the following spring. The larve

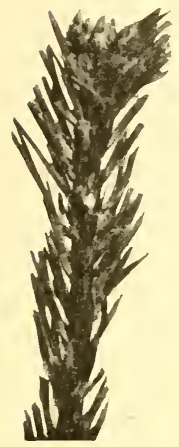

Fig. 165.-Foliage of Sints pine eaten by lerver of pine sow-tly. Injury done by tirst brood of the spuson.

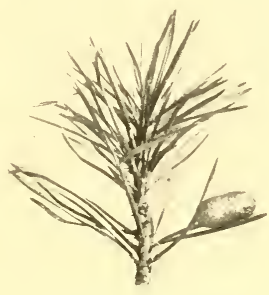

Fig. 166.-Pupal case of Lophyrus lini (pine setu- $f(y)$.

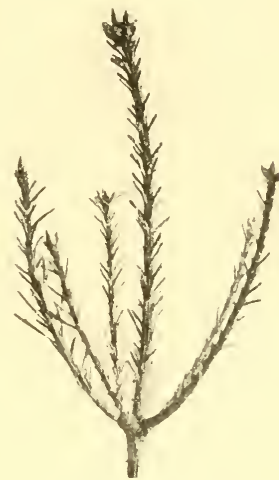

Fig. 167.-Foliage of Scots pine eaten by larvere of pine saw- Hy. Injury done by second brood of the season.

issuing from the second brood eat the foliage of the current year (see fig. 167).

In Northumberland the first male of the second brood appeared on September 1, 1904, and the females about a week later.

As this is a very troublesome pest, it follows that some specific remedies ought to be given. Keep the young woods in very good health, and encourage all birds which would open and pick the pupæ from their cases.

The larva might be collected by chipping off infested shoots and letting them fall into paraffin. The cocoons might also be collected, as far as practicable. For the perfect insects smeared traps night be laid against the young trees in April. It should 
be remembered that it is amongst the very young plantations that most damage is done.

\section{Lophyrus RUFus (Klıg).}

Miss Ormerod writes ${ }^{1}$ regarding this species :-

"I have also had observations, with specimens during this year, of much injury being done by the caterpillars of the Lophyrus rufus of Klug on three or four thousand acres of young Scots fir in Argyleshire. These caterpillars are of a greenish dusky grey, with black heads, a fine lighter line along the back, and a dusky line above the spiracles. The abdominal sucker feet and abdomen below yellowgreen. The specimens sent me on the 10th of June had spun their cocoons by the 23rd. The flies may be looked for from August onwards. The females are reddish; the males black, with abdomen beneath and legs red. It was observed that trees ten feet high were not so seriously attacked as those from two to six feet high."

\section{NEMATIN咂 (Nematides).}

This sub-family is of consiclerable interest in forest entomology, inasmuch as a great many of the species are arboreal feeders. Many of them are amongst the first insects to appear on the wing in spring. On a sumny day single specimens may be seen flying for a short listance, and then lodging amongst grass or other harbourage. They can then be very easily placed in a chip-box or bottle. They may also be collected from the flowers of sallow, which forms a sort of general food for spring insects. As regards feeding habits, they may be divided into two principal classes-viz., those whose larvæ feed on the foliage, and those which form galls chiefly on willows. They are injurious in the larval stage only.

As regarls size, they range from very small to medium-sized insects, perhaps from 2 to $12 \mathrm{~mm}$. They are for the most part smooth, shiny, and rather soft-bodied, variously coloured, with 9 -jointed antennæ, usually elongate, slender, and tapering; anterior wings, with simple, seldom-divided, radial cell. Hind wings always with two discal cells, and with completely enclosed lanceolate cell.

\footnotetext{
1 Manual of Injurious Insects, 2nd edition, p. 255.
} 


\section{Table of Genera. ${ }^{1}$}

Anterior wings with simple radial cell.

Lanceolate cell widely contracted in the middle.

Second and third eubital cells each receiving a recurrent vein.

Third to fifth, sometimes sixth and seventh, antennal joints of the male with a more or less prominent branch at the tip; antenne of the female somewhat compressed, and with sharp projection at tip of basal joints

Clabies, Illig.

Joints of antenne without projections at tip ; third antennal joint curved at the base, in the male with a short, blunt fork beneath, and in the female with a sharp projection

Trichocampe's, Htg.

Lanceolate cell petiolate.

Third transverse euhital wanting . . Euura, Newm.

Third transverse cubital present.

Claws bifid, elypeus usually emarginate.

Tip of the eighth dorsal segment of the male with a small, blunt, more or less awl-shaped projeetion; antenne of female filiform, small species 2 to $5 \mathrm{~mm}$. long; stigma often having clear base; sheath often pointed at tip; gall inhabiters . . . Pontania, Cost.

Eighth dorsal segment of male broaler, obtusely pointed, or not at all produced at tip; antennæ distinctly tapering toward tip; stigma not lighter at base; sheath not pointed at tip; body more robust.

Last ventral segment of male obtusely triangularly produced at tip; sheath of female of the usual form; posterior tibire simple.

Nesonotum and pleure shining; antennæ long and slender, usually lighter coloured beneath; head, viewed from the front, almost round; labium but slightly projecting; sheaths usually narrow and delicate . . P'teronus, Jur.

1 Adapted from 'Revision of the Nematine of North America,' by C. L. Marlatt. Washington: 1896. In this table three or four genera are omitted as they are not, so far as hitherto recognised, associated with forest insect.. 
Last ventral segment of male excavated at tip, not obtusely triangularly produced; sheath of female very broad, or the posterior tibiie and tarsi thickened.

Posterior tibize and tarsi very broad and flattened . . Cresus, Leach.

Posterior tibiæ and tarsi not flattened.

Posterior tibia and tarsi thickened, tibiæ externally with longitudinal furrow

Holcocneme, Knw.

Posterior tibiæ and tarsi simple; sheath very thick and stont. Nematus, Jur. Clypeus truncate.

Pentagonal area more or less distinct; eighth dorsal segment carinated, sub-produced; sheath simple; elongate species

Lygeonematus, Knw.

\section{Gemus Cladius.}

This genus, which is now known to systematists as Trichiocampus, is a part only of the old genus Cladins. The name Cladius is still kept for $C$. pectinicornus, \&c. It has the third joint of the antenne curved, and the species on Lombardy poplar has an orange-red abdomen.

\section{Cladius (Trichocampus) viminalis (Fall.)}

This insect may be found in the larval stage on the leaves of Lombardy poplar. The larve feed in company on the under side of the leaves, generally from three to five in a row, each larva touching its neighbour, and all keeping in perfect line. The larve are a beautiful light-orange colour, with dark head, and clothed with strong hairs. There are also rows of black flecks across the rings. Length from 15 to $22 \mathrm{~mm}$.

The female insect has black head, thorax, and antennæ; abdomen light-yellow; legs in all parts light-yellow. Wings with light-brown veins and stigma. The male is similarly coloured, but the antennæ are dark-brown. Length of female $9 \mathrm{~mm}$.; spread of wing about $18 \mathrm{~mm}$. Nale $6 \mathrm{~mm}$. ; spread of wing $13 \mathrm{~mm}$. 


\section{Eudra (Cryptocampus) l'entaniri, Cam.}

Large woody galls are formed by this insect on willow-stems, generally of the species Salis pentuntire. This inseet is not at all common, and certainly very local. Although the attacked bush is often very valueless either from an resthetic or an intrinsic point of view, yet the galls are often so numerically strong as to do great vital injury to the bush itself. An infested bush, from its extremely local habits, becomes quite an interesting object.

The galls themselves may le first noticed near the extreme encl of the twigs, being an enlargement on the twig (see fig. 168), about the end of June. I) uring the early summer montlıs the galls are of a close woody structure, but towards the autumn they are more or less hollow, and contain a comparatively large amount of dirty black frass. Several larve are found within one gall. It may happen on inspection that each larva is enclosed within a cocoon. This condition I found on January 5, 1900, but it must not be inferred that the larvæ are fully fed, as the cocoon may be either for protection or shelter.

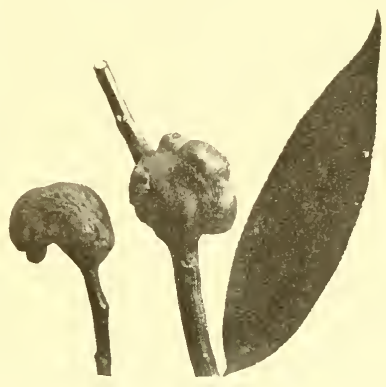

Fig. 168.-Galls of Eumra pentandræ on shoots of Salix pentandre.

The larvæ commence making their pupal cocoons about the mildle of April, for by April 28, 1900, they were all in the pupal stage.

The larvæ when full fed are about 8 to $9 \mathrm{~mm}$. long, of a uniform slaty-whitish colour, with darkish head. The six true legs are well developed, and there are six pairs of thoracic legs.

The flies hatch out from the 9 th to the 15 th of May. The length of the body is about 2 lines. Expanse of wings 6 lines; antennæ 9-jointed. Body wholly black; legs brown, with darkish trochanters.

\section{Pontaxia salicis (Christ.) \\ Nematus bellus, Zad.}

The galls are formed on the leaves of Sali, capree (goat willow). It is generally most abundant on hilly districts. In some seasons it 
is very eommon at Kielder, Northumberland. The galls are on the under side of the leaves (fig. 169), and as a rule a single specimen is found on each leaf, though at times two galls coalesce together. They may be either glabrous or slightly hairy, and as a rule the galls which coalesce generally develop min-

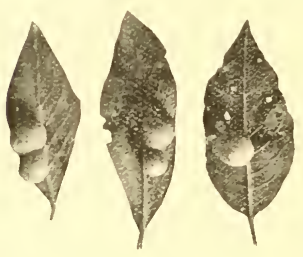

Fig. 169.-Galls of Pontania salicis on leaves of Salix caprea. iature warts. The colour is greenishyellow, with small reddish spots, and the average diameter from 6 to $8 \mathrm{~mm}$. It may be looked for from July to September.

Each gall eontains a single larvæ. The grub is very aetive, and the frass is found within the gall. As the larvæ pupate in the soil, it is well to gather the galls fairly early for artifieial breeding. The flies hatch out about the beginning of May (May 9, 1905).

Female. - Head and thorax black; antennæ dark-brown ; abdomen blaek, with yellowish bands at division of segments.
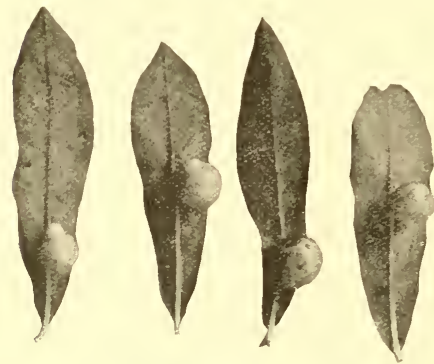

Fig. 170.-Gulls of Pontania bella on leazes of Salix viminalis. Under side of abdomen yellow and black. Legs pale, testaceous. Wings hyaline. Stigma dark-fuscous.

1Iale.-Colour very much as in female. Smaller in size, and antennæ stonter.

\section{Pontania bella (André).}

The galls of this species (fig. 170 ) very mueh resemble those of the ireeeding, exeept that they are always found on S. viminalie, whieh is perhaps the most important distinetion to the practical man.

The inseets are also very much like those of the previous species; but they hatch out much later in the season-viz, about the end of .June. 


\section{Pontania proxima, Lep.}

This species was sent by my friend Mr Forgan, Bowood, Wiltshire, in stems of golden willow. No swellings: only indication is small hole in stem. Larvæ bore in pith. This hatched May 14, 1902, in confinement.

Fly.-Head, body, and antennæ black. Legs more or less testaceous. Wings black. Antennæ 7 -jointed. Larva, white body, brown head, $\frac{5}{16}$ inch in length.

\section{Pontania gallicola (steph.) \\ Nematus vallisnerii, Htg. \\ Nematus yallicola (West).}

In almost every country ramble the leaves of Huntingdon willows may be seen covered with the bean-shaped galls caused by $N$. gallicola. The galls (fig. 171) are always formed on both sides of the leaf. They are of a rosy colour, and therefore contrast with the green leaf. A section of the gall, together with a description of its development, would be interesting. In the centre of the gall we get the parenchyma of the leaf so enveloped by the gall that this green substance becomes the food of the larva.

There are two broods in the year. By collecting the galls fairly early in autumn, before the larvæ quit them for pupation, they may be

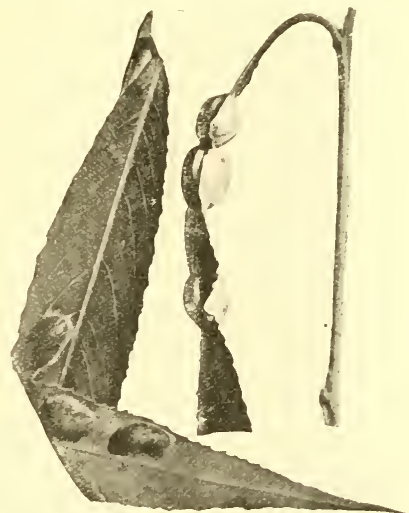
Fig. 171. - Galls of Pontania gallicola on
Huntingdon willow. easily hatched out artificially. 'They quit the galls, and form small leathery cocoons. The flies appear about 9 th Nay in Northumberland. The second brood is said to hatch out in August. 


\section{Pontania ischnocerus (Thom.)}

Nematus ischnocerus, Th.

I have only found this species at Kielder, Northumberland. Cameron gives three localities-viz., Rannoch, Braemar, and New
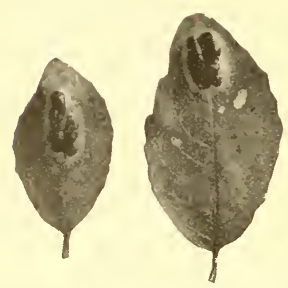

Fig. 172. - Ginlls of Pontania ischnocerus on speeies of Salix.

Galloway. Fig. 172 is a representation of the galls on the leaves of a species of Salix. This species cannot in any way be considered as an important forest insect, except in so far as it is of interest in a collection.

\section{Gemus Pteronus.}

This genus contains a number of species which have been selected from the old genus Nematus, as regards structure and lifehistory peculiarities. Perhaps the best plan for the student to master the same from a typical species is to work out the life-history of the gooseberry saw-fly, $P$. ribesii, Scop., hitherto known as Nematus ribesii. For specific characters the systematic student is advised to refer to the "Synoptic Table of British Pteromus," by Rev. F. D. Morice, in the 'Entomologist's Monthly Magazine' for June 1906.

\section{Pteronus salicis (Limn.)}

It often happens that in our early summer or late autumn rambles we find bushes of Salix canvere defoliated by sawfly larve, as in fig. 173. In this case the

Fig. 173.--Leof of gout willout (Salix caprea) euten by lerve of Pontania salicis. insects proved to be P. salicis, as identified by Rev. F. D. Morice.

The perfect insect has black antennæ, black or dark-brown stigma, and in both sexes a bright orange-coloured abdomen.

The insect is clouble-brooded, and can be very easily hatched out. 
Cronsus septentrionalis, Leach (Cameron).

Nematus septentrionatis, L.

This species is sail to be very common in some parts of the country; and Cameron says the larve feed on poplar, aspen, birch, willows, hazel, and mountain ash. I have not, however, found it on any of these plants, but in Cheshire it was very common on, and sometimes quite injurious to, aller. Fig. $17 t$ is from a plrotograph on alder.

The perfeet insect may easily be recognised by the peculiar flattened formation of the tibir and tarsi (fig. $175 \mathrm{~A}$ ), and black colour of the hind legs. Head and thorax black, abdomen black and brown, antennæe as large as the boly. Wings hyaline. Spreal of wings 16 mm. in male and $24 \mathrm{~mm}$. in female.

The larvæ (fig. $175 \mathrm{~B}$ ) are bluishgreen, with black head; head, extreme end of abdomen, and prolegs quite yellow; one or two rows of black dots along the body. Length about $30 \mathrm{~mm}$.

The perfect saw-fly is a black and light-red insect. In both sexes head, thorax, and anal portion of

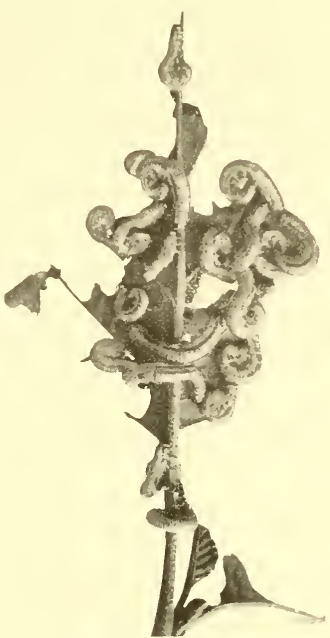

Fig. 174.-Larwp of Crousus septentrionalis on alder. abdomen black; remainder of abdomen light-brown. Wings hyaline; stigma in female black, in male light-brown. Length of male $7 \mathrm{~mm}$.; span of wings $16 \mathrm{~mm}$.; female $11 \mathrm{~mm}$.; span of wings $24 \mathrm{~mm}$.

I have not worked out the life-history of this species, but Jucleich and Nitsche say there is a double generation, the flies appearing in May and August. It is very probable that this may be so, as I have just found that larvæ collected at Catcleugh, Northumberland, on September 23, 1910, hatched out on May 31, 1911. It is not very common in Northumberland. 
Nematus (Holcocneue) Erichsonir, Htg. (the large Larch Saw-fly).

This insect, though fairly common in some parts of this country, is not even mentioned in any English literature relating to forest entomology. Cameron writes:" "Erichsonii does not appear to be a common species. I have only seen a specimen taken by the Rev. T. A. Marshall, of which I did not know the locality. Mr Dale records it from Glanvilles Wootton." In German literature Judeich and Nitsche, ${ }^{2}$ and also Niisslin, ${ }^{3}$ only slightly refer to this species. Packarl ${ }^{4}$

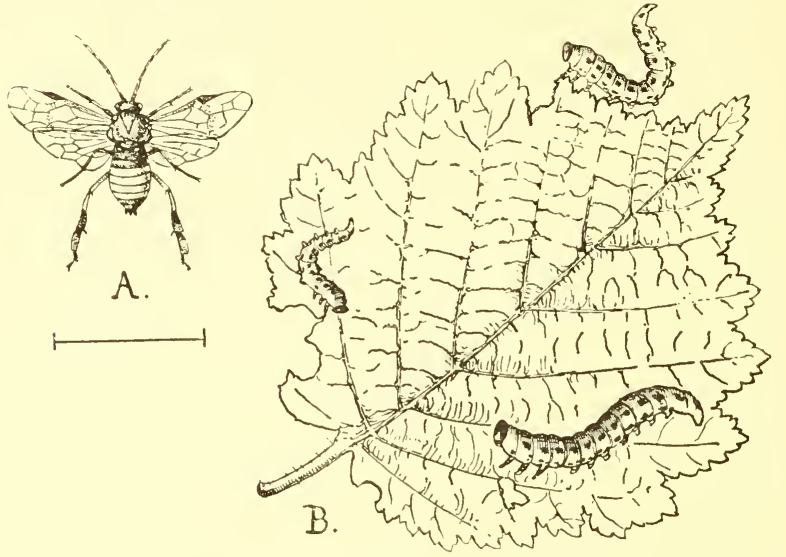

Fig, 175.

A, Crasus septentrionalis; B, Larva of Crasus septentrionalis. (From F. V. Theohald's "Animal Pests of Forest Trees.")

reports it as being injurious in some parts of America, and it is also recorded as being injurious in Canada. ${ }^{5}$ In 1906 it appeared in considerable numbers in Cumberland, so much so that the Board of Agriculture requested Dr R. Stewart MacDougall to inspect the injured

1 Monograph of British Pbytophagous Hymenoptera, vol. ii. p. 51.

${ }^{2}$ Forstinsektenkunde, Band i., seite 661.

${ }^{3}$ Leitfaden Forstinsektenkunde, seite 359.

${ }^{4}$ Fifth Report of the United States Entomological Commission. Forest Insects, by Packard. 1890.

${ }^{5}$ Canadian Entomologist, Nov. 18.84. 
plantations and report (see 'Journal of the Board of Agriculture,' October 1906). I had in the same year found this species sparsely distributed in Northumberland. As this hitherto rare species has suddenly appeared as a destructive insect, it affords a good case in point of the necessity for the student being well grounded in general entomology.

The damage done by this species consists in defoliating larch-trees of various ages (see fig. 176); and as the injury is done whilst the trees are vigorons, it is obvious that the increment is not only appreciably affected, but the health of the tree may be considerably impairer. As the larch is very susceptible to disease, it is important that everything be done to obviate injuries of all sorts.

Dr MacDougall thus describes the insect: "Asult.-The adult

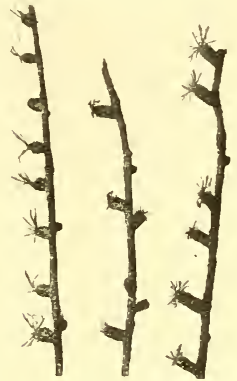

Fig. 176.-Foliuge of lareh injured by lerve of Nematus Erichsonii.
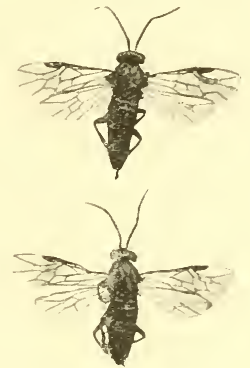

Fig. 17i.-Nematus Eriehsonii.

saw-fly measures up to $\frac{3}{8}$ inch, or a little over, in length, and in spread of wings just less than an inch (see fig. 177). The ground colour is black. The head and thorax are black; the first joint of the abdomen is black; then follow joints coloured red, the end of the abdomen again being black. The mouth parts, the two front pair of legs, except at the part next to the thorax, and the upper parts of the femora of the hind legs, are reddish or reddish-yellow. The tibice are yellowish or pale in the upper parts. The antennæ are nine-jointed and somewhat thick, and taper towards the apex. With a lens the head and thorax are seen to be sparsely and finely pubescent, and the thorax is markedly punctured. The wings are glossy, and slightly clouded below the stigma. 
" Eyy. - The egg is longish oval, and measures just over a millimetre in length. It is white in colour.

"Larv.-The full-grown caterpillar measures three-quarters of an inch, or a little over, in length (see fig. 178). It has a round, black, hairy head, with a single ocellus on

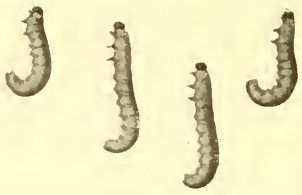

Fig. 178. - Larre of Nematus Erichsonii (slightly reduced).

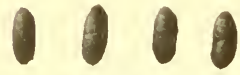

Fig. 179.-Pupol cases of Neuntus Erichsouii (slifhtly retumed). each side. On the upper surface, all down the back, the colour is greygreen; the sides are lighter; the under surface is yellowish-green. If one uses a lens, there will he seen on the abdominal segments transverse rows of minute warts with spines. The spiracles along each sicle are brown. The legs number twentyviz., three pairs of thoracic legs, which are black, and seven pairs of abrlominal legs, which have the colour of the under side of the borly. The head is followed by twelve segments or joints: 1, 2, and 3 are thoracic joints, and each bears a pair of legs; 4 to 12 inclusive are abdominal joints ; 4 has no legs; 5, 6, $7,8,9$, and 10 have each a pair of legs; 11 has no legs; and 12, the last joint, carries a pair of legs."

Fig. 179 is a representation of the pupæ.

\section{Lygenonemetus saxeseni, Htg.}

Nematus alietinus, Ch.

This insect, though often a very great pest on the Continent, is not, as a rule, very abundant in this country.

The injuries may, however, be recognised from the leading shoots of branches of spruce from twenty to sixty years of age being defoliated. This species has been recorded as being rather injurious in Cumberland, and I have found it fairly common at Kielder, in Northumberland.

The larva may be beaten from the spruce branches during the summer months. It is about half an inch in length, and of a uniform green colour, very much resembling a spruce needle. The eyes are black.

As regards the perfect insect, I have so far not been successful in hatching it, though several have pupated all right, and therefore 
camnot give any deseription. It would be well, therefore, for the student to work it out, more especially as it is not mentioned by Cameron except as a synonym; and the assumption that the abovenamed insect is the one responsible for the clamage on spruce is based on the description given by German writers, together with correspondence from Mr Morice.

\section{SIRICIDÆ (WOOD-WASPS).}

As regards forest insects, this family is represented by the genus Sirex. The injuries are chielly done by the larvæ to back-going standing trees, and timber of a secondary class is therefore further depreciated by the larval borings. The trees which are attackert are Scots pine, silver fir, spruce fir, and larch.

The genus sirex is represented in this country by two species ${ }^{1}$ -viz., Sirex gigas, Linn., and S. juvenrus, Linn. There are three species in Germany - viz., s.juv. enrus, s. gigas, and s. spectrum.

\section{SIREX GIGAs, Limn.}

This fine insect often attracts considerable attention in estate timber-yards, where logs of scots pine, spruce, silver fir, and larch

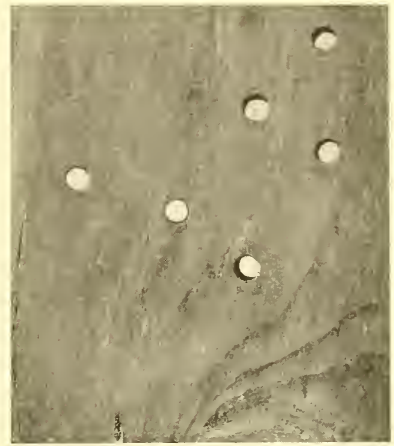

Fig. 18 ',-Plank of silwr fir (Abies pectinata) injured by sirex gigas. are eut up, more especially where the eut logs have been either lying for some time in the yard, or where sickly or previously blown trees (which were unfit for sale) have been brought to the sawmill yard.

This insect is eredited with being a very destruetive species, but this appears to be an exaggeration, inasmuch as it always attacks sickly timber. Fig. 180 is from a photograph of injuries done to a plank of silver fir (Abies jectimutu).

1 There is a third species-viz., S. noctilio-but it is very difticult for the practical man to distinguish it from $S$. jueveus. All three occur in England, but systematic men consicler that jurencus is evidently far rarer than noctilio. 
The female Sirex, which is armed with a long ovipositor, lays her eggs in s'cots pine and silver fir trees which are either sickly or injured. The full life-history does not seem to have been worked out, either by German or English entomologists, but it is said that the larvæ attain their full development in about seven to eight weeks, but that they live from two years in the larval stage, and appear as perfect insects the third year. They make a sort of rough semicircular route, at first boring deeply into the wood, and then turning towarls the ontside, in fact often just immediately within the bark. Although the perfect insects do not appear until July, both sexes may often be found within the logs in November as perfectly developed inseets. One of the best consignments of those insects I ever

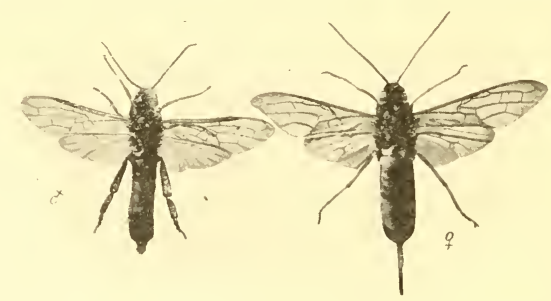

Fig. 182.-Sirrx gigas (marle), reduced.

Fig. 181.--Sirex gigas (female), redueed.

had sent was eaptured by a miner issuing from props within the coal-pit.

The larve are whitish and soft. The head is scaly, and armed with strong jaws, and there is a blunt hook at the extremity of the tail segment. They are about $1 \frac{1}{4}$ inch in length, and about $\frac{1}{4}$ to $\frac{3}{8}$ inch in diameter. I have never found any pupal stage except as tightly packed forms of the perfect insect.

The female (fig. 181) is usually 13 inch in length from head to extremity of ovipositor, and about $\frac{1}{4}$ to $\frac{3}{8}$ inch in breadth. The antennæ are filiform, yellow, and 18- to 25-jointed. The head is black and hairy; eyes and ocelli black. There are two yellow portions behind each eye. The thorax is wholly black and hairy. The abdomen is made up of nine joints, the colour being banded of yellow and black.

There is a black velvety band across the middle of the abdomen, on either side of which there is a yellow band, the abdominal segment 
being terminated by the ovipositor. The wings are over two inches in expanse, and the legs are yellow.

The male (fig. 182) is smaller than the female, and with comparatively long antennax. The abdomen is flattish and brown throughout, except the first segment, aljoining the thorax, which is black. The absence of the ovipositor is of eourse the salient point in quickly determining the sex. The legs are also darkish-brown.

\section{Sirex Juvexcus, Linn.}

The habits of this insect are almost identical with the preceding speeies. There appears, however, to be a difference of opinion

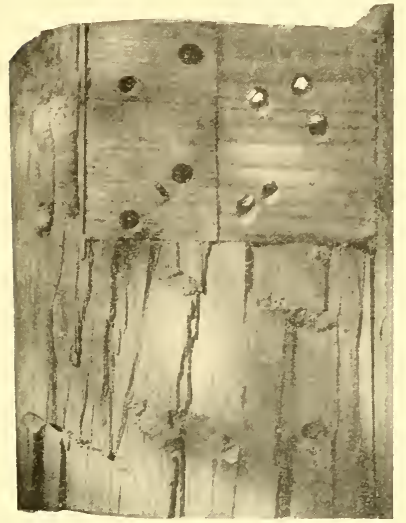

Fig. 183. - Symee timber injured by Sirex jurencus. $a$, slows transierse section of timber; $b$, slows longitudinal section of timber.

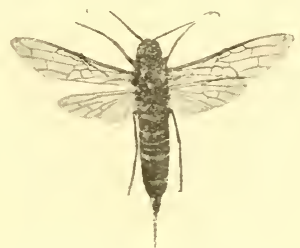

Fig. 184,-sirex juveneus (femele), reduced.

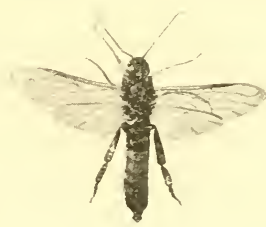

Fig. 185.-Sirex juveneus (male), reduced.

amongst various writers as regards the trees upon which they are found, and it is possible either species may be general feeders on the trees named; but so far as my observations go, I should say Sirex jucencus on spruce and lareh, and Sirec gigas on Seots pine and silver fir. Fig. 18.3 is a representation of injuries done to the timber of spruce.

The larvæ are narrower and more elongated, and more of a dirtywhite eolour.

In general outline the female (fig. 184) resembles that of Sirex 
gigas, except that it is smaller, and the antennæ and entire body of a shiny metallic or steel-blue colour. The legs are also darkish.

The male (fig. 185) resembles the female except in being smaller. The thorax and first thoracic segment are steel-blue. The legs are darkish, with the segments flattened.

\section{MISCELLANEOUS HYMENOPTERA.}

As the section of this order known as Phytophagous IIymenoptera is so large that it would require practically a lifetime for the student to grasp, it is obvious, having regard to the size

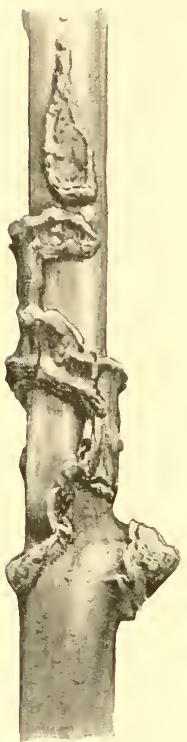

Fig. 18ti.-Injury done to ash stem by hornet.
(Drawn by P.J. Brown.) of the field in forest entomology, that any attempt to give correct systematic elassification in its entirety would overload the chapter. It is therefore deemed alvisable to give the following insects as "Miscellaneous Hymenoptera," without any attempt at elassification.

\section{Vespa Crabro, L. (Hornet).}

When one sees a hornet's nest, or rather the lornets moving in and out of their nest in a hollow of a tree trunk, they may be considerect as belonging to the realm of the general entomologist, rather than to the student of forest entomology. In this country they are confined to the south of England, and do damage to young stems of ash and alder. In Germany, where they must in some places be very numerous, Dr Altum gives a very detailed description of the damage they do to various forest trees, much after the illustration given. I received a damaged young elm from Newmarket, discovered by Mr Bonl, Lambton; and Mr Forgan, Bowood, Wilts, kindly forwarded me specimens of young ash-trees which were considerably damaged, of which fig. 186 is an illustration.

Fig. 187 is from a photograph of a hornet kindly sent me by $\mathrm{Mr}$ A. Cameron, forester, Longleat, Wilts. 
Riodites eglanterif, IItg.

The galls are found on leaves of dog-rose (Rosa canina), generally on under side of leaves, but also on upper surface and sometimes on leaf-stalks. They are very pretty spherical galls, about $3-5 \mathrm{~mm}$. diameter, with beautiful blending in colour of yellow, green, and red, having a small attachment to leaf, and with a large inner cell.

They may be looked for from July to September, but may be very easily overlooked. The galls, when

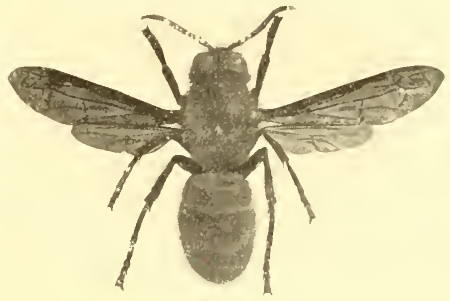

Fig. 187.-Hornet (Vespa Crabro). fully developed, fall to the ground. The larva pupates within the gall. Fig. 188 is a representation of the galls on the under side of the leaf.

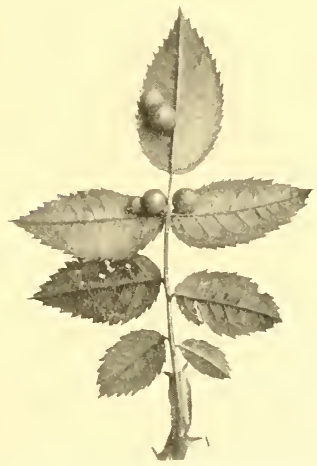

Fig. 185._Galls on under sidc of leaf of dog-rose (Rosa canina) caused by Rhodites eglanteria.

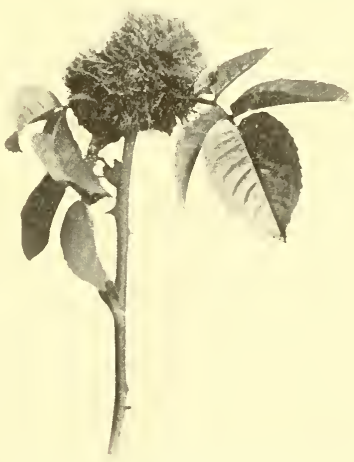

Fig. 189.- "Moss or pin-cushion gall," cured by Rhodites rosa.

Rinodites ros.e, Htg.

This insect, through its oviposition, causes the familiar growths on dog-rose (Rose cunina) known as "Robin's pin-cushion," "Moss galls," "Bedeguar galls," \&c. This gall (fig. 189) is common in every lane, 
and may be eonsidered one of the most remarkable gall-growths arising from insect agency, which eauses modification in the vegetable organism. It may originate either from a bud or leaf. First of all, we get a very sudden "moss-gall," and each hair is a beautiful feathered structure. Later on we get a conglomeration of woody cells, varying in number from three or four to thirty or forty. Each cell contains a single grub; the interior is smooth and clean, and the outside hardy and woody. The growth is complete by the end of $\Lambda$ ugust, and the first flies appeared in confinement June 9, 1901, Northumberland, anıl again on July 9, 1906.

\section{Megastigues spermotrophes, Wachtl.}

This insect, both in point of damage and structure, is entirely different from all the other genera and species belonging to the order Hymenoptera which we have been hitherto considering.

It is the only known hymenopterous insect directly injurious to the seed, and it belongs to the sub-order Petiolata, which are characterised by a constriction between thorax and abdomen. To this order belong the bees, wasps, and ruby flies, and a large series known as the Parasitica, of which a very large number of examples may be found from parasites bred from the various species of oak galls. In fact, Cameron gives speeies of Megastigmus as parasitic on several species of galls.

This insect has been very fully worked out by Dr R. Stewart MineDougall, ${ }^{1}$ by whose kind permission I herewith give the following notes from his valuable paper.

The damage was first discovered by $\mathrm{Mr}$ John Crozier, forester, Durris, near Aberdeen. So far as Scotland is coneerned, Durris may be almost called the home of the Douglas fir, and therefore Mr Crozier wrote in the following terms to Dr MacDougall :-

"The insect has, for some years back, been eausing a serious loss to our stoek of Douglas fir seed. I noticed its presence on coming here nine years ago, but it had no donbt been in the estate before that time. Seed was plentiful, however, and as the damage was comparatively trifling I did not pay much attention to the faet. Now, however, it lias assumed a more serious aspeet, as the seed

1 Transactions of the Royal Scottish Arboricultural Society, 1906. Vol. xix., Pt. I., p. 52. 
on many of the older trees from which I formerly collected my supply, in good years amounting to over 300 bushels, is not worth the trouble of gathering. I have raised some millions of plants on this estate, but unless this pest ean be kept in check, it will be impossible to keep up the stock from home-grown supplies."

Fig. 190 is a representation of injuries clone to the seeds of Ionglas fir (Psendotsuga Mouglasii). The small holes show the exit of the insects, and the seel is therefore totally injured.

1)r MacDougall gives the following description of the insect :-

"This insect, Meyastiymus spermotiophus, was first received by Wachtl, of Vienna, in 1893, and was deseribed hy him as a new speeies. In the spring of 1893 Wachtl got some speeimens of Megastigmus insects that had issuer from the seeds of the Douglas fir. From these speeimens Wachtl deseribed the male and female of the species, which description I now give, in translation, from Wachtl's paper:-

"6The female (fig. 191) is loam-yellow; the vertex of the head and the forehead to the base of the antennæ are red-brown; the central part of the face

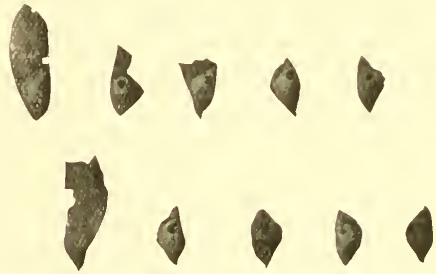

Fig. 190. - Serds of Dougles fir (Pseudotsugr Douglasii) injured by Megastigmus spermotrophus (slightly redued).

(epistome), the inner edges of the eyes, and the palpi, yellow; the ocelli red-brown, each edged with black, and sometimes connected with one another by means of black lines; never, however, is the entire inner surface of the ocellar-triangle dark-coloured; the eyes during life are shining coral-red, after death red-brown; antenne blackish-brown, the scape, and the part between the seape and the flagellum, reddish-yellow; the pronotum with a more or less broad yellow band at the hind edge; the sentum of the mesonotum generally red-brown; the outer side of the shoulders and the furrows of the parrapsides yellow; the surronndings of the bases of the wings to a slight extent black; the diaphanons wings finely black haired; the knob or elub of the ranus-stigmaticus longer than loroal, elliptical and black; the coxre of the fore-legs yellow; the pulvillus on all the legs black; the compressed abdomen reddish-brown on the upper 
side, with a larger or smaller black-brown or black spot at the base of the first segment, and becoming paler at the elges. This spot is sometimes wanting; on the other hand, the end of the body and the under surface of the abdomen are somewhat light-coloured; the sheath of the ovipositor is intense black.

" "All the flagellum joints of the thirteen-jointed antennæ are longer than thick, and become gradually a little less towards the apex of the antennæ; the first joint is the longest, the others practically agree in length; the three-jointed club is egg-shaped, and as long as the two foregoing joints taken together. The central part of the face is obliquely wrinkled, the forehead longitudinally

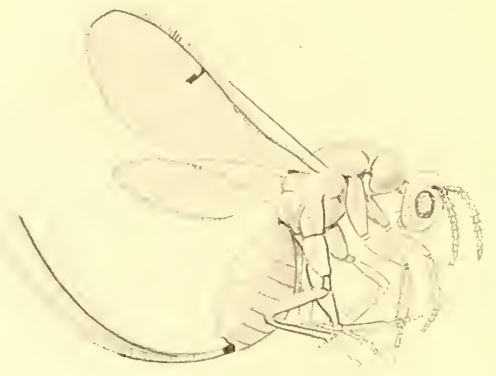

Fig. 191.-Megastigmus spermotrophus (female). (Drawn by P. J. Brown.)

wrinkled; the vertex of the head, the prothorax, the mesothorax, and the scutellum are transversely wrinkled; the post-scutellum, outlined by a fine deep line, is glossy and smooth except at the base and along the longitudinal middle line, where it is finely punctured; the metanotum is finely punctured, with a prominent longitudinal keel in the middle, and in the case of most examples, with a transverse ledge at the limit of its front third; the hind margin is glossy smooth, without sculpture. The face, mesonotum, all the coxe, the tibix and tarsi of the fore-legs and the middle and hind legs, are white haired; the vertex of the head and the forehead, the thorax, especially both sides of the furrows of the parrapsides, the scutellum other than the post-scutellum, the femora of the fore-legs and the 
hind edges of the segments of the abdomen, are beset with longer or shorter black bristles. The ovipositor is as long as the borly. The body length of the female measures from $3.25 \mathrm{~mm}$. to $3.5 \mathrm{~mm}$. (= roughly $\frac{1}{8}$ to $\frac{1}{7}$ of an inch).

"“The male (fig. 192) is orange-yellow; antenuæ reddish-brown; the pronotum has, in the middle of the front elge, a black transverse patch, which is somewhat elongated behind, in streak-like fashion, in the direction of the middle line, sometimes resolved into two spots or reduced to two points; the scutum of the mesonotum is reddish-yellow, and provided in front with a black-brown spot, paler behind, which sometimes only shows through the hind end of the pronotum more or less clearly; the bases of the wings and the metanotum are black; the tarsi of the forelegs, as well as the middle and hind legs, are retdishyellow ; the strongly compressed abdomen is brownish-red above, with a black longitudinal patch at its base, gradually narrowing behind and becoming paler at the edges.



Fig. 192.-Megastigmus spermotrophus (male). (Drawn by P. J. Brown.)

Sculpture, hairing, \&c., as in the female. 'The body length of the male measures from $2 \cdot 75 \mathrm{~mm}$. to $3 \mathrm{~mm}$. (= $=\frac{1}{9}$ to $\frac{1}{8}$ of an inch).'

"So far as I know, the larva has not till now been described. It is whitish in colour, and legless. The segments are well marked, and indeed the general appearance, including the wrinkled and curled form, is strongly reminiscent of a weevil grub. The marked horny head of the weevil grub, however, is absent. Instead, in the megastigmus larva, each of the two chitinised guawing jaws is somewhat sickle-shaped, the two jaws together remincling one of a pair of callipers. The apex of each jaw is pointed, and on the concave side is provided with marked teeth. These gnawing mouth-parts are red or yellow-brown in colour."

As regards the life-history of the insect, it of course hatches out (quite freely in confinement. Each infested seed contains a single larva, and when the fully developed insect emerges from the seed 
there is nothing left but an empty husk. The insects hatch out freely in May and June, and no doubt the insect contains only a single brood in the year. As the female flower or cone of the Douglas fir is very open in the scales, the female insect can have no difficulty in depositing an egg in each seed.

Haring regard to the recognised value of the Donglas fir as a tree, and to the unrecognised value as a shade-bearer, it is imperative that this insect should, as far as possible, be kept in check. There is, of course, no way of dealing with the perfect insect in the open wool, and therefore remedial measures must be taken with the seed. Hence Dr MacDongall's remarks may be given in full :-

"The cones should be gathered as soon as ripe (the latter half of October), and should at once be subjected to such treatment as will permit of the seed being abstracted. This seed should without delay be fumigated with bisulphide of carbon. The method is as follows :-

"Place the material to he treated in an air-tight receptacle. Pour the bisulphide of carbon into a saucer or sancers, or such shallow dish, and lay these on the top of the material. Close the receptacle. The bisulphile of carbon vaporises, and as its fumes are heavier than air, they sink down through the material. The receptacle should be kept closed for forty-eight hours. One onnce of bisulphide of carbon will do for $100 \mathrm{lb}$. of seed, or one ounce for every 50 cubic feet of airspace. The treatment should be arministered in not too cold a temperature. Bisulphide of earbon fumes, being poisonous, should not be inhaled by the operator, nor should a light of any kind be hrought near. If it is desired to store the cones during winter or longer, these must be similarly fumigated directly they are gathered.

"The results to be looked for from fumigation are-

"1st. The germinative capacity of such seeds as have not been infested is not interfered with.

" 2 nd. In infested seed, where the larva may not have made much progress in the destruction of the reserve in the seed, the larva will be killed, and the seed may germinate.

" $3 \mathrm{rd}$. In infested seeds, where the contents have been altogether or much destroyed by the larve, and which therefore would not have germinated, the larre will be killed, and the issue of the next year's brood of adults prevented. 
"The light seed blown through by the fan at cleaning time should be burnt at once, and where there has been attack, this will probably account for many of the pests."

As an insect-pest the Megastigmus is a very good case in point, as showing that forest entomology is a very large and imperfectly worked field. Though the insect had not been noticed until about 1897 or so by Mr Crozier, still it has, no doubt, been in the country for a very long period. At the same time, it is quite likely that its numbers have been considerably increased with imported seer from Western North America. It is possible that it may be very abundant on other estates throughout the country, either as an insect-pest where the seed of Douglas fir is available, or otherwise adapting itself as a parasite, either on oak-galls or other suitable hosts.

\section{Megastigues strobilobius, Ratz.}

Referring to the remarks on the previous species, and the probability of other species of Megastigmus in the country, I received in the early spring of 1906 a few seeds of silver fir containing larvæ from Mr A. C. Forbes, of the Armstrong College, Newcastle-on-Tyne, who had received a single cone from Longleat, Wiltshire. Fig. 193 is a representation of the injured seed.

On July 15 three female insects emerged, and the specimens were quite distinct in colour and other characters from the previous species, and I made the following note :-

Three specimens, all females. Black marked with yellow, vertex of the head black. Central portion of face yellow. Eyes red-brown. Antennæ blackish-brown (entire length); whole pronotum black. Wings hyaline black. Fore-legs, coxa, and tibia yellow, tarsus blackish. 2nd
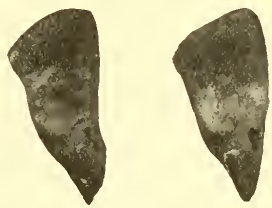

Fig. 193.- seeds of sitwer fir (Abies pectinata) injured by Megastigmus strobilobius. and 3rd pairs of legs vellow throughout, or darkish coxa, and other parts yellow. Abdomen on dorsal surface black, with yellow markings; under surface yellow.

In 'Forstinsektenkunde,' by Judeich and Nitsche, there is a note to the effect that Wachtl should not have priority for the 
discovery of a llepatigmus species as a conifer-seed enemy, as Borries had pointel out to Judeich by letter in 1887 an insect of the genus Torymus-viz, massive females, but no males, of Meyastigmus strobilobins, liatz.

\section{lieferenes to Literalure romsulted.}

Cameron, P. A. Monograph of the British P'hytophagous Hymenoptera. 3 vols. Ray Society.

Cameron, I. A. "The Galls of Mid-Cheshire"-Manchester Microscopical Society. 1892.

Carpenter, George H. Inseets: their Strueture and Life. 1899.

Jucleich und Nitsche. Lehrbueh der Nitteleuropäischen Forstinsektenkunde. Berlin. 1895 .

Macloougall, 1)r li. Stewart. Megustignus spermotrophus, Wachtl.

MacGillivray, Prof. Alexander byer. A Stucly of the Wings of the Tenthredinoidea, a super-family of Hymenoptera. Washington. 1906. (This is a most excellent work.)

Marlatt, C, L. Revision of the Nematina of North America. Washington. 1896.

Horice, liev. F. D. "Help-Notes towards the Determination of British Tenthredinicle" "-Entomologist's Nonthly Nagazine for Jan. 1903.

Niisslin, Dr otto. Leitfalen der Forstinsektenkunde. Berlin. 1905.

Orwerod, Hiss. Manual of Injurious Insects. 2nd edition. 1890.

Trail, Prof. James W. W. The Gall-making Hymenoptera of Scotland exclusive of those that live on Oaks). 1888. 


\section{CHAPTER VI.}

\section{LEIIDOT'ERA (Noths).}

Tne Lepidoptera are undoubtedly the most favourite order of insects, and, as far as ornament is concerned, they are the highest in the insect world. The majority of entomologists begin their studies with the Lepidoptera. They are very interesting in lreeling, from the larve being associated with special food-plants, and more especially in watching their development from the egr stage.

As regards the association of this order with arboriculture, it is of course obvious that it is somewhat difficult to know what species to adopt or reject, inasmuch as some of the rarest species are exclusively arboreal feeders, and on the other hand, some of the most direful forest pests belonging to this order may only appear in certain loealities at very long intervals of years. Perhays, therefore, the best methou will be to simply give the more general species, with as few details of generie and specifie characters as possible, beeause the student will find more available books on Lepidoptera, and probalbly more assistance from local naturalists, than in any other order of insects.

With reference to general characters, the Lepidoptera have foul wings; body and wings covered with seales, which are usually variegated in colour; venation more or less straight and withont eross veins. Imago with mouth only fitted for sucking, which is situated at the extreme end of a long coiled proboseis, capable of protrusion. The metamorphosis is complete, but abrupt; the larva has a large head and strong mandibles; the pupa often has the antenne adpressed, and cemented to the body; and the full development of the moth takes place within the pupal case.

The learl is in a large part made up of the compound eyes, the simple eyes or ocelli which are usually concealed by the antennæ, and the proboseis or trunk. 
The prothorax is small, the mesothorax large, and the metathorax small.

The abdomen varies according to sex. In the female it may be said there are seven segments dorsally and six segments ventrally. But one segment is concealed ventrally, and other two segments are modified in connection with the ovipositor, thus making in reality nine segments. In the male the abdomen is also composed of nine segments, and as a rule is more slender than in the female. At the extremity the anatomy is somewhat complex, but the general design shows two terminal claspers.

The legs are long, slender, and covered with scales. The tarsi are five-jointed, and terminating with two small claws.

The wings of the Lepidoptera are a remarkable feature of this order, inasmuch as they owe their beauty to the often exquisite blending of colour which adorns their surface. This delicate colour is due to the arrangement of minute scales, which overlap one another after the manner of slates on the roof of a house. They form very fine objects for microscopical mounts, and the young collector must always remember their delicacy, as the slightest touch of the finger will at once destroy the beautiful pattern of the wing.

A detailed study of the wings is of very great importance to the specialist in Lepidoptera, and requires, as a subject, a good deal of consideration to thoroughly understand. The most salient features are the size and form of the scales, the arrangement of nervures, the comparative size of the wing-cells, and the development of the wings during the pupal stage.

The egg shows great variety in structure, and also in the manner of deposition. In some cases the eggs are large, naked, and exposed; in other instances they are beautifully coated over with a substance bearing so close a resemblance to the food-plant that it is with great difficulty they can be found, while in other cases it is scarcely possible to discover them at all. There is also great variation as regards the interval of time between the deposition of the eggs and the hatching out of the larvæ. Thus, some hatch out in the autumn and feed for a short time, and then hibernate for the winter; while many, on the other hand, pass the winter in the egg stage, and hatch out only slightly in advance of the development of the food for the larvæ.

The larve of arboreal-feeding Lepidoptera show considerable 
diversity in apparent structure. They are generally composed of a head and twelve divisions or segments of the body. Those feeding on the surface of foliage have generally well-developed legs, and clothed with hairs, while those feeding within the tissues of the plant are either footless or with partially-developed legs and smooth surface.

In the pupe there is also great diversity as regards form and habit. In some, all parts of the future perfect insect are visible, while others are enclosed in a silky cocoon. Some bury themselves in the soil, while others pass their pupal stage within the leaf or other portions of the food-plant. From a structural and evolutionary point of view, the complex changes taking place within the pupal stage of a Lepidopterous insect are most remarkable, and would require a long and detailed study to thoroughly understand.

The mouth of a Lepidopterous imago presents a great change from the mouth of the larva, inasmuch as the one is adapted solely for sipping and the other for biting and masticating its food. As regards special structure, the mouth of the fully developed insect is somewhat difficult to understand, but the principal feature is a tube or proboscis which is rolled up when the creature is at rest, and protruded when it wishes to sip nourishment, as may be readily seen by the collector when the moth is enjoying his prepared banquet of "sugar." The proboscis, and the exact mode in which it acts, present many suggestive questions. Thus the length of the proboseis is adapted to the needs of the creature, inasmuch as the essential food often lies at the bottom of a floral vessel which could be reached in no other way except through the medium of a long tube. On the other hand, a short tube is often recognised on the mere surface-feeding moths, and still further in many species the mouth is atrophied, and minute anatomical investigation shows that the stomach is in a correlated condition.

With reference to classification, it is obviously unnecessary, having regard to the few species selected as arboreal Lepidoptera, to give too many details of the larger-sized sub-families. Students, however, as a general rule, may divide the order into two principal sections-viz., Marro-Lepidoptera and Micro-Lepidoptera. The former deals with the larger-sized species, and the latter with the smaller or very tiny creatures.

In the smaller-sized moths or Micro-Lepidoptera it is essential in 
some sections to give considerable attention to generic characters, as in certain cases the whole genus may not only be arboreal in habits, but as the characters are minute, microscopical examination of the salient features is indispensable.

\section{Syerinthus populi (Linn.) (Poplar Hawk-Moth).}

This moth, as the name implies, is found on the poplar. It is not so abundant as ever to be considered a pest, though fairly common as an entomological specimen. The larva lives on Lombardy and black Italian poplars. The moth appears about milsummer.

The eggs are deposited on the upper side of the leaves. They are

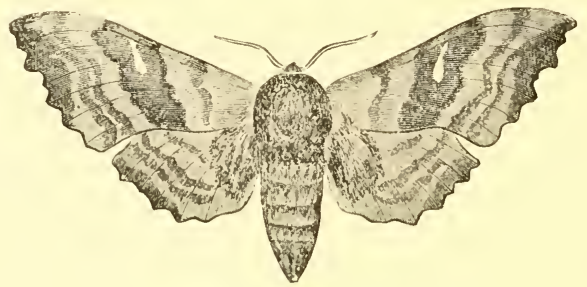

Fig. 194.-Smerinthus populi (Popler Hauk-Moth).

large and nearly globular, pale green in colour, and glued singly to the leaves. The embryo may be seen before hatehing.

The larvæ hatch out about the beginning of July, and the long caudal horn projecting from the last segment is quite a conspicuons feature. As development proceeds the horn is less eonspieuous, but stripes, spots, and markings on the lateral segments may be noticed, and after the respective moultings the larvæ develop a short, stont, yellow, caudal horn, and it is interesting to note the changed markings in comparison with the green colour of the leaf.

The moth, fig. 194, is a large heavy insect of a stone-grey colour, with a whitish spot on the fore wings and a brick-red bloteh on the hind wings. The wings are notehed at the margins, and the venation is fairly conspicuous. The body is soft and velvety-looking. The antennæ are serrated in the $f$, nearly filiform in the + . 
Suerinthus ocellatus, Limn. (Eyed Hawk-Moth).

The life-history and habits of this moth very much resemble the preceding species, and the larva is said to generally feed on the willow and apple, though I have found it feeding on the leaves of the black Italian poplar.

The moth, fig. 195, is more beautiful than the preceding species, and receives its specifie name in consequence of having a large eye-like spot on each of the hind wings. The fore wings present a beantiful,

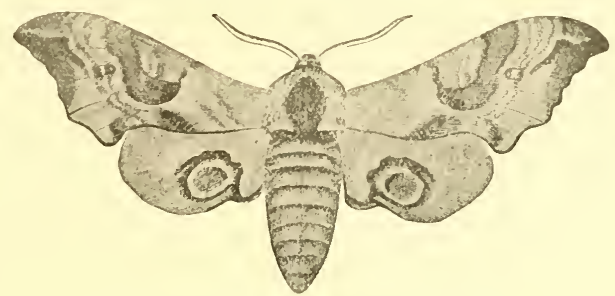

Fig. 195.-Smerinthus ocellatus (Fyed How $\mathrm{K}_{-M}$ Moth).

glossy, velvety appearance, which renders the veins less conspicuous than in S. propuli. The hind wings are of a delicate rosy tint.

\section{Trochilium (Sesia) bejbeciformis, Hub. (Hornet} Clear-wing of the osier).

The larvæ of this species are generally found in the base of stems of the goat willow (Sativ caprea). ${ }^{1}$ The holes which show whence the perfect insects have eseaped are often the first conspicuous indication of the damage. Such holes, however, are not always a sign that all the moths have escaped, for if a few euts be taken from sueh stems and placed in a box, say in April or May, we may anticipate moths emerging at the proper time for two consecutive years. The dates on which I found them appearing in Northumberland were July 10, 1901, and July 10-14, 1902. Fig. 196 shows a longitudinal gallery, and cross section of several galleries.

The larva is whitish, a little over an inch in length; head brown, tapering considerably belind; legs dark-brown and small.

1 Mr W. P. Grace, Whickham, Co. Durham, has since drawn my attention to this species doing considerable damage to Black Italian Poplars in his garden. 
The pupa is of a bright chestnut colour, with the wing-cases and antennx rather long and free from the body. In the in-

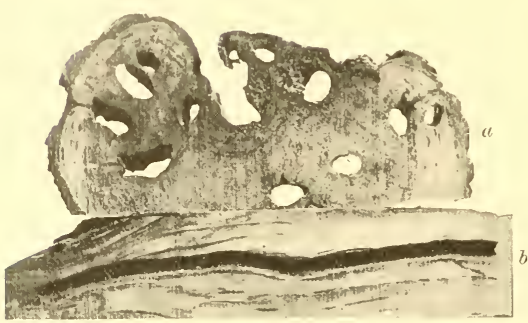

Fig. 196. - Timber of gout willer injured by larewe of Trochihum beinbeciformis.

$a$, eross section. $\quad b$, longitudinal section.

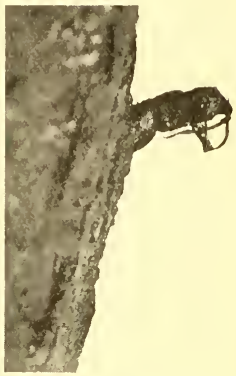

Fig. 197.- Pupel ease of Trochilimu bembeciformis projecting from trunk after the escape of the moth.

terior of the wood it is encased in a strong cocoon of white silk and gnawings of wood. After the moths hatch out, the empty

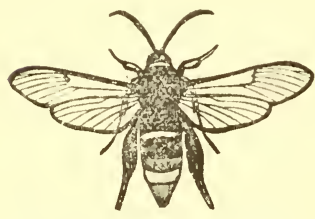

Fig. 198.-Trochilimm bembeciformis (Hornet Clear-Wing of the osier). pupal cases may be found lying in the hatching-box, or otherwise projecting from the stem, as in fig. 197 .

The moth, fig. 198, has a wing expanse of $1 \frac{1}{4}$ to $1 \frac{1}{2}$ inch. Wings transparent, costal edge dark orangebrown, and nervures dark-brown. Head dark-brown. Abdomen darkbrown, with conspicuous yellow bars across the abdomen. Antenne black, rather short and stout. Legs an orange-brown.

\section{Cossus ligniperda, Fab. (Goat Moth).}

The larve of the goat moth are often very injurious to various species of trees, as, for example, oak, elm, ash, willow, and poplar. In Cheshire I twice hatched it from oak gate-posts. It may be termed a south-country species, as it generally does not occur north of Yorkshire, and it is said to be most abundant near London. Fig. 199 rep- 
resents the injuries done to an oak stem or plank. I am indebted to Mr E. G. Wheler, of Claverdon Leys, Warwick, for this speeimen.

Mr F. V. Theobald says :-

"The goat moth liurve are the cause of the damage, for they are not only large but ravenous creatures, which tunnel right into the heart of the hardest wood, and in from six to ten years a large tree is completely killed by them, the whole trunk becoming a honeycombed mass. As many as two hundred have been found in a single tree. If once a tree is struck by this pest, it continues for years (usually until it is

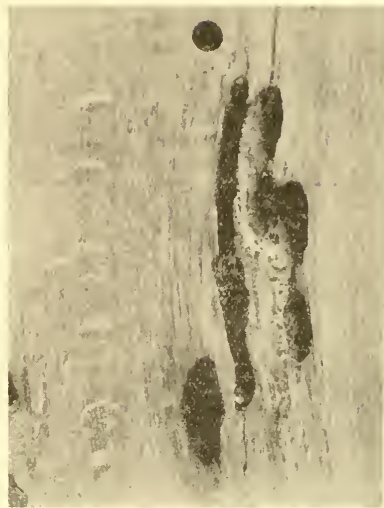

Fig. 199.-Oak plank injured by larve of Gout Moth. destroyed) to be a breeding-ground. It is quite erroneous to say they only attack sickly trees: perfectly sound and healthy ash and

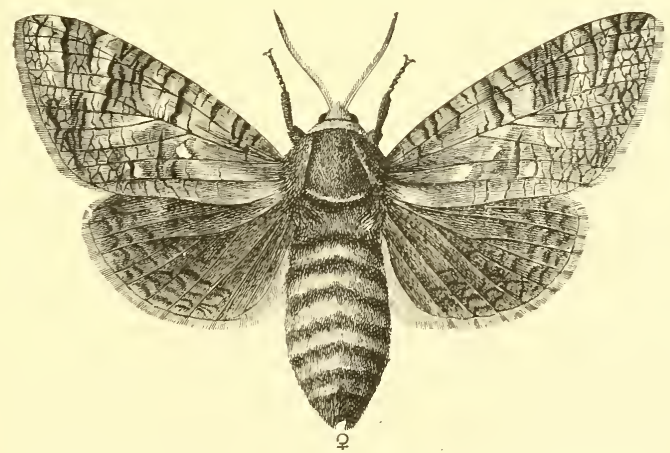

Fig. 200. - Cossus ligniperda (fiout $M \circ t h$ ). (From 'The Forester,' by J. Nisbet.)

elm have been observed to be attacked and eventually killed, and then the larvæ traced to the nearest tree that is unaffected. Nor are 
solitary trees and those along wood borders only infested, for I have found trees killed by the goat moth in the heart of dense woods.

"Infested trees may easily be told by the holes

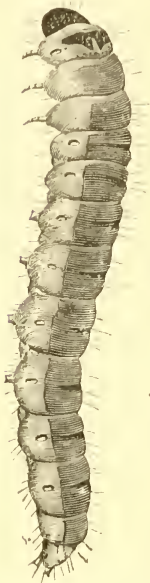

Fig. 201.-Larres of Fout Woth. (From "The Forester,' by J. Nisbet.)

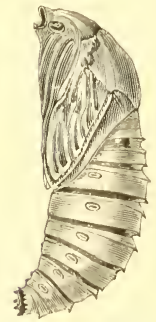

Fic. 202.- T'upe of foct ester,' ly. J. Nishet.) Aloth. (Fom The For-

in the trunks, the lying limbs, the wood chips thrown out of the holes, and the rough and suarled appearance of the trunks. Infested trees are sail to be easily recognised hy the foul odour they enit: this I lave failed in every case to notice, and some 150 trees that have been infested, and have sucembed to the attack, have been examined." 1

The moth, fig. 200, is a very large insect, with pectinated antenne in both sexes. Head reddishbrown; fore wings ashy-grey colour, mixed with a dash of brown, and hind wings more of a smoky-grey. The sexes are somewhat similar, but the female is much the larger, being sometimes 31 inches across. The moths appear in Jume and July, and at once deposit their eggs in the crevices of the hark.

The larva, fig. 201 , is from 3 to 31 inches in length, rather smooth and shining. Head small, shining black, the borly flesh-colonred, and the legs yellow. They live for about three or four years in the larval stage, and observers have recorded that it frequently has the habit of wandering from its food-plant and pupating in the soil. When it does pupate in the stems of trees, it makes a eocoon with chips and frass.

The pupa, fig. 202, is very stout, slightly curved with rings of sharp spines, and rather prominent wing-cases. The colour is a dark red-brown.

Collectors sometimes get the moth at "sugar."

\section{Zeuzera aisculi (Lim.) (Leopard Moth).}

The larva of this moth is destructive to various speeies of trees-viz., poplar, horse-chestnut, ash, elm, sycamore,

1 The Animal Pests of Forest Trees. 
birch, willow, hawthorn, ant several species of fruit-trees. It may be found feeding in the trunks, branches, or twigs. It is said to live from two to three years in the larval stage.

The larva is about $1 \frac{1}{2}$ to 2 inches in length, yellowish-white colour. IIead rather small, blackish-lorown; second segment has a broad dorsal plate. Each segment of the body has black spots, so that the entire larva has a spotted appearanee.

The moth, fig. 203, is very handsome. The ground colour of the wings is white, semi-transparent, with many large blue-black spots. Antennie black; abdomen grey or blackish.

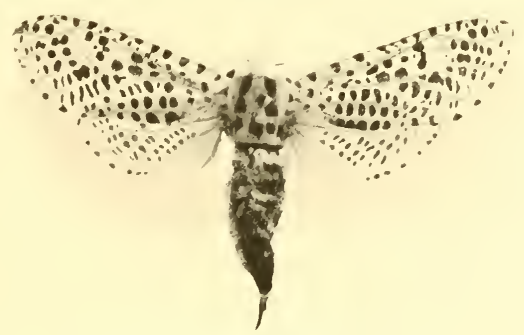

Fig. 203.-Zeuzera issculi (Lerqurll Mothi).

The expanse of wings is about $2 \frac{1}{2}$ or 23 inches in the female, but the male is rather smaller.

It appears on the wing from the end of June to the begimning of August.

Mr A. Gallie, Ringwood, Somerley, sent me a sample of damage done to young trees by the larvæ, which bore into the stems, and then they snap off.

Orgya axtiqua, Linn. (Common Vapourer Moth).

This is a moth which may be almost termed a universal feeder, inasmuch as the larvæ may be found on almost every tree and shmb. I have, however, not found it so numerically strong as to be considered a serious pest, though I found it very abundant in Delamere Forest, Cheshire, June 1895. 
The caterpillars, fig. $204 a$, are very noticeable from their peculiar tufts and bunches of hair. It is quite parti-coloured-a mixture of brown, grey, pink, yellow, \&c. The head is black, and behind the head two very long feathered bristles project, after the manner of antennæ; the segments are brightened with red spots, hairy bristles project from the segments, and four conspicnous yellow tufts spring from the dorsal surface.

The pupa, fig. $204 l$, is very stout, swollen in the middle, shining dark-brown, hairy, and enclosed in a small cocoon within the balls of leaves.

The male moth, fig. $204 c$, which flies in the day, is of varying

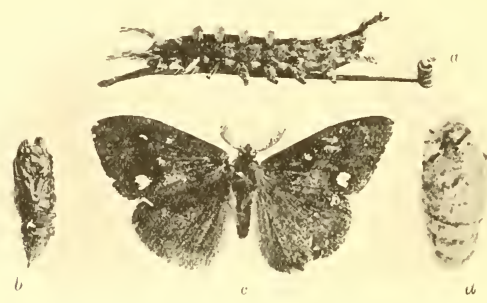

Fig. 204.-Orgyia antiqua (Conmon Vupurer Muth). $a$, larva ; $b$, pupa ; $c$, male; $d$, female. (Photo by A. Flatters.)

shades of brown or chestnut, and with a white half-moon-shaped spot near the lower outer edge of the fore wing. The antenne are short and pectinated.

The female, fig. $204 d$, is almost wingless, having short abortive wings, and of a uniform grey colour.

\section{Dicranura (Cerura) vinela, Linn. (Puss Moth).}

The caterpillars of this moth are sometimes very injurious to willow and poplar. I once found them eating hazel in Cheshire, and reared several moths from the caterpillars. I have had them reported from several places in the east coast of Scotland, and the reported injuries coincide with the following account from Miss Ormerod:-

"In 1885 especially, I had notes from Mr J. Low, forester on the 
Rothes Estate, Fife, of the caterpillars being at work in the middle of summer on Balsam poplars, from some of which they had entirely stripped the leaves. These trees had been planted in the previous spring, and were from four to five feet high, and in another instance the rapidity with which the caterpillars devoured the leaves was specially mentioned. I) uring the present year a very curions instance was reported to me from Lincolnshire, in which the little trees were so young and small that the quantity of woody material and bark removed by the caterpillar for its cocoon had so weakened the slender stem that the young poplar plant had broken off. In the specimen sent me, the slender stem was completely barerl of bark for some little distance from the hard cocoon, and the young plantation was reported to be practically destroyed." 1

From the species above mentioned which I hatched out, I found that the eggs were deposited about July 1. The eggs were brown, eircular, and about $2 \mathrm{~mm}$. in diameter.

Buckler gives the following description, viz. :-

"The eggs are laid either singly or two or three near together, on leaves of poplar, sallow, or willow. (I fancy poplar, any kind, is preferred by the larvæ, when they have the choice.) The egg is button-shaped, convex above, nearly flat underneath, fairly round, with a small pit at the apex, varying from $1.6 \mathrm{~mm}$. to almost $2 \mathrm{~mm}$. in wide diameter, slightly more than $1 \mathrm{~mm}$. high, the shell hard, glossy, but finely pitted all over, colour rich warm brown above, more smoky beneath, the central pit blackish, but ringed with yellowishwhite. There is a pale variety of the egg of a buff tint, the central pit still blackish, with light ring." 2

The larva, when full fed, is large, stout, and smooth. It may be easily recognised by the position it assumes, of arched body and forked tail, which, in fact, may be termed a fighting attitude. The fourth segment is surmounted by an angular hump, head black, and often partially withdrawn within the body. The prevailing colours of the caterpillar are brown and yellow, the former an angular portion along the back, and the latter conspicuons when viewed from the side.

The pupa is enclosed in a very hard shell-like cocoon, which may be found on the trunk of the food-tree, or, in fact, on any arljacent

1 Manual of Injurious Insects.

2 The Larvæ of British Butterflies and Moths. (Ray Society.) 
object. When glued on the stem, they display most excellent examples of protective resemblance (fig. 205).

The moth, fig. 206, is a very large handsome insect, antennæ pec-

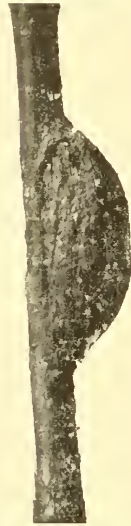

Fig. 205.-Pupe of Puss Moth on twig of birch. tinated in both sexes, very broadly so in the male. The female is the larger insect. It is of a greyish colour throughout, and the body is downy and soft in general appearancehence the name. Wings partially transparent, showing the venation, but more covered near the base, where there are several dark spots.

\section{Prgara bucephala, Linn. (Buff-tip Moth).}

The larvæ of this moth often do considerable damage to various forest trees by feeding on the leaves of elm, oak, and other trees. In some cases oak - trees have been quite defoliated, but as a rule the damage is easily recognised in early autumn, which consists of a defoliated bough, standing out quite conspicuously from the otherwise fully foliaged trees.

The moth, fig. 207, appears in May and June, and the eggs are laid

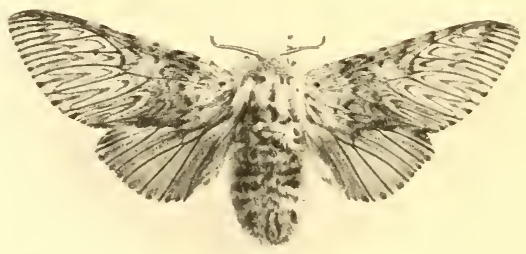

Fig. 206. - Dicranura vinula (Puss Moth).

in patches on the under side of the leaf. The moth may be found resting in repose during the day, with the wings folded narrowly across 
the body, and the pose so beantifully harmonises with a dead twig that it may, in fact, be easily overlooked. There is a conspicuous buff-coloured portion at the extremity of the wings-hence the name.

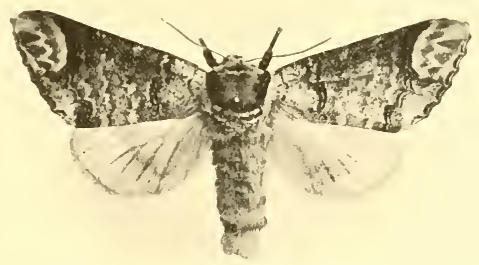

Fig. 207.-Pygara bucephala (Buff-tip. Moth).

The fore wings are of various shades of pearly grey or silvery grey, with mottled whitish markings. In fact, the wings may be briefly described as sparkling with silvery powder of a frosty appearance. The hind wings are whitish stonecoloured in appearance. There is a conspicuous raised crest on the thorax.

The caterpillars, in their very young stage, feed in company, but after the first larval moult they separate into parties of eight or ten, but do not move far from their birthplace-hence the damage is all done in one place. When resting, however, from feeding, they reassemble in comparatively large grouns, as seen in fig. 208. When full-grown they are about $1 \frac{3}{4}$ inch in length, rather soft and limp. Head black, body downy. The prevailing colour is a mixture

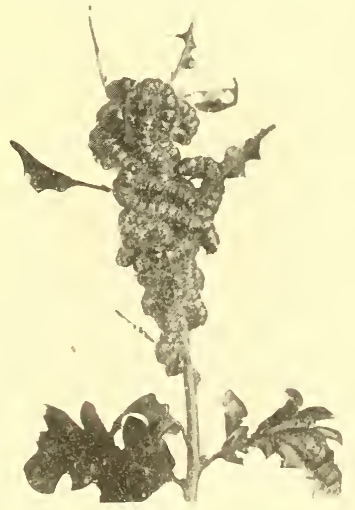
Fig. 208.-Lan of Buff-tin Moth on twig
of oak. of yellow and black. In the first three segments behind the head those two colours are blended in squares, but on the other segments 
the darkish colour is in fairly large patches, and the yellow colour in longitudinal lines. The yellow colour prevails to such an extent as to brighten the whole body, and thus the eaterpillar is a very pretty creature.

As this is often a very injurious insect, it is at times essential to adopt some remedial measures. This can best be done in the caterpillar stage, by shaking them down on a spread sheet, or otherwise collecting the larvæ and plaeing them in paraffin.

The pupæ may in some eases be kept in check by sprealing gas lime or hot lime round the roots of a previously infested tree.

\section{Fanily GEOMETRINA.}

The family of moths known as Geometens are of considerable importance in forest entomology, inasmuch as many species may be readily recognised on the foliage of trees by the peculiar habit of the larvæ, known as "looper grubs." This peeuliar habit arises from the method of the larva walking in the form of a "loop." A short observation of the creature will give a rapid dentonstration. The larva of a "looper grub" has six well-developel true legs in the fore part of the body, and four well-developed claspers at the abdominal end of the body. When at rest the ereature may be perfectly straight, but when it wishes to exercise locomotion it brings up the claspers against the true legs, and thus the greater portion of the body rises upwards in the form of an arch or loop. Then the creature alheres by the abdominal legs, and projects the whole body forward, and again draws the elaspers against the true legs, thus making the loop and moving the length of its own body forward each time.

The moths are not quite so easily recognised, but as a general rule they have well-developed wings (though in some cases the females are partially wingless), and the wings are generally folded ridge-wise when at rest.

Fidonia piniaria, Linn. (Bordered White Moth).

This moth is very common in Northumberland during the summer months. In the Scots pine woods they fly very abundantly amongst the heather and rough herbage. The larva is not particularly con- 
spieuons in the foliage to the naked eye. The caterpillars may be beaten from the foliage in September and October.

The egrgs are deposited on the needles of the scots pine.

The eaterpillars are lightish-green in colour. In the early stages they may be compared to threal-like worms, beatifully larmonising in colour with the foliage. When full-grown they change in colour, but still harmonise with the foliage. The prevailing colour is sea-green, with a whitish longitudinal line down the back, and a yellow line along cach sile of the borly, rumning parallel with the dorsal line. The eaterpillar (lig. 209) is from 1 to to $1 \frac{1}{2}$ inch in length. They are full fed about October. They pupate in the soil.

The pupa (fig. 210) is light-lrown in colour. It may be noter

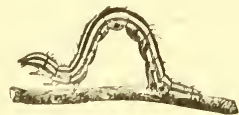

Figs. 205.-Larew of Lomdered th'hit Woth. (From 'Fonest l'rotection, by W. R. Fisher.)

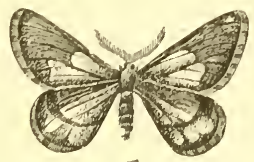

ऽ

Fig. 211.- Fidonia piniaria (molf). (From 'Forest Protection,' lyy W. R. l'isher.)

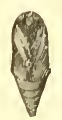

Fig. 210, P'uper of Jordered White Muth. (From 'liorest Protection,' by W. R. Visher.)

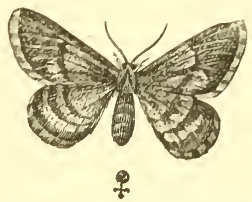

l'ig. 213. Fidonia piniaria (frmatr). (From 'Forest Protection,' lyy W. R. Fisher.)

that in this insect the pupal period is of comparatively long duration, and Altum points ont ' that full-fed eaterpillars and pupa are subject to being attacked by several natural enemies, both fungi and insects.

The male moth (fig. 211) has very strongly pectinated antemne, whilst those of the fenale are quite simple. The borly is slender, whitish-rgrey, and approaching to yellow at the extrenity. The prevailing colour of the wings is a mixture of dark-brown and white. The apical portion of the fore wing - at space about equal to one-half of the wing - is a brown-black colour, and the remainder of the wing is practically white, with brown streaks. The under wings are of a similar colour, but the white portion is more nixed with the brown colour, and sometimes ronghly divided into white and brown spaces.

\section{Forstzoologie.}


The female (fig. 212) is, as a rule, slightly larger than the male, being a little over an inch in expanse of wings. In colour both sexes are very unlike, the female being of a nearly uniform orangebrown tint above.

Both sexes fold their wings erect when in repose.

\section{Chemitobia brumata, Linn. (Winter Moth).}

To the fruit-grower in many parts of England this is a dreaded pest. It is also a most injurious forest insect, inasmuch as it feeds on several species of hardwood trees. In nursery-rows, in early summer, young

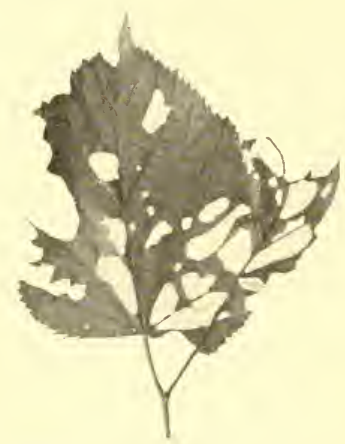

Fig. 213.-Foliage of lime-tree eaten by larve of Winter Moth.

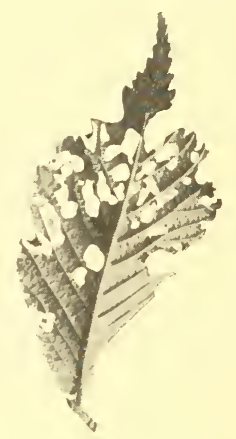

Fig. 214.-Leaf of uych etm eaten by larve of Hinter Woth.

lime-trees - more especially those of a comparatively large size which have just been transplanted the previous spring - are often defoliated by the voracious larvæ of this species (fig. 213). The foliage of the wych elm and sycamore, also, is often much destroyed by the larve of this species (figs. 214 and 215). The injuries done to the foliage are very similar to the ravages of certain species of Tortrices, and it is therefore very important, for purposes of verification, that the moths should be reared from the larval stage.

The moths appear about November, hence the name of "winter moth," and the males fly about in the evening. The males are winged, but the females are furnished only with abortive wings, which are practically useless in the service of flight (fig. $216 \mathrm{~B}$ ). 
The male moths (fig. $216 \mathrm{~A}$ ) have a wing span of about 1 to $1_{4}^{1} \mathrm{inch}$. The fore wings are of a light brown-grey colour, and marked by several faint transverse bands or bars. The hind wings are a pale greyishwhite colour. The antennæ are simple, and the body very slender.

The abortive wings and boly of the female are of an ashy-grey colour. The fore wings are brightened by irregular white markings. The colour harmonises very beautifully with the lichen covering the bark of the trees, on which it may be found. The abdomen is very large in proportion to the thorax, and thus the creature when at rest may, as Miss Ormerod remarks, be mistaken for a spider.

I have not found the eggs on the trees, but have examined them

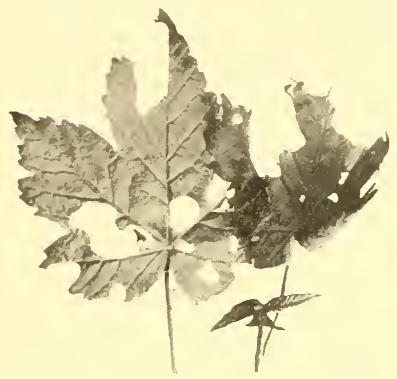

Fig. 215.-Foliage of syeamore eaten by larier of Winter Woth.

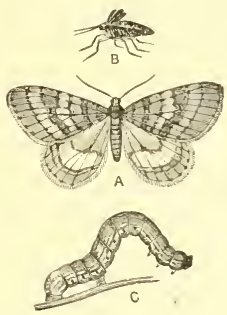

Fig, 216.-Winter Moth (natural size). A, male; $B$, female; $C$, caterpillar. (From 'The Forester,' by J. Nisbet.)

when deposited in confinement. At first they are a light-green colour, and later on they change to a beautiful light-orange. Prior to hatching they are a dark-green colour, from the colour of the encased caterpillar, and after hatching the empty shells are glassy and transparent. The approximate measurement would be about $\frac{1}{6}$ th of an inch in length, oval, blunt at both ends, and beautifully pitted over the surface. The hatching-cases were placed in a cool shed, and the eggs hatehed very irregularly. The first larve were recognised on February 10, 1905, and a few appeared every week until the begimning of April, when the bulk then hatched out. At first the larvæ are of a dirty-green colour, with dark heads. When full fed they are about an inch in length, green, with a dark dorsal line, and three yellow stripes along each side, and a dark-brown head. 
The pupa is a light-brown colour, and sliglitly encased in a very loose flimsy cocoon. In this species the pupal stage is a comparatively long one, and some specimens do not appear till the following spring. There is only one generation during the year.

As regards remedies, when the insect is very destructive to young trees or special trees in a park, the method adopted by fruit-growers may with advantage be copied. This consists in intercepting the female moths from climbing up the trees to deposit their eggs. The fruit-grower simply ties a band of grease-proof paper around the stem of the tree, and then smears the paper over with tar and cart-grease or other viscous substance, into which the female becomes embedded, and therefore cannot extricate herself. This prevention, however, is often overcome by the insects, inasmuch as the male frequently performs the apparently chivalrous action of carrying the female in cop. to the tops of the trees.

\section{Hrbernia defoliaria, Clerck. (Mottled Umber Moth).}

The larvæ of this moth are often very injurious to various species of trees, as, for example, hornbeam, white-thorn, hazel, oak, and syeamore. The worst attack I ever saw was in Sherwood Forest, May 26, 1896, when the larvæ were actually hanging by threads in shoals from the trees.

Newman thus describes the caterpillar: ${ }^{1}$ "The head is rather large, and not notehed on the crown; the boly is uniformly cylindrical, and without humps; the head is without gloss, and brown; the body has a broad dorsal area, of a clear brown colour : this area is bounded on each side by a very distinct, but narrow-waved, black stripe, and is also adorned with grey markings, which are particularly conspicuous at the interstices of the segments where they approach the black boundary stripe; below the boundary stripe the body is bright yellow; the spiracles are white, and the region surrounding each spiracle brown; the belly is greenish-yellow; legs and claspers pale. A beautiful but very abundant caterpillar."

The moth appears in October. The female is wingless, and the male has large wings and pectinated antennæ. The fore wings are of light-brown colour, usually with two dark-brown bands. The hind wings are paler, and have a dark spot in the middle of the wing.

1 British Butterflies and Moths, p. 105. 
Trachea pixiperda, Panz. (Pine-Beauty Moth).

This is the only species selected from the very large family of noeturnal moths generally known as Noctuæ. There are other species of arboreal habits belonging to this group, but this will probably be sufficient for the purpose of this work.

This speeies is exelusively an arboreal one. The larva feed on the twigs of Scots pine trees, and may be beaten from them in June and July. In colour the larva has a palebrown head, and the body varies from dark-olive to rich oil-green. It has five longitudinal white stripes. It is not often recorded as being numerically strong, and therefore cannot be considered as a pest.

The moth, fig. 217, appears in April,

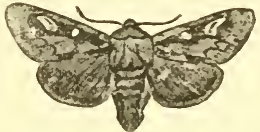

Fig 217.-Trachea piniperda (Pine-Becuty Moth). and may be found allhering to the bark. The antemnæ of the male are serrated and those of the female simple. The head is comparatively small. The fore wings are of a bright recklish-brown colour mixed with orange, and the hind wings are grey-brown.

Dioryctria abietella, Zinck.

The larve of this species are injurious to the cones of the spruce fir (Picea ercelsa) and silver fir (Alies pectinata), fig. 218. As the larvæ live within the cones during the latter part of summer and early autumn, the affected cones may not at first be recognised. When very much eaten, as represented in fig. 218, they are of course easily noticed, but in the early stages of the injuries it is best to collect the cones and lay them out singly on a clean floor or on a paper, and then select those from which the

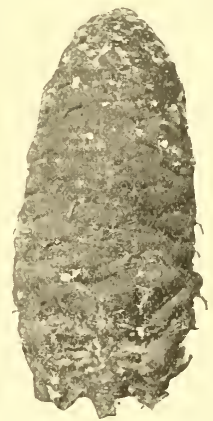

Fig. 218.-Cone of silver fir (Abies pertinata) partially eaten by lariwe of Dioryctria abietella. frass may be seen escaping. They may then be put aside in a vessel, and wait till the perfect insect appears in the following July.

The larva is of a dirty redlish or greenish colour, with darkish back and slightly sicle-striped. Head and shield brown. 
The moth (fig. 219) may be described as follows: Fore wings long and narrow, glossy lark-grey, with several wary black transverse lines. Basal and first lines preceded by a white fascia ; first line very

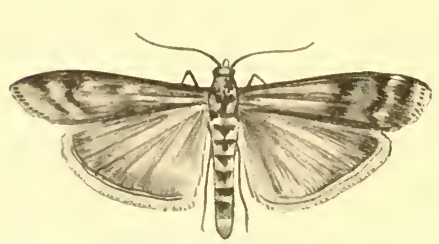

Fig. 219.-Dioryetria abietella (full size). (Drawn by P. J. Brown.) distinct on costa; second line angulated and bordered on its outer margin with a white line; an indistinct shaded grey line between it and the hind margin; a pale central spot on disc of wing. Hind wings concolorous. Length 22 to $25 \mathrm{~mm}$.

This species belongs to the family of Crambites, and typical moths of the same may be seen flying, or rather leaping on the grass fields, in a summer evening walk.

\section{FAMILY TORTRICID压.}

The moths of this family are comparatively small, and some naturalists have proposed for systematic considerations, as regards external anatomy, to merge it with the Tineidie. This suggestion, however, has not met with much support, and from an arboreal point of view the two families should be considered as quite distinct. The name Tortricidæ refers to the general habit the larvæ of those moths possess of rolling up leaves, or twisting and distorting shoots and buds. The mode of rolling leaves by small larvæ has been much discussed, and is probably due to definite operations of the larvæ, together with assistance derived from silk threads spun by themselves. These silk threads are rolled round the leaves, and they harden and contract from exposure to the air. After the leaf is thus bound by the tiny thread, the roll is still further perfected by the growth of the vegetable organism accruing from the interference of the caterpillar agency acting within the prescribed limits of the silken thread.

As a great many species of this family are arboreal feeders, a large field for investigation is presented to the student of forest insects. The prospective interest is still further intensified, as their life-history is involved in considerable obscurity, more especially in the egg stage, inasmuch as the moth often effectually conceals her eggs. The injuries are done just when growth is most active, and it is obvious, 
therefore, that this must have a very appreciable effect on the increment.

The imago stage is, as a rule, of short duration. Many examples may be found on the wing from March to November, but the majority of arboreal species are most abundant from May to July.

The general characters of the imago may be given as-head tufted with hairy scales, often partially hiding the eyes; the compound eyes usually large and spherical; antennæe invariably simple, and never so long as the anterior wings; thorax usually short; abdomen moderately stout in both sexes, more especially in female, and often terminated by a tuft of bristles in the male.

The larva is from $\frac{1}{2}$ to $\frac{3}{4}$ inch in length, usually with sixteen feet, head and shield horny, and the anal segment generally has a horny plate on the dorsal surface. The duration of life and habits vary according to the food of the species. Thus, for instance, those living on the foliage of decidnous trees must be fully developed prior to the fall of the leaf, or even before the leaves become too hard, while those feeding under bark can live comfortably throughout the winter months.

The pupa is either enclosed in a cocoon or web spun by the larva. The abdominal segment is often armed with minute spines. The pupal stage, like that of the larva, is also very variable.

\section{Tortrix viridana, Linn. (Green Tortrix Moth).}

There is perhaps no species of insect whose injuries are more conspicuous than those of the green Tortrix, or oak-leaf roller moth. Often as early as the end of May, or beginning of June, the larve are so abundant as to almost completely defoliate the trees. As this occurs just at the time when the tree is actively growing, it is obvious that in consequence of defoliation the loss of increment is enormous. By way of revenge, as it were, the tree subsequently produces a crop of late green shoots - Lammas shoots, as they are termed, - and though to some extent amendment may be made, yet it is just possible that there may be such a physical difference between the spring and autumn formed cells as to cause technical depreciation of the timber.

It is generally asserted that this species confines itself entirely to the oak. Such, however, is not always the case, as I have often bred it in comparatively small numbers from hazel and ash. It has been 
asserted by several German writers that when the oak does not yield sufficient food for the larvæ, they often leave the oak, and complete their full development on other species of trees-viz., lime, ash, beech, mountain-ash, maple, and other species of hardwoods. I have never found it on Turkey oak.

It is also worthy of note that while, generally distributed over the

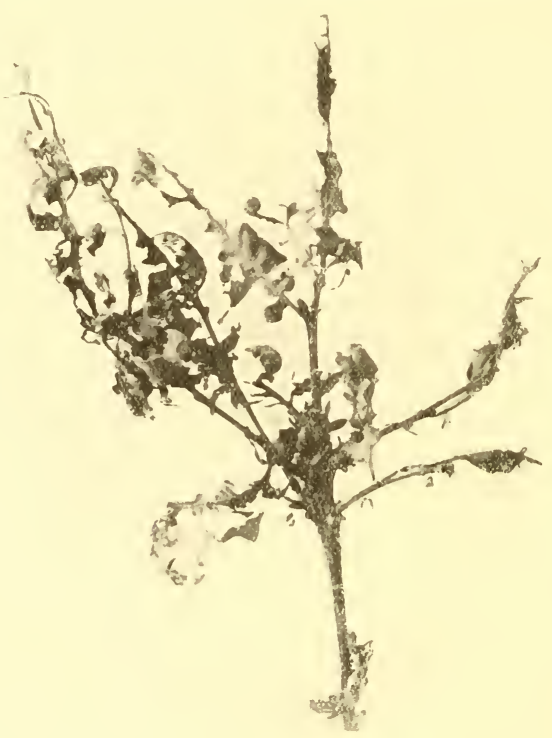

Fig. 220.-Foliage of oak destroyed by larve of the Green Tortrix Moth.

country, it is not a common species in Northumberland. One or two woods, however, on Tyneside are often badly attacked, and in Co. Durham it is frequently very common. Fig. 220 is a photograph of an injured oak-shoot.

The eggs are laid the season preceding the larval attack. They are doubtless deposited on the immediate vicinity of the buds, but opinions differ as to the precise spot, and I have not actually discovered them. 
The larvie are a slaty colour. The heal is a dark-bronze colour, a shade darker than the body, but not so dark as the shield of the head. On each segment may be found four minute black spots, which become more pronounced as they get olker. When full fed they measure about $\frac{1}{16}$ of an inch in length. They curl up the leaves for shelter, feed most voraciously, and when disturbed lower themselves by a slender thread.

The pupa is of a uniform dark-brown colour. Pupation takes place in the folds of the leaves, and the moths appear in swarms about the end of June.

The moth is easily identified, as it is the only pure green Tortrix we have. The fore wings are pure green, hind wings grey. Head, antennx, and bocly yellowish-white. Wing-span about 22 to $24 \mathrm{~mm}$.

This species, as has been asserted, is very injurious to the oak, but it should be noted that it is more injurious to the pednnculate than the sessile variety. As regards the discrimination of those two varieties, practieal men as well as botanists do not quite agree; but it may be said that distinct types are easily determined. The partiality of the insect for the pedunculate variety was pointed out to me by my friend Mr J. F. Annand in the Chopwell Woods, Co. Durham. In this ease the pedunculate variety was entirely defoliated, whereas the sessile variety was untouched. This peculiarity is noted by $\mathrm{Mr}$ Elwes, in his magnificent work on 'The Forest 'Trees of Great Britain and Ireland,' in the following remarks :-

"Another peculiarity of the sessile oak is referred to in a letter from the Hon. Gerald Lascelles to Mr Stafford Howard, in which he says: 'I doubt whether there is much difference between the timber of the sessile and perlunculate oaks, but I think that the sessile is straighter and cleaner in growth, and one thing is certain, that it is almost immune from the attacks of the eaterpillar (Tortrix viritana) which so often destroys every leaf on the pedunculate oak in early summer. Whether this does any real harm or not is a mootpoint, but I think it must be a check to growth, and that the trees would be better without it. I have seen a sessile oak standing out in brilliant foliage when every tree in the wood around was as bare of leaf as in winter.'

" $\mathrm{Mr}$ J. Smith, in the paper above referred to, pp. 29, 30, confirms Mr Lascelles' observations, and says that in 1888, which was the 
worst year for these caterpillars that he remembered, he passed throngh a wood composed of $Q$. sessilitior $\alpha$ in which, though it had been attacked by the caterpillars, they had left off, evidently either poisoned or starved. He also quotes a resident in the Forest of Dean, who, writing in 1881, says: 'It was strikingly evident last summer that the Q. robur pedunculata, or old English oak, was attacked by blight (? caterpillars) more severely than $Q$. r. sessitiflora ;' and Mr Baylis, who now has charge of Dean Forest, writes to me on the subject as follows: 'I can confirm the statement that the larva of the green oak moth defoliates $Q$. pectunculata very much more than Q. sessiliftora, and I think the reason is this: the latter is the first to come into leaf, and the leaf has time to get fairly tough before the caterpillar has reached its most destructive stage, which is about the time that $Q$. pedunrulatu is coming into leaf. I have frequently noticed this fact, that the oak with more decided pedunculate characters is almost invariably attacked rather than the other.'"

As regards remedies for this species, it is most difficult to know what to suggest, and it therefore affords a very good case in point as showing how difficult it is to cope with a real forest pest on a large scale.

\section{TORTRIX ribeana (Hub.)}

This species is a general feeder on many kinds of trees, and fig. 221 on hazel may be taken as a typical example of its injuries. The foliage is often entirely eaten by the larva of this species. At first they riddle the leaves very much indeed, and take alvantage during the day of the meaten portions of the under side of the leaf for shelter. Finally, they often denude the trees of the entire foliage, and pupate in the soil.

The larva and moth of this species are often very variable in colour and markings, and as there are several species doing similar damage, it would be well to verify the respective species by hatching out the moths from larvæ making injuries on hazel after the manner of the illustration given.

\section{Penthisa pruniana (Hub.)}

It often happens that isolated specimen thorns on lawns, and also patches of trimmed thorn hedges, show almost complete defoliation 
about the end of May and beginning of June. This is due to the voracious feeding larvæ of Penthina pmuniana. The larvæ commence feeding just as the foliage develops, so that the infested patch remains naked until the larvæ pass into the pupal stage-about the midlle of June.

The moth may be looked for about the beginning of July lodging amongst the foliage, and with a little patience may be easily boxed during the daytime.

The moth has fore wings blackish for two-thirds of their length, a

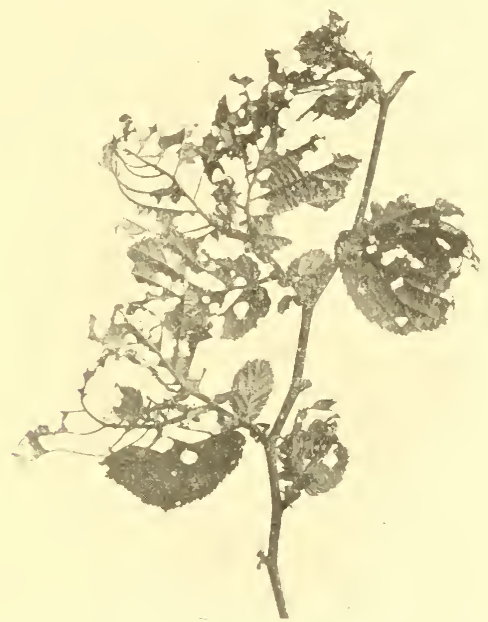

Fig. 221.-Foliage of hazel injured by larve of Tortrix ribeana.

space before middle of wing white, between basal patch and central fascia, sometimes erossing the wing, but always distinct on inner margin ; apical third white, clouded with grey, with about four small tooth-marks on costa; hind margin dark-grey. Expanse 18 to $20 \mathrm{~mm}$. All the species of this genus have similar markings, and are not easy to determine; but the short broad form of the wings will separate it from its allies. 
Hedia ocellaxa, Fib.

This species is very common in many parts of the south of England, and the larva is injurious to numbers of trees. Mr E. T. Connold sent me the specimen from which fig. 222 is taken, as showing typical injury to the variety of white-leaved poplar known as

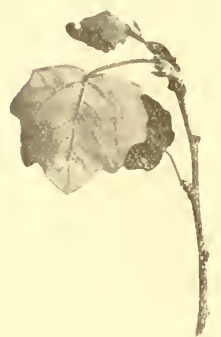

Fig. 222.--Learliug , himt of poplar injured by lerva of Hedya ocellana. Populus argentea. It will be noticed that when the larva injures the leading shoot, as seen in the illustration, consilerable clamage is done to young woods.

\section{Batodes angustioraxa, Haw.}

It often happens that many of the extreme twigs on the common yew are dead throughout the early part of summer, and having the appearance of being damaged by frost. This, however, is the result of the larva of this species. The larvæ hibernate during the winter in cocoons of hair and leaves of the yew-tree. They eat the woody portion of the twig, and thus canse it to wither (fig. 223). In early summer they may be beaten from the yews.

The larva is about half an inch in length, of a green or yellowish. green colour, with black markings on the sides, and having a dorsal line of a lightish-yellow colour.

The pupa is about 3 lines long, and of a pale-brown colour.

The moth has fore wings brown with reddish-brown markings, the basal blotch reaching disc of wing; central fascia broadest on inner margin, gradually narrowing to costa, and oblique by crossing the wing. On its outer margin on the costa is a pale-yellow spot. Then follows the ocellated blotch which extends to the anal angle; in the middle of it are some darker scales. Hind wings uniform dark-grey. Description from a $q$ specimen. Expanse 12 to $16 \mathrm{~mm}$.

\section{P.edisca occultana, Dongl.}

I have only found this insect once, and that was an attack on Pinus cembra in Northumberland, on plants which had been purchased preceding the attack from a public nursery in the Midlands. 
The plants in question were from 3 to 4 feet high, and the injuries consisted in the top shoots being arrested in their development. Every practical man knows that conifers in general make but a very short leading shoot the year following transplanting, and that in the early stages of growth the whorl of lateral branches stands erect and surrounding the leading shoot. In this particular case the injuries inflicted by the larve resulted in not only eating the young leaves,

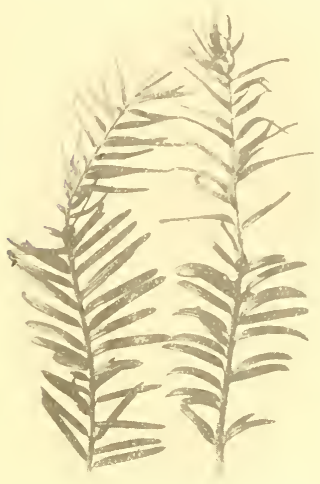

Fig. 223.-shoots of English yeu (Taxus baccata) injured by larve of Batodes angustiorana.

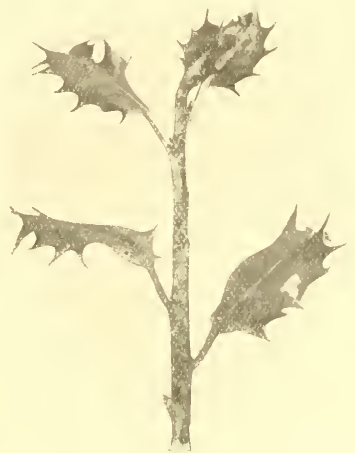

Fig. 224. - Shoot of hully injuied by Predisca ophthalmicana.

but in soldering the whole of this whorl together, so that in many cases the leading shoot and lateral branches were either very much weakened or otherwise killed outright.

\section{Penisca ophthalmicana, Hub. ${ }^{1}$}

If the holly hedges are examined about May or June, it will be found that the leaves of the terminal shoots are often drawn together by a small silken thread, thus forming a sort of rosette (fig. 224). It will be found that each rosette is tenanted by a single small caterpillar, and in many cases they are very abundant on hedges

${ }^{1}$ It is possible there are several closely allied species doing similar damage, so that implicit confidence should not be placed in the name of this species from the damage alone. 
which are switched or elipped annually. The rosette is not conspicuous until the larva is nearly full fed. It is of dirty-green colour, with black head and shield.

The pupa is about 4 lines long, of a rich brown colour, and slightly shining.

The imago appears about the end of June or begimning of July. The fore wings are of a lark smoky-grey colour. The hind wings are of a light-green colour. Eyes intense brown, and with a relvety appearance. Antennæe dull brown. Abdomen shining grey colour. Length about 6 to 7 lines.

This species cannot be regarded as very injurious, yet it does a considerable amount of damage to the surface of the hedge, inasmuch as, being often numerically strong, it appreciably affects the growth of the shoots. As the surface is the all-important point in an ornamental hedge, it would often be well to check this pest by simply entting or nipping off the tender shoots while they contain the larve, and either burning or throwing them into a bucket containing paraffin. This operation, though rather tedions, would have the effect of reducing the number of perfect insects, and therefore climinishing the attack for the following year.

Stigaonota regiana (Zeller).

If the loose projecting bark on very old sycamore-trees be lifted up during the winter months, small cocoons, sometimes quite a number together, may be recognised. In each cocoon there is a small larva, of a dirty - white colour, and about 4 or 5 lines long.

The pupa is about $3 \frac{1}{2}$ lines long, and of a light-amber colour.

The imago, which appears in June or July, is about 6 or 7 lines in expanse of wings, and when unfolded is certainly very pretty. The prevailing colour of the fore wings is chocolate, whilst on each wing there is a semicirenlar pateh of yellow, which, when the wings are closed, forms a beautiful circle in the midtlle of the folded wings. The effect of this marking is somewhat lost when the wings are spread out.

This species cannot on any account be considered injurious. It is quite possible, however, that the action of the larve canses the old bark to fall off sooner than it otherwise would do. 


\section{Genus limtinia.}

The genus Retinia is fomml amongst fir-trees, and in certain localities some species are quite dreatel enemies. In fact, it is possible that a consulting entomologist may receive more specimens of Retinia moliana than almost any other insect for identifieation. This species, being fairly well clistributed, may be sturlied as a type form of the genus. It is very easily hateher out artificially, more especially as it is generally full fel before it asserts itself.

Lepilopterists reeognise seven or eight British species, but the following is a synopsis of the important species:-

(a) In buds of Scots pine, with brownish-grey fore wings

R. turionana.

(b) In leating shoots of seots pine, with yellowish-rerl fore wings and silvery cross lines . . . . R. lmotiana.

(c) Forming a gall of resin as a larval chamber. Fore wings clark brown-green, with grey dusty covering . R. resinulla.

(1) Making a "rumning" side destruetion of leading shoot of larch or Scots pine. Fore wings brown, with dark-butf tip

R. cluplana.

Retinia turionana, Ibb. (Pine-bud Tortrix Moth).

This species has only once come under my observation as a pestviz, in Delamere Forest, Cheshire. The infested pines were from ten to twelve years of age, and the injuries were in the leading loud, as shown in fig. 225 .

The moths hatched out early in June. They were from 16 to Is $\mathrm{mm}$. in expanse of wings. The fore wings were of brownish-grey colour, with transverse lines. The hind wings were whitish. Heal and thorax ferruginous, and abdomen grey.

The larve are a yellowish-red colour, and rather less than half an inch in length.

Retrina buoliana, Schiff (Pine-shoot Tortrix Moth).

The habits of the larva are very much like those of $R$. turionuna, except that in lustiand the lealing hut or whorl of buds are not arrested in their early development, anct therefore all begin to 
grow at the same time; but the centre one soon droops and finally dies, in consequence of the centre of the shoot being entirely destroyed

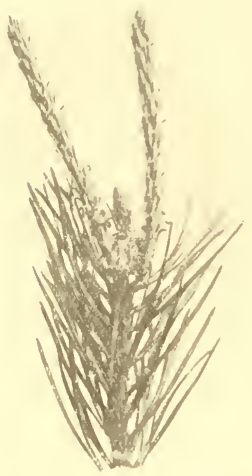

Fig. "25._- Irudiug, "bud of Scots pine itiured by lare of Retinia turionana.

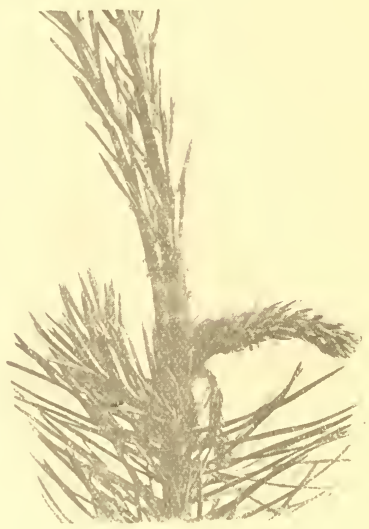

Figr. 226.- "Leading shout " of young Scots pine injured by larva of Retinia buoliana.

by the larvi. Fig. 226 represents a photograph taken from a twoyear seots pine plant in the nursery-line. The affected shoot, which contains a single larva, is lying to the right, and the normal shoots are very
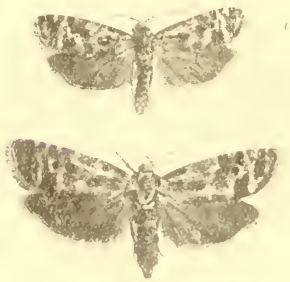

Fig. 227.-Retinia buoliana. $a$, inale; $b$, female. vigorous, but they are not shown in full length. In addition to injuries being done in nursery-lines, we often find young Scots pines and Austrian pines from six to ten years of age very much destroyed by this species. As a rule the injured shoots die, but a few exceptional cases are found on young trees with distorted or deformed leading shoots, accruing from the damage done by this insect.

The moth (fig. 227 ) is from 18 to $22 \mathrm{~mm}$. wing span. The fore wings are of yellowish-red colour; the red is brightened by silvery 
cross-lines, which are very variable in pattern. The lind wings are of a uniform dark-grey, being fringed with light pale-grey cilize. Head and thorax a pale-yellow colour; antenne brownish; eyes black; abdomen dark-grey.

The larva is from 6 to 7 lines long, dark-brown in colour. Hear and thorax black; legs small and black, very sluggish.

The pupa is about 5 lines long. The head, thorax, and wing-eases are a dark-brown colour, and the abdomen a light-chestuut colour.

Is regards the life-history, the moths appear about the end of July, and deposit their eggs at the tip end of the shoots. The larve hatch out late in summer, and gnaw the side of a bud, so as to cause a flow of resin, which covers the caterpillar over for the winter, and here they hibernate. In spring they wake up, attack the leading bul, giving rise to the injuries already referred to, and feed till about the latter end of June or beginning of July. They pupate within the infested shoots, and the pupal stage lasts from ten to fourteen days.

With regard to remedies, very little can be done except pick the injured shoots, together with the incased larva or pupa, about the middle of June, and then destroy the same. This would have the effect of diminishing the attack for the following year. The moths may be found lodging in the young shoots, and if collected shortly after hatching out, egg-laying might be checked.

\section{Retrixa resinella, L.}

This insect is sail to be confined to certain localities in the north of Scotland, and the only time I have ever seen it in numbers was in

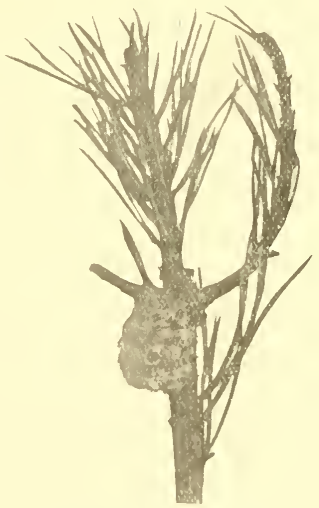

Fig. 228. - firll uf risill an sonts pine cunsed by Retinn resinella. Belgium in 1905. There is no mistaking it when seen, as it is simply a large gall of solid resin on the shoots of Scots pine at a spot representing what practical men would term the commencement of the growth the year before last (fig. 228). This spot at once suggests an 
important factor in the life-history of the insect-viz., that the gall takes two years to reach maturity. The generation is therefore a biennial one. The eggs are laid in May, just under the whorl of buds, which are bursting, or about to burst, into the growing shoots. The caterpillar bores into the pith, and this being the most active period in the life of the plant, causes the growth of a hollow gall resinous mass, about the size of a pea, and in this abode the larva passes the winter.

In the following spring the larva

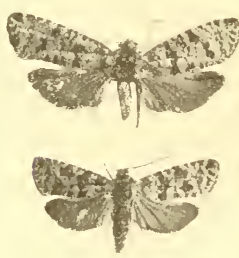

Fig. 229.-Retinia resinella. continues feeding, but meanwhile the gall rapidly increases in size to that of an average gooseberry. A section of a gall shows that it is divided into two ehambers by a strong vertical partition: in one the larva lives ancl pupates, and the other contains its excrement. The pupal period is very short, and the moth flies about May - the generation thus extending over two years.

It generally attacks trees from six to ten years of age, but, as a rule, the injury to the forest, or even to individual trees, is very trifling.

The moth (fig. 229) has a wing expanse of 16 to $18 \mathrm{~mm}$. Head, antennæ, thorax, and abdomen dark brown-green, or lightish grey dusty covering. Fore wings dark black-brown, with shining grey transverse lines; hind wings grey-brown; fringes pale.

The larva is about $11 \mathrm{~mm}$. long, and of an orange-brown colour.

\section{Fayily TINEÆ.}

\section{Genus Hrponomedta.}

In many parts of the country, more espeeially in lanes, we often find bushes defoliated and covered with a sort of net, in the interior of which are a large number of small larve of the genus ealled Hyponomeuta. They are popularly known as the small "ermine moths," but they are comparatively large for "mieros." 


\section{HYPoNomeUtA EVONYMLLUS (L.)}

The genus contains a number of species. The one generally foumil in the north of England is $H$. evonymellus. It is found on bird-cherry and spindle-tree, and the conspicuous feature of the damage is the defoliation of the bushes, together with the ganzelike spum webs, which protect the gregarious larve.

The moth (fig. 230) measures ahout $\frac{3}{4}$ inch from the tip of the wings. The upper surface of the wings is a lustrous white colour, and shows five rows of black

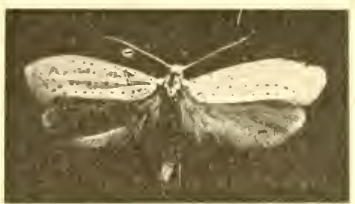

Fig. 230,-Hyponomeuta evonymellus. spots (over forty in all). The hind wings are dark-grey. The head and antemnæ are white, eyes black, and ablomen grey.

The caterpillar is about $\frac{3}{4}$ inch in length, and of a yellowish-grey colour. The head is black, and there are black spots on the segments.

After the caterpillars are full ferl they eongregate within the web, and pupate in a mass, for the mass of pupal remains may be found even in the following year, reminding one of the empty cases of the wasp or honey-bee. (Fig. 231.)

As regards the life-history of this species, I have only made observations in Northumberland. The moths appear about the first week in July. They deposit their eggs in clusters on the twigs, just

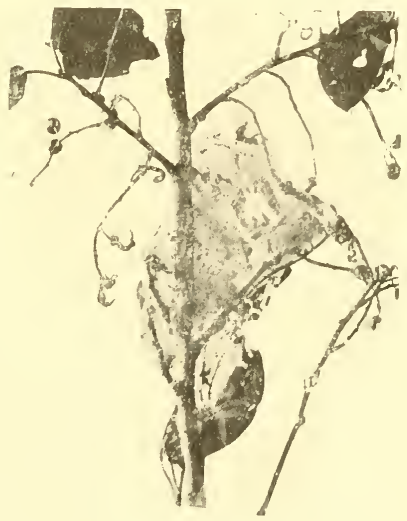

Fig. 231. - Webb and empty pupal ares of Hyponomeuta evouymellus. immediately below a bud, and they are most beantifully concealed by a delicate covering, the colour of which harmonises with the tiny stem so well that it is only after a most careful search they can be 
found at all. So far I have not been able to ascertain the approximate date at which the larvæ emerge from the eggs and betake themselves to the opening buds, but they do not assert themselves on the foliage until well on the middle of May. By this time the leaves are well developed, and thus afford plenty of food for the larvæ, which live gregariously, and spin a veil-like web over the colony. They are full fed by the middle of June, and the pupal stage completes their life-history.

As this species is in many eases very injurious, and as its host-plant, the bird-cherry or hackberry, has some claims as an ornamental tree, on account of its beautiful white flowers, it would be well in very bad cases to arlopt some remedial measures. It is obvious that we could only apply remedial measures in its larval and pupal stages.

As regards checking the larve, they may be (1) shaken down from the trees during the day on to a sheet, or (2) hand-picked by cutting off the web containing the larva, or (3) they may be sprayed with a paraffin emulsion. With regard to the last method, the following note is taken from the Board of Agriculture leaflet, No. 65 :-

"'The Board know of one ease in Perthshire where, in an extremely severe infestation, the proprietor, dissatisfied with the result of a paraffin spray, made up a strong solution of an arsenical sheep-dip, and by this means killed thousands of caterpillars. The caterpillars that had not been killed, or which on disturbance had let themselves down from the web by their threads, colleeted at the foot of the trees, and were easily destroyed. Great care, however, had to be exercised, as any leares touched by the material turned black and dropped off."

With regard to checking the pest in the pupal stage, this can best be lone by simply cutting off the webs when they are in the cocoon stage; but as this stage is a comparatively short one (about ten clays or a fortnight), no time would have to be lost in order to make it effectual.

\section{Prays curtisellus, Don. (Ash-bud Moth).}

This speeies seems to entirely confine itself to one food-plant-viz., the common ash (Fruximus excelsion), and is certainly very injurious indeed to plants in the nursery-lines from three to six years of age. It attacks the terminal bud, and thus causes the young ash to fork,a feature we do not by any means wish to see in young ash plants. 
Kaltenbach says ${ }^{1}$ that he "never found the larve in free-stancling or healthy ash, but more abundantly on young over-shadowed or thickstanding small trees." The result of the larval danage first asserts itself in the terminal bud, which does not develop along with the lateral ones (fig. 232), and as time goes on the leading bud dies, and we have a forked young tree, as in fig. 233. As soon as the leaves begin to grow the larva leaves the bud and bores itself into the leafstalk, and in consequence the leaf-stalk, together with the leaves, wither and die off. One larva goes from stalk to stalk, and thus kills several of them. $\Lambda$ fter the larva is full fed it spins itself into a

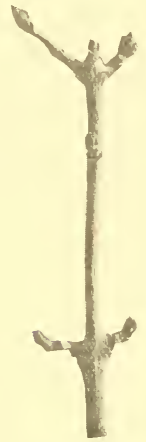

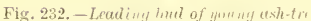
injured by lerve of Prays curtisellus.

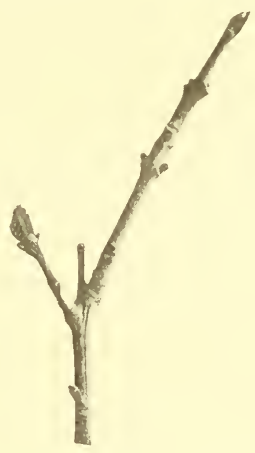

Fig. 233.- Yunue wsh-tree "forted" by lerve of Prays curtisellus.

silken cocoon, pupates, and appears in the imago form about July 1. Specimens sent from Chatsworth, Derhyshire, and those in Northumberland, hatehed out simultaneously.

The moth is a pretty whitish-grey insect. Head white and hairy; eyes black; thorax white; abdomen brown-grey. Fore wings when closed showing a white line in centre, and brown at sides, a kind of magpie colour. Fore wings when spread, whitish with brownish patehes. Hind wings brown-grey with light fringe. Wing span 14 to $17 \mathrm{~mm}$.

Larva with black head, and neck shield ; body of a dirty ashy-grey colour, streaked with reddish-green, tapering at both ends, and the

1 Die Pflanzenfeinde aus der Klasse der Insekten. 
belly dark-green. Length $12 \mathrm{~mm}$. Viewed with a lens, the colour very much resembles a healthy young ash stem.

Pupa dark - brown in fore part, and latter part of a very light greyish-yellow, enelosed in silken threads.

As regards the life-history of this species, I find there is a great difference between the aceount given by Judeich and Nitsche, as seen from fig. 234, and what I have found in Northumberland, inasmuch as the species is double-brooled in Germany, and only a single gener-

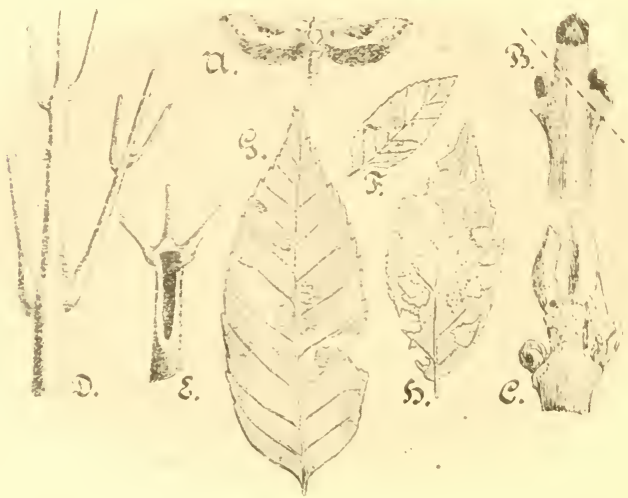

Fig. 234.-Prays curtisellus.

$a$, moth; $b$, bud injured in antumn ly young larva; $c$, the young larva has left the bud in spring and spun a protection for itself; $d$ and $e$, the young shoots destroyed by spring larva; $f, y$, and $h$, leaves eaten by summer larvit-i.e., larvæe of second brood. Copied from Judeich and Nitsche.

ation in a year in the north of England. It is, however, possible that the species may be double-brooded in the south of England, and it will be well, therefore, for students in forest entomology to verify this. Hence the illustration from Nitsehe may be very helpful. In the aceompanying illustration it will be seen that the spring brood lestroys the leading shoots and the leaf-stalks, as seen in $d$ and $e$. The larvæ of the second brood eat the leaves, as seen in $f, g$, and $h$, and then deposit eggs in the leading buds.

With regard to remedies, it is seareely possible to do anything exeept collect the larvæ when they are feeding in the leaf-stalks. 
This could easily be done in the nursery-lines, and also in a young plantation, though it would obviously be more practical in the nursery. Pruning by checking the worst of the double shoots should be done during the summer following an attack, as an ash is a tree which is very much depreciated in value if allowed to hecome forked.

In glens or valleys where ash has been planted in a very congenial position, much good may be done by eutting down the young damaged trees to the gromed and allowing them to spring up again, which in sheltered spots they do very rapilly.

\section{Geme; Depilessaria.}

The genus Depressaria is the largest of the sub-family Gelechiidæ, numbering just over forty speeies. They are remarkably characteristic from the broad flat appearance of the moths in repose. Wings two and a half times as long as broad, tip rounded, hind margin nearly parallel to anal angle; hind wings nearly as long as fore wings, with the hind margir indented near anal angle ; palpi long, ascending, curved, and often furnished in midlle with dense tufts of scales.

\section{Depressaria conterminella,} Zeller.

Fore wing reddish-ochreous : base of wing pale yellow, rather sharply defined. A pale ochreous spot on dise, and near it an oblique, crescent-shaped, black streak. A series of short black

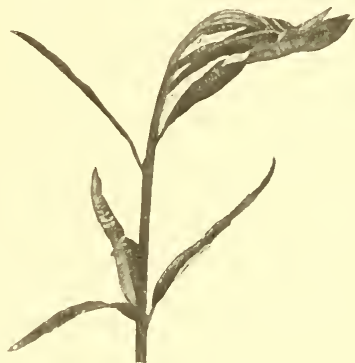

Fig. 235.-Leares of osier (Salix viminalis) drown together by larva of Depressaria eouterninella. marks along the costa; hind margin before cilia narrowly bordered with a black line. Ilearl and often thorax pale ochreons; hind wings uniform dark-grey. Length 18 to $20 \mathrm{~mm}$.

If osier-beds are examined during the latter end of May, it will be found that many of the lealing shoots present the appearance shown in fig. 235. If the whorl of leaves be unfolded, it will be found that a small wriggling larva has been protecting itself within 
the folded leaves and injuring the leading bud and shoot. This is the linrva of Depressaria conterminella.

It should be noted that several species of Lepidopterous larvæ do similar damage, so that the injury represented in fig. 235 should not be taken as solely due to the species given. The species in question, however, was most injurions in Cheshire to osier rods (Sulix viminalis). I am obliged to Mr J.

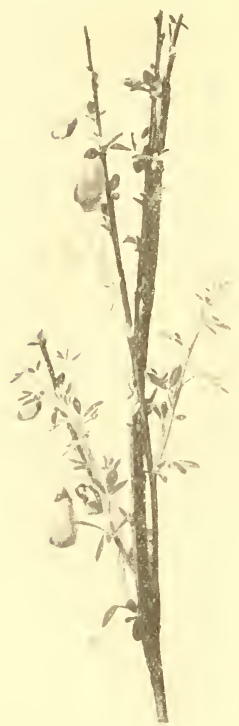

Fig. 236._- Shouts of troom drax"y togrther by laree of Depressaria assimilella. Collins, Oxford, for the identification of this species.

\section{Depressaria assimilelita, Tr.}

If an inspection of broom be made from Narch to the beginning of May, it will be found that the twigs are often very much drawn together, as in fig. 236. If the twigs are separated at the points where they overlap, it will be found that a small brown larva lives within the folds, and has injured them very considerably. This is the larva of Depressaria assimitella.

The moth appears in June and July. The fore wings are of a pale ochreous colour, and about 9 lines in expanse. The antennæ are dark-brown.

It cannot be said that this species is of any great economic importance, but it often happens that broom is grown for ornament or covert purposes, and in such cases the insect may be considered a pest. In order to effect remedial measures it would be well to top the broom while the ereature is in the larval stage, and burn the prunings. When broom is cultivated it is well to prune off the tops in any case, either in early antumn liefore the frosts appear, and thus prevent the winter winds from blowing the bushes about, or after the spring frosts and prior to the vigorons growth of early summer. Thus the adoption of practical work is a remedial measure against the pest. 


\section{Genus ArgrresthiA.}

Stainton ${ }^{1}$ gives the following characters for this genus-viz., "Imago, heal rough; the face smootlı; no maxillary pralpi; labial palpi rather short, the terminal joint blumt or slightly pointed; fore wings elongate; hind wings lanceolate, with long fringes.

"The insects of the genns digyresthia are distinguished by their position in repose, as the hind pair of legs are laid alongside the body, which is elevated at a considerable angle. the insect's hear being almost in contact with the sul)stance on which it rests."

\section{Argyesthia levigatella}

(H. Sch.)

In all probahility this is a forest insect which has escaped attention for a consiclerable time. The first record of it in this comntry is given by Dr Somerville and Mr John Bemnett so recently as July $190 \pi .^{2}$ The insect was not difficult to determine, from its damage to the larch, as a very good figure is given by Niisslin; and though not hitherto recorded

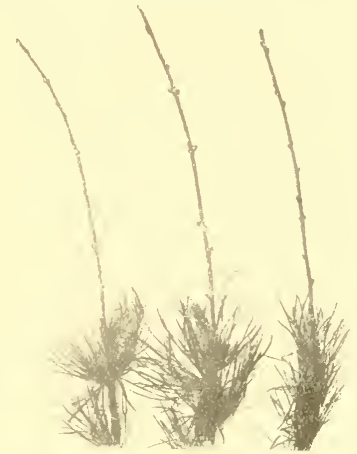

Fig. 237.-Tops af young lurch-tiees injured by lurece of Argyresthia lavigatella. in this country, it is just possible that it may have been overlooked, owing to the close resemblance of the damage accruing from the pineweevil (Hylobius abietis). At all events, I now find the creature fairly common in Northumberland, ant that I mistook the injuries as suggested. The larval action is that the leading shoot is killed, as shown in fig. 237 .

Dr I. S. MacI)ongall gives the following description of the insect: ${ }^{3}$

"Woth.-The moth is very small, measuring only 4 to 5 millimetres (less than one-fifth of an inch) in length and 10 to 12 millimetres in spread of wings. The fore wings are silver-grey and silky, with a

1 Manual of Butterflies and Moths.

2 Quarterly Journal of Forestry, vol. i., No. 3.

3 Journal of the Foard of Agriculture, rol. xiv., No. 7 . 
gloss like lead; the fore edges are somewhat darker; the fringes of these fore wings are grey or brownish-grey.

"The hind wings are dark-grey, and not so glossy. The face is white; the base of the antennæ is white, and the rest of the antennæ dark and light-ringed. There is a tuft of hairs on the head; the colour of the hairs is given differently by different Continental authorities, - in my own specimens the colour is yellow. The abdomen of the moth is dark-grey.

"Cuterpillar.-The larva is pale yellow when young, but later is pale grey with a dash of red, and is dark striped towards the hind end of the back. The head and the three front pairs of legs are black. The length, 6 to 7 millimetres.

"Pupa.-The pupa is dark-brown, with a black head; its hind end is distinetly pointed."

As regards the life-history of this insect, the moth appears in the latter end of May or beginning of June. The eggs are deposited in the lower part of the shoot of the current year. The egg soon hatches, and the tiny caterpillar bores below the epidermis. Meanwhile the shoot develops, but when winter overtakes the larva it hibernates in the hollow marle by itself. In early spring it awakes, and commences eating where it left off, with the result that the shoot is very much weakened, and thus the injury not only arrests development but finally kills the twig, as shown in fig. 237 , which was photographed in the latter end of June 1907.

The caterpillar is full fed about the end of April, so that the pupal stage is comparatively short.

As regards remerities for this pest, it is perhaps well to remember that the creature has only been recently recognised in this country, and therefore the full extent of the damage is not thoroughly understood. If the damage be done to twigs on trees from ten to twenty years of age, little could be effected; but if (as I have from preliminary observation discovered) on young trees the second year after planting, something might be done. One rarely sees larch plants in the nurserylines affected. The inference, therefore, is that weakly shoots are selected, as dead twigs are obviously a necessity for the final transformation of the creature. Hence the greater vigour accruing from careful planting would to some extent act as a check. When, however, the young shoots are attacked, the dead or dying twigs in the recently planted wood should be recognised as early as possible in 
April, and then, toyether with the lavea or jupe in the shoot, eut off and burned. This method is apparently tedious, and when the leading shoot is removed considerable disfigurement ensues, but as a tree the larch has wonderful recuperative powers of taking a lead from a side branch, so that the labour would be well repaid.

\section{Gracillarla syringella, Fab.}

This species is often very injurious to the foliage of lilac (syringu vulyaris). The larva live gregariously within the epidermal skins of the leares, and cause very conspicuous blotches, as seen in fig. 238 .

Mr Collinge has worked out the lifehistory of this species, and the following account is given by him $:^{1}$ -

"The observations and experiments were made on nine trees about five feet in height and growing five or six feet apart.

"The moths of the first brood were noted on May 24, rather later than in 1904. The eggs were noticed on both the upper and under surfaces of the leaves a few days later, 27 th and 28th, and the caterpillars hatched out on June 4. They at once made their way into the leaves, and commenced to feed upon the soft parenchymatous tissue between the upper anl lower epidermis. The largest number found in any

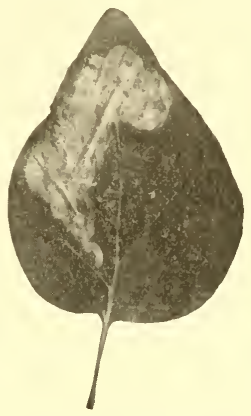

Fig. 238 - Leaf of liler (Syringa vulgaris) injured by the min. ing lerve of Graeillaria syringella. one leaf was thirteen.

"Sometimes the whole of one side of the leaf was tunnelled; in other cases the basal half was blistered before the apical; whilst in others the blisters were irregular and seattered over the leaf.

"The young larve are almost transparent and glossy; a little later they have a faint yellowish tinge, with a narrow median green line, caused by the green chlorophyll in the intestine. After feeding in the leaf for about three weeks, they creep ont on to the surface and commence to feed on the epidermis, the leaves rolling up laterally or from the apex. About ten days later they become full fed, and are slightly over a quarter of an inch in length, with a prominent brown 1 Report on the Injurious Insects and other Animals (Midland Counties), 1906. 
head. Here they remain for about ten days, then leaving the rolled leaves ant pupating in the axils of the leaves or branches, or even leaving the trees and crawling to fences, \&e. After fourteen or sixteen days the moths of the second brood make their appearance, and the life-cycle is again repeated, the pupal condition continuing throngh the winter.

"Preventire and Remedial Measures.-Picking off the leaves had but very little effect. Spraying with paraffin emulsion in May proved beneficial. There were very few blistered leaves on the two sprayed trees, whilst the remaining seven showed little else but blistered ones.

"Spraying with soda and potash in January killed or injured many of the pupæ, but as these trees were near a fence, many of the larvæ had left the trees, and were pupating in erevices and cracks in the fence."

\section{Genus Coleophora.}

Hitherto this genus has not received such special attention from economic entomologists as to assure us that the habits given by naturalists are over-reliable. At all events, it is a genus that would well repay special attention.

The perfect insects appear from the end of May to the beginning of Augnst. The larve hatch out in autumn, and in the early stage many species feed as leaf-miners, and after mining the leaves the individual larva forms a small case, within which it passes the winter in the larval stage. In the spring they recommence feeding by sucking the juices of the leaves, and each larva makes a larger case for itself in which it lives and pupates. The larva never moves out of its ease, and never exposes its body beyond the anterior (or true) legs, which are used in walking.

In the perfect insect the head is smooth, and the antenne are always erected in repose. The antennæ are slender, the basal portion smaller and covered with scales. The anterior wings are smooth, narrow, elongated, and pointed with long ciliæ. The posterior wings are very narrow, and fringed with long ciliæ.

\section{Coleophora laricella, Hub.}

The larvæ of this species are very injurious to the foliage of larch in spring,-so much so, that on account of the invisibility of the 
insect, and the conspicnousness of the damage, the injury is often attributed to frost. The general appearance, however, very much resembles the action of frost or singeing by fire, inasmuch as the leaves are half withered up, and practical foresters have therefore often associated this appearance with the commencement of "lareh disease." It is, however, possible that this insect may play a very important, thongh indirect, part in connection with the lareh disease

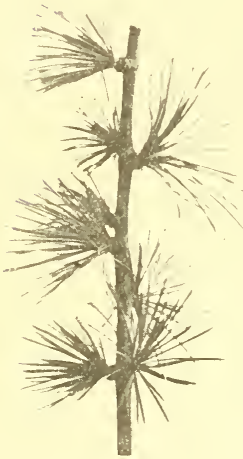

Fig. 239.--Normat foliage of lerch.

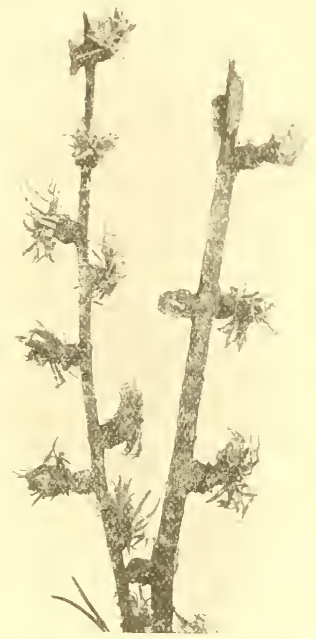

Fig. 240.-Folierge of lareh injured by luice of Coleophora laricella.

fungus (Peaiza Willkommii). The fungus is most active in spring months, and as the injuries eansed by C. laricella on the foliage, together with the obvions effect of checking the rate of growth, have a tendeney to reduce the plant lelow par, it follows that the fungus is materially assisted in its action, and can therefore do greater damage. Fig. 239 represents the normal foliage, and fig. 240 the injured shoots.

The small caterpillars which do this damage hateh out in July, and feed on the leaves of young trees from six to thirty years of age, but as a rule they are most destructive to trees of the latter age. $\Lambda$ t first 
the very tiny larve bore into the leaves or suck the juices. The damage is lone from apex to base, for about half the length of the leaf. The injured portion shrivels up, is light in colour, and therefore very conspicuous. Meanwhile the larve, when resting, bury themselves in the midcle of the cluster of leaves, but they soon change their mode of protection, as each individual larva forms a case for itself out of the injured leaves. At first the case is very lightly coloured, but it hecomes darker with age. The interior is lined with silk. When the caterpillar is feeding, the case stands erect, with the heal of the larva downwards. The larve go on feeding in this way throughout the season, so long as nourishment remains in the leaves, and then hibernate for the winter. Many of them go into cracks and crevices

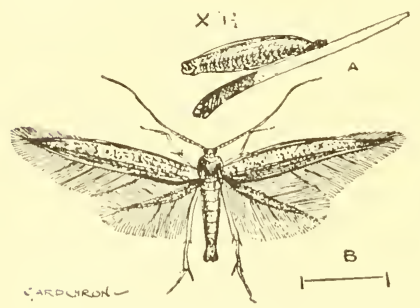

Fig. 24l.-Coleophora laricella. (From F. V. Theobald's 'Animal Pests of Forest Trees.') A, pupal case; B, moth. of the bark, or bury themselves amongst the lichens. A considerable portion of them lay themselves quite flat on the twigs, and butt against the natural ridges of the young twigs. The light-coloured cases harmonise well with the light-coloured bark. In this way they pass the winter, being perfectly immune to the effects of frost. As soon as the young larch needles burst forth in spring the larve wake up, carry their cases back to the needles, and commence feeling in real earnest, thus giving rise to the eharacteristic withering already referred to. The larvæ now grow very rapidly, and the original cases beeome too small. The tiny caterpillar then makes a fresh case.

The larve are a dark red-brown colour, and still darker head. Only the anterior pair of legs are at all moderately developed, and, with the exception of one anal pair of pro-legs, with which they fix themselves in the ease, the pro-legs are also but poorly developed. There is a black plate on the anal segment. The larva is about $5 \mathrm{~mm}$. long.

The pupa is small and brownish-black.

When the wings of the perfect insect are expanded they measure about 4 or 5 lines across. The head and anterior wings are grey, the posterior wings of a paler grey, and the abdomen of a blackish grey. (Fig. 2+1.) 


\section{Coleopiora fuscedinelda, Zell.}

This species is, as a rule, very common on alder, and is termerl the aliler-bud moth, in consequence of the larva feeding on the buds and destroying them prior to forming its ease, and then on the leaves.

\section{Coleophora sp.}

Some years ago I received from my friend, Mr Elder Cholmondeley, Cheshire, a quantity of birch twigs which had been utterly destroyed hy a species of coleophora. So far this species las not been ilefinitely identifiel. Fig. 242 is a representation of the damage, and the

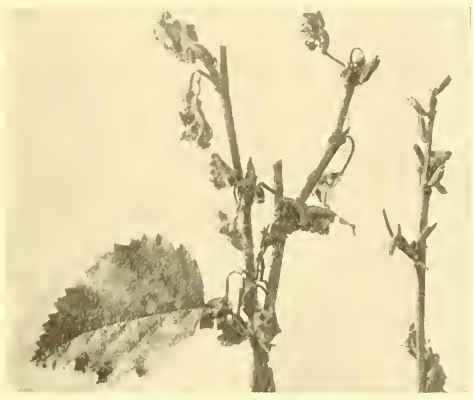

Fig. 242.-Coleophora sp. on bireh.

normal leaf at the bottom was adled for the purpose of identification. The larvie were very injurious, as the twigs were stripped of their entire foliage. After the larve had made their final cases, they destroyed the foliage by horing a hole into the leaf from the upper side and entirely eating the contents of the leaf, which lie within the two epidermal skins. Taking the hole as a centre, the larva eats all round the same, thus making a eireular pateh, but, as a rule, always keeping itself attached to the ease by means of its anal hooks, and on the slightest approach of danger drawing itself within its case. Sometimes it goes on feeling within the epiclermal skins away from its camp, hut, as a rule, it moves to a fresh spot, after eating the eireular pateh refured to, and then going on a fresh spot, until finally the whole of the green portion of the leaf is destroyed.

The imagines are considerably larger than the species on lareh. 


\section{Lithocolletis.}

This genus is very common on the leaves of several forest trees. The larva mines the leaves of trees and shrubs, sometimes simply creating a flat bloteh on the under side of the leaf, at other times making the blotch in such a manner that a pucker is produced either on the upper or under side of the leaf. The larva never quits the mine. Some species make no cocoons; others, cocoons of various kinds.

The perfect insects are very small in size. They have a rough head

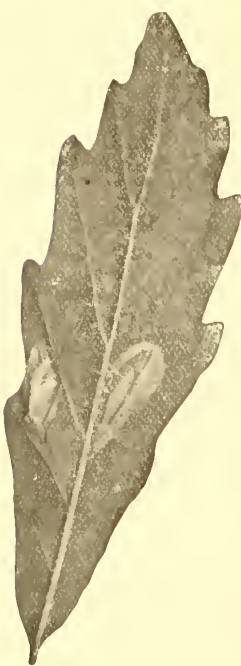

Fig. 243.-Typiral bloteh of Lithocolletis on Quercus psendo Turnerii - u specirs of everifreen outs. and smooth face. The antennx are rather long, but not so long as the anterior wings.

The larvæ have only fourteen legs and one pair of ventral pro-legs.

The pupa is either naked or enclosed in a cocoon, and in the former the wing-cases are quite free.

As regards artificial hatching, many species can be picked up in autumn, as the blotehes appear quite conspicuous on the fallen leaves. They may be colleeted and placed on the ground in a canvas bag for the winter months. In early spring they may be removed from the bags and placed in glass cases. The imagines appear in May.

\section{Lithocolletis messaniella, Zeller.}

The larve of this species are very injurious to the foliage of the evergreen oak (Quercus ilex). In the evergreen oak we find several distinct varieties of the tree, and it may be said, though the injuries of this species of moth are practically identical so far as the physiology of the damage is concerned, yet the general appearance of the damage itself is somewhat different. In the case of the holm oak proper, the leathery leaves are blotched "brown" and withered-looking. In the case of the other variety, the injuries are not so conspicuous on the upper surface, and on the under surface we get a delicate white patch, and prior to the eruption of the skin it looks as if a very fine piece of tissue-paper had been pasted on the under sicle of the leaf (fig. 243). 
The first time I found this species in abundance was on a holm oak (fig. 244) close to Checker House Station, when walking with the Mauchester Microscopical Society to Sherwood Forest, and after finding the respeetive stages of the iuseet 1 made the following note :-

" May 9, 1896.-Leaves considerably damaged; effect of damage shown on both sides of leaves, but most conspicuous on under side. Larva mines between under epidermis and thick fleshy part of leaf. The parenehymatous part of leaf not eaten, therefore upper surface appears brown and leathery, but not showing 'thin' as under sicle.

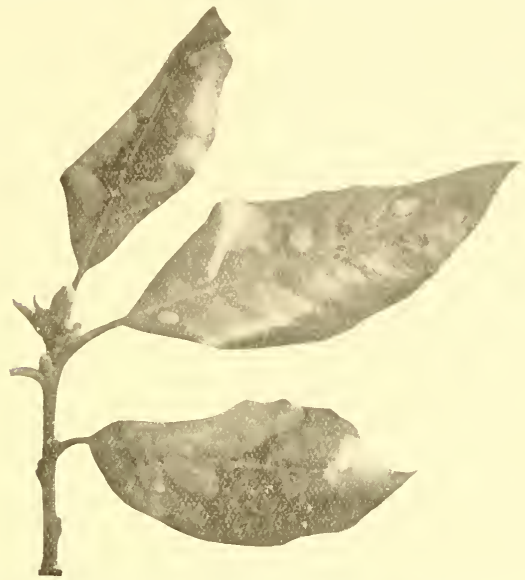

Fig. 244.-Injuries to foliuge of holm ork (Quereus ilex) by larre of Lithocolletis messaniella.

"Lated.-Full fed are rare to find at present,-now principally pupæ. Length $4 \mathrm{~mm}$. When young flattish, and round when fullgrown. Colour of first four segments white, with darkish head; remainder of segments saffron colour. The six thoracic legs short, and first pair longest. Pseudo-legs not very conspicuous.

"Pupa.-5 mm. long; dark-brown colour. Passes pupal stage in leaf. Very active, wriggling about at posterior end. Antennæ nearly full length of ehrysalis. The projection beyond attahment, and active anal end shows irregular 'forked' ent. Side view shows pupa has pointed horn and bent awl-shaped. 
"Imago.-Length about $4 \mathrm{~mm}$. to $4.5 \mathrm{~mm}$. Fore wings saffron colour, folded ridgewise. Under wings fringed." 1

This is rather a difficult species to check. However, one suggestion may be made. ' As regards the holm oak, every garlener dislikes it as a lawn tree, in consequence of its shedding its old leaves, about the end of April or beginning of May, just when every place is tidy and spring work very abundant: hence the hatred to the tree. It would be well, therefore, to burn all the leaves as soon as they fall off, or, if desired, the trees may be shaken to bring them off. Provided the fall is in April, many moths would be destroyed, but it is obvious that if not done till May the moths would have hatehed out, and the burning operations consequently useless.

There are several other species of Lithocolletis found on forest trees, but none of them can be considered as injurious, though they are, of course, interesting from a collector's point of view.

L. salicicolella causes blotches on the under side of the leaves of sallow bushes. The injured leaves may be looked for in September and October. The insect may also be found in May, so that there are two broods in a year.

L. coryzi is found on the leaves of hazel bushes. The blotch starts from the midrib, and the tip portion of the blotch is a sort of pucker, so that it is seen from the upper side. Imagines in May and August.

L. carpinicolella is found on the leaves of hombeam.

L. farginella is found on beech.

\section{Cemiostoma laburnella, Heyd.}

This species is responsible for the blotches cansed on the upper surface of the leaves of the laburnum (fig. 245). This species is very common in many parts of England, so much so that it is searcely jossible to examine a laburumm-tree without finding its leaves heavily blotched with a dirty green-whitish appearance. This is causerl by the larve mining the leaves. It is not so abunlant in Scotland, more especially as we proceed northwards, as it is in Lngland. Again, it may be mentioned that it is far more common on the English variety of laburnum (Cytisus Laburnum) as compared with the scotch variety (Cytisus alpinum). The latter variety has very

1 Trans. Manchester Microscopical Society, 1896. 
much larger leaves, and a brighter green bark, in younger stages, than the former.

If we examine the sheltered side of a laburnum-tree, or any adjacent palings, about the latter end of April or the beginning of May, we are sure to see a brilliant, little, white moth, with a few yellowish markings towards the apices of the wings. This is the imago of C. laburmella. It measures about $3 \frac{1}{2}$ lines across the expanded wings. The head and face are white, and the antennæ fuscous. The anterior wings are white, with yellow spots or bars across. The posterior wings are also white, with long ciliæ. The thorax is white, and the abdomen pale-grey. The legs are also white. When carefully examined under the microscope, this tiny moth is a

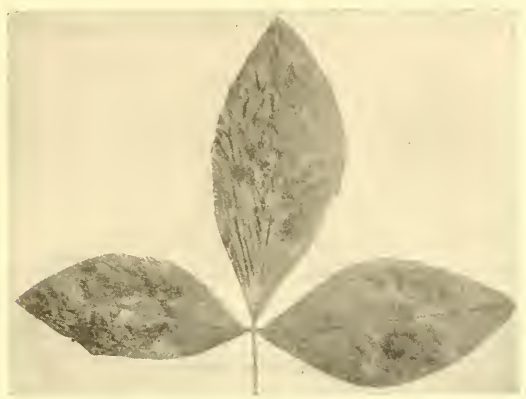

Fig. 245.-Foliage of laburnum injured by larve of Cemiostoma lahurnella.

very beautiful object, - so much so, that it seems to vie with the rich colours and brilliant markings of tropical insects.

The larva is about 3 lines in length, of a pale greenish-white colour, with sometimes a bright-green dorsal line, - due, of course, to the food taken from the green colouring under the leaf.

The pupa is encased in a white cocoon, pointed at both ends.

The life-history may be thus briefly described: The moths appear during the latter end of $\Lambda$ pril or beginning of May, and deposit their eggs on the under surface of the leaf, generally near the midrib. There are two broods in the year. In the first the larve are full fed about the early part of July. Then they leave their feelling-ground on the upper surface of the leaves and muate on the back of the 
leaves, more especially on the younger leaves, which have been forming throughout the summer season. The pupæ are long whitish objects, pointed at both ends, and encased within a very beautiful white cocoon. About the beginning of August, or after about ten rlays to a fortnight in the pupal stage, the moths appear. This brood deposits eggs in the same way as the moths of the second brood which appeared in spring. The larve feed as before, on the newly formed leaves. They are full fed about the middle or latter end of Oetober, when the caterpillars let themselves down by a slender silken rope to the ground, where they pupate, and appear as perfect insects about the latter end of April or beginning of May. About the latter end of Oetober the tiny larve may be seen on a sunny day dangling from the laburnum bush. They may be collected and put in a small box, as this species hatehes very well in confinement.

\section{References to Literature comsulted.}

Carpenter, G. H. Various papers on the Injurious Insects of Ireland.

Collinge, Wr. E. Reports on the Injurious Insects observed in the Midland Counties.

Kaltenbach, J. H. Die Pflanzenfeinde aus der Klasse der Insekten.

Kollar, V. A Treatise on Insects injurious to Gardeners, Foresters, and Farmers.

Meyrick, Ed. A Handbonk of British Lepidoptera.

Newman, Ed. Natural History of British Butterflies and Moths.

Ormerod, 1. O. Manual of Injurious Insects. 2nd edition.

Stainton, H. T. A Manual of British Butterflies and Moths.

Theobald, F. V. Various papers on Economic Entomology.

Wilkinson, s. J. The British Tortrices. 


\section{CHAPTER VII.}

\section{APHIDIDAE (Green-Fly).}

Throvgrout the whole comntry no class of insects is more universally clistributed or more leserving of the appellation "injurions" than the Aphiclitie or "Green-fly." The term blight is adopted for the destruction aceruing from this class of insects, which are inclividually small in size but collectively most injurious. They are to be found on almost every plant, and are soft-bodlied inseets, with compraratively long legs which are but poorly adapted for leaping. They are always found in two principal forms-viz., winged and wingless; and the largest are never more than a quarter of an inch in expanse of wings.

The body of the aphis is pear-shaped. The head, which is small in comparison with the rest of the body, has two compound eyes, and in the perfeet stage ocelli or supplementary eyes are often present,a feature which is well worth special consideration from a physiological point of view. During the litrval stage the eyes are very conspicuons. In fact, they are often quite obvious in the embryo stage, before the larve quit the eggs. They vary in colour from ruby reel to brown or even black.

The beak, which is always an important organ in insect structure, is peculiarly adapted to the destructive demands of the creature, and just shows that all insect anatomy is a modification of similar parts to meet the needs of the ereature. The beak proper is composed of three joints, which vary in length aceording to genus and species. Thus in the Stomiphis, a species living on oak, the beak is longer than the body, while in the genus Chermes it is very small inteed, the mouth being adapted to the food-plant. The former lives on oak deeply furrowed; the body reposes on the outer lard bark, while the long proboseis is a necessity to reach the bottom of the narrow fissure, where the juice can only be found. On the other hand, the 
short-beaked Chermes lives on smooth bark, on which the slightest tap would yield the necessary juice.

The antennæe are from three- to seven-jointed, and form good points for classification. They are very variable in length according to genera, and are also variable in the larvæ as compared with perfect insects of the same species. Henee it is essential in the discrimination of genera to know that we are clealing with adults.

The wings are thin, and of a beautiful transparent iridescent colour, folded ridge-wise over the body, but possessing poor powers of flight. In the wing of a typical aphis (fig. 246) the eubitus or post-costal nervure gradually expands into a semi-coriaceous stigma, whence proceed the veins of the wing. Fig. 246 is a camera-lucida sketch of the wing of Aphis sambuci, and may be considered as a very good example of a typical wing.

The following is an explanation of the characters :-
a. Cubitus or post-costal nervure.
b. Posterior marginal.
c. Costal nervure.
d. Cubital nervme.
e. First furcal.
$f$. Second furcal.
$g$. Second oblique.
h. First oblique.
i. Insertions.
k. Apical marginal.
l. Ntigmatic.
p. Hooklet.

1. Costal cell.

2. Basal cell.

3. First discoidal.

4. second discoidal.

5. Infra-marginal.

6. Marginal.

7. Second cubital.

8. First cubital.

9. Stignit.

The above is adapted from Buckton's Monograph, but in that work the wings of Siphonophora are used as a typical case.

The third vein, counting from the body of the insect, is twice forked in the tribes of Aphictince and Lachuine (fig. 246); once forked in the tribe Schisonemince (fig. 247); and not forked in the tribe Pemphigine (fig. 248), and also in Chermesince (fig. 249). In the lower wing of the typical aphis the post-costal vein gives off two oblique veins only. The wings are carried vertically when at rest, with the costal vein downwards. In the foregoing sketches we have typical wings represented, and the student would do well to study the wing venation of the family, more especially as it is not infrequent to find different venation on each side in some forms. 
The abdomen is composed of several rings, and is capable of much distension, this being dependent on the amount of food taken. The

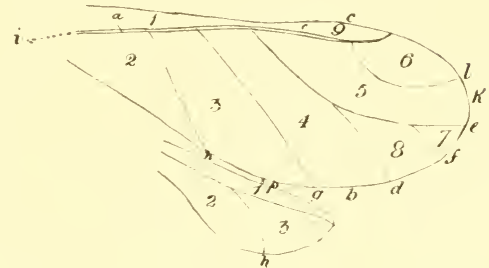

Fig. 246. - Ining of Aplis sambuci, with thind wein twice forked.

number of rings or somites is variable. On the sixth segment many genera have two important tubes or appendages, called cornicles,

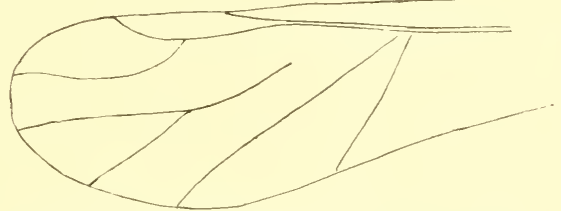

Fig. 247.-II"ing of Schizoneura ulmi, with third vein onee forlied.

which serve for the exudation of a liquid substance known as "honeydew"; others have none.

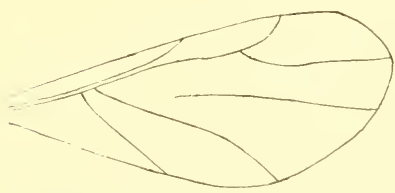

Fir. 24s.-Hing of Pemphizus pallidus, with third win stroight.

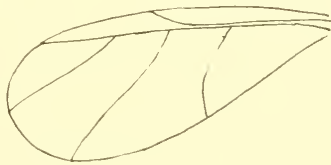

Fig. 249.-Uing of Chermes abietis, uith thirel iein struight.

The honey-dew itself is a substance which has given rise to a good deal of interesting thought and speculation. It is of a saccharine nature, and is consequently sought after by other insects, more 
especially ants, which not only sip the juices but extract the honeydew from the aphis by squeezing it from the comicles. I have often observed ants doing this on the iphides on elder.

The honey-dew is rery injurious to regetation, for not only does it have a tendency to choke up the stomata or breathing-pores of the leaves, but the injury is still furthur increased by the honey-dew forming a lodgment for soot, dust, and dirt.

The tail, though not an important appendage in the discrimination of genera or species, must not be forgotten in generic distinction, inasmuch as it is long in some, and short or entirely absent in others.

The life-history of an aphis presents many interesting points, either considered biologically or as evidenced by the mysterious appearance and disappearance of the so-called "blight" or "green-fly."

The aphis generally appears in numbers simultaneously with the green foliage. The first brood of the season originates either from a female which has hibernated during the winter months, or from eggs - that is, generally true eggs, resulting from male fertilisation. In the former case, the "stem-mother" (Stamm-mutter), as the Germans call her, very much resembles the queen wasp, inasmuch as she is the mother or founder of a whole summer's colony. As a rule, she is considerably larger and less active than any of her offspring.

The eggs of Aphididæ may sometimes be seen in autumn as small white specks on the stem, thongh generally they are green-brown or bottle-green. They become dark in winter, and, of course, are not so conspicuons as in the antumm months.

The brood arising from eggs which had been deposited in autumn, or from the "stem-mother" in spring, give rise to insects which are generally all females. These may be found in two forms - viz., winged and apterous. In many genera, when but a few days old, both forms are capable of giving birth to living young. Each individual insect produces from 90 to 100 progeny, and so on until about twenty generations are produced in a single season. Hence it will be seen by a progressive calculation that the numerical strength of the progeny produced by a single insect certainly becomes appalling, and the number just given is under rather than over the average.

In order to realise the numerical strength of aphis reproduction, Professor Huxley made some remarkable calculations, and has therefore put them in his own inimitable way. He calculated that if an 
aphis weighs $\frac{1}{1000}$ of a grain avoirlupois, and a stout man not more than two million grains, - about twenty stones, - then the tenth broor formed (exclusive of all the preceding hroods, supposing that the multiplication hal been altogether unchecked by the various canses which gencrally influence it) will exeed in weight five humdred million men, or about one-third the entire population of the globe. This calculation is made on the assmmption that each individual member could turn the scales at $280 \mathrm{lb}$, and also that each aphis is capable of producing only twenty young, whereas, accorling to Latreille, the average rate of production of a viviparous aphis during the summer months is twenty-five per day,-but this is greatly in excess, as far as this comtry goes.

Fortunately for vegetation, the aphis has several natural enemics to keep the enormous reproduction within bounds. Heavy rains act as a check, but, entomologically considered, the small Chalcirlidue, Hymenopterous parasites which pass their metamorphic stages in the interior of the aphidian bodies, are of inestimable value in keeping them down. Throughout the summer months the dead bodies of the Aphididæ may be found adhering to the food-plant. These bodies are mere chitinous shells, with a small hole whence the tiny Hymenopterous parasites have emerged. Ladybirds, horse-flies, Chrysops, and birls are natural enemies.

At the end of the season the last brood for the year is generally composed of males and females. In certain species males have not been discovered for a few years. But investigation seems to show that sooner or later males will appear-verifying what Andrew Knight said in 1799 regarding self-fertilisation, viz., that it is a "law of nature that organic beings shall not fertilise themselves in perpetuity." Subsequent research has borne out this statement in other animals. It is well known to every entomologist, collector, or economist that the number of insects depends very considerably on the conditions of the weather and the supply of food. The Aphididæe are certainly more susceptible to those external influences than any other class of insects. Should the weather suddenly become colder, a great number of winged specimens will appear, as they do also in the event of the food-supply becoming scarce.

It is neither by chance nor latent ability that apparently apterous individuals suddenly become winged, but apterous specimens give birth to young which develop wings. Hence the change from wing- 
less to winged specimens is the result of the short period necessary for the ushering in of a fully developed fresh brood, which will adapt themselves to natural changing conditions. In other words, the newly born brood will move to new quarters either in search of food or warmth. And here comes in a very common but erroneous notion -riz., that the sudden appearance of "blight" is due to "east winds." Now the fact is that the proverbial east wind has simply assisted the winged aphis, which, after all, is but poorly adapted for locomotion, to move from his native land to "fresh fields and pastures new."

Wringel forms are known at an early age as apterous larvæ, the "pupal" stage being that period when the wings are half-grown. Some species pass through these metamorphic stages hefore their life cycle is complete. Thus apterous larre, semi-winged pupæ, and winged imagines may be constantly found throughout the summer season on the foorl-plant.

In many species both apterous and winged females produce living young, but, according to Buckton and other observers, the pupæ never give birth to young. There are two classes of females apart from apterous and winged ones-viz., ovifurous and viripurous, the first reproducing themselves by eggs, the second by living young. It is asserted by many practical workers that the oviparous never becomes viviparons, or vice versa, the same individual aphis never producing eggs and living young.

The difference between the deposition of eggs and the production of living young on the part of the respective female insects would appear to be simply a question of time and stage of reproduction, but it affords a subject for actual investigation by dissection and serial section-cutting, in order to ascertain the morphological difference between oviparous and viviparous organs.

To the student of forest entomology it is not only essential to make a detailed study of the life-history of the various species as found on trees, but it is indispensable to study the species found on almost every plant, inasmuch as we get migratory species and dual or multiferous food-plants of certain species. Thus, for example, we get the hop aphis, the larch and spruce aphis, mealy plum aphis, together with root and trunk forms constantly changing from food-plant to food-plant. It is therefore obvious that this is a good case in point, showing that it is most essential for the economic entomologist to 
become, as far as possible, well acquainted with the structural details of the systematic student.

As regards terms for the family or sub-families, Buckton says-

"The Aphides have the following synonyms:

Aphides, Linnarus.

Aphide, Curtis, Westwood.

Aphirtina, Burmeister, Walker, Hartig.

Aphictime, Rondani.

Aphirlile, Passerini.

It is therefore rather difficult to know what precise term to adopt for the family or sub-family."

The family APHIDID $Æ$ may be divicled into six tribes-viz., Aphidinæ, Lachninæ, Schizoneurinæ, Pemphiginæ, Chermesinæ, and Rhizobinæ.

The following are the principal tribes and genera which are arboreal in their habits :-

Tribe Aphidinæ.-Upper wings with eubital vein twice forked; lower wing with two oblique veins. Antenne long, with seven joints: 7 th joint long, 3rd usually longest.

The following are the principal genera belonging to this tribe which are arboreal in their habits-
MYzus.
ApHIs.
Drepanosiphum.
Chattophorus.
Melanoxanthus.
Callipterus.

Tribe Lachniuæ (woolly).--Wings same as in Aphidinæ. Antennæ six joints, 7 th rudimentary. Genera-
Pterocallis.
Stomaphis.
Phyllaphis.
Dryobius. ${ }^{1}$

LACHNUS.

Tribe Schizoneurinæ.-Upper wing, cubital vein once forked; lower wing with two oblique veins. Antennæ six joints, 7 th rudimentary; 3rd ringed, 4th often ringed. Genus-

\section{SCHIZONEURA.}

Tribe Pemphiginæ (gall-forming).-Upper wing, cubital vein not forked; lower wing with one or two oblique reins. Antenne short, six joints; 7 th mdimentary. Genera-

\section{Penphigus. Tetraneura.}

1 The above is adapted from Buckton, as it is rather difficult to reconcile his classification: see vol. i. p. 94 and vol. iii. p. 11 . 
Tribe Chermesinæ (kermes, a red dye).--The genera of this tribe are varied in their habits, inasmuch as they are coccus-like, bark-feeders, gall-makers, or wool-spinners, and sometimes subterranean. GeneraChermes. Phylloxera.

Tribe Rhizobinæ.-The genera of this tribe are root-feeders, and hitherto have not been much investigated in the forest. There is a species very common on the dead leaves of Scots pine which may be found throughout the whole of the year, but hitherto I have not discovered any name for it.

In giving an account of the more common and destructive genera and species of arboreal Apthitliter, it may be suggested to the student that much valuable information on the havits and structure of these insects might be gained by studying many species of the genus Siphonophora, which are found on many varieties of plants. Thus, for example, Siphonophora rose is abundant on roses; $S$. muli $i$ on raspberry; $S$. avellune on hazel; and various other species of this genus are found on our common plants.

\section{Tribe APHIDIN杫.}

\section{Genus Mrzus.}

The chief generic characters are antennie about equal to the length of the body. Cornicles long, tail prominent. Wing venation much

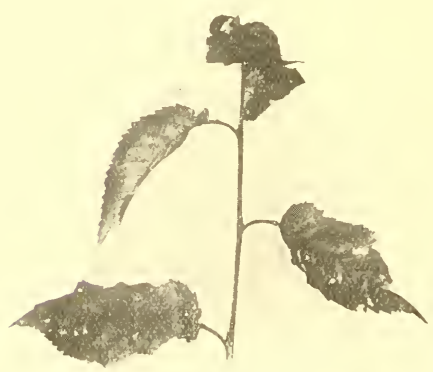

Fig. 250.-Terminal sñoot of wild eherry injured by Myzus cerasi. the same as in a typical aphis.

\section{Myzus cerasi (Fab.)}

This species is very common on wild cherry or gean of the forest, as well as on the cherry of gardens and orchards. The damage done by the insect is very easily recognised. The injured shoots form a sort of rough rosette of leaves (fig. 250), and the absorbing action of the insects, coupled with the exudation of honey-dew, add a sort of sooty appearance to the damaged shoot. 
The apterous viviparous female is wholly black in greneral appearance. Antemme not conspicuously long. The abdomen is of a very shiny black colomr. The cornicles are rather long. The eyes are a clarkish-brown colour.

The winged viviparous female is wholly and conspicuously black, with rather long antennæ and broad wings.

It is somewhat diffieult to preseribe a remedy for this species. It has been suggested to cut off the infested shoots or rosettes and destroy the same, but as the leading shoot is the portion generally attacked, this would obviously lestroy the young tree, so that it would be better to adopt some spraying measure, or otherwise shake the aphides into a vessel containing paraffin.

\section{Gemus Drepanosiphum.}

Rostrum short; antennæ very long, third joint longest; seventh joint very delicate; comicles large; tail inconspicnous. Wings long and narrow; eubital vein twice forked.

\section{Trepaxosipitum PLAtaxoIdes (Sehr.)}

This is a common aphis which lives on sycamore, and may be found simultaneously with the appearance of the foliage. It simply injures the plant by sucking the juices, and does not cause any malformations.

The eggs of this species may be found very plentifully on the bark of sycamore during the winter months. They are black in colour, and, when abundant, their glossy appearance on lichen and Protococus: virilis renders them conspicuous to the naked eye at some distance.

The larvæ are found on the young leaves just as the latter are bursting. When hatehing they are of a bright-green colour, with very long antennæ and conspicuously red eyes. In general appearance the body is so slender that the creature may be said to be all "legs and arms."

The pupal form, or stage between larva and winged insect, is very variable both in colour and general appearance.

The winged insects are also variable in colour, but the prevailing hue is bright green. The head is rather flat, the eyes are very prominent, and being of a golden-green colour, contrast very strongly 
with the head and body. The antennæ are black, long, and slender, and consequently liable to injury. There are two vertical black markings and five or six transverse bars on the abdomen, as well as similar markings on the under side. The legs are variable in colour. The tail is short and not very conspicuous. The cornicles are comparatively long.

This is altogether a handsome-looking aphis, and is suggestive of a lobster. It may be shaken in showers from the leaves. This species, however, is so very variable in colour that Buckton gives several varieties in both larval and perfect forms.

About the middle of April, just before the winged insects appear, large apterous specimens, very much larger than the general larva, and of a mahogany colour, may be founcl. Contrasting with the larvæ just referred to, it may be olserved that in proportion to the size of the body, the antennæ, cornicles, and tail are all comparatively short. The abelomen is large, warty, and bristly. At first sight this insect may be taken for a "stem-mother" or for some other species, but if kept in confinement for a few days it will be found to be a bloated parasitised form, whence parasites are hatched.

It has been asserted by several olsservers that the larve of this species always assume wings, and that conserquently the wingless specimens never give birth to young. In other words, only the fully developed female, which in this case is the winged specimen, gives birth to young. I have not fully verified this, but so far as my observations go, I am inclined to endorse this view.

The apterous oviparous female may be found in the autumn on the uncter side of the leaves, just before they fall. It is easily recognised by its darkish colour and elongated abdomen prolonged into a tail. The eyes are bright red.

This insect rather lends itself to a study of ovarian characters.

\section{Genu: Melanoxanthus.}

As this genus was founcled by Buckton, it is best to give his own description :-

"Body elliptical, rather flat, vertex flat between the antennæ.

"Antenne short. The third joint double the length of the fourth. The seventh equal to the sixth. Frontal tubercles inconspicuous.

"Nectaries short and pear-shaped, with trumpet-like mouths. 
Prothorax marked by two lateral teeth. Abdomen oval. Legs strong and short.

"Tail inconspicuous or none. Wings moderately long. stigmatic veins with their apices reflected."

In this genus it would be well for the student to carefully study the generic characters, inasmuch as the genus may be confouncled with Lachnus.

\section{Melanoxanthus salicls (Linn.)}

This insect may be found very abundantly on the two-year-old shoots of the common osier (Sali, viminulis). They are gregarions in their habits, and may be found clustering on the rods they select. The attacked rods may be afterwarls known by the deposition of a white mealy substance on the infected portion of the stem. They are very common in Cheshire about the latter end of Jume.

The apterous female is a very large insect. The body is of an oval

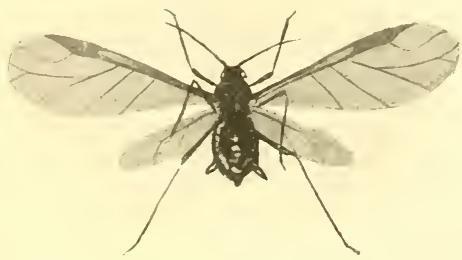

Fig. 251.-Melanoxanthus salicis. (From Buckton's 'Monograph of British A plides.' Ray society.) shape, and of a sooty greyish-black colour. Along the dorsal surface there is a faint median line of rulely diamond-shaped spots of a greyish-heliotrope colour, and also similar spots on the abdomen. The two largest spots are situated near the middle of the body. The basal half of the antennæ is of a terra-cotta colour, and the apical portion is blackish or dark brown. In proportion to the size of the body, the antennæ are comparatively short, the third joint being the longest. The legs are slightly pubescent, and similarly coloured to the antennæ. The cornicles are small and of a brightorange colour. The rostrum is fairly long, but appreciably longest in the young stage. The tail is not very long or conspicuous.

The pupa is somewhat similar to the above, except that the thorax is a more slaty colour.

The winged viviparous insect (fig. 251) is very large, but not so 
plump or oval as the apterous speeimens, and the spots are not so pronouneed.

On the whole, this is a very pretty aphis, the spots giving the entire body a very bright-looking appearance.

Mr Theobald in eorrespondence says-

"The eurious staining of the wood where they have been is interesting. I have found them in masses over a foot long in Hunts and Kent."

\section{Genus ApHIs, Lim.}

The genus Aphis, accorling to Buckton, contains 45 species, and it is a very important genus. In the first place, the name Aphis to a novice in entomological knowledge is very apt to be confounded with the whole family of Aphidida, and may therefore in a general sense be used to refer to every individual speeies. As there are 45 species in the genus, with fool-plants ranging from the small weed to the tall trees, it is obvious that some care must be taken in tabulation.

As regards the main points in the genus, linckton gives the following--viz. :

"Rostrum moderately long, the last joint skittle-shaped, and as long as the preceding. Antennæ shorter than the body. Frontal tubereles none or rudimentary. Seventh joint setaceous, and as long as the third. Cornicles cylindrical, and equally thick throughout. Cauda short, sometimes hardly visible. Legs moderately long. Wings generally shorter than the preeeding genera, but veining similar."

\section{Aphis crategi (Kalt.)}

In several districts in Cheshire during the season 1893-94 very much damage was done to young thorn hedges and young quicks by the Apthis cratcerji, young thorns in many eases being killed outright. There is no mistaking this pest. In conseqnence of growth being arrested, the shoots are eomparatively short, the leaves eurl up, and in general appearanee the infested plants look as if the leaves and young shoots are covered and killed with fresh soot (fig. 252).

If infested llants are examined during the winter months, the topmost portions will be found studded with dark-brown eggs. These eggs hatch out as soon as the leaves burst, and throughout the summer the insect pest in all its various stages may be found. 
It is very variable in colour and appearance. Hence Buckton remarks that "it is exceelingly diffieult to reconcile the descriptions of various insects named Aplis crate'fi by authors."

The apterous viviparous female is a bright-greencoloured insect with brown eyes. The antenna are shorter than the body. The third and seventh joints are the longest. The cornicles are eomparatively long, eylindrical, and equally thick throughout. The tail is short but conspieuous.

The pupa in many respects resembles the apterous specimens, but on the whole is very much smaller in size.

As I have not made any descriptive notes on the winged form (fig. 253) when

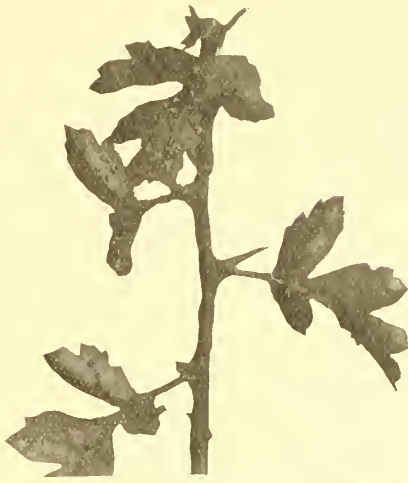

Fig. 252,-Eggs of $\mathrm{A}$ phis cratregi on thum.. . . nursery-line. 'xamining the living insect, and mounted specimens lose all colour, I append Buckton's deseription :-

"Head, neck, ring, thorax, and its lobes black, head broad and convex, abdomen shining brightgreen, with the same marked carination and minute pore marks of the larve. Cornicles long and straight, colour olive-green, antennæ and legs ochreous, pale, and hairy. Rostrum reaches to the second coxa. Tail conspicuous and green. Eyes bright red."

With regard to remerlies for this pest, we must either kill the

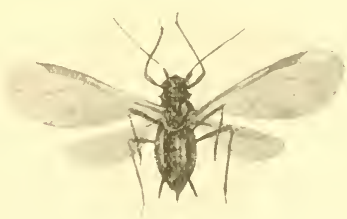

Fig. 253.-Aphis cratiegi. (From Buckton's 'Monograph of British $\Lambda$ phides.' Ray Society.) insect in the stages of its metamorphoses or destroy the eggs. The insect form may be considerably checked by syringing the foliage with a mixed solution of soft soap and (puassia chips. On the other hand, the eggrs may be got rid of, so far as young hedges are concerned, 
by simply "cutting down" the young thorns and burning the prunings. In transplanting such thorns previously eut down, care must be taken to lift plants with the best possible roots, and encourage as much as possible by attention and gool management. This plan I have adopted with considerable success. Hówever, under ordinary circumstances, it is certainly not advisable to cut down quicks the same year as they are planted, inasmuch as the shoots produced are not so strong as from those grown for a season prior to cutting off. When the young thorns are cut off the same season, or, perhaps, rather the same day, as they are planted, they are exposed to considerable risks. In the first place, the shoots are weak, and not able to withstand insect attack, as for example the aphis on the shoots during the summer, and also prior to the commencement of growth by the clay-coloured weevil (Otiormynchus sulcatus). The shoots, being comparatively weak, are more apt to be destroyed by rabbits or choked by weeds. Hence it is better to cut off the second year, wherever this method coincides with good local husbandry.

If young thorus in nursery-lines are very badly attacked with this species, and if such attacked quicks are not strong enough to go out,

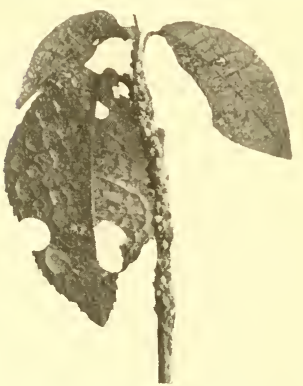

Fig. 254.-Aphis padi on bird-cherry. or otherwise not convenient to put out, it would also be well to cut them down in the nursery-lines, burn the tops, and dig in manure between the rows, so that a strong bushy thorn may be produced by another year.

\section{ApHis padi (Reaum.)}

This insect is very common on the young shoots of Prumus parlus (birdcherry). Fig. 254 shows the injuries, or rather the gregarious habits, of this species; but later on in the year, say about the middle of July, nearly every terminal twig of the birdcherry bush has been killed. It is therefore evident that severe injuries accrue from this species, as the development of the bush has to depend upon growth being produced in the latter end of the season.

The apterous viviparous female is of a yellowish-green colour, somewhat variegated with oval stripes, and more or less stained with a 
coloured mealy powder. Eyes black; antemne, legs, and comicles yellow, the last being rather dilated at the base.

The pupa is of a greenish or black colour. The prothorax is partially green, varying to light olive, and the abdominal portion is of a shining black colour. Eyes and cornicles black; antennæ and legs olive-green.

In the winged viviparous female the whole body is of a shining black colour, and brightened here and there with lightish spots. Antenne, eyes, and legs lightish-brown. Wings rather large, with somewhat conspicuous dark stigma.

\section{ApHis evonrues (Fabr.)}

This insect causes the shoots of Euonymus europrens to form a sort of rosette, very much after the mammer of the shoots on wild cherry. The insects cluster under the rolled leaves, and both apterous and winged forms are either a very dark-brown colour or otherwise wholly black.

\section{APHIS HEDER (Kalt.)}

This insect is often found very plentifully on ivy, and elusters of them may be discovered during the winter months where the position is rather warm. It is dark-brown or blackish colour, and it is said that the speeies found on holly is preeisely the same inseet.

\section{Aphis abietisa (Walker).}

This insect is often found very plentifully on spruce from May onwards throughout the summer. The apterous form is a brightgreen colour. The abdomen is somewhat elongated, and the cornicles rather long. The eyes are red. The winged form is rather small, and also of a light-green colour. The colour of this insect is somewhat variable, but it is easily recognised from being associated with the spruce, and by the seven-jointed antennæ and the forking of the wings.

During the winter months the apterous females of this species, which give rise to the summer's brood, may be found amongst the leaves of spruce-trees. 


\section{Aphis viberni (Sehr.)}

This is another speeies eansing the tip shoots to form into a rough rosette of leaves on Viburnum opulus, and the shining blackish insects may be found underneath the leaves.

\section{Aphis sambuci (Limn.)}

This insect is very plentiful on the young shoots of elder. They are very gregarious, and often cluster two or three deep, and thus form a covering from three to six inches in length on the shoots.

There are many species of the genus $\Lambda$ phis on forest trees and shrubs, but they may be all reeognised as belonging to this genus from their structure, and in nearly all eases the specific name coincides

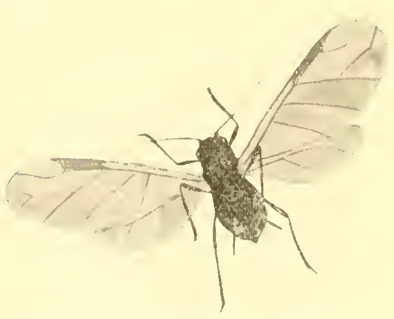

Fig. 255.-Apluis sambuci. (From Buckton's 'Monograph of British Aphides.' Ray society.)

the same, aceording to Buckton. tufted bristles; antenne much as in Aphis, and short compared with Drepanosiphum, very hairy; abdomen studded over with tubereles, each of which is surmounted with a tuft of bristles; cornieles very short, and in mounted specimens projected at right angles to the abdomen. Legs comparatively short and hairy. Wings veined as in Aphis.

\section{Chattophores aceris (Limn.)}

An aphis is found on the sycamore which may be readily confounded with Drepanosiphum platanoides previously described. This 
is chaitophorus arevis or "hairy aphis." It is common in many listriets, but I. first diseovered it in Sherwool Forest on May 25, 1896.

The general difference is that this speeies is more hairy, and is altogether smaller. The antennæ, legs, wings, and cornicles are all respectively shorter. The abdomen is studled over with tubercles, and each tubercle is surmounted by a tuft of bristles. The legs are comparatively short, and the wings are veined as in $A$ phis.

There is a unique interest attached to this species on accomnt of its special dimorphic forms. Its peculiar and interesting life-history may be briefly told. During the winter months the apterous oviparous female, which is the foundress of next year's broods of insects, may be found in the erevices of the bark, together with the dark shining eggs she had deposited in the erevices of the bark. From those eggs, which hatch in spring, we get the apterous viviparous females, which are comparatively small, of a greenish colour, and produce lightyellowish or clarkish larve. The latter are rather variable in letailed eolour.

The pupe are smaller than the apterous viviparous females, and have rather lightish-coloured legs and dark-coloured wing-eases.

Arising from this brood there are two varieties of winged viviparons females. The first variety to be consiclered is one with black head and thorax and greenish abdomen, which is ornamented with a few eross-bars. The cornicles are small and black, and the whole insect more or less hairy. The second variety is rather larger than the first, with comparatively larger wings, and the ereature is more pilose than the former variety.

It is, however, with regard to the young produced by those two varieties of female inseets that the chief interest is attachecl. The first variety produces normal inseets, which in turn give birth to other inseets, and so on throughont the summer season. The seeond variety produces a elass of insects so distinet, and differing so much from all wher Aphilicle, that it has not only receivel several synonyms, but a suggestion has been made to relegate this variety to a separate family, between Coceide and $\Lambda$ phididx. I fomd several specimens on the common syeamore in sherwool Forest, and tried to induce them to live in Cheshire, but without suecess. They are born in the early part of summer, and live until autumn, never moving from their early habitat or respective leaves, and, with the exception of moulting, undergoing 
no metamorphoses. In addition to these characteristics, the creature develops a strange morphological structure, inasmuch as peeuliar flabelle are attached to its dorsal surface.

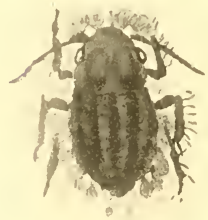

Fig. 256.-Chaitophorus aceris (speeial peculiar form). (From Buekton's "Monograph of British Aphides.' Ray Suciety.) In short, it is a peeuliar form of neuter gender, and contemporary with ten or twenty parthenogenetic generations (fig. 256).

I have found it common in Northumberland, on the under side of the leaves of the purple varieties of sycamore, and also on Acer colchicum rubrum. As the green colour of this creature contrasts with the speeies of those plants referred to, it may be fairly easily reeognised, though it must be remembered they are only mere pin-points in actnal size, and often difficult to fincl.

Mr Theobald informs me that it is common in Cambridge, Devon, and Kent.

\section{Gemus Callipterts.}

This genus is rather important in forest entomology, inasmuch as the species are all arboreal in their habits. Hence it may be well to state the generic characters as given by Buckton-viz. :

"Postrum stout, short, does not reach to the second coxæ.

"Antennæ very long, often tipped with blaek; third joint mueh the longest. Seventh joint variable in length, but rarely less than the sixth.

"Heat large, vertex flat, frontal tubereles none.

"Cornieles very short.

"Legs moderately long; longest in the males.

"Wings generally ample, iridescent, usually elouded with pigment at the extremities of the veins. Stigmata long. Stigmatie cells trapezoidal.

"Abdomen: in some species the apterous females are hirsute. The last abdominal ring is provided with two anal valves or papille."

In habits of life, however, they are quite distinet from other genera belonging the tribe, as those hitherto considered are all gregarious, while the Calliptera, especially in the winged stages, are more or less solitary. When they approach anything like gregarious habits, it 
will generally be found that they are the progeny of a single parent, congregated, as it were, together before leaving "lome."

\section{Callipteres betularies (Kalt.)}

This species is very abundant on bireh-trees, more especially birch coppice, during the summer months, and great numbers of it may be beaten from the foliage. The winged specimens are rather sluggish in their motions, and lo not take willingly to flight.

The apterous viviparous female is linear in form ; the boty is almost entirely green, with slight yellowish colouring in the anterior parts. The head is slightly covered with hairs; eyes red; antemne are very slender.

The winged viviparous female is of a light pea-green colour, and more smooth on the body than the apterous specimens; antenna very long and slender, and of a slightly brown colour. The third joint is very long. The middle portion of the thorax is yellow-orange spotted with brown. The front portion of the thorax is of a light-yellow colour; eyes beautiful light chocolate; legs uniformly light green, except the tarsus, which is dark brown. Wings moderately long and clear; stigmatic portion yellow ; veins dark brown, and slightly elouded at the tips.

\section{Callipterus Quercês (Kalt.)}

This species is found fairly common under oak leaves. The apterous oviparous female is a light-yellow colour. Antennæ shorter than the bouly. Eyes brown. The winged viviparous female is of a palegreen colour, leaning towarls yellow. The antenine comparatively loug, and the joints marked with a blackish colour, - a character which is well maintained in mounted specimens.

The young of this insect are at first very small and light-coloured, with conspicuously darkish or reddish eyes. These characters can be very well ascertained with the aid of a pocket-lens against the leaf as a background.

The more common species which may be lookel for are the following - viz. : Callipterus coryli, Goetze, on hazel; Callipterus carpini, on hornbeam; and Callipterus castanew, Buckton, on sweet chestnut. 


\section{TRIBE LACHNIN Æ.}

We now approach the second tribe of the family, known as Lachnine. The venation is the same as in the preceling tribe, but the antennæ are six-jointed. This character as revealed by the microscope is important to the systematist. To the economic entomologist, however, there is no general character as revealed by the injuries in the forest which can suggest a marked line of classification. The term Larknus means "woolly," and this character is well pronounced in the genus Phyllaphis, which is often very abundant on beech; but unfortunately many members of the genus Larhnus have no wool.

\section{Gemus Pterocallis.}

The characters of this genus may be described as rostrum short and stout; antenne shorter than in Callipterus, the difference in length being specially conspicuous in the apterous form ; six-jointed, but the sixth joint has a break in the middle, which might on indistinct examination be mistaken for a seventh joint. Cornicles small and stout. Wings shorter and narrower than in Callipterus, and most beautifully clouded; hence the term Pterocallis is derived from the Greek, and means beautiful wing.

Buckton describes three species as belonging to this genus, all of which are arboreal in their habits-namely, Pterocallis alni, on alder; $P$. juglandicolu, on the walnut-tree (Juglans regria); and P. tilice, on various species of lime, which, however, is so abundant on the ordinary lime-tree (Tilia europea) that it may be taken as typical of the genus.

\section{Pterocallis tillie (Linn.)}

The apterous viviparous female is of a uniformly lightish-yellow colour, with most beantiful light-red eyes. The antennæ, more especially in the young stage, are light and dark, the basal portion of each joint being light in colour, and the apical portion of the same joint being very dark. The contrasting colours therefore make the antemmæ rather beautiful objects.

The winged viviparous female is of a uniformly light colour on the under surface of the body, and on the upper surface she is of a yellow colour, with short dark bands reaching half-way across the 
abdomen. The thoracic portion of the body is also yellow, with two longitudinal dark bars on the lower portion of the thorax. The legs are variable in colour: the first two pairs are of a yellowish eolour, with darkish tarsi. In the hind pair, the portion adjoining the body is also a light-yellow colour, and the middle portion of the whole is eonspicuously blaek, and the tarsal portion light brown. Eyes same as in apterous form. The wings are eomparatively long and narrow; veins light brown, and broadly elonded at their apices.

\section{Genus Lachnes.}

This genus is rather interesting from a sylvan point of view, inasmueh as the speeies are all arboreal feeders. Aeeording to Bucktou, one species lives on willow, while the others prefer the oak or coniferous trees.

As regards the leading points which eharacterise the genus, it may be sail that the rostrum is very long and slender; antennæ sixjointed ; small cornicles; inconspienous tail ; very long legs and large wings, with the eubital vein twice forkerl.

Perhaps the most conspienous species are L. pini, on Seots pine, and L. lom!ripes, on oak, - the former, from the damage done to young Scots pine in early spring, and the latter, as conspienous by the eggs in autumn.

The inseets are very heavily bodied, and the winged specimens are but poorly balaneed for flight.

\section{LACHNUS PINT (Limn.)}

This speeies is found on Scots pine (Pinus sylvestris), and is fairly common, more espeeially in smoky districts, where the young trees do not thrive over-well. During the winter months the eggs, which are eomparatively large and blaek, may be found seattered amongst the leaves or on the bark of the shoots.

In late spring or early summer, when the inseets hateh out, they make their way to the very tips and there congregate themselves, and when an attempt is made to eollect them they beeome very aetive in their motions.

The apterous form is very large, of a dull brownish-grey colour, black eyes, slender antennæ, long legs, and the body rather hairy, but 
soft in structure. In mounted specimens the rostrum is often very conspicuous, and as a rule the front pair of legs are much more prominent than the antenne.

The winged specimens are much the same in colour as the above.

They may be beaten from

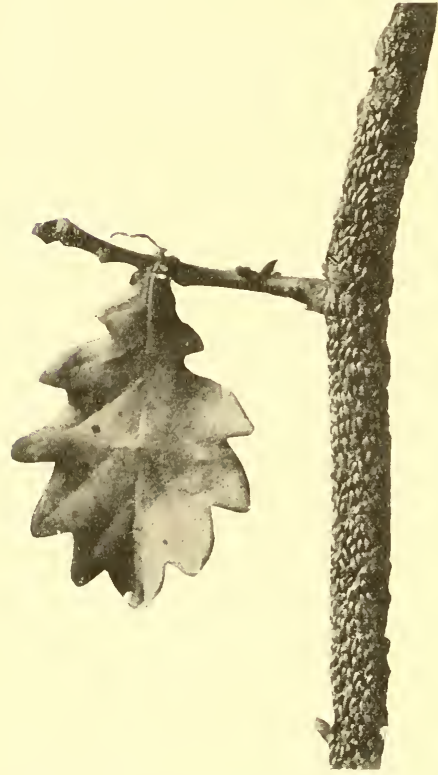

Fig. 257.-Eggs of Lachnus longipes on odk. Photographed in winter; leaf added for identification.

Seots pine trees throughout the summer, and as the wings are often folded flat over the body, they might be mistaken by a beginner in entomology for a species of ant.

Lachnes LONgipes, Defour.

This species is found on oak, and often on young shoots from oak stools. The eggs, however, as represented in fig. $25 \pi$, are the most conspicuous. They may be looked for in late autumn or during the winter months.

In early summer the apterous viviparous females may be found in masses on the shoots of oaks which grow as suckers from the stools or stumps of previously felled trees. They are fairly large in size, of oval form, and of a uniformly deep-brown colour. Eyes black, and cornicles small.

\section{Lachés viminalis (Fonse.)}

This species is found fairly common in some parts of the country on willow or osiers, and very harmful to willows and osiers in parts of South England. Wasps are greatly attracted to where they occur. 
It is apt to be confounded with Melanoxcenthus saliris, one of the most salient points of difference being the joints of the antennæ.

The other species described by Buckton in his Monograph are L. picere, which is said to be very abundant on silver fir and also on spruce near London; L. pinicolus, on larch and sicots pine; and $L$. marrocephalus, on spruce.

\section{Genus Phyllaphis.}

The following generic characters are from Buckton:-

"Rostrum very short.

"Head convex, smooth.

"Antemne moderately long, the third joint about double the length of the fourth; the fifth and sixth joints equal, the sixth furnished with a representative nail.

"Cornicles hardly visible, and lying flat to the body.

"Cauda almost obsolete.

"Body furnished with long flocks of wool-like fibre of a waxy nature.

"Wings long and broad. Stigma long and trapezoidal. Nervures not clouded.

"Legs moderate in size."

\section{Phyllaphis fagi (Linn.)}

During early Nay the leaves of beech-trees may

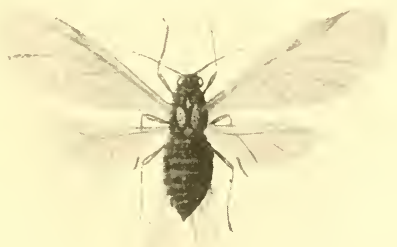

be found covered with a white woolly coating, produced by insects known as Phyllapllis fagi. In some cases large beech-trees are so badly attacked as to be partially defoliated in midsummer, and this being the growing season, the increment of the tree must be appreciably affected.

The apterous female is a light-grcen or yellowish colour. The general colour is, however, rather variable, as the abdomen is marked with spots or bars. The cornicles are rather small, and the joints of the antemne are about equal thickness throughout.

The winged female (fig. 258) is best examined by first lissolving the 
white fluffy matter, but this, unfortunately, rather spoils the colour. The general colour is yellowish-green, with darkish legs and antennæ.

Fig. 259 is from a photograph of the leaves of copper beech; and there is only one species in the genus which confines itself exclusively to the beech.

In the older writings of 'The Trausactions of the (Royal) Scottish

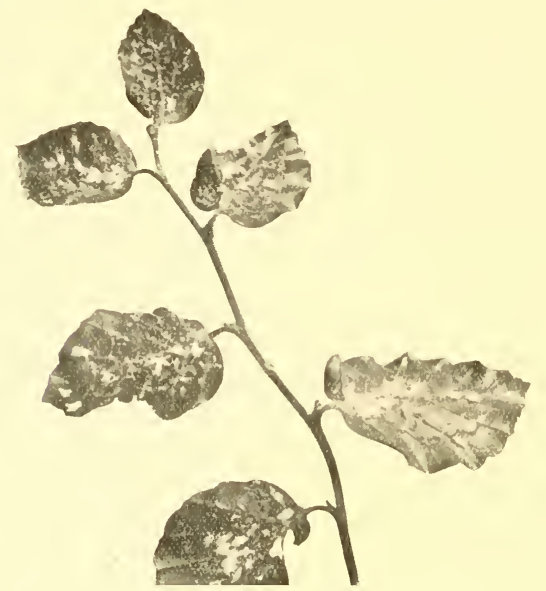

Fig. 259.-Foliage of comper beech (under side) covered with Phyllaphis fagi.

Arboricultural Society' several accounts of this insect are given under the name of Chermes fagi.

This species is particularly harmful around the London area.

\section{Genu: Stomaphis.}

As this genus, according to Buckton, contains only a single species, namely, $S$. querchs, which is said to be comparatively rare in England, it may be well, for the advantage of students, to simply give the following generic characters according to Buckton-viz:

"Head and eyes small. Antennæ slender, moderately long, sixjointed, third joint the longest, the sixth as long as, or longer than, 
either the fourth or fifth, the aborted seventh joint longer than in Lachemes.

"Cornicles very inconspicuous.

"Legs shorter than in Larhnus, and less stout. Tarsus biarticulate, tail none, rostrum very long in the apterous females, but shorter in the winged forms."

I have not found Stomallis, and therefore only give the generic characters.

\section{Gemus Dryobius.}

The following generic characters are taken from Buckton:-

"Rostrum rather long and thick, projecting beyond the poststernum-much longer in the young.

"Antemæe slender, six-jointed, with an unciform process in the sixth joint. Third joint more than twice the length of any other, the fourth and fifth joints about equal-the sixth less than half the length of the fifth.

"Cornicles conical, and very short.

"Cauda inconspicuous and rounded.

"Legs, the first two pair moderately long, the hinder pair disproportionately long; tarsus composed of two distinct joints.

"Wings moderately long in the males, but very short in the viviparous females. Stigmata rather long; cubital and first furcal veins issue from the same point, which is at some distance from the cubitus. The membrane of the upper wings variegated with brown, smoky fascire."

Buckton in his Monograph describes three species, but they appear to have been found either on the Continent or in the south of England; and as I have not found either of the species myself, I must simply refer the student to the generic characters.

\section{TRIBE SCHIZONEURIN仺.}

This tribe contains the dreaded "American blight" found on fruittrees, and the damage done to stem and roots is unfortunately only too well known to require description.

The species belonging to this tribe differ in two ways from insects belonging to the previous tribe, both as regards the structure of the insects and the nature of the injuries. 


\section{Genus Schizoneura.}

As regards the structural details, the following generic characters are given by Buckton-viz.:

"Rostrum moderately long in the adult, much longer in the young.

"Antennæ with six articulations, omitting the terminal unciform process.

"The first and second joints very short, the third much the longest, and in all cases either ringed or eupped; the fourth and fifth abont equal, and also usually ringed; the sixth joint rather shorter than the preceding, and ending with a rudimentary joint, a small tubercle sometimes separating the two parts.

"Cornicles rudimentary or none; legs short. Tarsi furnished with two claws. Body either powdered with a mealy substance or furnished with wool-like tufts.

"Wings moderately long, cubital, with a single furcation, anc in

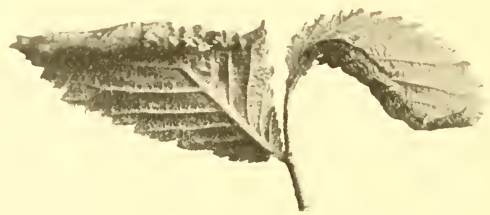

Fig. 2tio.-Leares of wych elm rolled by Schizoneura ulmi.

most species springing at some considerable distance clear from the cubitus. The post-costal nervures of the hind wings nearly straight, and giving rise to the usual two oblique veins."

With regard to the damage, it may be noted that in this tribe we find a reaction of the vegetable organism against the insect attack. In other words, we get gall structure and its modification. The various figures given by liéaumur and others would seem to suggest that those features have been recognised for a very long time.

The arboreal species chiefly confine their attacks to the foliage. The curling of the leaves of elm (fig. 260) is a very conspicuous feature throughout the country. If the curl arises from the gnawing of one stem-mother, then a single straight roll of half the leaf is the result, but if the same leaf is seized by more than one stemmother, then the deformed leaf assumes various distorted shapes. 


\section{Schizonecra ulmi (Limn.)}

The arboreal species most injurious in this country and throughout Europe is the Shlomenra ulmi (Linn.), and the most injurious arboreal species in America is known as Srhizonenir amerirana (liiley). ${ }^{1}$

The description given by European writers was suggestive of the two species being identical; but Professor Riley, on closer examination, found that the two species differ from each other in their methods of damage and structural details, thus showing that while we may deplore specific hair-splitting, hasty grouping is far from commendable.

Riley maintainel that, considered as a psendo-gall, the chief difference in the two speeies is that the stem-mother of s. ulmi attacks the upper side of the leaf, and the injured leaf in consequence rolls over; whereas the stem-mother of S. amrirana attacks the umder side of the leaf, and the injured portion rolls under. This observation was based by Prof. Riley on a specimen sent from England by Mr Buckton, but it certainly does not coincide with our own species, S. ulmi, inasmuch as the queen-mother attacks the under sicle of the leaf anit rolls under (fig. 260).

Hence it is evilent that we must have recourse to foreign literature, for though the various species may be more or less local, the genus may often be cosmopolitan. $\Lambda$ more comprehensive view of the genus will give a better grasp of the species.

The queen-mother may be found about the middle of May. She is apterous, of a dark-olive colour, mottled with dark-bluish tints, like the gloss on black grapes. The ereature is considerably larger than any of her offspring, which may be found either along with her or after her death. The boly is slightly covered with a cottony exudation arising from a series of pores on the back. In comparison with the body, the head and thorax are very small. The antennie and legs are short, hence the creature is very helpless. The antennæ are composed of six joints, the third being nearly half the entire length. It is highly probable that those stem-mothers hatch from eggs laid the previous autumn.

The winged specimens may be found very plentifully by the middle of June in the rolled elm leaves. The body of the female is wholly black in colour: the eyes are also black. The third joint of the

${ }^{1}$ Insects Injurious to Forest Trees. Packard, U.S.A. 1890. 
antemm is very long, being considerably longer than all the other joints put together, and beautifully ringed. The wings are moderately long, and the cubital vein is but once forked, which is an important point in generic classification.

\section{TRIBE PEMPHIGINÆ.}

Closely allied to the preceding group are the Pemphiginæ or gallforming aphicles. The insects live sociably, but instead of rolling leaves, form galls, - growths which, from a structural point of view, may be considered ligher in the scale of organisation than rolled leaves. The curious abnormal growths, caused by insects belonging to this tribe, appearing on the leaf-stalks or midribs of leaves, often displaying beautiful colours, have received a great deal of attention from various workers. The galls themselves, differing from one another in appearance and position, give rise to specific characteristic distinctions, apart from the structural points of the respective insects themselves.

In comparing the characters of the two genera, it will be ascertained that the rostrums are alike, and the antenne similar, viz., six-jointed; but the sixth joint in Pemphiginæ is larger than in Schizoneurinæ. It is, however, in the wings that the most salient struetural difference may be recognised. The cubital vein in Schizoneurinæ is forked once, whereas in Pemphiginæ it is not forked, but in both genera the cubital vein is unattached to the cubitus.

\section{Genus Pemphigus.}

The following are the generie elaracters according to Buckton :-

"Rostrum as in Schizoneura. Antenne short, with six joints, omitting the nail-like process. Third joint about equal to the three following taken together. The third, fourth, and fifth joints conmonly ringed; the sixth joint longer than that of Schizoneura.

"Cornicles wanting.

"Wings with no furcated cubital vein, - this vein, as in the last genus, being unattached to the eubitus; stisma large and trapezoidal ; the two oblique veins usually start from the same point. The postcostal nervure of the hind wing somewhat angular, from which angle the two oblique veins spring.

"Legs short, particularly in the apterous forms." 


\section{Pempingus bunsaries (Hart.)}

This species is foumd on the leaf-stalks of poplar (fig. 261), chiefly on the black Italian species, the black burry poplar, and also on the young wooly twigs of the Lombardy poplar. The gall is smooth, globular, highly coloured, and with an opening at the side. In July or August the leaves, with galls on the foot-stalks, having fallen prematurely, may be jicked up, and the insects fomnd in all their respective stages of metamorplioses.

The stem-mother (fig. 262) is larger than any of her progeny. The legs are short, and the creature comparatively helpless. The antennx are four-jointerl, and the cornicles absent.

The larva (fig. 263) is of a very lightgreen colour.

The pupa (fig. 264) is of a pale-green

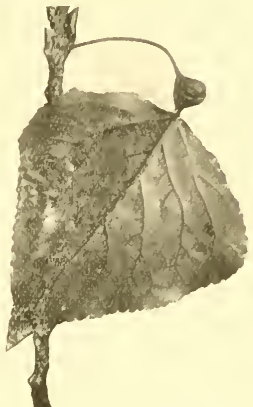

Hig. 261.-fioll wn lenf-strlli if popler entsed bis Pempligus bursarius.

colour, with a slight mealy dusting, and shows signs of wings at a very young stage. 'The antenne are longer than in the green aphis, but the joints are not easily distinguisherl.

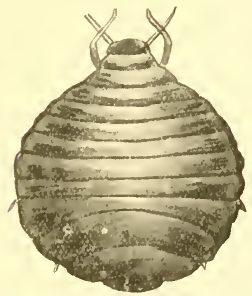

Fig. 262.- "Stem-mother" of Peniphigus bursarius. (l'rom camera-lucida sketeh.)

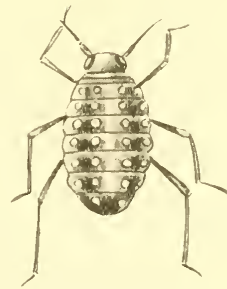

His. 263.-Larval stere of Pempligus bursarius. (From camera-lucida sketch.)

The winged viviparous female (fig. 26.5) is black, and the body and wings are dusted over with a white powdery matter. The antenne are six-jointed, the third joint being the longest; and the third, fourth, fifth, and sixth are ringed. Buckton says the sixth joint is smooth, 
but in the specimens I examined this joint was ringed like the others.

Common and harmful in Kent.

\section{Pemphiges spirothec.e (Koch).}

This speeies, like the preceding species, is also found on the leafstalks of poplar of the black Italian species (fig. 266), but it makes a

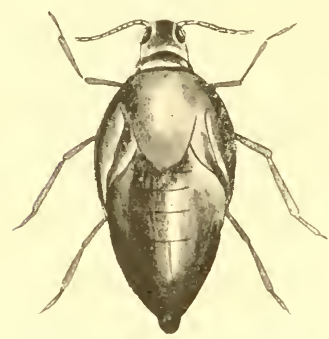

Fig. 264. - f'unal starte of Pemphigus bursarins. (From eamera-lucida sketch.) corkscrew-shaped gall. It is far from common, and very locally distributed. While living in Cheshire, I only found but one tree, growing on a bank alongside a brook, which annually yielded me a good crop of galls. The queen aphis punctures one side of the leaf-stalk to obtain nourishment, and the stalk in consequence bulges on the opposite sile. The gnawing and bulging causes the stalk to form a corkscrew - shaped gall, where the stem-mother and her progeny find a home and shelter in the folds. As the fully developed insects are about to escape the galls become more elastic, and

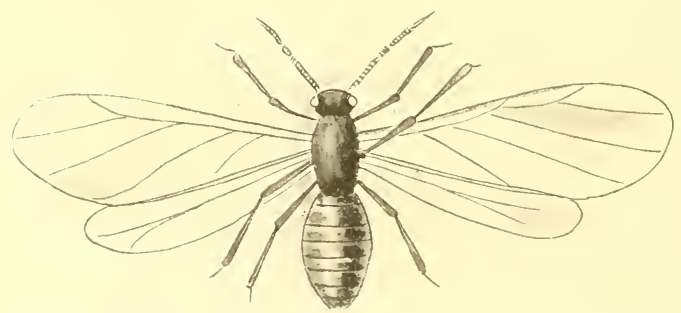

Fig. 265. - Winged form of Pemphigus bursarius. (From camera-lucida sketch.)

open easily. The gall is of a dull-green colour, and may be looked for from June to September.

The most ahundant crop of those galls I have ever seen was at Peterborongh, on the Lombardy poplar. 
The insects are smaller than those in the preceding species, and differ in a few minor specific points.

\section{Peuphigus palidous (Haliclay).}

In fig. 267 an illustration is given of $P$. pallirlus, which forms galls on the midrib of wych elm. The specimen from which the photo-

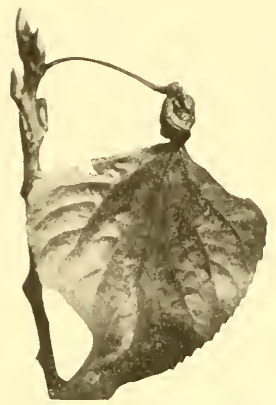

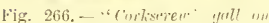
lerif-stulh of jusplar sorised by Pemplingus sjirothece.

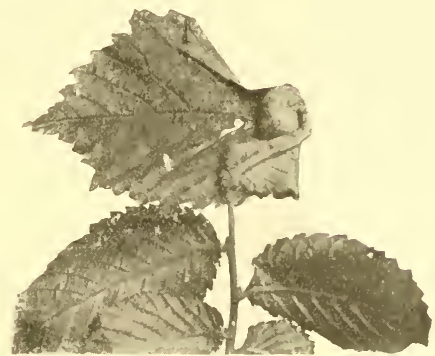

Fig. 267.-f'ull of Pomphigus pallidus mm midrit, of lenf of ungrh ilm.

graph was taken was found in High Legh, Cheshire, where it was very common.

The fully developed insect is somewhat variable in size. The hear and thorax are black; abdomen yellow; eyes rerl; antenne darkishbrown.

\section{Tetraneura ului (I) Geer).}

Closely allied to the Pempligus, and belonging to the same tribe, is the genus Tetraneura, with a single species, Tetraneura ulmi.

The galls of this species are found on the upper sile of elm leaves (fig. 26s) about the midlle of May. They are nearly one-fourth of an inch in length. I have frequently found the galls projecting from the folded portion of the leaves injured by Shrizonoura ulmi. Thus we get two species very closely allied entomologically, and practically united botanically. The entrance to the galls of Tetraneura is well closed, and guarded by hairs which doultless act as a protection against parasites. 
As compared with the preceding genus, the rostrum is comparatively short, the antenne short and six-jointed. The wings are similar to those of Pemphighs, "except that there is only one oblique vein in the lower wing."

The gall attains its full size prior to the complete development of the insect. The antennæ are four-jointed, the rostrum rather long in comparison with the body, and legs slightly hairy. Colour lark oak,

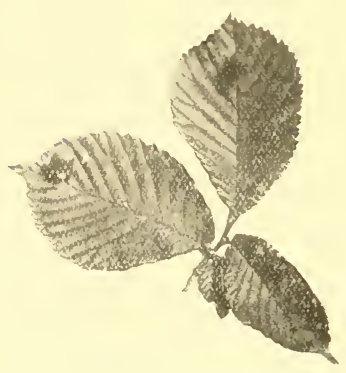

Fig. 268.-Golls of Tetraneura ulmi on leares of elm. and the insects very sluggish. In several places in the south of England it is very injurious to the foliage of isolated elms.

\section{TRIBE CHERMESIN 无.}

Perhaps in the whole realm of forest entomology there is no tribe of insects which presents such peculiar difficulties as the Chermesinæ, inasmuch as it is most difficult to present the biological importance, as revealed by the present state of our scientific knowledge, and the exact diserimination of our so-called species in such an amalgamated form as will be correct to the scientist, and also intelligible to the practical man. In other words, we have, in this group, two problems to face-viz., the alternation of a species from host-plant to host-plant, and on the other hand the determination of the so-called species on their respective host-plants as associated with their own peculiar injuries.

First, let us consider the alternating generations as given by Jucleich and Nitsche, ${ }^{2}$ and more recently by Niisslin ${ }^{3}$ from Cholodkorsky. In the former, two classes are given-viz., (1) Continuation or remaining on spruce, with clear parthenogenetic reproduction; (2) partly emigrating from the spruce to the lareh, with parthenogenetic or sexual reproduction. In the latter, which has been carefully worked out by Cholodkovsky, the gist of it may be summed up as follows:-

Typically the Chermes on spruce show five generations and an

${ }^{1}$ A detailed study of the tribe Chermesine, together with its associations as regards difficult problems in forestry, is at present being done by Mr E. R. Burdon, Cambridge University.

${ }^{2}$ Forstinsektenkunde.

${ }^{3}$ Leitfaden der Forstinsektenkunde. 
exchange of host-plant. Though the principal host-plant is always the spruce, only one generation belongs exclusively to the spruce. Other species on Scots pine and silver fir are (so far as our present knowledge appears to show) peculiar to themselves. This change of conifers referred to other than spruce is known as the intermentiate comifer (Zwischenkonifere) only in so far as the former brings: about the transport of the species, through the laying of eggs on the intermediate conifer, in order that they may return to the suruce. This changing of the insect from one species of tree to another is a most important point, as it clearly implies that this alternation is for the welfare of the species. This shows that it must have been difficult to discover and ratify by those Continental workers, and even difficult for the student in this comtry to verify.

The following is a short account of the alternation of the species on spruce known as $C$. vivitis, as given by Niisslin : '

"The 1st generation (fonndress) is a parthenogenetic female, wingless, with three-jointed antennæ, confined to the spruce and producing the spruce gall. The 2nd generation (migrans alatu) acquires wings after the fourth moult, receives at the same time five-jointed antenne, compound eyes, and three simple eyes. It develops in the gall on the spruce, and flies usually to one of the 'intermediate conifers,' where it lays its eggs on the needles. From these eggs springs the 3rd generation (emigrans), which resembies its ancestor of the 1 st generation (the foundress). It remains on the alternate host (the 'intermediate conifer') for hibernation, and lays eggs there in spring. From the eggs emerge either forms resembling the parent (exuluns) or the th generation (sexupara), which in every respect resembles the generation before the last (its 'grandmotherly generation'), the migrans alat", only it remains smaller, and is less prolific. From the beginning it is independent (fieilebend), and after the first moult varies somewhat. It lives and develops on the needles of the 'intermediate conifers,' and flies back to the spruce, where it lays eggs on needles. Out of the eggs come the two different forms of the 5th generation (sexuales)- the leaner males and the stouter females. Both are rather small, but do not diminish in size, and have four-jointed antennæ. The female, after pairing, lays in midsummer a single fertilised egg on the spruce, from which emerges the hibernating foundress. The fivefold cycle requires, therefore, two years and two different coniferous species for its completion.

1 Leitfaden der Forstinsektenkunde. 
"According to what has just been sail, we have in the Chermes cycle only three principal (chief or leading) forms-viz. :

1. The parthenogenetic (non-sexual or asexual) wingless form.

2. The parthenogenetic (non-sexual or asexual) winged form.

3. The sexual generation with male and female.

"But in reality the number is increased, as each of these forms varies more or less in the $3-4$ moulting stages. Especially does the appeanance of the insect change between the first and the last stage of the parthenogenetic winged form (migruns uluta)."

The question of how to form a precise recognition of the different species, and the various stages of the same species, is somewhat difficult to determine. It would be advisable to boil and stain the respective mother Chermes, as found on different food-plants, and compare their minute structure, such as chitin plates, wax glands, antennæ joints, legs, and so forth, together with the colour of the eggs and general habits of the creatures. In addition to this microscopical investigation, it would be well for the student to isolate the insect and the host-plant in order to verify the respective life-history stirges.

Secoml, as regards the so-called species, it would perhaps be well to consider them separately in the usual way, both as to their relation with other closely allied insects and the clamage on different trees. Hence, so far as the practical man is concerned, they may now be considered in the ordinary manner of genus and species.

\section{Gemus Cherues.}

This genus is exclusively arboreal, and the respective species are confined to conifers. They come near to the Coccidæ or Scale-Insects in point of anatomical structure, and nearer in general appearance of damage than any other tribe in the whole family. Thus the snowy appearance presented by the felt scale on beech, and the white fluffy matter on the stem of silver fir and Weymouth pine, are to the naked eye practically identical. The difference between the two families can only be decided by microscopical examination, and in fact, hetween the respective species of this genus, can only be decided by the most careful microscopical examination.

In structure the genus Chermes is characterised by the upper wing having three oblique non-furcated veins, and the under wing a single 
oblique vein. The antenna are normally five-jointed. The rostrum is very short, being used exelusively as a feeling-organ, and not specially for anchorage. The creature develops three or more long hairs, or setre as they are termed, by means of which it maintains a hold on the bark. In this respeet it very nuch resembles the Diaspinæ, or seale-insects, on the ash, alder, willow, \&c., as in both families the ereatures may be seen langling in the air, after they have been detached from the bark by birds or other natural enemies. There are no cornicles. The parthenogenetic females seerete wax, and for the most part show, on eareful examination, cleariy marked chitinous plates.

\section{Symopsis of the specien.}

Producing eomparatively large galls on the terminal and lateral shoots of the spruce (Picea exrelsa). The shoot often extenis beyond the gall . . . . . C. viritis.

Producing comparatively small, hard, elose galls on the teminal buds of twigs of spruce, and always arresting subsequent growth . . . . . . . C. strobilobius.

Prodncing a white covering on the stems or foliage of comparatively young larch-trees . . . . C.laricis.

Produeing a white covering on the twigs or branches of young Scots pine or Austrian pine . . . C.pini.

Producing a white covering on the branches or stems of Weymouth pine . . . . . C. corticalis.

Produeing a white covering on the stems or foliage of silver fir (Abies pectinata) or Abies Nordmamniana . C. picee.

\section{Chermes viridis (Ratz).}

This is a gall-forming species on the common spruce (Picen excel*a), the gall being in appearance like a pine-apple or pseudo-cone of Scots pine (fig. 269), each abortive shoot terminating in abortive leaves.

The structure of the gall varies, as in some cases it surrounds the young shoots, and arrests or retards future growth. At other times it may be found on one side of the shoot, thus doing only partial damage. When the leading shoot is attacked, the young tree is often very much injured. This variation of gall-formation is sometimes put down as the work of different species of Chermes. 
Let us try and follow the life-history of this species with its somewhat complicated life cycle. ${ }^{1}$

Generation I. The Foundress. - The first appearance of the gall may be looked for, according to season, about the middle of April. This is recognised by a small white speck at the tip of the shoot (fig. 270), in which the mother Chermes may be found depositing her eggs. This mother Chermes was hatched from a fertilised egg in autumn, and spent the winter months in the larval stage. In the spring the awakened larva began to feed, and after three moults she became the adult foundress. In about a month's time, after the first

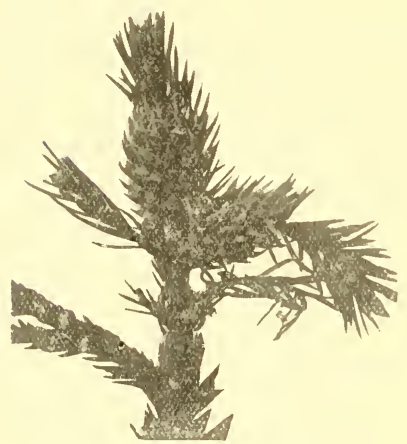

Fig. 269.-Gall of Cltermes viridis on spretere.

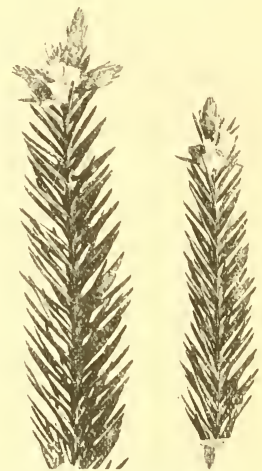

Fig. 270,-Early stage of glall of Chermes viridis on sprince.

appearance of the small white speck, the mother Chermes may be found surrounded with eggs. It will be found that the cottony down has increased in quantity, the young shoots developed from $1 \frac{1}{2}$ to $2 \frac{1}{2}$ inches in length, and the pseudo-cone or gall itself from $\frac{3}{8}$ to $\frac{1}{2}$ inch in length, whence arise deformed leaflets about $\frac{1}{8}$ inch in length.

The young larva are hatched outside the psendo-gall, which begins to enlarge before the larvæ are hatched out, and it is not quite clear how the vegetable structure reacts against the insect; but the gall slightly opens at the slits, and the young larvæe creep in. Afterwards

1 Having regard to the fact that this Tribe of insects has not yet received, in this country, the special attention required, the brief notice here given is merely an introduction to a very complicated subject. 
the gall closes up, and the transformations take place within the gall. It is computed there are about 2000 inhabitants to each gall.

From the middle of June to the end of August the winged specimens may be found emerging from the gall. They are very sluggish in their movements.

The "pupal" form presents a reddish-brown-coloured creature, whose borly appears "all made up of a piece." The eyes are of a darker brown colour than the body. The antennæ and legs are short, and the wing-eases slightly greenish; but specimens differ very much in colour. As might be expected, the insect is more or less corered with a resinous exudation.

The winged imago is of a golden brown colour, which deepens very much with age. The head is broad, and the eyes dark brown. The antennæ are short and five-jointerl, the last three joints being peculiarly straight on one side. The prothorax is comparatively broad and large. The abdomen is oval-shaped. Specimens mounted for some time show the abdominal segment to have a rather broken outline, and ending in a short ovipositor. The wings are comparatively broad, and vary in colour from a light to delicate greenish tinge. The renation is typical of other Chermesinæ.

One half of these insects fly to the larch and deposit eggs on the foliage, the other half remain on the spruce. This is the second generation known as Winged Migrants.

Generation II. The Winged Migraxts.-These winged adults just referred to deposit dark-green eggs on the needles of the larch, together with much white fluffy matter (see fig. 274). From these egrgs larvæ hatch in the autumn, which develop in Generation III.

Generation III. The Coloxists. - The larvæ just referred to suck the needles of the larch for a short time, but as the winter approaches they leare the foliage and insert themselves in the crevices of the bark of the larch. To some extent their presence may be recognised by a white woolly covering (fig. 2i2), and so the first year's wanderings are encled.

In the spring of the following year the creature moults three times, and then deposits bright yreen eggs. From these eggrs are hatched larvæ which develop into the adults of Generation IV.

Generation II. The Sexupar.e. - This is the generation which precedes the sexual generation. 
About the middle of September many insects will be found depositing eggs on the leaves, as seen in fig. 271 . In some cases an insect is found on almost every leaf. The head of the insect points towards the base of the leaf, and she generally places herself fairly near the base of the leaf. After lepositing the eggs the female dies, but the dead body is so placed that it forms a protection for the eggs. It

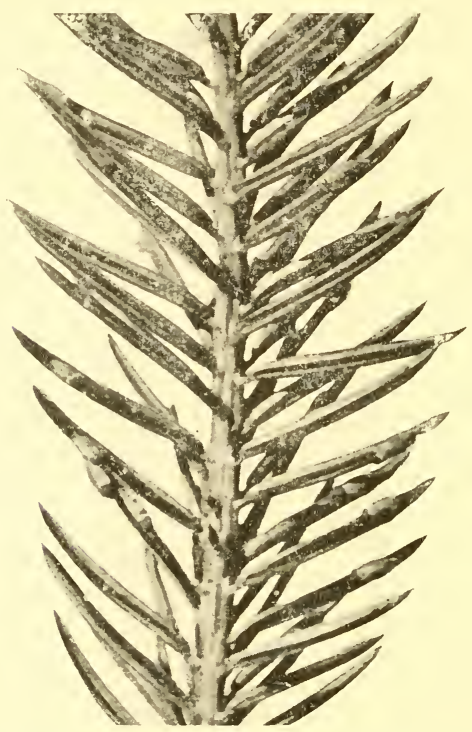

Fig. 271.- Hinged forms of Chermes abietis on spruee leares (enlarged). Found in antumn. This stage should be carefully studied, as it is considered the sexupure stage, which again produces the sexucl stage.

should be noted, however, that the eggs are not thrust ontside the body, as Ch. laricis, but on the contrary the ovisac is slightly extended and placed bodily on the leaf prior to the death of the creature.

These insects just referred to are, according to alternating generations, the return generation from the intermediate conifer. 
Generation I.-From the preceling generation we get males anl females, both sexes being wingless anl exceelingly minute. The fertilised female lays one egg, whence hatches the larva which develops into Generation I., and which remains at the base of the bud during the winter, producing in spring the appearance as in fig. 270 .

\section{Cinermes abietis (Kalt.)}

In dealing with Chermes virulis it was noted in Generation II. that one portion of the winged specimens proceeded to the larch and a portion remained on the spruce. The latter make galls on the spruce smaller than Chermes viritis, and the galls are said to be ripe in July. In other words, this species always remains on spruce.

\section{Chermes strobilobius (Kalt.)}

It is quite possible that this species has, by the practical man in this country, been hitherto confounded with Ch. abietis. The structural features, as illustrated by Judeich and Nitsche, do not show any strong salient points of difference, and in the absence of knowledge on the part of the student regarding verification of the alternating stage, it would he well to recognise the difference in the structure of the galls. In C. strotilobius we find the galls smaller, globular in form, and in colour resembling the unripe fruit of the wild strawberry. The development of the gall is such that leaves do not project beyond the gall. In the German literature it is said that there is a marked difference as regards the "over-wintering" (uberwintern) of the two species, inasmuch as in $C$. alinetis the stem-mother (Fundutrix) passes the winter at the base of the bud, whereas in $C$. strobilobius the creature winters in the top of the bud. It is therefore suggestive that the initial action of the respective insects produces the variation of gall structure.

As regards the life-history of this insect, it may be said that in a general way it compares with Chemes virilis. One chief point may be noted-viz., the wintering stage of Generation III. In Ch. viridis this stage hybernates on the bark of larch and deposits green enys in the spring. In Ch. strobitolius the wintering stage is at the base of larch buds, the eggs are of a light brown colour, and the mother free from wool. 


\section{Chermes laricis (Hartig).}

This species, considered as distinct for the practical man, and the remaining species of Chermes differ from the preceding, inasmuch as viritis is gall-forming, and those about to be considered protect themselves by a woolly covering. The evidence of the presence of virilis cannot in a general way be recognised by the naked eye until we find a white speck in late spring. This speck reveals the abode of the queen-mother. With regard to Chermes

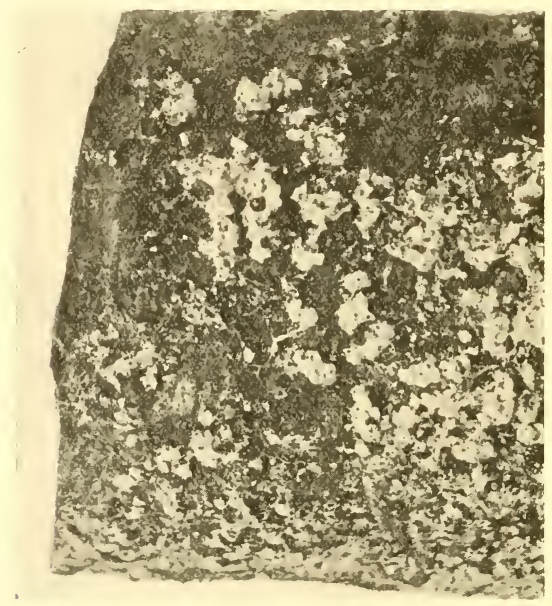

Fig. 272.-Chermes laricis on brirk of lareh.

laricis, on the other hand, considered as a distinct species, the queenmothers may be found throughout the whole of the winter months on the stems of young infected trees, their presence being indicated by the cottony covering on the stems ${ }^{1}$ (fig. 272). This is no doubt

1 Mr Theobald, in correspondence, says: "You cannot trace a single one on the stems in South England, where laricis swarms. The trunk aphis is found in Lincolnshire. There is no doubt it is different, and that there are two allied species." 
the main harbourage, but many specimens nay also he found hibernating just underneath the leaf-seales. ${ }^{1}$

In Cheshire, by about March 25, the queen-mothers may be found just beginning to make "a move." At this time they are very small, and much resemble the larve hatched out from eggs later on in the season.

The antennæe are very small, and partly hidden. They are three- or four-jointed, but the joints are not easily determined by the inch objective. The rostrum is short and stiff, with very long attached setre. The legs are short, and naturally not seen outside the bodily circumference. The tail is short, but is used by the insect in arranging her eggs, with which she ultimately becomes halfburied.

The eggs on the stem are freenish in coloni, glued together by a resinous turpentine, and further attached to each other and to the plant by delicate threads.

The larval forms which hateh from the eggs are mere pin-points in size, and a

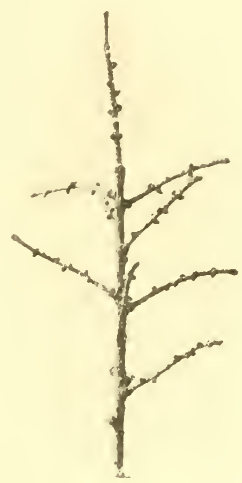

Fig. 273.-Foliage of lareh arrestod in development by severe attach of Chermes in early summer.

darkish colour. They spread themselves all over the tree, and do immense damage by sucking the juices of the plant. When numerically very strong, together with those arising from the buds, as in some local spots, they entirely defoliate, or rather retard the development of the foliage--so much so, that the severely affected trees may appear quite naked when others are in full leaf (fig. 273).

Later on during the summer the green leaves are heavily dusted with white-so much so, that they would appear as if covered with a slight shower of snow (fig. 274). If each speck be examined individually, it will be found that it is composed of mother and eggs covered by the white exudation.

1 The two forms-viz., those on buds and those on bark-are quite distinct. The latter is considered as one of the stages of $C$. viridis, and the former as one of the stages of $C$. strobilobius. 


\section{Chermes pisi (Koch).}

This species is found on Scots pine and Austrian pine. The white specks are generally found on the stems or branches of young trees, and also on the shoots (fig. 275). To follow ont the life-history of this insect, the lark-brown queen aphis shonld be looked for in May; and by June she is covered with brownish-yellow pedunculated eggs,

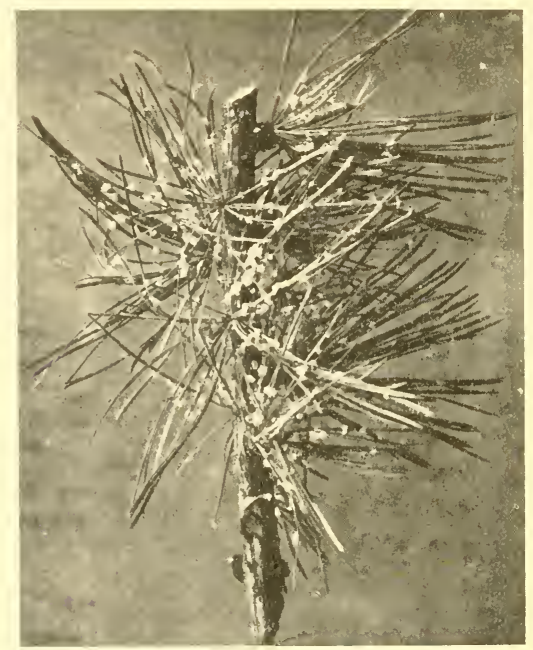

Fig. 274.- Chermes laricis on foliage of larch.

which soon hatch out into very active larvæ. The insect protects herself with long white silky filaments.

In early spring the white cottony matter covers the young shoots, as seen by fig. 276. It will also be observed that in this case, which is purely a typical example of severe damage, the shoot is considerably bent as compared with unattacked shoots, which are perfectly straight. In many cases, however, healthy trees recover from attacks of this kind and no serious injuries accrue, but, on the other hand, as will be seen from fig. 277, many of the young shoots die from the 
attack. This fig. was photographed from a plantation which was not in a very good state of health. If, as a rule, the health of the erop is fairly good, the trees "throw off" the attack, and no appreeiable damage is done. It is often found on young Scots firs in the nursery-lines, but if the general health of the plants is good they will soon get over the attack.

\section{Chermes corticalis (Kalt.)}

This species is very common in the south of England on Weymouth pine, and is said to do very great injury to the trees. It has

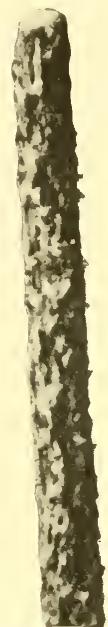

Fig. 275.-Chermes jini in stem of young Scots pine.



lig. 276.-Chermes pini on terminal shoot of scots pine.

been notably sent me from the sandy soils of Surrey, and I have found it bad on one tree in Kent. Fig. 278 is taken from a branch of Weymouth pine in a garden in Cheshire. I have not found this speeies in Northumberland, ${ }^{1}$ so that I am unable to give any description of the ereature.

${ }^{1}$ Quite recently Mr G. Ross, Hexham, sent me a specimen from Riding Mill, Northumberland. 


\section{Cherues PICE.e (Rtzb.)}

The bark-louse of the silver fir (die Tannenrindenlaus of the German) is very lestructive to young silver firs, comparatively young specimens of Alies Nordmanniana, and even fairly old trees of Alies nobitix. Fig. 279 is taken from the bark on a silver fir tree of about

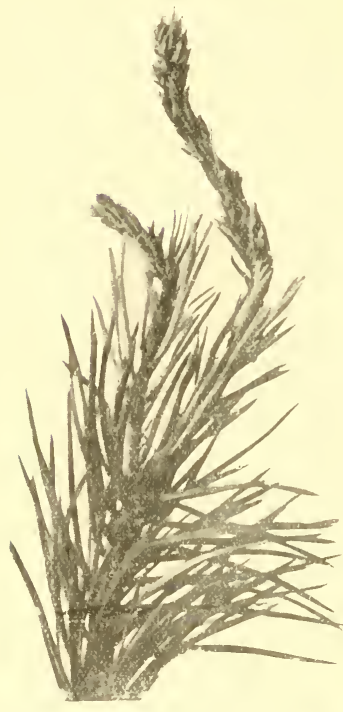

Fig. 277.-Terminal shot of sicots pine killed byl Chermes pini.

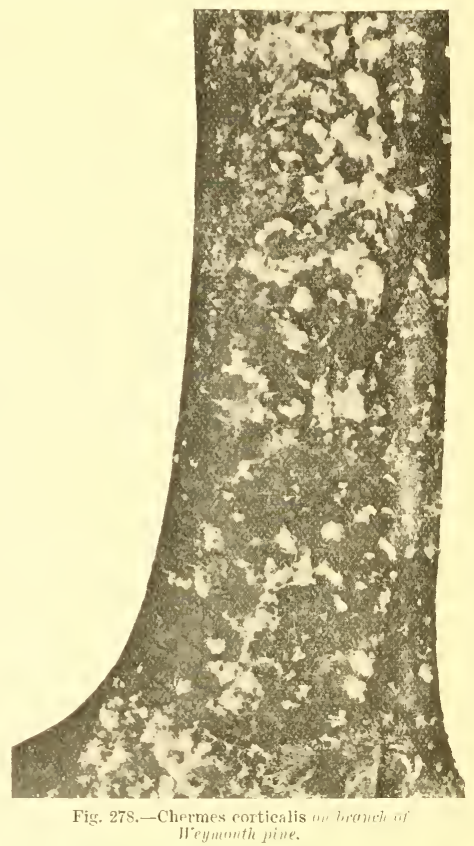

II eymunth pine.

thirty years of age. specimens of young silver fir trees in nuserylines are often killed ontright by this insect. It is considered that the last three species have no intermediate host.

It is to be hoped that the above account of the genus Chemes will show that they are of very great importance from an entomological point of view, and that much subsequent study is required in order 
to fully elear up the life-history of this hitherto partially studied genus. The aspiring student should therefore collect the various species of what hitherto has been termed stem-mothers on different trees, boil them in canstic potash, and stain with Crawshatw's magenta penny dye, as recommended for scalc-insects, and try to verify the various minute points of structural difference as shown in fig. 280 from Juleich and Nitsche, earefully noting and tabulating the results of his observations. Such a method would obviously be highly interesting and important, as in searching for the various anticipated alternating stages of the same insect on different trees, confirmation of the same creature changing from host-plant to host-plant would obviously be ratified.

Importance of the Genus Chermes in Forestry.

This genus is exclusively arboreal, and should be specially studied from a practical and scientific point of view. To the scientist the various species of insects change from one tree to another, and thus our so-called species are simply various stages of the same insect. But the practical man, often indifferent to specific distinctions, recognises the injurious effects on certain trees, and thus prefers to identify the species as coincident with the food-plant. Thus Chermes laricis may often be found very injurious to young

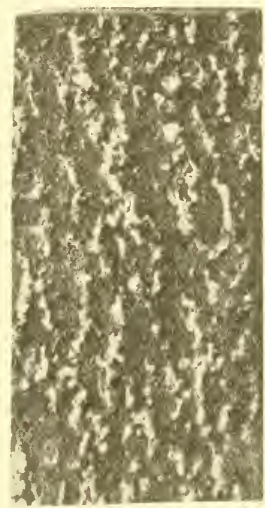

Fig. 279.-Chermes picea " bur of silver tiv.

larches of from ten to fifteen years of age, more especially on those trees growing in hollows or in damp spots; Chermes riridis on sprucetrees which are not growing in suitable places, and often in young spruce-trees in the nursery-lines; and Chermes picece is often found on young silver firs in the nursery, and on young trees of $A$. Nordmanniana. C. strobilobius is perhaps more destructive to young trees in the wood, especially those too much overshaded and not thriving well. The dead galls adhere very elosely to the twigs, and can often be seen after the infested tree is partially dead.

Now the question is, how are we to deal practically with those 
pests, having regard to recognised systems of "mixing" with those very trees which act as host-plants in the alternation of the species? Nuch has yet to be learnt from good sylvicultural conditions, careful work in planting with well-rooted plints, and also from experiment and observation. Take, for example, a suggestive case in point-viz., the growing of young silver firs. On many estates very fine examples of old silver fir trees can be found, and the modern forester with his high-class sylviculture cannot grow it. Without giving any definite opinion, much might be done in the younger stages by growing under shade of hardwoods in the nursery-say, plant a row of hardwoods, two or three rows of silver fir, and again a row of hardwools, and so

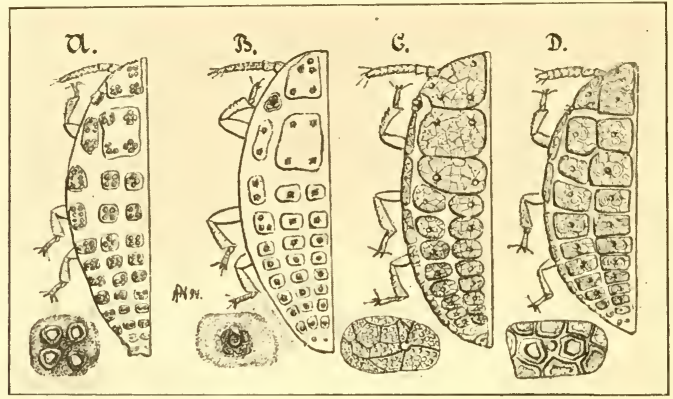

Fig. 280.-Hibernating wintor forms of four species of Chermes.

A, C. abietis; B, C. strobilobius; C, C. coccineus; D, C. siliricus; together with a highly magnified single chitin plate of each species. Copied from Judeich and Nitsche.

on throughout the nursery plot. ${ }^{1}$ Perhaps, also, an exception may be made to the general rule of much transplanting in the nursery. 'This tree should not be too often moved, but plants should be specially carefully taken up when they are lifted. Again, when transplanted in the forest, the silver firs shonld not be planted in the open, but as shade-bearers in late filling up, or otherwise solely as under-planting.

Then as regards the injurious effects of $C$. viritis as compared with C. strolitobius, it may be said, so far as real injuries are concerned, that the former is often injurious in the nursery-lines, more especially to those plants standing in the rows for three consecutive years, and

${ }^{1}$ I have found that Silver fir plants grown in this manner were free from Chermes, whereas plants of a similar age grown in the open in the same plot were killed outright by Chermes. 
the latter, as remarked, on comparatively young trees. As regards remedies for C. vividis in the nursery, this is a very good case in point where good husbandry is advantageous both to the seller and purchaser. A general saleable age of the spruce plants is five years-namely, two years in the seed-bed and three years in the rows, - 2 yrs. 3 yrs. of the nurseryman. When transplanting from the seed-bed they are, of course, placed very thickly in the rows, and if they do well, are useful stuff as 2 yrs. 2 yrs, but when unsold the nurseryman must either leave the crop as it is or otherwise compromise matters by interlining. The latter method does not give relief between plants, and the consequence is that they are afterwards weakly-much to the advantage of the Chermes. Again, three years in the nursery-line is conducive to bad roots, which, eoupled with the depreciation from the insect attack, means a very poor class of plant to the purchaser.

Hence, in order to maintain health and vigour, the practical remedy is, at the end of two years, transplant again for another two yearsprovided, of course, the seller could secure purchasers who recognise that quality and not cheapness is the essential of success. By doing si on suitable soil, we should get a better plant, and thus lessen the attack of the Chermes. This could always be done on private estates.

Another point in connection with the planting of spruce in the young woods associated with Chermes may be mentioned-viz, that in some paits of the counting the spruce should not be planted in the open amongst the more hardy species, but used more as an after-plant for filling up. In the latter case it will thrive better, and though attacked by C: rivilis, does not suffer to any appreciable extent, inasmuch as on vigorous plants the galls are often considerably on one side of the shoot, and thus the subsequent growth orercomes the attack.

Another point in connection with Chermes and practical furestry may be mentioned-viz., that it has been asserted by some obsercers that the mother Chermes on larch inomlates ${ }^{1}$ the tree with the spores of Peziza, which is the fungus causing the well-known "larch disease." Hence it would obviously appear that a mixture of spruce ancl larch would favour the insect, and consequently be conducive to the sprearl of larch disease. So far as the mixing of spruce with larch is collcerned, this theory does not square with actual results, inasmuch as

${ }^{2}$ It is just possible that the wounds caused br the insects form suitable sporebeds, just as apple canker will develop in the wounds of S. lanigeru. and can ouly do so in wounds. 
many instances of the "mixture" referred to may be seen throughout the country, where, with spruce as an undergrowth, the larch is practically free from disease, and likewise a very good commercial crop. On the contrary, it is just possible that the under-crop of spruce in a larch plantation, acting as a soil-protector, may have proved a great health stimulus to the larch crop, forming greater increment, and thus probably renderimy the larch less liable to clisease, inasmuch as the vigour of the larch is encouraged and the dreaded effects of the disease considerably minimised. Where spruce is used as a mixture with lareh it would be well also to add a sprinkling of beech, because the addition of beech foliage as surface litter considerably improves the soil conditions by accelerating decomposition, and the manurial action of the humus is therefore intensified. But while improved sylvicultural conditions may do much for the prevention of insect or fungoid diseases, it must not be inferred from the above remarks that spruce is the best mixture with lareh, though it nust be borne in mind that larch is not a suitable tree to grow as a pure crop, ${ }^{1}$ more especially after the cropl of young larches has passed throngh the pole stage.

It might again be noted that this genus is, in general appearance, practically ilentical with several other insect damage. Thus, for example, Chermes corticalis may be common on Weymouth pine, and Crmptocorcus fay $i$ abundant on adjacent beech-trees; hnt the one is an Aphis and the other a Scale-two quite distinct insects. Now this is very important to the entomologist; but it is often of far more practical importance to the owner of trees, inasmuch as the imperfectly trained entomologist is apt to make wrong dednctions and prescribe erroneous remedies. For example, I once knew of an expert entomologist advising a landed proprietor to cut down Weymouth pines as a remedy for the injuries of Cryptococeus far $i$ on beech, - a most absurd remedy, seeing that the two insects have no connection whatever.

\section{Genus: Phylloxera.}

Hitherto only one species has been found in this country, and the generic characters may be characterised by moderately

1 These remarks may be criticised by practical men, but in some cases the suceess of this "mixture," as showing the absence of "lareh disease," can be seen in certain parts of the south of England. 
long rostrum in the winged form, their jointed antennæ, eyes small, legs very short, and tarsi apparently single-jointed, with a double claw and pad. In this respect they eome very near in structure to the Cocidie or "seale-insects." As regards the wings, they are decidedly of aphidian strueture, inasmueh as we get a well-marked cubitus, whence spring their straight veins.

\section{Pliyllwere punctata (Licht.)}

The damage aceruing from this insect is often very conspicuous in a general way, and, except to the searching eye of the naturalist, the inseet itself may be easily overlooked. During the latter half of the summer the oak leaves begin to take a very sere colour, and thus we often hear it remarked that the drought is playing havoc with the foliage, or that winter is setting in early. Now the eause of this is due to our aphis, Plygllarerce functata, - a creature closely allied to the dreaded pest of France, and found abundantly on the under side of the oak foliage (fig. 281).

The yellow spots are caused by the mother aphis and her eggs or progeny, which surround her in concentric cireles. The mother has a very long ovipositor, by means of which she arranges her eggs.

The queen-mothers may be looked for early in June or latter end of May under a very small pucker, which might

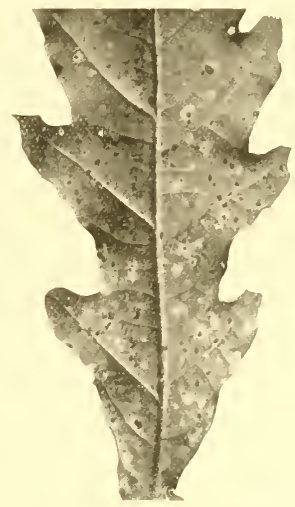

Fig. 281.- L mer side of ool iw $\mathrm{im}$ fested with Phylloxera punctata.

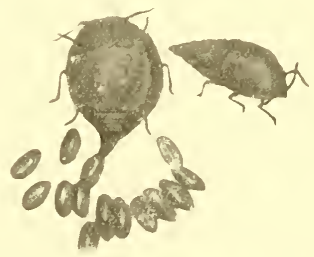

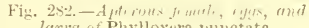
lerea of Phylloxera punctata. be mistaken for the beginning of some species of gall.

The female (fig. 282) in the centre of the yellow spot is a comparatively small creature, with flask-shaped body of an amber-yellow colour spotted with red. Head rather broad; eyes small; thorax harlly separable from abdonien, which terminates in an obtuse ovipositor; antennie three-jointed. 
Prior to hatching from the eggs, the eyes of the larvæ are very conspicuous. When first hatched they are of a yellow colour, with scarlet eyes and white antennæ and legs. It is said they moult four times before assuming the "pupal" stage. They are of a long oval form, of a gamboge-yellow, becoming darker with age, and variegated on the abdomen. The legs are short.

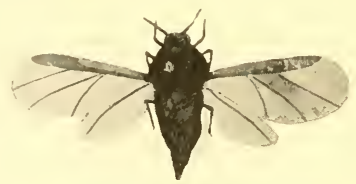

Fig. 2s3.-II'inged form of Phylloxera punctata.

Fig. 283 is a representation of the winged form.

My observations of this insect were made in Cheshire, where it was quite harmful. I have never found it in north Northumberland, but it is often met with in the south of the county, just on the borders of Durham.

\section{References to Literature consulted.}

Börner, Carl. Eine Monographische Studie über die Chermiden.

Buckton, G. B. Monograph of British Aphides. Ray Society.

Burdon. Some Critical Observations on the European Species of the Genus

Chermes. Journal of Economic Biology.

Judeich und Nitsche. Forstiusektenkunde.

M'Dougall, R. Stewart. The Geuus Chermes, Board of Agric. Jour., Sept. 1909. Niisslin. Leitfaden der Forstinsektenkunde.

Patch, Edith M. Chermes of Maine Conifers.

${ }^{1}$ I have recently found it at Pauperhaugh, Northumberland. 


\section{CHAPTER VIII.}

\section{Part I.}

\section{P S Y L L I D 㞋}

CONSIDERED as a distinct gromp, this family of insects is very easily overlooked, even by workers who have a fair knowledge of economic entomology, inasmuch as they may be mistaken for the Aphididæ or green-fly on the one hand, and the Cicadidæe on the other.

The following may be taken as the chief characteristics of the group : Head produced in front, but somewhat broad; eyes large and prominent; three ocelli present, one elose to each eye and the third in the middle of the forehead. Antennæe inserted in front of the head, usually ten-jointed, with two large basal joints, the remainder of the joints filiform, and terminated by a slender forked bristle.

The thorax is well developed. The wings, when at rest, are folded roof-wise over the body. As the wings are nearly all equally clear, they may be termed four in number, and not elytra and wings. The venation of the upper is very simple. The subcostal vein passes obliquely across the wing, ending in a small inclistinct stigma, and dividing the whole wing into seven distinct open cells.

The front pair of legs are rather shorter than the other two pairs. All legs are well formed for leaping. The tibir in the second pair of legs are somewhat longer than in the first pair, and still longer in the third pair. In the hinder pair the tibire have a few blunt spines at the apex. The tarsi are two-jointed, and terminated by a distinct claw. In the hinder pair of legs, the second joint of the tarsi, like the tibir, have also a few blunt spines. There is a very noticeable peculiarity in the adult insects on the food-plant-viz., that they take to flight very reluctantly from approaching danger, and seem to depend almost entirely on their leaping powers as a means of escape. 
The abdomen should be carefully noted, both as fresh or prepared specimens, as the genital segments are so clearly defined that the sexes are very easily determined, more especially if a side view be presented.

The development of the creature, from its early larval stages to the winged insect, forms a most interesting study, and should also he examined both as fresh and as prepared specimens. The former will show the wax cells, the latter the structural features. Witlaczil describes four distinct larval stages from embryo to imago, and the student will be well repaid by following up the development.

As regards classification, it may be noted that Dr Franz Löw, in his paper "Zur Systematik der Psylloden, 1878," divides the family into four sub-families - viz., Liviinæ, Aphalarinæ, Psyllinæ, and Triozinz. So far, however, as forest insects are concemed, the subfamily Psylline are the most important.

The Psylline are again divided into two genera-viz., Psyllopsis and Psylla. In the former genus we have two species on ash-trees, and in the latter there are several species found on different trees.

\section{Psyllopsis fraxinicola (Fuirst).}

If the foliage of our large ash-trees be beaten over an inverted umbrella during the summer months, we shall find a very large number of green Psyllidæ, amongst other insects. These are Psyllopsis fraxinicola. They cannot be said to be injurious to the foliage to any appreciable extent, inasmuch as they simply suck the juices, and do not deform the leaves in any way whatever.

The whole body of the insect is of a pale-yeilow colour, the tips of the antennze and the claws of the feet being often darkish-brown. Length $3 \mathrm{~mm}$.

\section{Psyllopsis fraxini (Linn.)}

In early summer the foliage of the young ash-trees in the nurseryrows is often rolled up, as shown in fig. 284, the main characteristic feature of the damage being that the whole of the compound leaf is injured. Sometimes a single componnd leaf springing from the stem may only be affected, and at other times the damage is so bad that almost the whole foliage is injured. As this injury appears most conspicuous just when the plant is most active, it is obvions that the growth must be appreciably affected. A careful examination will 
show that the individual leaflets are rolled towards the centre in a somewhat oblique manner. The natural green colour of the leaf is substituted by large brownish mottled streaks. As long as the injured foliage is attached to the plant, the leaflets are comparatively stiff; but if removed from the stem, they soon get as flabby and tender as tissue-paper.

If the leaflets are nnfolded we find a large quantity of "cottonwool," protecting larve and eggs. This diversity in the phases of development is therefore suggestive of the adult insects subsequently appearing at varying dates.

As regards larvæ and pupæ, it is difficult to determine where the one stage ends and the other begins, except that after one or two larval moults the wing-cases are more fully developed, and the latter stages may therefore he tormed pupe.
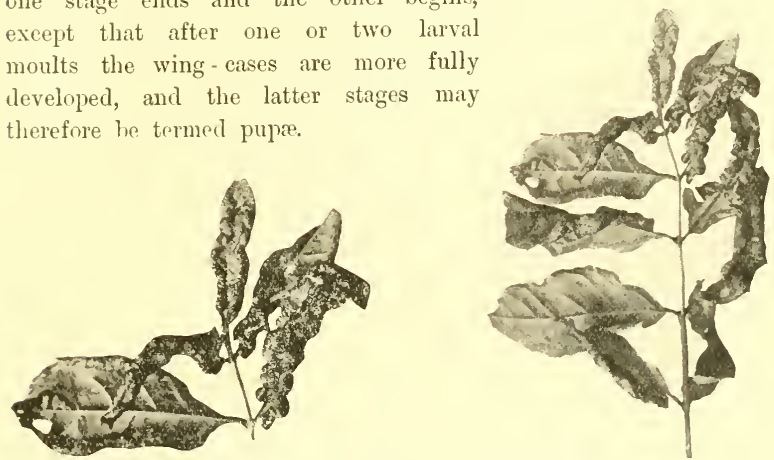

Fig. 284.-Leafets of ash injured by Psyllopsis fraxini.

The adult insect is somewhat variable in colour. The head is a reddish-yellow, with dark projecting eyes. Thorax a variable yellow with black markings; abdomen black above and yellow below. Antennæ ten-jointed, long and slender joints, becoming smaller towards the apex; last joint very small, and terminated by a forked bristle. Wings, smooth in cells, veins, and even edges. Clouled at edges. Legs a reddish-yellow. Length 21 to $3 \mathrm{~mm}$.

The clouded wings and brown makings of the body are quite characteristic features of this species, inasmuch as the colom of the insect harmonises in a very wonderful degree with the chocolatepinkish colour of the leaflets. 
The life-history of this species does not appear to have been worked out, but it would well repay any one to follow it out.

As regarls any remedial measures, it woukl perhaps be best to collect (by clipping off) the individual injurerl leaves while they remain in the young stages, and such elippings should be burned. In its younger stages the ash is a tree which is somewhat diffieult to grow to perfection in the nursery, but more especially in the young woods. Hence it is well to encomrage vigorous growth. The seedlings should be transplanted at a year old and grown for two years in the nursery-lines, and then either transplanted in the nursery or otherwise in the young woods, under the protection of wire-netting, and if possible also under the sheltering influences of more hardy species planted in advance. If they are transplanted in the nurserylines as one year, two years oli, or say 18 to 24 inches in height, they should be quartered the following year-that is, the best plants should be taken out, and so thin the crop that "spindling" is prevented in those which remain. The latter class should then make very useful trees for park planting, where a method of systematic groups at regular intervals, for continuity of effect, is the object in

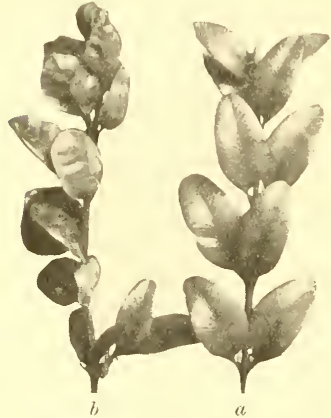

Fig. 285.-Lon zes of box injured by Psylla buxi.

$t$, thormal leaves; $b$, injured leaves. view. If, on the other hand, two-year seedlings are transplanted in the nursery, then it is often advisable to grow for one season and cut the plants down the following year close to the ground, taking care that only one good, strong, vigorous shoot will spring up. Attention to these practical points, together with any improvement on them, is the best antidote against any appreciable damage accruing from the injuries of the insect in question.

\section{Psylla bexi (Limm.)}

'This insect in its larval stages, and also in its early adult stages, causes the leaves of the box to curl up, so as to give rise to a sort of pseudo-gall, as seen in fig. 285. Fig. $285(\alpha)$ represents the normal twigs of box leaves, and fig. $285(b)$ shows the "galls" caused by the insects. 
The adult insects may be beaten from box plants, especially those with rolled leaves, in showers throughout the summer months, and otd specimens can also be beaten from box-bushes during the winter months.

An examination with the pocketlens will at once give the impression that the bodies of the tiny insects appear "to have been made" out of box leaves. In other words, the colour of the insect, as compared with the box leaves, is abont the best possible mimicry in the whole realm of forest entomology.

The prevailing colour of the insect is sea-green. Head and thorax palegreen; antennæ varying in colom from yellow to brown. Wings hyaline; abdomen green; legs yellowish-green, with darkish tarsi. Length $3 \frac{1}{2} \mathrm{~mm}$.

\section{Psylefa crategi (Schr.)}

The injuries caused by this insect are not of very much importance, and they are very apt to be overlooked. They may be found either on a hawthorn-tree or otherwise on a switched thorn-hedge, but more especially on the latter. Just as the young shoots begin to grow the larvæ of this species (fig. 286) seize hold of the extreme tip of the shoots and fasten themselves to it gregariously all round the tiny twig. The result is that, through

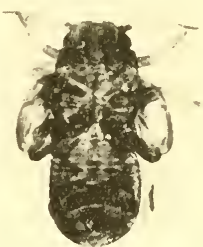

Fig. 286. - Young form of Psylla cratiogi on shoot of hatethorn.

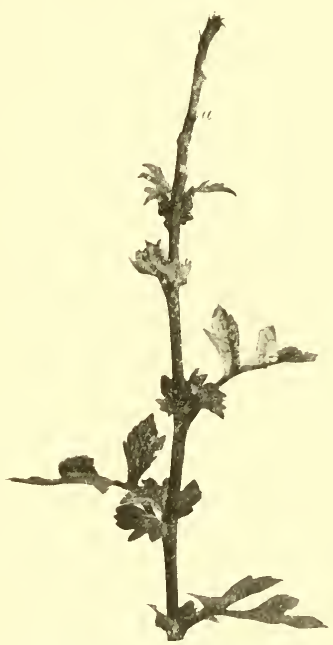

Fig. 287.-Tip of hurtherre shoot injured by Psylla cratizgi.

" shows tlie injured portion. sucking the juices, the injured portion dies off, as in fig. $287(a)$; and meanwhile the tiny larva remove themselves to the foliage, change to winged insects, and remain on the foliage all through the summer. 
The adult insect is greenish in colour, but head and thorax are almost white, abdomen darkish. Antennæ yellowish-green, legs reddish-yellow.

\section{Psylla alis (Limn.)}

About June 1 on an average season the tips of the branches of the common alder (Alnus ylutino:a) are thickly covered with a white woolly down, as shown in fig. 288. These are the larvæ of Psylla alni, and may by inexperienced entomologists be classified as Aphididæ, similar to American blight. The woolly covering acts as a protection for the creature during the early stages of its existence. At this stage

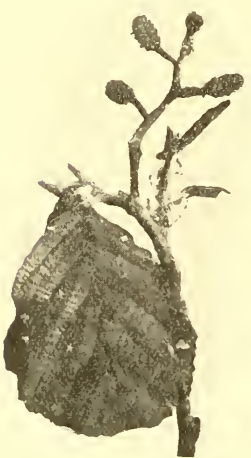

Fig. 2SS. - Twig of elder injured by Psylla alni. they are very easily disturbed, and set off rapidly as large white moving specks.

The larval and pupal stages cannot be very easily separated; but considering the more advanced stage as pupa, it is, when divested of its white overcoat, rather a handsome insect. The prevailing colour is green, with several dark transverse spots across the body. The anai segment is dark. The body shows "wing humps" at a very young stage. The head is not conspicuously separated from the thorax, nor the abdomen from the thorax. The wax hairs at the anal portion of the body are quite a conspicuous feature.

The perfect insect may be found throughout the whole summer. The prevailing colour is a light-green. Head and thorax yellowish-green, and studded with reddish markings; abdomen green. Wings perfectly clear. Costal and stigma veins green; other veins sometimes darker. Legs green, with dark tibire and claws. Length of insect when wings are folded about $5 \mathrm{~mm}$.

The sexes can be very easily distinguished-partly by the abdominal structure, and also on account of the antemne of the male being longer than the antennæ of the female.

It cannot be said that this insect is very injurions, as the summer foliage does not seem to have been injured from the effects of the larval and woolly secretions in spring. 


\section{References to Literature ronsulterl.}

Board of Agriculture Leaflet, $\mathrm{A} \frac{16-93}{\mathrm{I} .}$

Edwards, James. The Hemiptera-Homoptera (Cicadina and Psyllina) of the British Islands. 1896.

Riley, C. V. Notes on North American P'syllidie. Proc. of Biol. Soc. of Washington. 1854.

Witlaczil, Dr Emanuel. Die Anatomie der Psylliden. Wien. 1884.

\section{Part II.}

\section{CICADID㞋.}

This family of insects is generally overlooked by the practical man, inasmuch as he groups them along with the Aphididæe or "Green-lly."

The injuries are not so conspicnous as to arrest special notice. In fact, the injuries done by these creatures are of such a nature as to suggest asking the question, What is damage? As regards the damage actually done, three very general examples may be given-the first from the nursery, the second from the garden or orchard, and the third in the meadow. With regard to the example from the nursery, a walk alongside a plot of wych-elms, say from 3 to $5 \mathrm{ft}$. high, in August or September, coupled with a little observation, will show that the foliage has entirely lost its green hue, and is of a sulphury-yellow colour. If the leaves are slightly shaken, a shower of tiny active insects of a yellow colour, harmonising with the foliage, will dance about in all directions. These are known as Typhlocyba ulmi, and may be taken as the most injurious of forest Cicadiclæ. A similar example on pear-trees, more especially those on walls, will suffice for those in the orchard; and as regards those in the meadows, the most common example is that of the "cuckoo-spit " - that froth-like spittle substance which harbours the larva of a common example of a Cicadid.

Many varieties of deciduous trees harbour their own special species of Typhlocyba, and some of them are very beautifully marked, and would therefore form an interesting collection; but the following very 
brief account of them is intended only for a formal introduction to the family as associated with forest trees.

It has been remarked that they are very closely allied to Aphididæ, hence Buckton adopts the term Tettigide. The following table, ${ }^{1}$ which is perhaps chiefly of a microscopical character as regards tarsal structure, may therefore be given-viz. :

\section{ORDER RHYNCHOTA.}

\section{Súb-Order hoMOPTERA.}

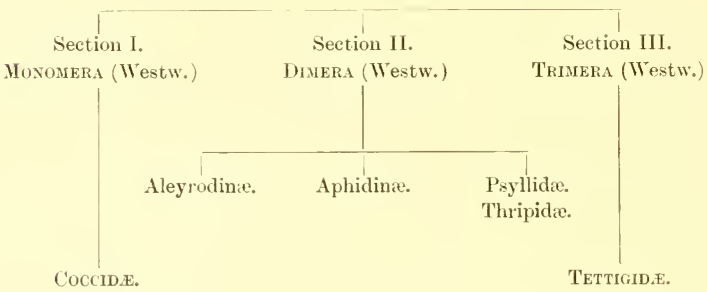

In size the British Cicadidæ show a considerable resemblance to the Aphididæ, but the most striking contrast is with regard to the wings, which are coriaceous, more especially the upper wings or elytra. This characteristic almost obliterates the venation. The under wings are also coriaceous, but not so dense as the upper.

The head is always more rounded than in the case of the Aphididæ -in fact, it may be termed frog-shaped. The antennæ are never very long: they are extremely slender, so much so that even under the microscope the joints are very difficult to count.

The insect feeds by means of a short proboscis, which is variable in length but always three-jointed.

No comicles are ever found on the body, nor any organs for secreting special exulation as a protective covering.

The legs contrast with the Aphididx, inasmuch as they are well adapted for leaping, the femoræ and coxæ having powerful muscles. The tarsi are three-jointed, but this is sometimes rather difficult to determine by observation.

${ }^{1}$ From Monograph of the British Cicadæe or Tettigida, by George Bowdler Buckton, vol. i. p. xxxiv. 
With regard to the life-history of the Cicarlide, they present some important differences from the Aphididæ. Males and females are present throughout the whole season, and the latter are always oviparous. The eggs, according to Westwood, vary in number from 300 to 400 . They are deposited in grooves of the leaves, eut by the female insect with her saw or ovipositor. The ineision being healed up by the flowing sap, the eggs hatch out in due course into six-legged active larve, which feed by means of a proboseis, and after moulting change into pupæe, which are also active and show embryo wings. These finally moult, and become active male and female insects. They feed by means of a rostrum, which also forms an anchor when the insects are asleep. The sap pumped up by this organ is ejected by the anns, thus differing from the majority of Aphididæ, which develop comicles for this purpose.

It will therefore be seen that the insects undergo incomplete metamorphoses, and are injurious in all stages.

With regard to typical specimens of Cicadidr, I will simply take a few of the most common species.

The most conspienons species is that known as the "euckoo-spit," so called because of the white froth or spittle with which the larval form protects itself. In early summer the froth is very common indeed on grasses and low plants. In the midst of the froth the larval metamorphosis is passed. The commonest species is known by the name of Philaneus spumaria, sometimes referred to the genus $A_{p}$ hrothora or "froth-bearer." The species in this genus are relatively large, and may be found plentifully on almost all kinds of bushes when beating for other inseets.

There is a curious opinion prevalent with regard to cuekoo-spit among gamekeepers. They miversally maintain that if a young pheasant swallows this froth it always proves fatal to it. However this may be, I cannot vonch for it other than on the strength of a keeper's opinion.

During the months of July and August a very beautiful and large insect belonging to this group may be beaten in consilerable numbers from the oak branches. The insect is about 4 or $5 \mathrm{~mm}$. in length. The head is brownish or a light-chocolate colour, and the body peagreen. It is called Macropsis Tanio. 


\section{SULB-FAMILY TYPHLOCYBIDÆ.}

\section{Genus Trphlociba.}

This genus is perhaps the most important as regards forest inseets, and kindred associations in several orchard or garden plants. These may be beaten in showers from the foliage of pear-trees, roses, elm, and alder. They are small yellowish insects, about the usual size of Aphididx, with elytra much larger than the body, but at once show by their active leaping powers that they differ from them. On examination with the lens or microseope they appear beautifully marked, with bright-coloured spots on the light-yellow bodyground.

\section{Typhlocrba ulai (Linn.)}

This species may be selected as a typical insect. The head is yellowish or greenish-yellow, with dark conspicuous eyes, and slender antennæ which taper to the finest point. The thorax is also yellowish, with dark transverse markings. The abdomen is divided into eight segments or somites, each of which is ornamented with a dark transverse marking, thus giving the insect a general appearance of being black and yellow. The upper wings or elytra are coriaceous, and the veins can only be slightly discerned with the microseope. The wings, or under wings, are lighter in colour and less coriaceous. They are longer than the body. The legs are yellowish, and slightly hairy. (See figs. 289 and 290.)

Mr Fred. V. Theobald has recently worked out the life-history of one of these insects, and the following extract is taken from his writings :-

$$
\begin{aligned}
& \text { "The OAK and Fruit Leaf-hoppel. } \\
& \text { "Typhlocyba Quencús, Fabr. } \\
& \text { "Typhlocyba flammigera, Amyot. }
\end{aligned}
$$

"Like all members of this family, the insect passes the winter in either the adult or nymphal stages. Hibernation takes place in any sheltered position. One may find them amongst fallen leaves at the foot of hedgerows, in box hedges, amongst moss and lichens on trees, and abundantly amongst conifers. In spring they appear again, and feed upon the young leaves. In June they were first noticed in numbers: possibly between their exit from winter quarters and June a generation had appeared. It was not until July 
that any marked dimage was done to the leaves of apple, plum, and damson; then all stages of the insect could be found at once, and the life-cycle easily followed. How many generations oceur in the year could not be deeided, but apparently more than two. The alult may be told by its beantifully marked anterior wings, with six bright-orange and vermilion spots on a milky-white ground, and with a large dusky network at the apex. They are subject to variation in regard to the markings.

"Their length varies from 3 to $3.9 \mathrm{~mm}$. I loth nymphs and adults feed mainly on the under side of the leaves, but by no means always.

"They are not very active, and can easily be taken at rest on a

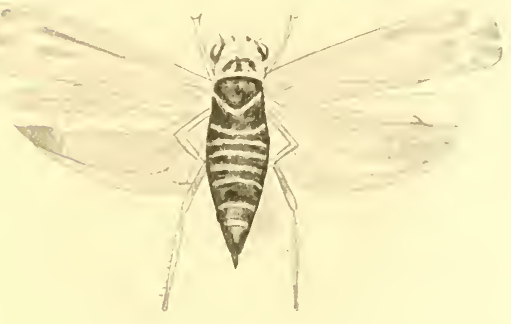

Fig. 289.-Typhloeyla ulmi. (Drawn by P. J. Brown.

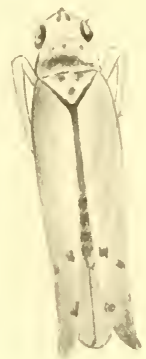

Fig. 2!0.-Typhloeyla ulmi. (Drawn by P.J. Brown.)

dull day. When disturbed they take a leap from the leaf, and then use their wings, often flying a couple of feet away.

"Egg-laying seems a laborions task. By means of the saw-like structure the female euts a slit into the under epidermis, and places one or more egrs just beneath it. A very minute and faint oblong spot marks where they have been laid.

"The ova are very delicate, white, and oblong-oval in form, somewhat curved on one side, and blunt at each end. When nearly ready to hateh they may be seen with a strong lens under the epidermis, their position being plainly narked by the dark eye-spots of the embryos. Length 0.041111 . 
"Eggs under observation were found to hatch in four days, but how long they had been laid was not known. Lingerland shows that the American Grape-vine Leafhopper (Typhlocylua comes) remains

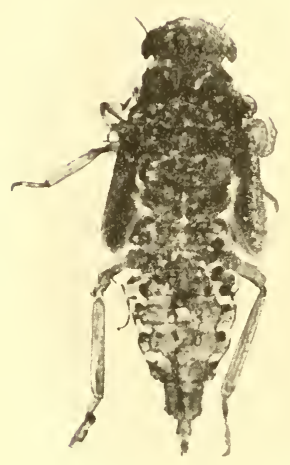

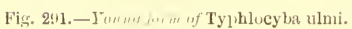
two weeks in the egg stage, and it is quite likely this is about the period taken by Typhlocyba quercûs.

"The young emerge on the under side of the leaf, and grow rapidly. There are four moults in the nympls stage. At first the young are very pale, but gradually become yellowish as the wing-buts develop. Towards the end of nymphal life they are most ravenous. The whole period of growth lasts from five to six weeks, the complete life-cycle probably taking fifty days. (See fig. 291.)

"They kept on breeding until the first week in October, but in very small numbers after the middle of September.

"Until they are mature these leaf-hoppers are very sedentary, and even when adult do not jump as do other members of their tribe." I

\section{References to Litercuture consulted.}

Buckton, (ieorge Bowdler. Honograph of the British Cicadie or Tettigidx. 1890 .

Edwards, James. The Hemiptera-Homoptera (Cicadina and Psyllina) of the British Islands, 1896.

Theobald, Fred, V. "New Hemipterous Fruit Pests in Britain" - The Journal of Economic Biology, 1907, vol. ii., Pt. I.

1 "New Hemipterous Fruit Pests in Britain," by Fred. V. Theobald, M.A. -The Journal of Economic Biology, 1907, vol. ii., Pt. I. 


\section{CHAPTER IX.}

COCCII) A (SCALE-INSECTS).

THere is perhaps no class of insects more puzzling to the practical husbandman, the economic entomologist, or the biologist who is anxious to gain a general knowledge of insect structure and lifehistories, than the Coccidæ or Scale-Insects. The student must rely almost entirely upon the microscope for the accurate determination of these insects, which from their minute size present exceptional difficulties. Even for general field-work it is necessary to have recourse to a strong pocket-lens; as to the naked eye, they may be confounded with lenticels-as, for example, those on birch-twigs. They may also be mistaken for certain micro-fungi on leaves or stems of various plants.

In the Introduction it was emphatically asserted that concentration in the study of forest entomology was indispensable, inasmuch as almost every natural order was represented, and thus as a branch of forest science, to the forester in particular, general versatility in entomology was impossible. Scale-insects, however, are to some extent an exception to this rule. The arboreal-feeding species of this important family are comparatively few, and therefore, in order to thoroughly understand the salient characteristics, it is necessary to glean information from all available sources. In other words, in order to thoroughly understand the special part, it is essential to make a general study of the available whole.

But though the arbereal species in this conntry are comparatively few in numbers, the forester, or student of forest entomology, can always obtain an abundance of material from varions plants cultivated under glass-the amateur greenhouse often being a happy huntingground.

Temperature and climatic conditions are important factors in the distribution and regulation of scale-insects. Hence warm greenhouses 
afford several important advantages to the student. Thus where the temperature is, comparatively speaking, perpetual summer, we find several broods occurring throughout the year, as well as the creatures in their various stages of metamorphosis. In the forest, on the contrary, many species are not only local in area but sparsely distributed, and all are single-brooded. In hothouses, through importation, plants are collected from various parts of the world, and thus, to some extent, we get in private greenhouses and public botanical gardens an approximate epitome of the scale-insects of the world. It is therefore evident that, in order to understand the life-history of many scales originally imported, but now acelimatised to our glasshouses, recourse must be had to foreign and colonial literature. Not only is it advisable to study the literature relative to foreign seales, but it is essential to study the microscopical structure of the foreign scales themselves which are to be found on our imported plants and fruits. And as the dead females answer best for microscopical examination, greengrocer's stalls may be looked upon as a very happy hunting-ground-more especially at a time of the year when life is dormant, and when the working entomologist may use his microscope as an instrument for original research in a comparatively fresh field.

But the stuly of foreign scales and the literature bearing on them has, in addition to its charms and pleasures, a very practical bearing, inasmuch as we find that some species are quite cosmopolitan in distribution. We also find that many species which are practically identical to the naked eye, and likewise in point of clamage, prove on microscopical examination and in their life-history to be quite distinct. Is regards the value of such knowledge bearing on the discrimination between foreign injurions scale-insects and the apparent introduction of any partieular injurious species into this country, as recognised only from naked-eye characters practically identical to the casual observer, one important case may be cited-viz., the San José scale (Aspridiotus pemicions) from California, as compared with the scurvy-bark lonse (Aspirliotus ostreceformis) of this country. The former is a sub-tropical insect, and would not likely withstand the rigours of a Western climate. In fact, it has not even established itself inder glass in this country.

In the year 1898 it was thought the San José scale-insect had established itself in this country, and so much was the scare felt 
that the Board of Agriculture invited Mr Newstead to give evidence before a special committee meeting at the House of Commons. As the result of previous studies, he was able to dispel all fears, and subsequent experience has amply justified his opinions.

As showing the wide geographical range of certain scale-insects and their adaptability to varied food-plants, one species, namely, the common mussel-scale (Iytilaspis pomorum), may be cited. Newstend says: "It oceurs as a pest in almost every part of the world where the apple is eultivated-in Europe, North and South, the United States, New Zealand, Australia, North Africa, and probably many other places."

The Coceide or scale-insects belong to the order Hemiptera, which is subdivided into two principal divisions - viz., Hemiptera-Heteroptera, which includes the bugs; and the Hemiptera-Homoptera, which ineludes Aphidide, Cieadæ, Psyllidæ, and Coceidæ or scale-insects. The last are broally distinguished from other families by the wale or roverin!/ which they spin to protect their bodies. Hence the Germans call them by the expressive term sichilllüuse (shield-lice).

Having often found that intelligent practical men lesignate scale-insects as a "very low form of life," it may be well to show their close relationship with other families which are grouped together in the same suborler. As in point of strueture and lifehistory they are very closely associated with other families of the sub-order, it may be well, even at the risk of repetition, to present the more salient features of each family as an educational advantage to the clearer discrimination of the relationship which exists between them. All the insects of the natural order Hemiptera are characterised by the

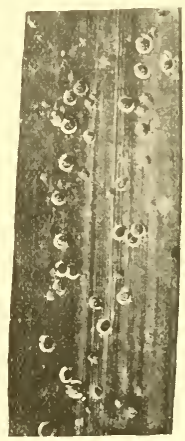

Fig. 292. - Ceratapluis latania (fringed aphis) $m$ in $p a t m$. Kunwn to horticulturist: as the "black-seel scale." possession of suctorial mouths, and therefore belong to that great division of Insecta known as Haustellata.

The Aphididie or plant-lice are soft-bodied insects, usually green, with long, rather slender legs, and not formed for leaping. They oecur in two forms-winged and wingless. The beak (proboseis), or feeding-organ, is often very long, and the tersus tro-jointert. One 
speeies of this family is often mistaken for a seale--viz., the fringect aphis (Ceratn,his latamine), known to hortieulturists as the "blackseerl seale": it occurs on palms, orehits, \&c. (see fig. 292).

The Psyllide very much resemble the Aphididx in general appearance, but their legs are formed for leaping. The wings are clear, the antennæ conspicuous, long, nine- or ten-jointed, and the eyes large and prominent. The tarsus is two-jointer.

In general appearance the Aleyrodidre are the nearest approach to the scale-insects, more especially so in their nymphal or pupal

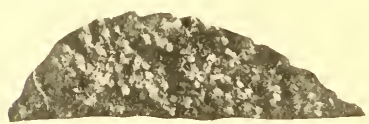

Fig. 293. - Sicule-libe secretion of A leurorles on leaf of tomato. stages. Their bodies are of an ivory-white colour, scaly-looking in appearance; both sexes are winged, and the tarsi two-jointed. They often deposit a scale-like secretion on plants (see fig. 293).

Aleyrotidre are found on tomatoes, \&e., in greenhouses, and on ivy, lime, and hazel in the woods.

The closely allied Coccid.e are broadly distinguished from the other families of the Homoptera just referred to by the following characteristics-viz. : In the females by being naked (Lecanium), clothed partly with secretion and partly with moulted skins (Diaspines), or clothed with white meal-like secretion (Dactylopius), and with wax-like plates (Ortheria). The tarsus in all the British species but one ${ }^{1}$ is composed of a single joint; there are also two foreign genera in which the tarsi are two-jointerl.

The larve are minute, and very active when young, usually naked, and the sexes are inseparable in the first larval stage.

The female undergoes a semi-complete metamorphosis, is apterous in all stages, has generally a well-developed rostrum, and, according to the genus, the legs may be present or absent.

The adult male undergoes a complete metamorphosis, and may be winged or apterous. It has no month or feeding-organs, but possesses six legs, eyes, and antenne.

It is important to bear in mind that both sexes secrete a varying quantity of waxy, horny, mealy, or resinous substanees for the formation of their shield-covering or scule, and that these secretions or coverings vary in form and colour. In fact, those differences are so 
elearly pronounced that they afford valuable data, not only for the distinction of sex, but for the separation of the various sub-families and genera. These remarks are applicable to the "scales" of both sexes, but more especially to the male seale or puparium.

Maskell ${ }^{1}$ gives the following microscopical characters :-

(1) The presence of only one joint in the tarsus, or fourth joint of the leg, in males and females.

(2) A single claw terminating the leg in males and females.

(3) Two wings and two halteres in the males.

(4) Two or more eyes or ocular tubercles, in addition to an ordinary pair of eyes.

With regard to the classifieation of seale-insects, it would be quite superfluous under "forest entomology" to give all those sub-families at present known in the British Isles, but the following genera, according to Newstead's Monograph, are arboreal in their habits :-

\section{SYNOPSIS OF SUB-FAMILIES."}

\section{Males with Simple Eyes.}

A. Ablomen of female terminating in a compound segment forming a definite pygidium. Anal orifice simple.

(1) Insects with a separate covering seale (puparium) composed partly of moulted skins (exuviæ) and partly of secretion. Adult females without legs; antennæ rudimentary; mentum monomerous . . . . . Diaspinæ.

B. Aldomen of female without definite pygidium. Anal orifice setiferous.

(2) Females with a posterior extremity cleft; anal orifice closed by a pair of dorsal plates. Larve with prominent setiferous lobes within the anal cleft . . . Lecaniinæ.

(3) Adult females with eleft extremity and anal plates, as in Lecanium. Larve with abdominal lobes, as in Dactylopiinat

Hemicoccinæ.

(t) Abdominal extremity not cleft, usually with a pair of more or less prominent setiferons lobes at margin. Abdominal extremity of larvæ similar . . Dactylopiinæ.

\footnotetext{
1 Scale-Insects of New Zealand. $\quad$ From vol, i. p. 67.
} 


\section{DIASPINÆ.}

The sub-family or group Diaspina may be defined, from a purely entomological point of view, as insects covering themselves by a shield or scale composed partly of discarted skins and partly of secreted matter. Two very common scales-viz., the species on ash, de., and the species on fruit-trees known as mussel seale-are very good examples of this sub-family. As there are, however, other forms of scale belonging to this group, it is often somewhat difficult to determine to what genus the scale really belongs. The first point to note is the form of the scale-whether it is linear or circular. But this in some eases is not always quite sufficient, as the male scale, or puparium, must be looked for to determine the genus. Hence the following eharacters may be given-viz. :

Female scale cirrular (fig. 294); male scale circular (fig. 295)

Aspidiotes.

Female scale rimular (fig. 296); male seale lineur (fig. 297)

DiAspis.

Female scale linear (fig. 298); male scale lineur (fig. 299)

Cinonaspis and Mrtilaspis.

These are most important points to remember, inasmuch as it is sometimes impossible to determine the genera until a male scale is found.

In fig. 294, which represents a female scale of the genus Aspitiofus, $a$ represents the first larval monlt, $b$ the second larval

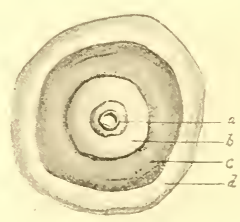

Fig. 294. - Female srale of Aspidiotus. ", first larval moult; $b$, second larval moult; $c$, portion representing sub-lying body of female; $d$, onter secretionary portion of scale.

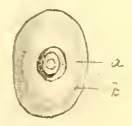

Fig. 295. - Mule scerle of Aspidiotus.

(", larval moult; $b$, secre. tionary portion.

moult, $c$ the unclerlying female, and $d$ the outer "scale" which is spun by the insect, and thus attached to, but extending beyond, the 
second larval moult. In fig. 298 we have the same characters in a female Chionaspis-viz, a representing the first larval moult, $b$ the second larval moult, and the remainder of the scale as the secretionary portion covering the body of the female. It would be well to study

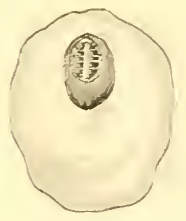

Fis. 296.-Female seale of Diaspis.

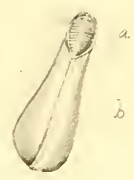

Fig. 297.-Mulc surle of Diaspis. $a$, first larval moult; $b$, secretionary portim.

the detailed characters as given more fully in the description of Chionuspis stlicis.

In figs. 295, 297, 299, male scales or pupariæ are represented: $a$ shows the larval monlt, and $b$ the scale covering the pupa of the male. In addition to the above characters, the student should thoroughly

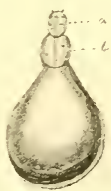

Fig. 298. - Female secele of Chionaspis and My tilaspis.

$a$, first larval moult; $b$, second larval noult.

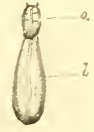

Figr. 299.-Mule scale of Chionaspis.

c, first larval moult ; $b$, secretionary portion.

master the microseopical characters of the pygidium under a $\frac{1}{4} \mathrm{in}$. or $\frac{1}{6}$ in. objective.

The pygidium, it must be remembered, is the anal segment, and after being prepared and mounted the respective characters of dorsal or ventral surface must be well studied. As the whole object is very thin when mounted as a microscopic preparation, it is obvious that careful focussing is required in determining the minute respective 
characters in either surface. This is very well illustrated in fig. 300 , taken from Newstead's Monograph, which gives a general representation of the pygidium. It would be well to make a detailed study of this figure, together with mounted specimens of the same. It is only by a careful study of the various organs attached to this portion of the abdomen that the specific characters of the sub-family Diaspince can be definitely fixed.

The genus Aspitiotus is generally considered the typical form of

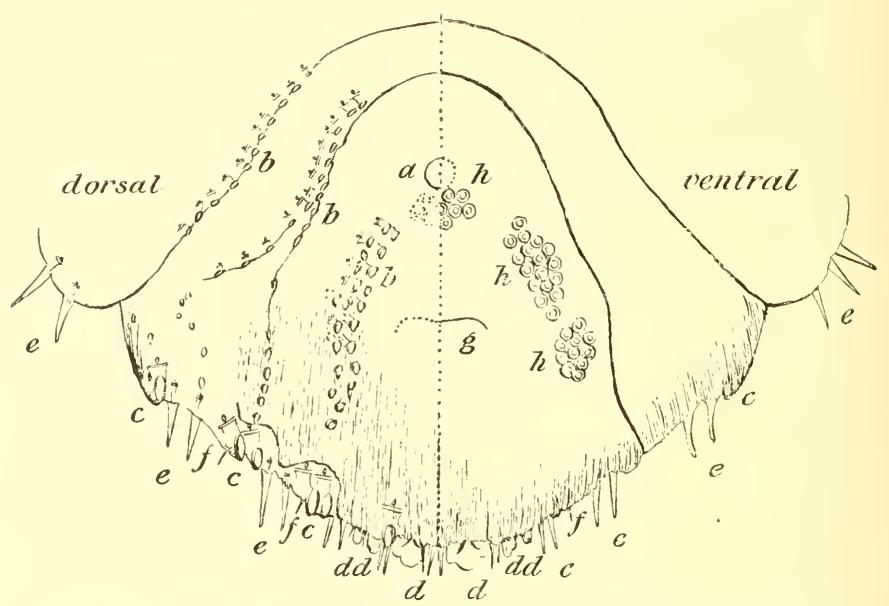

Fig. 300.-Pygitium, or anal segment, of Mytilaspis pomorum, showing dorsal and ventral parts. $a$, anal opening; $b$, dorsal tubular spinnerets; $c$, marginal tubular spinnerets with their more or less projecting pores ; $d$, median, second, and third pairs of lobes; $e$, plates ; $f$, spines ; $g$, vaginal opening; $h$, anterior, anterior lateral, anl posterior lateral grouped circumgenital glands. (From Newstead's 'Monograph of the British Coccidce.' Ray Society.)

Diaspid scale, but as the genus Chionaspis is more frequently met with in this country, it may be permissible to adopt it, from an arboreal point of view, as the typical scale, giving a full account of its life-history and structure.

\section{Genus Chionaspis.}

So far as arboreal insects are concerned, there is only one species in the genus-viz., C. salicis. The female puparium is elongate and 
pear-shaped (pyriform) and white, with exuric at the anterior extremity. Under a pocket lens the two larval moults may be distinctly recognised. The male puparium is elongate, and composed almost entirely of a pure white secretion, with the yellowish larval moult at the anterior extremity.

\section{CHIONASPIS saLICIS (Limn.)}

The scales of this species are very common on ash, willow, and other trees. In some parts of the country, notably in mil-cheshire, we find young ash-trees from six to eighteen years of age, and osiers from four years and upwards, completely covered with these scales. They are comparatively small, and if accurately measured would probably be about $.75 \mathrm{~mm}$. in length.

A cursory examination shows that two forms of scale appear on the stem. - the male form (fig. 301) and the female form (fig. $302)$. Sometimes we find both sexes on the same tree, at other times only females are found. In those cases where the male form preponderates, a whitish appearance is presented, as in fig. 301, where the male scales, or
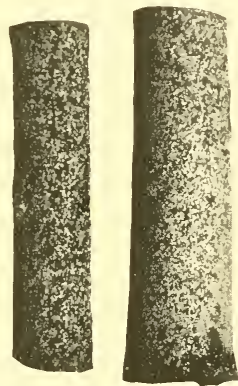

Fig. :301. - Mole sprtes of Clionaspis salicis on bark of a young ashtref.

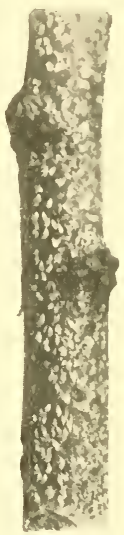

Fig. 302.-Female sertes of Chionaspis salieis on stem of a fiveyeur. old betsem poinleri. puparia as they are called, entirely cover the bark of the young stem. Those two forms, as seen collectively by the naked eye in figs. 301 and 302, and individually magnified in fig. 303 ( 7 and 3 ), represent the male and female forms of Chionasyis salicis.

If we lift a perfect female scale any time during the winter months, turn it over, and examine the under side with a lens, or as an oparue object with an inch objective, a considerable number of beautiful red eggs will be noticed (fig. $303(4)$ ). In my younger days, when working in the woods, I have often rubbed my thumb-nail 
against the bark infested with Chiomusyis, and sincerely designated the squashed eggs as "blood." Subsequent research with the microscope has yielded many happy hours with what was originally crushed in a careless and thoughtless manner. These eggs are of a chocolate colour in autumn, just after oviposition, but become

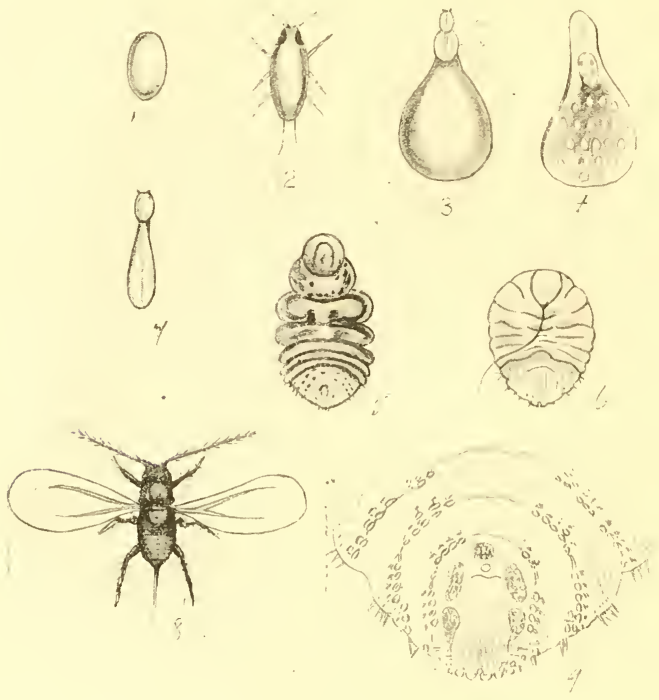

Fig. 303,- Life-history of Chionaspis salicis.

1, egg; 2, larva; 3 , dorsal surtace of female scale- $(a)$ first larval moult, $(b)$ second larval moult; 4, under surface of female seale, showing dead female and eggs; 5 , fully developed female at period of fecundation ; 6 , form of female seale at period of egg-deposition; 7 , male seale or puparium ; 8 , fully developed male; 9 , pygidium or anal segment of female as seen under $\frac{1}{4}$-inch objective.

lighter during the winter months. Now let us follow the development of these eggs. Fig. 303 (1) represents a single egg. The larvæ hatch out in Cheshire about the beginning of May, and by the middle of that month the infested stems may be recognised at a considerable distance, on account of the numerical strength of the larvæ, imparting quite a red colour to the stem. These larvæ (fig. 303 (2)) are at first 
very active, and measure approximately about the $\frac{1}{100}$ of an inch in length. They possess six legs (the tarsus being single-jointed, and terminated by a claw and knobbed hairs), comparatively long antenna of five or six joints, two eyes, and two very long transparent hairs at the posterior end of the body. Under imperfect magnification the segmentation of the abdomen cannot be clearly traced; hence I at first hastily, but erroneously, coneluded that "the posterior legs spring from the abdominal part, which is a unique feature in inseet anatomy." I In the course of two or three days they assume a quiescent state, and inserting their beaks (proboseis) into the bark of the tree, suck up its juices. As soon as the larvie assume this habit they enlarge eonsiderably, and the legs and the antennæ disappear beneath the boly. After the larva has grown for a short time it casts its skin, and it is after the first larval moult that the sexes are determined. The female scale develops into the form shown in fig. 303 (3), and the male as shown in fig. $303(7)$.

Now let us follow the development a little more fully, and first with regard to the female. After the first larval moult, which is represented by fig. $303(3 \mathrm{a})$, the creature develops and again moults, the second larval moult being shown by $l$ in the same figure. Up to this stage the ereature protects itself loy means of east-off skins, but the female now commences to further protect herself by means of a covering or "scale," which is spun by minute organs known as "spinnerets," and represented in fig. 303 (9). After the second larval moult the metamorphosis of the female insect is complete. The full development is shown by fig. $303(6)$, from which it will be seen she is simply an inert slug-like creature made up solely of body and mouth.

The rostrum or mouth serves the double function of feeding-organ and anchor, but in the latter capacity it is further assisted by the long hairs, or "setæ" as they are termed. And sometimes when the females are loosened from their host-plant by birds, they may be seen dangling in the air attached by the "setre" alone.

Prior to the deposition of eggs, which takes place in September, the body entirely fills the ovisac, but as the eggs are deposited the body gradually shrivels until it ultimately oecupies but a very small portion at the upper or anterior end of the scale. The female dies shortly after the eggs are deposited, and during the winter months the dearl female and the egrss may be found umler each scale.

1 British Naturalist, Feb. 1894. 
If a microseopical examination of the female be made in the winter months, the well-developed rostrum will be observed, but a special examination of the anal segments forming the pygidium (fig. 303 (9)) shows five groups of spinnerets and other important structures.

It is well to bear in mind that the pygidium yields the main characters which form the prineipal basis for the discrimination of species. The anal lobes, hairs, and other characters, requiring the lighest powers of the microscope, are all taken into account by the specialist. Hence at this stage it may he as well to give detailed characters of the female and pygidium of this species, as given by Newstead in his Monograph :-

"Adult female (fig. $303(6)$ ) elongate ovate ; cephalic, thoracic, and abdominal segments strongly defined, the former being distinctly trilobate. Colour dull crimson; cephalic extremity dull orange, mottled with crimson; pygidium bright orange; the dorsal spinnerets indicated by a double semi-elliptic series of clull crimson marks. Eyes black. Rudimentary antennæ normal. Each of the three free abdominal segments with about nine large tubular spinnerets at the margin, of the same character as those of the pygidium ; and the last segment presents a few stout, spiny plates. Pygidium (fig. $303(9)$ ) has five large groups of cireumgenital glands.

"Dorsal tubular spinnerets, short and cylindrical, are in twelve distinct series, forming three incomplete arches. Within the first series, and immediately behind the lateral circumgenital glands, are usually three other tubular spinnerets; anus and vaginal opening opposite. The median and second pair of lobes are well developed; the former have the margins rounded, or faintly and roundly serrate or dentate; the second pair are bilobed, the anterior lobule very small, and both have the margins rounded; third pair are also divided or bilohed, the posterior lobule usually dentate, the anterior lobule very minute, and sometimes both are wanting. There is a spine-like projecting pore between the median and second lobes; an angular one immediately posterior to the third lobe; and there is a third midway between the latter and the last group of plates. Two long spines at the base of the anterior lobule of the second pair of lobes. Of the plates, there is a short one between the median and second lobes; six others, long and spine-like, are arranged in three pairs, and followed by a group of four or five others."

It onght to be laid down as an axiom that only the full-grown 
female should be examined for specific points, ats the spinnerets and other microscopical characters are not fully developed till rifter the second lareal moult; and no doubt in a general way specific errors have occurrerl, and are likely to do so, by several workers examining the same species in two distinct stages.

The male seale (fig. $303(7)$ ) differs from the female (fig. $303(6)$ ) by having only one larval moult, by being lighter in colour, felterl, more linear, and earinated. The perfect male (fig. $303(8)$ ) contrasts with the female, inasmuch as it has two wings (though apterous specimens are often found), six legs, and two antenna, two eyes, and no mouth or feeding-organ. The male generally appears about the first week in July, and only lives from about three to seven days, but during that short space of time he has obtained the sole object of lis existenceviz., the perpetuation of his species.

The genitoires are large in proportion to the size of the ereature, varying from about one-third to one-half the length of the whole insect. We here see the adaptation to enviromment in the alnormal development of the penis-sheath requisite, considering that the female is stationary and helpless, and covered with a shell ; while we note in her the absence of eyes ant legs - both useless under an opaque shell. Hence we have a beantiful illustration of the elaboration of one part and the degeneration of others.

It may be as well to remark that previous to the publication of Newsteal's Monograph this species was known as Chionaspis tirarini, sign., but this and several other so-called species have been sunk as synonyms of $C$. saliris.

In order that the student may thoronghly understiml the lifehistory and structure of this important arboreal insect, it may be advisable to give a short epitome of the foregoing description, as illustrated by "figs." in figure 303. In fig. 1 we have a single egg. The eggs are found in winter as represented in fig. 4 , and hatch out in May. Fig. 2 represents a larva which is active for a short time; fig. 3 represents the dorsal surface of a fully developed female scale : $a$ is the first and $b$ the second larval moult. The sexes eannot be distinguished till after the first larval moult, and fig. 7 represents the male scale, showing the remains of only one larval moult, together with the secretionary portion; and fig. 8 represents the fully developed male, which appears in July, and copulates with the female, represented in fig. 5. It should be specially noted that at this period the female is 
relatively small and of a peculiar form : this stage of development is known in Coceid study as the periol of fecundation. After the act of impregnation the female ehanges her form, as represented in fig. 6 . This change in form is due to the body being filled with eggs, and np to the time when the eggs are deposited this stage is termed the period of gestation.

Thus, in a female Diaspid scale we have several stages-viz., the egg, larva (first and second monlt), period of fecundation, and period of gestation; and in the male we have egg, larva (one moult), pupa, and winged stage.

\section{Gemus Mrtilaspis.}

This genus, of which we have here only one species to consider, may be distinguished from Chionaspis by the mussel-shaped seale of the female. The scale is highly rounded, of a uniform light-brown colonr, and the second larval monlt is completely eorered by secretion.

Iale puparium rare, elongate, siles parallel, and there is a faint hinge-like depression towards the middle. It somewhat resembles the second stage female.

\section{Mrtilaspis pomorem (Bonelé).}

This seale-insect is unfortunately only too well known as a garden pest. It infests apple, pear, and plum amongst our fruit-trees, and hawthorn, mountain ash, cotoneaster, and wild-rose amongst our forest trees and shrubs. Its common name "mussel-scale" is a very appropriate one, inasmuch as it resembles, when magnified, our common mussel of the sea-shore. The seale differs from that of Chionaspis in being more elongate, less cirenlar, of a brown colour, and about an eighth of an inch in length. It is built up in the same manner as the ash-bark seale, bnt the first larval moult is yellow. Plant after plant may be found so thickly covered by the female seales as not to be able to get a pin-point down without tonching them (not only eovered with, but killed by, the seales), and yet not a single male seale is to be found. Hence the species was almost considered as parthenogenetic, and Mr Maskell says, "Male unknown in New Zealand and Europe, doubtful in America." It was not until July 1896, after nine years of observation, that Newstead diseovered the male on broom at Bearstead in Kent. As the male had hitherto been unknown, this was rather an important find. It may even now be 
considered as analogous to some species of Aphidx, in which males have only been found after an interval of several years, otherwise the sex may have been determined (as sexes of insects often are) by the food-plant. With regard to finding it on certain food-plants, Newstead remarks, "Here in England, however, I have met with it freely on cytisus and Vaceinium, and sparingly on heath."

Its habits are much the same as the Chionaspis on ash, \&e. At the end of Iugust or early in September the female lays her eggs, which remain under the scale during the winter. They are white, and hatch out in Cheshire about the end of May, but not until the middle of June (June 16, 1900) in Northumberland. The males, when found, have appeared in July.

Newstead gives the following detailed description of the pygidium -viz. : "Pygidium (fig. 300) with five groups of circumgenital glands, subject to great variation in number. Dorsal tubular spinnerets, small and cylindrical, are arranged in three series, - the first, opposite the lateral ventral glands, form a long scattered band terminating near the anus; intermediate series in a single row forming an incomplete arch, with an ontward lateral series extending from the middle almost to the margin ; third series following the articulation of the pygidium with the segment. On each side of median lobes along the margin are six tubular spinnerets, of which the second and third, and fourth and fifth, are arranged in pairs. Anus a little in front of the anterior group of ventral glands. Vaginal opening almost central. Median lobes almost as broal again as long; lateral margins usually straight; posterior margin centrally lobate, with one or two notches on either side. Second and third pair of lobes small, almost touching, have their margins rounded and entire or bluntly and irregularly dentate. Plates long and spine-like, usually one median and four lateral pairs." 1

\section{Genus Aspidiotus.}

Female puparium more or less circular, and either raised or comparatively flat in centre. Exuviæ central or conspicuously to one side of centre. Secretionary covering often very thin. Females show great variation in the character of the pygidium. Hence, from a microscopical or specific point of view, it is advisable to study every available species on different host-plants.

Male puparium eircular, but much smaller than the female scale.

1 Newstearl, vol. i. p. 196. 


\section{SrNopsis of Arboreal SPecies. ${ }^{1}$}

A. Pygilium with four, rarely with fice, groups of circumucnital glands. (1) Short serial group of lateral dorsal pores absent. Puparium rerldish-pink in the young, smoky-grey in the old examples. On oak .

Zonatus.

B. Pyglidim aluays with five groups of rivemyenital glants.

(2) Serial group of dorsal pores present. Puparium flat, convex grey with a darker central zone. Hitherto found on fruittrees.

Ostreæformis.

C. P!yidium with club-shruped glumls.

(3) Groups of tubular spimnerets connected, with pores on both surfaces of pygilium ; eircumgenital glands ahmost continuous. Puparium bright-fulvous. On holly . . Britannicus.

\section{Aspidiotes zonates (Framenfeld).}

This insect is found on vak, but, so far, it has been rarely recorded. One of the first diseoveries was by myself at Agden, in Cheshire, Sept. 1892. It has been found fairly often in Cheshire, but never occurs in any great numbers.

As regards life-history, the egg-laying takes place early in May, and the larvæ hateh soon afterwarls. As soon as the first larval moult takes place, the sexes not only assert themselves, but they separate, the males moving on to the leaves, and fixing themselves to the midrib and veins, and the females congregating on the stem. But though separated, it is, after all, only in the metamorphic stages, inasmuch as it is only for the requirement of pupal clevelopment on the part of the male. As the males emerge from the puparia on the leaves with fully developed wings, it is obvious they have no distance, or difficulty, to move from the leaf to the stem for muptial rites and associations.

\section{Aspidiotes BRITAxicis's (Newsteal).}

This is a species which, so far, has only been found on holly and a species of fern cultivated under glass in the immediate neighbourhood of London. The scales are circular, of a dusky-brown colour, and on the slightest disturbance fall readily from the leaf. The males can be distinguished from the females by the smaller size of the seale.

1 ILodified from Newstead's Monograph, vol. i. 
Is the two preceding species are not very common except in one or two special localities, it would be well for the student to study the habits and structure of an easily proeurable and elosely allier species -viz., Aspriliotus rstrerformis on plum, aplle, pear, and cherry. This speeies is very common in many parts of the country.

In the event of this speeies not being procurable, the student may fincl several speeies of Aspidiotus under glass, as in fig. 304 on Lapageria, and fig. 30\% on Stephanotis.

\section{(ienu: Diaspls.}

This genus has a cireular female puparium, and the remains of the larval moults lie hetween the centre of "scale" and its outer edge.

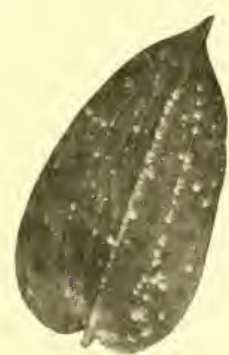

Fig. 304.- Sorle of Aspidiotus wo leof of Lapageria.

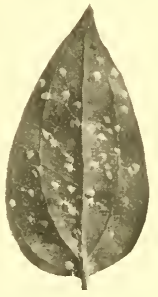

Fig. 305.—, wate of Aspidiotus on leof uf Stephanotis.

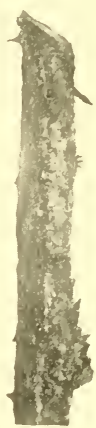

Fig, 30t,-iveli, of Aulit-

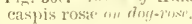

The puparium of the male is elongated and strongly ridged, elosely resembling the pupariun of Chionaspis.

In this genus proper we have no arboreal speeies, and the species on wild-rose, long known as Diaspris rost, has been named Aularaspis (Dicapis) row by Cockerell, and Newstearl has, somewhat reluctantly, adopted the change.

\section{Altacaspas (Diaspis) ros.e (Bonché).}

This scale (fig. 306) is found on the dog-rose (Rosa ranina), and sometimes on species of Rubus (bramble). It is fairly common in 
some districts, and entirely ahsent in others. I have, for instance, never taken it in Northumberland. It is generally found on the stems of very old plants, and then often so abundant as to completely cover the bark.

The female scale is of circular form, slightly convex, and from 2 to $3 \mathrm{~mm}$. in diameter. The central or larval exuviæe generally lies between the centre and the outer edge of the scale. It is of a dull canary colour. The exuviæ of the second moult is yellowish-brown, and the scale proper is a dirty-white-looking colour. Collectively, they give a sort of drab colour to the infested stem.

Prior to the deposition of the egg, the body of the female is of a dull orange-crimson, and the pygidium, which is rather conspicuous, is a bright orange. The body, though elongated, has a slight leaning towards a rough circular outline, and the front portion is almost a perfect semicircle. The outline of the body shows the segmentation very clearly.

The male scale is elongated, and very much resembles the puparium of Chionaspis. It is of a whitish colour, and the exuvia varies in colour from bright-yellow to red-orange. If examined carefully, it will be seen that the white portion possesses three linear ridges, the centre one being more raised than the other two.

The male of this species, and also the male of the genus Diaspis, resemble the male of Chionaspis, both as regards the form of the scale and the perfect insect. The body is erimson, and the wings whitish. The eyes are black, and the antennæ long and slender, with very delicate hairs. The legs are yellowish, and slightly pubescent.

There is an important point in connection with the life-history of this species, as compared with the genus Chiondsipis, and the advice given by Linnæus, "Observe and compare," is very applicable to the study of scale-insects. It has been noted that the larvæ of Chioncspis hatch out early in Nay, assume a quiescent stage after a few days' active existence, and that eggs are found underneath the scale from september to Мay. The active larvæ and eggs of $A$. roxe, on the other hand, are found throughout the year. I have found active larve, together with eggs and females, in November of one year, and also in Jannary of the following. Newstead says that the eggs are deposited in August, and that there is only a single brood in the year; and the apparently abnormal character of eggs and active larvæ being found together shows that where egg-laying extends over a consider- 
able period, the respective stages of the metamorphosis are often variable in point of time, resulting in an irregular appearance of the adults.

Hitherto I have dealt with a group of inseets which spin a covering or srale, in addition to using east-off larval moults, to protect their bodies. Now we come to a group in which the actual borly of the female is transformed into a covering or "scale" for the protection of eggs and larwe. This group is known as the Leeaniine, of which fig. $30 \pi$ represents a typical example of a Leconium scale found on syeamore.

The scales of the genus Lecanium, or "brown seales" of the gardener, are found on sycamore, hawthorn, hazel, and other plants. They have i general resemblance to brown dead buds. If a few of these scales are placed in a glass-eovered box about the middle of July, we should find that towards July 25 or so the box would be literally swarming with small chocolate-brown coloureal active larva. They are very small mite-looking creatures, measuring about $\frac{1}{100}$ of an inch in length. These small mite-like larve are the first stage of the "brown scales" referred to; and as there is a great difference in size and apparent

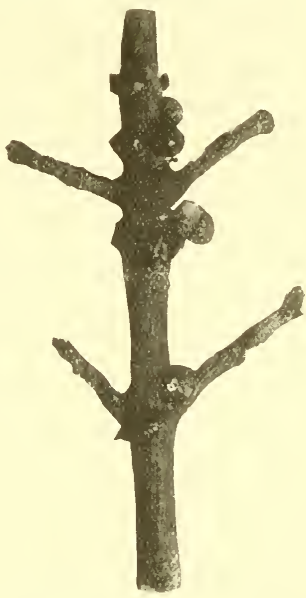

Fig. 307.-Femate sereles of 1.enamm capreat, "brown serle," on styormoro. structure between the small active larve and stationary brown deadlike scales, it would be well for the student to study the development of a Lecanium seale.

Under the one-inch objective the structure of the larvie will be seen to resemble that of the larvæ of Chionaspis. In their natural state they move about very actively for a time, and then settle down and begin to imbibe the juices of the plant.

As it is rather difficult, more especially for a beginner, to follow ont the life-history of a Lecanium on a forest tree, it is best to have recourse to stove or greenhonse specimens, and get a plant which is 
bally infested with "brown scale." For example, a comparatively small specimen of croton will often serve the purpose. In orler to understand the structural details, it is hest to prepare and mount a young adult, and examine it under the inch objective. It is then alvisable to carefully look for all the eharacters found in fig. 30 s. In the first place, see the mouth and sucking-tube, as at $a$ and $b$.

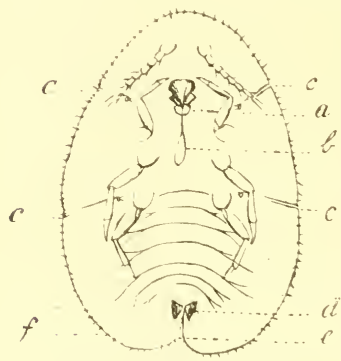

Fig. 308. - tdult female Lecenimm after treotment with potesh $\times 20$.

, mentum; b, rostral filaments, forming the sucking-tube: ecec, ventral channel leatins to spirates: $\iota$, anal plates or lobes (lorsal); $\epsilon$, anal cleft; $f$, mar ginal spines. (From Newsteat's' Mon. curiph of the British Coceidat.' Ray siociety.)

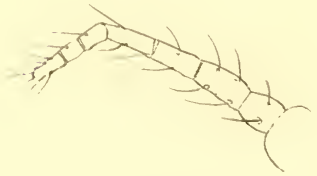

Fis. 30\%. Typical antenuer of femals? Lecanium. The antennie (fig. 309) should he well stulied, as the number and relative lengths of the joints often afford important points in elassification. At $"$ " c " we get the openings leading to the spiracles or stigmata, and these structures may be carefully stulied. At , 7 we find the anal plates or lobes; at e the anal cleft; and at $f$ the marginal spines. All these structures are clearly clisplayed in the young adults. The legs, like the antemne, should also be carefully noted uncler the field of the microscope.

But while the microseopist thus gains a general idea of the strueture, the fully developed "brown seale" is nevertheless a puzzling organism to the practical man. lerhaps it may be best understood hy adopting an illustration. In view, therefore, of making it intelligible, it is to be hoped that a very homely, if not grotesque, simile may be used. Most people are conversant with the tortoise-a creature moving along with short legs and hard hody. Now suppose this ereature was born with fully developed legs, but after one or two "moults" the body developed, say, fifty times its infantile size, while the legs remain the same as at birth, and also as a natural consequence the creature became absolutely helpless from such abnormal development, - we should have exactly an analogous ease to the development 
of a brown seale. If, therefore, the fully developed creature bw hoiler and mounter according to instructions given, we shall have a more or less circular form, representing the outer edge of the scale, and the internal appendages as represented in fig. 308. As already stated, the body is transformed into a covering for the eggs and larvie. Thus, speaking generally, the eggs are contained in the enlarged borly, and when the larva hateh out, they may often be found in a group umlemeath the scale.

When this stage of development is attained, the female is sometimes apparently, and often in reality, dead. In either case it shows, on the part of nature, a very beautiful arrangement. The modification of form and structure for the prospective requirements of her own progeny is a beautiful adaptation; but when we consider that the dead body of the female is transformed into a protective covering for the offspring, it shows a form of altruism, - the application of that law which reveals a struggle for the life of others, and which is in itself, certainly, a very beautiful adaptation incleed.

In studying those ereatures in a natural state, from an arhoreal point of view, it would be best to mark a badly infested plant for examination, and make regular visits to the same. If, therefore, the attacked portion be examined during autumn, it will be ascertained that the small larve are somewhat diffienlt to find. They have, of course, lost the activity of early youth, together with (to the naked eye) characters and their appendages. They are now transformed into small seales, measuring perhaps approximately about 1 or $\frac{1}{30}$ of an inch in length, comparatively flat, and in colour harmonising well with the fool-plant. They are to all appearance lifeless, and in this comatose state pass the winter. At the same time it must be remembered that before winter sets in the larvæ will have passed through their first moulting stage. In spring, glassy elongated juparia of the male nay be found (see fig. 310), and if collected in late spring or early summer the perfect insect can be hatcherl artificially.

After copulation, the females develop rapidly until they measure about $\frac{1}{8}$ to $\frac{3}{16}$ of an inch in diameter. As males are not always foumd associated with the female seales, it is quite possible they may at times be parthenogenetic.

In Cheshire the females reached maturity by July 1 . If a number of speeimens are placed under glass about the time referred to, it will 
he found that some of the scales will soon appear perforated, and the case swarming with small Hymenopterous parasites. Hence, probably, the harmony of colour in the early stage was a means of protection against natural enemies.

The salient characters of the sub-family Lecaniine, according to Newstead," are: "Adult females either naked or covered with secretion, forming a test or ovisac. Abdomen in all stages with a more or less defined cleft, and on the dorsal surface at the base of the cleft are two more or less triangular lobes or plates. Legs and antennæ generally retained, but a few forms are apodous, and have rudimentary antennæ. Mentum generally monomerous or dimerous. Males generally possessing wings, either with or without caudal filaments. The puparium of the male is generally of a glassy nature.

"Larve with large setiferous anal lobes, placed within the posterior anal cleft."

\section{Syxopsis of Genera (arboreal).}

A. Females naked. Ovisac behinel and partly beneath the posterior extremity of the body . . . . Pulvinaria.

B. Females naked-no ovisac.

(a) Females retaining legs and antemnæ. Old adults hollow beneath . . . . . Lecaniux.

(b) Females without antennæ and legs; body with two internal pouches. . . . . Phrsokermes.

\section{Gemus Pulvixaria.}

The male scale of this important genus cannot be separated from the male scales of the genus Lecanium or "brown scale." In the younger stages we cannot distinguish the female scales of the one genus from the other. The adult species are, however, quite distinct. We may define the adult female Lecanium as a brown seale proper, and the adult female Pulvinaria as a brown scale with a white ovisac attached to the scale itself, and extending behind and beneath the insect proper.

\section{Pelvinaria vitis (Limn.)}

The specific name of this species would suggest that it may be looked for only in the vinery. Such, however, is not invariably the

1 Vol. ii. p. 5. 
case, for though under glass it may be found on vines and peaches, out of doors it may be found on various trees-viz., hawthorn, birch, hazel, willow, alder, cotoneaster, and others.

Refore the publication of Newstead's Monograph this species was known by a number of synonyms, according to the respective foodplant-viz., Pulvinaric betule, $P$. salicis, P. populi, P. persica, de. It is therefore very helpful to fincl these specific names have now been sunk as synonyms of $P$. vitis.

Whilst I have found it sparsely distributed on the various trees enumerated, I might just add that the most common part of an old tree to find it is on the young bark formed by occlusion either after pruning or where the stem had been previously stripped of its bark by accident.

If this scale be found just as the eggs are deposited (at the period of parturition), the smooth, white, plump ovisac, together with the overlying scale of chocolate-brown colour and slight corrugations, makes a very pretty object. But soon, however, it changes. The scale grows darker, while the onter edges of the body curve inwards and upwards, becoming detached from the ovisac, and only fixed to the food-plant by the cephalic area. At this stage, also, the dermis is very heavily wrinkled.

The antennæ are generally composed of eight joints, though at times there are only seven. The legs are ordinary, with simple digitules to the tarsus.

\section{Pulvinaria vitis, var. riliesice (Signoret).}

to far as the naked-eye characters of this insect are concerned, it very much resembles the preceding species, but as it may often be found in districts where $P$. vitis does not exist, it would be well to study its life-history and microscopical characteristics.

Fig. 310 is from a photograph of this species on Ribes sanquineum, found at Lyham, Northumberland.

Newstead gives a very full and interesting account of it, and the following is his summary-viz. :

"We find that there is but one brood in a year. The larvæ hatch in June and the early part of July, the first moult taking place from the middle of July onwards; the second moult is in August, when a sexual difference is first observer. Pupation takes place towards 
the end of August, the males appearing in September. They then fertilise the females, when the latter moult again for the third time. Hibernation commences shortly afterwards, and the insects remain dormant until the spring. Egg-laying takes place at the end of April and thronghout the early part of May. In all probability the periods here set forth may vary slightly, accorling to the season."

The male (fig. 311), copied from Newstead's Monograph, is clescribed as dusky reddish-crimson or blackish-crimson in colour, with black eyes;

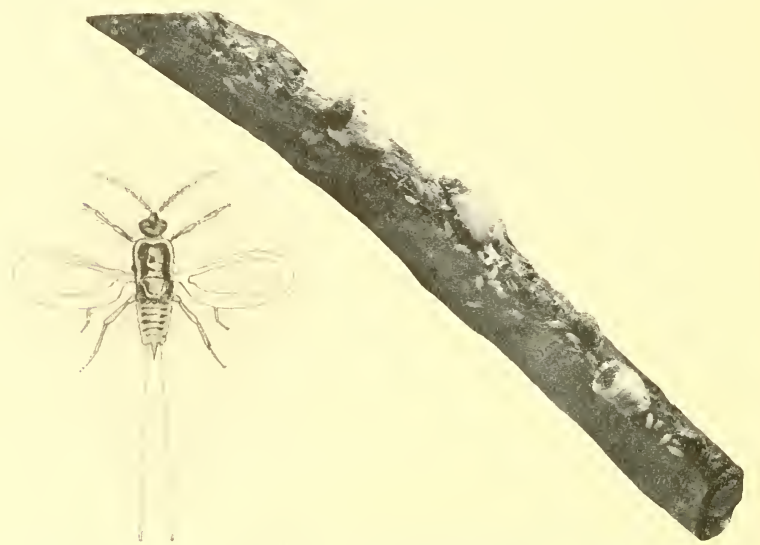

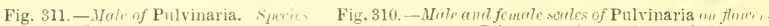

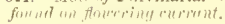

inu currout, Ribes sanguineum (untural :ize).

long, slender, and ten-jointed antennæ. Two very long caudal filaments at posterior encl. Length, including caudal filaments, 2 to $3 \mathrm{~mm}$.

Having in a general way referred to the characters and life-history of the genus Lecanium, it may now be best to give the salient characters of the arboreal species, according to Newstead.

\section{Gemu: Lecanidu. ${ }^{1}$}

Adult females, some low, convex, others hemispherical above, hollow beneath at the period of parturition.

'Adapted from Newstearl's British Coccide, vol. ii. 


\section{Synopsis of arboreal species.}

1. Adult female highly convex, sometimes hemispherical, and more or less rugose. . . . persirer and var. rengli.

2. Adult female with a delicate marginal fringe, and usually with a dorsal fusiform swelling, Coxa one-third the length of the tibia

ciliatum.

3. Idult females more or less hemispherical, spheroid, or oblatespheroicl.

(a) Dorsum with conspicuous tubereles; anal lobes rounded . . lituberculatum.

(b) Dorsum rounded, with two to four short, deep, irregular grooves radiating from the anal cleft; sides of body comparatively smooth. Legs and antennæ short

raprere.

\section{Lecaxiuy PERsick, var. coryli (Limn.)}

I have only found this species in the adult stage-viz., on Cotomeaster mirrophylla, growing in a cemetery near Leamington, Warwickshire. The colour is bright reddish-brown, more or less hemispherical, of a very uniform pattern and size.

\section{Lecaniun ciliatum (Newstead).}

I found this seale fairly common on oak-coppice shoots at High Legh, Cheshire. The female may be first recognised, about the latter end of May or beginning of June, by the conspicuous fringe which surrounds the body. This is the period of fecundation, and it may be compared to a large specimen of "mealy bug" we find in greenhouses. The whole body is covered with a whitish farinose secretion, including the two anal lobes which project beyond the body.

As this stage of the life-history of the species in question cannot be called a starting-point, though in all probability the student may also recognise them in the forest at the same stage, the following note as regards life-history is taken from Newstead:-

"The larve hatch towards the end of July. At least one moult takes place before winter, and the insect grows to some extent before hibernating. In spring (March) the female appears, and is then about 
$3 \mathrm{~mm}$. long, bearing upon its back the singular square-shaped excrescences, which are composed partly of secretion and partly of the effete skin of the previous moult. The latter is not east off', but splits or divides into squares, and these, as the insect grows, become more and more widely separated. In May another moult takes place, the newly cast skin carrying with it the marginal fringe and all the old exuviæ and secretion. After the final moult the insect grows somewhat rapidly," and the periol of fecundation is therefore reached.

Later on the female at the parturition period assumes a chestnutbrown colour, with a highly eonvex swelling in the central area. The whole seale retains slight traces of the original waxy covering, with a shining surface and a fringe of delieate hairs at the outer margin of the scale.

The antennæ usually consist of eight joints, but this number is not always constant, as seren is often found. The legs are comparatively short, with unusually well-developed coxæe.

\section{Lecanium bitcberculatum (Targioni-Tozzetti).}

The adult female scale of this species is a large, brown, highly convex seale, with two pairs of sub-torsal shining tubercles projecting considerably beyond the contour of the seale. It is found on hawthorn hedges, more especially in the eastern and southern parts of England, but it is very local. It has several characters which go to determine it as a distinct species, but these are of more importance to the specialist in scale-insects than to the general student of forest entomology. It is, however, one of the most beautiful and best marked of all the British species.

\section{Lecaxium Capree (Linn.)}

This insect may be called the common brown scale of the forest, as it is found on quite a variety of food-plants-viz., hawthorn, apple, elm, sycamore, oak, alder, willow, hazel, lime, horse-chestnut, laurel, wild sloe, \&c. (see fig. 307). Careful observation and comparison of similarly aged specimens will show that this scale varies very much in form accorling to the food-plant. Thus on elm and horse-chestnut the insects are smooth and spherical, while on lime and hawthorn they are more flat, slightly elongated, and wrinkled. During life the 
colour is of varying crimson shades, but after death the colour is invariably chestnut-brown.

The antennæ are variable, and may be eomposed of six, seven, or eight joints. It is, however, possible that eight is the typical number, but two or more joints may be so fused together as to lose all trace of segmentation.

It is also considerer that parasites have a peenliar influence in determining the form of the scales.

The insect not only varies in colour during the period of parturition, but even more so during the period of fecundation. Hence the variety of form in the two stages has given an endless number of specific synonyms, and coccidologists and general entomologists must be grateful to Newsteal for placing them all under one speeies.

With regard to the life-history of this species, I found that the lirve of insects from sycamore hatehed out, in confinement, on May 25th. This was in Cheshire, and the specimens having been kept in a warm room, it is possible that this was rather early.

The larvæ move about quite promiscuonsly for a time on leaves and shoots, but early in the autumn they all betake themselves to the shoots and moult. They pass the winter in a comatose state, and the sexes assert themselves in early spring; but there is generally a

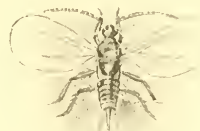
preponderance of females, and in some eases males cannot he found.

In Cheshire Newstead found that males hatch about the end of April or beginning of Mray, but in Northumberland I found, after keeping puparia for two days in a eool room, that males appeared on May 23 in 1901. Allowance must be made for the lateness of the north, but it would seem as if twenty days to a month clapses from the appearanee of the males to hatehing of the larvæ. The student will be well repaid by following out the life-history of a Lecanium, as it is in some respeets a typical example of how variable in point of time larval development and emergence may be.

Newstead thus deseribes the male (fig. 312): "Pale crimson, with the head, thoracic bands, and apodema crimson-black; abulomen, legs, 
and antennæ paler and dusky. Eyes and ocelli black, shining, and of the latter there are four dorsal and six ventral. Candal filaments comparatively short. Halteres pale red, tumed back over the thorax when the insect is at rest. Wings rather short, and suddenly widened at base. Stylus nearly as long as the abdomen."

I have found this insect sparsely distributed on all the food-plants enumerated. As a veritable pest, however, I have found portions of herlges near the city of Chester, and also in other parts of midCheshire, killed outright by this insect. It is also somewhat remarkable that I always found this scale most injurious where the hedges were either cut twice in one season or on cottage-garden hedges cut only once in a season, and more especially where the cutting was done very early in the autumn.

\section{Genus Physokerues.}

The larvæ and early stages are quite identical with Leranium. After this, however, the structural details differ from Lecanium, inasmuch as in Ph!lsoliemes the holy at egg-deposition is eomposed

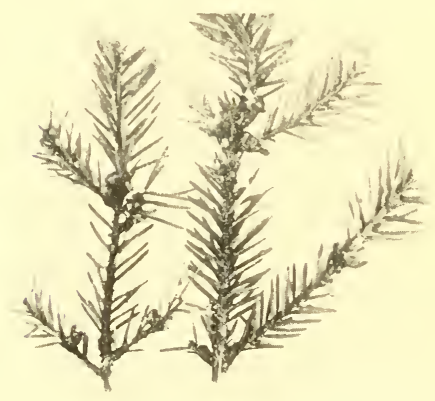

Fire. 313.-Scales of Physokermes alvetis es found in the "forkings" of the young turigs of common syruce. of two chambers, both of which are filled with eggs; and also in the adult scale no traces of antenne or legs are found.

\section{Physolermes abietis} (Geoffrey).

This insect is always found on spruce (Picea excelsa). The scale is very much like a Lecanium in general appearance. It may be looked for on the younger twigs of spruce, and more especially in the "forkings" of the young twigs (fig. 313). The colour, generally a dull chestnut, harmonises well with the food-plant, which may be a means of protection against natural enemies. Newstead says he has hatched from this scale a chalcid parasite, Encyitus scaurus, Walk.; a 
small beetle, Brarluytaras varius; and a small dipteron, Diplesis latilulorum, Winnz.

The life-history somewhat resembles that of a Leranium, but the anatomical structure is altogether different and quite unique. Newsteal says the eggs may be found in the pouches at the beginning of June, and the larve hatch towards the end of July. This observation was made in Cheshire, and therefore liffers from notes I have made here in Northumberland-viz, to the effect that on August 2, 1900, I found eggs, and on September 1, same year, I also found eggs, and placed the insect containing them in a small box, but the observation was neglected until September 21, when the larva firm those of the latter rlute which had hatched ont were all dead. The larva hide themselves rather effectually on the young twigs during the winter months. Hitherto no males have been found. The creature has an internal double-chambered marsupial pouch, into which she places her eggs for incubation. This peculiar structure can best be seen by embedling the body in paraffin wax and making sections by means of a microtome. Legs, antemm, and other appendages are not found after boiling the body in potash, but a peculiar rough tesselated surface can be seen after the chitinous body has been prepared for microscopic examination.

I found this species very plentifully at Pollok, near Glasgow. As a rule, it is very common on sickly specimens which are considerably injured by Chermes alietis. In healthy spruce-trees no appreciably ill effect accrues from the presence of this scale, but the more weakly trees, which act as shade-bearers, are often killed outright by this species and the associated chermes.

\section{Sub-Famly DACTYLOPIIN æ.}

"Adult females active or stationary, nakel or covered with mealy, cottony, waxy, horny, or glassy secretion.

"Antennæ and legs either well developed, rudimentary, or entirely absent. When present, the last joint of the antenne is usually much longer than the penultimate. Anal lobes generally small or ruclimentary.

"Larve, exhibiting anal lobes and setiferous anal orifice, similar to those of the adult female.

"The females of this division are distinguished ehiefly by the 
character of the anal lobes, which, although varying in degrees of development, are always present.

"In Dactylopius the ovisacs are usually formed of loose, white, flocculent secretion, often quite devoid of form, and aggregated in masses on the food-plant.

"In Cryptoroccus the ovisacs are also felted, and often so thickly packed together as to completely cover the bark of the tree.

"The males are characterised by the comparatively short and somewhat complex structure of the genital armature.

"The male puparia are generally felted." 1

\section{Sryopsis of the Genera.}

A. Adult females stationary, enclosed in a glassy or horny fringed ovisac (test) . . . ( (I.) Asterolecanium (1).

B. Adult females active, covered with mealy secretion, not enclosed in ovisac.

(a) Female antennæ of eight joints . (II.) Dactrlopius (2).

$B B$. Adult females enclosed within ovisac at gestation.

(a) Female antennæ of nine joints . (III.) Pseudococcus (3).

(b) Female antennæ of six, rarely of five or seven, joints

(IV.) Ripersia ( $t$ ).

C. Adult females stationary, living from the earliest stage within the ovisac ; antennæ and legs rulimentary or absent.

(a) Anal orifice of adult female with four spiny hairs

(V.) Criptococcus (9).

(b) Anal orifice of adult female with six long hairs

(VI.) Antonina ( 7 ).

$C C$. Antennæe and legs present; anal orifice with six flattened hairs

(VII.) Apterocuccus (8).

$D$. Anal lobes of adult female very large, body with long marginal or dorsal spines . . . (VIII.) Eriococcus (5).

E. Body of adult female with numerous short conical spines

(IX.) Gruxococcus (6).

The above "synopsis" is copied in full from Newstead's Monograph, vol. ii.; and though all the genera are not arboreal in their habits, it is important that the stuclent, more especially a horticultural student, should study at least a typical species from each genus.

${ }^{1}$ Adapted from Newstead's Monograph. 
The arboreal genera are: Asteroleranimm, Pseulococcus, Cryptorocrus, and Apterococcus. With the exception of Asteroleconium, these genera are, so far as our present knowledge goes, exclusively arboreal.

The remaining genera - viz., Dactylopius, Ripersia, Antonina, Eiriococos, and Gymococtus-are, as regards food-plants, very varied indeed. Thus Dartylopius ("mealy-bug"), of which five speeies are at present known, may feed on numerous greenhouse plants, grasses, or sea-pinks; Ripersia on a hothouse fern, on Stephanotis, roots of grass, and even subterranean ants'-nests; Antonina on bamboo; Eivococcus on gorse, grasses, or heath; and Gymnococeus on stovehouse plants.

Genus Asterolecaxium.

The females of this genus are completely enclosed in a sac of opaque or semi-transparent waxy or glass-like secretion. This ovisac is usually termerl a "test," and the margins are generally furnished with a fringe of waxen rouk or plates.

The adult females are apodous, and the antemnæ are either absent or rudimentary.

\section{Asterolecanium variolosum (Ratz.)}

This is a species which I found very common in Cheshire, on the tips of the young oak shoots. The female scale artheres very closely to the young twig, - so much so, that she actually causes a depression to be formed, and where they are numerically strong, often kill the twig. The appearance presented may be compared

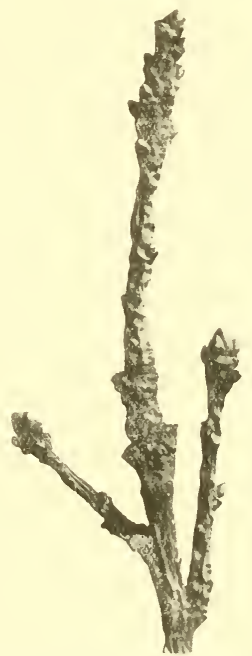

Fis. 314.-Depressions on tuigs of ork callsed by Asterolecanium variolosum (urturel size). (if the simile is not considered too grotesque) to the features of a person who has suffered severely from small-pox (fig. 314). The ovisae is made up of a "test" or scale, which is of a circular shape, and around the lateral sides a curious fringe may be seen under the microscope. The eolour of the scale varies according to age: thus 
in summer it is green, and in winter brown. Underneath this scale or "test" may be found the actual body of the insect, lut in the living specimens it is almost inseparable from the scale, hence it is best to select dead specimens for microscopical examination.

After treatment with potash, details of structure can only be seen under high powers, of which the salient features are spinnerets and rudimentary antenne.

\section{Gemu: PaEddococcus.}

The genus Preudocuras is deciledly arboreal, and in many respects resembles the mealy bug, more especially in the larval stage.

\section{Pseudococel's aceris (Signoret).}

In fig. 315 a typical example of this scale is represented on hornbeam. To the naked eye this scale appears as a small white speck

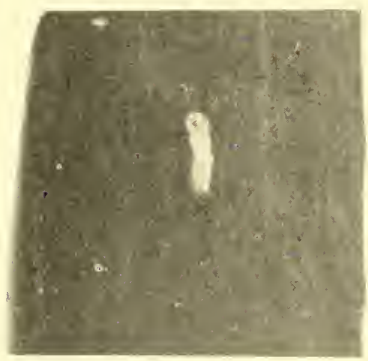

Fig. 315.-Psendoeocens aceris tu bur t, of lintulyeth (intthithl size). on the food-plant. It is found on various forest trees and shrubs, inchuling sycamore, hombeam, mountain ash, elm, oak, and grorse or other plants. On the last-named food-plant it is sometimes very thickly coated on the spring leaves, and at other times only sparsely distributed. Though never so numerically strong as to be considered a pest, it has nevertheless an interesting life-history. The female insects, as seen in the illustration, should be looked for towards the end of May or begiming of June. They may be then placed in a box, together with a very small portion of the host-plant upon which the insect rests. The larw hatch about the midcle of June, and they are mere pin-points in size, and of a light-yellow colour. The antennie at this stage are composed of six joints, the terminal joint being as long as three succeeding joints. They have large prominent eyes, of a brown colour, with just a slight tinge of 
hue. The legs are similar to those of other coccil larve. The body at first sight appears to be in one piece, but the abdomen is segmented and fluted, each flute terminating in a single hair.

The species illustrated on hombeam, on which I tried to make a few observations, was taken from a tree in my garden in High Legh, Cheshire. I found the larvæ hatched out about the middle of June, but I failecl to diseover their presence again until September. It is true that the bark of the partieular tree in question was very much covered by the alga known as Protocorens viridis, and would thus provicle ample shelter and covert

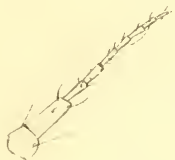

Fig. 316. - Antemue of Psendococeus aceris. (Canera-lneida sketeh.)

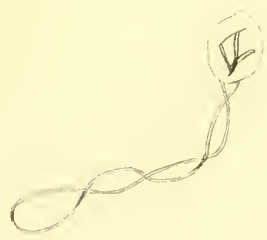

Fig. 318. - Rostiun of Psendococens aceris. (Camera-lucida sketch.) for the ereatures. By that time they had enlarged considerably,

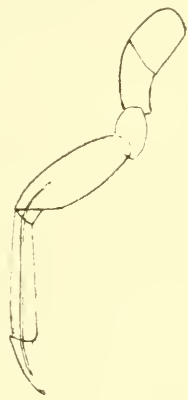

Fig. 317.-Lry of Psendococeus aceris. (Camera-lucila sketch.)

and could be found in comparatively large numbers swarming on the lower region of the trunk. At this stage they are still larve, but the sexes then assert themselves and separate. The males remain in the sonth or lee sile of the trunk, and the females go higher up, on the branches, generally in the cleft. Accorling to observations made daily with this species, on a laburnum-tree, Newstead says the females reawaken in Narch, a few days hefore the males, desceml the trunk, copulate, and return to the branches. This seems all the more remarkable inasmuch as the males have wings and well-developed legs, and could easily move in the direction of the female residence. In May the females spin their eocoon, which 
takes about three days. The eggs are laid during the construction of the cocoon, and the larvæ hateh out, as previously mentioned, about the middle or end of June.

I found larvæ of this species very plentifully in thom hedges at Prestbury, Gloueestershire, Sept. 10, 1906. In general appearance they very much resembled the "mealy bug" of greenhouses. They were yellowish, with a white dusty covering over the body. The parent seales with their ovisaes were situated on the twigs, but the young larve in question were congregated in a streak along the miirib of the leaf, and generally on the upper side.

The female can be easily detached from the ovisac without the aid of a lens. The body is simply an ovate sac of a yellowish colour. If the body be boiled in potash we get rather an interesting object. The antennæ are composed of nine joints (fig. 316), of which the second is usually the longest, but the antennæ are often variable. The legs and the outline of the rostrum can also be clearly traced. Fig. 317 represents a camera-lucida sketch.

Fig. 318 is a camera-lucida sketch of the rostrum.

\section{Gemus Cryptococous.}

"Adult females stationary, living within a felted ovisac. Antenne rudimentary. Posterior pair of legs rudimentary ; anterior and intermediate pair absent. Anal legs normal. Larva with anal orifice, as in the arlult female. Antennæ of five joints." 1

\section{Criptococeds fagi (Barensprung).}

This insect is very common in many parts of the country, and is, in fact, one of the most dreaded pests of the arboriculturist. At the same time, it may be noted that it often confines itself to comparitively small areas, or to isolated park trees. In general appearance the trunks and larger branches of beech-trees infested with this pest present the appearance of a shower of snow having frozen. This pest has been graphically termed the "felt scale" by Miss Ormerod. Fig. 319 is a representation of this seale on beech.

Where the pest is but sparsely distributed on the stem little damage accrues; but it is sometimes found about a quarter to half an

I Newstead, vol. ii. p. 214. 
inch in thickness, and when such is the case the bark separates from the stem, and the tree ultimately dies in consequence.

This insect confines its attacks exclusively to the beech (Fayus sylvetica), and, by reason of its whitish appearance, must not be confounded with the various species of Chermes (Aphidre) on larch, silver

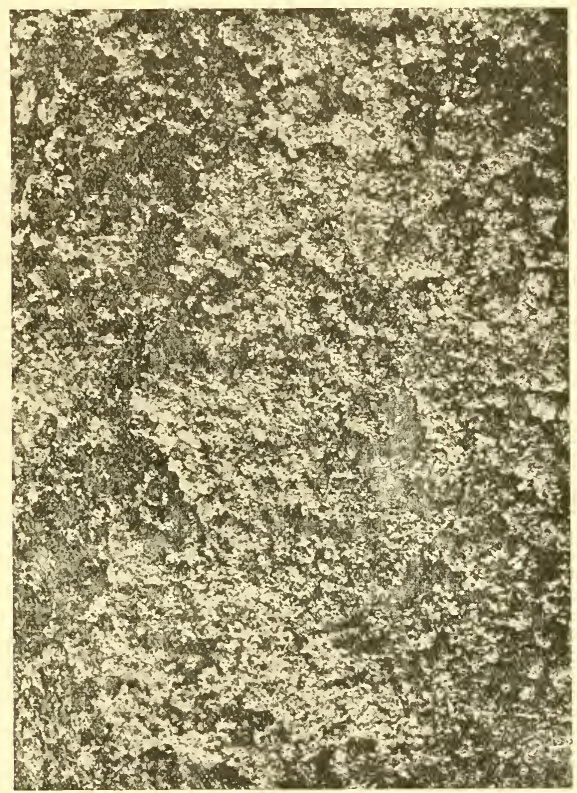

Fig. 319.-Cryptococeus fagi on bepeh. (From F. V. Theobald's 'Animal Pests of Forest Trees.')

fir, Weymouth pine, \&c. It should also be noted that the "copper beech" is all but immune from this insect-pest. In fact, I have occasionally seen cases where the copper beech was grafted on the common beech, of the pest appearing fairly thick on the stock or common beech portion, and the copper beech portion above having only here and there the smallest possible specks on it. 
On moving the white covering about midsummer, the insects may be found in all their respective stages.

The adult female is of a sulphur-yellow colour, about half a line, or $\frac{1}{2} 5$ of an inch, in length, convex above and below. The creature is both wingless and legless, and has, therefore, no power of locomotion. The month-organs are placed on the under side of the body, and are composel of long hair-like appendages, forming mouth or suckingtube and anchorage. She covers her body with the white waxy secretion, which is impervious to rain, and here she lives, lays her eggs, and dies.

The larvæ, in shape and appearance, very much resemble other coceid larve, being active and yellow in colour. The eyes are rather conspicuous, and of a purplish colour. The antemre are five-jointed, and terminated by a forked bristle. The legs are short and stout.

As a rule, they are found under the living or dead bodies of their parents or in the same felted mass, for the larvæ also seerete a white waxy covering, thus adding to the white materials, and also aiding in the destruction of the tree. Occasionally the larvæ move to the fresh portions of the bark, secrete a covering over their borlies, and thus spread the injuries over the trunk.

The eggs are also of a lemon-yellow colour, and comparatively large for the size of the insect.

As regards the life-history of this insect, it may be said that much may yet be done by the inquiring and observant student, inasmuch as eggs, larve, living and dead females, may at various periods of the year be found all huddled together. However, it is possible that the majority of the eggs are deposited in July, and that some hateh out in the autumn months and pass the winter as active larve, whereas the majority hateh out in spring and soon after evolve into fully developed females.

At various seasons of the year I have often fouml very active specimens of acari amongst the insects.

Considering the alarming spread of this pest, preventive and remedial measures ought to be taken in order to save many specimen trees in pleasure-grounds, parks, the neighbourhood of villages, and forests generally.

Some years ago, as a remedy, I tried a solution which proved very successful. To make it, take about half a gallon of soft water, boil, and dissolve about $1 \mathrm{lb}$. of soft soap and about $1 \mathrm{lb}$. of common soap; 
ard a handful of sulphur, one pint of paraffin, and about the same quantity of turpentine. Then add about four gallons of soft water to this mixture. Churn well with a syringe, and when cold, store away in a stoppered barrel to prevent evaporation. Apply with a whitewash brush about May, just as the larvæ are hatching out, but before application ehurn well with the syringe, to ensure the mixture of the ingredients. ${ }^{1}$

I did not measure out the ingredients in exact proportions, but took care not to add too much paraffiu and turpentine. I have, however, in practice, been fortunate enough to have been associated with healthy beech-trees in Northumberland, and therefore have not harl an opportunity of putting this mixture to the test on a large seale, but all those who have tried it maintain that it answers well. In fact, I had several portions of beech lark sent from various parts of the country showing the good effects accruing from the applieation of this mixture.

A most interesting remedial measure has been brought under my notice at Blagdon, in Northumberlant. With an inch augur bore three holes at about equal distance right into the centre of the trunk, about three feet from the ground, and sloping slightly towards the root of the tree. Into these holes place as much flowers of sulphur as ean be conveniently got in, and then cork them firmly up with a plug of soft wood. This should be done in the autumn, and will be found suceessful. It was first adopted about thirty years ago, and the trees which were then operated on are now in comparatively good condition.

Though this remedial measure may be adversely eriticised by many practical men, nature would seem to suggest some analogous form of treatment by inference from the copper beech being all but immune, and also from the fact that certain species of fruit-trees are immune from Ameriean blight and scale-insects.

From an able and interesting leaflet of the Board of Agrieulture the following insectieides for this pest are recommended :-

(1) Parafjin emulsion.-Mix equal proportions of soft soap, dissolved in boiling water, and paraffin, and churn them up by means of a foree-pump or syringe. When required for use add twenty times its bulk of water, and again churn.

1 This has been adopted by the Board of Agriculture. See Leaflet No. 140, Remedy "No. 2." 
(3) Caustic alliuli wash.-Dissolve $1 \mathrm{lb}$. of commercial caustic soda in water, then $1 \mathrm{lb}$. of crude potash or pearl ash in water. When both have been dissolved, mix the two well together; then add $\frac{3}{4} \mathrm{lb}$. of soft soap, stir well, and add sufficient water to make up to ten gallons. Coution.-Do not mix in painted vessels of any kind.

\section{Geme: Apterococcus.}

Adult female stationary, living within the ovisac. Legs persistent. Antennæ six joints. Male apterous. Antennæ seven joints. Male puparium felted.

\section{Apterococces fraxini (Newst.)}

In some parts of the country this scale is fairly common. I found it frequently in Cheshire, and again in some instances in Northum-

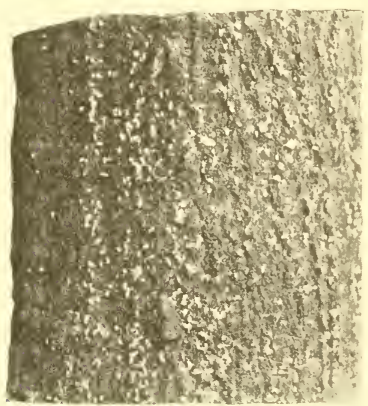

Fig. 320.-Apterococcus fraxini on bork of ush. berland. As a rule, it is generally found on isolated trees, or otherwise extremely local on hedgerow trees. It is found on trees of varying ages, from fifteen years upwards, hut most abundantly on trees from thirty to forty years of age with comparatively smooth bark. When it is fomm on old trees, it is sparsely scattered in the fissures of the rough bark. The general appearance of this scale somewhat resembles the genus Dactylopius or mealy bug, inasmuch as the bark is spotted with numerous white specks (fig. 320). If an individual sac be examined during the winter months, it will be found to contain two or more female insects.

The adult female is of a bright-red colour, somewhat globular in shape, with six-jointed antennæ, short legs, and very long rostral filaments. A microscopical examination of a prepared female insect, under high power, reveals special rings of spines surrounding the anal orifice, and a few tubular spinnerets on the dorsal surface.

The male is apterous, of a bright-red orange colour, with black 
eyes. The antennæ show seven and sometimes eight joints, and at the junction of the third and fourth joint a curious ball-and-socket arrangement may be seen. The genital armature is comparatively short. The males appear in considerable numbers during October and November, and during the day may be seen actively moving on the bark.

I found the larve hatching out in Derbyshire about the latter end of June 1906, and abont a fortnight later of the same year in Northumberland.

\section{References to Literature ronsulted.}

Cockerell, T. D. A. Notes on the Geographical Distribution of Sicale-Insects. Smithsonian Institute. 1895.

Comstock, J. H. Report on Scale-Insects. 1881.

J)ouglas, J. W. Some British and Exotic Coceidie. E. II. II. 1891.

Fuller, Claude. Artieles in Australian Papers.

Howard, L. O., and Marlatt, C. L. The San José Scale. U.S.A. Bulletin, No. 3. 1896.

Hunter, s. J. Scale-Insects Iujurious to Orchards. University of Kansas, Lawrence. 1898.

Lea, A. Il. Neale-Insects. Western Australia. $189 \mathrm{~S}$.

Lewis, Richard. Papers on Scale-Insects.

Lounsbury, Chas. P. Coccidie or Scale-Insects. Cape of Good Hope. 1907.

Maskell, II. II. Seale-Insects of New Zealand. 1887.

- Various papers from 1883.

IIorgan, A. C. F. Scale-Insects. Portugal. 1888.

Newstead, R. Monograph of the British Coccida. Ray Society. 2 vols. 1900-1902.

Newstead, R. The Injurious S'cale-Insects and Mealy Bugs of the British Isles. Journal of the Royal Horticultural Society. Also separate papers from E. M. M. 1891.

Quaintance, Ml. S. American Aleurodidie. 1900.

Sule, Karl, Studie o Coccidech. 1895.

Tryon, Henry. Scale-Insects, Queensland. 1898. 


\section{CHAPTER X.}

\section{IIPTERA (Two-winged Flies).}

Frow an entomological point of view, the orler Diptera is very important, inasmuch as it is, to a large extent, an unworked field, requiring a good deal of careful study, and having admittedly an unsettlect question of classification. Viewed by the economic entomologist, it traverses a very wicle field. Thus we have the troublesome flea, the annoying house-fly, and the irritating summer-evening midge. There are several species which feed on carrion or decayed vegetahles, and destroy obnoxious matter, both in the animal and vegetable kingdoms, and a number of species which take an active part in disseminating some of the most direful diseases. From a husbandry point of view, the familiar names of warble-fly, onion-fly, carrot-fly, Hessian-fly, and many others, suggest the importance of the subject. In the forest they are, as a general rule, not so destructive as some of the insects previously dealt with, but their small size, minute characters, and interesting life-histories suggest them as interesting studies to the microscopist, the general biologist, and the practical man.

The structure of the Diptera can be best made out by taking a house-fly as a typical insect. The chief character is, of course, the "two-winged" structure. They are sharply marked off from all other orders of insects by the reduction of the hind-wings to mere knobs, "balancers," or halteres as they are termed. The whole mechanism of flight is entirely dependent on the two wings, but it is patent that the creatures bound through the air with greater ease, more gracefulness, and apparently, as it were, more command of will, than any other group of insects.

The head is usually very convex in form, large eyes, and with so slender and flexible a neck that the head all but turns round on a pivot. The order shows that there is great diversity and modifica- 
tion of mouth-parts. Thus the house-fly takes its forl by a sucker arrangement; and the equivalent of mandibles and maxillar, dc., of other insects are modified into organs for piercing in the mosquito. The antenne of the order vary much in length and structure.

The legs are usually very slender, and vary much in size. The legs of the house-fly and "daddy-long-legs" are cases in point. The feet end in two claws and a sort of pad. The wings are also variable, and the venation requires the greatest attention, so far as iletailed studies are concerned.

The abdomen is generally made up of eight segments, indicated by numbering from the base - that is, the part attached to the thorax. The last or anal segment is of peculiar shape, and contains the generative appendages, and consequently the sexes are very easily determined in many tribes of the Diptera. These characters are, of course, variable, but in the male they may be either a sort of louble forceps with central penis, or lamelle and penis sheath. In the female the last segment is prolonged into an ovipositor or vaginal sheath, and has two basal lobes. ${ }^{1}$

With regard to classification, the order may be divided into two sections-(1) Orthorrhapha and (2) Crclorrhapha.

(1) The larva in this section has a more or less perfectly developed chitinous head, and the pupa escapes by a $T$-shaped rent in the larral skin.

(2) In this section the larva has no chitinous first head, but is quite acephalous, and the pupa escapes from the larval skin by a circular opening.

The Orthorrhapha are divided into two sub-sections-viz., the Nematocera and the Brarhycera, the former having threadlike and many-jointed antenna, the latter having the antenne composed of two or three segments with a lateral bristle or arista.

The principal families of Diptera which cause injuries in the forest are Cecirlomyiüle, Phytomyzidu, and Agromyzidue.

The first-named is numerically considered the strongest, and the following characters of the family are given by Mr Theobald : ${ }^{2}$

1 The student who wishes to pursue the special structural details of Diptera would do well to consult a very detailed chart by the Rev. W. J. Wingate, in the 'Transactions of Nat. Hist. Soc. of Northumberland and I)urbam,' vol. ii., 1906.

${ }^{2}$ An Account of British Flies, by Fred. V. Theobald, Hp. 50, 51. 1892. 


\section{FAMILY CECIDOMYIDÆ.}

"Ocelli often absent. Thorax with no transverse suture. Antemne long, composed of many segments (10-36). Wings with only few nervures. Coxæ not elongated, femora not thickened, no spurs on tibie. Delicate milges or gall-flies whose larvæ are provided with an anchor process beneath the head end.

\section{Gemus Cecidomyia.}

"Antennæ long and moniliform or cylindrical; generally verticillate, 13-36 joints. Wings hairy, and have densely pubescent margins. Three or four longitudinal veins. There are two types of wings. In the first type the third vein is forked, thus representing the third and fourth veins, which have united for most of their length. In some rare cases this fork may become obliterated. In the second type of wing the four veins are separate and simple. We must note in these insects a curious longitudinal fold between the second and third longitudinal veins, present in most Cecidomyidæ."

The following are the more important as regards arboreal insects -viz. :

$$
\text { "Cecidonyla, Lw. }=\left\{\begin{array}{l}
\text { Dasyneura, Rid. } \\
\text { Rhabdophaga, Westw. }
\end{array}\right.
$$

"Same number of joints in the of antennæ as in the $q$. The joints may be pedicelled or sessile. The second longitudinal vein reaches the margin of the wing before its tip.

$$
\text { "Iiplosis, Lw. }=\left\{\begin{array}{l}
\text { Phytophaga, Rd. } \\
\text { Brema, Rid. }
\end{array}\right.
$$

"The antenne of $\hat{\delta}=26$ to 27 joints; that of the $q=14$ to 15 . The joints are pedicelled. The second longitudinal vein reaches the margin beyond the tip. The joints of the antenne of the $\hat{\delta}$ double the number of those of $q$.

\section{" Hormomyia, Lw. = Axgelinia, Rid.}

"This sub-genus is distinguished by the gibbose thorax, which is often drawn over the head. The second longitudinal vein ends as in the preceding sub-genus. Wings without lustre. 


$$
\text { "Asphondilia, Lw. }=\left\{\begin{array}{l}
\text { Crlindrocera, Lioy. } \\
\text { Phyllophaga, Ril. }
\end{array}\right.
$$

"Antennæ with short hairs of equal length; joints eylindrical and sessile; no verticils. Same number of joints in $\hat{\delta}$ and $q$. Second longitudinal vein reaches the margin of the wing, beyond its tip. Wings shiny."

As the insects in the family are so very small in sizc, it might be best for practical purposes to consider them according to the injuries they inflict on the respective arboreal food-plants - viz. :

(1) Foldings and rollings of leaves.

(2) Galls on leaves.

(3) Galls on stems or stalks.

(4) Various injuries or deformities of shoots, \&c.

It is, however, not practicable to attempt reconciling this arrangement with systematic classification.

Hitherto this family has not been very carefully studied in forest entomology, and the chief points for the discrimination of species are very minute, so that recourse must be had to the microscope. The main points are, the "breast-bone" in the larval stage-an "anchor process" found on the first thoracic segment; the venation of the wings; and the genitalia of the males.

By stupefying the insects with chloroform we can very easily examine with the inch objective. It is necessary to do this, however, in order to carefully note all the characters, more especially as they change colour rapidly after death, and they are most fragile to mount as microscopic slides.

\section{Cecidomyia (Dastneura ${ }^{1}$ ) Marginemtorquens, Winn.}

This insect is found on the common osier (Salix viminatis), and forms galls on the edges of the leaves,-often on both sides of the leaves, - and rolled from the base to nearly the apex (fig. 321). These galls or foldings are on the under side of the leaves, and rolled towards the midrib. The rolled portion of the leaf is generally smooth, and of varying shades of colour, from pale-green to purple and chocolatebrown. The galls appear early, and may be found from June to

1 The generic names given in parentheses are those usually adopted at the present time. I am indebted to Mr Theobald for this improved arrangement. 
October. It is quite possible there are several broods, as I have hatched them out in confinement in Northumberland from the beginning of July to the end of October; and as the larvæ pupate within the galls, artificial hatching is very simple, provided we see that they are in the pupal stage prior to being placed in a glass-covered box. By stupefying the insects with chloroform we can very easily examine them with the inch objective.

Hale.-The body and antennæ are darkish-brown colour; antennæ 15- to 16 -jointed, as long as the body. The thorax slightly reddish; abclomen yellowish-brown; wings covered by darkish hairs. The
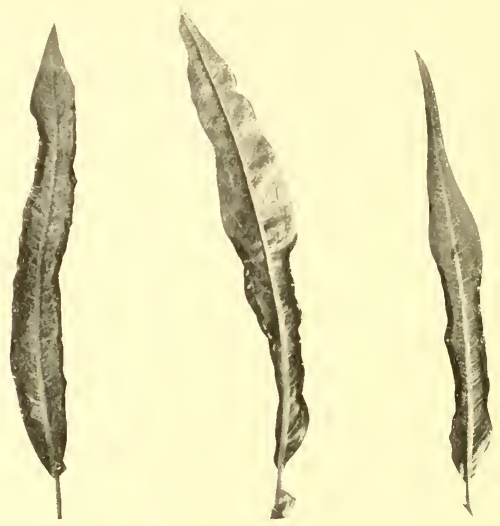

Fig. 321.-Leaves of Salix viminalis rollea by Cecidomyia marginemtorquens.

legs are of a lightish colour, and slightly tinged with red at the joints. Length 1 to $1 \frac{1}{2} \mathrm{~mm}$. (Fig. 322.)

Female.-The body is of a lark-grey colour, with rather comparatively longish halteres. Face light-grey; the wings are clear, but hairy, more especially at the edges. Eyes large, deep velvetyblack. The head and thorax black, with stiffish erect bristles; abdomen dark-grey above, light-grey beneath. The antennæ lightgrey, with a darkish tinge throughout. The legs are light in colour; oviduct long and slender. Length 1-2 mm. (Fig. 323.)

The conspicuous difference between the antennæ of the male and 
female, together with the small size and fascination of getting good mounts, make this an interesting mieroscopical object.

\section{Cecidomia (Dasyneura) crategi, Wimn.}

This species is found on the eommon thorn, but more especially on clipped hedges. The gall (fig. 32t) is often a common aucl familiar roadside objeet. It is formed of a tuft or rosette of leaves on the tips of the young shoots, and generally on shoots at the top of the hedge, which grow after the previous year's eutting. There is generally only one gall on the top of each shoot, but they are often found

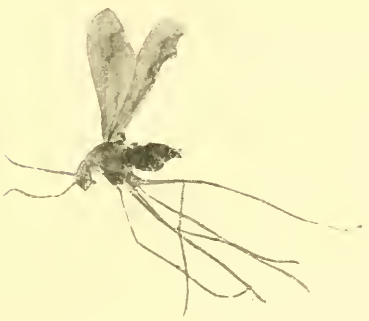

Fig. 32.2-Ceeidomyia maryinemtormens (nutle).

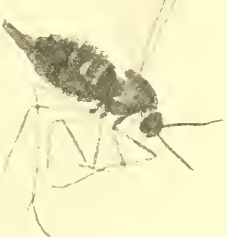

Fis. 323.-Cuecilonyia maryinemtorquels $($ femole $)$.

so numerous that scarcely a twig is left untouched. The larva live gregariously within the eluster of the deformed sessile leaves. Eaeh leaflet is thickly studded with short, stiff, blunt, erect hairs, which provicle proteetion for the larvie.

"Imago black, with yellowish palps. Antennæ 16-jointed in of, 15-jointed in $q$. Oviduct long, and yellow at the tip. Sirles of thorax and metathorax flesh-eoloured. Abdomen Hesh-colonred, with black bands. Halteres white. Wings hyaline; black pubescence and costa. Second long. vein bends forward at its junction with the transverse veinlet, then, passing in an almost straight line, joins the costal a little distance from tip of wing. Length, $\frac{3}{4}$ lin." 1

${ }^{1}$ An Account of British Flies, by Fred. V. Theobald, p. 67. 


\section{Cecidomia (Dastieura) taxi, Inch.}

This species is found on both the English and Irish varieties of yew. It forms a cone-shaped gall of tufted leaves (fig. 325). There is only one larva in each rosette, and it lives and pupates within the gall. The imago emerges either in the last week of May or first week in June. This species is diffieult to rear artificially, therefore it is important to place them in confinement about Nay 20 or so; and as the galls shrivel up very quickly, it is advisable to gather fresh specimens every two or three days about the date mentioner. sin far as this species is concerned, dates are important,

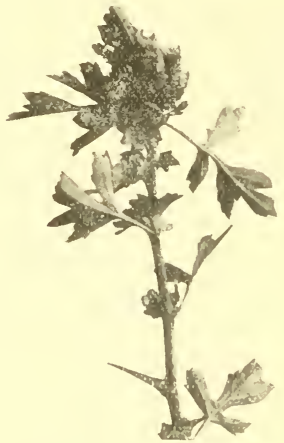

Fis. :24.-Shuot of har therm herlyt injured by Cecidomyia eratiegi.

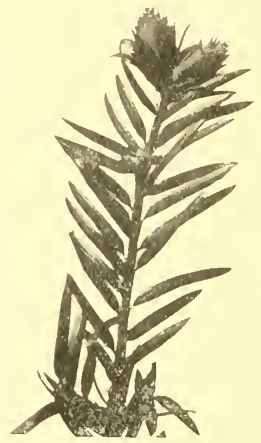

$\mathrm{Fin}$ 325,-Twin of un in w red 7y, Cecidomyia taxi.

having regard to the difficulty of rearing. I have gathered them for artifieial hatehing about the middle of May, and they have all shrivelled up so mueh that they never hatched; and again I have gone to the trees about June 10, and the "bird had fled," leaving the empty pupa-case on the extreme tip of the rosette.

Male.-Antennæ 15-jointed; joints verticillate pilose; basal joints red, others light-grey. Eyes large, black; thorax orange beneath, dorsum black. Halteres bright orange; abdomen light-grey, with dorsal orange streak; genital armature light-brown; wings light-grey, slightly hyaline, legs of a uniform light-grey, anterior pair slightly orange-coloured.

Female-Antennæ light uniform grey, very pilose, 18-jointed. Thorax light yellowish - orange beneath, above pilose dark. Wings 
as in male; abdomen orange, with paler oviduct, and coverenl with black hairs; legs uniformly darkbrown, with greyish pubescenee.

Cechomima(Rhabdophaga) rosaria, Lw. (Willow Rose-gall Midge). ${ }^{1}$

The galls caused by this insect (fig. 326) are fairly common in Northumberland, more especially in the hilly districts, where there is an abundance of scrub of the goat willow (Salix raprea). The galls may be found throughout the winter months after every leaf has disappearecl, and as many of the larve pupate within the gall, it is well to collect them when dry for artificial

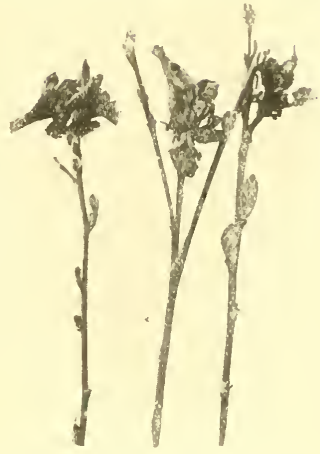

Fig. 326.-Shoots of Salix caprea injurel by Cecilomyia rosaria.

breeding. The inseets appear about the middle of May, and deposit their eggs in the terminal shoots. The gall very soon forms, as I have found it by the first week in .June. The gall itself is simply a rough rosette of leaves formed in consequence of growth being arrested.

Alult insert, female.--Expanse of wings about $6-8 \mathrm{~mm}$. Antennæ lightish, inclining to grey on ulper side. Thorax greyish, very hairy. Abdomen flesh-colourecl, telescopic portion of segments very elastic, other portions dark and hairy, under side uniformly flesh-coloured, with greyish silken hairs. Eyes black, wings greyish, veins dark-grey.

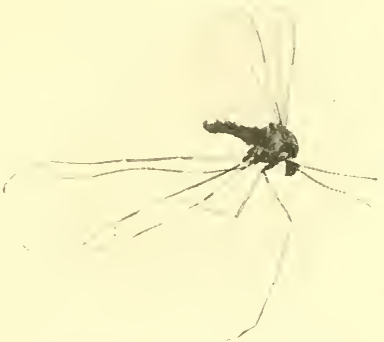

Fig. 327.-Cecidomyia rosaria (mule). Halteres light. Legs greyish, with red feet.

Male.-Antennæ greyish-black, and joints very hairy. Eyes black. Base of wing flesh-coloured. Thorax darkish grey, hairy. Abdomen uniformly grey, and hairy. Legs same as in + . (Fig. 327.)

1 In hatching out this species care should be taken to "select" the rosettes only, apart from buds on the twigs, in consequence of there being another and distinct species found within the buds. 


\section{Cechomita (Rimaboophaga) saliciperda, Duf. (ITillow-wood Midge).}

This species injures the stems, from two years old and upwards, of several species of willow, and can therefore be readily distinguished

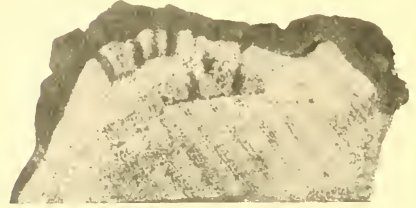

Fis. 325.-Section of willum ste on shomint injuries arused by Cecidomyia saliciperda. from $C$. salicis, which contines its attacks to young twigs. In figs. 328 and 329 we have a representation of the damage done to a species from Kew Gardens. Fig. 328 represents a cross section of the stem, showing the depth of the injuries; and fig. 329 represents the damage as revealed by a very thin shaving or "slab" taken off.

As I received the specimens after the insects had hatched, I give

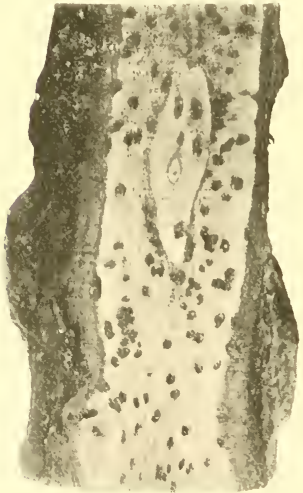

Fin. 320,-Pertiun of bark und wood 'rut off to shur the injurics of C'ecidomyia saliciperda. the following account from $\mathrm{Dr}_{\mathrm{r}}$ Ii. Stewart Macl ougall : ${ }^{1}$

"This is a tiny fly, 2 to $3 \mathrm{~mm}$. long (the female is a little larger than the male), with head and thorax black or blackbrown, and with black hairing. The wings are milky white, with whitish hitirs.

"The eggs, rounded and orangevellow, measure $0.40 \mathrm{~mm}$. in length.

"The larva is rounded at both ends, or somewhat spindle-shaped. It has a well-marked anchor process, and on magnification little projections can be seen on the edge of the body, and warts on the top of the body.

"The pupa is bright yellow, the limit of the wings reaching to ring $t$ and the feet to ring 8 . At the base of the antemia two brown horns can be seen.

"The females lay their eggs on Salic alba, S. firagitis, s. caprea, s. purpurea, s. viminalis, and exeeptionally on white poplar.

1 Journal of the Association of Economic Biologists. 
"The parts ehosen for egg-laying are most commonly ahout two years of age and more, with twigs up to three inches in cliameter.

\section{"Lite-history.}

"The female does not bore (her oripositor is too weak), but lays her eggs in chains or rows on the bark. The larve bore into the bark, but by the time they enter below it the cambium has already made the first layers of wool. Owing to the irritating presence of the larve, the cambium gives rise to irregular streak-like growths, through which the pests make longish excavations; the galleries are irregular. Between the larval galleries the wood is normal in condition. It is possible that the larva may not really need to bore in, as the activity of the cambium, with its wood formation, may be sufficient to enclose them.

"For a time the bark stretches, accommodating itself to the increased thickening, so that only spindle-shaped swellings show; but ultimately it ruptures and hangs down in shreds. For pupation the full-fed larva betakes itself to the periphery, pupation taking place under only a thin external layer, which is easily broken through by the two horns of the pupa. The empty pupa skin, with-its 'forehead horns,' may be seen jutting from the round hole until the weather removes it. The bark from which flies have issued may he seen rildled with small holes.

"There is one generation in the year, the larve tumnelling from June or July till the next April, Iay, or Jume.

\section{"Measurs of Preservation and Remedy.}

"1. Cut off and burn infested shoots before issue of the brood. A very observant forester will recognise the swelling before rupture of the bark, and should remove it. Another sign of larval presence is the poor leafage. The cut-away parts must not be left lying, else development and issue may be completed.

"2. Streak over with tar the places attacked, as though the pupa may jush its way through, and the fly will be caught in the sticky material."

Cecidonya (Rhabdophaga) heterobia, Lw.

This species, which gives rise to the malformations as seen in fig. 330 , is, I have found, often very closely associated with $C$. marginem- 
torrquen: Both species were found in the nursery. C. marginem. torrquens: was in great evidence on the leaves of Salix riminalis, but no terminal buds were infested. On the other hand, the terminal buds as represented in the figure were infested on the species of willow known locally as the Wentworth seedling golden willow, and some of the leaves were rolled as in Salic viminalis (fig. 330), but not to any appreciable extent.

The male is abont 5 to $6 \mathrm{~mm}$. in expanse of wings. Colour blackish on back, and grey on belly side. Eyes black. Antenne

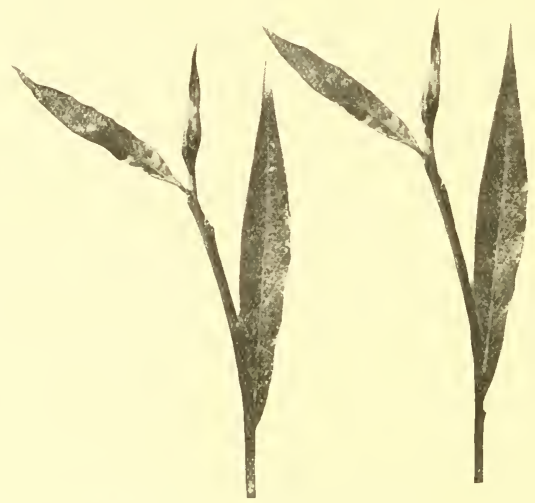

Fig. 330. - Leenlime sunts of a speris a w willow injured by Cecidomyia beterobia.

darkish-brown. Palpi lightish-grey. Thorax clothed with greyish hairs. At base of wings a yellowish-orange. Wings hyaline, and clothed with greyish hairs. Veins dark-grey. Legs lightish-grey. Abclomen uniform dark-grey. Gentalia dark-brown.

Cecidomia (Rhabdophaga) salicis, Schrk.

(Willow-twig Milge).

The gall which is formed by this insect is found on various species of willow throughout the latter part of the summer and winter. The gall is formed by the gregarions larvæ feeding upon 
the pith, and thus eausing the woody cells which surround it to swell out, as in fig. 331. The galls are always found on the twigs of the tree or bush, and between the internotes.

The perfeet insects hatch out about the midlle of May (May 10, 1905, in Northumberland), and (leposit their eggs in the twigs of last year's' shoots. The larvæ soon hatch out, and by their united action, which ereates a form of symbiosis, stimulate excessive growth at the afleeted part. The larve feed right on throughout the winter, and pupate within the gall about April. The exit of the flies may be recognised either by the flightholes or by the empty pupal-eases projecting from the gall.

The fly is about $6 \mathrm{~mm}$. in expanse of wings. Eyes black. Antennie dark. Wings hyaline, and at the base they are of a light vermilion colour.' Halteres

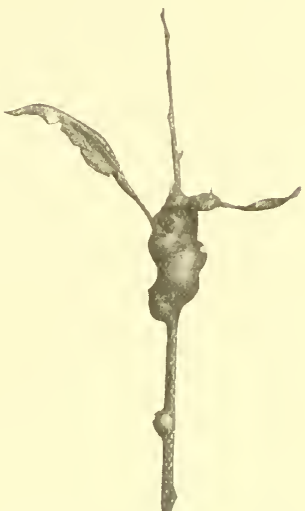

Fig. 331.-Twig of Salix cajurea i. jureal by Cecilomyia salieis.

white on the knob portion, and same eolour as wings at base. Thorax darkish, with two yellow-grey longish strips. Abdomen variable in colour, sometimes dark above and red below, but as a rule darkish-grey ahove, and light with a covering of silvery-grey hairs below. Fig. 332 is a representation of the male.

The larve and pupe are of a light-yellow or orange colour, ancl, as a rule, from 12 to 30 are found in a single ehamber.

Cecidomya (Dasteneura) tiliam volexs, Rubs. (= C. salicis, Sehrk.)

This species forms galls on the terminal shoots of lime-tree branches and

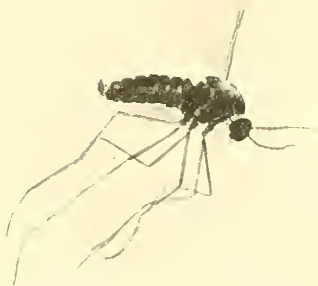

Fig. 332.-Cecidomyia salicis (mole). the base of the leaf-stalk, about the size of a pea. The leaves are deformed and disfigured, and growing with the point of the shoot 
spoiled, but are found principally on shoots growing as suckers from wld stem. (See figs. 333 and 33t.)

Larva yellow-orange colour, $2 \mathrm{~mm}$. long. Head long, thin, and pointed, footless. Has habit of anchoring anal end, raising head, and making a motion or two in the air, then placing head to tail end, thus making body a sort of loop, and then giving a high and clear leap off the table to a distance of two or three inches. Mr Theobald says:

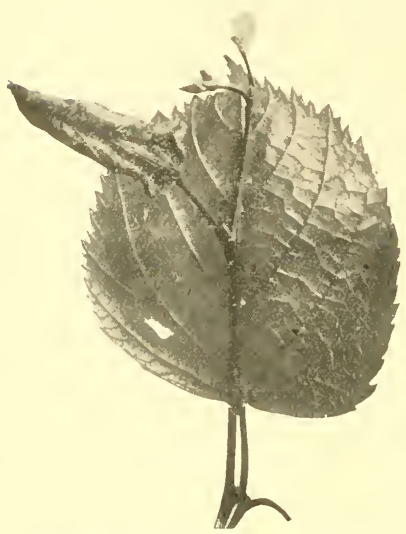

Fig. 5.n3.-Len of lime-tw inmal by Cecidomyia tiliam volens. A normal leat is placed behind the injured leaf for identitication.

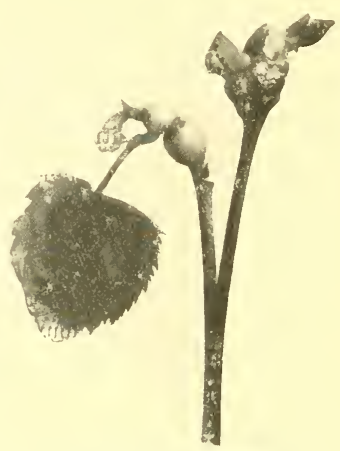

Fig. 33t. - Sheort wo lime-tide ingereal by Cecidomyia tiliam volens.

"I have found this very harmful on clipped and trimmed limes used as 'blinits' in suburban gardens."

\section{1)iplosis (Clinomiplosis) Botllaria, Wtz.}

This species is shown by the photograph (fig. 335). The larve live in a sort of pea-pod-shaped recess formed by rolling the leaf inwards, and stimulating the growth of the leaf in thickness. The larvæ secrete a liquid and, as it were, half swim in it. They are white with a central streak of green in the body. It is said they fall to the earth, pupate, and appear as flirs in the following May. I found them very common at Bellingham, in Northumberland, about 
the middle of June every conseentive year, but have not sueeceded in hatching the insect.

Miuller, in 'Gardener's Chronicle,' 1870 , gives the following descrip. tion of this insect: "It is reddish-yellow, with a white beak. Its thorax shows three narrow, short, pale-brown streaks; the poisers arre pedunculated and whitish; in the segments the abdomen is brown, each segment with a fine brownish lateral streak; the head border of the segments beneath is fringed with long whitish hairs. The six legs are long and slender, brownish, and elothed with a white pubeseence. The wings are comparatively large, and sparse greyish hairs, and suffused with a weak iridescent violet; their veins are brownish.
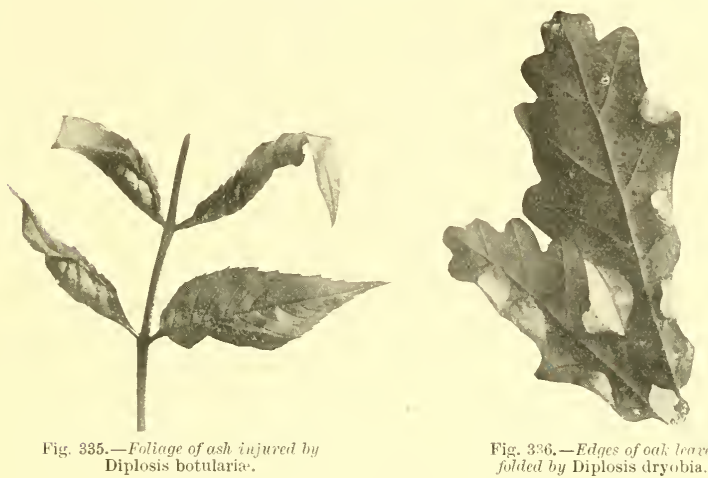

Fig. 336. - Edges of oak lom $2 \%$ folded by Diplosis dryobia.

The feelers are brownish, 26-jointed in $\delta$ and $1 t$ in $q$. The latter furnished with a short ovipositor."

\section{Diplosis (Macrodiplosis) pryobia, Lw.}

This species causes the leaves of oak to fold over, as depieter in the illustration (fig. 336). The folded portion is of a light-yellow colour, and the larva live within the folded portion. They pupate in the ground.

1 found this species very common in Cheshire in the hedges. It often happened in that part of the eountry that young oaks grew up in the thorn hedges, and were of eourse switched with the thoms, and this species was generally found on the foliage of those hedge oaks. 


\section{Diplosis (Harmanda) tremule, Wtz.}

Theobald says: "The larve of the 'aspen gnat' seem to form two kinds of galls : the first are formed on the leaves of Populus tremulathese are red galls, the size of a pea; the second kind is the wellknown gall formed on the leaf-stalk: each gall is inhabited by a single larva, which pupates in the gromnd (Wimnertz)." I

I found what I now suspect to have been the first form, in June 1897 , in High Legh, Cheshire, but the latter I have never found, and am indebted to Mr E. T. Connold for the form as shown in fig. 337.

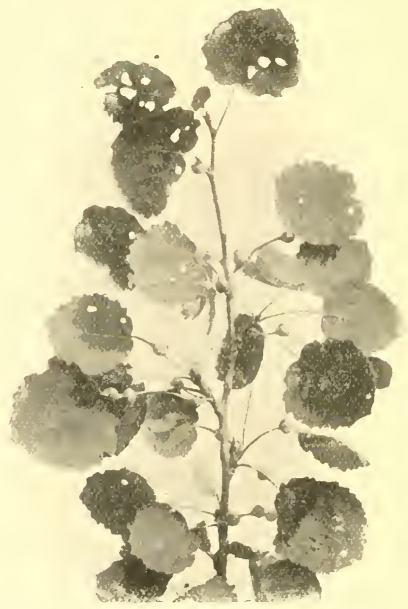

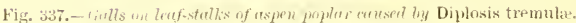
(From plioto by L. T. Connoli.)

Theobald thus describes the Hy: "Imago-dorsum blackish-brown, with two rows of whitish-yellow hairs; abdomen dark-brown, with thin flesh-coloured incisions and white hair. Posterior half of seventh ring and the rest of the abdomen flesh-coloured; $\hat{\delta}$ genitalia black; 9 yellow. Wings large, grey, with thick blackish-grey hairs, third longitudinal vein bending in an almost straight angle to the posterior edge; 1 to $1 \frac{1}{2}$ lin."

${ }^{3}$ An Account of British Flies, by Fred. V. Theobald, p. 75. 


\section{Hormomya (OLigotrophus) PILIGER, Lw.}

The larve of this insect cause galls on the leaves of the beech (Fayjus syllicatica). The galls (fig. 338) are pilose, more or less gregarious on the upper surface of the leaf, but as a rule generally arranged near the midrib. The colour is somewhat variable-at first yellowish, then gradually deepening to various shades of red or brown. They may be found from the beginning of July right on to the end of the summer. The larve pupate within the gall.

\section{Hormomyia (Oligotrophus) capree, Wtz.}

This is a pustule-forming gall, as it were, inasmuch as it may be compared to an eruption arising from a sting on the midrib of the

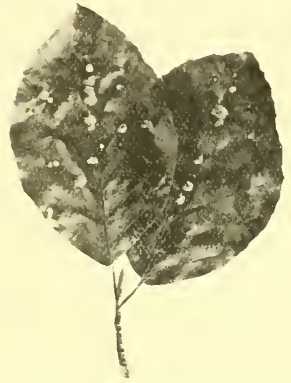

Fig. 33s. - Galls on upper surfuee of beech leaves cutsed by Hormomyia piliger.

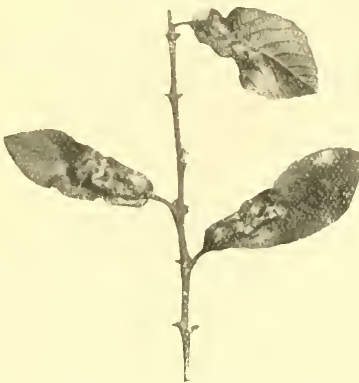

Fig. 339.-Lentes of goat willow yuried by Hormomyia caprex.

leaves of Satic raprea (fig. 339). The midrib itself is more or less conspicuous, while the gall is simply the adjoining portion of the leaf, transformed into a hard woody structure. The colour varies from pale-green to pale-yellow. It may be found from June to October. The larve pupate in the ground, and the flies emerge during the spring.

\section{Hormomya (Mikiola) fagi, Hartig.}

The gall is formed on the upper surface of the leaf, and is a glabrous cone-shaped structure about $4 \mathrm{~mm}$. high. The colour varies from green to yellow, and reddish. It may be found from 
July to September. When fully ripe it falls to the ground, where the larvæ pupate, and the flies emerge the following spring. I have found it in Alnwick parks, but it is not so conspicuons on the leaves as C. pitiger:

Asphontulia sarothami, Lw.

This insect is important from a collector's point of view, but may easily be overlooked, as the galls formed by the larvæ very much resemble the unopened flower-buds (fig. 340). They are larger in

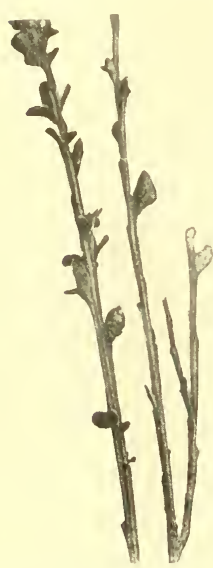

Fig. 340.-Galls on broom coused by Asphondylia sarothamni. size, and comparatively hard in the outer structure, being lined with a greyish pubescence, and containing a single larva. The metamorphosis takes place within the gall.

The flies (fig. 341) hatch out from the beginning to the end of June, and in order to follow out the development they may be looked for about the first of May, as they are then in the larval stage. The pupal stage is comparatively short.

As compared with the Cecidomyia, the flies are very much larger, and the venation of the wings more distinct. Body dark-grey, head dark, and wings brown and hairy. Antennæ of female 13- or 14 -jointed, the three joints at the tip being very small in size.

Fig. 342 is a photograph of the pupal form.

\section{Lasioptera rubi, Heeg.}

The larva of this insect cause galls on the stems of the common bramble (Rulus firuticosus) (fig. 343), and it is of course more interesting as an entomological specimen than a forest insect. I have only twice found it-once in Cheshire, and very plentifully near Ville la Villiers, Belgium. It is, however, said to be very common in some parts of the south of England. It is harmful to raspherries, forming galls on the canes as on the bramble. The size of the galls is very variable, inasmuch as the gall may be simply a slight excrescence.

With regard to the description of the species, Theobald says: "In their habits they resemble the Ceridomyjidre, infesting plants much in 
the same way. The larve are much the same as in the Cecids, having the same peculiar reddish hue and curious 'breast-bone.'"

The larvæ live in excrescences on the stems of various Rubi, and metamorphose in the galls. They appear in May.

Imago.-Brownish-black; antennæ of of hlack, shorter than the

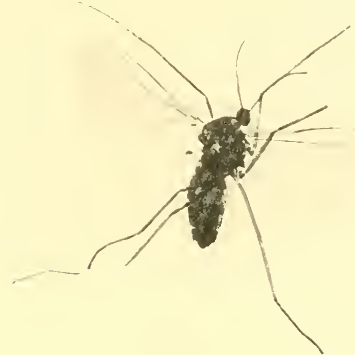

Fig. 341.-Asphondylia sarothami.

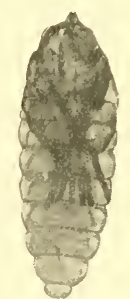

Fig. $342,-P u p a$ of Asphondylia sarothamni.

head, 22 -jointed. Palpi white; head white and brown. Thorax Geep black with a silvery white band around the edge in front, with two pinkish or golden stripes partly along the top; seen in certain lights, in others the centre of the thorax is black; scutellum tawny. Abdomen black, with four silvery bands slightly broken in the middle. Abdomen and of genitalia covered by white hairs. Legs also covered by silvery hairs and scales. Wings clear; costa thick and dark, in the middle a white spot; root of costa also pale. o resembles of, only the antennæ are 24-jointed. Ovipositor yellowish-white ; long ;

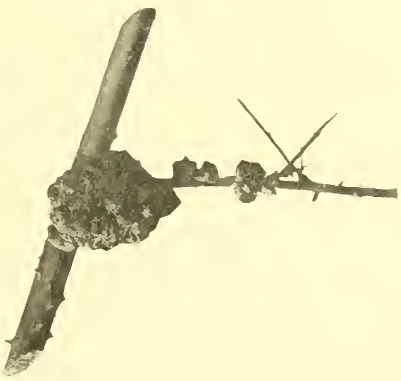

Fig. 343.-Gall on stem of bremule antsed by Lasioptera rubi. no lamellæ. There are beautiful scales on the venter of the abdomen as well as the legs. Ifter leath the colours turn browner, and the white hairs less silvery. 


\section{Cecidomyia (?) PICE. Henschel.}

In the spring of $1906 \mathrm{I}$ began to dissect a number of cones of the common spruce, with a view to looking for the larve of Megastigmus. In one batch the cones showed a number of light orange-coloured larvæ. These were put aside in glass jars, and from Nay 13 to May 20 the jars simply swarmed with specimens of Cecidomyia. Reference to available English literature has failed in giving any account of this species, but the more important German text-books give two species-viz., C. pirere as living in the seeds of the common spruce,

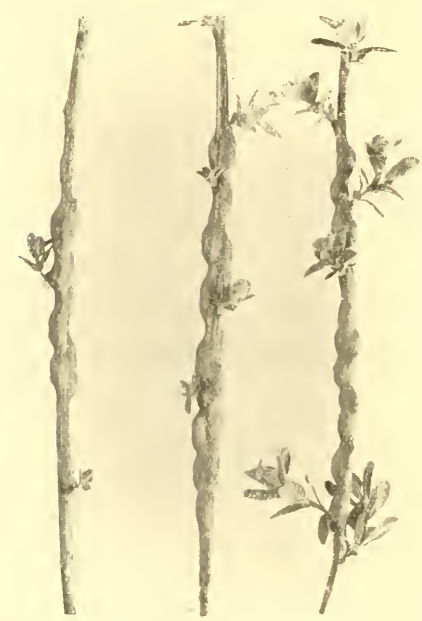

1isr. 344.-Gitls wh stom of speries of willow causen by Agromyza schineri. (From plioto by E. T. Connold.) and $C$. abietiperila, Hensch., as living in the shoots of spruce. The species in question would appear to coincide with the former. A careful dissection, however, showed that not only many of the seeds were eaten by the larvæ, but also a very large proportion of them had hollowed out the thicker portion of the bracts.

\section{Fanily AGROMYZIDÆ.}

The larvæ of this family are said to mine leaves and do other damage, but I have not hatched out any of those insects.

As regards family characters, Theobald states: "No costal bristles. First longitudinal vein short, the auxiliary connected with it at tip; posterior transverse vein far distant from the border. Front with strong bristles. Border of mouth with vibrissa on each side. Third joint of antennæ rounded, terminal bristle bare or pubescent."

\section{Agromyza schineri, Gir.}

This species is found on willows, and I am indebted to Mr E. T. Comnold, st Leonards-on-Sea, for the photograph as shown in fig. 344 . 
The gall is formed, through the agency of the cambium, on the side of the twig. Growth is complete in September; the larva pupates in the ground, and the fly emerges in spring.

\section{FAMILY PHYTOMYZID尼}

In this family the larræ are leaf-miners, and, so far as the species to be considered are concernerl, they pupate within the leaf. The puparia are barrel-shaped. According to Rev. IV. J. Wingate, there are several genera and species in the north of England, but as regards identification of species and association with damage I have only hatched two species.

As the species on snowberry leaves makes markings very much after the manner of the larvæ of several micro-lepidoptera, it would be well for the student not to be over-sanguine in naming insects from markings without verification by hatching. It would be well to bear in mind, also, that in those species where pupation takes place within the epidermal skins of the leaf, specimens should not be placed within the hatching-box until the creature has reached the pupal stage.

Chromatomyia obscurella, Fln.

Phytomyza riylostei, Kalt.

The leaves of snowberry (Symphoricarpus racemosus) are often thickly covered over with white trailing galleries, as in fig. 345 . In fact, in several parts of Northumberland in some patches this species is so common that it was almost impossible to get a leaf without markings.

The insect causing this damage has a donble generation in a year. The first generation appears in spring, probably in May, and the larval markings appear in June. At first the larva moves very irregularly around a common centre, but afterwards it "mines" more rapidly, making long winding galleries. The larvæ pupate within the leaf, and the flies appear in the last week in July. 'The flies of this brood immediately deposit eggs on the leaves which have developed during the summer, and the larvæ make similar markings to those of the first generation, and pupate within the leaves, which of course fall to the ground in autumn.

The flies, which are like small house-flies, are matt black. Eyes dlark red, wings hyaline. 
Chromatomia hicis, Curtis.

Phytomya ilicis, Kalt.

(Holly Leaf-miner.)

In many parts of the country this pest, known by the name of the Holly Leaf-miner, is very abundant. In fact, it is quite the exception to find specimens of the common holly, Hodgkin, and a few other varieties, to be quite free from it. (Fig. 346.)

The flies are very easily hatched out by artificial means, if the infested leaves on shoots from the previous year are gatherel, after the larva has changed to the pupal stage, by the latter end of April or

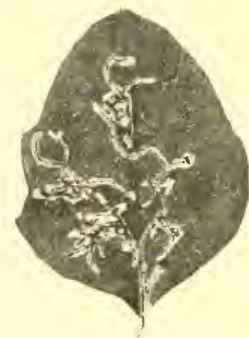

Fig. 345.-Leaf of suoviberiy mened by Chromatomyia obseurella.

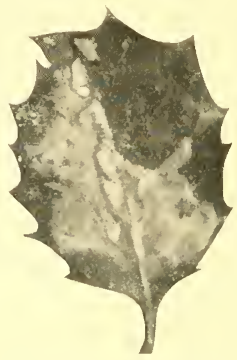

Fig. 346.-Leof of holly blotelued by Chromatomyia ilicis.

beginning of May. In Northumberland the flies hatch out in the first week of June.

In general appearance the fly resembles a small specimen of the common house-fly. Expanse of wings, $3 \frac{1}{2}$ to $4 \mathrm{~mm}$. Eyes of a shining chocolate colour. Body, as a rule, entirely black and hairy. Wings hyaline; veins black; halteres waxy white. Under side of abdomen sometimes slightly yellow, and on upper side of abdomen there are frequently narrow whitish bands across the segments.

The full-grown larva is about $3 \mathrm{~mm}$. long, white and footless, and the puparium is rather shorter, barrel-shaped, and of a leathery colour and texture.

As regards the life-history of this species, I have several times tried to work it out, and so far as my observations go, they coincide with the following description from Mr Collinge, the University College, Birmingham :- 
"Early in June the female fly deposits her eggs on the under sile of the leaves; so far as my observations go, only a single egg is pliteed on each leaf, and on the midrib close to the leaf-stalk. In seven or eight days the larva hatelies out, and makes its way into the vessels of the midrib, and then commences to slowly travel forwarls. In reptember, October, or November it leaves the vessels, and tumnels its way into the soft green tissue of the leaf, forming galleries which give the leaf a blistered appearance.

"Iiy the following April the larva is mature, and it now bites through the epidermis in order to provide an exit for the fly. Like many other flies, it retains its last larval skin as a protection for the thin, white, pupal case. The puparium is of a flattened oval form, and marked by a number of regular transverse segments - the original segments of the larval skin. Within this is a second skin, which is the true pupa."

As regards any remerlial measures against this pest, it is certainly $\mathrm{very}$ difficult to suggest anything which would be at all practical. $\mathrm{Mr}$ Collinge advocates spraying the foliage with paraffin near the time of the flies hatching out, so that the bushes may be made offensive to the females about to deposit their eggs. Spraying with diluted paraffin as a check against egg-laying is often productive of good results in some garden and farm erops, but it is obviously more difficult to carry out in practice in the forest.

As the damage is always on the leading shoots, all prunings done in autumn or winter to hedges or bushes should be burned. It may, however, be remarker that only judicious pruning of trees or bushes is intended, as the clipping of hollies into certain stiff forms is quite an objectionable feature. Healthy hollies sherl their leaves in spring, and those may be burned; but this would not in any way check the pest, inasmuch as the blistered leaves on the ground have discharged their parasitic pests a year or two prior to falling off:

\section{FAMILY BIBIONID压.}

The members of this family, many of which are of a good size, are mostly black, or black and yellow. No one can fail to find several species along the banks of our streams or in damp woods from May till september. Larve phytophagous, on living plants, rotting vegetable matter, dung, \&c. 


\section{Bibio Marci, L. (St Mark's Fly).}

This insect is known as a dung-fly, and has never been considered as a forest insect. Its connection with forestry was introduced to me through Mr Thring, Boughton Kettering, who sent me samples of oneyear seedling ash very much eaten on the thick portions of the root. Thie damage varied in appearance, and was therefore suggestive of being the work of different insects. $\mathrm{Mr}$ Thring kindly sent me some larve on ash seedlings. They changed into pupæ near the end of Narch, and hatched out flies (fig. 347) about the beginning of May,
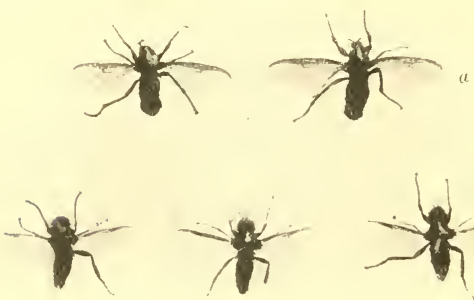

Fig. 347.-Bibio marci. ", females; $b$, males.
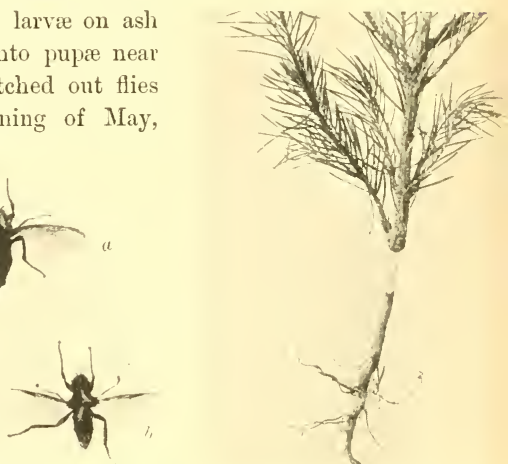

Fig. 34s.-A three-your-oltl spunce injure by larve of Bibio marci in nursery line.

which were identified by Rev. W. J. Wingate, Bishop Auckland, as Bibio marci. Judeich and Nitsche say they are not of much importance in forestry; but the roots in question were very much injured, and Mr Theobald informs me that they are often very injurious to the roots of hop and other plants. Fig. 348 shows the injuries done to a young spruce by the larva of this fly.

\section{Bibio Johannis, L.}

On 11th May 1911, Mr J. P. Robertson, forester, Chatsworth, Derbyshire, sent me a sample of two-year larch seedlings which were being destroyed by larvæ in the soil. The roots of the seedlings were entirely eaten up, and altogether about 50,000 larch 
seedlings had been destroyed. The larvæ appeared in groups of three to five, and about three inches below the surface.

Unfortunately the larvæ, which accompanied the injured plants, had become somewhat dry in transit, but one specimen of Bibro apveared amongst the seedlings. This speeimen escaped before I could give it special attention, and the larvæ all died in a few days.

Specimens were also sent to Oxford by Mr Robertson, and have been identified by Mr. G. H. Grosvenor ${ }^{1}$ as Bitio johannis.

It is generally supposed that the larvæ of these flies are introduced with manure or leaf-mould, but in this case no such dressing had been applied to the plot for four years. It is also rather remarkable that, in this case, the adjoining plot, which contained lareh plants one year older, were untouched.

Many larva of the Bitionide are likely to be found during nursery operations in spring, and the flies can very easily be hatched ont, but it would be well for the forester not over-conversant with systematic details to send them to a specialist in Diptera, to ensure that the species may be correctly determined.

\section{References to Literature consulted.}

Bimnie, Francis G. On the Asphondylix of the Glasgow District. Nat. Hist. Soc. Glasgow. 1876 .

Cambridge Natural History. Insects. Part II. 1899.

Colliuge, Walter E. Report on the Injurious Insects of the Midland Counties. 1904-6.

Collinge, Walter E. The Life-history of the Pear Mirlge. 1905.

Frank. Die Krankheiten der Pflanzen. 1896.

Gardener's Chronicle, various articles from. 1870.

Judeich und Nitsche. Forstinsektenkunde. 1895.

NaeDongall, R. Stewart. Proceedings of the Association of Economic Biologists. Vol. i., Part I. 1905.

Nüsslin. Leitfaden der Forstinsektenkunde. 1905.

Theobald, Fred. V. An Account of British Flies. 1892.

Theobald, Fred. V. Various miscellaneous writings.

Verrall, G. H. A List of the British Diptera. 1901.

Wingate, Rev. W. J. A List of Durham Diptera. Transactions of the Natural History Society of Northumberland and Durham, vol. ii. 1906.

1 Quarterly Journal of Forestry, July 1911. 


\section{CHAPTER XI.}

\section{HINTS ON COLLECTING, PREPARATION, ANI) MOUNTING.}

In giving a few hints to those about to make a start in the study of forest entomology, perhaps it may be assumed that students can be divider into two classes--viz., those who wish to study the subject partially as a branch of scientific forestry, and those who are anxious to follow it ont thoroughly as a division of economic entomology. It is just possible that both classes may at the commencement be undecided how they will follow it up, and it will therefore be advisable to begin in as simple a way as possible. Perliaps it may be said that one of the charms of the study of natural history is to spend as little money, and develop a taste and skill for making as many of the necessary requirements, as possible. Unfortunately, this idea is seldom put in practice.

As a walk through a forest in midsummer will appear to any one not conversant with entomology simply a chaotic confusion of insect life, it would be well for all aspiring students outside the guiding influence of a college to join some local field club, or otherwise seek the guilance of a local entomologist. Having done so, they may begin to collect anything and everything within the forest, and solicit the assistance of local naturalists for naming and classification.

To all those who have not had the benefit of any special course of systematic training, it may be said that in this study, as well as in many others, it is advisable to eultivate a general broad aequaintance with the whole subject of entomology.

It is, of course, necessary to have a simple outfit of that class generally recommended for boys about to begin the collection of moths-viz, a net, chip-boxes, a pocket lens, two killing-bottles,- 
cyanide of potassium and chopped young laurel-leaves, - a few settingboards, with the accompanying entomological pins and braces.

With regard to the killing-bottles, the cyanide should be prepared by a local chemist; and as regards the laurel bottle, only the young leaves, about three-quarters grown, of laurel (Cerasus laurocerasus) should be used. To the rural student, or the young forester enthusiastic of spenting his spare time profitably, the above-mentioned ontfit will suffice for a season or two. And as regards storage of captures for a time, the collected insects may be placed in store-boxes and labelled.

Having devoted some time to the study in general, it becomes essential to begin the study of pure forest entomology. The student must decide to do so in earnest, and to be prepared for difficulties and failures. It will now be obvious that a more expensive outfit is necessary, but again there will be no harm even if the more or less wealthy student "make haste slowly."

So far as the actual forester is concerned, the one on a small estate has the advantage, inasmuch as he can supervise most of his work on foot, and therefore have greater opportunities for observation, than one on a large property, whose time is largely taken up in travelling.

It is necessary, first of all, to recognise the actual damage, and then ascertain the cause of it. A little practice will soon enable him to distinguish between insect and fungoid damage. It will be necessary to take the damaged portion home, together with the injurious grub or insect, and submit it to some arrangement for development anil observation. The ohservations should be most carefully tabulated in a note-book.

It is, of course, essential to carry a simple outfit of boxes and collecting apparatus in the pocket; but they are so light that they will not in any way interfere with clothing, nor will the placing of a specimen in a box interfere with his duties. On the contrary, the cultivating of this habit of observation will do a very great deal to improve the individual.

In addition to collecting the damaged portion during the actual hours of duty, it is also advisable to go out in the evenings and beat the larvæ or perfect insects from their respective trees. Thus we shoull have a double method of study-viz., recognising the actual damaged part, striving to ascertain the cause of it, and also discovering the special insects which attack any particular tree. In the latter methor the comparatively young student may place all his captures 
from one tiee together in a specially prepared cage, and then finally arrange the perfect insects according to the respective trees from which they have been hatched ; but, on the other hand, the special portion of damage should be most carefully kept by itself, and the perfect insects arranged together with the actual damaged portions in entomological order.

As time advances and the student makes progress, it will be advisable to become more specific and less general. In fact, the correct method of study would probably be to take a few special insects and work them thoroughly out by means of study and observation. Having regard to the shortness of human life, and the desire, or necessity, for other subjects, the student of forest entomology must carry on simultaneously a number of observations with special insects and their damage. Hence it is necessary to have separate hatching-boxes for each species, but with regard to what is the best plan, individuals will naturally differ from one anotluer. The simplest plan, of course, is to collect the larve just as they are about to change to pupæ, for then they require little or no attention. However, this is in many cases practically impossible, and it must therefore be remembered that moisture is invariably the most important essential in insect life. This may be obtained either from a bed of damp sand placed in the hatching-case, or from the food-plant itself. Hence two simple methods may be given. The first is, simply to collect as many old glass jan-jars, from a pint to a quart capacity, as may be required, place a little damp sand in the bottom, insert a fresh potato in the sand, stick the stalk of the food-plant into the buried potato, change the food from time to time, lieep down the mould, and patiently await the results. Where moisture is not so absolutely important, as, for example, in bark-beetles, the following plan will often suffice-viz., get an empty negative or lantern-slide box, cut out a hole in the top, leaving a little over half an inch of rim all round, get a spoiled negative or lantern-slide (a by no means rare article in the hands of an amateur), glue the cleaned glass to the rim left in the top, and you then have a glass-covered box wherein you can place your specimen and watch the results, noting daily all important points of development, and tabulating the same in a note- and sketch-book kept specially for the purpose. It may be well to remark that the hatehing referred to should, if possible, be kept in a shed or outhouse. 
Having hatched or collected the special insects, now comes the question of setting and storing; and to follow this out properly, the student unfortunately requires leisure and money. At the same time, it is no exaggeration to say that the real charm of the study begins at this stage.

With regard to the actual setting, it will, of course, vary with the family of insects, and also with the size of the individuals. Suppose we begin with any of the larger moths, the usual style of settingboards with braces and pins may be adopted, or the style of setting with glass, suggested by $\mathrm{Mr}$ Newstead and recommended by Mr Day, late of Knutsford, Cheshire. In lieu of the cardboard braces, I would recommend strips of transparent tracing-paper as being lighter, and also as showing the wing in position with more reliable accuracy. The setting of the smaller moths (micros) is more difficult, and it would be well to get a few practical hints from any worker in this group.

It is, of course, advisable to have the smaller moths well relaxed before attempting to set them. They should be handled as carefully as possible, and braced down either with tracing-paper, bristles, or silk thread and pins.

As regards beetles, the larger-sized specimens-the set specimensmay be often seen with a pin through the body, and slightly raised above the surface of the store-box; or otherwise the individual beetles. may be mounted on a small card, and a pin placed through the card. The latter method is obviously the neatest. In either case, the setting is practically the same. First of all, see that the insect is well relaxed, brush the legs and antennæ carefully out with a delicate red sable brush, and fix the body and appendages well down on paper with gum-tragacanth or gum-arabic. When it has stood for a considerable time, until the body is perfectly stiff, float it off in water, and then finally transfer it to a clean card, and fix it carefully down with seccotine squeezed out of the tube and thinned down with a little glacial acetic acid.

The smaller-sized beetles are, of course, more difficult to deal with, and the following hints may be given. First get the insect well relaxed, and place the creature, under side upwards, on a very soft bed, with a slight depression to receive the insect. There are two classes of beds which may be recommended-viz., a piece of sheet cork, or perhaps better still, a well-dried portion of the white fungus from dead birch, known as Polyporus. The small insect must be tempor- 
arily, but firmly, held in this position by gentle pressure, either by an entomological pin or stiff bristle inserted in cork, and used as a sort of pressure-bar, or by the careful manipulation of a soft silk thread. Having arranged matters so, brush ont the legs and antennæ with a delicate sable brush, or the "sportsman's feather" from a woodcock's wing. When in correct position, brush them over with a slight moistening of absolute alcohol, and allow it to remain for a short time, say until two or three more insects are similarly treated. The effect of this

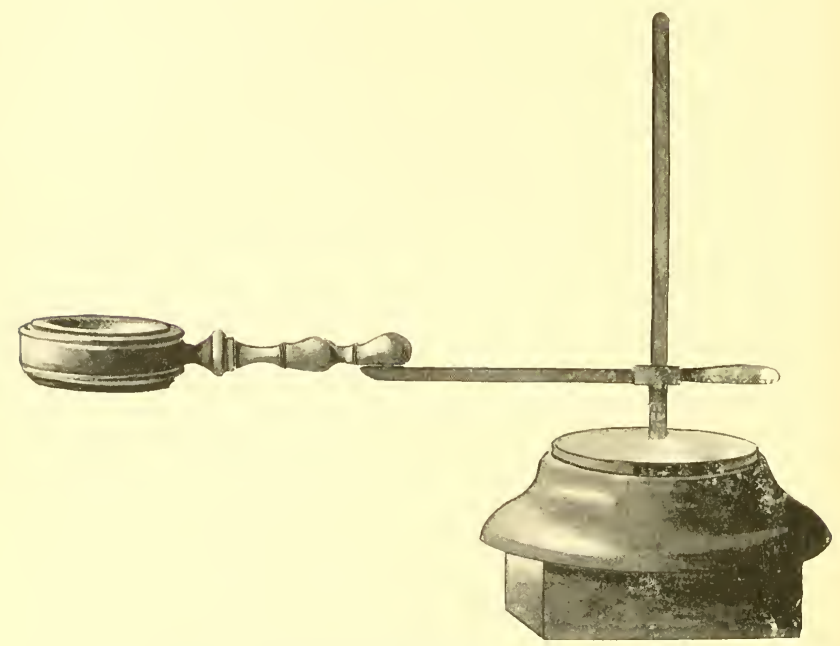

Fig. 349.-Simple correngement for dissecting specimens under a magnifying-gless, wr. for monutind small sipcimens for the microstope.

brushing with alcohol is to stiffen the legs into their desired position. Then remove the insect, and place it on a card in seccotine. It is of course advisable to do the preparation referred to under a lens or magnifying-glass, as in fig. 349 .

Hitherto the setting of insects has been considered, but it must be remembered that many of the specific characters are very minute, and also that the major portion of forest entomology is purely a microscopical stndy. Hence, though it is impossible to give anything like 
a full account of microscopical manipulation, a few general remarks, together with some practical hints as regards special insects, may be helpful to the young student.

As regarls the choice of a microscope, it is, of course, best to get what is termed a good stand, as accessories can always be added. The principal lenses required are the inch and quarter-inch objectives. A power lower than the inch is very useful, but the greater portion of practical work is always done with the inch objective. For the examination of opaque objects a bull's eye condensor is required.

A small ontfit of, say, a spirit-lamp, a pair of scissors, a small dissecting-knife, a few slips and cover-glasses, a bottle of balsam and henzole, and a pair of forceps, are abont all that are required for a start.

Now let us prepare and mount a slide of some simple object. Take a few slips and cover-glasses, and have them thoroughly cleaned: then select a simple object, say a wing of a house-fly or the scales off a butterfly's wing, gently warm the slip over the spirit-lamp (this is not always done even by experienced workers), place the object in the centre of the slip, drop a little balsam on the object, and with the forceps lift a well-cleaned cover-glass and let it just "feel" the Hame of the spirit-lamp, so that any natural moisture may be removed, and let it fall with its own weight on to the balsam on the slip, gently press it, and keep it in position with a clip, lay it aside for a short time, and the operation is completed,-you have a mounted slide. Great care should be taken to prevent air-tublles, as they are the deadly enemy of mounts. Such is the simple method of mounting-viz., to fasten the object hetween two glasses with Canada balsam, as this resinous substance is highly refractive, and brings ont the details of structure.

It would, of course, be well for the young student in a rural district to get assistance from a naturalist friend in mounting, \&e. A good useful microseope and simple outfit cost about $£ 8$.

In setting the insects hatching out from oak galls, the following methods, either for microscopic slides or cabinet specimens, may be adopted. First of all, get the insects separated from the galls by the usual method of stupefying by chloroform. When under the influence of the anæsthetic, place them in a clean empty box with a glasscovered top, and when they revive and become active in the box, "tap" them rapidly into a sancer containing boiling-water. When they 
touch the boiling-water, many of them will immediately spread out their wings in the correct position for setting, — in fact, appearing perfectly set on the surface of the water. Select the best-looking ones, anil float each insect on to a separate microscopical cover-glass, and then place the wings, antennæ, and legs in the correct position: remove the moisture by means of clean blotting-paper, and then drop methylated spirits on to the insect: lay them aside, and cover them over with a large inverted glass, - a large champagne-glass which has its foot broken off is a very good thing for this. We have then the insects well set either for microscopic slides or cabinet specimens; and it may be noted that the principle of the method adopted is to make the delicate insects as far as possible set themselves.

If specimens are intended for the microscope, it will be necessary to place the insect on the cover-glass with the unter surface upurards, place on it a drop of absolute alcohol, and allow it to evaporate uncler the bell-jar glass, - which, by the way, should be so arranged as to allow a little air to enter from below. When the alcohol has evaporated, it will be found that the insect adheres firmly to the cover-glass, and when in this condition, immerse it in oil of cloves for twelve hours, and again remove the surplus oil of cloves with blotting-paper. Then place a drop of xylol or benzole, according to the balsam which is used, and allow this partially to evaporate; then place a drop of balsam on the insect again, allow it to stand for, say, twenty-four hours under the bell-jar; prepare a microscopic slip in the usual way, place a drop of balsam on the centre of the slip, and then turn over and press the previously prepared insect on the cover-glass into the balsam on the slip. We have then a well-mounted slide for ordinary purposes.

If, however, a more transparent object is desired, the following method may be adopted: Prepare the insect as previously described, and when it is well set on the cover-glass and thoroughly free from moisture, separate it from the cover-glass and place it in liquorpotasse. It should be bome in mind that when well set in this way, the insect will, with careful handling, always remain in this fixed position. Hence it may be allowed to remain in the liquorpotassæ for one or two days, then float it on to a cover-glass, and place it (by careful floating) on to clean water. Thus it may be gradually washed in this way in water, alcohol, and xylol respectively, until quite transparent. Then float it on to oil of cloves 
aud prepare it for mounting, under side upwards, as in the previons method. By this method we get a better slide for recognising special structural points.

If a specimen of a gall insect be required for general entomological cabinet purposes, the following method of mounting may be adopted : In addition to preparing the insect as in the first method, get a piece of clean white cardboarl, punch a hole in it with a $\frac{5}{5}$ in. or $\frac{3}{4}$ in. punch, then attach with secotine a piece of thinner cardboard to the punched portion, and lay the amalgamated cardboarl aside to get thoroughly dry. Thus we have a circular cell of carlboard; in this place the previously prepared insects, and according to space fix them neatly in the prepared cell with a very tiny drop of seccotine. Lay the insects aside for a time, see that they are kept free from dust, and then finally seal them over with a microscopical cover-glass, a shade larger than the cell. The latter should be done with considerable care, and either of two fixing mediums may be used-viz., Kay's Coagnline, or "brown cement." In either case place a series of tiny drops around the elge of the cell, but not quite touching one another; then let a cover-glass, well cleaned and warmed over a spirit-lamp, fall on the edges of the previously laid drops, again lay it aside until partially dry, and then warm a glass microscopical slip over a spirit-lamp and press gently on the cover-glass, and finally run a ring of the medium round the edge of the cover-glass, and the whole is completed. This method of preparation makes an excellent opaque microscopical slide for revealing the natural colours of the insect.

The small Cecidomyidæ may also be made to "set themselves" for microscopical slides. First stupefy them with chloroform, then pick a single sprecimen, male or female, place it on a clean cover-glass, place a drop of absolute alcohol on the insect, allow it to evaporate, and then mount in balsam in the usual way. The placing of the alcohol on to the tiny insect is, however, rather difficult. It should, as it were, be allowed to creep under the insect, and so let the delicate wings adhere gently and properly to the cover-glass. If, on the other hand, the alcohol were allowed to drop on to the tiny insect, the wings would double up, and, as a microscopical slide, we should have a complete failure. The alcohol dehydrates the natural moisture in the body of the insect, and as the insects are very delicate, it is well to move them about as little as possible. As the Cecilomyidie change colour rapidly after leath, it is best to examine the unpre- 
pired insect while under the influence of chloroform for specific characters.

In giving a short account of the preparation of sicale-insects for the cabinet and the microscope, I am not only indebted to Newstcad's valuable Monograph, but to personal assistance from Mr Newstead himself long before the book was published.

For cabinet purposes, and for the study of external characters, where the number and variety of species are the chief objects in view, small cork slips of 3 inch $\times 1$ inch, and covered with white or black paper, according to the colour of the species, may be used. But where it is intended to display the "scale" from an educational point of view, together with the nature of the damage it causes and the more salient details of structure, a suitable space should be allotted to it in the cabinet.

As, however, the scales are almost exclusively a microscopical study, it is indispensable to give a short account of the necessary preparation. In scale-insects we have two great divisions, - one where the body is protected by the scale, the other where the actual body is the scale itself. The former class is well represented by the Diaspinx, Psendococens, dc. ; the latter by the Lecanium and Pulvinaria. Now let us begin with the Diaspine, and no better example could be taken than the Chionaspis on ash, willow, \&e., as found in winter. Under a weak lens, reading-glass, or arrangement as in fig. 348 , lift up a female scale, and underneath this we find the dead female surrounded by eggs. Collect a number of those female insects, and place them in a sancer of water. Be it remembered they are mere tiny specks, and can only be lifted with a needle or woodcock's feather. Now we must boil it in, say, a ten per cent solution of caustic potash $(\mathrm{K} O H){ }^{1} \quad$ The strength need not be too accurate, about two penny sticks in a pint of water would do. Place the insects in a portion of this solution contained in a very small tube, and stoppered with cotton-wool. Place this small tube inside a larger one, containing water, and boil the two tubes in a small enamelled cup over a spirit-lamp for about fifteen minutes. Pour out the boiled insects from the inner tube into a saucer of clean water, pick them up with a needle, and re-boil them in clean water for a short time, transfer them to dilute and then to absolute alcohol, and

I have, since writing this, obtained better results with some species by slow soaking in cold caustic potash than boiling as mentioned above. 
from this again transfer them into another glass containing absolute alcohol and a weak colouring of one of Crawshaw's dyes, which are sold in penny packets, and which form a very good medium for staining scale-insects. Then with the aid of a large but weak lens lift them out of the stain, on the tip of a woodcock's feather, and place them on to a prepared cover-glass. Arrange them as carefully as possible, and absorb the moisture with a clean-cut portion of blotting-paper. Then the specimens may be allowed to remain under oil of cloves for a short time, which may in turn be replaced by a drop

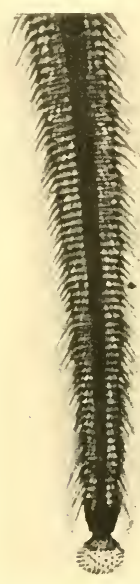

Fig. 350.-Proboseis of honey-bee. (From photo by A. Flatters.)

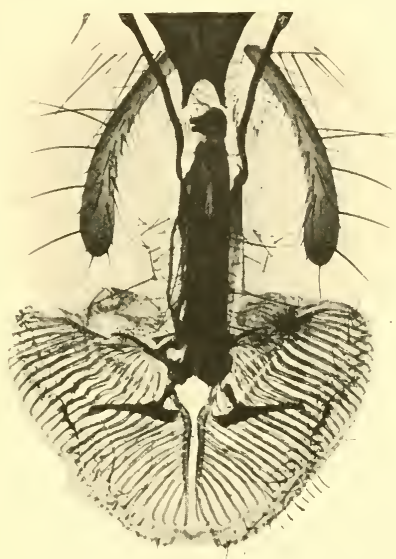

Fig. 351.-Tongue of hors:-fly. (By A. Flatters.)

of weak xylol and balsam, and this again further replaced with thin balsam and xylol. The latter may be allowed to remain under an inverted glass for a short time, and then finally mounted on to a glass-slip by pressing the cover-glass with the scales into the halsam on the slip.

This method may be termed mounting the object on the coverglass, and is certainly, for this class of work, better than mounting on the slip. All workers, more especially beginners, know full well that when an object is mounted on the slip and the cover-glass after- 
warls applied, the valuable object has often been found outside the cover-glass in the superfluous balsam, so that mounting carefully the opposite way generally gives better results.

With regard to the preparation of the larger specimens, as, for example, the female scales of Lecanium and Pulvinaria, they may be boiled in canstic potash in a test-tube (not in an inner one, as with the very small species), then boiled in clean water, then transferred to absolute alcohol ${ }^{1}$ with stain for a day, oil of cloves for another day, and finally mount in xylol balsam.

In addition to studying the more salient points of the anatomy of
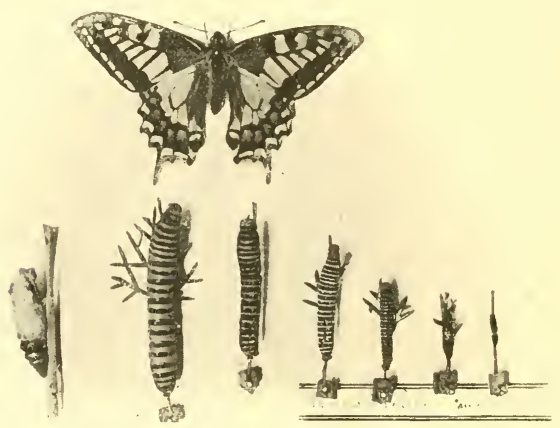

Fig. 352.-Life-history stages of "swallow-tail" Butterfly (Papilio machaon). (Photo from specimens prepared by $\mathbf{M r}$ L. Greening, Warrington.)

forest insects, the student would do well to study the details of minute insect structure as revealed by microscopical investigation. There is obviously no end of objects outside forest insects, thus giving the student not only a wider outlook, but teaching him many a valuable lesson from indirect subjects. Take, for example, the case of figs. 350 and 351-the proboscis of the honey-bee and the tongue of the house-fly. Not only do subjects like these show marvellous mechanism, but they throw a strong sidelight on such delicate anatomy as the mouth parts and feeding organs of scale-insects, green-fly,

${ }^{1}$ It is best, in many cases, to begie with diluted alcohol and gradually strengthen it to absolute alcohol. 
\&c. In the case of all insects which suck the juices from the foodplant, as contrasted with those which eat the vegetable direct, it is obvious that the vegetable cellular structure must be ruptured, and therefore many disease spores may thus find a ready entrance into at favourable host. Hence the obvious necessity of careful investigation in many diseases, and the incalculable value of trained laboratory research work.

such are a few "hints" to the student from the writer's point of view ; but it is possible that even advanced enthusiastic students may show a greater desire for life-histories than minute investigation. Hence fig. 352 may be taken as a typical case of the life-history of an insect, inasmuch as we see the successive stages of larval development. In the example given we have, of course, an excellent instance of the correct method for cabinet purposes; but in reality all insects should be worked ont on similar lines, and the various stages notel and tabulated in a book kept for the purpose. 


\section{CHAPTER XII.}

\section{LIST OF TREES WITH INJURIOUS INSECTS.}

THE following "list" is given in order that the student may more readily identify the insect from the damage. Almost every reader will be able to determine different trees, and the insect may therefore be recognised from the brief note defining the nature of the injury, or otherwise guiding the student as to where to refer for descriptive information.

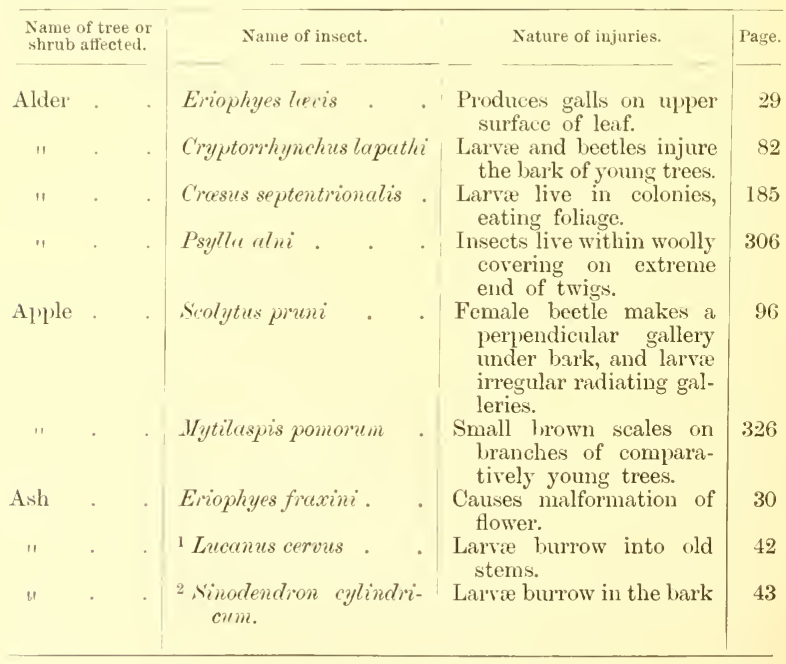

I Also found on oak, hornbeam, holly, and beech.

2 Also on beech and holly. 


\begin{tabular}{|c|c|c|c|c|c|c|}
\hline \multicolumn{3}{|c|}{$\begin{array}{l}\text { Name of tree or } \\
\text { shrub affected. }\end{array}$} & \multicolumn{2}{|l|}{ Name of insect. } & Nature of injuries. & Page. \\
\hline Ash & . & . & Rhagium inquisitor & . & $\begin{array}{l}\text { Larve live under bark of } \\
\text { decayed logs. }\end{array}$ & 56 \\
\hline$" 1$ & . & . & Iylesinus crenatus & . & $\begin{array}{l}\text { Female makes short gal- } \\
\text { leries under thick bark } \\
\text { of old trees. Larvæ } \\
\text { make irregular galleries. }\end{array}$ & 101 \\
\hline$"$ & . & . & " fircini. & . & $\begin{array}{l}\text { Female beetle makes a } \\
\text { double-armed gallery } \\
\text { under bark. Larvie } \\
\text { make galleries at right } \\
\text { angles to mother gallery. }\end{array}$ & 103 \\
\hline$"$ " & . & . & " oleiperda & . & $\begin{array}{l}\text { Female beetle burrows in } \\
\text { small twigs and larva } \\
\text { make irregular galleries. }\end{array}$ & 105 \\
\hline$" 1$ & & . & I'espa ('rabro (homet) & . & $\begin{array}{l}\text { Insect damages bark of } \\
\text { young trees. }\end{array}$ & 192 \\
\hline$" 1$ & . & . & Chionaspis salicis. & . & $\begin{array}{l}\text { Small white scales on } \\
\text { stems of comparatively } \\
\text { young trees. }\end{array}$ & 321 \\
\hline " & . & & Apterococcus fraxini & . & $\begin{array}{l}\text { White scales on bark of } \\
\text { old trees. }\end{array}$ & 350 \\
\hline 11 & . & . & ${ }^{1}$ Zenzera cesculi. & . & $\begin{array}{l}\text { Larva burrow in young } \\
\text { stems or branches. }\end{array}$ & 208 \\
\hline " & . & . & Proys curtisellus . & . & $\begin{array}{l}\text { Larva lives in leading lund } \\
\text { of young tree, which it } \\
\text { kills, and thus canses a } \\
\text { forked stem. }\end{array}$ & 234 \\
\hline$" 1$ & . & . & Diplosis botularie. & 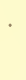 & $\begin{array}{l}\text { Iusects form jea-pod-like } \\
\text { galls through foldings } \\
\text { of leaf. }\end{array}$ & 364 \\
\hline " & . & . & Bibio marci. & & $\begin{array}{l}\text { Larve eat roots of young } \\
\text { plants in nursery. }\end{array}$ & 374 \\
\hline " & . & . & Psyllopsis fiaxinicola & . & $\begin{array}{l}\text { Insects found on foliage } \\
\text { luring summer. }\end{array}$ & 302 \\
\hline 11 & . & ${ }^{\circ}$ & " ficarini & - & $\begin{array}{l}\text { Insects cause leaflets to } \\
\text { roll. The rollings are } \\
\text { of a brown variegated } \\
\text { colour. }\end{array}$ & 302 \\
\hline Beech & . & . & Dorcus parallelopipedu & & $\begin{array}{l}\text { Larve bore into back- } \\
\text { going trees. }\end{array}$ & 43 \\
\hline$"$ & . & . & 2 Melolonthe vulgaris & & Larve feed on roots & 44 \\
\hline$"$ & . & . & ${ }^{3}$ Agrilus viridis & & $\begin{array}{l}\text { Injwres the bark of stems } \\
\text { of young trees. }\end{array}$ & 48 \\
\hline " & . & - & Orchestes fagi. & & Larve injure the foliage. & 80 \\
\hline " & . & - & Rhopalomesites Tardyi & & $\begin{array}{l}\text { Larve eat timber of par- } \\
\text { tially decayed trees. }\end{array}$ & 84 \\
\hline
\end{tabular}

${ }_{1}$ Also found on elm, sycamore, hawthorn, and several other trees.

${ }^{2}$ Injurious to practically all nursery stock. ${ }^{3}$ Rare; found only in south of England. 


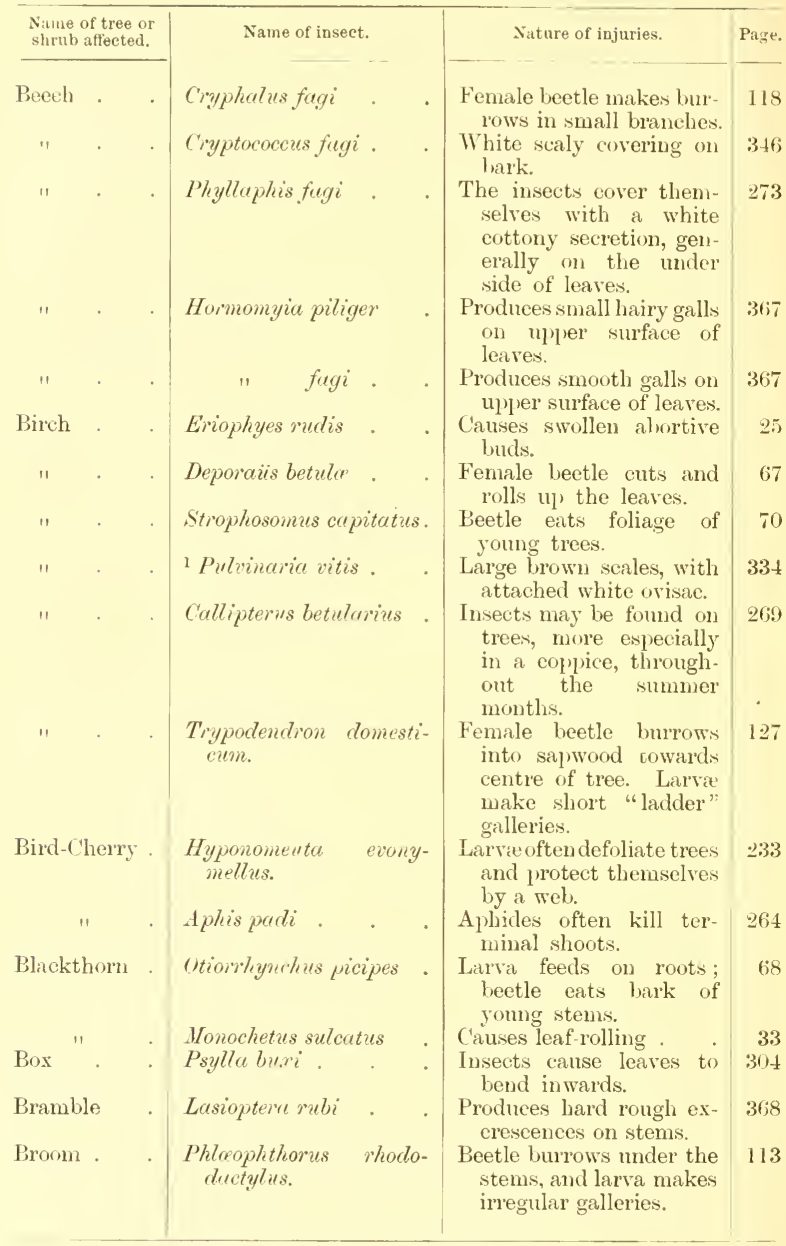

1 Also on hawthorn, hazel, willow, alder, \&c. 


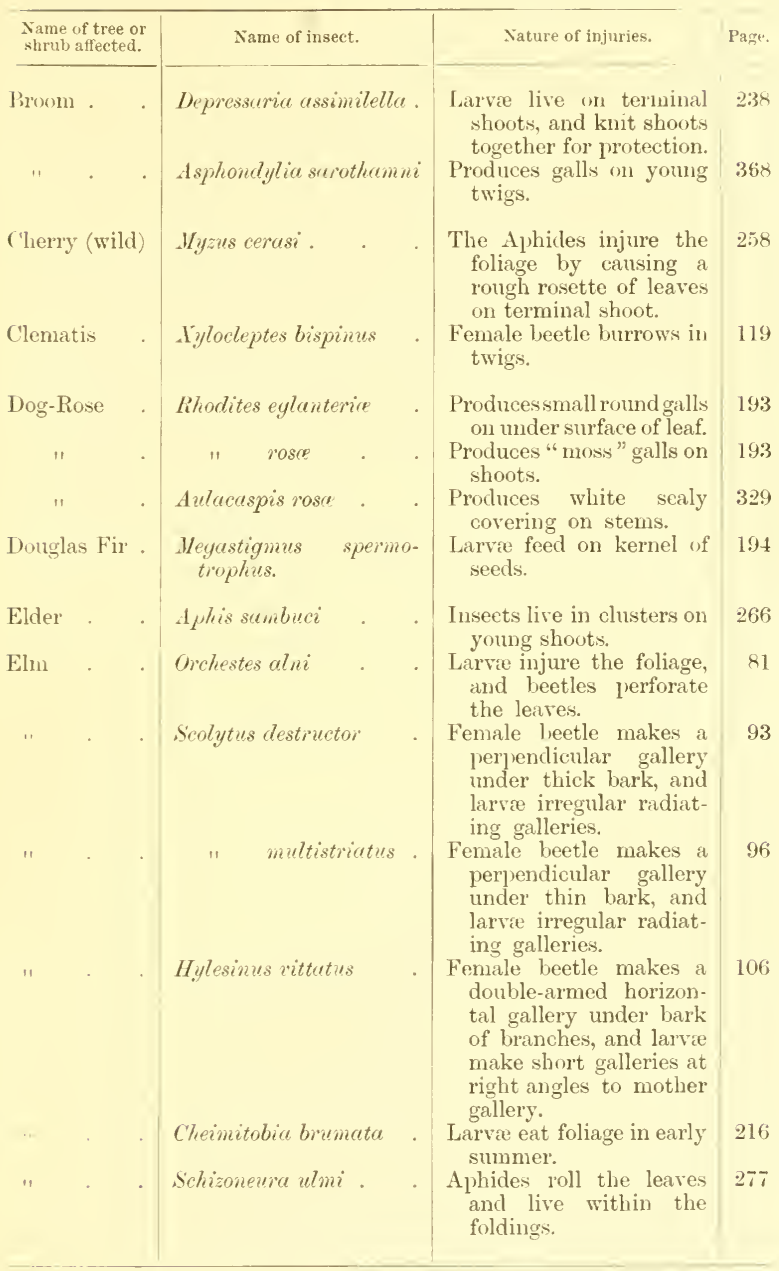




\begin{tabular}{|c|c|c|c|c|c|c|}
\hline \multicolumn{3}{|c|}{$\begin{array}{l}\text { Name of tree or } \\
\text { slirub affected. }\end{array}$} & \multicolumn{2}{|l|}{ Nam } & Nature of injuries. & Page. \\
\hline Elm & . & & Pemphigus pallidus & . & $\begin{array}{l}\text { Inseet forms gall on mid- } \\
\text { rib of leaf. }\end{array}$ & 281 \\
\hline$"$ & . & . & Tetraneware ulmi. & . & $\begin{array}{l}\text { Insects form galls on } \\
\text { upper surface of leaf. }\end{array}$ & 281 \\
\hline & . & . & Typhlocyba ulmi & . & $\begin{array}{l}\text { Sulphur-coloured insects } \\
\text { may be beaten in } \\
\text { showers from foliage } \\
\text { during the summer. }\end{array}$ & 310 \\
\hline Field ] & Maple & & Eriophyes macrochelns & & $\begin{array}{l}\text { Produces conical galls on } \\
\text { mpper surface of leaf. }\end{array}$ & 28 \\
\hline 11 & & . & " macroskynch & & $\begin{array}{l}\text { Produces small galls on } \\
\text { mpler smrace of leaf. }\end{array}$ & 28 \\
\hline Hawth & torn & $\cdot$ & goniothorar & . & Causes leaf-rolling & 31 \\
\hline " & & . & Priobium castuneum & . & $\begin{array}{l}\text { Larva lives in dead stems } \\
\text { in hedges. }\end{array}$ & 01 \\
\hline 1 & & . & otiorrhynechus picipes & . & $\begin{array}{l}\text { Larra feeds on roots, and } \\
\text { beetle eats bark of } \\
\text { young stems. }\end{array}$ & 68 \\
\hline$" 1$ & & . & $T, i$ & . & Larva eats foliage. & 173 \\
\hline$"$ & & - & Nytilasp & . & $\begin{array}{l}\text { Small brown seales on } \\
\text { branches of compara- } \\
\text { tively young trees. }\end{array}$ & 326 \\
\hline$" 1$ & & . & Penthina prumiana & . & $\begin{array}{l}\text { Larve often injurious to } \\
\text { latehes of trimmed } \\
\text { helges and isolated } \\
\text { lawn-trees. }\end{array}$ & 224 \\
\hline$" 1$ & & . & Aphis crutegi & . & $\begin{array}{l}\text { The insects do consider- } \\
\text { able injury to leading } \\
\text { shoots of young thoms } \\
\text { and heiges. }\end{array}$ & 262 \\
\hline '1 & & . & Cecidomyia crategi & . & $\begin{array}{l}\text { Inseets form a rough } \\
\text { rosette of leaves on ex- } \\
\text { treme twigs, more es- } \\
\text { leeially on hedges. }\end{array}$ & 357 \\
\hline 11 & & . & Psylla cretergi & . & $\begin{array}{l}\text { Extreme end of terminal } \\
\text { shoot often killed by } \\
\text { the young close-adher- } \\
\text { ing inseets. }\end{array}$ & 305 \\
\hline Hazel & & . & Erioplyes avellance & . & $\begin{array}{l}\text { Canses swollen abortive } \\
\text { buds. }\end{array}$ & 24 \\
\hline$" 1$ & . & . & Bulaninus nucum. & . & $\begin{array}{l}\text { Larva eats the kernel of } \\
\text { the nut. }\end{array}$ & 83 \\
\hline$" 1$ & . & . & Diyocetes alini . & . & $\begin{array}{l}\text { Female makes burows in } \\
\text { dead twigs. }\end{array}$ & 121 \\
\hline$"$ & . & • & ix ribeana. & . & $\begin{array}{l}\text { Larve often defoliate } \\
\text { bushes in early summer. }\end{array}$ & 224 \\
\hline Holly & . & - & Aspidiotus britannicus & . & $\begin{array}{l}\text { Dusky brown scale on } \\
\text { leaves. }\end{array}$ & 328 \\
\hline
\end{tabular}




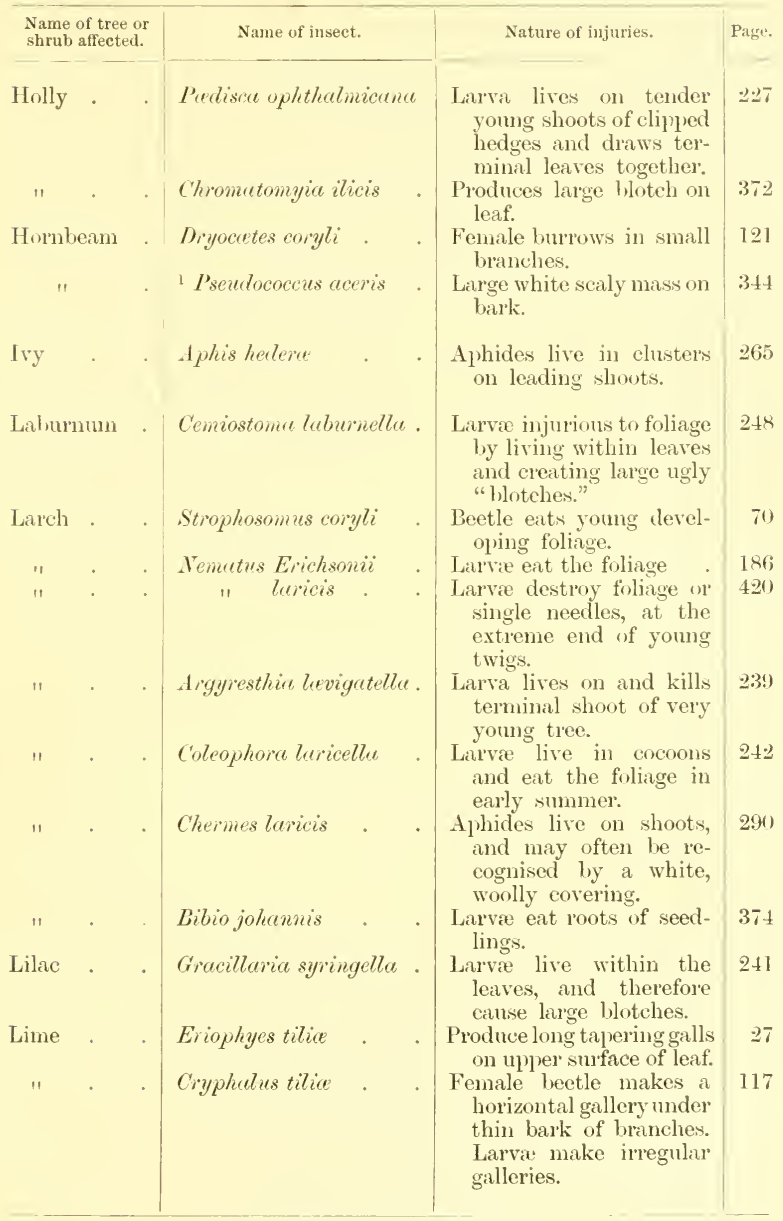

1 Also on sycamore, oak, ash, elm, gorse, \&c. 


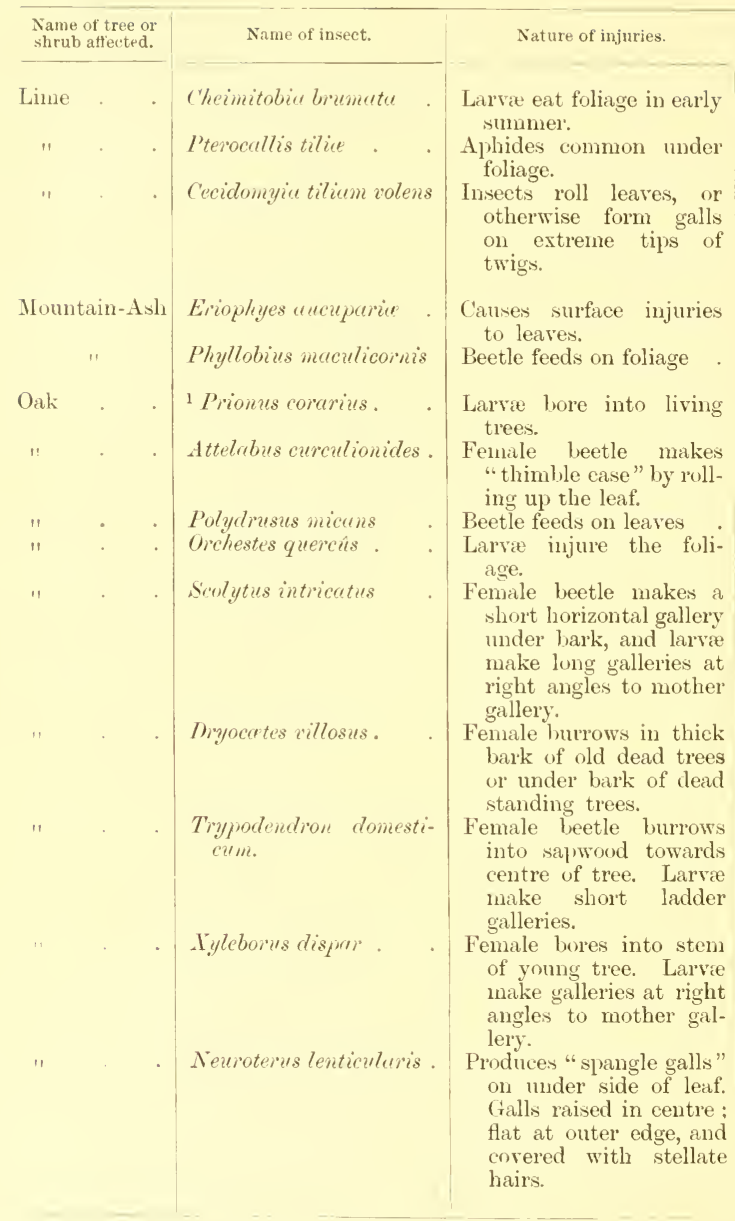

Page.

216

270

363

1 Rare; confined to south of England. 


\begin{tabular}{|c|c|c|c|c|}
\hline \multicolumn{2}{|c|}{$\begin{array}{l}\text { Name of tree or } \\
\text { slirub affected. }\end{array}$} & Name of insect. & \multirow{2}{*}{$\begin{array}{l}\text { Nature of injuries. } \\
\text { Produces "currant galls" } \\
\text { on Hlowers or leaves. } \\
\text { Galls globular, soft, } \\
\text { and suceulent. }\end{array}$} & \multirow{2}{*}{$\begin{array}{l}\text { Pagre. } \\
143\end{array}$} \\
\hline Oak & . & Spathegaster baceurum. & & \\
\hline$" 1$ & . & Newroterus fumipennis & $\begin{array}{l}\text { Produces galls ou under } \\
\text { side of leaf. Centre of } \\
\text { gall concave, edges con- } \\
\text { spicuously turned up. }\end{array}$ & 144 \\
\hline$" 1$ & . & spathegaster tricolor & $\begin{array}{l}\text { Produces galls on under } \\
\text { side of leaf ; in clusters, } \\
\text { and hairy. }\end{array}$ & 145 \\
\hline$" 1$ & . & Neuroterus leviusculus. & $\begin{array}{l}\text { Produces galls on under } \\
\text { side of leaf. Galls are } \\
\text { nearly smooth, white } \\
\text { or yellowish, the outer } \\
\text { edge turned up. }\end{array}$ & 145 \\
\hline$"$ & . & spathegaster albipes & $\begin{array}{l}\text { Produces spindle-shaped, } \\
\text { smooth galls, causing } \\
\text { fairly deel', indenta- } \\
\text { tions of leaf. }\end{array}$ & 145 \\
\hline$"$ & . & Neuroterus numismatis. & $\begin{array}{l}\text { Produces "button galls" } \\
\text { on under side of leaf. } \\
\text { Galls are depressed in } \\
\text { centre, surface covered } \\
\text { like silk velvet. }\end{array}$ & 146 \\
\hline$"$ & . & " ostreus. & $\begin{array}{l}\text { Produces small, spotted, } \\
\text { pellet-like gall on mid- } \\
\text { rib of leaf. }\end{array}$ & 146 \\
\hline$" 1$ & & Spathegaster aprilinus & $\begin{array}{l}\text { Produces "thin" galls, pre- } \\
\text { senting the appearance } \\
\text { of an undeveloped bud. }\end{array}$ & 147 \\
\hline " & & Aphitothrie radicis & $\begin{array}{l}\text { Produces large many- } \\
\text { chambered galls at } \\
\text { hase of trunk near } \\
\text { surface of roots. }\end{array}$ & 147 \\
\hline$" 1$ & & rorticis & $\begin{array}{l}\text { Produces galls in young } \\
\text { bark around a pruned } \\
\text { branch. }\end{array}$ & 148 \\
\hline " & & globuli & $\begin{array}{l}\text { Produces globular green } \\
\text { galls, projecting fron } \\
\text { bud seales. }\end{array}$ & 148 \\
\hline " & & Andricus infutor. & $\begin{array}{l}\text { Produces galls in inflater } \\
\text { portion of the terminal } \\
\text { twig. }\end{array}$ & 149 \\
\hline " & & " carvator. & $\begin{array}{l}\text { Produces galls on leaf, } \\
\text { cansing an irregu- } \\
\text { lar globular swelling. } \\
\text { These galls have al- } \\
\text { ways an inner gall. }\end{array}$ & 150 \\
\hline
\end{tabular}




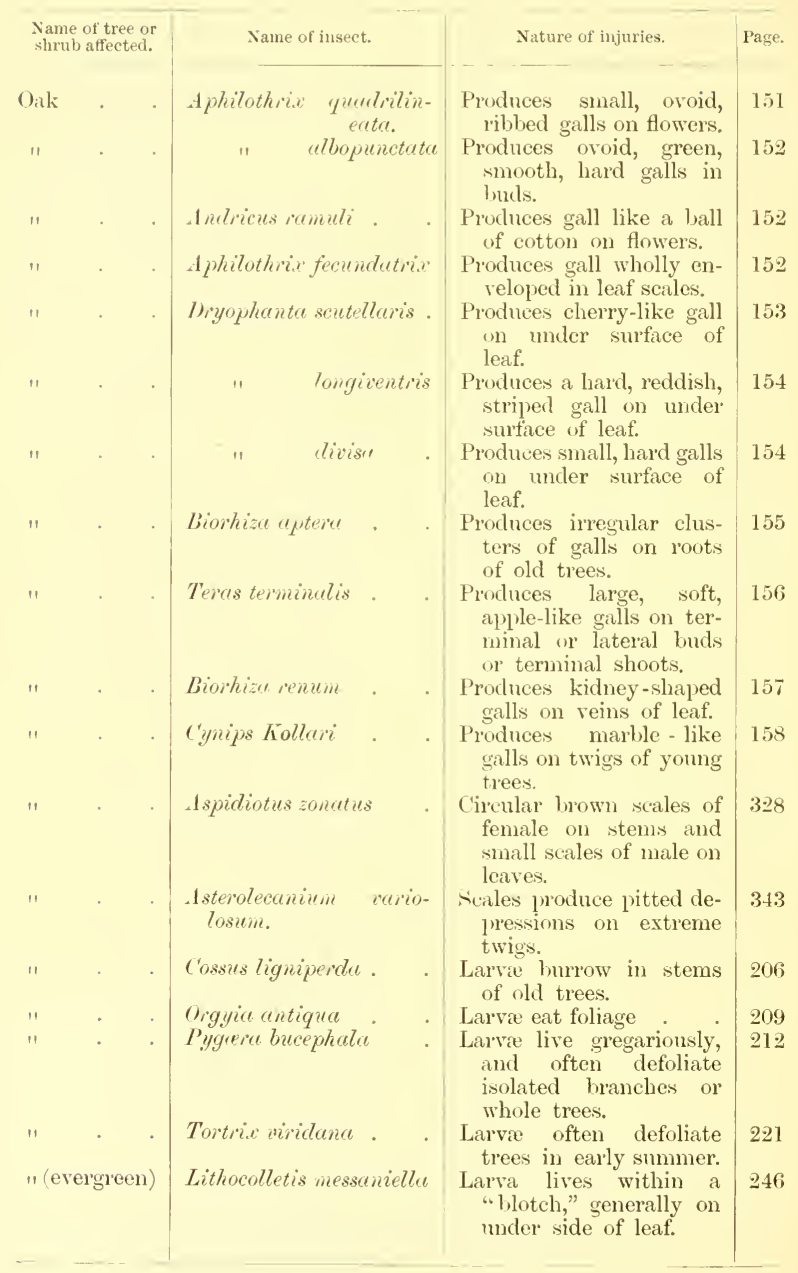




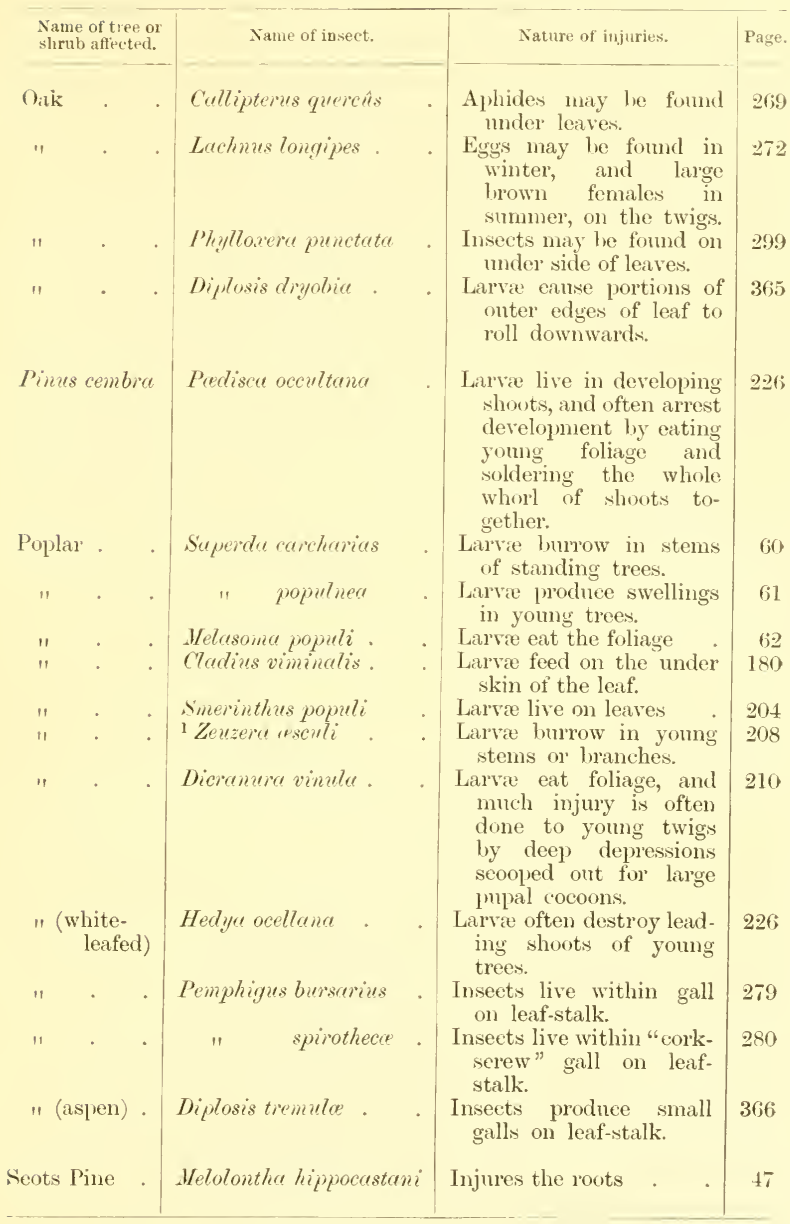

${ }^{1}$ Also on elm, sycamore, haw thorn, and several other trees. 


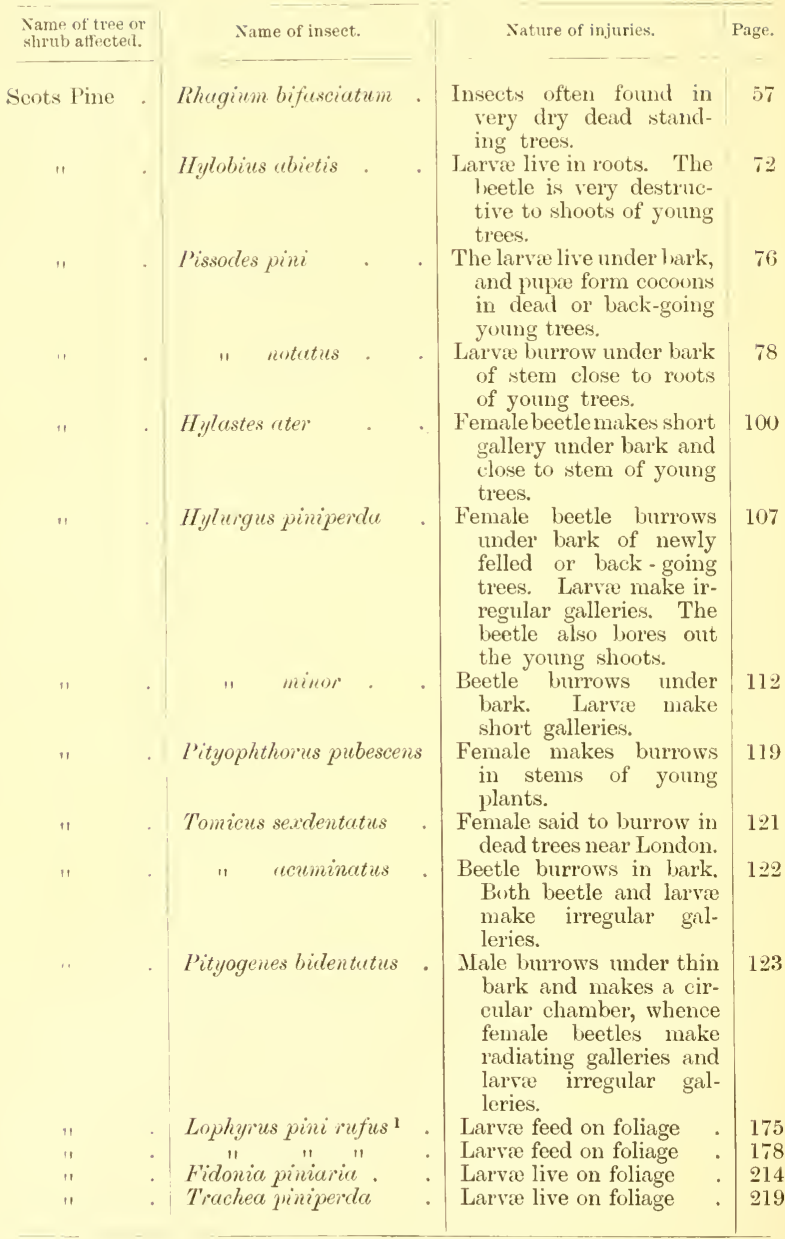

1 See also Appendix, page 421. 


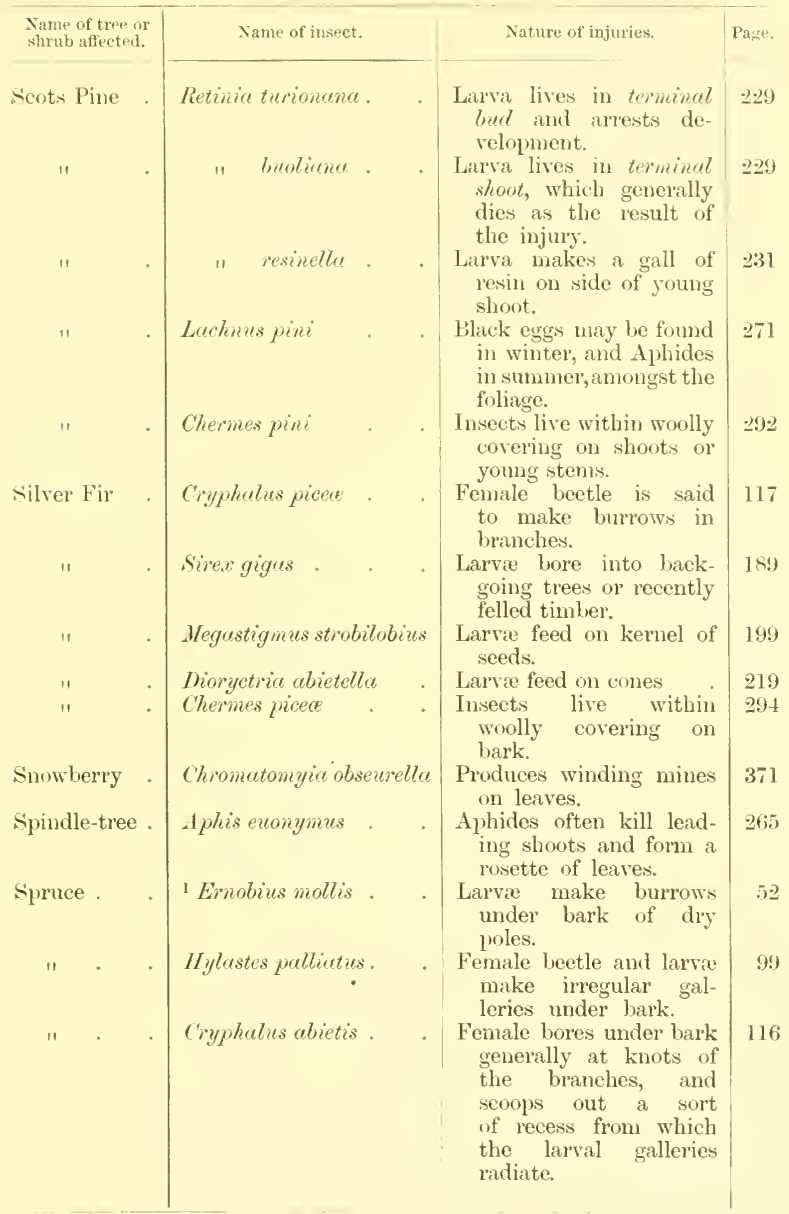

I Also under bark of larch paling. 


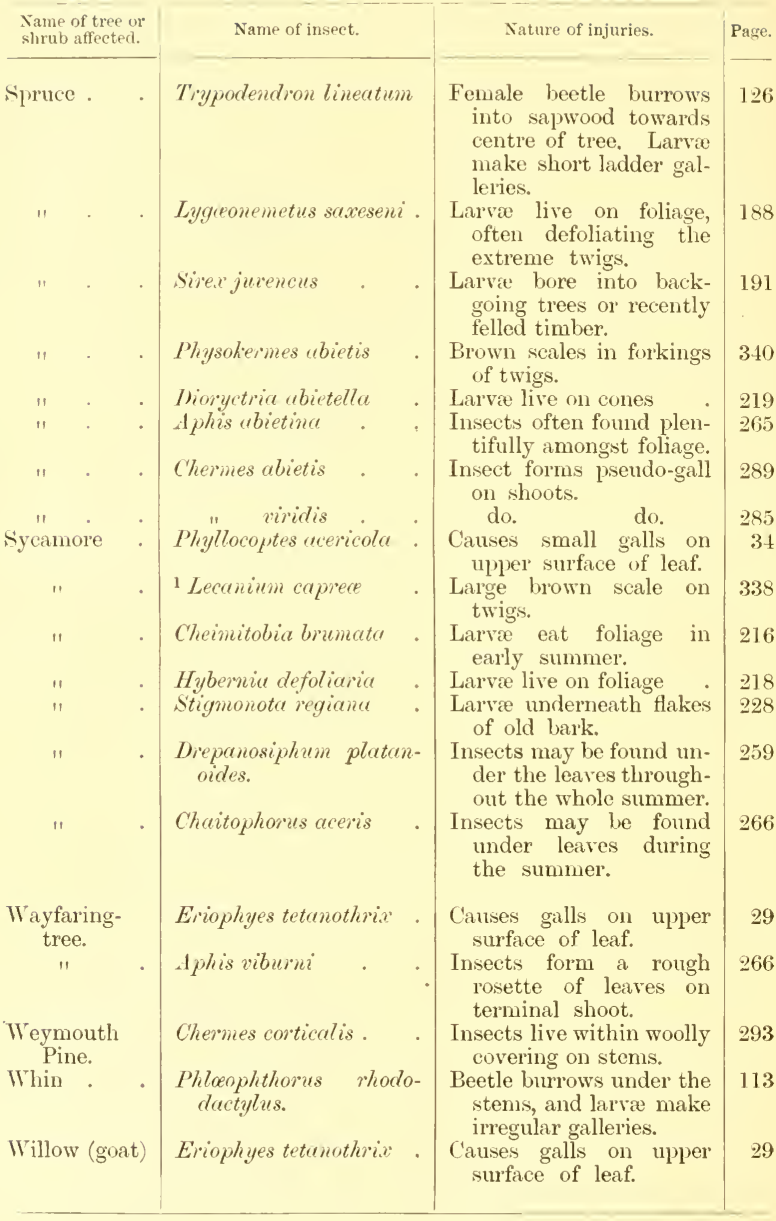

1 Also on hawthorn, apple, oak, eln, chestuut, lime, \&c. 


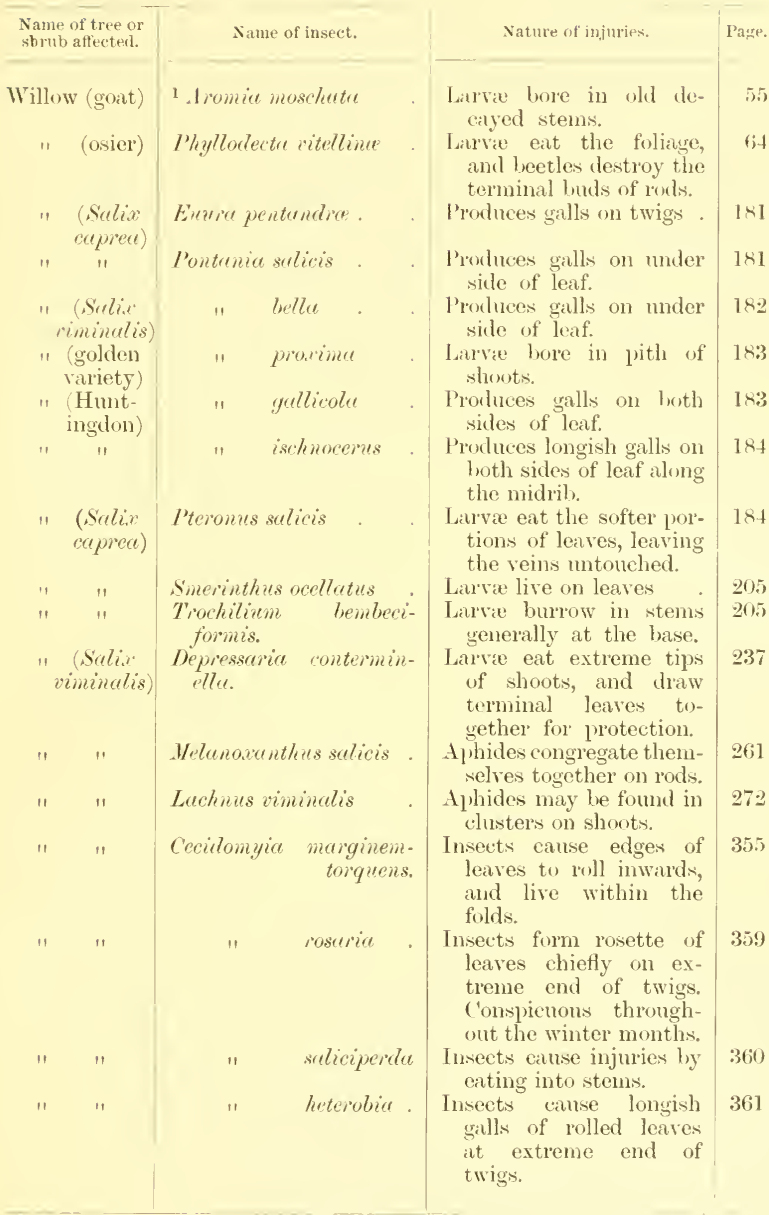

1 Also attacks lime-trees. 


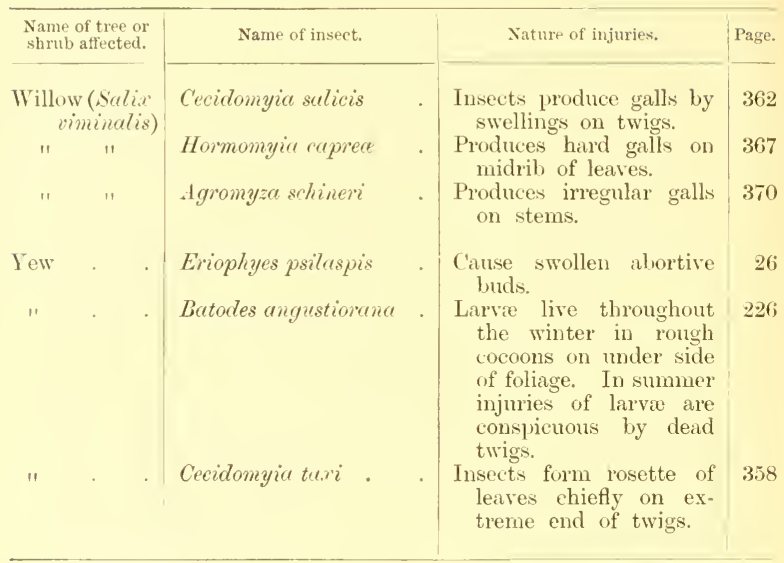




\section{CHAPTER XIII.}

\section{BENEFICIAL INSECTS.}

Is the foregoing chapters it will have been noted that all inseets considered are injurious to a more or less extent, and the inquiring or philosophic student will naturally ask, Are there no beneficial forest insects? In a general way an affimative answer may be given, but in defining "beneficial" insects it is necessary that some qualification should be made. Thus we may divide our subject into three main divisions - viz., (l) the question whether insects play any part in the fertilisation of flowers; $(2)$ the part which insects may play in aiding the rapid destruction of certain refuse in the woods; and (3) the very great part played by parasitic insects-i.e., insects living on other insects.

As regards the first division, it may be said that the majority of our forest trees are wind-fertilised, but there are, of course, probably others which are not so, together with many flowering-shrubs, and it is just possible that this may be to some extent an unworked field.

With reference to the second division, it is obvious that we can get into eloser association with this part of the subject. Thus, much dead wood is often left lying in woods, and the forester desires its early destruction. Many species of insects may be found within rotting wood which doubtless assist in the disintegration of the parts. This, however, may be considered as having a very indirect hearing, inasmuch as many of those insects found in rotting wood may be looked upon as being there purely for shelter or moisture. One notable exception, however, may be given-viz., the case of any insects which may aid in the destruction of roots left in the ground. In Scotland and the north of England it may be observed that in the roots of Scots pine, after being eut for three or four years, very small, cleareut, gimlet-like holes can be seen in the solid roots. It will be obvious 
to the practical man that the effect of these holes is to let moisture into the body of the root, and so hasten its decay. Thus the more rapid destruction of the roots accruing from the insect may well be considererl as an advantage.

The insect doing the work referred to is a beetle termed Asemum striatum. The larva is about an inch in length, of a whitish colour, broad at the thoracic portion, and tapering very much in the abdominal segments.

The beetle is of an oblong shape, a dull-black colour, and deeply sculptured. The legs are brownish-black, with deep-black tarsi.

With reference to the third division of our subject, it may be noted that it can be divided into sub-divisions, as it were-viz., insects which prey directly on other insects, and those which are parasitic, or in many cases indirectly kill other insects.

As regards those which feed directly on injurious insects, perhaps the best example is the Coccinellidæ or "lady-bird" beetles. There are several species of them, and they live on insects, more especially Aphides. They feed on these insects both in the larval and beetle stages. Some species pupate on the leaves of trees, and to a beginner in forest entomology the rolled-up pupa is a somewhat puzzling object. These beetles should be carefully studied in every detail, for not only are they very good friends, but the males often differ so much from the females that they may at first be mistaken for distinct species.

Many of the Colonial writers give very interesting accounts of the great advantages of introducing a species of lady-bird or Vedalia (Novius carlinalis), the notorious Australian bug destroyer. The bug referred to has been kept in check in many parts of the world by the Vedalia. So that a very good hint is given to encourage ladybird beetles.

The field of beneficial beetles in forest entomology is rather an unworked one, and Mr R. S. Bagnall has recently demonstrated this by showing that the beetle Epurrea angustala is a parasite on the genus Trypodendron, and this obviously suggests that the parasites of the Scolytidæe are entirely an unworked field.

There are many other species of beetles which might be well considered as beneficial, as, for example, many of the ground-beetles, which live on the larvæ of various insects, or other creatures, which in turn feed on the roots of young trees in the nursery.

The larvæ of some species of Diptera are very beneficial in 
keeping down green-fly, \&c., and may often be found amongst these pests.

The most important parasite insects belong to the order Iymenoptera, and the following concise account of the families which may be considered as beneficial is taken from Professor Carpenter's work on 'Insects, their Structure and Life':-

"Ichneumonidæ. - The Ichneumonitre or Ichneumon-flies are an exceedingly large family. The feelers are straight, long, and manyjointed, tapering towards the tip; three ocelli are always present on the crown. The wings have for the Hymenoptera a complex neuration; a distinguishing character is the presence of two cells between the cubitals and the second posterior cell (at the anal angle of the fore-wing). Rarely wings are quite absent. The stalk of the elongate hind-body is attached to the lower or hinder of the first abdominal segment, which is very large, while the metathorax is relatively short, so that the middle and hind pairs of legs are inserted close together. The trochanters have two segments. The females are provided with oripositors, which in some cases are several times as long as the body : by means of these they lay their eggs in the bodies of caterpillars. The forms with exceptionally long ovipositors, such as Thyssa, prey upon wood-boring grubs: this species lays her eggs in the burrows of sirex, on whose grubs her larvæ feed as external parasites. In most cases, however, the Ichneumon maggots feed internally on the juices of their victims. Over 6000 species of Ichneumonidæ are already known, and the family is distributed in all parts of the world.

"Braconidæ.-The Braromitle are a large family, closely allied to the Ichneumonid"," but distinguished by having only a single cell on the fore-wing, between the cubitals and the second posterior cell. The larvæ live like those of the Ichneumons, and the range of the family is equally wide.

"Chalcididæ. - The chalcidide" are a very large family of small Hymenoptera, distinguished from all the preceding families of Petiolata by their elbowed feelers, which have from seven to thirteen segments. The pronotum is partially free, and does not reach back to the insertion of the fore-wings. The neuration is very simple: a single thick nervure runs from the base of the wing to the costa, giving off at its termination a very short branch. The trochanters are divided. The Chalcididx are frequently of brilliant metallic 
colours. Over 4000 species have already been described, and they oceur in all parts of the world. The eggs are laid in galls, or in nests of the higher IIymenoptera, so that the larva may feed on the contained maggot. Some species attack the caterpillars of moths, and others, like Chalcis' orreta, feed in pupe.

"Proctotrypidæ.-The Proctotiypide" are a large family of small Hymenoptera, distinguished from the Chalcinlites by the pronotum being closely fused with the mesothorax, and reaching back to the bases of the fore-wings. The neuration varies greatly : in some genera a few nervures and cells are present; in others, none. The hind-body is pointed at the tip, and the ovipositor is tubular. The trochanters are usually segmented, but in some genera they are simple. The larve live parasitically within the bodies of insects; those of some very minute species find food enough in other insects' eggs. In some Proctotrypicle the larva in its first stage is broad in front, and tapers behind to a point whence spring several tail-processes; this is ultimately ehanged into the ordinary Hymenopterous maggot. Some genera of the sub-family Mymarince, tiny and delicate insects with narrow wings fringed with long hairs, are aquatic in their habits, and their larve are believed to feed in the eggs of dragon-flies. The Proctotrypicte have a world-wide range, and must number many thousands of species."

The above remarks are given simply with the idea of suggesting the field of study for the student. As a general rule, the student will find sufficient scope, along with other subjects, in confining hinself entirely to the injurious species. If, however, he can possibly study "beneficial insects" as here indicated, he will find the best method of doing so to simply collect the varions species in the hatching-boxes. In the case of some insects this is specially interesting, as for example in the "oak-apple" gall, from which various parasites hatch out nearly all the year round. Again, it may be said that it is essential to know something of parasites, as, to a beginner, they may often in the hatching-box be mistaken for the real injurious species. It is also of considerable importance to study parasites, as in certain cases they may change their habits, as, for example, in Megastigmus, which has been long known as a parasite on "oak galls," and recently has been discovered as a deadly enemy to the seeds of Douglas fir. 


\section{CHAPTER XIV.}

\section{INSECTICIDES AND GENERAL REMEDIES.}

WHEx dealing with forest insects and showing them in the cabinet or life-history cases from an educational standpoint, one is generally asked the question by practical men, What is the best way of getting rid of them? It will have been noticed that throughout the whole of this work general and not specific remedies have been given. As regarls the latter, or the insects considered, it will be obvious that, while there are some very notable exceptions, as a general rule only sickly or back-going trees are usually attacked. Hence it is apparent that there are two practical methods to be adopted-viz. : (1) to maintain good health or encourage vigour either for trees or shrubs individually, and for woods or plantations when considered collectively ; and (2) that where we do get certain insects attacking healthy trees in nursery or plantation, special remedial measures must be adopted.

With regard to good cultivation, it may be said that in making the following remarks it is not intended that the methods should be usually adopter in order to lessen insect attacks; but, at the same time, it is certainly true that in many cases bad methods of cultivation, together with careless workmanship or inattention to details, are points very much to the advantage of inseets. Hence the absence of inseets and gool husbandry are often very closely associated. It will perhaps be most practical to consider what may be done in the nursery, the young plantation (ornamental or commercial), the middleaged wood, or in old woods prior to replanting.

As regards the nursery, more especially the estate nursery, for general plants the first thing to consider is the selection of a good site. The nursery should not, e.g., be in the neighbourhood of an old Scots pine wood or where Scots pine branches are likely to lie unburned after heavy falls, as this would enclanger young Scots pine or Austrian 
pine to be subjected to attacks of Hylurgus piniperda. Again, the site ought to be considered as regards shelter, for while it is obvious that too much shelter is not advisable for subsequent planting in the open, still it is much better to err on the side of shelter, and then never plant out before young growth is fully matured, as, on the other hand, too much exposure results in an absence of constitution and vigour; hence growth is often not in proportion to anticipations, and insects have an advantage.

Again, it is possible that selection of seed is a point more important than hitherto considered. It is perhaps true, ${ }^{\circ}$ as many scientists have asserted, that the vegetable organism, unlike the animal, does not "liand on" the disease of the parent. Still, there is in all probability an inherent weakness from the parent, and therefore a natural predisposition to disease, - another point in favour of the insect.

So far as the actual management of the nursery is concerned, too many details cannot be given, as such would simply be an epitome of nursery management. Great care should be taken as regards good handling, as the very first thing to be considered is a good root on the plant, and careful lifting of the stock; and as regarls the transplanting of seedlings and young trees generally, it is in most cases essential to transplant or sell ont always following two years' transplantings.

Much may be done to maintain a good constitution in young trees, as prevention against insect attacks by transplanting at the proper age. Take, for example, beech seedlings. If they are transplanted at two years of age, they grow strong and healthy without any insect attack; but if they are transplanted when only one year old, they are often injured by the woolly aphis (Phyllaphis fagi). On the other hand, ash seedlings are less liable to injuries from the tiny moth, Prays: curtisellus, when transplanted at one year old and left for two years in the nursery-line, than when transplanted at two years old and left two years in the nursery-line: besides, the former make the better plants.

The question of cleaning in summer has to some extent a beneficial influence, both as regards the stimulating of the growth and the keeping down of the weeds. ${ }^{1}$ As regards the latter, it may be said that weerls not only choke young plants, and therefore weaken them, but it is possible that some species of green-fly may be assisted by weeds.

1 The continual use of the dutch-hoe is a great stimulus to plaut growth. 
The method of digging between rows of plants in autumn has a very marked effect in producing greater growth, and thus lessening insect attack. Mr J. W'. Robson, nurseryman, Hexham,-a nurseryman of nearly fifty years' experience,--informs me that he has often experimented with autumn and winter digging as a means of stimulating growth and lessening insect attacks. By taking a plot of plants, say thorns, and digging and leaving undug alternate patches, he has found that the undug portions made less growth and suffered heavily from green-fly, whereas the dug portions made long shoots of growth and were practically untouched by insects. By autumn digging, too, the frost pulverises the soil, and facilitates the subsequent summer cleaning.

It often happens that many plots of hardwood in the nursery are very much injured by insects. For example, ash plants at three years of age (that is, two years in seed-bed and one year in nurseryline) are injured by Piays: cuitisellus and other insects - so much so that, with forked and bushy tops, they are practically useless. This may be got over by cutting down to the ground in early spring, and then giving sufficient attention to see that the plants spring away with only a single shoot. The result is that we get very good, healthy plants.

There are several other points which may be attended to with very beneficial results, as, for example, burning of all prunings of hedges, holly bushes, yews, \&c. In the growing of fruit-trees, certain varieties assert themselves as being practically immune from such direful pests as American blight and mussel scale, and perhaps this suggests the advisability of attending to certain species or varieties as regards ornamental trees, shrubs, or willows, fe. Much might also be done in the way of green cropping, green manuring, and so forth, according to local circumstances or the experience of practical men.

As regards preventive measures against insects in young woods, it is even more important than in the nursery, inasmuch as the majority of reports against forest insects (although perhaps due to better facilities for observation) come from young woods. In the majority of cases the real cause of injury is primarily due to carcless or indifferent planting. Practical men, or men who ought to be practical, will write to newspapers stating that certain areas can be planted for sums which cannot even raise the plants. Siceing that a plantation is for a period of a hundred years, why should it not be properly done? Do what is 
right in principle,-- get the full return of work from the workmen, making quality a leading feature, - and the insect pest will often disappear. What are correct principles in planting? The answer may be varied according to the class of planting. Thus we may have here (1) planting on a large area, chiefly pure or mixed, only by grouping aceording to soil conditions; (2) a mixed plantation on previously cultivated land; (3) elumps or groups of trees for landscape effect; and (t) replanting of old woods.

(1) Planting on a large area.-If the ground be quite bare and the herbage not very rough, the usual method of notehing may be adopted with very good healthy results; but if, on the other hand, the surface conditions are against using a small plant, then unless some extra care in preparation be adopted, the results will not be so goorl, and therefore much to the advantage of insect attack.

(2) As regards planting with the object of forming a new plot on previously cultivated land, more especially in a pasture field, the plants are rather difficult to get away, and often hang on for a considerable time. It is from this elass of planting that we often get very severe attacks of Chermes on lareh, and, in fact, many lareh plants are killed with the aphis. This attack might often be considerably reduced if a little more attention were given to a few practical details. In the first place, the wrong size and age of larch plant is used-viz., two years two years, or four years old; and some use one year three years, which is even worse. The plea is that a large plant is used to save expense of eleaning. A smaller plant and attention in keeping down the grass will give better results. The best results of planting a mixed plantation, including larch for early returns, would be to plant off plougherl land and keep the grass and herbage down for two years. The planting could be theaper done, both as regarls plants and labour; and even if following a green crop, it would pay to allow for "unexhausted improvements," inasmuch as being in every sense better as regards soil conditions there would be comparatively no blanks and no insect attacks. As an experimental comparison, it may be noted that when planting on grass land it is often essential to have fires when preparing for planting, as when burning old hedges and so forth. The lareh plants on the burned patches do infinitely better than those on grass, and never show signs of Chermes.

(3) In planting ornamental clumps for landsrape effect, the best 
remedy against insects is to trench the ground. Not only do the trees grow ever so much faster as compared with pitting, but the more rapid landscape effect and the greater increment amply compensate for the initial outlay in trenching.

(4) In replanting, it may be noted that careless or indifferent managrement of the woodland, in the period intervening between the cutting of the old erop and the replanting, not only gives every advantage to the dissemination of insects, but the essential conditions of soil are often so much placed out of order that the next crop is weakened and more liable to be injured by insects. All branches should either be carted off the ground or burned on the spot, which of course destroys the breeding-ground for many species of beetles. Then in many cases, more especially pure Scots pine woods, the ground should be well stocked with cattle or sheep three or four years prior to replanting. The effect of this is that the soil is so much trodilen away from the old stools that the bark falls off, and the stools are more unfit for breeding-places. Scrub bushes are prevented from getting up, which also often serve for the propagation of many species.

As regards the advantage of "stocking" with eattle or sheep, it should be noted that, as a result of pasturing, the "spongy" layer underlying the rough turf disappears. This is a great improvement to the soil, inasmuch as the spongy layer is acid in reaction, and contains nitrogenous matter derived from the decayed plant residues of which it is composed. In the rough state the nitrogenous matter, however, is not directly available as a plant food, but must be converted into a soluble and available form by the action of the nitrifying organisms always present in the soil. It will therefore be obvious that the ground can be more cheaply and successfully replanted; and as the plants will not only do better and give a more regular crop, as compared with planting on rough umprepared ground, the young trees get better over the most eritical period against the attacks of insects.

With regard to the prevention of insects in young woods, it may be said that again it is essential to adopt sound sylvicultural principles, and as a rule the insects will not be troublesome. One rotable exception is the Retinia or pine-shoot moth, which does not disappear under good management as many others do. In young plantations it is well to see that they are planted "thick" and kept so. Secure a rapid canopy, get all grass killed off" us quiclity as possille, and keep the soil eonditions right by having a covering of leaves from the 
shade-bearers - beech and other trees-and growth will be very much stimulated. It has been proved by the Woburn and other experiments that grass has no place in an orchard; and as the case of young woods is practically analogous, it would be well for the health of young woods if the grass could be got rid of as soon as possible by the density of the young thick crops.

In the nursery-lines many species of hardwood trees do very badly, partially owing to insect-damage, and are often considered too good to destroy. This class of trees, after being planted for a few years, could be cut down to the ground, and then they would come away as strong young trees, provided they are well sheltered with the remainder of the crop, or under the protection of netting, and receiving attention for the first year.

In dealing with Insecticides, or the destruction of certain insects by the application of special chemicals and mixtures in varying degrees of strength, or otherwise by the application of special mixtures as sold hy respectable firms or individuals, it will be obvious that in a work of this class it would be very improper either to support or condemn any "mixture" in the market. It is therefore considered advisable to simply give a few general principles.

In the first place, it should be remembered that the use of any insecticide should be, as far as possible, applied intelligently (1) as regards the life-history of the insect; $(2)$ what is to be the actual or prospective effect on that particular stage of the insect under the anticipated remedy; and (3) how far such remedies may be practicable.

It is important to bear in mind the structural and physiological functions of an insert (1) as regards the structure of the mouth and method of feeding; (2) the method of respiration or breathing; and (3) in some special cases the method of reproduction. The application of effectual insecticides must be through one or other of these mediums.

As regards the poisoning of the insect through feeding, it must be borne in mind that there are three distinct methods of feeding-viz., biting, piercing, and sucking. The piercing and sucking forms, however, are not always easily separated. Now take a typical case of general insecticide application-viz., spraying, and consider obvious results. The biting form of mouth, as seen in the beetle, would take the liquid along with the full structure of the leaf; or if the insect only ate the upper surface of the leaf, leaving the veins and under 
surface, it would obviously take a very large proportion of the insecticile on the leaf. But if the insect were literally of the piercing type, the proboscis would pass through the smallest possible quantity of the poison on the surface, and feed on the pure vegetable sap underneath. It is therefore obvious that before any good results could accrue, we should require to get the vegetable organism to incorporate the poison with its own sap. How far this can be done is still to a large extent a question for future scientists, but nature does give us some very gond suggestions in this direction. Take, for example, the case of some scales with their piercing mouths-viz., Ciyptororeus fari or felt scale on beech and Mytilaspis pomorum or mussel scale on fruittrees. In the former case the copper beech often shows itself as practically immune alongside the badly infested trees of the common beech, and in the latter certain varieties of fruit-trees are practically immune while the surrounding trees of other varieties are literally killed. Hence the practical inference is to either raise immune varieties, as in fruit-trees, or if possible to so feed the vegetable organism as to contain some ingredient so amalgamated with the sap as to be inimical to the animal parasite.

With regard to the breathing-apparatus of an insect, it should be remembered that breathing is not effected through the mouth, but through slits or openings termed breathing-pores or spiracles. If these openings are varnished over, the insect will be asphyxiated. Thus, therefore, we get the suggestion of applying insecticides in the form of an emulsion or thick spray. Nothing answers this purpose better than soft-soap, because it adheres to the skin, and other ingredients may be added within certain limits and according to the species of insect and nature of injuries. Such ingredients are quassia, paraffin, tobacco, sulphur, turpentine, caustic soda, caustic potash, \&c. The addition of any of these ingredients has the effect of corroding the skin, and so intensifying the action of the emulsion. The skin of insects is composed of a substance known as chitine. This substance is more or less of a horny nature, and has the chemical formula of $\mathrm{C}_{9} \mathrm{H}_{15} \mathrm{NO}_{6}$. It is practically unaffected by alcohol, ether, acetic acid, alkalies, or even when boiled in caustic potash. It may, however, be dissolved by concentrated mineral acids, but as the latter would injure the vegetable organism, it follows that insecticides must be so composed as to act on the insect without doing injury to the plant.

The reproduction of insects may to some extent be checked, as for 
example in the Aphides. In this family the young are brought forth alive, so that by using any insecticide which would so injure the creature as to prevent it giving birth to young we should be checking the pest considerably.

Insecticides are now employed with great success, especially in horticulture; but obviously they are more difficult to apply in forestry, particularly in the forest proper. It appears best, therefore, to suggest remedies in a general way for the nursery and individual or ornamental trees.

In the nursery remedial insecticides may be classified under four heads: (1) fumigation; (2) dressing the soil ; (3) spraying; (4) miscellaneous.

As regards fumigation, it may be done in an open shed when removing from the nursery to the plantation, or when foreign plants have leen purchased, or with a costly preparation on groups or individual trees.

As fumigation has not been alopted to any great extent in this country, the following account of Mr Lounsbury, Government Entomologist, Cape of Good Hope, ${ }^{1}$ may be given :-

"Fumigation with hydrocyanic acid gas is applicable for the destruction of scale insects on citrus-trees, and to a large extent on other trees. It is without doubt the most efficient remedy for this purpose yet brought into practical use. The eggs of the insect do not succumb to the gas unless this is used at a much greater strength than what is necessary to destroy the insects themselves. One treatment suffices for the destruction of those species in which the young are produced alive. Successive treatments at the ordinary strength are necessary to destroy all stages of egg-laying species, but it is more advisable to give several treatments at this strength than a single one which would destroy the eggs, because of the liability of seriously injuring the trees in the latter case.

"In general, the treatment consists in covering the trees with an air-tight cloth made in the form of a tent or sheet. The gas is then generated beneath this cover by acting on potassium cyanide with sulphuric acid, the amounts of the chemicals used depending upon the dimensions of the tree. The coverings are removed after the expiration of half or three-quarters of an hour, by which time the gas is largely spent. Great care must be taken in the use of the gas, as it ${ }^{1}$ Report for the year 1906, p. 130. 
is highly poisonous not only to insects but also to the higher forms of life. When proper precantions are taken, however, there need be no more danger in its use than in the employment of arsenical sheep-dips or strychnine for other farm purposes.

"It is desirable to have various sizes of the eoverings ; and withal, the initial outfit demands an outlay so considerable, that not every orchardist will find it economical to provide himself with an equipment for his sole use. But by co-operation among a number of growers, the expense per tree treated may be lowered to a figure which leaves a handsome margin of profit in the benefits which acerne from the operation. After the first expense for the equipment the chief item of cost is the labour, but this expense is not much, if any, greater than the expense of spraying eitrus-trees. When purchased in large quantities the chemicals are not expensive. The cyanide may be procured in London at 10d. per lb. in $224 \mathrm{lb}$. lots, and the sulphuric acid in Cape Town for 50s. per case of $168 \mathrm{lb}$. : one merchant sells the acid at $26 \mathrm{~s}$. per ease of $122 \mathrm{lb}$. Estimating the eyanide to cost $1 \mathrm{~s}$. $6 \mathrm{~d}$. per $1 \mathrm{~b}$. and the sulphuric acid $4 \mathrm{~d}$., the expense of the chemicals necessary for a tree ten feet in height would be about 3d."

With reference to dressing the soil, various mixtures have been used, but the one which has recently found most favour with practical men is Vaporite. ${ }^{1}$ It should be sown broadcast in the soil prior to digging, and when thus applied it gives off a vapour that destroys the larvæ of many insects, as, for example, wire-worm, leather-jackets, and others which pass their larval stage in the soil.

As regards spraying in the nursery, various commercial washes may be used, and of course it may be noted that practical men will differ in their opinion. It will therefore, perhaps, be best to give what may be considered a kind of mixture which can he used with the knapsack spraying arrangement or the hand syringe.

Get an old boiler of, say, 16 gallons capacity. Boil about 7 gallons of soft water; add and well mix in this about $10 \mathrm{lb}$. soft-soap, together with about 1 gallon of paraffin. Then boil in a separate vessel about $5 \mathrm{lb}$. quassia chips. Strain and add to the above. This will form a kind of stock solution, and when quite cold add and mix well. in about 100 gallons of soft water (three old paraffin easks), and apply with syringe.

\footnotetext{
1 There are several classes of a similar preparation on the market.
} 
As it is very difficult to apply any insecticide to trees collectively, it becomes therefore a question how far we can apply any dressing to ornamental or special trees individually, together with the cost of the same. The best report I have received bearing on this is given by my friend Mr Thomas Bond, Lambton Park, Co. Durham, regarding treatment on old beech-trees badly infested with Cryptocorrus fayji. Taking as his guide the Board of Agriculture leaflet No. 140, and the treatment No. 2, which is the same as that given in chap. ix., p. 348, of this work, and mixed on a firly large scale, he says: "We secured a 25-gallon portable boiler and placed in it the following quantitiesviz., 2 gallons soft water, 4 lb. soft-soap, 4 handfuls sulphur, 4 pints paraftin, and 4 pints turpentine. After boiling and mixing these ingredients, we added 16 gallons of soft water, and then allowed it to cool before application. Then after well churning the mixture we placed some in a paint-pot and rubbed it on the stems and large branches with a large paint-brush, which we found better to use than a whitewash - brush. We had, of course, to use ladders, but we brushed it well into all the crevices of the bark. In this way we went over 60 trees at a cost of about $4 \mathrm{~s}$. per tree, including labour and materials. The operation was begun on the 3rd of May, but was not completed till the 28th of the same month, owing to wet weather retarding the work. In the month of August we noticed very small specks of the 'felt' appearing in the crevices of the bark, possibly coming from larve which had been secure from the reach of the mixture. The treatment was certainly a success, and with another slight application the following year we hope to be able to eradicate the pest. Having regard to the size and value of the trees from a park point of view, the expense was not excessive."

There are, of course, many other practical points which might be enlarged upon that go to keep down the injurious species of insects in this country. We rarely hear of any species becoming such alarming pests in this country as on the Continent or in America. This is probably due to the major portion of our forests being "mixed" woods, as contrasted with "pure" woods abroad. The effect of this is that there is no preponderating advantages to any single species of injurious insect.

Another point of importance which should receive special attention is the encouragement of the various species of birds that live, or partially live, on insects. The destruction of certain species of birds 
is perhaps neeessary in orler to protect our fruits, our field erops, or our game-preserves; but on the other hand, the preservation of certain kinds of beneficial birds should be rigidly enforeec. The question of interfering with the "balance of Nature" is always a serions problem, and great caution, combined with intelligent forethought, should be exereised. On the one hand we get certain animals preserved by killing their natural enemies, but on the other hand we may have a lireful pest mexpectedly assert itself as the result of killing natural enemies.

\section{References to Literuture consulted.}

Board of Agriculture Leatlets, \&c.

Collinge, Walter E. Reports on Injurious Insects, \&c.

Theolald, Fred. T. A Text-Book of Agricultural Zoology. Chiefly chapter on the prevention and destruction of insect pests. 


\section{A P PENDIX.}

THE following notes, from subsequent observations on a few of the more important destructive species, are offered with a view of supplementing the information already given in this volume.

\section{Nematus Erichsoni, Htg.}

As this is a scheduled insect, I asked and obtained permission from the Board of Agriculture to keep a few in strict confinement for observation purposes. I found that in practically all cases the various lifehistory stages coincided with the observations given by $\mathrm{Mr}$ Gordon Hewitt. ${ }^{1}$

On .June 1, 1910, eggs were deposited in the main stem of a young larch-tree three years of age, which was grown f,urposely in a flowerpot. They were deposited in the crevices

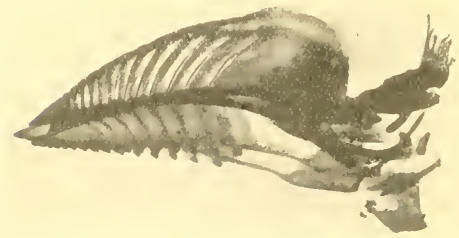

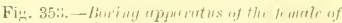
Nematis Erichsonii. of the bark and in double rows. The position of the eggs was not easily determined until a few days before hatching, when the expanded eggs lacerate the bark and so kill the twig. They are whitish in colour, pointed at both ends, somewhat after the shape of an ordinary hen's egg.

The larvæ hatched on

June 15, or fifteen days after egg-deposition. Amongst 100 specimens hatched from larvie received from the Lake district the previous year, all were females. Fig. 353 is a microphotograph of the saw or boring apparatus of the female.

Regarding remedial measures for this insect, it may be said that a deal of good work has no doubt been done by many writers drawing

1 The Journal of the Board of Agriculture, December 1908. 
attention to the value of parasitic insects and other natural enemies, as, for example, Mesolius aulicus, a Hymenopterous parasite, together with the suggestion of encouraging ecrtain species of birds, and even voles, which eat the cocoons or perfect insects. As regards voles, it must be remembered they are themselves very injurious to young trees, inasmuch as they eat the roots and bark. While recognising that all these suggested remedies have a practical value, I am much inclined to believe that the best remedy is to be found in improved soil conditions. This has been very well put forward by Mr.J. F. Annand, Lecturer in Forestry, Armstrong College, Newcastle-on-Tyne. ${ }^{1}$

In the Lake district, where this insect is a direfnl pest, the planting of mire larch has been extensively adopted; and as regards favouring the insect nothing better could be done. This arises from the fact that in pure larch crops we get a light canopy which promotes a very grassy surface, thus forming an ideal condition for the cocoons during the whole of the pupal period. On the other hand, where there is a mixed wood, or where an exceptional beech-tree, group of beeches, or other shade-bearing trees exist, thus producing a surface of dead foliage (contrasted with the grass referred to), either no cocoons are found or else the cocoons perish long before the pupal period is completed.

In the Lake district wherever patches are to be found with a bare surface of decaying foliage there is a marked diminution of damage. Hence, from inference, the question arises, how are we to treat our existing woods so as to minimise the damage, or how are we to mix our young woods, in the process of planting, with such a variety of shade-bearing species of trees as will reduce the prospective injuries of this insect? In other words, the question arises, what are we to recommend on sylvicultural principles as prevention or remedies, either in the formation of young plantations or as treatment in the older woods?

It is hoped from the above remarks that the point has been made clear to the effect that the best of all remedies has been in introducing and maintaining such surface conditions as will act in the dual capacity of being inimical to the development of the pest and stimulating to the crop. To deal with this question at any great length would be equivalent to giving a sylvicultural account of the larch as a forest tree. As this is not intended, the following brief notes are given more from an entomological than a sylvicultural point of view, inasmuch as the entomological aspect should adapt itself to the special peculiarities of crops or the variable intentions of the practical planter.

Tewly-planted woods. - These may be of two kinds-viz., $(a)$ pure, and $(b)$ mixed.

As regards pure woods, it must be remembered that the larch is a tree with a very light foliage, consequently a grassy surface specially favourable for cocoon development will ensue from the planting of a pure crop of larch. The grassy surface could to some extent be

I "Observations on the Large Larch Saw-Fly," 'Quarterly Journal of Forestry,' July 1910. 
checked by eloser planting, but in the cultivation of larch it is recognised that the individual trees grow more or less equal in height in the struggle for existence, therefore too close planting and probable heavy thinning for subsequent under-planting would in many cases not produce a correct type of tree for a final crop. In addition to this, it must be remembered that no matter what the number planted per acre may be, in the majority of cases only a relative proportion will show sufficient stamina to justify the prospect of reaching healthy maturity. Hence, having regard to the law of "Natural Selection," we see the obvious necessity of planting at such distances, compatible with subsequent financial results, as will eventually produce a sufficient number per acre for a final crop.

With regard to planting larch in "mixed" plantations, it may be noted that the larch may be planted either with the object of forming a portion of the final or semi-final fellings or otherwise as a tree for early returns. In either case, while the trees are quite young, spraying, hand-picking, or beating the larve into inverted umbrellas might give good results, but the mixture should be so formed as to produce such surface conditions as will kill the grass or other herbage as speedily as possible, and so render the surface detrimental to the pupal stage of the insect.

As regards middle-aged woods, or plantations where the trees are too large for spraying with any insecticide, no better remedy can be adopted, provided the pest has not gained too strong a hold of the crop, than simply by underplanting and encouraging the growth of sycamore, ash, hazel, de., which may spring up naturally. Thus we get better surface conditions and accelerated growth in the larch.

As far as old woods are concerned, much would have to be left to the discretion of the owner or the practical man in charge; but as regards the pupal stage, some mitigative measures might be accomplished in allowing the entrance of stock in stormy weather, and handfeeding them, burning of stray branches from wind-falls, or thinnings in small disseminated fires, and other similar devices. As regards checking in the caterpillar stage, the following practical suggestion from Mr Annand's paper might be considered, namely, that as far as possible summer felling, when the larvie are in "full feed," may be adopted, and then burn the branches together with the larvie, and so arrange the fires as to have the effect of burning as much of the grassy surface as possible.

\section{Nematus laricis, Htg.}

For the past two or three years attention has been directed to injuries to the tips of very young larch-trees. Fig. 354 is a representation of the injuries, though perhaps not quite on a large enough scale to be considered typical. The small larva harmonise in colour so well with the foliage that they are apt to be overlooked by the practical man. 
On Sept. 2, 1910, I found a few larve of this species and placed them in a glass jar. These must be considered very late specimens, but they pupated in a few days' time, and hatched ont on June 10, 1911. On July 12, 1911, 1 found several specimens of the larvie at Warkwortl, Northumberland. They showed themselves as being more partial to Larix Amerirema than to the European larch.

The caterpillars are of a green colour, about 15 mm. in length. The head is brown. As a rule, they may be considered to be about full fed towards the end of July or middle of Angust, although oc-

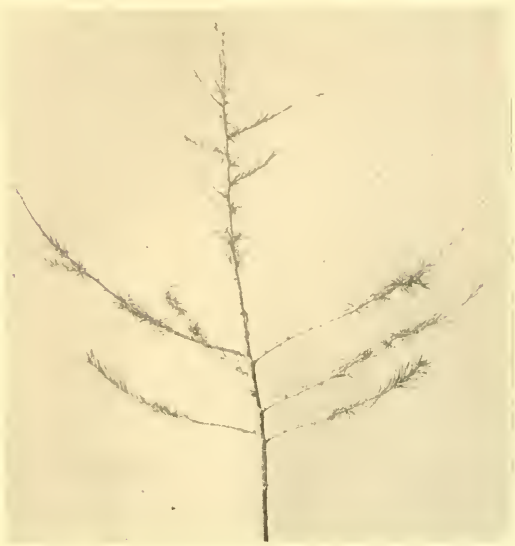

Fig. 354. - I six-year-uld larih injured by larew of Nematus laricis. The leaves, or needles, at the extreme tips have been destroyed by the larvie. casionally they may be found later. They eat the single leaves on the shoots of the current year, and so contrast with the larve of Nemutus Erichsonii, which devour mainly the foliage or "tufted" leaves arising from the older portion of the branches.

The perfect insect is black in colour; legs light yellowish-brown, with blackish tarsi; wings slightly iridescent, stigma brown, nervures black or dark brown. Length $12 \mathrm{~mm}$.

\section{Lophyrus ruFus (Klug).}

On July 3, 1911, I discovered this species for the first time in Northumberland. A six-year-old plantation of Scots pine showed evidence of having been rather severely attacked by the larve of this insect. It was rather late for specimens, but after a considerable search I succeeded in finding about a dozen in the larval stage.

The larva has black shining head and legs. The body is of a greenish dusky-grey colour with a lighter median line, and a rather darkish line above the spiracles. The abdominal sucker feet are of at light yellowish-grey colour.

On Sept. 9 four saw-flies hatched out. The specimens were all 
females. The body is of a darkish-red colour, and approaching to black about the middle of the body on the dorsal surface. Legs of a uniform lightish-brown colour. Antenne dark-brown; eyes and ocelli black and smooth.

As compared with $L$. pini there are several points of contrast. The larve are quite distinct in colour, and the larvie of rufus feed on the foliage of last yeur, whereas pini eat the foliage of the current year. Lophyrus pini is always double-brooded, while $\dot{L}$. rutus is singlebrooded. Thus we have in this species a good example of the value of systematic study to the practical man. The two species of sawflies in question are not very widely separated, so far as structural details are concerned, and yet the life-histories vary considerably. It often happens that the economic entomologist only recognises distinct species through the medium of the damage, whereas when "beating" insects in a general way a knowledge of structural points would enable ¿ "recoguition" prior to the evidence of injuries.

\section{Argyresthia Levigatella, H. Sch. (the Larch-shoot Moth).}

It has recently been recorded from several districts, more especially on the Colesborne estate, Gloucestershire, ${ }^{1}$ that considerable damage is being done by this tiny moth to larch plantations under thirty years of age. The injuries are represented in fig. 237, page 239. At Colesborne the damage is thus described by Mr John Irvine, the forester on the estate: "Healthy growing trees suffer as much as the weakly diseased ones, and larch in all aspects and situations, whether in pine woods or mixed, are attacked; isolated trees seem to suffer as much as those growing in masses, the leaders being attacked as well as the side shoots."

With a view of ascertaining whether the damage was on the increase in other parts of the country, I wrote to Mr J. W. Robbins, forester, Escrick, Yorkshire, who has given considerable attention to this species. He replied to the effect that he did not consider it was appreciably on the increase in that district.

As regards remedial measures, it would appear from the life-history of the insect that the only effective way in dealing with this pest is to cut off and destroy the affected shoots in the spring, say about the middle of May. If concerted action on the part of owners of woodlands were adopted in cutting off the shoots as suggested, the pest would be minimised for the following year.

There is an important point in connection with the name of this insect which may be noted-viz., that specialists in micro-lepidoptera are inclined to consider the correct name as A. atmoriella, Banks. The practical man will of course be content to call it by the name of "The Larch-shoot Moth."

${ }^{1}$ Quarterly Journal of Forestry, July 1911. 


\section{N J) E X.}

Note.-The names of insects given as synonyms thronghont the book and names not at present generally adopted are printed in itrlics.

Abdomen, 11

Abnormal buts, 20

Acanthocinus adilis, 55

Agrilus viridis, $4 \mathrm{~S}$

Agromyza sehineri, 370

Agromyzida, characters of family, 370

Aleyrodidi, 316

Andricus eurvator, 150

fecundatrix, 152

gemmatus, 148

inflator, 149

noduli, 148

ramuli, 152

Anobiide family, 50

Anobiina, generic divisions and characters of, 51

Antenna, typical, 10

Aphididr, general characters of, 251 honey-dew of, 253

oviparous and viviparons, 2.56

sub-families of, 257

Aphilothrix albopunctata, 1.52

eollaris, $1 \pm 9$

corticis, 148

feeundatrix, 152

globuli, 145

quadrilineata, 15]

radicis, 147

Aphis, characters of gemus, 262

abietina, 265

cratregi, 262

enonymus, 265

hedera, 265

parli, 264 sambuci, 266

viburni, 266

Apterococcus fraxini, 3.j0

Argyresthia, generic characters of, $2: 39$ lievigatella, $239,4: 2$

Aromia moschata, 5i)

Arthropoda, divisions of, 3

Asemum striatum, 404

Ash-bark beetles, 101

Ash-bud Moth, 234

Asphondylia sarothammi, 36s

Aspicliotus, generic characters of, 327 britannicus, $32 \mathrm{~s}$ zunatus, 328

Asterolecanium, generic characters of, 343

variolosum, 343

Astinomes adilis, $5 \mathrm{~s}$

Attelabus curculiomides, 66

Anlacaspis rosie, 329

Balaninus, generic characters of, s:3 unenm, 83

bark beetles, descriptive character's of, 85

Batoles angustiorana, $2 \cdot 26$

Beech Agrilus, 4s

Beetles, descriptive details of, 37 classification of, 40

Beneficial insects, 403

Bibio johannis, 374

marci, 374

Bibionidie, eharacters of family, 373

Biorhiza aptera, 155

renum, 1.5 
Blind bud of currant, 1!)

Bordered White Moth, 214

Braconidæ, 405

Breathing organs, 12

Buff-tip Moth, 2I:

Butterfly, development of, 7

Callipterus, character's of gemus, $26 \mathrm{~s}$ betularius, 269

quercûs, 269

Cecirlonyia, characters of genus, 354

cratiegi, $35 \%$

heterobia, 361

marginemtorquens, 3.j.

picete, 370

rosaria, 359

saliciperta, 360

salicis, 362

taxi, $35 \mathrm{~s}$

tiliam volens, 363

Cecidomyidie, characters of family, 354

Cemiostoma laburnella; 248

Cerambycidit, $5 \tilde{5}$

Cerataphis latani:, 316

Ceratoneon vulyare, 3t

Cerura vinula, 210

Chaitophorus, characters of genus, 266 abnormal form of, 267 aceris, 266

Chalcidida, 139,405

Cheimitobia brumata, 216

Chermes, characters of genus, 254 importance of genus in forestry, 295

abietis, 249

corticalis, 293

laricis, 290

picer, 294

pini, 292

strobilobius, 2\$9

viridis, $2 \$ 5$

life-history of, 286

Chermesina, characters of tribe, 282

Chionaspis, characters of genus, 320 salicis, 321

Chromatomyia olsseurella, 371 ilicis, 372

Chrysomelina, 62

Cicadidit, 307

Cimbicides, 172

Cladius viminalis, 180

Clay-coloured weevil, $6 \mathrm{~s}$

Clinodiplosis botulurice, 364

Clytus arietis, 55
Coccidie, general characters of, 313317

synopsis of sub-families, 317

Cockchafer, 44

preventive and remedial measures against, 46

Coleophora, generic characters of, 242 fuscedinella, 245

laricella, $24: 2$

sp., 245

Coleoptera, 37

Uollecting, 376

Cossus ligniperda, 206

C'rosus septentrionalis, 18j

Cryphalus, characters of genus, 11.5 abietis, 116

fagi, 118

picer, 117

tilia, 117

Cryptocampus pentandru, 181

Cryptocoteus fagi, 346

Cryptorrhynchus lapathi, s2

Cynipide, details of structure, 138 groups of, 140

Cynips Kollari, $15 \mathrm{~s}$

Dactylopiine, $3+1$

Dasyneura marginemtorquens, 355

crategi, $35 \%$

taxi, 358

tiliam volens, 363

Deporaüs betulie, 67

Depressaria, characters of genus, $2: 37$ assimilella, 238

conterminella, 237

Diaspinæ, 318

Diaspis, 329

Dicranura vinula, 210

Digestive organs, 13

Digging in autumn, 409

Dioryctria abietella, 219

Diplosis botulariz, 364

dryobia, 365

tremulæ, 366

Diptera, general character's of, 352

Doreus parallelopipedus, 43

Drepanosiphum, generic character's of, 259 platanoides, 259

Dryobius, characters of genus, 275

Dryocretes, generic characters of, 120 alni, 121

coryli, 121

villosus, 121 
Dryocitina, 114

Dryophanta divisa, 154

longiventris, 154

scutellaris, $15: 3$

Dryophante folii, 153

Eccoptoryaster scolytus, 93

Eggs of insects, 4

Elm-bark Beetlc, 9:3

Entomology, principal orders, 3

Epurea angustala, $4(1) 4$

Frineum, 19

Eriophyes, life-history and microscopical characters, 21

fastidious as to food, 35

physiological functions, 22

species causing malformation of

flowers, fruit, or leaves, 30

species living in buds, 23

species living in galls, 27

aucuparix, 32

avellane, 24

axillaris, 29

fraxini, 30

goniothorax, 31

litvis, 29

macrochelus, 2S

macrorhynchus, 28

psilaspis, 26

rudis, 25

tetanothrix (laeris), 29

tilize (typicus), 27

tiliarius, 30

Eriophyidie, 19

Eriophyine, sub-family, 2:3

dissemination of, 36

Ernobius mollis, 52

Euura pentandre, 181

Eyed Hawk-Noth, the, 205

Eyes of insects, 9

Fidonia piniaria, 214

Forest Entomology, definition of, 1

Fumigation, 414

Gall-flies, setting of, 381

Gall-mites, 19

Geometrina, 214

Goat-moth, 206

firacillaria syringella, 241

Freen Tortrix Noth, 22I

Harmandia tremulit, 360

Head of insect, 9
Heart of insect, 14

Hedya ocellana, 226

Holcocneme Erichsonii, 186

Hormomyia capree, 367

fagi, 367

piliger, 367

Hornet, $19: 2$

clear-wing of the osier, 201).

IIybernia defoliaria, $21 \mathrm{~s}$

Hylastes, characters of gemus, is ater, 100

palliatus, 99

Hylesinina, 9s

Hylesinus, characters of genus, 11) 1

erenatus, 101

fraxini, 103

oleiperda, 10.5

vittatus, 106

Hylesinus piniperlu, 107

Hylobius abietis, 72

preventive and remedial measures against, 74

Hylurgus, generie characters of, $10 \%$ minor, 112

piniperda, 107

piniperda, preventive and remedial measures against, 111

Hymenoptera-oak-galls, 130)

characters of, 164

miscellaneons, 192

saw-flies, 164

Hyponomeuta evonymellus, 233

Ichneumonidie, 405

Insect, general definition of, $: 3$

Insecticides, 407

Insects, relative position in the animal kingdom, 2

Lachnine, characters of tribes, 270

Lachnus, characters of genus, 271

longipes, 272

pini, 271

viminalis, 272

Lamiidæ, 58

Larve, typical forms of, 5

Lasioptera rubi, 368

Leaf-wasps, 172

Lecanium, general characters of, 331 generic characters of, 334

bituberculatum, $33 \mathrm{~S}$

caprea, 338

ciliatum, 337

persice, var. coryli, 337 
Leg, structure of, 11

Leopard Moth, :0s

septentrionalis, 1\$5

rallisnerii, 183

Lepidoptera, general characters of, 201

Lithocolletis, characters of genus, 246

carpinicolella, $24 \mathrm{~s}$

coryli, 248

faginella, 245

messaniella, 246

salicicolella, 248

Longicornia, characters of, 53

family divisions of, 54

Lophyriles, 175

Lophyrus, characters of genus, 175 pini, 175,421

rufus, 178,421

Lucanidx, $4: 2$

Lucanus cerrus, 42

Lygronemetus saxeseni, iss

Macrodiplosis dryoline, 365

Nacropsis lanio, 309

Marble gall, 158

Negastigmus spermotrophus, 194 strobilobins, 199

Melanoxanthus, characters of genus, 260

salicis, 261

Melasoma populi, 62

Melolontha, characters of genus, 44 preventive and remedial measures against, 46

hippocastani, 47

vulgaris, 44

Mikiola fagi, 367

Monochetus sulcatus, 33

Mottled Umber Moth, $21 \mathrm{~s}$

Mounting, microscopic, 3s 1

Musk Beetle, 55

Myelophilus piniperda, 107

Nytilaspis, generic characters of, 326

pomorum, 326

Myzus, generic characters of, $25 \mathrm{~s}$ cerasi, $25 \mathrm{~s}$

Nail-galls, 27

Nematince, 17s generic divisions, 179

Nematus alietinus, 188

bellus, $1 \mathrm{sil}$

gallicola, 183

ischnocerus, 184

Nematus Erichsonii, 186, 418

laricis, 420

Nervous system, 12

Neuroterus fumipenuis, $1+4$

leviusculus, 145

lenticularis, $1+0$

numismatis, 146

ostrens, 146

Novius cardinalis, 404

Oak-apple, 156

Oak-galls, 130

alternating generations of, $1+1$

development of, 132

relation to theory of evolution, 134

synoptical table of, 159

their economic interest and teachings, 162

Ocelli, 9

Oligotrophus caprene, 367 piliger, 367

Orchestes, generic characters of, so alni, 81

fagi, so

quercûs, 81

Orgyia antiqua, 209

Otiorrhynchus picipes, $6 \mathrm{~s}$ sulcatus, 69

Pædisea occultana, 226 ophthalmicana, 227

Pemphigine, characters of tribe, 27S

Pemphigus, characters of genus, $27 \mathrm{~s}$ bursarius, 279

pallidus, 281

spirothece, 280

Penthina pruniana, 224

Philaneus spumaria, 309

Phloophthorus, characters of genus, 113

rhododactylus, 113

Phratora vitellinu, 64

Phyllaphis, characters of genus, 273 fagi, 273

Phyllereum, 20

Phyllobius maculicornis, 71

Phyllocoptes acericola, 34

Phyllocoptinz, 33

Phyllodecta, characters of genus, 64 vitelline, 64

Phylloxera, characters of genus, 298 punctata, 299 
Physokermes, characters of geuus, 340

abictis, 340

Phytomyza xylostei, 371 ilicis, 372

Phytomyzidic, characters of family, 371

Phytoptidie, 19

Phytoptus aceris, 34

calycophthirus, 25

myriadeum, '2s

ribis, 19

rudis, 25

taxi, 26

Pine-Beauty Moth, 219

-bud Tortrix Moth, 229

-shoot Tortrix Moth, 2:29

P'ine weevil, 72

Pissodes, characters of genus, 75

notatus, 78

pini, 76

Pityogenes, characters of genus, 122

biders, 123

bidentatus, 123

Pityophthorus, characters of genus, 118

pubescens, 119

Polydrusus micans, 71

Pontania bella, 182

gallicola, 183

ischnocerus, 184

proxima, 1S3

salicis, 181

Poplar Hawk-Moth, 204

Poplar-leaf Beetle, 62 large Longicorn Beetle of, 60 small Longicorn Beetle of, 61

Prays curtisellus, 234

Priobium eastaneum, 51

Prionus corarius, 54

Proctotrypidie, 406

Psendococens aceris, 344

Psylla alni, 306

buxi, 304

erategi, 305

Psyllidæ, 301

Psyllopsis fraxinicola, 302 fraxini, 302

Pterocallis, characters of genus, 270

tilix, 270

Pteronus, characters of genus, IS4 salicis, 184
Pulvinaria, characters of, 334

vitis, 334

var. ribesize, 335

Pupa, typical, 6

Puss Nloth, 210

Pygiera bucephala, 212

Reproductive organs of female, 15 organs of male, 17

Respiratory organs, 12

Retinia, eharacters of gemus, 229

buoliana, 229

resinella, 231

turionana, 2229

Rihabdophange heterobia, 361

rosctivit, 359

salicis, 360

Rhaginm, characters of genus, 56 bifasciatum, 57

inquisitor, 56

Rhodites eglanterix, 193 rosie, 193

Rhopalomesites Tardyi, 84

Rhynchophora, characters of, 66

Rhynchota, 30s

Saperda, generic characters of, 59 earcharias, 60 populnea, 61

Scale-insects, 313

Scarabieidie, 44

Schizoneura, characters of genus, 276

ulmi, 277

Schizoneurina, 275

Scolytidie, descriptive characters of, 85

Scolytinæ, character's of sub-family, 92

Scolytus, characters of genus, 93

destructor, 93

Geoffiroyi, 93

intricatus, 97

multistriatus, 96

pruni, 96

Sesia bembeciformis, 205

Sinodendron eylindricum, 43

Sirex gigas, 189

juveneus, 191

Siricidae, 189

smerinthus ocellatus, 205

populi, 204

Spathegaster albipes, 145

aprilinus, 147 
baccartm, 143

tricolor, 145

vesicatrix, 146

spraying in nursery, 415

stag-beetle, 42

Stigmonota regiana, 228

Stomaphis, characters of genus, 274

Strophosomus, characters of genus, 69

capitatus, 70

coryli, 70

structure of insects, 8

Taphrina, 20

Tenthreciinide, 172

Teras terminalis, 156

Tetranema ulmi, 281

Thorax, 10

Tinese, 23:

Tomicns, characters of genus, 121 acuminatus, 122 sexdentatus, 121

Tortoiseshell butterfly, development of, 7

Tortricide, 220

Tortrix ribeana 224 viridana, 221

Trachea piniperda, 219

Tracheæ, 13

Trichiocampus viminalis, 180

Trichiosoma, characters of genus, $17 \cdot 2$ tibialis, 173

Trochilium bembeciformis, 205
Trypodendion, characters of genus, 125

domesticum, 127

lineatum, 126

quercûs, 1:28

Two-winged flies, 352

Typhlocyba ulmi, 310

flammigera, 310

quercuss, 310

Typhlocybidie, 310

Typical insect, 4 mouth parts, 9

Vapourer Moth, 209

Tedalia, 404

Tespa Crabro, 192

Jolivlifex aceris, 34

IVashing large trees, $\mathbf{4 1 6}$

IV asp Beetle, 55

IVillow Beetle, 64 -twig midge, 362 -wood midge, 360

Winter Moth, 216

Wood-Wasps, 159

Xestobium tessellatum, 52

Xyleborus, characters of genus, 128 lispar, 12s

Xylocleptes, characters of genus, 119 bispinus, 119

Zenzera asculi, 208

THE EN I). 



Forest entomology, 